$$
\begin{gathered}
\text { Universidade de Brasília } \\
\text { Instituto de Ciências Sociais } \\
\text { Departamento de Antropologia } \\
\text { Programa de Pós-graduação em Antropologia Social }
\end{gathered}
$$

\title{
o compromisso de casar e o desejo de amar: experimentos existenciais entre jovens abastados na cidade de Nova Délhi.
}




\section{o compromisso de casar e o desejo de amar: experimentos existenciais entre jovens abastados na cidade de Nova Délhi.}

Tese de doutorado apresentada ao Programa de Pós-graduação em Antropologia Social da Universidade de Brasília para obtenção do título de Doutora em Antropologia.

Orientadora:

Profa. Dra. Antonádia Monteiro Borges

Brasília, 2015 


\title{
Resumo:
}

Esse trabalho versa sobre experimentos existenciais de jovens abastados na cidade de Nova Délhi em relação ao romance e à sexualidade. A tese enfoca uma fase liminar na vida dessas pessoas, a saber, os anos que antecedem o matrimônio em que às expectativas sobre o casamento - ideal e normativamente arranjado -, somam-se, em muitos casos, romances pré-conjugais proibidos e ocultados dos pais. 0 modo como os jovens valorizam ou não o amor como prelúdio ao casamento tem destaque na investigação que também visa refletir sobre o papel desempenhado pelas experiências dos namoros entre os interlocutores da pesquisa nos processos de individuação em sua formação como pessoas.

Palavras-chave: amor, sexualidade, moralidade, casamento, romance no Sul Asiático.

\begin{abstract}
:
The present work is about existential experiments carried out by wealthy youngsters living in New Delhi regarding romance and sexuality. The thesis focuses on a liminal period of these young persons lives, which are the years immediately before marriage. While living the expectations and anxieties concerning the marital alliance a number of these persons experience tabooed and secret pre-marital romances hidden from parents and community, since marriages are ideally and normatively arranged. The positive valorisation of the idea of love as a prelude for marriage to some of these youngsters deserved a prominent attention in the investigation that is also aimed to analyse how the romances experienced by the interlocutors in the fieldwork play a role in the individuation process in their formation as persons.
\end{abstract}

Keywords: love, sexuality, morality, marriage, romance in South Asia. 


\section{Agradecimentos}

Aos funcionários do DAN, nas pessoas de Rosa, Cristiane e Jorge, agradeço os préstimos e a disposição em ajudar a vencer a burocracia e permitir que nossos trabalhos sejam realizados com mais tranquilidade.

Aos professores das disciplinas que cursei durante o doutorado, agradeço a sabedoria que compartem com seus alunos e o competente direcionamento nas discussões teóricas: Antonádia Monteiro Borges, Lia Zanotta Machado, Luís Roberto Cardoso de Oliveira e Marcela Coelho de Souza, suas aulas foram importantes de diferentes maneiras.

Ao CNPq, agradeço a bolsa que propiciou a dedicação exclusiva ao doutorado e ao presente trabalho por quatro anos. Agradeço à CAPES pela concessão de bolsa de estágio sanduíche no exterior, pelo programa PDSE, permitindo um proveitoso estágio no Sociology Department da Delhi University.

Aos funcionários, professores e alunos da Pós-graduação em Sociologia da Delhi University, por permitirem que desenvolvesse as atividades necessárias ao desenrolar da pesquisa, pelas dicas e ajuda preciosa em momentos de dificuldade. Em especial, agradeço a disposição da professora Janaki Abraham em coorientar esta tese no estágio sanduíche. Suas indicações de leitura e as conversas sobre o trabalho de campo que eu realizava foram importantíssimas à conclusão desse trabalho. Obrigada, ainda, Janaki, por acolher-me afetuosamente em momentos aprazíveis em sua casa. Agradeço ao professor Satish Deshpande todo o empenho em permitir minha afiliação ao Sociology Department. Agradeço à Sweet Aggarwal os préstimos, e a simpatia, como secretária daquele departamento. Aos colegas Vasundhara Bhojvaid, Subashim Goswami, Ishita Dey, Sebanti Chatterjee, Mohd Sayeed, Hoda Bandeh-Ahmadi, Prasenjeet Tribhuvan, Jyoti Gupta e, em especial, Chayanika Pal e Nandini Hebbar pelas conversas e trocas de notas de campo e bibliografia, uma vez que seus trabalhos possuem intersecções com o

tema dessa tese. À professora Janaki Nair da Jawaharlal Nehru University agradeço imensamente todas as conversas e a indicação dos livros pelos quais iniciei as buscas bibliográficas. À ela devo, ainda, a apresentação à Janaki Abraham.

À Antonádia Borges - que dizer da pessoa que exerceu tamanha influência em minha formação como antropóloga -, devo desde a primeira ida à Índia, que constituiu a abertura para um mundo tão radicalmente diferente de tudo que já havia vivido, até a 
conclusão desse trabalho; graças à sua dedicação, paciência e inspiração para seguir fazendo antropologia é que esta tese existe.

Às professoras Adriana Piscitelli, Fabiene Gama, Mariza Peirano e Cristina Patriota e ao professor Cláudio Pinheiro, agradeço por aceitarem o convite para participar da banca de defesa e pela disposição em ler esse trabalho. À Mariza e ao Cláudio agradeço, ainda, as indicações de leitura e os comentários valiosos quando da defesa de qualificação do projeto de pesquisa que redundou na presente tese. À Cristina, agradeço por se dispor a presidir a banca na ausência de Antonádia. Sua presença caiu como uma luva na conclusão de mais uma etapa de minha formação, da qual você fez parte como professora, na graduação e no mestrado, como arguidora na defesa da monografia de graduação e como componente da banca nas seleções de mestrado e doutorado.

Quanto aos amigos que fiz na Índia as palavras são insuficientes para expressar a gratidão e o carinho que despertaram em mim. Se aposto em experimentos existenciais nesta tese é porque vocês mostraram que, a não ser por meio deles, a existência jamais alcança sentido: agradeço por abrigarem-me em suas experiências existenciais, por me ensinarem tanto e pelo afeto que me dedicaram.

Aos colegas do GESTA - Grupo de Estudos de Teoria Antropológica - agradeço a leitura de grande parte deste texto, suas críticas e questões contribuíram muito para a gestação e o nascimento desta tese, obrigada Roberto Sobral, Isabele Bachtold, Nathan Virgílio, Denise da Costa, Luiza, Claudia Luzo e Gustavo Belisário. Aos colegas do doutorado, agradeço os momentos de troca de ideias e o companheirismo nas aulas e nos corredores do DAN, que bom que pude contar com vocês: Júlia Brussi, Simone Soares, Pedro Pires, Yoko Nitahara, Gretel Echazú, Rafael Almeida e Paula Balduíno. Aos dois últimos agradeço ainda a experiência compartilhada de ministrar Introdução à Antropologia e a amizade.

Agradeço às queridas Andressa Lewandowski, Carol Pedreira, Julia Otero e Nicole Soares pela força e companheirismo nessa coisa de fazer doutorado e escrever tese. Aos amigos Michel Alcoforado e Maria Soledad de Castro agradeço o acolhimento e a escuta em diferentes momentos do processo de feitura da tese, bem como as ocasiões de descontração e esquecimento da mesma para que, num momento seguinte, pudesse voltar a ela com mais afinco.

Aos meus BraucAmigos, agradeço o compartilhar da vida há tantos anos em irmandade e deleite, obrigada Andrezza Sisconetto, Bruno Siqueira, Manuella Dias Prudente, Rodrigo Vallim, Fernando Maluf e Fabiana Araújo. 
De modo mais que especial, agradeço minha irmã, Jacqueline, pela força e torcida e minha mãe, Divina, por ser a pessoa que é e por sempre me confortar, animar, corrigir e, acima de tudo, me amar.

Ao meu companheiro André, agradeço toda a ajuda e o apoio, sempre e em tudo. Obrigada pela leitura desse texto e por ouvir as histórias que meus amigos e eu construíamos no tempo em que eu estava distante e no qual você me esperava voltar da Incredible India com ainda mais carinho do que quando eu partira, todas as vezes. Descobrir o amor ao seu lado tem sido uma aventura grandiosa e feliz! 


\section{Sumário}

Introdução

\section{Capítulo I - Primeiro as coisas primeiras}

De como o trabalho de campo se deu

Uma casa para chamar de lar e amigos para chamar de meus

O compromisso de casar e a vontade de amar: construindo um objeto de pesquisa ---- 50

"Will you say something so embarrassing about me?" Ou como escrever? 56

\section{Capítulo II - As pessoas e a paisagem moral na PG}

Preâmbulo 60

Do's and dont's na PG e em Délhi --.-- 65

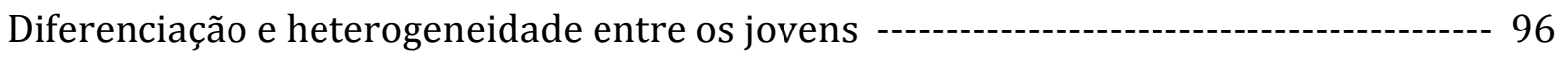

\section{Capítulo III - Main Tumse Pyaar Karte Hun}

O amor: um só ou vários?

A Question of Silence? 0 dilema da sexualidade na Índia contemporânea --------------- 120

O amor de Shubhi e Patrick

Lovania e os paradoxos do desejo

\section{Capítulo IV - Yeh Jawaani Hai Deewani!}

Da busca pelo amor romântico e a busca pela individuação

Rekha, "you won't have an inter-caste marriage"

Entre amores e arranjos: o modo de se individuar dos garotos

Os jovens podem escolher, desde que sejam razoáveis

Yolo! You Only Live Once

A modo de conclusão sobre as diferenças apresentadas por garotos e garotas quanto ao 


\section{Capítulo V - Shubhi Kee Shaadi}

Algumas nomenclaturas correntes para o casamento 269

"Now it has turned into a love marriage" 276

Dos casamentos arranjados como um sistema 297

Apontamentos finais 313

Referências Bibliográficas 318

Caderno de Imagens 323 


\section{Introdução}

Esta tese é resultado de um grande desafio: contribuir para o conhecimento antropológico contemporâneo sobre a Índia desde a perspectiva do Brasil. É preciso não esquecer que aquele país tem sido objeto de especulações e imaginação, as mais diversas, desde que viajantes e mercadores ocidentais por lá aportaram em séculos longínquos, sobretudo em relação a dois temas que continuam a capturar os imaginários sobre a Índia: o hinduísmo e o sistema de castas, ambos diretamente ligados a outras duas ideias, hierarquia e holismo. Muito já se escreveu e se aventou, portanto, sobre essa porção geográfica do globo que se convencionou chamar de Índia, mesmo antes da constituição do estado-nação em 1950.

Nas ciências sociais, a Índia obteve lugar de destaque na obra de pensadores como Max Weber que erigiu uma teoria sobre estratificação social, lançando mão do caso do sistema de castas indiano, no segundo volume intitulado Hinduismus und Buddhismus de seu reconhecido trabalho Gesammelte Aufsätze zur Religionssoziologie, publicado em 1921. Antes dele, Marx e Engels se apoiaram na Índia para desenvolver seus argumentos acerca do modo de produção asiático. No Brasil, onde a influência francesa foi sentida na constituição das ciências sociais desde o primeiro curso da área na USP nos anos 30, a interpretação antropológica da Índia e de suas castas se deu a conhecer mais amplamente pela obra de Louis Dumont que, em livros como Homo Hierarchicus e 0 Individualismo, passou a representar o que havia de mais sofisticado na maneira de olhar a Índia e seu sistema de castas. Diferentemente do Brasil, na Índia a interpretação dumontiana sobre aquela sociedade e seu sistema de organização social suscitou respostas e debates intensos a partir do momento em que foi publicada. Aceito amplamente fora da Índia, Dumont passa a ser ora aceito com ressalvas, ora sistematicamente rechaçado no interior daquele país.

Nesta tese não se ignorou a produção dumontiana sobre a Índia, tanto por reconhecer sua sofisticação do ponto de vista sociológico, quanto por sua importância histórica para a formação das ciências sociais na própria Índia, que de certo modo se constituiu no diálogo com Dumont e seu parceiro de publicações, David Pocock. Adicionalmente, optou-se, contudo, pelo diálogo intenso com uma produção indiana mais recente e conectada aos temas da tese. Desse modo, a discussão sobre a vigência do 
sistema de castas se dá em conversa com produção que por vezes critica duramente Dumont e por outras, com ele dialoga, este último o caso de Patricia Uberoi, autora bastante relevante para este trabalho e para o campo de estudos de casamento e do parentesco na Índia, área de reflexão para o qual esta tese pretende contribuir .

0 pertencimento de casta, no modo hierárquico das pessoas se organizarem e se reconhecerem, ficou, não sem surpresas, patente durante o trabalho de campo e aparece nos capítulos seguintes em situações que vivi com meus interlocutores e no discurso que legitima os casamentos arranjados e deslegitima os denominados casamentos "por amor". A preocupação com a chamada pureza de casta, e por conseguinte com a manutenção da ordem hierárquica, sedimenta uma das mais importantes regras do parentesco na Índia, isto é, a endogamia de casta. Além do sistema de castas, temas como comunidade e religião e as noções de individualismo e holismo permeiam toda a tese, fazendo presente o diálogo com Dumont e, concomitantemente, com os demais autores que aparecem ao longo do texto, dos quais, repito, alguns se afastam grandemente de Dumont, sendo talvez os casos mais exemplares os de André Béteille e Parveez Mody, como se verá adiante. Neste ambiente, de grandes teorias e disputas acadêmicas, meu objetivo pode ser considerado mais modesto, mas, espero, etnograficamente revelador para a antropologia contemporânea.

A tese constitui um esforço de escrita etnográfica sobre o trabalho de campo realizado na cidade de Nova Délhi no qual acompanhei o cotidiano de jovens com idades entre dezoito e trinta anos que se desdobravam entre a vontade de experimentar o romance antes do casamento, por vezes expressando o desejo de "casar-se por amor", e a expectativa familial de que tivessem um "casamento arranjado". Convivendo intensamente durante 11 meses (em períodos de dois a quatro meses por ano entre 2012 e 2015) com os moradores de um pensionato situado em um setor afluente no sul da cidade, os jovens de classe média alta e pertencentes a castas consideradas superiores (upper castes), e de quem me tornei amiga, fizeram-me perceber que eram muitas as complexidades vividas, e a mim apresentadas, pelas pessoas em "idade para casar", no que se refere às suas expectativas, ansiedades, preocupações e experiências em relação ao namoro - ou romance pré-conjugal -, à sexualidade, à moralidade pública e ao casamento. Ao longo do texto, exploro o modo como as pessoas com quem convivi se colocavam frente ao imperativo das famílias que pretendiam casá-los: desejando e 
ansiando ou rechaçando e tentando retardar o processo de arranjo de seus próprios casamentos.

Fazer um casamento arranjado no norte do país significa, do ponto de vista formal, observar, sobretudo, os ideais normativos de exogamia de gotra, isto é, a obrigatoriedade de casar-se fora do mesmo grupo patrilinear, e da endogamia de casta, ou seja, casar-se na mesma casta ou sub-casta. Acrescida a esses dois principais requisitos para o casamento está a tendência, presente em todo o norte do país, à hipergamia, fazendo com que, desejavelmente, os casamentos aconteçam com noivas de status ligeiramente inferior ao da família do noivo, mantendo uma assimetria de prestígio e status entre tomadores e doadores de esposas, esses últimos os detentores de menor prestígio nas alianças matrimoniais.

Tais regras de parentesco mostraram-se em processo de transformação, tanto no trabalho de campo, quanto na produção acadêmica recente sobre os casamentos indianos. Constituem parte desse processo o arrefecimento dos limites da endogamia de casta, fazendo com que algumas vezes casar-se na mesma varna passe a ser visto como um casamento endogâmico, e, ainda, a crescente relevância, sobretudo nos centros urbanos, da classe social como elemento definidor da endogamia: para manter status e posições hierárquicas casar-se na mesma classe social seria cada vez mais importante.

Outra fonte de transformações nas estratégias matrimoniais seria o movimento na direção de uma individuação que se verifica entre jovens de castas altas, oriundos de famílias de classes médias e altas nas paisagens urbanas. Em meus períodos de campo defrontei-me reiteradamente com a disposição dos interlocutores da pesquisa em fazer de suas vidas realmente "suas". A demanda por autonomia tinha seu oposto complementar na assunção corrente de que jovens solteiros não são adultos. Ao modo próprio de uma fase liminar, os jovens que conheci eram tratados pelas famílias e comunidades como "filhos" e "filhas" e "meninos" e "meninas". Para eles, o casamento, seria o sacramento que marcaria a entrada na vida adulta, sobretudo no caso das mulheres, que na sociedade patriarcal hindu passam do domínio paterno ao marital, indo compor a família extensa do marido e deixando a família natal, seguindo a regra de virilocalidade. 
Nomeio como processos de individuação a conformação de disposições de vida que desafiam a socialidade predominante que se verifica no contexto indiano contemporâneo, em que, como diziam meus interlocutores, pais são como chefes e têm a prerrogativa de decidir pelos filhos no tocante à escolha do curso superior a ser cursado, da carreira profissional, e das alianças matrimoniais. Além disso, os passos diários dos jovens de ambos os sexos são também vigiados pela moralidade pública em seus lugares de origem e mesmo nos espaços públicos da metrópole para a qual acorrem para estudar e/ou trabalhar. O policiamento moral das atividades dos jovens pode ser percebido, por exemplo, em casos recentes de abordagem de casais jovens em praças e parques abertos por parte de policiais e até mesmo da detenção de cerca de quarenta casais não casados que se encontravam em hotéis de Mumbai, os quais estampam os jornais de circulação nacional nos últimos anos. Tais incidentes se dão sem respaldo legal, mas com respaldo estatal.

Em que pese a independência financeira, já alcançada por muitos de meus interlocutores, nenhum ou nenhuma delas havia recebido dos pais a outorga do direito de fazer escolhas para seus futuros, algo pelo quê ansiavam. Como pude observar na convivência com rapazes e moças provenientes de diferentes regiões e comunidades, desde o ano de 2012, residindo no pensionato que fazíamos de lar, e mesmo desde o Brasil pela comunicação frequente por diferentes mídias e redes sociais, tais pessoas faziam relevantes seu desejo de empreender escolhas, de ter privacidade para o que consideravam como assuntos de foro íntimo (notadamente os flertes, romances e intimidades sexuais que experimentavam secretamente), e de "serem livres". Tais anseios eram expressos tanto por falas em diversos momentos ordinários e extraordinários que partilhamos, quanto por comportamentos que exibiam nas relações que eu observava e naquelas que estabeleci com eles.

Às práticas e vivências que lhes permitiam colocar em movimento seus desejos por individuação dei o título de experimentos existenciais, numa clara referência ao existencialismo filosófico de Karl Jaspers e Albert Camus, os quais afirmam que o entendimento do ser e do sentido da existência não está dado, mas somente pode ser encontrado no viver, de modo a afirmar que a existência precede o ser.

Em seus experimentos existenciais, meus amigos e amigas mantinham relacionamentos amorosos escondidos dos pais, das comunidades de origem e dos 
senhorios de nosso pensionato e governavam seus afetos e a própria sexualidade, desafiando o poder paterno que vê no exercício da sexualidade e da afetividade romântica pré-marital lascívia e motivo de desonra familiar, novamente de modo mais acirrado no caso das mulheres. Amor e desejo também seriam um empecilho aos arranjos matrimoniais, pois que do ponto de vista da moralidade hegemônica. Se deixados à própria sorte para escolher os nubentes seguiriam seus impulsos juvenis, deixando-se ludibriar pela atração física ou sexual e por intenções românticas que nada tem que ver com os modos legitimados socialmente de se fazer os casamentos nas diferentes comunidades que conformam o território e o estado nação indiano.

Índices das disposições de se individuar, isto é, de se diferenciar da família e da comunidade, fazendo escolhas pessoais autônomas e obtendo privacidade e liberdade para namoros e experiências sexuais tomavam a forma de viagens secretas com os pares românticos; de desavenças verbais com os pais para postergar o momento do arranjo de seus casamentos e em negociações tensas para o consentimento de um namoro e, por conseguinte, de um casamento "por amor", o qual desafiaria a endogamia de casta e a prerrogativa de escolha dos cônjuges detida pelos mais velhos.

Diferentemente de casos explorados na literatura indiana, notadamente nos trabalhos de Prem Chowdhry, Parveez Mody e Shaline Grover, em que os jovens que buscam um casamento que chamam de "love marriage" - discursiva e categoricamente contraposto à "arranged marriage" - rompem com as famílias natais pondo-se em fuga, ou sendo expulsos e desabonados pelos próprios familiares e comunidades, os jovens que tive a oportunidade de acompanhar enquanto teciam seus experimentos existenciais buscavam negociações que lhes permitisse não romper com a famílias, mas antes, delas obter consentimento.

Morar na capital do país, longe dos pais (por vezes num lar com a família extensa, chamada em inglês de joint family) e das comunidades de origem, assegurava certa mobilidade e anonimato com os quais os jovens contavam como aliados para suas atividades cotidianas que poderiam ser tomadas como desafiadoras da moralidade vigente pelos pais. Dentre estes contavam-se os hábitos de comer carnes no caso daqueles de famílias vegetarianas; de consumir álcool e outras substâncias alteradoras da consciência; da compra conspícua de lazer e bens de consumo e, claro, de namorar e ter intimidade sexual fora do casamento. Tais práticas permitiam aos jovens com quem 
convivi experimentar estilos de vida que queriam construir para si, discrepantes daqueles desejados pelos pais.

Como é amplamente reconhecido na literatura que trata da constituição da pessoa na melanésia e no sul-asiático, e aqui refiro-me especificamente à Marilyn Strathern e McKim Marriott, respectivamente, os sujeitos não se constituiriam ao modo de indivíduos com fronteiras distintivas e bem demarcadas entre o self e o outro, numa ideologia em que o mundo interior do sujeito é sobre-valorado em detrimento das interrelações que estabelece com os outros seres que compõem o mesmo cosmos, mas como divíduos constituídos e constituintes de outros seres e substâncias. Seguindo essa orientação teórica, uma distinção se estabeleceria na socialidade de um lado e de outro. Entre grupos individualistas valorizar-se-iam, predominantemente, as relações interpessoais em que cada parte na relação comporta-se, pensa e vive em acordo com a ficção de uma internalidade que se constituiria de dentro para fora; de outro lado teríamos divíduos em que as fronteiras entre si e o outro não são definidas ou cerradas, mas permeáveis a substâncias, afetos e características morais intensamente partilhados ou firmemente evitados no caso de pessoas com diferentes graus de pureza e impureza, para tomar o caso específico da sociedade hierárquica de castas.

A angústia e os desafios que enfrentavam para burlar as regras familiares faziam de suas experiências empresas dignas de serem chamadas de experimentos existenciais por desafiarem os apoios do viver e por colocar tais pessoas próximas de situaçõeslimite, aquelas em que o chão desaparece de baixo dos pés do sujeito, ou a defrontar-se com o absurdo da existência. Embora não tenha desejado fixar as histórias de meus interlocutores no interior de uma teoria filosófica, entendo que a angústia e o sofrimento experimentados ao se esforçarem para constituírem-se em indivíduos num movimento que resiste aos esforços familiares e comunitários de mantê-los como divíduos, isto é, como pessoas que são porosas e compostas de substâncias e emoções próprias e de outras pessoas conjuntamente, constitui um novo modo de constituição da pessoa no contexto investigado.

No caso dos jovens com quem convivi fazia-se patente a progressiva acomodação das duas assunções, abraçando concomitante e complementarmente diferentes disposições no entendimento do que os constituía como pessoas. Explico: apropriei-me e, de certo modo, adaptei o entendimento de Stanley Tambiah de que pessoas ao redor 
do mundo todo engajam-se em "diferentes ordenamentos de realidade". Assim era que muitos de meus amigos conseguiam desvencilhar-se do medo, da culpa e da angústia de comer carnes e sorver álcool sendo brâmanes de famílias que condenam a ingestão de tais substâncias - uma vez que são poluidoras temporárias da pureza permanente dada pelo nascimento naquela casta - tendo em vista um entendimento biomédico de que se carnes não faziam mal a algumas pessoas, por que fariam a outras se seres humanos são todos iguais organicamente? Ao mesmo tempo, em momentos rituais, períodos funerários e de luto e em festivais religiosos o entendimento biomédico era suspenso em função do entendimento do consumo de tais substâncias como prejudiciais a si e aos outros por quem velavam, bem como aos deuses. Em outro caso exemplar, de modo semelhante, uma de minhas principais interlocutoras fiava-se em novenas e jejuns ao deus Shiva em sua busca por um noivo tanto quanto em sites de matrimônio, em anúncios publicados em jornais e nos brokers contratados pelos pais na busca pelo mesmo noivo. Seguindo a orientação de que existem "múltiplos ordenamentos de realidade" pude compreender que tais engajamentos não eram antagônicos ou contraditórios, mas complementares e, possivelmente, harmônicos para meus amigos e companheiros de pesquisa.

Das transformações no modo de constituição da pessoa no ambiente em que vivi, destaco o fato de que meninas e meninos ansiavam por manter, ou já mantinham, relações íntimas e sexuais, essas tidas como absoluto tabu fora do casamento por exporem os sujeitos à troca de substâncias entre pessoas de diferentes graus de pureza dadas pela casta, e a diferentes níveis de status e prestígio dados pelas diferentes posições que ocupam nas hierarquias de casta, classe e gênero. Aponto, ainda, que é muito presente a ideologia de que sexo com fins que não o da procriação seria poluidor e nocivo não só pelo contato com substâncias potencialmente perigosas, mas, no caso dos homens, porque a descarga de sêmen acarretaria perda ou diminuição da força vital e da masculinidade. O contrariar dessas orientações fazia igualmente parte de um novo entendimento do que constitui as pessoas no viver desses jovens.

Desafiando assunções como essas em favor de outras orientações de vida, os jovens exibiam o que considerei como índices, no sentido peirciano de signos, de uma conformação de pessoa que passa por uma espécie de fechamento das fronteiras porosas que constituem os divíduos. Dito de outro modo, meus interlocutores buscavam romper com a definição de pessoa que é conformada nos interstícios da tentativa da 
comunidade de colonizar a vida do sujeito e na tentativa do sujeito em viver às margens da comunidade, como sugerido por Veena Das. Assim é que reivindicavam espaços e tempos para se fazerem indivíduos com possibilidades de fazer escolhas, tais como quem seriam seus pares amorosos e seus cônjuges. Dessa forma, aproximavam-se de uma ideia de amor romântico presente no mundo euro-americano em que cada indivíduo é visto ideologicamente como único, especial e insubstituível, o que asseveraria dentre tantas possibilidades virtuais de cônjuges, a escolha de um ser especial com quem fazemos alianças maritais e mantemos as instituições do matrimônio monogâmico e da família.

Em anseios que se manifestavam em frases como "quero alguém especial em minha vida" e "desejo encontrar alguém para compartilhar a vida e ser feliz", como diziam minhas amigas que buscavam um par romântico, seja para o namoro ou para o casamento, ou em declarações como "meu namorado é tão especial que ele tem sido minha vida nos últimos anos" e "ele me faz sentir única e especial" encontrei índices de que a socialidade preponderantemente holista, tão celebrada por Dumont, já se encontra desafiada por uma assunção que valoriza indivíduos específicos como par amoroso e conjugal em detrimento de sujeitos indistintamente intercambiáveis que ocupariam o papel social de um marido ou de uma esposa. Nesse movimento, sobretudo as garotas, procuravam se colocar também como sujeitos e agentes individuais de suas vidas e não apenas como objetos de alianças matrimoniais entre famílias e comunidades em trocas de mulheres que veem e vão com dotes e prestígio.

Para tanto, resistiam a dois ideais normativos que impactavam diretamente a vida dos jovens indianos com quem convivi: i) o fato de o casamento ser uma instituição impositiva, isto é, as famílias não vislumbrarem para seus filhos a possibilidade de uma vida sem o casamento; e ii) o fato de o amor/romance (com a decorrente intimidade afetiva e sexual) dever ser construído no interior do casamento e não antes dele. 0 amor, a paixão e a atração erótica seriam vistos como empecilhos para uma boa escolha dos cônjuges, como lascívia que turva a visão do que realmente importa, isto é, o dharma (duty, conforme Uberoi, 2006). O compromisso com a família e com a comunidade seria portanto de obedecer os pais, detentores da prerrogativa de escolher os cônjuges, pois saberiam levar em conta na escolha os aspectos que definem um casamento bemsucedido: a endogamia de casta; a exogamia de gotra; combinações astrológicas dos possíveis pares - com o objetivo de assegurar uma união auspiciosa -; aparência física 
compatível entre noivo e noiva - requisitos como cor da pele, altura e "compleição física" -; idades apropriadas - sendo a noiva idealmente cerca de três anos mais nova que o noivo -, mesmo nível socioeconômico, formação educacional nos moldes escolhidos pelas famílias e trabalho e renda compatíveis com o desejo e a realidade das famílias. Esses últimos requisitos de ordem educacional, econômica e de status são comumente chamados nos anúncios de jornais, nas agências de casamento e por meus interlocutores de background.

Quanto ao modo como é visto o amor na Índia, no exame da literatura antropológica pertinente, deparei-me com uma diferenciação entre as noções de amor construídas no Sul Asiático e no mundo euro-americano. Do lado ocidental, tem-se a conformação de um complexo ideológico de amor romântico, que é tido como o prelúdio suficiente e necessário para a união matrimonial. A partir de um dado momento da história ocidental, o romantismo teria se estabelecido como uma ideologia que orienta estratégias matrimoniais. 0 amor romântico seria o elemento que legitima os casamentos, não mais feitos como alianças políticas e econômicas, mas como uniões amorosas. Essas sociedades teriam construído uma ligação entre o amor e o casamento em que o amor seria um sistema de conhecimento a estruturar o modo de fazer os casamentos, ideia que aproveito de Alfred Gell. 0 amor romântico, entendido como um complexo ideológico, ligaria dois indivíduos únicos e especiais de modo aparentemente arbitrário e permitiria o casamento entre eles. De maneira contrastante, no subcontinente indiano, o amor, seja como um sentimento ligado ao amor erótico ou à emoções românticas, não constituiria o mesmo sistema de conhecimento e seria uma noção "extraestrutural", ainda segundo Gell, que não é levada em conta no modo de se fazer casamentos.

Indico tal distinção teórico-conceitual para dizer que trato do amor romântico, portanto, não como um sentimento ou emoção específica - dado que sentimentos e emoções românticas e eróticas são mais difundidas em diferentes épocas e lugares do que se costuma imaginar -, mas como uma ficção que se transformou, ao longo do tempo, em elemento suficiente e necessário para o casamento no mundo euroamericano. Reitero o entendimento antropológico de que características como atração erótica, afeto, ciúme, medo da perda e ansiedade na separação, dentre outros, estão presentes em culturas não-ocidentais. No entanto, tais características não seriam suficientes para afirmar que o amor romântico, ideal que também contém essas 
características, esteja presente em todos os casos. A particularidade do amor romântico residiria no modo como duas pessoas, de maneira supostamente arbitrária, eleger-seiam mutuamente como cônjuges. Conta para uma tal noção de amor como aquilo que legitima os casamentos a valorização de cada sujeito como um indivíduo único e insubstituível, noção proeminentemente desenvolvida em contextos individualistas, de onde se conclui que, em contextos holistas, o amor romântico não necessariamente constituiria o modo de fazer casamentos, ao menos legítima e normativamente, por representar um tipo de união matrimonial que privilegia a vontade e a escolha de indivíduos em detrimento das relações familiares e comunitárias.

Resulta da assunção, de que o amor romântico não legitima os casamentos na Índia, que a tese seja permeada pela noção de segredo como uma ferramenta que permitia os já mencionados experimentos existenciais. Ao manter em segredo seus relacionamentos amorosos e suas experiências sexuais, cada um desses interlocutores criava tempo e espaço para serem indivíduos em relação a outro indivíduo, o par romântico, sem a mediação, o cerceamento e o controle dos pais, da família e da moralidade pública. Esta forma de individuação era posta em evidência quando os segredos me eram narrados, pois na manutenção do segredo criava-se uma distância e uma especificidade da relação dual, entre o par amoroso, em detrimento das demais relações de ordem familiar e comunitária. Nesse movimento, uma diferenciação entre os sexos acontecia e me era anunciada no modo como rapazes e moças valorizavam de maneiras diferentes o romance e os relacionamentos pré-conjugais. Essa diferença se constituía também em diferenças nos modos de individuação levados a cabo por ambos os sexos.

Contrariando a afirmação de que ninguém espera que paixões levem do namoro ao casamento, feita por Patricia Uberoi sobre os casamentos na Índia, algumas de minhas amigas e amigos realmente alentavam essa expectativa. Faziam isso dando vazão a um sentimento que denominavam em inglês como love. A língua inglesa, aliás, era habilmente dominada pelos interlocutores e muitas conversas anotadas no diário de campo eletrônico foram mantidas nesse idioma no presente texto. Embora tenha estudado hindi por sete meses numa escola, não conseguiria manter as conversações, no nível em que se deram, nessa língua, o que não constituiu impeditivo para a pesquisa, já que o manejo do inglês, e até o uso de gírias norte-americanas, faziam parte de um 
repertório, discursivo e prático, que meus amigos acionavam para viver e demonstrar a modernidade, que consideravam como algo positivo.

Na nomenclatura aqui adotada para se referir às pessoas que aparecem na tese, termos como rapazes, garotos, meninos e guys são acionados para falar de indivíduos jovens do gênero masculino e as palavras moças, garotas, meninas e girls são acionadas ao me referir a jovens do gênero feminino. Essa terminologia diz respeito ao fato de que tais pessoas atravessam, no presente período de suas vidas, como já dito, uma fase liminar, pois se, seguramente, já não são mais crianças, ainda não são, contudo, consideradas adultas. Os mais velhos se referiam a elas e a eles com termos como beta/betee (filho/filha); larka/larkee (garoto/garota), em hindi, e girl e boy/guy, em inglês, de acordo com o gênero presumido de cada pessoa. Entre os próprios jovens, os termos girls e gals ou boys e guys eram utilizados para se referir aos diferentes gêneros. Nenhuma ou nenhum deles referiam-se a si mesmos como a woman ou a man, o que me levou a traduzir os termos usados em hindi e em inglês por garotos/garotas, meninos/meninas e moças/rapazes, em português.

Utilizo, em diferentes momentos do texto, os termos amigos/amigas para me referir a meus interlocutores, ou melhor, às pessoas que por onze meses me acolheram, dispensaram-me cuidados, fizeram-me rir, ensinaram-me e até me irritaram, não necessariamente nessa mesma ordem. Algumas dessas pessoas seriam, por mim consideradas, amigas em qualquer contexto e em qualquer lugar do mundo que as encontrasse. Com outras, afinidades foram construídas por meio da interação que a pesquisa exigia. Não faço, contudo, distinção entre elas na nomenclatura utilizada aqui, pois tenho em mente uma máxima que há muito me acompanha no tema da amizade: philotes isotes. Uma tradução aproximada para a expressão grega aprendida numa aula de filosofia seria amigos são iguais ou a amizade acontece entre iguais. No contexto da pesquisa, o tipo de acesso que me foi permitido era seguramente o que uma amiga, ou uma pessoa em pé de igualdade, teria. Numa sociedade hierarquizada como a indiana, fui primeiro considerada uma amiga pelas pessoas que aparecem aqui e elas me permitiram viver em suas companhias partilhando refeições, quartos, cabines de trens, quartos de hotéis, mesas de restaurantes e bares, alegrias, tensões e tristezas à maneira própria de amizades. 
Diferentes autores referem como, em contextos de classes médias e altas, caso do trabalho de campo que empreendi, o acesso do pesquisador pode ser consideravelmente distinto daquele entre classes populares. Shaline Grover, autora indiana que fez trabalho de campo em bairros populares de Délhi, afirma que "in contrast to middle class colonies where people are hesitant to offer accounts of their lives, most people in my field site conversed about marriage and love with surprising ease and frankness" (Grover, 2011: 17). Minna Saavala, que desenvolveu sua pesquisa sobre valores morais nas classes médias em Hyderabad, sul da Índia, ao mapear seu campo, aponta o quanto estudos sobre a vida cotidiana das classes médias são escassos no caso indiano:

"The reason why such accounts of the social realities of the Indian new middle classes have thus far been rare is partly based on the difficulty of studying this group. People who consider themselves middle class are in the throes of constant, even fierce struggle over prestige and propriety, and they are very reluctant to give any outsider access behind the scenes of their life project. The need to keep up appearances is pronounced and interviews and surveys are not very fruitful means of deconstructing commonplace cultural narratives and repetitions of the self-evident." (Saavala, 2010: 2-3)

No caso brasileiro, Piscitelli fez notar algumas dificuldades que encontrou ao trabalhar com famílias de camadas altas em sua pesquisa de mestrado:

"Minha experiência em Serro Verde foi oposta, provavelmente, a da que vivem os antropólogos que trabalham com pobres ou com pessoas marginais, num sentido ou noutro, à sociedade. Penso ter sido vista, pelas pessoas com quem trabalhei, como uma estrangeira pobre, que pretendia imiscuir-me em suas vidas, apoiada no duvidoso encanto de uma curiosidade cientificamente legitimada. De meu ponto de vista eles eram os outros. Mas uns outros altivos que pareciam imaginar-se como integrantes de um universo culto, rico e poderoso." (Piscitelli, 1990: 35-36)

A autora refere ainda que dentre as camadas médias era tida como uma igual e que, assim, algumas pessoas lhe ofereceram "o calor de algumas amizades" (Idem: 40) durante a pesquisa. Esse foi precisamente o meu caso: mesmo estando entre jovens cujas famílias são de castas consideradas superiores e financeiramente abastadas desde muitas gerações anteriores, fui desde o princípio tida como uma igual. Provavelmente por ser, dentre outras características, estrangeira, branca, estudante de doutorado e de classe média, embora longe de ser abastada fui, contudo, acolhida como amiga. 
Por fim, antecipo ao leitor a noção de paisagem moral, que tomo emprestada de Yunxiang Yan, como um instrumento que me permitiu pensar as transformações e as continuidades na moralidade pública hegemônica em Délhi sem pensá-la como condicionante ou determinante das vidas das pessoas com quem convivi. Ao contrário disso, penso que as pessoas que aparecem nessa tese estavam interagindo constantemente na paisagem moral em que viviam e eram tanto afetadas quanto afetavam essa paisagem. Nesse movimento, compunham, na interação com outras pessoas, diferentes paisagens morais dentro de uma mesma cidade, em que códigos de vestimenta, alimentação, socialidade, comportamento e linguagem variavam de paisagem para paisagem.

Passo a apresentar os capítulos e as principais noções, histórias e ideias de que trata cada um deles. No capítulo I, trago reflexões sobre o trabalho de campo, as condições de entrada nele, a constituição do objeto de pesquisa e as negociações sobre a pesquisa com os interlocutores. O trabalho de campo etnográfico se deu em um pensionato na cidade de Nova Délhi, onde morei por um período total de onze meses em diferentes temporadas e onde residem cerca de trinta jovens de ambos os sexos, pertencentes à classe média alta e de castas tidas como superiores que, por residirem numa grande metrópole, longe da vigilância familiar e das comunidades de origem, contavam com a mobilidade e o anonimato urbanos como aliados no desenvolvimento de suas experiências existenciais relacionadas ao romance e à sexualidade das quais trata a tese.

O capítulo II demonstra como o pensionato onde o trabalho de campo se deu constitui um feixe de índices do ambiente urbano das camadas médias e altas no norte da Índia de modo geral, permitindo afirmar que o que se passava na vida dos jovens que vivem nesse pensionato faz parte da vida urbana da Índia contemporânea e não constitui exceção à ela. Isso equivale a dizer que o que foi vivenciado na companhia de jovens em um pensionato na capital do país pode ser relacionado às tendências de transformação na moralidade, na sexualidade, nos afetos e no modo de se fazer casamentos em outras grandes cidades indianas. Exploro ainda os temas da privacidade, intimidade, vontade/volição que remetem à chave indivíduo e sociedade num momento de liminaridade desses jovens e, portanto, de formação da pessoa. 
O capítulo III visa desenvolver uma discussão bibliográfica da noção de amor no contexto sul-asiático e apresentar histórias de momentos que vivi com os interlocutores ou que me foram relatadas para demonstrar como tais noções se aproximam e se afastam das vivências dos jovens hoje em dia. Busco contrastar as noções de amor estabelecidas pela teoria sociológica/antropológica naquele país e as noções etnográficas que encontrei: nessa assunção, basicamente, o amor é aquilo que esses jovens nomeiam como tal. Vários deles me apresentaram suas teorias sobre o tema que serão exploradas como teorias sobre o amor. Os casos etnográficos mostram como o fim último do romance seria o casamento; quando esse não ocorre, as categorias de "failed love" e "failed romance" aparecem.

No capítulo IV, indago por que o amor constituiria indivíduos na Índia. Por transformar relações puramente, ou ao menos predominantemente, sociais/coletivas, isto é, os casamentos, em relações pessoais duais. Isso é feito mobilizando e manipulando as noções de arranged marriage e love marriage. A ideia da escolha do parceiro ou da parceira no casamento é central nessa formulação, pois meus interlocutores viviam experimentos existenciais por meio do namoro/romance e da idealização do encontro amoroso na direção da individuação. 0 capítulo persegue as diferenças apresentadas em campo entre os gêneros na valorização do amor e na individuação alcançada por meio dele: se os processos de individuação estão fomentando um novo modo de constituição da pessoa estar-se-ia, ao mesmo tempo, transplantando antigas distinções de gênero nesse processo.

No capítulo final da tese retomo a ideia de que o amor representa, na vida daqueles interlocutores, o anseio e a possibilidade de ser único, especial e insubstituível e de que, não obstante isso, sua nobre finalidade é o casamento. Esse capítulo apresenta a trajetória pessoal de uma das principais personagens da tese, a jovem Shubhi, cujo casamento se deu em janeiro de 2015. Trata-se de um caso bem-sucedido de um matrimônio que foi chamado de love marriage, mas que manteve, ao mesmo tempo, as famílias dos nubentes satisfeitas. A intenção é explorar o modo como o amor constitui um novo requisito para o casamento, mas não o único, nem mesmo o mais importante, ingrediente dos matchmakings. 


\section{Capítulo I}

\section{Primeiro as coisas primeiras}

\section{De como o trabalho de campo se deu}

A história desta tese se inicia no ano de 2009, quando estive por dois meses na Índia, deslocando-me entre diferentes cidades do norte ao sul do país. Dessa experiência resultou a escrita de minha dissertação de mestrado intitulada "Comida, pessoas e deuses: etnografia de eventos alimentares na Índia". Embora versando sobre o tema da comida como um sistema simbólico, já mencionava naquele trabalho a importância do casamento arranjado como instituição social e o quanto o assunto havia sido tema recorrente de minhas conversas com as pessoas que conhecera então (Gomes, 2010).

Em 2012, cursando o doutorado, regressei àquele país, desta feita com destino exclusivo à Nova Délhi, objetivando iniciar uma pesquisa cujo objeto seria o sistema de casamentos arranjados na capital indiana, mais especificamente os arranjos (matchmakings), os quais têm se dado, além do modo convencional, isto é, pelas redes de contato das famílias, também por anúncios em jornais, sites de matrimônio e agências de casamento (marriage bureaus). Esses últimos eram o local onde eu tencionava desenvolver o trabalho de campo.

As visitas a três diferentes marriage bureaus me fizeram, contudo, abandonar a ideia original, pois não me foi permitido acompanhar o trabalho dessas agências, nem verificar os arquivos dos clientes, chamados de perfis (profiles), nos quais constam as informações de cada candidato ao matrimônio e a inscrição classificatória estabelecida pelos envolvidos sob a forma de características atribuídas a ambas as pessoas (rapaz e moça) que comporiam o casal. Essas características dizem respeito a atribuições (físicas, socioeconômicas e de personalidade) desejadas para a noiva ou noivo e descritivas de quem preenche o perfil, isto é, de quem se oferece como noivo ou noiva.

Mesmo com cartas de apresentação da coordenação do Departamento de Antropologia/UnB e da professora Janaki Abraham do Sociology Department da Delhi 
University, os gerentes e/ou donos das agências não me quiseram perto por muito tempo. Inicialmente muito gentis e receptivos, eles logo começaram a me evitar e a negar, terminantemente, acesso aos arquivos, alegando a sua confidencialidade. Por mais que eu tentasse explicar a natureza do trabalho etnográfico, esses profissionais entendiam como trabalho de campo algumas entrevistas que eu deveria fazer para, em seguida, desaparecer da vida deles. Após os contatos iniciais, as entrevistas passaram a ser remarcadas - alegava-se a falta de tempo para me receber -, de modo que, em duas das agências, sequer consegui entrevistar alguém. A Dra. Janaki Abraham havia me adiantado e previsto essas dificuldades, uma vez que ela mesma fizera trabalho de campo em agências desse tipo no sul do país quando de sua pesquisa de doutoramento. ${ }^{1}$

Meu olhar foi paulatinamente sendo voltado, então, para os problemas existenciais e teóricos que me apresentavam, concomitantemente, a convivência com vários jovens moradores de Nova Délhi e a literatura acadêmica indiana sobre casamento, amor, romance e sexualidade na Índia. Ao ser introduzida às histórias de alguns desses jovens, passei a vislumbrar algo inusitado: o fato de que, fiando-me na literatura até então pesquisada, julgava serem inexistentes os namoros e romances préconjugais, algo que, como mostraram meus interlocutores, não é acurado afirmar sobre a paisagem moral urbana na Índia.

A ideia de paisagem moral, cunhada por Yan, parece-me bastante apropriada para pensar as mudanças correntes na moralidade e nos afetos na Índia. Investigando as transformações na moralidade em cidades chinesas, o autor afirma:

"In nature, growing plants, blossoming flowers, flowing creeks, and floating clouds animate the earth and the sky. In a similar vein, the new ideas, ideals, and actions of individuals and the constant negotiations about their appropriateness bring life to the norms, values, and behavioral patterns in a society: this is the moral landscape. The regeneration of life bestows the unbounded beauty of nature; the remaking of the person - the moral person makes the moral landscape into a limitless space of public reflection and intelectual exploration." (Yan, 2011: 36).

Antes de chegar a esse ponto, no entanto, teço algumas considerações sobre o trabalho de campo, porque até aqui falei do trabalho de campo que poderia ter sido e não foi. Passo a falar do trabalho que de fato empreendi, pois acredito que o modo como ele se desenvolveu informa também a construção do objeto de pesquisa.

\footnotetext{
${ }^{1}$ A tese de Abraham foi defendida na Delhi University em 2007, sob o título "Gender, Status and Class: A Sociological Study of the Thiyyas".
} 
O primeiro período de campo teve lugar nos meses de fevereiro e março de 2012, ocasião em que parte da bibliografia foi coletada e em que desenvolvi contatos e relações que me permitiram realizar o presente trabalho. Fui recebida na Delhi University pela professora Janaki Abraham, que juntamente com Janaki Nair (da Jawaharlal Nehru University - JNU), a quem conheci em 2009, indicaram-me a ponta do novelo que fui desenrolando na pesquisa bibliográfica para os estudos dirigidos: além de textos clássicos, foi-me apresentado material bibliográfico bastante recente por ambas e a partir deles fui expandindo as buscas. Também passei a integrar, nesses dois meses, o grupo de moradores do MD International Inn, uma espécie de pensionato na região de South Delhi, onde passei a conviver com as pessoas, rapazes e moças indianas, que constituem os meus interlocutores. MD International Inn era o nome de outrora quando funcionava como um hotel e que ainda aparece nos cartões de visita do estabelecimento. Os moradores e o proprietário costumam chamar o lugar de PG, abreviatura de paying guest, nome dado aos moradores que pagam o aluguel para viver na casa.

Mais duas incursões em campo ocorreram em 2013 e 2014, por intervalos de quatro meses, e um último curto, porém profícuo, período de campo se deu em janeiro de 2015, com a duração de três semanas. Em 2013, permaneci no país entre os meses de março e julho, quando o verão alcançou as temperaturas mais quentes do ano, chegando a 45 graus na capital. Em 2014, o campo foi realizado entre o final de janeiro e o final de maio. Nesse período, fui beneficiária de uma bolsa CAPES pelo Programa de Estágio de Doutoramento Sanduíche no Exterior (PDSE), tendo sido coorientada pela professora Janaki Abraham. Desse modo, ao todo foram quase 11 meses vividos naquele estabelecimento em Nova Délhi, que também é a casa de mister Kapoor, o qual logo será apresentado, mais dois meses de socialização na Índia levados a cabo em 2009, somando, portando, 13 meses de intenso aprendizado das cores, sabores, aromas, línguas (inglês e hindi), sotaques, gestos e afetos da Incredible India, para usar uma expressão cunhada pelo governo indiano na indústria do turismo.

A cada uma das vezes que retornei à Délhi, encontrei novos desafios e pessoas diferentes residindo no pensionato onde o trabalho de campo foi desenvolvido. Havia também, contudo, uma espécie de reconhecimento de que eu aprendera algo a mais desde a última vez que aportara ao país. Tomar táxis na chegada; conversar com motoristas, funcionários da casa e pessoas nas ruas; portar-me em templos e lugares públicos; vestir-me apropriadamente para cada ocasião; saber lidar com a burocracia 
em várias instâncias ou tratar professores, mestres, sacerdotes e pessoas mais velhas com a devida reverência, por exemplo, tornavam-se atividades cada vez menos complicadas. Os amigos que fiz a cada uma dessas estadas - e que continuaram em contato, mesmo quando me encontrava no Brasil, por meio de telefonemas e redes sociais - convenciam-me de que eu estava no caminho certo; de que eu conseguia, enfim, entender um pouco mais de tudo que se passava, não só à minha volta e com as pessoas com quem convivi, mas dentro de mim mesma, numa espécie de embodiment da experiência etnográfica que aqueles deslocamentos no tempo e no espaço me permitiram. Sim, pois chegar à Índia e chegar ao Brasil por quatro anos consecutivos não se tratava apenas de efetuar um deslocamento no espaço, mas no tempo - o que me fazia sentir drasticamente a mudança dos quase quarenta graus de Brasília para os oito de Délhi no mês de janeiro ou a passagem do clima de monção em Délhi para a seca de Brasília em julho.

Para além da mudança nas estações e das oito horas e meia de variação no fuso horário, confundiam minha mente e meu corpo os ritmos díspares nas duas capitais. 0 tempo próprio para a vida acontecer em cada uma delas varia muito. Diferentemente de Brasília, Délhi demora até o meio da manhã para acordar de fato, os mercados abrem as nove ou dez horas. 0 movimento deles é precedido por varredores limpando a poeira e as folhas secas das ruas com pequenas vassouras que mais parecem espanadores de pó, o que os faz curvarem-se até o chão para executar sua tarefa. Nesse ínterim, trabalhadores e estudantes em distintos tipos de transportes - metrôs, ônibus, carros, auto-rickshaws, cycle-rickshaws, motocicletas e bicicletas - percorrem as vias públicas para chegar ao trabalho, às escolas e às universidades. 0 almoço e o jantar ocorrem, respectivamente, por volta das duas da tarde e das nove da noite. 0 horário preferencial para os banhos é pela manhã, antes de qualquer outra atividade - já que os que performam poojas (adoração aos deuses) devem estar limpos para fazê-lo. 0 comércio fecha por volta das nove ou dez da noite. Após esse horário, tanto eu quanto qualquer das outras moradoras não nos sentíamos à vontade para cruzar o portão de entrada e ir comprar nem mesmo água do outro lado da rua desacompanhadas. Os mercados têm dias distintos para a folga semanal: o Aurobindo Market, que se encontra bem em frente à PG, fecha às terças-feiras, o Hauz Khas Market, às quintas, em Green Park Main Market as portas estão cerradas nas quartas-feiras. Aos domingos, todos eles se encontram funcionando a pleno vapor, contrastando enormemente com a ideia cristã ocidental de 
guardar o domingo para o descanso. Assim era que a constatação de que o tempo é construído relacionalmente me golpeava sempre que retornava à Índia ou ao Brasil.

Foi apenas na terceira vez que estive no país, em 2013, que comecei a intuir que o tempo das relações e dos afetos também era diferente em relação ao meu ambiente de socialização no Brasil. Provavelmente isso se deve à percepção das transformações nas próprias relações que eu entabulava com meus amigos e com colegas da Delhi University ao longo dos consecutivos períodos de campo. Ao mesmo tempo, passei a notar que as relações deles com amigos, namorados e esposos também têm um tempo distinto para que coisas como telefonemas, encontros, intimidade sexual e o amor acontecessem se comparados aos tempos dessas relações no Brasil (esses tempos serão explorados nos capítulos seguintes). ${ }^{2}$

Fazer o trabalho de campo de modo seriado parece ter sido o que possibilitou o acompanhamento do desenvolvimento das relações amorosas de meus amigos e a consolidação de minhas próprias relações com eles; eu voltava a cada ano para dar continuidade ao estabelecimento de afetos e confiança mútuos. Se não fosse assim, Shubhi, que tem uma participação fundamental nesta pesquisa, não teria tido tempo de se apaixonar por um de nossos inmates em 2012, romper o relacionamento com ele no ano seguinte, arranjar um noivo, apaixonar-se por ele e se casar em janeiro de 2015. Nossa amizade, tampouco, teria sido engendrada de modo que ela me confiasse detalhes de sua vida íntima, mesmo quando não os confidenciava a amigos mais antigos, ou me considerasse uma de suas maid of honor (madrinha de casamento). A expressão aqui não é acurada, uma vez que nos casamentos hindus a figura das madrinhas e padrinhos não existe, mas ela assim se expressou quando me convidou para ficar hospedada junto a ela no hotel onde aconteceram os diversos momentos rituais que precedem e se estendem até depois do casamento, com uma duração total de quatro dias.

\footnotetext{
${ }^{2}$ Esse trabalho não tem pretensão de empreender uma comparação entre os relacionamentos afetivos no Brasil e na Índia. O que faço aqui é tão somente reconhecer o ponto de partida da pesquisadora, isto é, apenas admito que meus parâmetros iniciais para a percepção que tinha da temporalidade dos afetos na Índia eram calcados na socialização no contexto brasileiro, em que vivi desde sempre até a experiência da vivência em Nova Délhi. Ao mesmo tempo, não se trata de impor uma categoria nativa brasileira para os relacionamentos na Índia. O tempo certo para cada passo (any move) nas relações que me foram apresentadas era referido por meus interlocutores, bem como quem deveria dar o próximo passo - um telefonema, adicionar o outro no Facebook, enviar um torpedo no WhatsApp, expressar interesse num perfil no site de matrimônios etc. - na interação, se o rapaz ou a moça. Penso em Strathern, quando essa reflete sobre a comparação em antropologia: "O que se torna objetável em grande parte das análises comparativas é o descentramento da correlação inicial, como se ela de alguma forma se situasse entre ou através de várias sociedades e não fosse gerada inicialmente por uma delas." (Strathern, 2006: 85). Ou seja, é preciso sempre reconhecer o ponto de partida.
} 
Competiram para a troca de afetos e comunicação, ademais, a curiosa sensação que meus amigos narravam de que poderiam dizer-me o que fosse sem que eu os julgasse moralmente, algo que, segundo eles, sempre acontece com os amigos indianos, os quais, por via de regra, farão algum tipo de censura ou julgamento quando o assunto é namoro e sexualidade. "You are not judgemental", diziam eles a meu respeito. Vim a saber com o tempo que isso se devia também ao imaginário que têm do Brasil e do ocidente de modo mais amplo: "people are more liberal there" ou "the mindset is broader outside India".

Aos poucos os estranhamentos que senti desde 2009, começando pelos ardentes e inusitados sabores e aromas da comida indiana até as dificuldades com o inglês indiano e com o hindi, foram se dissipando e dando lugar a um reconhecimento das cidades indianas como lugares nos quais eu já sabia me portar, locomover-me, comunicar-me, defender-me, divertir-me, enfim, viver. Foi só então, pela terceira estada no país, que pude ter calma e serenidade para perceber outros estranhamentos menos óbvios que aquele da boca ardendo com a comida e a cabeça doendo ao final do dia pelo esforço de compreender e me fazer entender em inglês e num arremedo de hindiª . Daí em diante, o principal estranhamento dizia respeito ao que comecei a sentir e nomear como uma ausência de privacidade, como se, à medida que fui me tornando realmente parte daquela comunidade em modelo reduzido, como gosto de pensar na PG, passasse a ser submetida ao que os demais membros eram submetidos. A principal marca disso passou a ser o modo como minha vida, meus passos diários, minha relação com o marido que ficara no Brasil, meus hábitos mais íntimos, passaram a ser devassados, presenciados e até controlados, em alguma medida, por aquelas pessoas, o que ficará claro mais adiante.

Apenas após frequentar regularmente a escola Hindi Guru Language Institute, em 2013 e 2014, pude falar e trocar afetos com pessoas da casa que não se comunicam em inglês. 0 aprendizado dos afetos, aliás, foi a maior conquista desses períodos consecutivos. Sentir-me querida e querer bem a cada um dos sujeitos que aparecerão aqui foi o que possibilitou não só o desenvolvimento da pesquisa, mas,

\footnotetext{
${ }^{3}$ Utilizo a noção de estranhamento no sentido empregado por Peirano (2014): “Tudo que nos surpreende, que nos intriga, tudo que estranhamos nos leva a refletir e a imediatamente nos conectar com outras situações semelhantes que conhecemos ou vivemos (ou mesmo opostas), e a nos alertar para o fato de que muitas vezes 'a vida repete a teoria'." (Peirano, 2014: 378).
} 
fundamentalmente, o despertar de uma experiência existencial que, como diz Soledad, amiga e colega de profissão, trata-se de uma dádiva: poder viver em dois mundos. ${ }^{4}$

Explico: o que se passou com a pesquisadora nesses onze meses de vivência entre amigas, amigos, mestres (acadêmicos e de yoga) e professores (de sociologia/antropologia e de hindi) é que comecei a conseguir viver em Délhi quase como que em um segundo lar, de tal modo que, de volta ao Brasil, logo nas primeiras semanas, penoso era-me viver em Brasília falando com meus vizinhos (inmates) e amigos indianos somente pelos programas WhatsApp e Skype. Igualmente difícil era não responder, inconscientemente, sorry a qualquer um na rua; não ter mais as revigorantes sessões de ashtanga yoga, com Seema Sondhi, a duas quadras de casa; não sentir nunca, em canto algum, o cheiro de curry a borbulhar de uma grande panela; não contar com a mobilidade possibilitada pelo bom serviço de metrô de Délhi, bem como pelos cycle e auto-rickshaws - o que me faz sentir como uma planta enraizada ao solo por não saber dirigir numa cidade como Brasília -; não ter Mitlesh, o cozinheiro, saudando-me pela manhã com um sorridente namaste seguido da pergunta: “-Aap kaise hain?-" [Como você está?]; não poder andar com meu celular na mão em todos os lugares sem temer têlo roubado e, finalmente; não ouvir o delicado som da sineta das bicicletas e cyclerickshaws nas ruas abarrotadas de sáris e echarpes coloridas. ${ }^{5}$

Com o tempo, ir e vir ficavam, respectivamente, mais fácil e mais penoso. Não que eu não sentisse, chegando a Délhi, a falta da facilidade de tomar um bom café, café preto, como dizemos no Brasil, sem qualquer traço de leite ou excesso de água e açúcar; de pagar "barato" por uma cerveja e saboreá-la da calçada de um bar ou num evento ao ar

\footnotetext{
${ }^{4}$ Maria Soledad Marocca de Castro é doutora em antropologia social pelo PPGAS/DAN/UNB. Por ocasião de minha visita a sua casa em Nova Iorque, em julho de 2014, conversávamos sobre os estranhamentos que ela sentia quando voltava ao Brasil que a faziam perceber o quanto já estava imersa na vida Nova Iorquina e, porquanto, vivendo em dois mundos. Comentei que sentia o mesmo quando voltava da Índia para o Brasil. Esse diálogo me inspirou a apreender, num nível existencial, o conceito teórico de Tambiah sobre os "diferentes ordenamentos da realidade", cujo texto eu havia lido logo após o regresso do campo, em 2014, por sugestão de outra colega antropóloga, Stella Paterniani.

${ }^{5}$ Em minha primeira experiência como etnógrafa, durante as Cavalhadas na cidade de Pirenópolis, por três anos seguidos o som dos guizos pendurados aos cavalos nos dias de festa eram para mim como o doce em que se lia "coma-me" na história de Alice. Algo que, se não me transportava para outro mundo, fazia-me sentir, definitivamente, que já me encontrava numa realidade mais encantada que a de meus dias ordinários. No segundo período que passei em Délhi, em 2013, na segunda manhã como colega de quarto de Rekha, acordei com o som mágico da sineta de uma bicicleta, usada como uma espécie de buzina. Sorri e senti que aquele era o som transcendental do meu campo em Délhi, as ondas sonoras que materializavam para mim o fato de estar vivendo numa das maiores metrópoles da Ásia. Talvez soe curioso ao leitor que minha mente tenha escolhido o diminuto som de sinetas de bicicleta em meio a todo o rebuliço de buzinas de carros, ônibus e caminhões, sempre lembrado quando se trata de caracterizar o ruído das cidades indianas, onde ler os dizeres "horn please" na traseira dos veículos é assustadoramente comum. Ocorre, por certo, que não se pode prever de que modo o campo se inscreverá em nós.
} 
livre ${ }^{6}$; de poder abraçar fortemente um amigo na rua quando me encontro, inadvertidamente, com um e beijá-lo na face, algo impensável para a etiqueta corporal indiana, que evita o toque; de cruzar uma avenida sem me preocupar com a mão inglesa, que inverte o fluxo dos veículos e o lado do volante nos carros. Ainda assim, para desespero de meus entes brasileiros - e de minha orientadora que se exasperava ao ver que eu ainda não aterrissara definitivamente no Brasil para escrever a tese -, eu sentia mais dificuldade de me readequar aqui do que lá. Gosto de pensar que isso acontecia por ter empreendido um trabalho etnográfico, no qual, como afirma Peirano, "a etnografia abala nossos estilos de vida e nossas ideias de existência; abala nossa crença moderna na referencialidade dos sentidos e impõe uma reflexão sobre a multiplicidade de modos de vida" (Peirano, 2014: 385). Gosto de pensar também que era mais fácil chegar à Índia do que voltar ao Brasil porque me transformei nos últimos anos, desde a graduação até o doutorado, numa etnógrafa, e como "etnógrafos fomos/somos ávidos em conhecer o mundo em que vivemos, nunca nos conformamos com predefinições, estamos sempre dispostos a nos expor ao imprevisível, a questionar certezas e verdades estabelecidas e a nos vulnerar por novas surpresas" (Idem: 389).

Apresento as reflexões sobre o trabalho de campo inspirada também por Goldman (2003), por sua vez inspirado em Favret-Saada, pois considero a orientação de ambos válida para meu próprio trabalho em Nova Délhi. Diria que ser afectada pela temporalidade, pela moralidade e pelos afetos na Índia teve papel decisivo nessa pesquisa. A afecção não se trata, como ambos afirmam, de tentar promover uma empatia com os interlocutores da pesquisa, ou uma identificação total da pesquisadora com os pesquisados, nem de pensar que o "tornar-se nativo" seja, de fato, uma possibilidade, mas de: "ser afetado pelas mesmas forças que afetam o nativo, não de pôr-se em seu lugar (...). Não se trata, portanto, da apreensão emocional ou cognitiva dos afetos dos outros, mas de ser afetado por algo que os afeta e assim poder estabelecer com eles uma certa modalidade de relação, concedendo 'um estatuto epistemológico a essas situações de comunicação involuntária e não intencional'." (Goldman, 2003: 465).

\footnotetext{
${ }^{6}$ A cerveja, mesmo em Brasília, é mais barata que em Délhi. As bebidas alcoólicas são fortemente taxadas na Índia e nem todos os estabelecimentos têm licença para vendê-las. Também não é possível encontra-las em supermercados ou mercearias, apenas em liquor shops, que são frequentadas, quase que exclusivamente, por homens e têm grades de ferro nas portas. O consumo alcoólico em espaços públicos também é proibido por lei, bem como qualquer outra substância psicoativa que não seja prescrita por médicos. Mesmo o uso religioso de maconha não deve ser realizado em vias públicas, embora todos tomem bhang, bebida a base dessa planta, em festivais hindus como o Holi e o Shivaratri. A polícia também fará "vista grossa" ao ver um Sadhu, homem santo, tragando seus enormes cachimbos de marijuana e haxixe em cidades sagradas, templos e locais de peregrinação hindu.
} 
Embora eu não estivesse na Índia para me casar, como estão os meus amigos, ao menos na intenção de suas famílias, estava igualmente submetida à moralidade que envolve os casamentos, o romance, a sexualidade e as relações de gênero. Em 2009, ao chegar a Mumbai, senti todo o peso de ser uma mulher trajando roupas ocidentais na Índia; nunca em minha vida até ali, aos 29 anos de idade, havia sentido olhares tão perturbadores. Vi-me, até que aprendesse a me vestir adequadamente, inquirida e acusada pelos olhares de homens e mulheres em todos os espaços por onde passava. Algo em mim era inadequado, a começar pelas roupas que - consideradas decentes do lado ocidental do globo terrestre e que, de fato, até a África do Sul haviam passado despercebidas - revelavam a pele dos antebraços ou pronunciavam o desenho do colo, o que ali tem uma leitura que varia entre o pouco usual e o flagrantemente imoral mesmo em espaços urbanos da Índia moderna. Isso se dava porque faz parte da moralidade pública o controle sobre a mulher, expresso também pelas roupas. Cito a reflexão de Abraham:

"While the terms gunghat and purdah are used specifically for the covering of the body, they also imply the effacement of the woman through the veiling of the voice and the eyes - ankhe ka purdah (the purdah of the eyes) and awaz ka purdah (the purdah of the voice), and seclusion more generally. This extends to other ideas of what constitutes the 'modesty' of a girl or woman or in turn the 'honour' of a family or community. Decisions to withdraw a girl from school or from some forms of work outside the house may be informed by these ideas of maintaining 'honour'. These ideas of 'modesty' and 'honour' as I discuss later are a masquerade for the larger complex of veiling that controls a woman's ability to participate equally in political life, limits her ability to claim her right to resources or prevents the exercise of her own volition, especially in matters of sexuality. At the same time, it is important to recognise that girls and women learn how to produce 'respectability' through their use of spaces and clothing, while simultaneously testing the boundaries of this control." (Abraham, 2010: 201)

Tomou-me algum tempo saber produzir a respeitabilidade de que fala Abraham. Em 2014, cinco anos depois da primeira chegada à Índia, quando viajaria com Shubhi de Délhi a Udaipur, combinamos de nos encontrar no corredor do primeiro andar da casa, onde ficavam nossos quartos, para dali ir tomar um auto-rickshaw que nos levaria à estação ferroviária. Shubhi raramente usa roupas chamadas por ela mesma de Indian clothes, preferindo jeans, saias, calças de tecido com blusas e vestidos. Nunca a vira vestir um sári ou salwar kameez até que, para minha surpresa, ela surgiu no corredor trajando uma combinação de churidar e kurta, traje composto por calça e bata longa até 
os joelhos, massivamente usado por mulheres jovens na Índia, o mesmo que eu usava na ocasião. Ao expressar minha surpresa quanto ao fato ela respondeu:

- Look at you! Even you know that traveling by train it is safer and more comfortable to wear Indian clothes!

Esse acontecimento gerou entre nós duas uma interação semelhante ao que Favret-Saada chama de comunicação involuntária, exemplificada no texto de Goldman pelo ouvir dos tambores dos mortos durante um ritual funerário em Ilhéus. Outros momentos que me fizeram sentir que era afetada pela mesma moralidade que minhas amigas e amigos aconteciam quando saía com um dos rapazes da PG sozinha, isto é, sem outras moças nos acompanhando. Almoçar ou tomar um café com Patrick na lanchonete perto de casa equivalia, invariavelmente, a ter olhares inquisidores e repreendedores voltados em nossa direção, isto é, pessoas se demoravam em me medir da cabeça aos pés com o cenho fechado. A ideia acionada pela visão de uma moça estrangeira e um rapaz indiano era de que, possivelmente, algo não sancionado pela moralidade vigente estava acontecendo entre ambos, ou seja, um romance. Para minhas amigas, os olhares se repetiam, bastando que não houvesse qualquer símbolo do casamento, como alianças nos dedos dos pés ou o sindoor (sinal vermelho na fronte que a mulher casada deve carregar), para surtir o mesmo efeito quando saíam sozinhas com um rapaz. Em outro desses momentos, ao atravessar uma rua em Old Delhi, extremamente lotada de pessoas e veículos, tive minha mão segurada por Anindya, que levava a mim e um casal de amigos poloneses para conhecer o interior do mercado Chandni Chowk. Em pouco tempo, ouvi os gritos de um senhor muçulmano vindo em nossa direção. ${ }^{7}$ Minha reação foi de, imediatamente, sentir-me envergonhada e soltar a mão de Anindya. Mesmo sem traduzir instantaneamente suas palavras o fiz com seu olhar e sua voz. O senhor dizia, segundo Anindya, em hindi:

- Tumhe sharma nahin ati? [Aren't you ashamed?]

Ele censurava meu amigo Anindya por estar segurando a mão de uma pessoa do sexo oposto em público. Os olhares, gritos e regras morais que legislam sobre os corpos, e que eram igualmente dirigidos a meus amigos e a mim, forjaram uma comunicação involuntária. Éramos todos, sem dúvida, afetados pela paisagem moral nas menores

\footnotetext{
${ }^{7}$ Adivinhava o pertencimento do senhor em questão à comunidade muçulmana pelas vestes brancas, constituídas de uma calça e uma bata, pela barba longa e por uma touca também branca, essa geralmente usada em momentos de oração.
} 
atividades do dia a dia, desde a manhã quando escolhia o que vestir até o anoitecer quando me recolhia ao meu quarto, nunca saindo à noite sozinha.

Refletindo sobre o ocorrido em Old Delhi na companhia de Anindya, cheguei à conclusão de que na vizinhança de Hauz Khas o fato poderia ter chamado a atenção, mas, provavelmente, não geraria a reação daquele senhor, isto é, o grito que ele nos dirigiu. Fui compreendendo nesses incidentes que a paisagem moral, dentro da mesma cidade, não é sempre a mesma. Diferentemente de Old Delhi, uma cidade medieval construída por Akbar, à época imperador que governava o norte da Índia, Hauz Khas Village é um ambiente frequentado pela juventude das classes médias e da elite de Délhi e por turistas do mundo todo para lazer, alimentação e compras. É um local onde o consumo de álcool, cigarro, carnes - inclusive bovina - e os ambientes de dança e flerte constituem uma espécie de exceção, juntamente com alguns outros pontos da cidade, aos demais espaços públicos dessa metrópole, fazendo surgir paisagens morais dentro de outras paisagens morais.

É pelas paisagens morais, acredito, que reconhecemos quando temos a oportunidade de viver em dois, ou mais, mundos. Soledad e eu, talvez, só tenhamos nos dado conta de que vivíamos em dois mundos pelo treinamento dado pela antropologia. Meus amigos e amigas indianas também vivem em mais de um mundo ao mesmo tempo. Sem formular dessa maneira, elas e eles vivem, concomitantemente, em mais de uma paisagem moral, sem a necessidade de se deslocar de um país a outro, como fazemos, Soledad e eu, quando vamos do Brasil para os Estados Unidos ou do Brasil para a Índia. É também esse o pano de fundo desta tese, o modo como os jovens com quem convivi protagonizam suas vidas engajando-se - no que aproprio para diferentes fins os termos de Tambiah - em múltiplos ordenamentos de realidade (Tambiah, 1990). Minha própria experiência na Índia me ajudou a entender como é possível, difícil, sofrido, complexo e, não obstante, regozijante, poder viver em diferentes mundos ao mesmo tempo, compondo paisagens morais diversas. Algumas pistas de como é viver uma vida entre diferentes paisagens morais aparecerão nos capítulos seguintes.

Passo agora a apresentar o espaço onde convivi com os interlocutores deste trabalho, como se deu a construção do objeto de investigação e de que modo as negociações em torno da participação deles na pesquisa foram se desenhando. 


\section{Uma casa para chamar de lar e amigos para chamar de meus}

Em Délhi pela primeira vez, antes de chegar ao pensionato onde a pesquisa de campo foi desenvolvida, fiz uma estadia de seis dias na casa de uma família muçulmana que alugava quartos para turistas em seu apartamento. Eu havia encontrado a casa de senhor Ali no sítio hostelworld.com, onde o apartamento constava como uma pousada chamada Starry Nights Guesthouse.

As constantes brigas entre o pai e o filho - realizadas em kashimiri, língua da região da Cachemira de onde veio a família nos anos que se seguiram à partição da Índia, evento que deu origem ao Paquistão - e nas quais as mulheres, esposa e nora, mantinham-se absolutamente caladas, iniciaram já na segunda noite em que estive na casa e me afligiam ainda que eu permanecesse em meu quarto. Desse aposento podia ouvir o filho, Muzzafar, e o pai, senhor Ali, esbravejando e dando murros na mesa da sala. Saí dali sem entender o que se passava na casa na qual havia também três crianças pequenas, filhas de Muzzafar e sua bela e amável esposa Aminah, e um funcionário, Obdi, que limpava, cozinhava e lavava as roupas. As crianças entravam em meu quarto a qualquer hora do dia, já que eu deixava a porta aberta, algo que me sugeriu o senhor Ali no primeiro dia: como era sua casa e não uma verdadeira pousada, disse-me para sentir-me como hóspede da família e não como alguém de fora, além do mais, continuou, um dos membros da família poderia precisar usar o banheiro dessa suíte. Claro que isso não estava referido quando fiz a reserva e parte do pagamento pela estadia, por meio do sítio na internet. As crianças faziam deveres escolares em inglês desde tenra idade (a mais nova contava apenas dois anos) e falavam comigo nesse idioma.

A casa ficava na vizinhança de Lajpat Nagar I, bairro residencial com pequenos mercados em algumas ruas e um famoso e grande mercado central, ao qual voltei nos anos seguintes, acompanhada de amigas, para fazer compras. 0 que não havia no local, e de que eu sentia falta, eram cyber cafés onde eu conseguisse acesso à internet e telefones públicos para fazer ligações enquanto ainda não providenciava um chip local para meu aparelho de celular. 0 preço desse quarto sairia, por mês, em torno de $\mathrm{R} \$ 700,00$ (setecentos reais), valor que eu considerava bastante alto. Havia feito a escolha do local pela vizinhança. Quando pedi indicações à Professora Janaki Nair, ela me disse que dentre as opções que eu havia pesquisado aquela era a mais interessante: próxima da JNU (Jawaharlal Nehru University, onde ela leciona), numa vizinhança amigável e segura para uma mulher estrangeira sozinha. 
Essa última preocupação acompanhou-me do primeiro ao último período de campo. Todos os meus amigos e professores cuidavam para que eu estivesse protegida dos perigos que rondam as mulheres na Índia e que variam dos desrespeitos na rua olhares, abusos verbais, toques - até o medo maior que se instalou na capital nos últimos anos: o estupro. Conheci de perto o que as feministas criticam na Índia como um nefasto problema, a ideia de que é preciso proteger as mulheres - e de passagem controlá-las, mantê-las reclusas para tanto - em vez de ensinar os homens a respeitá-las. Em 2013, a primeira vez que pisei fora de casa com Patrick foi para ir à farmácia no Aurobindo Market onde ele me fez comprar um spray de pimenta: para minha defesa pessoal, disse ele. A construção do medo também faz as mulheres se protegerem do perigo representado pelos homens no Brasil, mas os cuidados das pessoas ao meu redor eram mais intensos na Índia. Talvez de nível mais aguçado, a natureza do medo que eu devia sentir na Índia era, no entanto, a mesma do meu país de origem.

Desde o Brasil, eu já pensava em me mudar da casa de senhor Ali tão logo conseguisse um aluguel mais em conta, para pagar por mês e não por dia, como fazia naquela primeira semana. Em meu segundo dia em Délhi, liguei para Meena, que conhecera em Trivandrum quando por lá estive durante três semanas em 2009. Como mantivemos contato pelo Facebook, eu sabia que ela agora residia em Délhi, após concluir seu mestrado em economia no Centre for Development Studies (CDS), pois havíamos falado antes de eu sair do Brasil. Ela convidou-me para jantar numa cantina chamada Andhra Bhavan em Central Delhi.

No jantar, mencionei que procurava outro lugar para ficar e pedi que me avisasse se ela soubesse de algo. No dia seguinte, Meena me ligava com a notícia de uma vaga disponível em um hostel onde uma amiga dela de trabalho morava. Meena trabalhava com Pryia em uma ONG que lida com políticas públicas, mais especificamente com tributação e orçamentos para políticas sociais do governo, e me contou da intenção da colega de se mudar de um quarto individual para outro que acomodasse duas pessoas, a fim de economizar dinheiro. Fomos apresentadas numa tarde após o expediente de trabalho delas e mudei-me, dois dias depois, de Lajpat Nagar I para Hauz Khas, ambas vizinhanças ao sul de Délhi. Começava assim minha convivência com cerca de trinta jovens de 17 a 34 anos, vindos de diversas regiões do país, falantes de diferentes línguas natais, que apresentavam sotaques variados quando utilizavam o inglês para se comunicar, mas que tinham em comum o fato de serem filhos de famílias abastadas, 
além de estarem em Délhi por motivo de trabalho ou estudo. Alguns vinham de cidades pequenas, outros das capitais de seus respectivos estados, mas viviam vidas diferentes da anterior pelo fato de, conforme me explicaram, estarem longe de seus lares, em muitos casos uma joint family, nos quais a vida dos jovens é bastante regrada e vigiada de perto pelos mais velhos, sobretudo no caso das moças. ${ }^{8}$

Foi assim que aconteceu de eu ir morar em um quarto no pensionato de propriedade de mister Kapoor tendo Pryia, uma indiana de 25 anos à época, como roommate. Pryia fez graduação em Bachelor of Commerce em Bangalore, onde nasceu, e cursou o mestrado em Social Policies na London School of Economics. Foi por intermédio dela que fui conhecendo inicialmente os demais moradores e os funcionários da PG.

A casa, um prédio de quatro andares, mais um terraço e um subsolo, este alugado para uma academia de ginástica, fora um hotel que pertenceu ao pai de mister Kapoor e agora está transformado pelo filho - que a herdou, juntamente com dois irmãos que brigam na justiça pelo lugar - em um pensionato que recebe paying guests de vários lugares da Índia e do mundo. Cerca de trinta pessoas vivem nos cinco andares da casa.

A maioria dos quartos é dividida, sempre por pessoas do mesmo sexo morando num mesmo quarto. A visita de rapazes a quartos de moças e vice-versa é proibida, embora tal regra seja burlada de vez em quando. 0 preço do quarto individual girava, em 2012, em torno de 20.000,00 rúpias ( $\mathrm{R} \$ 730,00$ aproximadamente) e o do quarto para dividir era de 12.500,00 rúpias para cada ocupante do quarto ( $\mathrm{R} \$ 450,00$ ). Esses valores são altos para o padrão econômico indiano, isto é, pessoas pobres não moram ali; quem pode pagar esse valor é considerado um membro da classe média alta ou da elite econômica na Índia.

\footnotetext{
80 conceito de joint family é bastante difundido na Índia como um todo, independentemente da região. Trata-se de organização social na qual vivem juntos os membros de um grupo de agnatos, isto é, são famílias que seguem a regra da patrilinearidade e da patrilocalidade. Geralmente constitui-se de duas ou três gerações residindo na mesma casa: um casal com filhas solteiras, filhos solteiros ou casados e a prole dos filhos homens casados, os quais trazem as esposas para viver sob o mesmo teto. As filhas mulheres são, por sua vez, enviadas à casa do marido, logo que casadas, e passam a compor, com seus futuros filhos, a joint family do marido e não mais a da família natal. Os primos e primas que residem numa mesma joint family costumam tratar-se como irmãos e irmãs. Muitas vezes meus interlocutores diziam algo sobre um irmão ou irmã e, em seguida, explicavam tratar-se de um primo ou prima, ou afirmavam: "my brother, real brother", para enfatizar que se tratava de um irmão e não de um primo. 0 mesmo acontece quando as pessoas especificam os familiares em seus perfis no Facebook, na rede social muitos que figuram como irmãos e irmãs são primos e primas, atualizando virtualmente o sistema de parentesco tal como é concebido e vivido fora do mundo virtual.
} 
Morei com Pryia por dois meses em 2012; com Rekha por quatro meses em 2013; sozinha por quatro meses em 2014; e com Lovania por três semanas em 2015. Em 2014, a única vaga disponível na casa era um quarto individual no primeiro andar e foi ali que me instalei. A palavra sozinha, no entanto, não deve ser tomada ao pé da letra, pois apesar de, em tese, o quarto ser só meu, foi a vez que mais tive que dividi-lo com Rekha, Lovania, Shubhi e Maya, que vinham me visitar o tempo todo em que estavam na casa, individualmente ou em grupo. 0 fato de eu estar sozinha no quarto deu a elas o direito de bater à minha porta para conversar, assistir à TV, fazer uma refeição, usar o banheiro, espiar meu guarda-roupas e a mala que mantinha em cima de uma pequena mesa (procurando pelas lingeries usadas no Brasil ou pelo que eu havia trazido de diferente dessa vez), conversar com o namorado por telefone ou Skype quando a roommate da visitante estivesse no quarto delas etc. Se antes havia alguma inibição por parte das garotas em visitar-me quando eu dividia o quarto com Pryia ou Rekha, naquele quarto "individual", ela desapareceu completamente. Essa experiência me rendeu uma convivência incrível com elas e a percepção definitiva de que o termo privacidade na Índia tem outro significado, diverso do que aprendera no Brasil. A privacidade pode ser criada sem que haja separação de ambientes. Por exemplo, para criar privacidade para sua conversa com o namorado, Praveen, Rekha vinha ao meu quarto para falar com ele pelo Skype quando Maya, sua roommate em 2014, estava no quarto delas. Rekha falava com Praveen em hindi e Maya poderia entender todo o conteúdo da conversa, ao passo que eu teria somente uma ideia do que discutiam, levando em conta a pobreza de meu hindi e a velocidade com que Rekha falava. De igual modo, Shubhi e Lovania, ao sentir vontade de ir ao banheiro, não interrompiam a conversa comigo para ir ao quarto delas que se encontrava no mesmo andar, mas continuavam falando comigo ao usarem meu banheiro, bastando fechar a porta para que a privacidade delas fosse mantida. Quando era minha vez de falar pelo Skype com o marido que se encontrava no Brasil, não havia incômodo por parte delas em presenciar a conversa, uma vez que eu falava em português e, assim, elas não se sentiam intrometendo-se numa conversa entre esposos que não se viam há meses. Ao contrário, no caso de Lovania, ela gostava de cumprimentar seu jeeju (marido da irmã mais velha) enquanto eu falava com André.

Voltando à casa, sua localização, dentro da região chamada Hauz Khas, é considerada chique (posh): as pavimentações são boas, há calçadas em algumas vias, muitas árvores pelas avenidas e ruas, praças com parque infantil e grandes mercados como o Aurobindo Market, o Green Park Market e o SDA Market (Safdarjung Developent 
Area é o nome de uma parte da vizinhança de Hauz Khas). A cerca de quinze minutos andando da PG está a Hauz Khas Village, antiga aldeia que foi, aos poucos, sendo gentrificada e expulsando seus moradores para se transformar num reduto de galerias de arte, lojas, restaurantes, cafés e bares. A poucos metros da casa, do outro lado do Aurobindo Market, fica Green Park, uma das gated communities mais nobres de South Delhi e de Délhi como um todo. Délhi é, aliás, dividida setorialmente. Há a New Delhi e a Old Delhi, que fica em Central Delhi. Além disso, conforme a dispersão geográfica, a cidade se divide em distritos que fazem parte da National Capital Region (NCR).

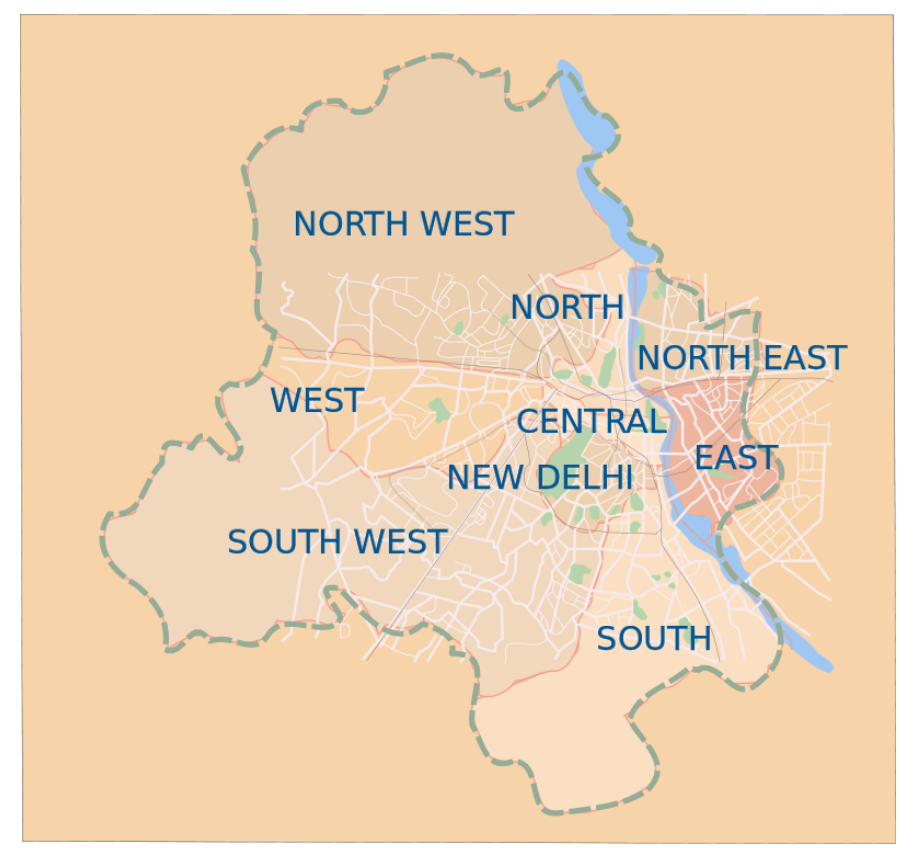

South Delhi é considerada detentora de um estilo de vida diferente do resto da capital, com centros de compra e lazer, vizinhanças e escritórios que definem South Delhi como única. Frases como "Yes, you can call me a Southy because I never go out of South Delhi, I don't mind" - proferida por Pryia quando um dos rapazes sugeria que fossemos explorar outras áreas da cidade - ou a orientação da professora Janaki Abraham de que eu teria que explicitar que a pesquisa fora feita naquela porção da cidade porque afinal de contas South Delhi tem suas características próprias, são exemplos de como os moradores de Délhi percebem a área. Tais comentários me faziam pensar que mencionar South Delhi seria como aludir à Zona Sul estando no Rio de Janeiro.

Alguns dos hóspedes trabalham em lugares relativamente próximos à PG. Dentre esses, uma parte toma auto-riquixás para o trabalho, outra parte vai caminhando. Também ficam próximas à casa duas estações de metrô que nos ligam a toda a capital e a 
outras cidades, como Gurgaon, núcleo empresarial e comercial que concentra um grande mercado de trabalho e para o qual se dirigiam, todos os dias, Patrick, Rekha, Anyndia e alguns estrangeiros que faziam intercâmbio de trabalho no país em 2012.

Não há separação por gênero entre os andares na casa. Mister e Mrs. Kapoor, um casal de mais de cinquenta anos de idade, vivem no primeiro andar, num quarto logo de frente para a escadaria que conduz do térreo a esse piso. Ambos passavam a maior parte do dia fora no primeiro ano. Ela trabalha como diretora de um colégio de propriedade do casal no mesmo bairro e ele tem um escritório de negociação de artigos de decoração. Quando em casa, os dois jantavam na sala de estar usada como área comum por todos que ali residiam em 2012. Em 2014 a sala de estar e jantar havia sido suprimida. Em seu lugar havia um novo escritório, com entrada e saída para a rua contígua à da entrada principal do prédio que fica numa esquina. Mister Kapoor ainda decidia se alugaria o escritório ou se ele próprio o ocuparia, já que havia deixado de pagar aluguel em seu antigo escritório em outra parte da cidade e trabalhava, desde o final de 2013, em um dos quartos do térreo, logo em frente à recepção, transformado em escritório. Depois dessa mudança, os jantares coletivos passaram a agregar menos pessoas. Alguns começaram a fazer as refeições nos respectivos quartos. Outros, que não gostavam de levar comida para o quarto devido ao cheiro que se instala no aposento, comiam numa pequena mesa perto da recepção e até no próprio balcão da recepção, uma vez que à hora do jantar, Lakhan, o gerente, já havia ido embora. Dileep e Joh costumavam almoçar sentados à escada da cozinha, que fica num nível mais baixo do restante da casa. Muitas vezes acompanhei-os e nesses momentos nos faziam companhia, ainda, Mitlesh, o ajudante de cozinha, e Rani, a arrumadeira mais antiga, que passou a ajudar na cozinha no período em que o cozinheiro precisou se ausentar, voltando à sua aldeia natal por ocasião do nascimento de um filho. Os Kapoor jantavam, em 2014, no escritório provisório de mister Kapoor, mantendo o hábito de jantar mais tarde que os hóspedes. Mitlesh colocava a mesa para o jantar da família em vasilhas de onde os proprietários se serviam em pratos de porcelana.

Quando a sala de jantar ainda existia, os Kapoor se sentavam para a refeição enquanto ainda havia outros moradores no aposento. Nessas ocasiões, mister Kapoor conversava bastante com seus hóspedes. A senhora Kapoor se mantinha mais calada. As oportunidades que tivemos de conversar melhor aconteceram quando o senhor Kapoor não estava presente. Algumas das melhores impressões que obtive da vida conjugal na 
Índia provêm desse casal. ${ }^{9}$ Os jantares na PG propiciaram meus primeiros momentos de socialidade com os amigos de Délhi. Uma grande mesa oval de madeira com oito cadeiras servia de local para as refeições dos hóspedes e da família proprietária em 2012 e 2013. Além de mister e Mrs. Kapoor, Rahul, um dos três filhos, estava residindo ali na segunda temporada que passei na casa, em 2013, num quarto no terceiro andar e, em 2014, a filha recém-chegada de Londres residia no quarto andar. Em 2015, contudo, ela havia retornado à capital inglesa e Rahul continuava no terceiro andar.

Todos os moradores são servidos em bandejas de metal ou plástico pelo cozinheiro que as entrega aos hóspedes na cozinha - com exceção dos Kapoor que, como disse, comem em pratos de porcelana. ${ }^{10}$ Em seguida se dirigiam para a sala de jantar que contava ainda com sofás e poltronas, um altar doméstico para a deusa Durga, um móvel com uma televisão antiga por cima e uma mesa de centro. Algumas vezes, quando várias pessoas decidiam jantar ao mesmo tempo, os sofás e poltronas eram também utilizados, já que não cabiam todos à mesa. Animadas conversas e discussões costumavam acontecer ali, e ainda acontecem no balcão da recepção, sobre os mais diferentes assuntos: cinema, esportes, economia, casamentos, política, diferenças de hábitos em cada estado de onde eles vêm, o dia de trabalho ou de faculdade/cursinho de cada um etc. Quando alguém é novo na casa, o inquérito sobre de onde ele ou ela vem, o que faz em Délhi e até quando fica é feito nesse momento.

Não é difícil se ambientar, a maioria dos moradores é bastante comunicativa. Mais que isso, eu diria, os ambientes que conheci na Índia não reservam muito espaço para a privacidade. Tudo que num jantar com muitas pessoas quase desconhecidas não seria perguntado no Brasil, pode ser perguntado sem cerimônia na Índia: indagações

\footnotetext{
${ }^{9}$ Em sua vida cotidiana, identifico muitos comportamentos e situações que eu só conhecia pela literatura sobre casamentos na Índia. Por exemplo, a senhora Kapoor uma noite contou a mim e a outras moradoras da PG como haviam sido seus primeiros anos de casada. Falou da dificuldade de se adaptar à nova família (patrilocal), com a agravante de ter ido morar na casa de seus in-laws longe da Índia, apenas um mês após o casamento. Um dia passou mal, já em estado avançado de gravidez, nas ruas geladas de Londres e se recorda de nunca ter se sentido tão só em toda a sua vida: _It was so difficult, because I didn't know anybody, my family was so far. I mean I had a family, the new family, but they were people that I didn't know." Ela foi socorrida por alguém na rua que chamou uma ambulância e ligou para a nova família dela, os pais de mister Kapoor. Seu depoimento, que emocionou a todas que a ouvíamos, remete diretamente ao que autoras como Uberoi (2006) e Dhawan (2011) afirmam quando analisam a ideia naturalizada na Índia de que às mulheres é que cabe se ajustar ao casamento, sendo, inclusive, considerados como falha delas os casos de divórcio. Também pude sempre observar o modo como a senhora Kapoor mantém sua voz num tom baixo e polido, ao passo que o senhor Kapoor está sempre falando alto e rindo muito.

${ }^{10}$ Além da louça utilizada para a refeição, outra diferença era que seus chapatis (pães) continham ghee (manteiga de leite clarificada), ao passo que os nossos eram plain (simples); ademais, sempre havia no jantar da família Kapoor uma salada, normalmente composta de tomates, pepinos, cenoura, rabanete e cebola crus, que não era servida no nosso caso.
} 
sobre o que se faz; quanto se ganha; se eu me casara de modo arranjado ou por amor; se tinha filhos; por que não os tinha; o que faziam meus pais; se ser socióloga era considerado uma profissão de status no Brasil; qual era o trabalho de meu marido; se seu emprego remunerava bem; que carro ele dirigia; se nossa festa de casamento havia sido grande; e muitas outras perguntas eram enunciadas. 0 que eu considerara inicialmente como uma invasão de minha privacidade foi se mostrando ser o modo rotineiro das pessoas interagirem. Embora minhas amigas e amigos reclamassem da intromissão e vigilância de seus pais em suas vidas, elas e eles faziam o mesmo comigo. Se eu saía com amigos da Delhi University, por exemplo, meu celular não parava de tocar e receber mensagens SMS e WhatsApp enquanto todos não soubessem onde eu estava, com quem, fazendo o quê e a que horas estaria de volta. Assim que um deles percebia minha ausência na PG sem ter avisado, entravam em contato uns com os outros até descobrirem onde eu estava. Uma noite, em 2013, saí com Anirudh e Pryia, que já não residiam mais na casa, e fiquei sem bateria no celular. Rekha - minha colega de quarto naquela temporada -, Lovania, Shubhi e Patrick não sossegaram até que Patrick tivesse a ideia de contatar Anirudh, que esclareceu que estávamos juntos em Hauz Khas Village e que ele me deixaria em casa antes de seguir para seu apartamento, como sempre fazia comigo e com Pryia.

Ao contrário das pessoas desconhecidas com quem entabulei conversas em meu primeiro ano na Índia, em 2009, meus amigos da PG nunca perguntavam se qualquer chegante era casado ou solteiro, pois a condição de estar morando numa PG é considerada indício de que a pessoa era solteira, pois se fosse casada por que que estaria morando em um hostel? Muitos deles se mostravam surpresos quando eu dizia que era casada. Outros se surpreendiam ainda mais quando eu respondia suas perguntas sobre se meu casamento havia sido arranjado ou por amor:

- I had a love marriage. In Brazil we don't have the concept of arranged marriage.

- Really?

- Yes, at least not anymore.

- Since when?

- Oh, I would say that at least since a hundred years ago. 
A informação de meu estado civil causava efeitos diversos em meus interlocutores. Era um alívio para alguns saber que eu contava 33 anos e era casada, seria estranho para eles que eu fosse solteira com essa idade. Dado o tema de minha pesquisa e o tipo de perguntas que eu fazia, muitas vezes ligadas a relacionamentos amorosos, sexualidade e casamento, com essa informação eu afastava ideias equivocadas sobre o motivo para minhas questões; quando revelava que era casada, assumiam logo que naquelas perguntas não havia mais que curiosidade intelectual e de pesquisa. Outros achavam bastante incomum que eu fosse casada e passasse longas temporadas fora de casa. Em um caso, a revelação levou ao afastamento de um dos interlocutores que, após saber minha idade e estado civil, abandonou o hábito de vir conversar comigo durante os almoços em 2013, quando a sala de jantar ainda existia. Eu era vista pelos rapazes como alguém já fora da idade que os interessaria de modo romântico, o ideal normativo para a formação dos pares na Índia é de que a moça deve ser de dois a três anos mais nova que o rapaz e eu era mais velha que todos os hóspedes da casa, com exceção de Shivani, uma mulher divorciada de 34 anos que chegou à casa em 2013. Quanto às moças, eu era vista como alguém experiente, por ser mais velha e por contar dez anos de casada, que poderia lhes falar de assuntos como vida conjugal, namoro e vida sexual ativa, temas tabus para moças solteiras e sobre os quais elas se mostravam extremamente curiosas.

Das apresentações logo se passava a conversas, brincadeiras e piadas, sem grande diferença entre os mais novos e os veteranos de casa. Em uma semana, os mais brincalhões começavam a fazer comentários jocosos sobre os novatos: no meu caso, sobre futebol - como Neymar e Ronaldo eram péssimos jogadores na opinião de Viplav, jovem advogado, cujo irmão mais velho, Hemanshu, de mesma profissão, também residia na casa - e sobre eu querer casar as pessoas ali para ter sobre o que falar em minha pesquisa por exemplo.

Pryia havia chegado um mês antes de mim, de modo que nenhuma de nós duas era veterana na PG. Esse posto era de Shubhi e Lovania, que dividiam, até o início de 2015, um quarto ao lado do aposento dos Kapoor; de Dileep e Patrick que residiam no mesmo andar das meninas em 2012; em 2013 residiam no quarto andar e agora residem, respectivamente, sozinho no mesmo aposento no quarto andar e em Gurgaon, num flat alugado; de Anirudh e Hemant, que dividiam uma suíte no quarto andar e se mudaram (o primeiro para um flat perto dali, com um amigo da faculdade que veio 
trabalhar em Délhi como advogado; o segundo para Jaipur, sua cidade natal, após ter se casado); e de Kaushik, que morava sozinho no quarto andar (e que em 2014 dividia seu aposento com Anyndia, que chegara de Orissa e era funcionário do State Bank of India). Todos eles moravam na PG há pelo menos um ano.

Outras formas de interação, além daquela que ocorria nos jantares, eram o almoço e os passeios que fazíamos em grupo. 0 almoço contava com muito menos presenças, já que a maioria dos moradores levava a comida preparada pelo cozinheiro de manhã em pequenas vasilhas para o trabalho, algo que, como eu discutia na dissertação, é bastante comum na Índia devido à preocupação com a preparação da comida do ponto de vista da oposição entre pureza e impureza, pois alimentos podem ser fonte de pureza e impureza não permanentes, isto é, certas comidas podem purificar ou poluir uma pessoa dependendo de sua casta, gênero, idade, religião ou período do ciclo de vida. Existem ingredientes culinários vedados ou prescritos para cada casta, comunidade religiosa, idade, gênero e ainda para períodos específicos do ciclo de vida, como durante a menstruação, o período de idade fértil dentro do casamento ou a viuvez. ${ }^{11}$

Invariavelmente, almoçávamos na casa, além dos funcionários, Patrick, Dileep, Shine, Ishita, Soumita e eu no primeiro ano. Nos anos seguintes, Ishita e Soumita haviam se mudado, mas outros moradores haviam chegado, como Joh (estudante de sociologia proveniente de Calcutá, capital de West Bengal), Krishna (estudante de arquitetura vindo de outra cidade também no estado de West Bengal), Isham (natural de uma pequena cidade de Haryana que viera fazer cursinho para os exames de ingresso na universidade) e alguns outros estudantes com os quais não consegui estabelecer mais que conversas banais sobre o calor ou a chuva, conforme o dia. Patrick e Dileep trabalhavam em casa em 2012, ambos eram sócios em uma empresa que desenvolve websites e logomarcas para empresas. Agora Dileep dirige o negócio sozinho desde que Patrick começou a trabalhar em Gurgaon como pesquisador consultor em uma indústria de produtos odontológicos no ano de 2013.

Os lugares de origem eram importantes para meus interlocutores, pois designam a comunidade à qual se pertence. Algumas vezes, entretanto, pessoas vivendo no

\footnotetext{
${ }^{11} \mathrm{O}$ filme Lunch Box apresenta esse costume de levar a comida de casa para o trabalho, mas ali, diferentemente da PG, as marmitas (dabha) são transportadas da casa ao trabalho pelo famoso sistema indiano que, como os personagens do filme se orgulham de dizer, nunca erram uma entrega. No enredo do filme, no entanto, é justamente um erro na entrega que coloca o par enamorado em contato.
} 
extremo norte do país eram, na verdade, bengalis, isto é, originalmente vindas da porção nordeste do país, que haviam migrado em algum momento. Como se verá adiante, a comunidade constitui aspecto muito importante no processo de arranjo dos casamentos, uma vez que está imbricada com a casta sendo bastante comum pessoas referirem às castas como oriundas de regiões geográficas determinadas do país. Assim, é frequente ouvir, por exemplo, sobre os Kayastha da Bengala, os Patel de Gujarat ou os Marwari do Rajastão.

Voltando aos moradores, Dileep e Patrick ficavam, naquela época, praticamente o dia todo na PG e foram, sempre, dois ótimos amigos e professores de tudo que eu aprendi em Délhi, desde como pegar o metrô para a Delhi University, situada do outro lado da cidade em North Delhi, até explicações para coisas que outras pessoas diziam e eu não entendia por dificuldades com o idioma cultural dos casamentos, do romance e da intimidade na Índia. Dileep tem formação em psicologia e debatíamos longamente sobre a visão junguiana do amor, especialmente o fato de que esse autor é enfático quanto à possibilidade de se amar mais de uma pessoa ao longo da vida e mesmo concomitantemente, visão que contrasta bastante com as noções modernas de amor na Índia, discutidas adiante no capítulo III, e mesmo com o amor romântico ocidental, tendo sido, contudo, apropriada mais recentemente pelos movimentos de poliamor. Após os almoços, os rapazes e as moças íamos à barraquinha de tchai que fica bem em frente à PG, do outro lado da rua, na calçada do Aurobindo Market, mercado a que recorríamos para comprar água, colocar crédito nos celulares, comprar livros, jornais e revistas, pães ou biscoitos e fazer lanches rápidos na unidade da rede de lanchonetes Wimpy presente ali. Aquelas garotas haviam vindo à Délhi para estudar, com exceção de Soumita que já trabalhava, mas estava afastada do trabalho nesses dias graças a uma forte dor nas costas. Soumita, assim como Pryia, graduou-se Bachelor of Commerce (mais comumente chamada de B. Com) e trabalhava numa empresa. Shine prestava os exames para ingressar na faculdade de Moda. Ishita acabara de iniciar o curso de Administração de Empresas.

Outra turma também se reunia para sair à noite. Pryia, Jorge, Engin - vindos da Colômbia e da Turquia, respectivamente, e que faziam intercâmbio de engenharia - e eu éramos os mais assíduos no primeiro ano. Frequentávamos um lugar chamado Bromfy, um $p u b$ dançante que realizava festas chamadas "Diasporic Night" em que havia tantos indianos quanto estrangeiros de todos os cantos do mundo. Em outras ocasiões, além de 
outros estrangeiros, juntavam-se a nós para ir ao karaoke, distante um quarteirão da PG, Anirudh (advogado de 24 anos), Patrick (26 anos, formado em odontologia), Kirti (26 anos, arquiteta que trabalhava em escritório do ramo e em julho de 2013 se mudou para Saint Louis para cursar o mestrado) e Pratyushi (27 anos, economista que trabalhava para o governo e se mudou de lá ainda em 2012). Fomos também, na minha primeira estada em campo, ao Kasbah, restaurante e night club, numa noite de Bollywood, isto é, com músicas indianas que fazem parte das trilhas sonoras dos filmes produzidos no país e que arrastam multidões aos cinemas e às casas de dança em ocasiões como essa.

Nos anos seguintes, outros lugares foram frequentados em grupo, a cada vez com novos integrantes, como Anyndia que passou a dividir o quarto com Kaushik e, diferentemente do primeiro, adora sair à noite e tomar cerveja; ou Raghavendra, amigo de Anyndia que mora em Mumbai, mas vai a Délhi regularmente e saía conosco quando na cidade. Nayan, outra advogada, mudou-se para a casa ao final de 2013 e igualmente saía conosco em 2014. Alguns antigos moradores da casa, mesmo havendo se mudado, continuavam sendo amigos de alguns daqueles que ainda viviam no lugar. Pryia e Anirudh, por exemplo, tornaram-se amigos próximos, sempre em contato e saindo juntos, mesmo depois que ambos se mudaram, em 2012 e 2013, respectivamente. Kirti também havia se mudado quando regressei em 2013, mas era bastante próxima tanto de Anirudh quanto de Pryia, antes de partir para Saint Louis. Patrick, que se mudou da casa em dezembro de 2013, por sua vez, continuava se falando e se encontrando com Shubhi e Lovania. Anyndia que se mudou de Délhi em 2014 foi, contudo, um dos poucos dentre os moradores da PG convidado para o casamento de Shubhi em 2015, vindo de Bhubaneshwar, capital do estado de Orissa, especialmente para o evento. De modo que, a cada ano, pude contar com novos amigos que eram acrescentados a essa rede de relações que gravitava em torno da $\mathrm{PG}$, ao mesmo tempo em que alguns antigos moradores que haviam se mudado mantinham contato comigo e/ou continuavam a se ver entre eles mesmos, o que não quer dizer que não houvesse preferências ou desafetos, e que, em alguma medida, eu tinha que contornar para não prejudicar minhas próprias relações com cada um deles.

Outros locais que frequentamos nos anos seguintes incluem: a boate Capitol, localizada dentro do hotel Ashok; o clube Shiro, sediado no hotel Samrat; diversos bares e restaurantes em Hauz Khas Village, em Khan Market, em Greater Kailash e em Cannaught Place, dentre outros. Todos esses hotéis, mercados ou centros comerciais são 
frequentados pelas classes médias e pela elite econômica da cidade de Délhi. O que não impede vendedores, ambulantes, pedintes, motoristas e pessoas em geral de circularem pelas redondezas desses espaços. Ao contrário do Brasil, os lugares mais "chiques" das cidades que conheci na Índia misturam perfeitamente pobreza e riqueza, tradição e modernidade, antiguidade e high tech, luxo e lixo, numa mistura que constitui uma paisagem sempre heterogênea e inusitada ao olhar estrangeiro.

Em 2013 e 2014 voltamos a nos reunir várias vezes na casa de Anirudh e Kartik, os quais dividiram por dois anos um flat a algumas ruas da PG, e na casa de Pryia, que por sua vez dividia um apartamento com Yashtri e Niki, provenientes, respectivamente, de Mumbai e do Nepal. Nessas ocasiões, comprávamos bebidas na liquor shop mais próxima, pedíamos comida e ouvíamos música e conversávamos ao consumir o que tínhamos comprado para aquela noite. Rekha, Shubhi, Kaushik, Patrick e Anyndia foram também convidados para algumas ocasiões na casa de Anirudh, além de estrangeiros que viveram na $P G$, como Amélie, uma garota francesa, e Elena, uma moça russa que vivia no Cazaquistão.

A convivência entre todos era, no mais das vezes, amigável, com algumas pessoas mais reservadas, outras mais extrovertidas. Alguns grupos menores se formavam dentro do quadro maior dos moradores. Não eram organizados segundo a região de onde vinham, que como já dito constituíam suas comunidades, ou pelo pertencimento religioso, nem por idade. Eu observava que as amizades mais próximas eram estabelecidas mesmo por afinidades eletivas e por gostos pessoais. De igual modo, desinteresses ou indisposições mútuas eram construídas com base no comportamento. Por exemplo, era para muitos irritante que Kaushik estivesse sempre fazendo zombaria de alguém ("He is always mocking people"), mesmo de quem não se considerava amigo dele, caso de Shubhi e Lovania desde o primeiro ano e de Patrick e Dileep nos anos seguintes. Para Rekha e Anindya, no entanto, era justamente isso que fazia dele uma pessoa divertida e engraçada. Esses últimos podiam ser vistos sempre juntos nos jantares e em passeios pela vizinhança e várias vezes me juntei aos três.

Muitos na casa não gostavam de Soumita. Ela era tida como fofoqueira e havia vivido um relacionamento amoroso com um rapaz que não acabara bem e, por isso, vivia dizendo que "men are dogs". Os rapazes se irritavam porque ela generalizava, segundo eles, a personalidade do ex-namorado que a abandonara para os homens em geral; as garotas, com exceção de Shubhi que era sua amiga, achavam-na estranha ou 
problemática, impressão que, fui descobrindo, tinha que ver com o romance dela no passado e com um comportamento (como gostar de sair à noite, rir e falar alto, viver cantarolando com um fone aos ouvidos pelos corredores da casa) que as outras garotas consideravam vulgar. 0 fato de que ela passou a ficar muito tempo trancada em seu quarto após um diagnóstico de depressão a levou de volta, em 2013, à Calcutá, sua cidade de origem e onde a família reside.

Em relação aos funcionários, as interações variavam. Há na PG sempre dois homens que trabalham na cozinha. Eram uns em 2012 e outros dois em 2013. Ainda em 2013 chegou à casa como ajudante do cozinheiro um jovem chamado Mitlesh, que contava dezessete anos àquela época e completou dezoito durante minha estadia em 2014 , embora a meus olhos parecesse ainda ter quatorze ou quinze anos. ${ }^{12}$ Ambos ocupavam um aposento no quarto andar e eram os únicos funcionários a morar lá. Em 2014 o cozinheiro titular foi para sua aldeia natal, pois a esposa havia dado à luz, e nunca voltou. Mitlesh passou a ser o cozinheiro. Em 2015, um novo ajudante, ainda mais novo que Mitlesh, estava residindo na casa junto a Mitlesh. Há o senhor da lavanderia, a qual funcionava no segundo andar em frente ao quarto que dividi com Pryia em 2012 e agora funciona no terraço. Este cuida da roupa dos Kapoor e dos hóspedes que assim o desejam, mediante pagamento extra. Dois porteiros se revezavam dia e noite na entrada do prédio e houve troca desses funcionários entre os anos 2012 e 2014. Ficam do lado de dentro do portão, sentados numa cadeira à sombra, de onde cumprem a função de pedir aos hóspedes que assinem um caderno de entrada e saída da PG com o horário de movimentação de cada hóspede. Segundo Anirudh, numa cidade violenta como Délhi, mister Kapoor precisa ter algum controle de quem entra e sai de sua casa. E se alguém, dentre seus hóspedes, um dia desaparecer ele tem o registro de quando essa pessoa saiu pela última vez da casa. Se alguém de fora quer entrar na $\mathrm{PG}$, deve fazê-lo acompanhado do morador a quem veio visitar e assinar o caderno. É vedada a visitação de pessoas do sexo oposto, isto é, rapazes só devem receber rapazes, moças só devem receber moças. 0 nome do rapaz mais novo que trabalha como porteiro é Vikram; o mais velho, um senhor que contava mais de cinquenta anos, é chamado por todos os moradores de uncle, como é de costume quando um jovem se dirige a um senhor desconhecido ou de quem não

\footnotetext{
12 Como muitos jovens que ocupam funções do tipo ajudante (em qualquer atividade), motorista de cyclerickshaw, vendedor ambulante, engraxate etc., Mitlesh não aparenta a idade que tem. É muito comum as pessoas que exercem tais ocupações terem a estatura baixa, a pele escura, o peso mirrado e uma postura cabisbaixa, confundindo, sobre suas idades, aqueles estrangeiros que olham pela primeira vez para essas pessoas.
} 
sabe o nome. Eu o chamava de sir, assim como ao senhor da lavanderia, e nenhum dos moradores soube me dizer seus nomes, todos os chamavam apenas uncle.

Apesar da explicação de Anirudh, a única violência que pude perceber em Délhi era a sexual, isto é, de um tipo que os porteiros pudessem, porventura, impedir - claro que há muita violência na gentrificação dos bairros, na exclusão social, na desigualdade de gênero etc., mas essas não justificam a presença dos porteiros, nem diminuem com ela. Em 2013, quando me preparava para voltar à cidade, o estupro coletivo de uma estudante de medicina que se encontrava num ônibus coletivo acompanhada do namorado ganhara os jornais e os noticiários no mundo todo. Não obstante esse tipo de crime, a violência gerada pela desigualdade social é ínfima: roubos, assaltos, furtos são coisas raras das quais nunca fui testemunha ou tive notícia enquanto estive na Índia, mesmo ao andar por áreas consideradas potencialmente perigosas por alguns de meus amigos, isto é, bairros pobres.

Ainda assim, nas vizinhanças abastadas, chamadas de gated communities pelo fato de conterem portões em algumas ruas fechando completamente o acesso de veículos ao seu interior depois de certa hora da noite até as seis da manhã, cada casa tem seus watchmen, que como o nome diz, vigiam o ritmo e a moralidade das ruas. Como será explorado adiante, os espaços públicos na Índia formam uma paisagem moral, expressa também por uma etiqueta corporal, em que os ocupantes dos espaços policiam-se uns aos outros constantemente: atividades como andar de mãos dadas, beijos e abraços praticados por pessoas de sexo oposto, o uso de álcool, cigarro e outras drogas, roupas curtas ou mais reveladoras para mulheres, dentre outros, são fortemente coibidos, tanto pelos olhares desencorajadores, quanto, por vezes, por xingamentos ou broncas de watchmen ou pessoas mais velhas.

Há ainda na casa três mulheres encarregadas da limpeza de todo o prédio, excluindo a academia que funciona no subsolo. Elas são Rani, uma senhora viúva de uns cinquenta e tantos anos, e duas moças jovens e solteiras, Maya e Kavita, que não eram as mesmas de 2012 quando voltei em 2013, mas que se mantiveram até 2015. De todos os funcionários da casa, o único que fala inglês é Lakhan, o gerente. Os demais falam hindi e só consegui começar a me comunicar com eles após estudar essa língua a partir de 2013. Os outros moradores da casa conversavam com Lakhan e com o cozinheiro apenas, falando o estritamente necessário com os trabalhadores restantes. As exceções eram Patrick, Pryia, Anirudh e Anyndia, que conversam com todas as pessoas nas ruas ou em 
casa indistintamente. Esses são sempre gentis e respeitosos inclusive com as pessoas mais simples, como motoristas de riquixá, vendedores, varredores de rua etc. À exceção de Pryia todas as outras garotas eram rudes, ou pelo menos secas, sobretudo com as arrumadeiras. Lovania, quando lhe perguntei pelo nome da arrumadeira mais velha, respondeu que seu nome, Rani, significa rainha.

- So you remind that she is a queen.

Havia um claro tom de deboche quando disse que a arrumadeira era uma rainha. Acontecimentos como esse me faziam perceber a clara hierarquia mantida pela maioria dos moradores entre a família Kapoor, os moradores e os funcionários, esses ocupando o último lugar na hierarquia social da casa. No caso das moradoras em relação aos funcionários do gênero masculino havia, ainda, uma distância guardada em nome da separação que deve haver entre mulheres e homens que não sejam da mesma família. Nenhuma delas cumprimentava ou conversava com os porteiros a não ser para perguntar se havia correspondência ou para dar instrução sobre alguma encomenda que haviam feito e que receberiam pelo correio. Com exceção do senhor da lavanderia e do porteiro mais velho que ficava na entrada desde 2013, os outros três porteiros que conheci e até Mitlesh, o assistente do cozinheiro, passaram a me tratar de modo diferente quando tentei transgredir essa regra e os cumprimentava e perguntava como estavam. No sorriso e na voz quando me respondiam passaram a insinuar uma intimidade que não havia entre nós. Em pouco tempo, comecei a tratá-los como os demais moradores o fazem e esse comportamento cessou. No caso de Mitlesh, Lovania o repreendeu e ele voltou a exibir seu comportamento respeitoso para comigo. Assim, continuei a conversar com ele, algo que ela também fazia. Tive de me submeter à hierarquia existente dentro da PG para que as pessoas soubessem como se portar em relação a mim. Ao transgredir as interações prescritas por essa hierarquia, eu bagunçava o esquema analítico de algumas pessoas que faziam parte da vida na casa.

Voltando ao grupo de moradores, íamos também, aos finais de semana, a lugares turísticos e históricos da cidade como a Jama Masjid (Grande Mesquita) em Old Delhi; Purana Qila (Forte Antigo); Humayun's Tomb (tumba do imperador muçulmano Humayun) e o magnífico Qutab Minar (um minarete de 72 metros de altura, o mais alto do mundo, com uma mesquita e ruínas de palácios no local também). Todos esses monumentos foram construídos pelos Moghuls, ou seja, na época em que grandes conquistadores muçulmanos governaram a maior parte do norte da Índia. Patrick é o 
único muçulmano dos moradores da PG e ele me explicava sobre a arquitetura, os elementos decorativos (como os versos do Alcorão escritos em persa nas mesquitas) e as orações (namaz) que eram performadas nas mesquitas. Ninguém nunca fez qualquer diferença entre ele e os demais moradores da casa, não que eu soubesse pelo menos. Patrick afirmava não ser uma pessoa religiosa: não frequentava mesquitas, não se preocupava em comer alimentos que fossem halal, isto é, próprios ao consumo por muçulmanos segundo as regras dietéticas do islamismo, nem praticava o namaz, orações que devem ser feitas em horários específicos do dia com o orador voltado na direção de Meca. Era latente, no entanto, o fato de que tais monumentos evocavam, sobretudo para ele, conflitos antigos (como as batalhas medievais entre exércitos hindus e muçulmanos), recentes (como a partição do país e a vinda de refugiados do extremo norte para a região de Délhi) e contemporâneos (como a perseguição política e social aos muçulmanos pelos Hindutva - movimento nacionalista hindu que busca forjar uma identidade nacional calcada no hinduísmo). Délhi é, nesse sentido, uma cidade repleta de índices da convivência e do conflito inter-religioso.

Além dessa sessão que apresentou o ambiente de meu trabalho de campo etnográfico, outras informações sobre os moradores e a rotina de nossas convivências surgirão nos capítulos seguintes. Por ora, passo a falar sobre a construção do objeto da pesquisa aqui apresentado.

\section{O compromisso de casar e a vontade de amar: construindo um objeto de pesquisa}

Enquanto ainda mantinha vivas minhas expectativas sobre o trabalho de campo nas agências de casamento comecei a descobrir dentro da casa um universo intimamente relacionado ao tema chave daquelas intenções. As complexidades vividas, e a mim apresentadas, pelos amigos em idade para casar ("marriageable age") no que se refere às suas expectativas, ansiedades, preocupações e experiências em relação ao casamento, ao romance e à sexualidade passaram a chamar mais e mais minha atenção, a começar pela inescapabilidade do casamento, isto é, o fato de que as famílias não vislumbram para seus filhos a possibilidade de uma vida sem o casamento.

Essa assunção está introjetada entre a maioria de meus amigos e se coaduna com as pesquisas de Uberoi (1993; 2006), Mody (2008), Grover (2011) e Pappu (2011), 
dentre outros. Pappu argumenta mais diretamente sobre a quase impossibilidade de permanecer solteiro ou solteira devido ao estigma social dirigido à solteirice ("singlehood"). 0 caso da mulher solteira seria particularmente delicado. Segundo a autora, a mulher não casada é simultaneamente impensável e um enigma. Implícita no termo solteira está a referência à ausência de uma figura masculina e à ausência de relações sexuais sancionadas com um homem. Em suma: a mulher solteira é aquela a quem falta algo, isto é, um marido. 0 enigma ao qual se refere a autora é a ideia de que há algo errado com a mulher que não se casou. Presume-se que haveria algum problema que fez dela incapaz de arranjar um marido. Várias são as categorias agrupadas nos termos single e unmarried: mulheres viúvas, divorciadas, abandonadas pelos maridos e as que nunca se casaram. De todas elas, no entanto, as últimas figuram como uma anomalia. Há um reconhecimento social dispensado às mulheres viúvas, abandonadas e mesmo às divorciadas que não existe no caso da mulher nunca casada.

De acordo com Uberoi, a condição de pessoa (personhood) é alcançada, no caso das mulheres, mediante o casamento (Uberoi, 2006: 93). Biswas (2011) aponta, nesse sentido, que o casamento é uma instituição usada pelo estado para controlar a intimidade entre as pessoas e, ao mesmo tempo, forjar sujeitos através dos "estados civis", que na Índia marcam e tangenciam as relações entre as pessoas e suas interações com o Estado. Termos como second wife; mistress; divorcée e deserted woman disseminariam normas hegemônicas de formação de sujeitos (Biswas, 2011).

Ainda solteiros, meus amigos demonstravam a força e a vigência do sistema de casamentos arranjados, o qual tem um peso normativo do ponto de vista sociocultural na sociedade indiana. Uberoi (1993) chama a atenção para o fato de que nas aulas dos cursos de parentesco os alunos invariavelmente dirigiam a discussão para o casamento, mostrando que mesmo jovens acadêmicos não estão livres da pressão dos pais na direção do casamento. A autora cita a consciência dos jovens frente às questões que o casamento suscita:

"The ambivalent attitudes to the study of family and kinship in India tend to surface conspicuously in the classroom situation, and to become focused in particular on the institution of marriage. For every post-graduate student in an Indian classroom is aware that marriage partners are being urgently sought for them by their friends and relatives; that a mature girl's reputation and virginity are subjects of constant scrutiny and public comment; that their chances in the marriage 'market' have already been decided by their academic choices; that a male student's success in the competitive 
examinations will entitle him to a dowry of several hundreds of thousands of rupees; that in any case the final clinching of a marriage deal will involve material trade-offs of considerable dimensions; that wife-givers in these arrangements will be expected to pay ritual respect and substantial periodic prestations to their wife-takers; and that for women it will often mean a traumatic rupture of primary kin relations and a difficult process of adjustment to a subordinate status in a family of strangers." (Uberoi, 1993: 2)

Comecei a observar o modo como as pessoas com quem convivi se colocavam frente ao imperativo das famílias que pretendem casá-los: ora desejando e ansiando, ora rechaçando e tentando retardar o processo de arranjo de seus próprios casamentos, bem como, em alguns casos, tentando convencer os pais a acatarem suas escolhas para os cônjuges. Algumas dessas pessoas experimentam relacionamentos amorosos que contrariam a vontade dos pais, invariavelmente ocultados da família, que permitem vislumbrar processos correntes de mudanças na moralidade e nas práticas relacionadas ao casamento, ao sexo e ao romance naquele país. As atividades que desempenhávamos juntos acabavam por mostrar, mesmo em pormenores, a moralidade indiana dominante no que diz respeito a essas instâncias. Foi na companhia de meus amigos que fui aprendendo a reconhecer as diferentes paisagens morais de Délhi.

Durante os passeios, por exemplo, no primeiro daqueles lugares que fomos conhecer, havia placas pedindo aos visitantes que mantivessem o decoro no interior do complexo de Purana Qila. Guardas com apitos sinalizavam para jovens casais que voltassem quando adentravam ruínas de palácios. Fui descobrindo nesses eventos que o assunto que me interessara, ou seja, os casamentos, estão inseridos num escopo mais abrangente: o da moralidade. Uma moralidade que não encoraja intimidade, namoro ou romance pré-conjugais. Que cerceia o contato físico ou a proximidade com o sexo oposto por meio do purdah - prática de uso do véu para cobrir a cabeça em templos e frente aos familiares do marido e que também designa a separação (seclusion) entre mulheres e homens que não façam parte da família (Abraham, 2010). Uma moral que tem na etiqueta corporal a obrigação de evitar a demonstração de afeto em público, mesmo após o casamento, coibindo beijos, abraços e mesmo o andar de mãos dadas, a não ser entre pessoas do mesmo sexo, como é tão comum vermos nas ruas da Índia entre dois garotos. Desde 2009, eu observara que a demonstração mais efervescente de carinho em público entre pessoas do sexo oposto eram os olhares apaixonados que casais trocavam numa praia de Trivandrum onde, completamente vestidas com sáris e salwar kameez, as pessoas ficavam a contemplar o pôr-do-sol. Tais olhares, profundos, tem um nome em hindi (nazar) que aparece na literatura e na poesia sobre o amor na Índia. 
Embora mantendo a heteronormatividade, a etiqueta indiana do contato corporal público permite a proximidade dos corpos de mesmo sexo, o que não leva, contudo, a uma leitura das mãos dadas ou do andar abraçado entre dois rapazes como um comportamento que remete à homossexualidade. A heteronormatividade no território indiano está inscrita não só na moralidade, mas na lei que prevê como ilegal o ato sexual homossexual. ${ }^{13} \mathrm{~A}$ letra da lei diz que a penetração sexual entre dois homens é tipificada como crime passível de punição de prisão. Uma lei que não considera, desse modo, crime o ato sexual entre duas mulheres, não porque essa relação seria permitida, mas porque sequer teria sido cogitada pelo legislador, conclusão a que chegamos Pryia, Anirudh e eu numa longa conversa sobre essa legislação.

Nos clubes noturnos, nos parques e jardins abertos, nos cinemas, nas ruas e nos shoppings, nunca avistei pessoas de sexo oposto de mãos dadas, abraçadas ou se beijando. A exceção eram casais estrangeiros no Bromfy nas noites diaspóricas e, vez ou outra, um rapaz indiano com uma moça branca, nunca o contrário. Jorge, o colombiano, certa vez tentou beijar Pryia enquanto dançavam. Ela se afastou dele, que havia bebido, e, logo em seguida, ambas fomos embora do local. Rapazes indianos, que também haviam bebido, algumas vezes tentavam se encostar ou tocar com a mão partes de meu corpo, de Pryia e de suas outras amigas estrangeiras. Jorge sempre falava da atitude desses rapazes nos jantares da PG, em tom debochado e dizendo que nunca vira tal coisa em lugar nenhum do mundo:

- Guys that instead of trying to talk to girls start trying to touch them against their will.

Após essa noite, ele não podia mais dizer essas frases que irritavam os moradores indianos da PG, pois ele tentara beijar Pryia ainda que ela demonstrasse não querer beijá-lo, mas apenas dançar com ele. Ainda assim, todos os estrangeiros com quem conversava sobre o assunto achavam extremamente estranho o comportamento dos rapazes indianos nesses clubes. Pryia um dia disse que eles faziam isso porque achavam

\footnotetext{
${ }^{13}$ Trata-se da chamada Seção 377 do capítulo XVI do código penal indiano. Essa lei data de 1860, período em que a Índia estava sob o domínio britânico. A lei criminaliza atos sexuais que seriam "against the order of nature", incluindo atos homossexuais. Em dezembro de 2013, uma polêmica acendeu o país, pois a lei vinha sendo considerada inconstitucional desde 2009, com base em uma decisão da Suprema Corte de Délhi que havia afirmado o ato sexual consensual entre adultos como legal. A Suprema Corte da Índia, no entanto, alegou que era preciso uma lei que alterasse aquele código para que a referida seção fosse revogada. Ainda segundo a Suprema Corte da Índia, essa seria uma questão para o parlamento e não para o judiciário decidir. Desse modo, desde 19 dezembro de 2013 a lei do período colonial está em vigência, o que foi considerado um grande retrocesso pelos movimentos de direitos humanos e pelos ativistas dos Gay Rights no país.
} 
que se estávamos dançando num clube noturno era porque éramos "fáceis", pior ainda no meu caso, pois a visão que paira no imaginário local é de que "white women are easier". Ela também disse que aqueles rapazes que agiam assim eram cheap guys, se referindo ao fato de não serem, como Shubhi e Lovania gostam de dizer, educated ou distinct guys.

Meus amigos foram me apresentando suas experimentações existenciais, as quais permitiriam vislumbrar que não há espaço legitimado socialmente para o romance e a intimidade sexual antes do casamento, algo que alguns de meus interlocutores ansiavam ter ou já estavam experienciando, embora sem o conhecimento das respectivas famílias. Como lembra Uberoi, namoros não são a via para o casamento e não gozam, portanto, de legitimidade social:

"Nobody really expects that adolescent crushes and affairs of the heart will lead through courtship to marriage, despite the celebration of romance in the popular media. In fact, romance has only dubious legitimacy, and marriage, quite clearly, some other function." (Uberoi, 1993: 2)

Não obstante isso, muitos de meus interlocutores experimentavam relacionamentos amorosos que esperavam redundar em casamento. A investigação foi sendo voltada, então, para as vivências desses jovens às vésperas de um momento crucial do ciclo de vida, constituído pelo matrimônio na Índia, à maneira mesmo de um ritual de passagem. Numa espécie de fase liminar, minhas amigas e amigos lidavam com as expectativas pessoais e coletivas - da família e das comunidades - sobre seus futuros que deveriam, normativa e idealmente, incluir um casamento. ${ }^{14}$ Essas pessoas, se, de certo, já não são crianças, também não são ainda consideradas adultas. Morando longe da família e mesmo trabalhando e cuidando de suas finanças, não lhes era permitido cuidar de suas vidas. Era o que Rekha e Patrick me afirmavam sempre. A primeira, logo no começo de nossa convivência no mesmo quarto em 2013, sentenciava:

- Parents are like bosses, they want their children to respect them and do exactly what they want.

\footnotetext{
${ }^{14}$ Nesse sentido, a própria PG faz as vezes de uma comunidade, pois os moradores e os proprietários vivem às voltas com conversas que envolvem a expectativa do casamento das pessoas que ali residem. Mister Kapoor e Shivani, a moça de trinta e quatro anos recém-divorciada, não poupavam conselhos à Lovania em sua busca por um pretendente. Diziam, sem a menor cerimônia, por exemplo, que ela deveria emagrecer para arrumar um bom noivo, já que acima do peso como estava suas chances eram diminuídas consideravelmente.
} 
A participação dos pais em toda e qualquer decisão definitiva para a vida dos filhos, desde o curso pretendido na faculdade até a escolha do cônjuge, é tida como certa e desejável, uma vez que o suposto é que os jovens não sabem escolher, se deixados à mercê de suas vontades seriam levados por sensações como atração física e volúpia (lust), esse o modo como é visto o amor na moralidade hegemônica indiana (Uberoi, 2006; Mody, 2008).

Nesse sentido é que afirmo que as vivências desses jovens são experimentos existenciais que lhes permitem testar e manipular, de modo semelhante a uma investigação laboratorial, o estilo de vida que querem construir pra si. A construção desse modo de vida passa pela conquista do amor romântico, a presença de alguém especial em suas vidas e para quem sejam também únicos, que os ajude a, como pessoas, constituírem-se, também, em indivíduos. A ideia de amor construída, e a mim apresentada, por meus amigos é em muitos aspectos semelhante à noção de amor romântico quanto a várias de suas características e será tratada no capítulo III. Dentre elas destaco, por ora, o ideal do amor como meio para a realização pessoal. A expectativa de encontrar o ser amado e com ele ser feliz numa história de amor é característica proeminente do amor romântico tal como desenvolvido no contexto europeu e espraiado posteriormente para todo o ocidente (Lobato, 1994: 17-18) e, em tudo, semelhante aos desígnios de meus amigos. A maior parte deles, sobretudo as garotas, demoram-se longamente em vislumbrar um amor que traria a felicidade em suas vidas.

Assim é que a PG acabou se me apresentando como uma paisagem privilegiada na qual pude mirar os processos de transformação nos afetos e nos arranjos matrimoniais vividos por jovens abastados provenientes de diversos lugares da Índia. 0 ambiente de maior liberdade da PG em relação a seus lares e cidades de origem, em que pesem as muitas regras do lugar que o impedem de se tornar tão livre, proporciona uma espécie de efervescência existencial que dificilmente eu encontraria se convivesse com esses amigos em cada um de seus locais de residência natal. Esse fato será explorado no capítulo II, mas devemos reter no momento a ideia de que a convivência em pensionatos, alojamentos e outros tipos de moradias temporárias e que congregam pessoas de diferentes origens, idades, formações, afiliações (religiosas, de casta e de gênero) e gostos pessoais forjam ambientes em que as experimentações, o desafiar de velhos hábitos, práticas e regras e a criação de novos estilos de vida são elevados a uma potência máxima, como aponta Serrano (1998). Em sua tese de doutoramento, o autor 
explora as relações sociais que ocorriam dentro da Casa dos Estudantes do Império, em Portugal, onde viviam alunos vindos de diferentes países africanos, ex-colônias de Portugal, e onde se configurou a criação de intelectuais e ativistas que desempenharam papéis decisivos para a formação dos movimentos de libertação de países africanos como Angola, objeto de estudos do autor.

Como afirmei acima, o modo como o trabalho de campo se deu informa a construção do objeto de pesquisa. Se o que fiz foi viver com essas pessoas, essa tese só poderia ser sobre a vida dos jovens com quem convivi, tendo como espinha dorsal as experimentações existenciais que orquestram durante sua formação como pessoas, mais especificamente no campo dos afetos, no modo como se relacionam, ou anseiam se relacionar, amorosamente; no modo como descobrem e exploram, ou não, sua sexualidade; e no modo como definem aquilo para o que não estão destinados, visto que o casamento indiano não depende do amor, mas pelo que anseiam mais que tudo em muitos casos.

Por fim, na última sessão desse capítulo, permito ao leitor entrever como se lidou com o tema do anonimato e do consentimento nessa pesquisa.

\section{Will you say something so embarassing about me? Ou como escrever?}

0 título dessa sessão remete à fala de Anirudh numa noite de 2014 em que, tomando uma cerveja e comendo um tandoori de frango num restaurante chamado Beeryani $^{15}$ em SDA Market, indaguei-lhe se gostaria que eu mudasse seu nome quando fosse escrever sobre ele em minha tese. Com o humor que lhe é característico, respondeu:

- Will you say something so embarrassing about me that I would have to change my name?

- Of course no!

\footnotetext{
15 Biryani é o nome de um famoso prato da culinária Moghul, apreciado contemporaneamente em toda a Índia e não apenas no berço do império Moghul, ou seja, o norte do país. 0 que se encontra em conformidade com o que afirma Nandy (2011) sobre a formação recente da ideia de uma culinária nacional indiana. $\mathrm{O}$ nome Beeryani brinca com a junção das palavras beer e biryani.
} 
- Then no. - e rimos.

Em outra oportunidade havia perguntado a Pryia e Anirudh se poderia falar deles em minha pesquisa, caso eu achasse que devia. Ambos se entreolharam e Pryia disse rindo:

- Our lives are so uninteresting that she is considering not writing about us.

Foi nesse clima de negociações sobre a aparição dos momentos que vivemos juntos e das histórias que me contavam que se deram as permissões para que eu os tomasse como, além de amigos e companheiros da vida que vivi em Délhi, participantes e interlocutores nesse trabalho. Algumas pessoas gostaram da ideia, sugerida por minha orientadora, de poder escolher os nomes que figurariam como seus nesses escritos e o fizeram. Outras insistiram para que eu colocasse seus nomes correntes. Em alguns casos, enquanto conversava com uma dessas amigas, por exemplo, ela me contava algo e pedia que eu mantivesse o segredo - como ficará claro mais adiante, ter segredos faz parte da estratégia para criar privacidade e intimidade, algo fundamental no processo de constituição dessas pessoas de modo mais individual -, então eu dizia:

- But you know that I am intending to write about all these things that we talk about.

Shubhi me respondeu naquele momento:

- But by then I will be married and this will not be a secret anymore.

Desde o princípio todos sabiam ser eu uma estudante de sociologia/antropologia em busca de minha pesquisa de doutorado e faziam perguntas sobre a investigação. Quem nunca passou pela saia justa de explicar sobre o que é sua pesquisa aos chamados nativos, que atire a primeira pedra. No primeiro ano, eu dizia que minha pesquisa era sobre os casamentos arranjados e as formas atuais de matchmaking nos marriage bureaus. No segundo ano voltei pensando nos casamentos por amor e já disse que queria escrever sobre eles, mas sem saber ainda muito bem o quê. Em 2014, após ter defendido o projeto de qualificação, pude responder de modo mais apropriado que gostaria de pensar e escrever sobre as aspirações e as relações amorosas que eles vinham compartilhando comigo. Traduzi meu plano de trabalho para o inglês, o que era 
necessário também para a aprovação da candidatura ao programa de doutorado sanduíche, e enviei a alguns deles que se mostraram interessados em ler.

Um deles, Patrick, mostrou-se tão interessado na pesquisa que ele próprio faz sobre o assunto, que quis assistir ao seminário em que apresentei os resultados preliminares dessa investigação no âmbito do Research Scholar Group (RSG), na Delhi University. Na ocasião, além de assistir e fotografar o seminário - a fotografia é um de seus hobbies - Patrick também fez perguntas quando estas foram abertas aos presentes. Como eu completava meu aniversário de 35 anos naquele dia e havíamos combinado de almoçar juntos tive a oportunidade de receber as devoluções desse amigo sobre meu trabalho, bem como a dos colegas de pós-graduação daquela instituição ao final do seminário durante a sessão de nimboo tchai (chá de limão) que sempre ocorre após as atividades do Sociology Department, numa barraquinha em frente ao bloco do departamento e que pode contar com professores e alunos ou apenas alunos, como era o caso naquele momento.

A ideia de que Patrick já faz pesquisas sobre o assunto desta tese me ocorreu por via das reflexões de Borges (2009) sobre seu trabalho no Brasil e na África do Sul utilizando o que ela chama de etnografia popular. Fazem parte desta noção as ideias de que essa é uma "atuação etnográfica que busca fazer pesquisas junto/com as pessoas que nos recebem em campo, as quais compartilham conosco seu cotidiano de investigação constante" e de que é preciso tomar "os interlocutores de campo como companheiros intelectuais" para produzir de modo equânime a teoria etnográfica, composta pelas teorias do pesquisador, da disciplina e do interlocutor. Observa-se que o papel destinado por ela às teorias nativas não é aquele que Turner (2005) chamou de exegese nativa, por exemplo, e que ocuparia um lugar menor na teoria antropológica, sendo a interpretação mais relevante a do antropólogo treinado para desvelar as estruturas invisíveis a outros olhos. ${ }^{16}$ Depreende-se do trabalho de Borges a colaboração entre pesquisadores brasileiros e sul-africanos e pessoas que vivem nos lugares estudados, tanto no Brasil quanto na África do Sul. O presente trabalho, a depender da fortuna desta autora, intenta seguir o mesmo preceito, ouvindo as teorias que Patrick e

\footnotetext{
16 Cito Borges: "A definição de etnografia popular apresentada neste texto busca esclarecer um tipo de relação de pesquisa em que o antropólogo é apenas um a mais dentre as pessoas que dedicam boa parte de seus cotidianos a fazer perguntas, formular hipóteses, testar alternativas e a inventar teorias a respeito de suas vidas e da vida dos Outros." (Borges, 2009: 23)
} 
outros já desenvolveram enquanto vivem, e ao mesmo tempo pesquisam, o romance e a sexualidade. ${ }^{17}$

Voltando ao tema do anonimato/sigilo na pesquisa, embora eu tenha optado por modificar nomes daqueles que se manifestaram nesse sentido, concordo com Goldman (2003) quando afirma que a estratégia não assegura necessariamente o anonimato. Pela descrição, participantes dessa pesquisa podem reconhecer seus pares. Nesse caso, considero que a escolha de outros nomes, como Patrick, seja mais uma escolha estética que uma vontade de permanecer anônimo. Em outros casos, como apresentei acima, os participantes vocalizaram sua despreocupação total com o tema.

Em tempo, apesar de ter consultado meus interlocutores sobre a possibilidade de incluir suas histórias na tese, concordo com Goldman que a ideia, importada das ciências biológicas, de utilizar o modelo do consentimento informado nas ciências sociais não seja produtiva, ou mesmo possível, por pressupor que "no momento mesmo da investigação, o pesquisador saiba já onde deverá chegar" (Goldman, 2003: 471). Como também afirma Goldman, a opção de utilizar o consentimento informado, por vezes dá ao autor a sensação de que pode dizer qualquer coisa, já que se pediu autorização. Isso não acontece nesse trabalho, todas as histórias contadas têm uma razão heurística para aparecer no texto e não colocam os atores em situação de fragilidade.

Dito isso, no decorrer dos capítulos, em momentos oportunos, continuarei a informar o leitor sobre as colaborações que surgiram no encontro etnográfico vivido nos onze meses de trabalho de campo entre os moradores de uma PG. Lugar que considero, aliás, detentor de um feixe de índices da paisagem moral de Nova Délhi, o que passo a discutir no capítulo seguinte.

\footnotetext{
17 "No caso dos estudos a que me dedico, não tenho 'conhecido mais' do que as pessoas com quem faço pesquisa. Tenho meramente deixado de saber tão pouco. Tenho aprendido o quão compensador é evitar as fórmulas canônicas da 'suspeita'. Aquelas que preenchem as lacunas de nossa ignorância com cadeias explicativas que estão 'para além' ou 'por trás' do que nos apresentam os 'nativos', mas que nós [antropólogos] conseguimos (onipotentemente) enxergar." (Borges, 2009, 39)
} 


\section{Capítulo II}

\section{As pessoas e a paisagem moral na PG}

Este capítulo apresenta e analisa a vida na PG como uma paisagem moral detentora de vários índices da vida urbana entre as classes abastadas no norte da Índia no que respeita à moralidade, à sexualidade, ao romance e às expectativas quanto ao casamento. Exploro os temas da privacidade, intimidade e volição que remetem à chave indivíduo e sociedade num momento de liminaridade - isto é, a passagem para a vida adulta mediante o casamento - e de formação da pessoa. Irei expor e analisar outros temas e noções imbricadas nessa chave, como o controle social e moral por meio de "câmeras de segurança" e assinaturas no caderno da portaria, dentre outros, como índices da vigilância sobre os jovens e suas relações. Pretendo demonstrar, ainda, a diferenciação e a heterogeneidade entre os moradores que, apesar de pertencerem à castas altas e à famílias abastadas, exibem grande diferenciação interna quanto a assuntos como moralidade, romance, sexo e escolhas pessoais.

\section{Preâmbulo}

Na noite de 25 de abril de 2014, desci com Lovania ao piso térreo da PG para apanhar o jantar e encontramos Dileep e Joh, que já faziam a refeição, de pé, próximos ao balcão da recepção. Recebemos a comida de Mitlesh na cozinha e, quando voltávamos para o quarto dela, como as vezes fazíamos, decidi ficar um pouco com os rapazes. Depois que a sala de jantar fora desfeita, os jantares na recepção eram a opção para aqueles que queriam conversar antes de se recolherem a seus aposentos. Muitos chegavam do trabalho por volta das sete ou oito horas da noite e iam direto à cozinha. Nayan, Swarna e Kushibo, por exemplo, adentravam a PG, cumprimentavam quem estivesse na recepção, trocavam algumas palavras, pegavam o jantar na cozinha e seguiam para seus quartos. Dileep, Joh, Kaushik, Anyndia, Rekha e Ashutosh geralmente permaneciam no térreo para fazer a refeição. Sempre que os via jantando no balcão, 
juntava-me para ter a oportunidade de conversar com alguns deles a quem só encontrava nos jantares. Propus a Lovania naquele momento:

Fabíola: - Hey, lets eat here tonight? We can talk to these guys a little bit.

Lovania: - You carry on, I will have my dinner up stairs. Come to my room whenever you finish. - Muito dificilmente ela abria mão da rotina de jantar no quarto, fosse sozinha ou na companhia de Shubhi.

Fabíola: - Do you mind if I stay here?

Lovania: - No, not at all.

Fabíola: - Ok, see you upstairs in some time!

Encostei ao balcão junto aos garotos e ficamos a conversar. Joh começou a importunar Dileep como fazia muitas vezes:

Joh (apontando para Dileep): - This is the man, Fab! This is the CEO of Axioms! He is the capitalism in person.

Fabíola: - Oh, really? Tell me more, Joh. - (risos)

Dileep: - Oh my God! Here comes Joh again. And this is the guy, the Marxist, the old Marxist!

Fabíola: - By the way did you know the CSSS in Kolkata? - perguntei a Joh, que estuda sociologia na Delhi University e é natural de Calcutá, onde fica o CSSS (Centre for Studies of Social Sciences) que conheci em 2009.

Joh: - Oh, yes, "the center"!

Fabíola: - Ya, right "the center"! - (risos)

Joh: - Yes, sure. Of course I know. Had you been there?

Fabíola: - Yes, I did, five years ago. Very nice place, great professors.

Joh: - And did you have classes with Satish Deshpande here?

Fabíola: - No, I didn't. But I do know him, I have seen some of his lectures, but I am not taking classes at DU, just attending seminars and being supervised by Dr. Janaki Abraham. But of course I know professor Deshpande.

Joh: - Oh, man, she knows him, he is the guy! His classes rocks! He knows so much about Marx! She is a Marxist as well, Dileep!

Fabíola: - Wow! Hold on, I never said that, Joh! Of course I do like Marx writings a lot, that's what I said! But I do not consider myself a Marxist. 
Dileep: - Haha... Only you have the courage to say that you're a Marxist, Joh! See, he thinks I'm the capitalism in person, but capitalism is spread everywhere. Here inside this PG itself! Did you know that Kapoor is increasing the rent again? He's a capitalist pig, not me!

Fabíola: - Really? No, I didn't know. I don't think he is going to increase mine, because I am already paying 18.500 rupees. And Lakhan didn't tell me anything.

Dileep: - Oh, yes in your case he must have increased when you arrived. - (risos)

Joh: - Ya, man, you are right, capitalism is inside this place. Also it is control upon our lives. We cannot do whatever we want. There are so many rules...

Dileep: - Yes, everything you find in society you will find inside this place too. Capitalism, hierarchy, control, lack of freedom... - Dirigindo-se a mim: - You wanna know about romance, about love, this is happening here too.

Fabíola: - Yes, I'm sure you are right. I have been paying attention to this. But Kapoor doesn't control our lives, does he?

Joh: - He tries his best, man. He tries his best... Couple of days ago he came to me saying that Krishna told him that the Internet speed was low because I was downloading blue movies in my room.

Fabíola: - What? Krishna told him what?

Joh: - Ya, Krishna told him that he saw me downloading and watching porn from my computer.

Fabíola: - And he really did? I mean did he see you watching porn? Do you guys watch it together? - (risos)

Joh: - No, we don't. Probably there was something on my computer that made him think so and he went to tell Kapoor.

Fabíola: - But if you were [watching porn] how does it concern Kapoor? Is there a rule that forbids watching porn inside PG?

Joh: - No, not watching, but downloading. Because people are complaining that the Internet is slow, so Krishna told him it was my fault. Then Kapoor called me and told me to stop doing that. He told me that if he gets to hear about me downloading blue movies again he would call my dad and tell him about it.

Fabíola: - And what did you tell him?

Joh: - I told him to come to my room and check my computer. I told him that he would not find any blue movies there.

Fabíola: - Why? Why did you tell him this? What you do in your room shouldn't be his problem, no? 
Joh: - Yes, but if he calls my father I'm screwed! My father will be damn mad at me.

Fabíola: - Oh, ok... Now I got you. That capitalist pig! - (risos)

Terminamos o jantar e subimos as escadas. Despedi-me deles no segundo andar, à porta do quarto de Lovania, de onde em pouco corri para meu quarto para anotar, o melhor que pude, toda essa conversa. Nos dias que se seguiram, todos ficaram sabendo desse incidente e as fofocas da semana tiveram do que se ocupar por algum tempo, graças a Krishna e ao próprio Joh, que de tão desesperado com a possibilidade de que Kapoor fosse, de fato, ligar para seu pai, tentava em vão obter a simpatia dos outros em seu favor narrando a história até para os funcionários da casa. 0 que ele conseguiu foi que a história chegasse aos meus ouvidos várias vezes, vindo de pessoas diferentes.

- Yeah, man, I don't know why Joh is telling this story to everyone in PG - disse Anindya quando estávamos no restaurante Beeryani, acompanhados de Rekha e Kaushik.

- He must be desperate trying to figure something out, like if Kapoor is going to tell his father - arriscou Rekha.

A história rendeu, além de risadas e fofocas por algum tempo, a ideia de que eu poderia pensar na PG como uma paisagem na qual encontraria o que se pode encontrar fora dela, na paisagem moral de Délhi de modo mais amplo. Naquela conversa, chamoume a atenção, de imediato, o fato de Dileep enumerar hierarquia entre os demais elementos que estão presentes na vida social e que eu poderia encontrar também ali. Fiquei pensando se no Brasil ou em outro país onde a ideia de hierarquia não seja tão premente essa categoria viria à tona tão facilmente. Provavelmente não, é o que continuo a pensar.

Além da hierarquia, o controle sobre suas vidas e a falta de liberdade foram duas ideias que surgiram nas falas de Joh e Dileep sobre a vida dentro e fora da PG. Passei a empreender então uma busca por outras dimensões da vida de meus amigos que estavam presentes na casa e fora dela, relacionadas ao meu objeto de estudo. Terminei por entender que a moralidade vigente fora da casa é mantida dentro dos limites físicos da PG. Isso talvez se deva ao fato de que, como é explicitado no contrato que os moradores assinam na chegada, a PG é o lar dos Kapoor. 
Utilizando a teoria dos signos de Peirce, tomo a noção de índice ("como um signo que se refere ao Objeto que denota em razão de ver-se realmente afetado por aquele Objeto" (Peirce: 1972: 101)) para afirmar que alguns elementos com os quais me relacionei na PG - objetos, falas e ações - são índices da moralidade corrente nos grandes centros urbanos da Índia contemporânea. A vigilância de mister Kapoor, aqui manifesta sobre Joh, é um índice da paisagem moral de Délhi, pois essa moralidade é o que informa as ações de mister Kapoor, ou seja, é o Objeto que afeta sua atitude, por mim tomada como índice.

A compreensão de signo aqui pode se assemelhar àquela de rituais e eventos como reveladores privilegiados de objetos de estudo, pois "rituais e eventos críticos de uma sociedade ampliam, focalizam, põem em relevo e justificam o que já é usual nela; se há uma coerência na vida social como antropólogos acreditamos, então o tipo de análise que se aplica a rituais também serve a eventos" (Peirano, 2001: 8). Derivam também da análise de situações vividas em campo como eventos duas importantes características, 1) o fato de que, na corrente pesquisa, não se prestou mais atenção ao que as pessoas dizem do que ao que as pessoas fazem, pelo contrário, aquilo que as pessoas faziam foi tão ou mais relevante para minha análise que aquilo que elas diziam; e 2) ao mesmo tempo, esse tipo de análise não separa o dito e o feito como opostos, mas reconhece os ditos como feitos, isto é, reconhece a dimensão pragmática das falas. Disso resulta que:

“Considerando-se esta dimensão básica, é preciso então ressaltar que a etnografia é bem mais que um mero descrever de atos presenciados ou (re)contados - a boa etnografia leva em conta o aspecto comunicativo essencial que se dá entre o pesquisador e nativo, o "contexto da situação", que revela os múltiplos sentidos dos encontros sociais. A ênfase [está] na dimensão vivida como meio de acesso a visões de mundo (...)." (Idem: 11)

Como afirmei no capítulo anterior, o que vivi em Délhi durante onze meses é o que me permite escrever essa tese. Na casa onde vivia, a moralidade dominante me afetava do mesmo modo que fora dela. É por isso que julgo pertinente dizer que as falas e ações dos jovens com quem vivi são também passíveis de ser tomadas como índices da vida dos jovens abastados nos grandes centros urbanos no norte da Índia. Passo a expor nossas vidas dentro da PG na intenção de permitir ao leitor vislumbrar, por meio de índices, a moralidade corrente e a vida na paisagem moral que venho tentando descrever e qualificar. 


\section{Do's and Dont's na PG e em Délhi}



Como se pode ver acima, Do's and Dont's é o que aponta uma placa afixada na entrada do Friendship Park que fica no caminho da PG para o Green Park Market e que diz aos usuários do parque como se comportar ali. Mais de uma vez, apontei a meus amigos a placa enquanto perguntava provocativamente:

- What do they mean with "no antisocial activities"?

Algumas respostas me foram dadas quando passava por ali com Patrick e Rekha, ocasião em que o rapaz disse que significavam "foreplay" e Rekha se acabou de rir, e quando caminhava com Anyndia e Kaushik e estes me disseram:

Kaushik: - You know they don't want people to get cosy in the park.

Fabíola: - What you mean with cosy Kaushik?

Anyndia: - Dude, basically they don't wanna people to make out here, thik hai [ok]? - respondeu Anindya.

Como dito antes, a demonstração física de afeto em público entre um casal é vista como indecorosa, mas, como aprendi, mais que isso, a demonstração de afeto entre um homem e uma mulher é antissocial por relegar a segundo plano as outras relações sociais tidas como mais importantes que aquela entre o casal, isto é, as relações - e as 
decorrentes obrigações - com os pais, com os outros membros mais velhos de uma

família e com a comunidade de modo mais amplo. ${ }^{18}$

\section{Essa mensagem também estava clara em outra placa no interior do complexo} arqueológico de Purana Qila, onde se solicitava aos visitantes manter o decoro naquele local.

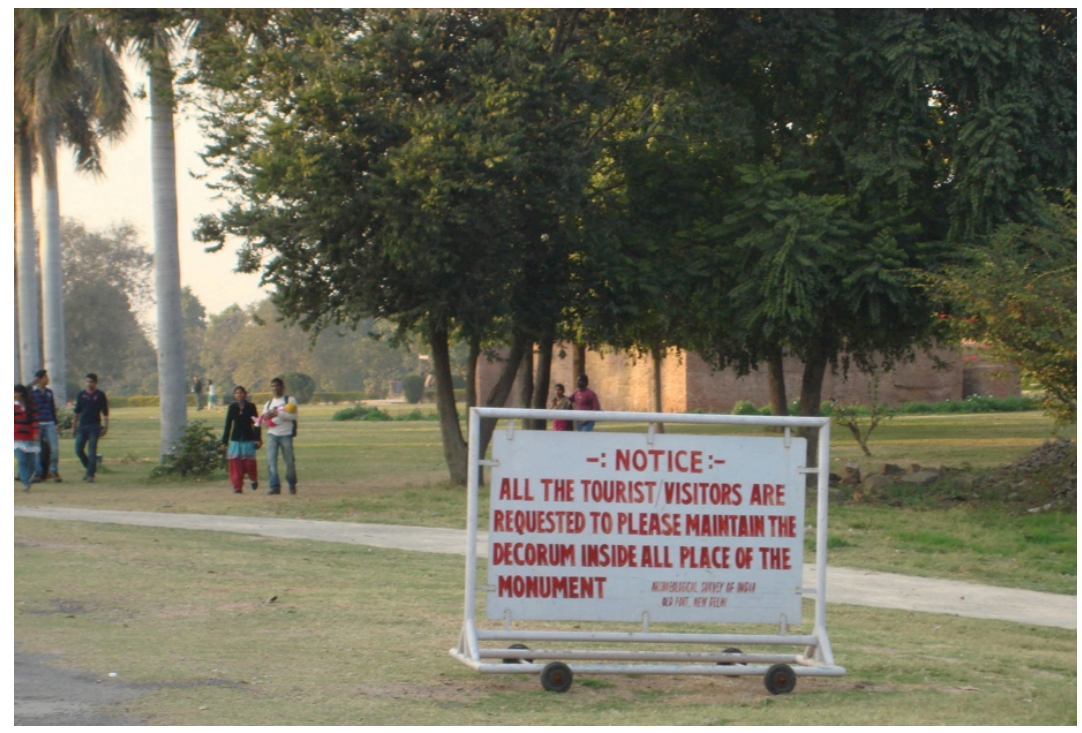

\footnotetext{
${ }^{18} \mathrm{O}$ sentido de comunidade acionado aqui tem mais de uma acepção e pode referir-se à comunidade de casta, comunidade religiosa ou comunidade de vizinhança, no caso das aldeias ou mohallas (vizinhanças em pequenas cidades). As comunidades de casta tem sua existência e importância reafirmadas no parentesco, mediante os casamentos endogâmicos, em momentos rituais os mais diversos como festivais religiosos em que cada casta tem seus próprios ritos e maneiras de adorar seus deuses, em preferências para transações comerciais, na empregabilidade para essa ou aquela atividade laboral, no consumo específico de alimentos e outras substâncias, em encontros familiares etc. As comunidades de vizinhança, por sua vez, dizem respeito às interações sociais que acontecem no cotidiano de uma aldeia ou mohalla, nos mercados, nas ruas, na coabitação de uma mesma paisagem moral, eu diria. Comunidades podem prover às pessoas um sentido de pertencimento, podem prestar ajuda econômica e social aos membros em necessidade e, característica importante para o meu trabalho, comunidades atuam no controle social por meio de estratégias que podem envolver desde o banimento da comunidade até as negociações cotidianas em torno da respeitabilidade, da honra, do prestígio e do status da família ou da pessoa. Segundo Van Wessel (2001) as comunidades, quer de casta, quer de vizinhança, teriam sua importância e o controle social que sempre exerceram nas aldeias diminuídos nas cidades uma vez que outros modos de interação surgiriam, os quais seriam mais individual que comunitariamente orientadas: "In urban middle-class life, there is no caste or village council or village-style social control to be feared. Established morality does place well-defined limits on personal freedom, but this morality is countered by a multitude of messages and facilitating conditions. There are opportunities for education that help to create careers independent from family and community, and individuals and families can quite easily choose to live a life relatively separate from relatives and members of the caste community. Many participate in segments of the labour market where recruitment often does not take place on the basis of time-honoured community membership and credibility but through more diffuse forms of networking and competence, which facilitates a relatively independent functioning of the nuclear family as an economic unit. Surely, the fear of being slandered and rejected by the community is still very much there. Although caste fellows may now often not have the power to harm the economic interests of a family of which a member has married out of caste, the social avoidance that is the core material of social sanction now, is hard to bear. But with all the high sensitivity to prestige and honour that exists, there is also a distinct awareness throughout the middle class that the power of agents of social control is not absolute, and is certainly a lot less than a few decades ago." (Van Wessel, 2001: 121-122). A convivência com os interlocutores em Délhi mostra o quanto o controle social ainda é grande sobre suas vidas, mas a autora pode estar certa quanto ao fato de que na paisagem urbana existem brechas que permitem às pessoas negociar e burlar o controle, algo que meus próprios amigos narravam.
} 
Desde o início, pensei nessas placas como índices da moralidade hegemônica vigente nos espaços públicos por onde eu passava em diferentes lugares de Délhi. Ao assinar meu segundo contrato de paying guest com mister Kapoor, em 2013, resolvi pedir à Lakhan que me deixasse ter uma cópia do documento. Como ele nunca me atendia, decidi tirar fotos do contrato que assinara. Não sem surpresa, notei que vários outros índices estavam inscritos no acordo feito entre hóspedes e proprietário. Um índice do patriarcado aparecia reiteradamente por meio do campo "nome do pai", nos formulários que tínhamos que preencher. Em um deles podia-se ler inclusive "Rajvi Kapoor son of Vickranjit Kapoor" quando da apresentação da parte denominada "the Owners" no contrato. Na apresentação do hóspede, parte denominada "Paying Guest", havia um espaço em branco para o preenchimento do nome e, em seguida, outro campo "daugther/son of" em que o nome do pai, nunca da mãe, deveria ser preenchido. ${ }^{19} 0$ contrato que permitiu construir dados para essa pesquisa, não era alvo de atenção por parte de meus amigos indianos. Enquanto o fotografava Lovania me perguntou o que eu fazia e porque tinha interesse naquele documento.

- Is there something wrong? Any problem with mister Kapoor?

Respondi que não e que apenas desejava ter uma cópia do documento, o que ela pareceu ter achado estranho. Percebi que a maioria dos hóspedes não recebe cópias do contrato assinado e não se preocupam com isso. Ninguém pensava em contestar legalmente as regras do contrato, e isso numa PG em que segundo Anindya, "if you shack the building lawyers will fall from the windows", referindo-se ao fato de que muitos moradores da casa são advogadas e advogados. ${ }^{20}$ Quando perguntei a Anirudh sobre a legalidade do contrato ele afirmou que havia "too many flaws" para que ele, como advogado, levasse o documento a sério. Ao contrário de Anirudh, posso afirmar que muitos moradores o faziam.

\footnotetext{
${ }^{19}$ Todos os documentos que preenchi na Índia (desde os pedidos de visto na embaixada ainda no Brasil, passando por documentos na universidade de Délhi ou até para adquirir um chip de celular) faziam a mesma exigência: o nome do pai ou do marido. Esse é para mim um índice do entendimento da mulher como pertencente sempre a um homem, pai ou marido, que por ela deve se responsabilizar. Em meu caso, eu preenchia sempre o nome de meu marido, pois considerava útil deixar que soubessem que eu era casada. No caso da PG, como os jovens são ainda solteiros, o nome do pai é que era sempre solicitado, para ambos os sexos.

${ }^{20}$ Lembrando rapidamente agora me vêm à cabeça: Anirudh, Kartik, Viplav, Hemanshu, Nayam, Swarna, Ashutosh e a nova moradora que chegou para ser colega de quarto de Maya quando Rekha se mudou para Mumbai.
} 
Eu já havia notado que interditos fora da casa eram também interditos dentro da PG e vice-versa. Desde 2012, eu sabia que não eram permitidas visitas de garotos a quartos de garotas e vice-versa, regra que também consta do contrato. No apêndice B do documento, pode-se ler as "regras da casa", tais como os horários de funcionamento da cozinha e das refeições e outras de cunho absolutamente moral como:

$\square$ No male members in girls rooms and visa versa.

$\square$ All visitors must leave by $10 \mathrm{pm}$ each day.

$\square$ All visitors ID with full proof address must be provided in advance for permission. Please don't bring anyone in at the last moment expecting them to be allowed to stay. Specially late at night. Remember this is our home!! (Os pontos de exclamação constam do contrato.)

$\square$ No alcohol in any of the public places in the building.

A primeira dessas regras é um índice daquilo que chamei a atenção no capítulo anterior quando falava da separação de gênero que deve haver entre pessoas que não são da mesma família. Para manter a respeitabilidade e a honra, mulheres devem ficar protegidas do contato com homens que não façam parte da família. Saavala (2010) analisa as relações entre mulheres e homens em ambientes de trabalho em que os trabalhadores são recrutados das classes médias (white-collar jobs) na cidade de Hyderabad. Ela aponta o quanto o cuidado com a reputação feminina é redobrado quando há convivência direta entre os sexos não regulada por relações familiares, caso similar ao que ocorre na PG, em que mister Kapoor acaba por fazer as vezes de uma autoridade paterna na tentativa de segregar os sexos:

"When educated women enter offices, such as call centres, as workers on par with their male colleagues, the situation demands that women be particularly vigilant to retain their good reputation. Male-female interaction between non-relatives is regulated by avoidance, in North India mostly by the females themselves, and in South and East India, more then in the Hindispeaking North, also by men." (Saavala, 2010: 37)

Lembro que, na casa, os moradores proveem de diferentes regiões do país, e é curioso observar como essas pessoas reclamam da vigilância de mister Kapoor ao mesmo tempo em que dão essa vigilância por esperada, como certa e normal, tanto é assim que quando pegas em delito, as moças e os rapazes se desculpam e imploram a Kapoor que não leve o caso a seus pais, os quais, eles assim temem, poderiam tomar 
atitudes como trazê-los de volta para casa ou acusá-los de desrespeitar e abusar da confiança dos pais, o que por si só pode gerar uma situação bastante indesejada pelos filhos, como Joh apresentava naqueles dias.

Seguindo a análise do contrato, a proibição do consumo de álcool em qualquer espaço da casa, a não ser dentro dos quartos, também é um assunto moral. Como explorei na dissertação de mestrado (Gomes, 2010), a comida e outras substâncias que se ingere têm a capacidade de poluir e também purificar as pessoas. Refiro-me aqui ao conceito de pureza e impureza temporárias (Dumont, 1992), isto é, aquelas que não são dadas pelo nascimento numa determinada casta, mas pela quebra de tabus no curso da vida, por exemplo, pelo contato com materiais classificados como puros e impuros. No âmbito da alimentação, são considerados tabu: as carnes para certas castas; as comidas cozidas, se preparadas por pessoas de castas consideradas inferiores; o compartilhamento de substâncias entre pessoas de diferentes níveis de pureza (por meio dos fluidos corporais, da comida cozida, dos utensílios como copos, pratos ou talheres, dado que são tocados por saliva); e o contato com tecidos orgânicos mortos como o manuseio do couro de animais, cadáveres humanos, animais abatidos, o corte de cabelos e unhas, dentre outros. Incluem-se ainda entre as substâncias poluidoras as bebidas alcoólicas e ingredientes como alho e cebola, visto que são consideradas substâncias que aumentam a libido, a virilidade e o apego material. Esses são considerados hot food e devem ser evitados por certas algumas pessoas, como mulheres e homens viúvos e por quem esteja se dedicando a buscas espirituais. São, por outro lado, indicados para homens da varna Kshatrya, castas de soldados, guerreiros e lutadores, por aquelas mesmas razões: aumentar a virilidade, a agressividade, o apego às paixões mundanas. Como se vê, ingredientes ou substâncias não são puras ou impuras em si mesmas, mas dependem de relações entre as pessoas e das pessoas com as substâncias (Madan, 1987).

Entre os fluidos purificadores se encontram a água por excelência e cinco produtos da vaca (o leite, a coalhada, a manteiga, a urina e as fezes). Como argumentei alhures, a comida e a bebida também compõem a pessoa hindu e são consideradas assuntos morais na Índia. Podem, ainda, expressar pertencimentos de gênero, casta, idade, estado civil e, evidentemente, pureza e impureza. Embora não conste do contrato, a comida na PG é vegetariana, seguindo a dieta dos proprietários, herdada do pertencimento à sua casta, os khatri do Punjab. É vedado, inclusive, cozinhar qualquer 
tipo de carne na cozinha da casa, sendo liberado o cozimento de ovos, leite e manteiga, únicos produtos de origem animal permitidos. A inscrição da interdição do álcool no contrato apenas reitera a moralidade esperada dentro da casa.

A legibilidade dispensável da "lei seca", encontra seu oposto complementar em outra regulamentação que, ao contrário, embora inscrita no regulamento, não tem efeitos previstos ou esperados. Ao final do contrato, lê-se uma frase que, todos sabíamos, figura ali sem nenhuma intenção de ser cumprida:

"We trust you will enjoy your stay in our home. If you have any suggestions please inform Lakhan of any queries".

Um caderno de anotações ficava no balcão da recepção onde Lakhan passava a maior parte do dia. Toda e qualquer solicitação ou reclamação devia ser anotada ali. Para utilizar a ideia de Austin de felicidade de uma locução performativa, nem sempre uma reclamação tinha resultado feliz, não apenas no sentido de ser atendida, mas sequer de ser escutada. Qualquer pedido demoraria a ser atendido, quando o fosse. Por dois meses, em 2012, esperei que o vazamento na pia do banheiro fosse resolvido, mas quando voltei em 2013, e fui para o mesmo quarto, ainda a água respingava em meus pés quando escovava os dentes e lavava o rosto. Também esperamos, Rekha e eu, em 2013, que fosse solucionado outro problema no encanamento do banheiro que fazia a antiga banheira de mármore acumular a água que não descia pelo ralo quando tomávamos banho. ${ }^{21}$ No dia em que escrevi uma reclamação a esse respeito no caderno notei que Amélie, a moradora do quarto antes de mim, havia feito o mesmo ainda no mês anterior. Rekha e eu falamos com Lakhan pessoalmente por uma semana até que ele se cansasse de nós e resolvesse a questão. Graças a isso, achei interessante ler o que outros haviam escrito no caderno. As reclamações acabaram por ter assim uma destinatária insuspeita. Além de reclamações sobre o funcionamento das instalações da casa, sobre ar-condicionados estragados, refrigeradores barulhentos etc., encontrei sugestões como as de Krishna de que o almoço e o jantar deveriam ter outros vegetais que não batata todos os dias; ou de Nayan que reclamava que o café da manhã e o almoço de domingo

\footnotetext{
${ }^{21}$ Acima da banheira havia um chuveiro. Normalmente, porém, utiliza-se um balde e uma caneca para os banhos, tomados no interior da banheira vazia. Eu utilizava o chuveiro, mas minhas colegas de quarto preferiam encher os baldes e tomar banho despejando água sobre o corpo com canecos. Os baldes e canecos se encontravam nos banheiros de todos os hotéis em que estive na Índia, inclusive para o casamento de Shubhi, num hotel bastante caro.
} 
haviam sido convertidos em um brunch servido das oito às doze horas. Ela pedia que as refeições voltassem a ser como eram antes. Nenhuma dessas sugestões foi atendida até o começo de 2015.

Por outro lado, tais inscrições me faziam perceber o quanto o fato de a PG servir comida aos hóspedes era importante. Primeiro por ser como eles dizem "home cooked food", algo que, eu argumentava também na dissertação, é muito importante tendo em vista a capacidade da comida de passar qualidades morais, afetos e cuidados de quem cozinha para quem come, tornando o conhecimento das condições de preparo da comida algo muito importante, que vai além de um cuidado que seria da ordem do discurso biomédico ou sanitarista. Segundo, porque comer em grupo ou com o colega de quarto reforça o caráter de comunidade que a PG emula para muitos que preferem continuar a viver ali em vez de alugar um flat na cidade, como fizeram Pryia, Anirudh, Kartik e Patrick posteriormente.

Os três primeiros verbalizavam explicitamente que o fizeram buscando mais liberdade e privacidade para suas vidas. Pryia me dizia que após os vinte e cinco anos ela se sentia muito desconfortável em dividir um quarto com alguém que não era nem um familiar nem um companheiro. Ela não teria problemas em morar com os pais ou com um marido, se viesse a se casar, mas não queria mais viver tão perto de alguém com quem não tinha intimidade. Pryia já havia dividido quarto com garotas em Londres quando frequentou o mestrado, depois vivera comigo e, em seguida, com Rekha. Após essas experiências mudou-se com duas amigas para um apartamento de três quartos em Malvya Nagar, bairro vizinho de Hauz Khas, também em South Delhi. Segundo ela, a necessidade de privacidade tinha de ser satisfeita com pelo menos um quarto só pra ela, algo que ela expressou quando eu voltei à Délhi em 2013 em uma frase que era mais ou menos a seguinte:

- Once you are an adult it is strange to share your room with people other than your parents or a life partner. I couldn't stand that anymore, I needed some privacy.

Argumentos semelhantes foram usados por Anirudh e Kartik que dividiam um quarto na PG. Em 2012 Anirudh vivia com Hemant. Quando este último voltou à Jaipur para se casar, Kartik, que havia sido colega de faculdade de Anirudh, estava vindo trabalhar como advogado em Délhi e procurando um lugar para morar. Anirudh 
convidou-o para dividir seu quarto e viveram ali por alguns meses até decidirem alugar um flat de dois quartos. Mudaram-se para Green Park Extension, a poucos minutos caminhando do Green Park Market; contrataram uma arrumadeira e cozinheira e recebiam amigos constantemente em sua nova casa. Os senhorios, um casal de idosos que vivia no primeiro andar do prédio de três pisos, exigiam silêncio e que não trouxessem mulheres para a casa. Ambos disseram concordar com as exigências ao firmar o acordo, mas percebendo logo que os senhorios dormiam cedo, começaram a fazer pequenas festas (get-togethers) em casa, tomando sempre cuidado com o barulho nas ocasiões em que lá estive.

Aqueles que se mudaram marcavam sempre que não entendiam por que os jovens que permaneciam na $P G$ o faziam. Anirudh, Kartik e Patrick sugeriam jocosamente a Lovania e Shubhi, as moradoras mais antigas da PG, que elas deveriam ser incluídas na partilha do imóvel que era disputado por Kapoor e seus irmãos, pois já haviam pago tanto aluguel que seria suficiente para adquirir o quarto que dividiam. Quando Anindya esteve em Délhi para o casamento de Shubhi, Lovania seguia morando no lugar após a partida de Shubhi, Anindya lhe disse:

- Dude, you will end up turning yourself into some furniture in that place. Like you will be one more of PG's pillows.

A brincadeira claramente a irritou e ela respondeu que se casaria um dia e então também se mudaria da PG. O fato é que Lovania, bem como outros jovens que residem na casa e ali foram permanecendo ano após ano durante o trabalho de campo, parecem se sentir muito à vontade com as condições de vida na PG que mimetizam a vida de um lar numa joint family ou numa comunidade, incluindo-se aí a não-privacidade, entendida não como ausência, mas como a presença de contato próximo com pessoas que fazem as vezes de família para jovens adultos não casados.

A preocupação com a segurança e com a respeitabilidade é contemplada pela vigilância e pelo regramento do senhor Kapoor. No contrato, nos artigos 11 e 12, podese ler a preocupação dos proprietários com visitantes que não moram na casa, bem como com a manutenção das regras: 
11. "The Paying Guest shall not cause any disturbance at any time and may permit guests or any outsider to enter the premises only with the permission of the Owners."

12. "In the event that the Paying Guest misuse any of the facilities in the premises or causes any disturbance or delays in making payment of the Paying Guest charges, or breaking the house rules attached, this Agreement shall stand terminated forthwith."

0 artigo 12 abre três observações do que pode ocorrer caso as regras do contrato, ou da casa, sejam violadas:

(I) The Paying Guest may at the sole discretion of the Owners be evicted immediately.

(II) The Paying Guest specifically agreed and confirms that the Owners shall be entitled to enter the rooms allocated to the Paying Guest for the time being and to remove all belongings of the Paying Guest and dispose of them.

(III) Security deposit will be forfeited. ${ }^{22}$

Para tanto, bastaria que alguma perturbação (any disturbance) acontecesse. No artigo 15, volta-se a esse tema:

15. "The Paying Guest will adhere to the house rules as per Appendix B provided by the Owners from time to time. These can change without notice. Any breach of the house rules will be deemed as a disturbance."

Em 2013, antes de retornar à Délhi, soube por intermédio de Patrick que câmeras de segurança haviam sido instaladas em todos os corredores e aposentos de uso comum

\footnotetext{
${ }^{22} \mathrm{O}$ aluguel é sempre pago adiantado e paga-se, quando da assinatura do contrato, um seguro, de mesmo valor do aluguel, que só será devolvido ao hóspede no momento da desocupação do quarto. O contrato rege que esse montante seja retido a título de garantia do pagamento do aluguel e de reparo a qualquer dano físico, ou moral, como vemos acima (any disturbance), no espaço da casa. Algumas vezes os hóspedes em mudança se preocupavam se o dinheiro iria ser facilmente devolvido ou não à eles. Elena, uma jovem do Cazaquistão, não recebeu tal depósito porque não notificou Kapoor de sua mudança com um mês de antecedência, como pede o contrato. Anirudh e Kartik levaram mais de dois meses para receber de volta o dinheiro depositado porque Kapoor alegava que como os dois estavam se mudando o valor era alto para que ele levantasse a quantia rapidamente, embora nesse caso ambos tivessem notificado Kapoor em tempo hábil. Nunca tive problemas em receber meus depósitos de volta no dia em que partia. O fato de os moradores serem chamados de hóspedes e não de locatários também se faz presente no contrato, afirma-se, assim, que eles não tem direitos de locatários, são juridica e moralmente, como tento demonstrar, apenas hóspedes da família que pagam para viver ali, daí o termo paying guests. Esse arranjo é bastante comum: minhas amigas e amigos haviam vivido em outros lugares como esse em Délhi ou nas cidades onde cursaram faculdade longe dos pais, colegas da Delhi University me contavam o mesmo.
} 
da casa. Alegadamente elas serviriam para aumentar a segurança, dissera o senhor Kapoor; mas todos assumiam que se destinavam a vigiar os moradores e os funcionários. $\mathrm{O}$ controle sobre os hóspedes, como sugeriam Joh e Dileep, também tinha seus signos indicadores presentes no Apêndice B do contrato:

$\square$ Keys are left at reception before you leave the building. Failing which the locks will be removed.

चEvery one signs the book going out and coming in.

$\nabla$ If you plan to be away at night or for a few days please let us know in advance. In the interest of safety of all our guests we should be aware if there is any issue of any kind. Especially if you have not made it back to home."

O que chamava mesmo minha atenção, no entanto, era a batalha que o senhor Kapoor travava constantemente para manter moças e rapazes apartados, motivo pelo qual as câmeras haviam sido instaladas, na visão dos hóspedes. Desde 2012, casos de meninas visitando o quarto de meninos, e o contrário também, chegavam a meus ouvidos. Foi por Kirti, que um dia veio ao meu quarto e de Pryia em 2012, que ambas ficamos sabendo que Agostina, uma argentina que dividia o quarto com Shine, havia surpreendido a colega com a porta trancada por dentro enquanto Dileep estava no interior do aposento. Uma noite, ao chegar em casa antes do esperado, Agostina encontrou seu quarto trancado com o trinco e, batendo à porta insistentemente, obteve de Shine a resposta de que não poderia deixá-la entrar naquele momento, pois ela não estava sozinha, Dileep se encontrava trancado no banheiro. Shine disse ainda à Agostina que ela poderia voltar em alguns minutos e ele já teria ido embora. Agostina correu até o quarto de Noosha, jovem californiana de ascendência israelense, que dividia o quarto com Kirti e reportou o ocorrido às duas. Assim que Agostina saiu de seu quarto, Kirti veio nos contar o que se passara no quarto de Shine e Agostina no andar térreo da casa.

Em outra ocasião, Patrick teve problemas com mister Kapoor porque, segundo o primeiro, Soumita contou a este último que, passando pelo quarto de Patrick e Dileep para chegar a seu próprio quarto, ao fim do corredor no primeiro andar, vira Lovania e Rekha dentro do aposento dos rapazes. Patrick me contou isso quando retornei em 2013 e esse era o motivo pelo qual ele não falava mais com Soumita. Ele tributava a ela a informação de Kapoor, pois Soumita passou pelo corredor, chegou-se à porta e, deliberadamente, não foi convidada a entrar. Em poucos instantes, Kapoor ligava de 
outro ponto da cidade sabendo que as meninas se encontravam no quarto dos rapazes. Soumita não fora convidada a entrar porque Patrick sabia que tanto Rekha quanto Lovania não gostavam dela. Ele próprio já não gostava muito de Soumita antes disso acontecer, como eu me lembrava de ter ficado sabendo ainda em 2012. À noite, Kapoor foi ao quarto de Lovania dizendo que arrumasse suas malas, pois sairia da PG ainda naquela noite. Chorando, Lovania foi até a senhora Kapoor pedindo que essa intercedesse por ela, para que o senhor Kapoor não a colocasse para fora da casa. Rekha viajara a trabalho antes de Kapoor chegar e, por isso, escapara da bronca. A senhora Kapoor disse à Lovania que iria convencer o marido a não expulsá-la se ela prometesse que isso não tornaria a acontecer e assim se fez, a ponto de ela correr o risco, segundo seus amigos, de se tornar parte da mobília.

Poucos dias depois, era Patrick quem estava no quarto de Rekha e Amélie, jovem francesa que morou na casa vários meses até que Kapoor instalasse as câmeras e a fizesse decidir se mudar - era muito para ela ter um estranho, com quem mantinha relações apenas comerciais, vigiando seus passos no lugar onde morava e pagava o aluguel, foi o que ela disse posteriormente. Depois que ela partiu eu vim a ocupar o quarto com Rekha, mas naquela noite Amélie estava passando mal e Rekha havia chamado Patrick, que sempre fazia as vezes de médico na casa. Quando alguém tinha dores, febres, indisposição, gripe, tosse ou resfriado era a ele que se recorria primeiro para prescrever comprimidos, xaropes, pastilhas etc. Por ser dentista, Patrick entende um pouco dessas coisas, segundo alguns dizem na casa. Assim, Patrick estava no quarto das duas quando recebeu uma ligação de Kapoor para que descesse até a sala de jantar onde se encontrava. Ao descer, o senhorio lhe perguntou, já esbravejando, o que ele estava fazendo no quarto de Rekha e Amélie. Patrick tratou de explicar que a garota ardia em febre e que ele já estava indo buscar um remédio na farmácia do Aurobindo Market quando Kapoor lhe telefonara. Mister Kapoor então mudou sua reação e passou a mostrar preocupação pelo estado de Amélie; disse ao rapaz que corresse até a farmácia e buscasse o medicamento necessário. Não se soube, desta feita, quem teria contado a Kapoor sobre a presença de Patrick no quarto, ou mesmo se ele teria visto algo pelo sistema de câmeras nos corredores. 0 fato é que mesmo com a porta aberta (gesto que tinha a intenção de declarar que nenhuma intimidade sexual ou amorosa acontecia no aposento, que vizinhos/colegas/amigos estavam apenas conversando), sempre que rapazes e moças permaneciam juntos dentro de quartos uma violação na moralidade esperada dentro da casa estaria supostamente acontecendo. 
Eu pensava comigo, se estão só conversando poderiam fazê-lo no terraço, ou no térreo, não contrariando assim as regras da moralidade corrente, digo, de mister Kapoor. Mas, nesse caso, diziam-me, qualquer pessoa poderia chegar e fazer parte do momento de sociabilidade, o que em algumas situações não era desejado. Explico com um caso específico: por essa época, Rekha estava irritada com Viplav por estar se mostrando muito íntimo dela, com toques e tratamentos verbais como honey e sweetheart, que faziam-na sentir-se desconfortável. Esse comportamento começou quando ficavam em grupo no terraço, geralmente na companhia de Amélie, Elena e de outros rapazes, como Patrick, Dileep, Anindya e Kaushik. Desses, no entanto, apenas Viplav se portava do modo que a importunava, o que a levou a evitar a presença dele. Amélie e Rekha passaram a chamar Patrick para ficar com elas no quarto conversando, pois ali Viplav, ou qualquer outra pessoa indesejada, não entraria. Fiquei sabendo então que, embora na noite referida Patrick estivesse cuidando da saúde de Amélie, em outras ficavam os três conversando, assistindo TV e dando risadas.

Em março de 2013, antes de eu chegar a ser colega de quarto de Rekha e depois que Amélie se mudou, Shivani ocupou o quarto por poucos dias. Shivani acabara de voltar dos Estados Unidos porque se divorciara do marido com quem deixara o filho de quatro anos por algum tempo até que a vida dela se estabilizasse de volta à Índia e pudesse ir buscá-lo, o que aconteceu em alguns meses - quando regressei em 2014 o filho estava morando com ela na PG num quarto individual e uma babá vinha ficar a manhã toda com o garoto e levá-lo para a escola após o almoço, já que Shivani trabalha desde que chegou à Délhi. Rekha comentou com Patrick que não estava se entendendo com Shivani, a qual passava por um momento muito complicado, trazendo, involuntariamente, uma atmosfera de sofrimento para a vida de Rekha, para quem já havia estresse e tristeza suficientes em sua própria vida, graças às constantes discussões com o namorado - que se mudaria para a China em pouco tempo - e às pressões no trabalho, onde exerce a função de gerente de marketing numa grande multinacional. Disse que Amélie havia falado bem de mim e, sabendo que eu havia pedido a Patrick para falar com Lakhan e reservar um quarto para mim, perguntou a Patrick o que ele achava de eu ir para o quarto dela e eles arrumarem outro quarto para Shivani. Começou assim uma trama que me envolvia sem que eu dela soubesse até chegar a Délhi em março de 2013. Preciso dizer que contava para a antipatia de alguns na casa o fato de Shivani ser divorciada, a ponto de ser referida com a alcunha "the divorcee lady". Shivani 
contava nessa época trinta e quatro anos de idade. Seu casamento durara pouco, havia sido arranjado, e sobre isso ela dizia:

- Marriage is like lottery: you never know what you will get.

A implicância de Rekha com Shivani era também um índice do estigma que acompanha mulheres divorciadas na moralidade indiana. Rekha pediu à Shivani que deixasse o quarto com o argumento de que havia uma moradora que residira naquele quarto no ano anterior que estava voltando para a PG e desejava ficar ali. Essa pessoa era eu, embora não tenha dito nada à Patrick sobre em qual quarto gostaria de ficar. Shivani se recusou e Rekha e Patrick foram recorrer à Kapoor, que se negou a compactuar com o plano, afirmando que eu ficaria muito bem em qualquer outro quarto e pedindo que deixassem Shivani em paz. Patrick argumentou, no entanto, que Rekha estava tendo problemas com Shivani e que não a queria mais como colega de quarto. Kapoor pediu à Rekha que tivesse paciência, pois Shivani passava por um momento difícil e não deviam importuná-la com mais um dissabor. Sem seguir as orientações de Kapoor, porém, Rekha e Patrick continuaram tramando pela saída de Shivani do quarto. Falaram com Lakhan que foi perguntar à Shivani se ela desejaria ficar em outro quarto. Enquanto isso, Rekha também dizia à Shivani que queria que ela saísse do quarto, que eu chegaria naquela semana e, por isso, ela devia desocupar a parte dela no aposento; Rekha se oferecia para ajudar a fazer a mudança se fosse o caso. Shivani ligou para os pais, que haviam ido junto com ela alugar o quarto na PG, e contou a eles o que estava se passando. Eles então ligaram para mister Kapoor perguntando por que estavam brigando e fazendo sofrer uma moça que já estava tendo problemas demais para se recuperar de um divórcio. Disseram ainda que não era para isso que pagavam o caro aluguel da PG. Kapoor ficou extremamente nervoso e convocou Rekha e Patrick para uma conversa. Contou a ambos da chamada de atenção que levara e disse que se eles não parassem de criar problemas para Shivani iria colocar os dois para fora da casa. Rekha disse então que Shivani finalmente concordara em deixar o quarto e estava já arrumando suas coisas e que eu poderia ficar com Rekha quando chegasse em dois dias. Kapoor disse que estava muito bravo com ambos por terem importunado a moça e que era melhor que eles parassem de tramar coisas, que se eu fosse ficar no quarto e Shivani concordara estava bem, mas se visse Patrick frequentando nosso quarto colocaria nós três para o meio da rua. Foi assim que cheguei em 2013, para ser colega de quarto de Rekha, já com uma indisposição de Shivani em relação a mim e com uma vívida 
promessa de que mister Kapoor colocaria também a mim para fora da casa se visse Patrick em nosso quarto. Promessa que me fazia intuir que mister Kapoor acreditava que havia na atitude de Rekha e Patrick interesse em que eu ficasse no quarto para talvez permitir que Patrick viesse ao quarto, o que Shivani não permitia. Patrick e Rekha não tinham interesse amoroso um no outro, o que o senhor Kapoor não tinha como saber, pois Rekha escondia seu namoro com outro rapaz de quase todos na casa e o relacionamento de Patrick com Shubhi era um tanto velado também.

Após ter convivido com Amélie e, em seguida, comigo, Rekha dizia que não se dava bem com garotas indianas, que havia descoberto que garotas estrangeiras eram mais liberais, menos intrometidas (nosy), que não a julgavam por seu namoro e que respeitavam a privacidade dela. Essa fala me fazia voltar a meus pensamentos sobre o que eu entendia como a falta de privacidade na Índia. Fui entendendo que algumas pessoas com quem convivi também se incomodavam com a falta de privacidade, seja na PG ou fora dela; para outras pessoas, porém, essa falta de intimidade lhes foi imputada apenas por mim e não por elas mesmas.

A privacidade, essa que acionamos quando dizemos "isso é assunto meu, de minha privacidade", e que Rekha acionava para dizer que as meninas indianas não respeitavam, que fez alguns amigos se mudarem da $\mathrm{PG}$, não é, na paisagem moral indiana, um suposto, nem sequer um valor legitimamente estabelecido, a não ser para aqueles empenhados em transformar essa paisagem, caso de alguns de meus interlocutores. Esses, assim como os sujeitos da pesquisa de Yan (2011), estão empenhados em fazer parte de uma transformação, como o autor afirma ao tratar o que chama de deslocamento de uma ética coletivamente orientada para uma ética individualmente orientada na China:

"In everyday life, this is mostly reflected in the legitimization of individual desires for intimacy, privacy, freedom, and material comforts as well as in the actual pursuit of these desires. Unlike the traditional family, in which a person was nothing more than the personification of the family line, the contemporary individual is more interested in his or her personal happiness and the well-being of a narrowly defined private family. This is aptly illustrated for example, by the changing nature of marriage transactions." (Yan, 2011: 9) 
A etnografia que empreendi me faz pensar, de modo semelhante à Yan, que a noção de privacidade expressa a vontade pessoal de que o coletivo fique de fora de alguns assuntos considerados individuais, o que sabemos, embora em processo de mudanças, não faz parte da moralidade dominante na Índia para muitas instâncias, como o casamento, as relações familiares e até as conjugais. Há, nas relações conjugais, apenas um assunto considerado individual, que requer a privacidade e que só deve ser expresso sob essa condição. Trata-se da expressão da afeição amorosa, como afirma Abraham (2011) ao analisar as imagens produzidas nas cerimônias contemporâneas de casamento que contam com inúmeros fotógrafos e camera men que insistem em coreografar poses que representariam o romance nos álbuns de fotografia e nos vídeos de casamento. Para a produção de tais imagens, é demandado dos casais que demonstrem afeto e carinho mesmo quando, em muitos casos, os cônjuges acabaram de se conhecer:

"Often one can see the couple looking very unsure and very embarrassed. It is significant that the public demonstration of affection is in complete contrast to public morality in Kerala in which couples are not to show affection in public or even in their house (other than in the privacy of their room)." Abraham, 2011: 271

Essa foi a noção de privacidade que encontrei reiteradamente em todo o material bibliográfico consultado: a privacidade que permite a expressão da afeição amorosa e que oculta, por conseguinte, a sexualidade como desejo ou expressão do amor conjugal. A sexualidade que pode existir publicamente é, voltaremos a isso, a que diz respeito à reprodução e à maternidade no caso das mulheres. É a essa privacidade, referente à sexualidade, que mister Kapoor vê como sua obrigação cercear. Apesar da vigilância, em pessoa ou através das câmeras e do auxílio dos funcionários que tudo veem e tudo ouvem na casa, o proprietário nem sempre conseguia impedir que relacionamentos proibidos, isto é, relacionamentos sexo-afetivos entre pessoas do sexo oposto, acontecessem dentro da casa.

Lembro que, na moralidade pública indiana, a interdição do contato inter-gênero se faz acompanhar de uma permissividade do contato intra-gênero. Em conversas com Patrick e Pryia, por exemplo, ambos falavam de um aprendizado ligado ao erotismo entre pessoas do mesmo sexo, de descobertas da sexualidade e da iniciação sexual com o mesmo sexo, que não são moralmente reprováveis e nem mesmo consideradas excepcionais ou extraordinárias. Anirudh e Vishnu, um amigo de Trivandrum que veio 
visitá-lo numa ocasião, discordavam veementemente quando Pryia e eu discutíamos isso certa feita na casa de Anirudh. Pryia lhes disse que talvez pela classe social deles, por serem de cidades grandes não reconhecessem a iniciação sexual entre garotos como uma prática corrente. Vishnu se preocupou categoricamente em dizer que o fato de rapazes andarem de mãos dadas, abraçarem-se e beijarem-se na face não significava de modo algum um indício de homossexualidade. Pryia e eu concordamos e sua fala nos fez pensar que o que sugeríamos era lido por Vishnu como uma acusação. O que me levou à leitura de que ele negava justamente a possibilidade que seu contato com outros rapazes fosse da ordem da homossexualidade. Ele não negava a intimidade corporal com rapazes, negava que fosse homossexual. 0 que, para mim, reforça a ideia de que o contato com o mesmo sexo não é visto como excepcional. Quando perguntei a Patrick, em outra ocasião, se ele havia experimentado algum tipo de contato sexual com rapazes ele pareceu receber minha pergunta como algo trivial. Estávamos jogando, em grupo, "Truth or Dare" e, supostamente, eu devia fazer perguntas indesejadas e embaraçosas, mas não foi assim que ele a recebeu. Limitou-se a perguntar: "Are you talking about any experience randomly or penetration itself?" Respondi: “Anything, not necessarily penetration." E ele respondeu: “Then my answer is yes.”

A cada ano eu vinha a saber de mais e mais casos de namoros dentro da PG. 0 primeiro foi o de Shine e Dileep que se relacionaram por algum tempo, antes que o rapaz começasse a evitá-la. Embora ele sempre tenha negado, todos na casa passaram a assumir que havia um romance, e mesmo sexo, entre ambos, devido ao fato de terem sido pegos trancados no quarto por Agostina e à outra ocasião em que Shubhi, Lovania e Patrick voltaram para casa tarde e Patrick encontrou Shine no quarto que ele dividia com Dileep. Shine nunca negou seus sentimentos amorosos pelo rapaz e sua curiosidade por sexo, evidenciada nos interrogatórios que fazia com Agostina sobre o tema e que incomodavam a argentina. Dentre os comentários que ouvi, constava que Shine lhe perguntava de que modo se fazia sexo e pedia para experimentar as lingeries de Agostina.

Logo no dia de minha chegada em 2013, Patrick me contou que ele e Shubhi estavam, nas palavras dele, "hanging around together". Imediatamente perguntei:

- Do you mean like dating? 
- Yes, dating. But be careful with this word in India. I suppose that in Brazil people can go to the movies or go for a dinner and say: I had a date. Right?

- Yes, I think so.

- But here if you say so people will assume that it implies sex too. So be aware, when someone says that wants to go on a date with you, you already know, Indian dates include sex. - (risos)

- Ok, got you! So you were saying that you are dating Shubhi. Regular date or Indian date?

Rindo da malícia de minha pergunta, Patrick respondeu:

- Indian date.

Continuamos conversando do lado de fora de seu quarto, no corredor, enquanto eu tentava avisar meu marido, pelo Skype do computador de Patrick, que já chegara à PG. Patrick contou que ambos estavam namorando desde o final do ano de 2012. Havia, portanto, uns cinco meses que o relacionamento começara. Perguntei se as pessoas na casa sabiam disso. Ele disse que sim, que àquela altura as pessoas sabiam, mas não tinham a exata dimensão do relacionamento deles, pois ambos eram muito discretos. Perguntei se Kapoor também sabia e a resposta foi que, se ele sabia, não haviam sido eles que contaram. 0 namoro de Patrick e Shubhi perdurou por aproximadamente um ano e será tratado no Capítulo III.

Nos anos seguintes, vim a saber que Abgail, uma alemã que morou na casa em 2012, namorara um rapaz indiano também morador da casa e que a moça indiana que dividia o quarto com ela achara preservativos no cesto de lixo do banheiro indicando que ambos estavam fazendo sexo ali. Foi por Abgail que primeiro ouvi sobre a dificuldade que era para casais jovens arranjarem um quarto num hotel na Índia. 0 próprio namorado se recusara a tentar novamente dar entrada num hotel, após ser indagado pelos funcionários do estabelecimento, na primeira tentativa, se Abgail era uma prostituta. Meena, que namora um rapaz inglês desde quando cursaram juntos o mestrado em Trivandrum, também me contou que nas vezes em que deram entrada em hotéis em diferentes cidades da Índia ela fora tida como prostituta. Noto que, em ambos os casos, o casal era composto por um indiano/a e um estrangeiro/a, no entanto, a acusação da prostituição recaiu sobre as moças a despeito da nacionalidade. Sexo antes do casamento só seria feito por profissionais do sexo, é o que parecem afirmar os funcionários dos hotéis quando fazem a leitura da moça solteira que dá entrada num 
hotel com um rapaz. Quando meu marido esteve em Délhi, em maio de 2013, não ficamos na casa do senhor Kapoor, pois isso não seria permitido. Hospedamo-nos no Oscar Hotel, estabelecimento vizinho à PG. Os funcionários não fizeram objeção quando reservei o quarto, mas exigiram que ambos preenchêssemos fichas com nossos dados e documentos de identidade. Essa exigência faz garotas indianas temerosas em dar entrada em hotéis porque, desconfiam, os funcionários do hotel podem contatar seus pais e as delatar. Anirudh me dizia, sobre isso, que, em Délhi, os hotéis que aceitariam alugar quartos para casais jovens sem criar problemas eram os de Pahar Ganj, uma vizinhança que é reduto de turistas com pouco dinheiro (backpackers), da qual a professora Janaki Nair aconselhou-me fugir dizendo que era "crowded and not safe". ${ }^{23}$

Anirudh também me contou, em 2013, que, mesmo com as câmeras nos corredores, ele levara uma garota para seu quarto na casa após descobrir que por algum tempo as câmeras de vídeo ficaram sem funcionar, apenas com a luz vermelha que indica seu funcionamento ligadas, o que se devia ao fato de Kapoor estar economizando nos CDs que eram usados para gravar, isto é, as câmeras estavam ligadas, mas não registravam nada.

Fui percebendo ao longo dos sucessivos períodos de trabalho de campo que, dentro da casa, não obstante a atmosfera de total policiamento moral das atividades dos moradores, relacionamentos amorosos e sexuais aconteciam bem debaixo dos bigodes de Kapoor. Esse cenário parece estar em consonância com o que descreve Grover quando afirma:

"In Delhi's bastis [bairros pobres] and resettlement colonies, representations of romance in popular cinema, awareness of modern state laws that permit inter-caste marriages, and metropolitan freedom combined

\footnotetext{
${ }^{23}$ Em agosto de 2015 uma operação policial na cidade de Mumbai adentrou quartos de hotéis e exigiu provas de que os casais hospedados nos hotéis eram casados, os que eram solteiros foram detidos e levados à delegacia sob alegação de "ofensa pública por obscenidade". As redes sociais e alguns veículos de comunicação indagavam como poderia ser uma ofensa pública se os casais estavam em quartos de hotéis mantendo, portanto, relações de modo privado. $\mathrm{O}$ escândalo repercutiu nacional e internacionalmente como sendo mais uma manobra de policiamento moral ("moral policing") com apoio, e nesse caso execução, do estado indiano. Matérias de jornais que noticiaram o fato na Índia e fora dela incluem: "Mumbai: Cops round up couples from hotels, social media lashes out", acesso em: http://www.hindustantimes.com/mumbai/mumbai-cops-round-up-couples-from-hotelssocial-media-lashes-out/article1-1378176.aspx ; "The latest target of India's morality police: Unmarried couples in hotel rooms", acesso em: https:/www.washingtonpost.com/news/worldviews/wp/2015/08/10/the-latest-targetof-indias-morality-police-unmarried-couples-in-hotel-rooms/ e "Forty couples are dragged out of their hotel rooms by police and arrested for indecent behaviour in Mumbai because they are unmarried", acesso em: http://www.dailymail.co.uk/news/article-3193566/Forty-couples-dragged-hotel-rooms-police-arrested-indecentbehaviour-Mumbai-unmarried.html .
} 
with close-knit urban neighbourhoods are all rapidly enhancing courtship practices." (Grover, 2011: 76)

À medida que minhas relações com os moradores da casa, com amigos seus, e com aqueles que se mudavam e com quem eu continuava a me relacionar foram se adensando, compreendi que o que está em grande parte dos livros de sociologia e antropologia indianos no tocante a relacionamentos amorosos pré-maritais é apenas parcialmente correto. Essas obras não vislumbram o que fui percebendo mais e mais entre meus interlocutores: que os namoros fazem parte da vida amorosa dos jovens nas paisagens urbanas naquele país. 0 que os livros acertam em apontar é que tais relacionamentos não gozam de legitimidade, acabando, no mais das vezes, sendo escondidos e mantidos em segredo da família e da comunidade. Assim é que vim a descobrir que o segredo é uma categoria importante na vida desses jovens.

O segredo é importante, pois ele busca evitar o policiamento moral que não apenas os pais ou mister Kapoor exercem, mas qualquer membro da comunidade também. No caso de Joh e seus blue movies, Krishna foi quem disse à Kapoor que o colega estaria baixando esse material. Quando Rekha e Lovania estavam no quarto de Patrick, Soumita havia, supostamente, sido a delatora. Do mesmo modo que o policiamento moral sobre jovens enamorados em parques e praças públicas acontece por parte de policiais, sem qualquer respaldo legal como argumentam Sen (2010) e Menon (2007), pessoas comuns, isto é, não investidas de qualquer autoridade estatal, vigiam e tentam controlar qualquer ato que considerem que atente contra a moralidade. ${ }^{24}$ Importa ressaltar que investidos ou não de autoridade legal, o que se faz ao controlar a sexualidade por meio da moralidade é exercer poder, como afirma Sen:

\footnotetext{
${ }^{24}$ Sen (2010) e Menon (2007) também exploram o escândalo provocado por uma famosa atriz do cinema indiano quando afirmou publicamente numa entrevista de 2005 que era um absurdo que um homem esperasse ou exigisse se casar com uma mulher virgem. A declaração da atriz causou comoção e indignação da parte de políticos, ativistas do nacionalismo hindu, da imprensa conservadora etc., e gerou protestos de grupos de mulheres do estado de Tamil Nadu, berço da atriz, pois, supostamente, aviltava a moral das mulheres tamilianas. A controvérsia culminou na retratação pública da atriz (Kushboo) e de alguns dos que haviam lhe dado suporte. As autoras também citam a perseguição a jovens casais que ficam próximos ou de mãos dadas em espaços públicos (praças, parques e jardins abertos) por parte da polícia em alguns estados do país. Policiais chegaram a espancar jovens em Meerut, cidade próxima à Délhi. De igual modo, a TV e o cinema com conteúdo erótico ou pornográfico são cerceados ou censurados no país, inclusive com o apoio de algumas divisões dos movimentos feministas indianos, que veem nessas formas de expressão apenas a exploração e objetificação dos corpos femininos e não a possibilidade de uma expressão erótica ou do desejo por parte das mulheres também. Sobre o engajamento de feministas com a censura, ver Ghosh (2008). Em março de 2015, o filme "Cinquenta Tons de Cinza”, que causava rebuliço na mídia mundial, foi banido na Índia e sua exibição nos cinemas foi proibida.
} 
"Sexuality is not a private matter and is linked to public privileges and persecutions; it intersects with gender, law, religion and nationality, directly affecting health and human rights. It is a contested terrain the world over although constructed differently in different places and at different times, it remains a site where power is played out. (...) sexuality as an issue remains contentious, there is a gap between the sexual practices and the legal provisions, it is so deeply 'morally' embedded in the 'neutral' law that this paper shall provide an overview on how recent incidents and the colonial law only reinforce that there are moral and legal codes controlling and recreating sexualities and intimacies in India." (Sen, 2010: 1)

Mais adiante, a autora atesta a ausência de autonomia que os jovens enfrentam em questões de moralidade e sexualidade na Índia:

"There is also an indication [of] how little space there is for individual here, this is evident in individual adults not being allowed to drink in public (because they are women), discouraged from choosing their partners (because of caste endogamy), disciplined to control sexual desires (because sex outside marriage is wrong) and punished for showing affection in public (because Indian culture does not allow a public display of intimacy). Thus, what is culture, morality and, subsequently, proper sexual conduct is at times decided by fundamentalist religious groups or community members or even the courts of law." (Idem: 2)

A ausência de espaço para a autonomia individual em assuntos amorosos e sexuais é uma característica que não foi imputada por mim à socialidade encontrada no campo, mas um direito advogado por feministas do país e por pesquisadores estrangeiros igualmente (Sen, Biswas and Dhawan (2011); Dhawan (2011); Srivastava (2007); Dell (2005); Uberoi (1993; 2006)). Além do mais, o indivíduo como um valor também é tratado na Índia por sociólogos como Béteille (1986), para quem valores como o indivíduo e a igualdade foram incorporados aos valores morais e legais da nação no momento de sua construção e explicitamente expressos na constituição. Nos debates que levaram à promulgação da constituição indiana, os ideais de justiça, igualdade e a autonomia individual, em detrimento da hierarquia do sistema de casta, eram forças motrizes, como indica Béteille:

"If there is an overall design in the Constitution, that design may be said to put equality in the place of hierarchy and the individual in the place of caste. Hierarchical values are repudiated, and the commitment to equality is strongly asserted; but the repudiation of collective identities of the kind on which the traditional hierarchy rested in not as clear as the repudiation of hierarchy itself." (Béteille, 1986: 123) 
Quanto a essa última afirmação, o autor destaca ainda:

"The most striking feature of Indian society today is the co-existence of divergent, even contradictory, belief and values. Hierarchical values are in evidence everywhere; yet people proclaim loudly, and not always insincerely, that equality should be placed above every other consideration. Individuals compete with each other and claim their dues as individuals in a growing number of fields; yet loyalty to caste, tribe, sect, clan, lineage, and family have a continuing, and in some fields an increasing, hold over people." (Idem: idem)

Para Béteille, não há demérito em se debruçar sobre ideias alienígenas. Ele o faz sem desmerecer os problemas que a Inglaterra trouxe para a Índia, e aponta:

"Why should we disregard or devalue certain aspects of contemporary Indian reality on the ground that they had their origin outside India? A society may owe as much to other societies as it does to its own past." (Idem: 132)

Segundo Béteille, assim como no caso da Índia, é possível pensá-la como uma sociedade não estática e homogênea, é preciso olhar para o ocidente tendo em mente seu passado e seu presente. Aqui o autor faz uma crítica a Dumont em seu método comparativo:

"Civilizations do indeed differ form each other, but they also change. Global contrasts become misleading when they direct attention away form historical processes. Hence we must contrast not only India with the West but also the past with the present. We must above all avoid representing a society or a civilization as some kind of unchanging substance that is totally impermeable to influences from outside. The modern world is one in a sense in which the medieval or the ancient world was not." (Idem: idem)

Inspirado em Simmel, quando esse pensador define dois tipos de individualismo no mundo moderno, os quais chama de "individualismo de igualdade" e "individualismo de desigualdade", Béteille afirma que o individualismo ocidental moderno nem sempre tem como consequência a igualdade, concluindo que "social equality and individual autonomy may not be as inseparably linked as they were once believed to be, but it is difficult to see how any modern society [entre as quais ele inclui, obviamente, a Índia] can discard or neglect either of these two ends" (Idem: 128). 0 que desejo explicitar aqui é que o indivíduo e a autonomia individual são valores positivados, não por mim nessa 
tese, mas por autoras e autores indianos antes de mais nada. Do mesmo modo que acredito não estar positivando o individualismo, não desejo romantizar o holismo, muitas vezes idealizado no ocidente como mais humanitário ou menos perverso. Vis somos todos, humanos holistas que hierarquizam e discriminam por casta, ou humanos individualistas que exploram e apartam por classe, raça/cor, etnia etc.

Voltando à Sen, ao controle social e ao policiamento moral, a autora aponta ainda o quanto a lei está perpassada pela moralidade dominante e o quanto a intersecção entre a moralidade e a lei criam noções do certo e do errado e expectativas normativas de conduta, sobretudo, para mulheres:

'A 'good girl' ought to be soft-spoken, polite and obedient. She ought to marry. She ought to be a mother. If she dares to stray a little out of these prescriptions, it is seen as a momentous act of defiance. If she chooses to marry a man of her choice, it can create considerable tremors, and if she decides to marry a girl, it rattles the sexual 'foundations' of society. This image of a 'good woman' needs to be in our minds as we go through the following incidents and analyse how there has been a deviation/challenge from that stereotype. People in India have time and again taken up the morality markers in their own hands. The [analysed] incidents give us an understanding of what behaviour is unacceptable in public spaces. Violence may be inflicted if that norm is deviated." (Sen, 2010: 2) ${ }^{25}$

$\mathrm{Na} P \mathrm{PG}$, exemplos do controle social por meio de certo alijamento do grupo eram também encontrados. No capítulo anterior, afirmei que muitos na casa não gostavam de Soumita por conta de seu comportamento. Como disse, Soumita teve um romance que durou dois anos e que ela revelara a todos, inclusive aos pais. Quando o relacionamento acabou, por conta de brigas com o namorado que seria muito ciumento, Soumita passou

\footnotetext{
${ }^{25}$ Os incidentes a que se refere a autora são - além dos supracitados episódios da polícia abordando violentamente jovens casais em lugares públicos na cidade de Meerut, próxima à Délhi, e a controvérsia envolvendo a atriz Kushboo - o espancamento de mulheres em um pub em Mangalore em 2009, onde uma dúzia de homens do movimento Hindutva (Hinduness) atacaram mulheres que consumiam bebidas alcoólicas no interior do pub "stating that they were going against Indian culture and tradition" (Sen, 2010: 3); expulsões das aldeias e assassinatos de jovens que se atreveram a realizar casamentos no interior da mesma gotra (clã consanguíneo patrilinear) por Panchayats (autoridades políticas locais das aldeias) no norte do país; o fechamento e a proibição de funcionamento de dance bars no estado de Maharashtra em 2005, sob alegações de depravação, ofensa à moralidade pública e corrupção (das dançarinas profissionais que protestaram contra a medida por considerarem que ela lhes retirava o direito ao trabalho que haviam escolhido); e o suicídio de um professor da Aligargh Muslim University em Allahabad em 2010, o qual teria sido flagrado por uma reportagem de TV, com a colaboração da universidade, fazendo sexo com outro homem, razão pela qual teria sido suspenso da universidade e teve sua vida pessoal devassada, levando-o ao suicídio. Em todos esses casos, a autora mostra como as acusações e ações dos perseguidores não tinham respaldo legal, mas as decisões judiciais, ainda assim, não defendiam as vítimas, visto que os magistrados, policiais e políticos envolvidos estão imbuídos mais da moralidade corrente que da legislação vigente.
} 
a dizer aos quatro ventos que "men are dogs!". Descobri aos poucos que o fato de Soumita ter esse relacionamento afetivo em sua história de vida fazia com que algumas outras pessoas na PG a vissem com maus olhos e até a evitassem, embora nunca explicitassem exatamente o que queriam dizer. A este respeito Rekha me falava:

- You just can't be friends with someone like her.

Quando pedi para ela me explicar melhor o que queria dizer, apenas respondeu:

- I don't know, I just don't feel like being her friend or hanging out with her. From the first time I saw her I just felt like that.

Rekha também namora um rapaz de sua cidade - Indore, no estado de Madhya Pradesh. Conheceram-se na escola e foram amigos por muito tempo antes de iniciarem o namoro à distância, pois ele residia em Mumbai quando os conheci e agora reside na China. Diferentemente de Soumita, no entanto, Rekha contava a poucas pessoas sobre seu relacionamento. Por muito tempo, apenas Amélie, Elena, Patrick e eu soubemos sobre Praveen na PG. Depois Shubhi e Lovania também souberam. Por fim, Kaushik e Anyndia tomaram conhecimento por um acidente de comunicação, pois Rekha pôs-se a falar de Praveen numa noite em que bebeu um pouco mais e os rapazes vieram a saber do namoro dessa forma. Soumita, por sua vez, vivia contando de sua experiência de relacionamento e inclusive assumia abertamente que havia iniciado sua vida sexual. Em 2012, eu anotara em meu caderno de campo declarações dela como a seguinte:

- Even in the villages they are doing the crime.

Dizia rindo, ao chamar sexo de "crime". Ela afirmava que os jovens, mesmo nas aldeias, estavam tendo vida sexual ativa escondidos de seus pais, os quais reagiam violentamente quando descobriam o que estava acontecendo, o que na visão dela era uma hipocrisia. Talvez por não ser, segundo ela mesma, uma pessoa hipócrita, Soumita assustasse as pessoas, que dela tinham uma visão negativa por se desviar do estereótipo da "boa garota". Ela não fazia uso do segredo que mantinha os relacionamentos de meus outros interlocutores salvaguardados do policiamento e do julgamento moral. Rekha, por exemplo, nunca falava de sexo quando estávamos em grupo, a não ser para afirmar em alto e bom som que ainda era virgem e que o mesmo se passava com Praveen, o namorado. Caso também de Lovania que, tendo vivido dois namoros anteriormente, 
mantinha-se virgem aos vinte e oito anos de idade, dizendo que só faria sexo com o homem com quem ia se casar, depois do casamento.

Se dentro e fora da casa eu percebia continuidades entre o que meus amigos me mostravam e o que a produção antropológica indiana tematiza, tive certeza de que estava em uma paisagem moral que não diverge do que tem acontecido com outros jovens que acorrem às metrópoles indianas para trabalhar e estudar, ou mesmo que nasceram e cresceram ali, como Ravi, o marido de Shubhi - que será apresentado no capítulo III. Como ficara evidente, o fato de o senhor Kapoor tentar ao máximo e não impedir os encontros sexuais e amorosos dentro de sua casa indica que o mesmo ocorre com jovens que não residem na PG, mas em cidades, com ou sem os pais. Isso se dá em parte porque a cidade provê a possibilidade de mobilidade e anonimato, que permite aos jovens, ao menos aqueles empenhados nisso, experimentar relações amorosas e sexuais antes do casamento.

A vida na metrópole propicia um anonimato que meus amigos afirmam não existir em cidades menores (towns) ou nas aldeias (villages) da Índia, uma vez que nesses lugares a vida pública não se mantém muito apartada da vida privada: todos nas ruas e nos mercados sabem quem é quem, sobretudo se são moças e rapazes de famílias conhecidas. ${ }^{26}$ Sobre a diferença entre aldeias, pequenas e grandes cidades na prática do purdah - entendido aqui como o uso do véu e também como a produção da respeitabilidade pela evitação entre os sexos nas relações interpessoais -, afirma Abraham:

"Furthermore, neighbourhoods in a city are often far more impersonal and differ in the nature of relatedness between residents of a mohalla [vizinhança]. What may differentiate particular city spaces from town spaces is the degree of anonymity and the corresponding difference in the practice and experience of veiling. While the lack of anonymity in a town may be binding in terms of the expectations of veiling for a woman, the fact that people can be recognised on the street means that women often view

\footnotetext{
${ }^{26}$ Os mercados são lugares vivos e comunitários na Índia. Mesmo em Délhi, uma metrópole, os mercados são como comunidades com paisagens morais próprias. O Green Park Market, por exemplo, é um mercado em que, até pouco tempo, não se servia comida não vegetariana e até agora não se serve álcool. Todos os estabelecimentos mais antigos são vegetarianos, as exceções são as recentes unidades do Dunkin Donuts, do Pizza Domino's, do Costa Coffee e do Cafe Coffee Day, redes de lanchonetes e comida rápida. Como discutia na dissertação, a ampla instalação desses estabelecimentos nas cidades indianas a partir da década de noventa, com a liberalização da economia e da política indianas, tem contribuído para acelerar o processo de secularização da alimentação no país. Quando íamos sair em grupo da PG, escolhíamos o lugar de destino de acordo com o que queríamos fazer: para tomar cerveja e drinks, íamos à Hauz Khas Village ou ao SDA Market; para cafés, comida de rua, sobremesas e compras pequenas, o Green Park Market, ou mesmo o Aurobindo Market em frente à PG, estavam de bom tamanho.
} 
neighbourhoods around where they and their parents' live as comparatively safe." (Abraham, 2010: 214)

Tomando a perspectiva dos estudos de antropologia urbana, Abraham afirma que a cidade grande (city) e a cidade pequena (town) difeririam por uma questão apenas de escala. A autora mostra como os espaços urbanos são negociados e gendrados (gendered) em práticas do dia a dia enquanto se define o público e o privado - assim, ela não toma essa dicotomia como dada a priori, mas como produzida nas práticas cotidianas. Para a autora, "understanding the neighbourhood as relational (McDowell, 1999) is therefore critical to appreciating how gender is produced differently across spaces in a town" (Idem: 215). Embora eu tenha encontrado na literatura consultada vasta aceitação de que as cidades diferem das aldeias em socialidade, e eu não negue isso por ter indícios etnográficos, minha aposta aqui é a de que se pode ter uma compreensão maior da vida das pessoas que empreendem um trânsito frequente entre cidades e aldeias no contexto indiano, se atentarmos para, como sugere Abraham, o fato de que espaços são construídos e negociados relacional e situacionalmente. 0 que também sugere Yan, com sua noção de paisagem moral. Espaços e paisagens são compostos e recompostos dependendo de onde, como e quem está envolvido nas transações cotidianas que se dão em tal ou qual paisagem. Como eu dizia no capítulo anterior, a paisagem moral de Old Delhi difere da de Hauz Khas Village por construções históricas e relacionais, de longa data, no caso da primeira, e, das últimas duas décadas, no caso da segunda. Pessoas que frequentam os dois ambientes não se portam, não se vestem e não falam do mesmo modo nas duas paisagens. É difícil em Old Delhi ouvir as pessoas falando em inglês. Naquela vizinhança e em outras chamadas de tradicionais, eu me desdobrava ao máximo para fazer render minhas lições de hindi, sob pena de não ser entendida quando pedia por indicações ou quando comprava algo. Nesse último ponto, aprendi com Amélie que eu tinha mais chances de não ser explorada nos preços quando negociava em hindi. Já em Hauz Khas Village, era majoritariamente em inglês que as pessoas se comunicavam.

Nesse sentido, o que eu vislumbrava em Délhi é que jovens do sexo oposto se permitiam frequentar parques, jardins, praças, monumentos históricos abertos e terem alguma intimidade amorosa contando com o anonimato da metrópole e com a diferenciação na paisagem moral dentro da mesma cidade. Nas ruínas de Hauz Khas Village, por exemplo, era extremamente comum avistar moças e rapazes sentados à grama, ou em partes das antigas construções, de modo bastante próximo: com os 
ombros se tocando; com a mão de um deles repousando na perna do outro por alguns momentos; tirando fotos abraçados - abraços que duravam o instante do clique fotográfico - ou, muito comumente também, a garota posando para a foto tirada pelo rapaz; conversando baixinho; uma vez ou outra, avistava um rapaz deitado com a cabeça no colo de uma moça. Cenas como essas são tão comuns que aparecem na descrição do lugar em blogs e sítios da Internet sobre os lugares turísticos de Délhi. Logo que cheguei à cidade em 2012, quando ainda não a conhecia bem, consultava sites para ver fotos dos monumentos e saber um pouco mais da história dos lugares. Foi assim que li, numa página sobre Délhi, a respeito da invasão de casais românticos em Hauz Khas:

"As I tiptoed inside the dark chambers and halls of the madrassa [escola muçulmana], I found the corners teeming with loners, friends and lovers. Most were lovers. Those whom I talked to had no idea of Hauz Khas's history and they didn't care. What mattered was that the place was secluded and there were remote chances of parents catching them 'red-handed'. I met two smokers from Karol Bagh, a giggling couple from Jamia Millia Islamia University, a love-struck pair from a Ghaziabad engineering college, two lovers from Shahdara followed by yet another couple and one more couple and a couple again and then also a couple and a couple too and yes one more couple and no, I'm not exaggerating." (extraído do blog "The Delhi Walla", postagem do dia 06 de maio de 2009, por Mayank Austen Soofi) 27

Como o autor da postagem afirma, casais jovens procuram esses ambientes fiando-se no anonimato, isto é, na esperança de que seus pais, pessoas conhecidas ou mais velhas não os encontrarão nesses lugares improvisados para intimidade e privacidade, a céu aberto e livres à visitação. Os lugares que são citados como de origem dos jovens no excerto não são próximos, o que indica que os casais, provavelmente, teriam chegado ali de metrô, mobilidade que ajuda no anonimato. No ano seguinte encontrei, em outro blog, a indicação dos melhores lugares de Délhi para encontros amorosos. A postagem intitulada "5 Best Parks in Delhi for Couples to Romance" aparece no sítio Insight India: a travel guide. Ali pode-se ler uma introdução destinada tanto aos casais que procuram os parques para namorar quanto aos possíveis turistas estrangeiros para que não se assustem e entendam o contexto que faz casais jovens indianos procurarem um parque a céu aberto para ter intimidade:

"Young and looking for a place to get cosy with your lover? Are you in Delhi? If answers to both these questions are yes then you need not look

\footnotetext{
${ }^{27}$ Acesso em: http://thedelhiwalla.blogspot.com.br/2009/05/city-guide-hauz-khas-near-green-park.html
} 
further. To our oversexed readers, we present a list of 5 best parks in Delhi for couples to romance. Keep in mind that the thoughts presented in this post are strictly our contributor's. If you happen to be visiting Delhi from abroad, especially Europe or any of the 2 Americas, it is logically assumable that you are already shocked by the city's cultural idiosyncrasies. Yes, although a little difficult to digest, Delhi is a cultural hypocrite! She will impress and disgust you in equal measures. Since the premise of this post is couples and PDA (Public Display of Affection) in Delhi, let's just say public tolerance towards couples' hormone laden gestures of expressing love and affection varies in congruence with Delhi's multicolour demography. To sum it all, it depends! Let us first understand the definition of PDA in context of the Indian psyche."

Prossegue o autor oferecendo sua definição de "demonstração pública de afeto" no contexto de Délhi, ainda presumindo os leitores estrangeiros e locais:

"It's pretty much the same as in the West, the only difference here is that even kissing/smooching/snogging is considered equally taboo. Indians, particularly Delhiites [pessoas de Délhi], have a weak palate for absorbing love (read horRekhally) crazed puppies trying to draw the world map on each other with their bare hands. Delhiites can be particularly unforgiving if they catch you in the middle of "the act" and will not hesitate to give you a giant piece of their mind, all the while threatening to report the matter to one or both your parents. So what do the average, desperate Delhi couples do to, well, "nurture the flower of love"? Easy sleazy, they visit any of the several notorious couples' parks in Delhi and indulge in uninhibited, unabashed celebration of their emotions! If you too have been looking for some places in Delhi for couples, you could not have landed at a better place! For readers' convenience, the 5 parks have been presented as a countdown in ascending order of notoriety." 28

O que se segue na postagem é a descrição dos lugares tidos como os melhores para um encontro amoroso - incluindo o complexo histórico de Hauz Khas -, indicações de como chegar ao lugar, como a estação de metrô mais próxima, e um item chamado "risk quotient", que diz respeito ao risco de os casais serem pegos pela polícia ("policeman"), pelos guardas do lugar ("security guard") ou por um transeunte obstinado em vigiar a moralidade ("there might be the odd Uncle lurking somewhere!").

Dentre os achados em buscas na Internet sobre o controle social imposto aos casais jovens na metrópole e suas táticas para burlar a vigilância e conseguir ter momentos de intimidade, o que mais chamou minha atenção foi a notícia de um jornal que dava conta de um escândalo envolvendo funcionários do metrô de Délhi alugando

28 Sushant Sharma aparece como autor da postagem. Acesso em:
http://insightsindia.blogspot.com.br/2013/07/best-parks-delhi-couples-romance.html 
banheiros públicos para que casais tivessem alguns momentos a sós. A manchete intitulada "Rooms inside Delhi metro stations rented out to couples", explicava que funcionários da limpeza do metrô haviam sido flagrados por uma reportagem fazendo tal barganha:

"The sting CD showed a toilet cleaning staff member demanding Rs 500 [rupees] from a reporter who posed as a customer asking for space in the station's washroom for him and his woman friend. The attendants then revealed that rooms inside the station could be rented for Rs 300-500 [rupees] per hour. The sting operation was reportedly carried out at several Delhi Metro stations including Race Course, Paschim Vihar, Ashok Park, Green Park and Madipur." (The Times of India, 18 de setembro de 2013) ${ }^{29}$

As informações transmitidas nesses veículos midiáticos davam exemplos do que eu lia na literatura antropológica sobre as possibilidades ofertadas aos jovens casais em relações pré-conjugais nas cidades. Elas me falavam, ainda, do que um dos jornais chamou de "couples seeking privacy" em Délhi, no episódio do aluguel dos banheiros nas estações do metrô. ${ }^{30}$ Tanto as falas de meus amigos quanto algumas leituras que fiz estavam em consonância com a ideia da cidade como um lugar para a liberdade, assim expressada por Gupta:

"'City air makes free' was true for India, not in a legal sense as in medieval Europe, but in a more general manner. Towns could provide opportunities and a break with the past. This has been seen over the last hundred years. (...) Ascriptive status, as understood until the mid-twentieth century, divided urban dwellers on the basis of the manner of speech, apparel, and social mores. Today, the marker of class divisions is income - proclaimed by lifestyle and location of home." (Gupta, 2003: 469)

É preciso ter em mente que é nas cidades que surge a chamada "nova classe média" indiana. ${ }^{31} \mathrm{E}$ a autora nos lembra que a cidade liberta, mas também separa por

\footnotetext{
${ }^{29}$ Acesso em: http://timesofindia.indiatimes.com/city/delhi/Rooms-inside-Delhi-metro-stations-rented-out-tocouples/articleshow/22672732.cms

${ }^{30} \mathrm{O}$ episódio foi noticiado, além de pelo The Times of India, por vários dos jornais de grande circulação como o Hindustan Times (acesso em: http://www.hindustantimes.com/newdelhi/delhi-metro-workers-renting-out-roomstoilets-to-couples/article1-1123532.aspx); o India Today (acesso em: http://indiatoday.intoday.in/story/couplesrent-toilets-at-delhi-metro-stations-dmrc/1/310310.html) e o First Post (acesso em:

http://www.firstpost.com/india/sting-reveals-delhi-metro-staff-renting-out-rooms-to-couples-seeking-privacy1117215.html).

${ }^{31}$ Saavala (2010) e Van Wessel (2001) definem a "nova classe média" indiana como aquela formada no período pós-liberalização da economia, ocorrida nos anos 90. As novas ocupações laborais implantadas, referentes sobretudo ao campo da tecnologia de informação, e o sistema de contratação dado pelas regras do mercado e não mais pelo recrutamento com base nas castas, bem como a mobilidade social que essas mudanças incentivaram
} 
classes. Para os efeitos de meu argumento aqui, importa ressaltar que viver naquela metrópole, com a subsequente distância dos pais, permitia àqueles jovens mudanças de comportamento, de vestuário e de consumo, o que pude perceber de um ano para outro na PG. Os jovens que conheci, sobretudo as garotas, recém-chegados de seus lugares de origem usavam, majoritariamente, roupas "étnicas" e/ou roupas "comportadas", saíam pouco de casa para lazer e alimentação, alguns chegavam mesmo a pegar sua comida na cozinha e ir comer no quarto, evitando muito contato com os demais moradores. Quando voltei em 2013, essas mesmas pessoas estavam usando muito mais roupas ocidentais (que chamam de western clothes, em oposição às Indian clothes) ou roupas mais justas e curtas, saíam à noite, iam ao cinema e frequentavam os malls para fazer compras. Como numa tarde em que passeávamos por DLF Promenade - shopping de luxo num complexo que abriga outros dois shoppings, incluindo o DLF Emporium, referido como um dos mais caros da Ásia -, passando por uma vitrine repleta de lindos sarees e salwar kameez, Shubhi comentou em tom de desprezo:

- Indian clothes, who wears that?

Mudanças como essas não eram alvo de vigilância por parte dos Kapoor, que não interferiam no modo de vestir, nem nos horários de saída e chegada da casa, desde que preenchêssemos o caderno com nossas assinaturas. Tampouco éramos vigiados quanto ao consumo. Todas essas instâncias são, no entanto, segundo meus amigos, vigiadas pelos pais. Shubhi, Rekha e Lovania me diziam como os pais não permitiriam que saíssem à noite do modo como faziam na PG.

- Here I can take my car, with whomever I want and go and come whenever I want. This is totally different in Chandigarh when I stay with my father - disse-me Shubhi em uma de nossas frequentes conversas em 2014, ano em que convivemos mais.

Anirudh e Anindya, embora os pais soubessem que ambos bebiam e fumavam, jamais o faziam na presença deles, pois seria um acinte:

fizeram nascer essa "nova classe média". Meus interlocutores não se incluem nessa categoria. Até onde pude averiguar eles proveem de famílias abastadas desde, pelo menos, a geração dos avós e de castas consideradas altas (upper caste). Em suas falas, aparecem indicações desse pertencimento de classe e de casta, como será tratado ainda neste capítulo. Para as duas autoras, o que caracteriza as classes médias seria a combinação de um poder aquisitivo, expresso pela ocupação profissional, pela posse de bens e pelo padrão de consumo, e, ainda, por valores morais específicos, esse o cerne da discussão nos dois trabalhos. 
- My father doesn't care, he used to drink when he was young, but my mom would take it as a provocation - disse-me Anirudh mais de uma vez. A ausência da vontade de casar era mais uma provocação que a mãe de Anirudh imputava ao filho, como veremos no quarto capítulo.

Lovania, em 2015, quando me contava como conhecera outras amigas que estavam presentes no casamento de Shubhi, as quais haviam morado com elas em outra PG, também em Délhi, mas em anos anteriores, falou-me de como a PG de mister Kapoor era melhor que as de antes:

- This place is a heaven. It's a bless to live in this place. No one bothers if you are going out and in at night, and it's clean and spacious like no other place that I lived in here in Delhi.

Como eu pude observar, os pais bem que tentavam continuar a exercer controle sobre a vida dos filhos. Morando há uns oito anos fora de casa, desde a graduação cursada em Davangere, no sul do país, Patrick recebe todos os dias uma ligação de seu pai. Lovania, Shubhi e Rekha também falavam com seus pais diariamente. Shubhi me contava que se ela não conseguisse atender a ligação do pai, ainda que, por vezes, em meio ao horário de trabalho, como secretária executiva de uma empresa chinesa que trabalha com implementação de infraestrutura na Índia (construção de estradas, aeroportos, portos etc.), era certo que iria escutar uma bronca tão logo o pai conseguisse lhe falar. Segundo ela, o pensamento do pai é de que não importa o que os filhos estejam fazendo, eles devem sempre se lembrar de que o compromisso com os pais vem primeiro.

Os jovens que vi chegar à PG haviam vindo com os pais ou com um irmão mais velho. Em uma ocasião em 2013, eu estava lendo no interior da suíte que dividia com Rekha quando Lakhan bateu à porta. Ao abrir, vi que estavam com ele um rapaz e sua irmã. Lakhan disse que estavam lá para olhar o quarto, que teria uma vaga em pouco tempo com minha partida. Ambos fizeram perguntas como, por exemplo, se Rekha era uma boa garota, se a comida era bem preparada, se vegetariana ou não vegetariana, se o lugar era tranquilo ou barulhento, como era a vizinhança etc. Essa moça era Maya e ela passou a ser colega de quarto de Rekha quando parti naquele ano. Quando voltei no ano seguinte nos aproximamos, embora ela e Rekha não se dessem de modo algum. Ela bem que tentava, mas Rekha não fazia gosto naquela convivência e não procurava ser amiga 
de Maya. Ao final do primeiro semestre de 2014, Rekha se mudou para Mumbai, graças a uma promoção que conseguira no trabalho. Maya permaneceu no quarto - o mesmo no qual morei, primeiro com Pryia, em 2012, depois com Rekha, em 2013 -, com uma nova roommate. Shivani, mesmo após ter sido casada e ter um filho, também chegara à PG acompanhada da família natal, à quem ela voltara a "pertencer" após o divórcio. Ela quisera ficar em Délhi e não na casa dos pais, numa aldeia em Uttar Pradesh, por achar que na cidade teria mais chances de retomar sua vida. Dizia que na aldeia o julgamento moral por ser divorciada pesaria mais, não só a ela mesma, mas aos pais também. Ela dizia que a vida na América era muito diferente dali e que tinha que se acostumar novamente com a vida na Índia. Eu achava Shivani extremamente corajosa e forte por ficar em Délhi trabalhando e criando o filho pequeno sozinha, mas ela via com incômodo minha visão sobre ela. Quando eu disse a ela que era bom vê-la tão bem ao voltar em 2014, ela retrucou:

- Why? What you mean? I have always been fine!

- I am saying because last year you were looking sad sometimes. At least I had this impression.

- But that was long ago, I had just come back that time. No, no... I am fine since long now...

Não só nesse dia, quando comíamos hambúrgueres na lanchonete Wimpy em Aurobindo Market, mas em outras ocasiões, Shivani fez questão de mostrar que a admiração que eu sentia por ela advinha de certa pena e ela não achava que eu devia sentir pena dela. Eu pisava sempre em ovos ao falar com Shivani, pois constantemente ela reclamava de alguma coisa, mas, se eu mostrasse empatia ela retrucava com certa agressividade defensiva.

Os pais fazem muitas recomendações a mister Kapoor quando vêm deixar seus filhos e filhas. Shine estava "dando trabalho" para mister Kapoor ("troubling his life") em meu segundo período na casa, em 2013. Rekha ouviu uma conversa na sala de estar em que o proprietário explicava ao pai da garota que era melhor ele arranjar outro lugar para a filha morar, uma vez que não tinha como vigiá-la do modo como o pai desejava. Shine se mudou algum tempo depois. Como dito, já em 2012, Shine era motivo de fofocas dentro da PG. Uma noite, por volta das oito horas, Patrick, Dileep, Shine, Kaushik e eu 
passeávamos pela rua no Green Park Market quando Shine recebeu uma ligação de sua mãe. Ela começou a me puxar pela calçada até alcançarmos a cabine de um caixa eletrônico de banco. Enquanto entrávamos na cabine ela me explicou:

- I'm not supposed to be out at this time in the night.

Fez um sinal para que eu ficasse calada e atendeu ao telefone dizendo para a mãe que estava em seu quarto conversando comigo. Colocou-me ao telefone com a mãe, que segundo Shine fala pouco inglês. Disse à senhora, um tanto embaraçada, que sua filha era adorável e que era um prazer falar com ela ao telefone, ela agradeceu e eu voltei o telefone para Shine. Em 2013, Shine já cursava a faculdade de moda em Délhi e as fofocas da casa eram em torno dos namoricos dela na universidade, esse o motivo da preocupação do pai e da tentativa de terceirizar o controle da moça para mister Kapoor.

Acontecimentos assim remetiam meu pensamento a leituras que fiz sobre o modo como os pais vigiam e controlam os jovens na Índia. Uberoi (2006), Grover (2011) e Mody (2008) discorrem longamente sobre como a fase que vai da puberdade ao casamento é fonte de preocupação para os pais e toda a família (irmãos mais velhos, avós, tios). 0 grande "risco" é que uma moça se envolva afetiva ou sexualmente com um rapaz e tenha sua honra, e a da família, destruída; no caso dos rapazes, teme-se que uma moça lhe roube o coração e a obrigação e obediência para com os pais se dilua. Os pais não costumam deixar que as garotas saiam de casa sozinhas, mesmo para ir à escola ou ao trabalho, preferem que haja alguém da família acompanhando-as ou que saiam em grupo com outras meninas. Mody aponta como a enorme difusão atual de telefones celulares no país permite aos jovens driblar um pouco essa vigilância e ter alguma privacidade com amigos e namorados secretos em conversas virtuais. Uberoi também faz entrever como a cultura do namoro (courtship) não goza de legitimidade na Índia, algo que adviria do fato de os casamentos terem acontecido, por séculos, tão logo os jovens estivessem "sexualmente maduros", isto é, tão logo atingissem a puberdade, e ao fato de o amor romântico não ser uma prerrogativa para o casamento: o amor, diz-se, vem depois do casamento, não antes (Uberoi, 2006; Mody, 2008).

\section{Diferenciação e heterogeneidade entre os jovens}


Como não poderia deixar de ser, sou levada a falar, ainda que brevemente, de dois temas sempre presentes no imaginário ocidental sobre a Índia: a religião e o sistema de castas, os quais eu, no entanto, demorei a perceber como relevantes para meus interlocutores.

Como citei no capítulo anterior, Patrick é o único dos moradores de origem islâmica. No primeiro ano de campo, pude notar, certa ocasião, o Alcorão aberto sobre um apoio de madeira em cima da mesa do quarto que dividia com Dileep. No ano seguinte, quando se mudaram para o quarto andar, o livro não estava mais visível e Patrick, que se afirmava não religioso, disse que lia o livro como uma forma de estudo sobre a vida, motivo pelo qual também lia o Bhadgavad Gita que o colega de quarto lhe presenteara, mas que tais leituras haviam deixado de entretê-lo, acarretando o encaixotamento das duas obras por ocasião da mudança de andar.

Joh, cujo nome é Joseph, vem de uma família católica. Não cheguei a conviver com ele de modo que me permitisse afirmar se ele se considera praticante ou não da religião da família em que nasceu. No entanto, sei que seus hobbies são jogar futebol, fumar maconha e ler Marx. Desconfio, por essas características, que ele não seja muito católico.

Todos os demais moradores são de famílias hindus. Dentre eles havia os que iam a templos e/ou possuíam deuses e altares domésticos em seus quartos e os que não apresentavam comportamentos religiosos. Anirudh e Pryia, por exemplo, são de origem brâmane e não demonstram nenhum sinal de devoção hindu. Ambos contrariam, inclusive, a disposição religiosa que veda o consumo de bebida alcoólica e certos ingredientes culinários de acordo com a casta. 0 primeiro come carnes, algo vedado pelas regras dietéticas aos brâmanes, pois as carnes os poluiriam. Em sua casa natal, ele diz não fazê-lo, pois a comida é unicamente vegetariana e, de todo modo, ele agrediria os pais se o fizesse. A única vez em que saímos e ele não pediu carne foi num dia em que seu tio-avô havia falecido. Nesse caso, ele guardou jejum de carnes por alguns dias em luto pelo tio, mostrando que mesmo para ele, que não carrega sinal ou comportamento visível de religiosidade, a comida não é totalmente secularizada. A segunda, por sua vez, embora vegetariana desde o nascimento afirmava ter comido carne por um tempo em sua vida e, por escolha, voltado a ser vegetariana. Ela não abdicava, contudo, de alegrar seu espírito com algumas cervejas ou vinho sempre que saíamos. Em seu caso, outro sinal de ausência de devoção aos deuses é que ela nunca sabia me dizer nada que eu 
perguntava sobre as divindades e os rituais nos templos que visitamos juntas a título de atividade turística em Délhi, Orcha, Khajuraho e Amritsar. Ela me dizia brincando:

- I'm so useless, I can't even tell you about these things.

- Yes you are! - eu replicava jocosamente.

Já Lovania, Soumita e Rekha tinham altares domésticos em seus quartos. Quando cheguei em 2013, o quarto que ocupara com Pryia, em 2012, não era mais exatamente o mesmo, pois Amélie o havia decorado com cartazes de eventos culturais da Alliance Française, onde trabalhava, e Rekha utilizava uma mesa de centro, que eu usara para amparar minha mala, para dispor ídolos de Durga, de Bala Krishna (o Krishna criança), de Ganesha e de Sri Sai Baba (o santo faquir do século XIX, não o guru do século XXI), além de uma foto de sua mãe, falecida há alguns anos. Pelas manhãs, eu podia ver Rekha orando em frente aos deuses e à foto da mãe e, vez ou outra, acendendo um cordão que funciona como pavio numa pequena vasilha de cobre em que ela despejava uma pequena quantidade de manteiga de leite formando uma vela. Shine, Krishna e Kaushik frequentavam os templos próximos à $\mathrm{PG}$, de onde voltavam pra casa com as marcas de tinta vermelha ou laranja na testa, feitas pelo pandit (sacerdote) do templo como uma espécie de bênção. Kaushik se mostrou, desde 2012, o mais erudito de todos eles em conhecimento dos épicos como o Mahabharata, o Ramayana e o Badgavad Gita, dos rituais hindus e até mesmo de astrologia védica (kundali), a qual é usada para prever a compatibilidade astral dos possíveis casais quando dos arranjos para o casamento.

Em 2014, com uma frequência maior na casa de Anirudh, após alguns drinques, esse e seu colega Kartik começavam a discutir mitos hindus. Em uma noite, começaram a fazê-lo para explicar-me sobre os quadros em sua sala de estar, um deles mostrava Shiva e a primeira esposa Sati morta em seus braços. ${ }^{32}$ Algumas vezes eram acompanhados do próprio Kaushik e de Anyndia, que se dizia cético e não seguidor do hinduísmo, mas que nesses momentos acabava por desfilar seu conhecimento do assunto, atribuindo-o à sua origem também bramânica. Nesses momentos, Pryia ficava desinteressada e mesmo impaciente com o tópico das conversas. Quando eu disse, naquela noite, que o deus hindu que mais me interessava era Krishna, Pryia retrucou:

\footnotetext{
${ }^{32}$ O ritual de imolação das viúvas na pira funerária do marido, tratado por Veena Das (1995), tem o nome "sati" relacionado à morte da deusa Sati, que eu não sabia, antes do esclarecimento de meus amigos, tratar-se da primeira esposa do deus Shiva, a quem eu sempre vira acompanhado nos templos de sua segunda consorte, a deusa Parvati, reencarnação de Sati.
} 
- Oh really? The god with several girlfriends? The one that left Radha to her own fate after taking her as his lover?

Pryia não idealizava nem um pouco a história de Krishna e comentei:

- Ya, thinking by this angle... it might be kind of a misogynist myth.

Nesse ponto, Kartik interrompeu-nos com seu bom humor usual, sorrindo ele disse:

- Oh my gosh, she barely knows English but she knows the word misogynist.

Pryia saiu em minha defesa, dizendo que ela pensava sim que Krishna era, de fato, um deus misógino. Essa interlocutora talvez tenha sido a única a nunca se trair na obstinação em orientar sua vida de modo secular em todo o tempo de meu trabalho de campo. Todos os demais, acabaram, em um momento ou outro, demonstrando que viviam de acordo com mais de uma orientação de vida. Anirudh, por exemplo, em outra noite, disse que, às vezes, quando tem um problema a resolver ou se vê compelido a tomar uma decisão, tenta orientar-se pelo Mahabharata, pois segundo ele:

- All the moral dilemmas of this life are displayed there with a wise solution.

Tudo que desejei naquela hora foi que Pryia estivesse lá para contrapor, como fazia sempre, essa afirmação.

Lovania, que não frequentava essas reuniões particulares na casa de Pryia e de Anirudh, explicava-me mitos e rituais de acordo com momentos que passamos juntas, em templos de Délhi ou Udaipur, cidade que visitamos no estado do Rajasthan, e mesmo em seu quarto, ao me falar de que tipo de atividade ela realizava nos poojas diários em seu sacrário doméstico.

Um dia, ao me visitar no quarto em que morei sozinha, ela encontrou um pacote de incensos na poltrona de veludo alaranjado que ficava nesse aposento e pediu que eu os retirasse para que ela pudesse se sentar. Ela mesma quase fez isso, porém, no momento em que ia tocá-los, percebeu que se tratava de uma caixa de incensos e então se conteve. Em seguida, me explicou que agarbatti (incenso) é um objeto usado em poojas e que como ela estava menstruada não deveria tocar nenhum objeto puro, pois estava, ela mesma, impura. Na ocasião, também me explicou que não praticava pooja 
nesses dias, não tocava as imagens dos deuses e deusas em seu altar doméstico e trocava, assim que o período menstrual acabava, os lençóis que usara naqueles dias, não importando que ainda estivessem sem sujeira aparente, pois estavam poluídos pela impureza da menstruação. Ela também me explicava que em sua casa natal, numa joint family, as mulheres não cozinhavam naqueles dias nem iam ao templo.

Quando assistíamos a novelas pela TV, Lovania me explicava porque o personagem que era sogro de outra personagem ralhava com ela na sala de estar por adentrar o aposento sem usar o véu cobrindo os cabelos; as noras, sobretudo recémcasadas, explicava, devem fazê-lo na presença dos sogros e era isso que sua cunhada (bhabi, esposa do irmão mais velho) fazia na presença do pai de Lovania em Rudrapur, cidade natal dela, que, apesar de lá ter nascido, dizia-se sempre Bengali, pelo fato de que sua família, paterna e materna, provinha da Bengala. ${ }^{33}$ Se eu não tivesse convivido intimamente com Lovania pelos últimos três anos não teria percebido que a jovem, diretora de recursos humanos de uma grande empresa de telecomunicações, e que cursou duas pós-graduações, orienta sua vida às vezes pela formação educacional e profissional que seu trabalho requer, outras pela astrologia, outras pela filosofia hindu, e outras, ainda, combinando todas essas sensibilidades, o que ocorre, por exemplo, em sua busca por um noivo, na qual utiliza um perfil num site de matrimônios, flerta com rapazes no WhatsApp e faz novenas para Shiva lhe conceder um bom marido.

Apresento essas passagens da vivência com meus amigos por querer fazer entrever que eles se movem por paisagens morais que divergem, que apresentam matizes, e que eles se comportam de modo a não destoar drasticamente da paisagem moral na qual se encontram e que ajudam a compor. Lembro-me de Krishna, que, em 2013, contava-me que ao visitar os avós numa aldeia na Bengala tinha de comportar-se de modo diferente do habitual na PG para não chamar a atenção. Segundo ele, certo dia, num almoço na casa da avó, pessoas da vizinhança que haviam sido convidadas para um pooja trouxeram comidas prontas em bandejas de suas respectivas casas. Ao final da cerimônia, Krishna provava de tudo que havia sido colocado à mesa quando sua avó lhe disse, reservadamente, que não comesse de uma das bandejas, explicando-lhe horas

\footnotetext{
${ }^{33}$ As grandes diferenças regionais na Índia, enfatizadas tanto pelos autores [Karve (1993); Trautman (1993); Uberoi (1993)], quanto por meus interlocutores, fazem com que, mesmo após várias gerações longe da terra natal, pessoas e famílias se digam punjabi ou bengali ou rajasthani etc. As diferentes regiões deram origem a diferentes grupos de casta também. É fácil, como já mencionado, nas falas de meus amigos, ouvir que essa ou aquela casta é originária de uma certa região. As diferenças regionais estão presentes nas línguas faladas, nas regras de casamento e parentesco, na culinária, nos rituais, nos nomes de deuses (que são chamados ora de Ganesha, ora de Ganapati conforme a região) etc.
} 
depois, quando os convidados haviam ido embora, que se tratava de um prato trazido por uma vizinha de casta inferior à da família de Krishna e que, portanto, poderia fazer mal ao rapaz. Ele, que dizia não acreditar nessas coisas, escandalizou a avó ao provar do prato e dizer que mostraria assim que ela estava enganada. A mãe de Krishna interveio e tomou partido da matriarca dizendo que Krishna poderia sim ser prejudicado por aquela comida e que desrespeitara a avó com sua atitude. Krishna contava também que, em outra ocasião, a avó se preocupou com o neto e quis levá-lo ao templo para que o pandit lhe limpasse do toque de um lagarto de parede, o que se devia ao fato de os lagartos serem aparentados do demônio Ravana que poluíam pessoas através do contato. Nessa ocasião, Krishna não se opôs e foi com ela ao templo. Ele dizia:

- See, here we can eat together and eat all of us the same food. But back in my grandparent's village they believe in things that people here don't believe anymore. Like the story of the lizard, I didn't mind that. Lizards are god's creatures, but my grandma felt better after taking me to the pandit. She thought she was saving me, so be it.

Se meus interlocutores apresentavam diferentes disposições pessoais em relação à vida, uma coisa eles tinham em comum. A condição socioeconômica dos moradores, como já disse, era evidenciada a começar pelo poder aquisitivo que permitia morarem naquela PG. Elementos como consumo, gosto, ocupação profissional, modo de vestir-se e outros marcadores estéticos forneciam mais informações a esse respeito e eram percebidos entre eles mesmos e, com o tempo, por mim. Quanto ao pertencimento religioso, nomes e sobrenomes diferenciam, de saída, hindus, católicos e muçulmanos, sendo, no entanto, o comportamento e as afinidades pessoais os responsáveis pelo desenrolar das relações. Os sobrenomes são também importantes indicadores no reconhecimento dos pertencimentos de casta.

Em uma noite na casa de Anirudh, por exemplo, estávamos já com o humor alterado pelas doses de cerveja, vodca e vinho que cada um havia sorvido, à exceção de Kaushik que não consome álcool. Pelas três horas da manhã, enquanto Rekha descansava no sofá da sala de estar, Anirudh, Kaushik, Anyndia e eu discutíamos o sistema de cotas para castas desprivilegiadas, chamadas de backward ou schedule castes, nas universidades e empregos públicos. Todos eles se manifestavam contra a política. Ao perguntar de que casta eles eram descobri que, além de Anirudh, eram também brâmanes Kaushik, Anindya e Kartik, que já dormia a essa altura, em outro aposento da casa. Perguntei a eles: 
- What about Rekha, is she a Brahmin too?

- Well, her name is Rekha Rathore she is most probably a Kshatrya, not a Brahmin - respondeu Anirudh.

- Right, I think you must be right, her family has many members working in the Army - completou Kaushik sabendo que a carreira militar é bastante seguida por membros da varna Kshatrya, que são considerados um grupo de guerreiros, soldados e lutadores, tendo seus nomes ligados a grandes governadores e estrategistas de guerra do passado e a heróicos guerreiros míticos, como os deuses Krishna e Rama.

Continuei a perguntar:

- What about Shubhi e Lovania?

- Do you remember their surnames? - inquiriu Anirudh.

- Shubhi... no I don't. But Lovania is Biswas - respondi.

- Biswas... I'm not sure if she is a Brahmin... but I'm sure she is not from a scheduled caste.

- By the way, does anyone in PG is from a scheduled caste? - argui novamente.

Todos disseram que não sabiam ao certo, mas que muito provavelmente não havia ninguém nessa condição na casa. Alguns dias depois perguntei a Lovania qual era sua varna, ao que ela me respondeu:

- Sweet, I'm not sure.

- How is that so? You don't know?

- Yes, I don't pay attention to these things.

Descontente com a resposta, comentei, em outra ocasião, com Pryia e Anirudh sobre a fala de Lovania. Pryia então me disse: 
- Well, this can happen, some people are not sure about the Varna they belong to. But if she is not aware it means she is from an upper caste. If she were from a lower caste she would know for sure.

Anirudh consentiu com um gesto de cabeça. Diferentemente dele, Pryia era radicalmente a favor das cotas para pessoas de castas desprivilegiadas e eu sentia muita falta dela nas discussões sobre isso, já que os rapazes tinham visões parecidas a que Anirudh certa noite nos contou, a qual anotei no caderno de campo assim:

- See, I am not totally against the reservations based on caste. My point is that they should last for some time, not forever. Like, I am a Brahmin, ok? My grandfather was a Brahmin, he was a rich man, rich to an extent that he had a huge farm and was the only one in the region to have a telephone at home. But what about me? I am a Brahmin and I had to study, really hard, went to the Law School, had to crack the exams to become a lawyer, had to get a job, and I work like sh** to make money... on the other hand you have scheduled caste people getting seats at the university and government jobs regardless their family are rich, because they are the second or third generation to have the reservations assured... so I am a Brahmin, but nobody gives a sh**...

Anirudh não concordava quando Pryia e eu dizíamos que, a despeito disso, muito provavelmente, ele havia sido tratado com privilégios e prestígio a vida toda por ser um brâmane. Ele insistia, num discurso que privilegia a meritocracia, que havia se esforçado para conseguir o que alguém pertencente a uma das "scheduled castes" havia conseguido de graça. Não havia meio de convencê-lo que aquelas pessoas teriam continuado a ser discriminadas negativamente não fossem as cotas para castas consideradas inferiores.

Ainda em 2012, estávamos indo de táxi ao clube noturno Kasbah quando o assunto da discriminação de castas surgiu por uma questão minha. Anirudh respondeu:

- Forget about caste... caste sucks, fu** the castes...

Em sua resposta, Pryia delatava o pertencimento de casta de Anirudh e condenava a orientação política dele quanto ao assunto:

- Oh, yes! Very easy to forget about castes when you are a Brahmin! 
Pratyushi, que estava conosco naquele momento, e sempre discutia acaloradamente com Anirudh na sala de jantar sobre a orientação política e econômica neoliberal recente de seu país, concordou com Pryia. Pratyushi era economista e seu autor favorito, o Nobel de economia Amartya Sen, era citado para advogar uma noção de política econômica mais justa socialmente. Nessas discussões, Pryia, Pratyushi e eu fazíamos um bloco acusado de ser "socialista" e Anirudh, Kaushik, Dileep e outros formavam o bloco que chamávamos, também derrogatoriamente, de "elitistas".

Em 2014, por ocasião do casamento do irmão de Meena em Calcutá, ela comentou ser Kayastha. Aproveitei para perguntar o significado disso. Ela explicou que Kayastha é uma casta originária da Bengala que não é nem brâmane nem kshatrya e se encontra em posição de status intermediário entre as duas varnas, tendo sido equiparada aos brâmanes em outras épocas em matéria de prestígio. Sua ocupação profissional tradicional é a de escribas e, modernamente, de educadores e intelectuais. A família de Meena, bem como ela própria, é de acadêmicos institucionais, tendo seu avô sido proprietário de uma universidade em West Bengal. Meena, como Pryia e Pratyushi, é a favor de políticas sociais de discriminação positiva. Digo isso para afirmar, mais uma vez, que, apesar de serem todos abastados e de castas consideradas superiores, as visões políticas de meus interlocutores divergiam, como divergiam também as opiniões e as disposições sobre a moralidade, o romance e a sexualidade.

Foi costurando conversas e prestando atenção a comentários corriqueiros aqui e ali que percebi o quanto as afiliações de casta informam as relações sociais na Índia, incluindo grupos como aquele com o qual convivi, cujos membros procuravam sincera ou retoricamente negar a diferenciação e a consequente hierarquização por castas. Fui percebendo que momentos diversos no curso da vida, atualizam os pertencimentos de casta. Krishna foi colocado frente a essa questão, por exemplo, quando quis comer algo que havia sido preparado por alguém de uma casta tida como inferior. Ragavendra, numa noite no restaurante Beeryani, falava de namoro quando disse ser um Marwari e explicou como os casamentos Marwari acontecem. Na ocasião, Lovania me esclareceu que os Marwari são um grupo proveniente do Rajastão cujas famílias seriam extremamente ricas. Como dizia Ragavendra, os Marwari são endogâmicos (como as demais castas o são) e seria difícil não se casar com uma Marwari portanto. Os casamentos são por excelência o acontecimento que atualiza e perpetua a "pureza de casta". Nos casos dos casamentos por amor, que geralmente são intercasta, são 
considerados pelas famílias uma tragédia que desafia e faz sentir o peso que o sistema de castas continua a exercer, não obstante as políticas sociais afirmativas e as disposições constitucionais que proíbem a discriminação por casta.

Deriva, ainda, dos pertencimentos de casta a relação com os alimentos e com outras substâncias, como dizia acima. Por exemplo, Kaushik é vegetariano e não consome álcool em hipótese alguma. Essas diretrizes de comportamento são dadas pelo fato de ser Kaushik um jovem filho de uma família brâmane que segue, por opção pessoal, segundo ele, as regras impostas pela noção de hereditariedade, isto é, pelo fato de as pessoas de uma mesma casta herdarem hábitos alimentares, profissões, regras de casamento etc. Como Anirudh e Anyndia o fazem, Kaushik poderia optar por não seguir essas regras quando longe da casa dos pais, caso dos primeiros, mas não o faz. Kaushik também não namora, afirma tranquilamente ser virgem aos vinte e seis anos de idade; diz que vai se casar virgem e que o fará de modo arranjado, com a moça escolhida por seus pais. Esses preceitos são acionados por ele tendo como fundamento o hinduísmo, e Kaushik os segue do mesmo modo que os demais não os seguem em vista de outras premissas, como orientações da ordem do discurso biomédico em certos casos. Por exemplo, de que o sexo faz parte da vida e é só mais uma função biológica do corpo, como afirma Shubhi. De que não faz sentido algum não comer carnes, como afirma Anirudh, porque elas são deliciosas e se algumas pessoas podem comê-las e isso não lhes faz mal por que fariam a ele? Ou que a vida é bem mais divertida e dotada de sentido quando se bebe de vez em quando, como diz Anindya. Embora de mesma varna, esses jovens apresentam comportamentos diferentes quanto a elementos que geralmente seriam regulados pelo pertencimento de casta. Quando escolhem não seguir tal regulação o fazem opondo-se, conscientemente ou não, a ela e, quando a seguem, têm um comportamento $\mathrm{x}$ ou y orientado pela casta. Os que apresentam comportamentos desviantes daqueles prescritos pelo pertencimento de casta o fazem com base no engajamento com outras ideologias presentes no contexto em que vivem, optando por seguir, ou desafiar, um ou outro ordenamento de realidade. ${ }^{34}$ Tambiah (1990), ao se debruçar sobre as noções - sempre antagonizadas na história das ciências sociais - de causalidade e participação (poderíamos também dizer racionalidade e misticismo ou ciência e religião), convincentemente, apresenta o modo como ambas sempre estiveram presentes, em qualquer tempo, em todas as sociedades:

34 Utilizo o termo ideologia no sentido empregado por Dumont (1992), isto é, como conjunto de ideias e valores. 
"A simultaneidade de disposição desses dois modos de ordenamento do mundo aponta para nossa cada vez maior percepção de que pessoas de todas as culturas e sociedades engajam-se em distintos gêneros de discurso que se relacionam e são acionados por diferentes contextos de comunicação e "prática" (tal como definida por Bourdieu). De acordo com a ocasião e o contexto, nós invocamos, empregamos e manipulamos corpus de idiomas e conceitos, culturalmente disponíveis e adaptados para se encaixar em diferentes sistemas de conhecimento, estilos de racionalidade e retórica, e modos de experiência emocional. Nesse sentido, nós somos flexíveis e plurais e nos engajamos em muitos modos de fazer-o-mundo. E apesar de sociedades e culturas de fato se diferenciarem umas das outras pela variedade de discursos que cada uma permite e incentiva, certamente não há notícia, até agora, de uma sociedade conhecida como praticante inveterada de apenas uma das orientações." (Tambiah, 2014: 34)

Os momentos ordinários e especiais vividos com meus interlocutores apresentavam como, na prática, os indianos e indianas que conheci orientam suas vidas por diferentes ordenações de realidade, tentando criar a vida que querem pra si. Como índice dessa disposição de vida, minha amiga Lovania não faz distinção formal entre ir ao templo adorar o deus Shiva, pedindo que ele lhe conceda um bom marido, e o ato de preencher um perfil eletrônico num site de matrimônios com a mesma finalidade. Tampouco Anirudh deixa de ser um brâmane por comer carnes e consumir álcool, ele se porta como um quando recorre ao Mahabharata para se orientar. Ao mesmo tempo, Anirudh não pensa que, nos processos legais em que atua como advogado no ramo do direito empresarial, ele possa usar o Mahabharata para fundamentar suas petições. São os assuntos de seu âmago que o levam a pensar no épico hindu. No caso de ambos os amigos, tais disposições não são antagônicas ou incongruentes para quem as exerce, elas se complementam e se harmonizam.

A ideia de tratar a PG como uma paisagem moral em que vários índices da moralidade hegemônica de Délhi e de outras grandes cidades indianas se apresenta implica afirmar que a moralidade pública não determina o pensamento e as atitudes, ou orientações de vida, das pessoas. A paisagem moral provê possibilidades de atitudes, de comportamentos, de inclinações. Desse modo, assim como aprendemos há muito que devemos negar os determinismos geográficos das paisagens físicas, devemos também rechaçar os determinismos morais. Pensar em paisagens morais, nesse sentido, é abrir a visão para possibilidades mais que para determinações.

No capítulo seguinte, trato das possibilidades que meus amigos tiveram em negociação com as paisagens morais em que vivem e os agenciamentos que 
empreenderam para construir experimentos existenciais a partir dessas possibilidades, no que respeita aos assuntos do coração e da sexualidade. De modo semelhante à paisagem moral encontrada por Yan na China contemporânea, meus amigos vivem numa paisagem moral embebida no conflito entre o dever e o desejo. 


\section{Capítulo III}

\section{Main Tumse Pyaar Karte Hun ${ }^{35}$}

Esse capítulo trata das noções de amor presentes na Índia e de relacionamentos amorosos vividos e narrados por meus interlocutores. Começo por expor as noções mais estabilizadas de amor na literatura que trata das construções sociais desse sentimento no Sul Asiático, derivadas de diferentes tradições e desenvolvidas em distintos períodos históricos, para, em seguida, apresentar as tramas de vida de alguns interlocutores a fim de mostrar como suas histórias compõem narrativas que recontam os conceitos e os contextos possíveis para o amor e o romance no contexto indiano contemporâneo, ao mesmo tempo em que inventam e criam novas possibilidades.

\section{O amor: um só ou vários?}

Em sua etnografia sobre casamentos por amor, na qual ouviu jovens que buscavam as cortes de Délhi para oficializar, e assim tentar legitimar perante a família e a comunidade, as uniões conjugais que haviam escolhido, Mody (2011) aponta que o sentido do amor/romance não é unívoco na cosmologia indiana (o seria em algum lugar do mundo, aliás?). 0 amor indiano tem mais de um termo para ser expresso e diferentes acepções conforme a fonte que se consulta: se os poemas devocionais da tradição Bhakti; se os épicos e demais textos sagrados do hinduísmo; se textos religiosos mais recentes; ou as diferentes aspirações e sentidos modernos que estão sendo construídos desde o período colonial. Quanto à acepção mais contemporânea, aposta-se que haveria uma influência da moral vitoriana, a despeito de esta não ser a única nem a mais significativa na conformação do amor na Índia.

\footnotetext{
${ }^{35}$ Esse é o modo pelo qual meus interlocutores responderam quando perguntei como diziam "I love you", em hindi. Alguns afirmaram, contudo, que preferiam dizer a frase em inglês, por ser mais simples. "It's just a three word sentence in English", falou-me Lovania.
} 
Alertada pelas leituras inicialmente empreendidas, as quais davam conta de que as construções do amor na Índia divergiam daquelas ocorridas na Europa a partir do romantismo e que vieram a sedimentar os modos de fazer os casamentos modernos, fui em busca da bibliografia que tratasse do amor no subcontinente indiano para responder a questões que me eram feitas sempre que apresentava minhas ideias, decorrentes do trabalho de campo, a colegas antropólogas e antropólogos. Diante do inegável fato de que meus amigos indianos amam, alguns amando a ideia do amor/romance, mesmo sem alguém que preencha, por ora, o lugar do ser amado, interlocutores da academia me perguntavam, "mas o amor na Índia é um conceito que remete diretamente ao amor romântico ocidental? Não haveria uma noção indiana do amor romântico?" Buscando responder a essa questão é que trago a discussão abaixo.

Uma das formas de abordar o assunto, e que julgo pertinente, seria observando a transformação das ideias a esse respeito. Orsini (2007) historiografa o desenvolvimento da noção de amor no Sul Asiático e apresenta o que considera os cinco "principais repertórios em que noções, emoções e estórias de amor foram desenvolvidos" naquela região: o repertório sânscrito, que compreenderia os épicos hindus, poemas e códigos morais como o Kamasutra e as leis de Manu; o repertório oral, constituído de canções, lendas e contos; o repertório perso-arábico, centrado em injunções religiosas, poemas sufis, textos seculares sobre ética e conduta e canções do gênero musical ghazal; o repertório religioso, poético e filosófico Bhakti; e, por fim, os repertórios modernos expressos em termos como prem e pyar, em hindi, e love, em inglês. A seguir, trato os repertórios sânscrito e Bhakti em conjunto, pois apresentam contrastes que ajudam a entender melhor suas respectivas construções. Para tanto, sigo a apresentação de Orsini e acrescento outras leituras pertinentes.

Ao falar do repertório sânscrito é preciso esclarecer que o sânscrito é considerado a "eterna língua dos deuses", a produção literária nessa língua é altamente erudita e elitista, uma vez que o sânscrito era ensinado apenas aos homens e tão somente àqueles pertencentes às castas altas, mormente aos brâmanes (Dwyer, 2000: 16-17).

O repertório sânscrito fornece normas para uma boa vida, ou para a vida que deve ser vivida de acordo com o Dharmashastra, espécie de código moral hindu do bem viver. Nesse sentido é interessante observar que no Dharmashastra impera a noção do casamento como um instrumento para alcançar objetivos mais elevados na vida e não 
como possibilidade para a gratificação pessoal (Mody, 2008). Essa visão estaria inserida no conceito de dharma (duty, em tradução adotada por Uberoi; righteousness, em tradução de Orsini). 0 amor conjugal, rati, embora reconhecido nos textos sagrados era considerado menos importante que o dharma e o praja (progenia) (Uberoi, 2006: 121; Mody, 2011: 16). ${ }^{36}$ Os três objetivos do casamento seriam, assim, dharma, praja e rati, exatamente nessa ordem de importância. Estamos ainda numa seara em que o amor erótico não era cerceado moralmente como passará a ser em momentos históricos seguintes, como afirma Orsini:

"Before modern Indian high culture turned resolutely moralistic, sexual love and passion were recognised as an area dense with meanings and positively valued, at least for certain classes of people in certain contexts: the king, the householder and his wife, the courtesan. Ascetic or moralistic condemnation of love and sexuality were always but one strand of tradition in South Asia." (Orsini: 2007: 5)

Os três objetivos a serem alcançados em vida seriam: kama (amor erótico; desejo; prazer sexual), artha (riqueza, prosperidade) e dharma (dever moral), seguido pelo ideal de obter moksha (liberação dos ciclos de vida pela reencarnação) na morte. Contudo, no código de Manu, datado como sendo do século II da era cristã, o kama já aparece como um perigo:

"Having reluctantly accepted the necessity of kama as the basic driving force, Manu then cautions strongly against its dangers. Desire should be controlled and (...) acting out of desire is disapproved of. As attraction for sensory objects, kama leads dangerously to addiction (Manu 4.16), for 'desire is never extinguished by the enjoyment of what is desired' (Manu 2.94), and as lust it is listed among the ten vices which the king must refrain from (Manu 7.44-52)." (Orsini, 2007: 7)

O mais famoso tratado sobre a noção de kama, o Kamasutra, se notabilizou, erroneamente, como um guia para o prazer sexual. Trata-se, na verdade, de bem mais que isso:

"In their taxonomic urge to describe and classify every aspect of human existence, the Shastras (authoritative texts) provided the nagaraka, the citizen of the classical courtly polity, with descriptions of and prescriptions about sexual behaviour as well. Vatsyayana's Kamasutra, the oldest and most famous Shastric text on kama, instructed the nagaraka on the importance of acquiring knowledge and of setting up a well-appointed house and a

\footnotetext{
${ }^{36}$ Mody traduz rati por amor (love), enquanto Uberoi traduz por desejo (desire), em ambos os casos trata-se do
} desejo ou do amor conjugal, isto é, no interior de um casamento. 
sophisticated daily routine; on the kind of women suitable for love affairs (young girls, married women or widows and courtesans) and on the need for go-betweens. Then he proceeded to detail sexual advances (including embraces, kisses, scratching and biting and penetration), followed by instructions on how to acquire a wife, on the duties and privileges of the wife, on liaisons with other men's wives (overall discouraged) and on how to behave with courtesans." (Idem: 8)

A noção de kama aparece em textos literários tanto quanto em textos médicos e a visão integral desse conceito conecta intimamente comida, estações do ano, saúde corporal e atividades sexuais. A poesia e a medicina nesse repertório compartem a visão de que cada estação do ano tem atividades, comidas, modos de vestir e de se comportar que são adequados. Assim, para o inverno, por exemplo, seriam adequados certos alimentos e bebidas e "in addition, 'attractive, excited young women with full thighs and buttocks, whose bodies are heated from the effect of incense, saffron and youth, banish the cold"' (Idem: 10).

Na poesia Bhakti (poesia devocional que se ocupa do amor do/a devoto/a por Krishna), há termos que descrevem os tipos de mulheres - veshya (cortesã), svakiya (esposa) e parakiya (a mulher de um outro) - e os tipos de amor em relação a elas. 0 amor (prem) com uma parakiya, por exemplo, seria exaltado na poesia Bhakti como o maior dos prazeres: o desfrute do amor carnal com a mulher de outro homem. É, contudo, altamente condenado nos textos épicos em sânscrito que consideram o adultério uma das maiores faltas morais. 0 amor entre o deus Krishna e a deusa Radha é, por excelência, a representação desse sentimento, uma vez que Radha, a mais amada das namoradas e devotas (gopis) de Krishna, é casada com outro homem. Esse mito explora o "reconhecimento do amor carnal/desejo como essencial a certos tipos de devoção, mas não como meio de fazer casamentos - ao menos não casamentos mundanos". Isto é, o "relacionamento entre Radha e Krishna, que durante eras tem sido visto como, ao mesmo tempo, erótico e realmente místico, não é nunca consumado em casamento, pois isso seria corromper e transformar seu amor igualitário" (Mody, 2008: 16).

No repertório sânscrito, os épicos apresentam outros casais divinos, como Rama e Sita e Shiva e Parvati, que servem como ideal para os casamentos terrenos. No épico Badgavad Gita, em que Krishna é o protagonista ao lado de Arjuna e seus quatro irmãos (os Pandavas), casados com Draupadi, o amor de Krishna e Radha não é apresentado. 0 casal cósmico tem seu amor explorado posteriormente no Gita Govinda, séculos depois desse período em que os mitos épicos apresentam casamentos em que a fidelidade é 
imprescindível. A suspeita, infundada, da traição de Sita é sua desgraça. Raptada pelo demônio Ravana e por ele mantida cativa, Rama teme que Sita o tenha traído e, embora sofra com a distância da amada, apenas após ela provar sua inocência é absolvida e reintegrada ao reino de Rama. Quem a salva do domínio de Ravana é, contudo, Hanumam, fiel amigo de Rama. Outra importante noção que advém desses mitos é a de que a esposa, seja ela a deusa ou a esposa terrena, deve amar e adorar o marido como seu deus, ideologia conhecida como Pativrata (pati: marido; vrata: adoração). Curiosamente, a noção de amor conjugal ventilada por esses mitos não é tratada detidamente por Orsini. Lobato, Dwyer, Mody e Uberoi são quem melhor trabalham a mitologia que informa até hoje o ideário sobre os casamentos, sendo citada pelo pandit que executa a cerimônia, conforme Dwyer aponta e eu pude presenciar. De acordo com essas autoras, a orientação sobre o amor nesses mitos é de que ele deve ser intensamente cultivado pelas mulheres, em relação a seus maridos, e tratado com cuidado pelos homens, que poderiam se desviar do dharma, caso amassem com o mesmo afinco suas esposas. Haveria assim uma assimetria no amor conjugal que requer das mulheres o dever de amar seu marido e dos maridos o dever de colocar o kama em segundo plano.

Assim o que se tem é: o repertório sânscrito constrói a noção dúbia de kama, necessário, porque parte integral da vida, mas perigoso e que deve ser cuidadosamente refreado ${ }^{37}$; na poesia Bhakti, tem-se a noção de prem que difere do kama, pois "it is total self-surrender and is oblivious to the rules of the world" (Orsini, 2007: 23). O primeiro, anterior cronologicamente, dirige-se ao rei e ao chefe de família, provendo regras de conduta moral a essas categorias. O segundo, iniciado por volta do século VI, no sul da Índia e expandido para o norte, trata-se de um movimento religioso centrado na pessoa do devoto/devota e na relação de amor (prem) entre este/esta e seu deus (Krishna), desenvolve, contudo, na poesia, a ideia de um amor sensual e erótico. Orsini aponta que a natureza simultaneamente carnal e divina do amor entre Krishna e suas gopis (devotas/amantes) é referido nos dias de hoje por meio de músicas no cinema indiano, no qual o amor romântico enaltecido tem relação direta com a noção de prem advinda

\footnotetext{
$37 \mathrm{O}$ mito em que Kamadeva, o deus do amor, é queimado por um fogo saído do terceiro olho de Shiva, o deus da ascese, afirmaria que o amor/desejo é inimigo da ascese. Por outro lado, Shiva seria, ele próprio, a representação da dualidade desejo/ascese, uma vez que ele é o grande asceta e yoguin a meditar eternamente nas montanhas do Himalaya, mas é, ao mesmo tempo, um amante viril (Orsini, 2007: 7). Lembro ainda que Shiva é o marido perfeito para a esposa ideal, Parvati, no panteão hindu. Duas das representações de Shiva são uma figura andrógina sentada em postura meditativa no gelo do Himalaya e o chamado Shivalingam, uma forma fálica que é adorada por seus devotos.
} 
do movimento Bhakti (Idem: 27). Posso atestar, contudo, que o erotismo desse amor é apenas aludido, não havendo manifestações abertas de amor carnal em Bollywood. As coreografias, roupas e olhares são sensuais, mas o contato corporal entre o par romântico, chamados na mídia e pelas pessoas que conheci de herói e heroína, é mínimo.

0 repertório oral sucede o repertório sânscrito no esquema da autora, embora seja difícil precisar seu surgimento, sobre o que ela diz:

"The oral repertoire of epics, tales and songs, while difficult to date, has been a major component of South Asian culture and is still, in direct or indirect ways, accessible to people in South Asia, whether they be highly literate or illiterate, living in urban centres or rural areas. (...) Oral epics, to be found almost everywhere on the subcontinent, usually depict a patriarchal and essentially male world (save for the few female-centred 'sacrificial epics') and reveal a powerful sexual fear." (Idem: 11)

A questão de gênero é bastante marcada nesse repertório no que se refere ao tratamento diferenciado do amor para cada um dos dois sexos. A paixão, quando vivida pela mulher, geralmente toma a forma do adultério, "reconhecido como uma inevitabilidade humana e, no caso da mulher, explicitamente justificado quando o marido é impotente, desatento ou simplesmente fora de casa por muito tempo" (Idem: 13). A visão que se tem da mulher por esse adultério, no entanto, é dúbia e mais negativa que positiva. A autora a ilustra com uma anedota desse repertório:

"How oral tales can express the commonsensical misogynist view of women as essentially duplicitous is clear in this Urdu tale from the cycle about the Mughal emperor Akbar and his wise minister Birbal: one day Akbar said to Birbal, 'Bring me four individuals: one, a modest person; two, a shameless person; three, a coward; four, a heroic person.' Next day Birbal brought a woman and had her stand before the emperor." (Idem: idem)

Inquirido sobre o significado da presença de uma única mulher em vez de quatro pessoas, como ordenara o imperador, Birbal responde que a mulher tem as qualidades dos quatro tipos de pessoa demandadas pelo soberano:

"When she stays in her in-laws' house, out of modesty she doesn't even open her mouth. And when she sings obscene insult-songs at a marriage, her father and brothers and husband and in-laws and caste people all sit and listen, but she's not ashamed. When she sits with her husband at night, she won't even go alone into the storeroom and she says, 'I'm afraid to go'. But then, if she takes a fancy to someone, she goes fearlessly to meet her lover at midnight, in the dark, all alone, with no weapon, and she is not at all afraid of robbers or evil spirits.'” (Idem: 13-14) 
De todo modo, afirma Orsini, o repertório oral contribuiu de maneira fundamental na ampliação dos discursos sobre o amor no Sul Asiático. Estudos recentes, citados por ela, dão conta de que é por meio dessa tradição oral que os discursos sobre amor nas aldeias têm sido veiculados contemporaneamente.

O repertório perso-arábico apresenta construções expressas pelos termos ishq e muhabbat, que também são usados hoje no norte da Índia para designar sentimentos amorosos. A partir do século XI, o rico repertório introduzido no Sul Asiático por grandes impérios islâmicos (Gasnávidas) traz, assim como a tradição sânscrita, múltiplas noções de amor, religiosas e seculares, àquela região. 0 entendimento islâmico do amor seria, entretanto, divergente do hindu quanto à sexualidade:

"Islamic understandings of love, Christopher Shackle points out (...), have been at the most general level of cultural definition 'coloured by the strongly anti-ascetic character of Islamic teachings on sexuality, where the well known Prophetic saying that "there is no monkery in Islam" indicates both a sharp divergence from a powerful tradition within Christianity and a marked contrast from the Indic privileging of sexual continence'. While married love and the need for sexual satisfaction were valued, the woman's power of sexual attraction was especially feared as fitna (chaos), hence the need to place restrictions on contact between sexes, to cover the body and keep to separate spaces." (Idem: 15)

Muhabhat conota o amor entre pais e filhos e entre deus e o crente. Ishq seria o amor mantido pelo ser amado e é mais excessivo que o muhabhat. Há ainda, nesse repertório, a noção de hawa designando paixão, desejo em geral e luxúria em particular. Essa última noção ligava também o amor à loucura. Textos prescritivos encorajavam o prazer e o amor, mas também recomendavam o controle da paixão.

Nesse ponto, sou levada a rememorar o texto de Lobato, uma vez que a autora ao tratar da história de Layla e Majnun, oriunda do mundo árabe, traz o tema da loucura que o amor não controlado pode desencadear. Majnun, após ser impedido de consumar seu amor por Layla, casada à força com outro homem, passa a vagar pelo mundo e é considerado louco, é então que passa a ser chamado de Majnun ("literally, the 'crazed'”, segundo Orsini: 20):

"Qays tenta esconder seus sentimentos. Mas longe de Layla, ele se torna um Majnun, isto é, um louco, incapaz de ocultar suas emoções e de continuar a desempenhar seus deveres e obrigações sociais: 'ele tinha perdido não apenas sua amada mas também a ele mesmo'. Como um Majnun, ele passa a vagar pelos desertos e pelos bazares e tendas de toda a Arábia, cantando os 
poemas em que expressa seu sofrimento por estar separado de sua amada." (Lobato, 1994: 103) 38

Lobato e Orsini apontam que em seu amor excessivo Majnun esquece suas obrigações religiosas e sociais e até a obrigação de manter sua amada em segredo para evitar desonrá-la. A associação de Majnun com o deserto simbolizaria sua escolha pela selvageria (wilderness) e a rejeição da sociedade humana por conta do amor (Orsini, 2007: 20). O amor seria antissocial porque a loucura do amor tornaria as pessoas antissociais, privilegiando o fortalecimento da relação entre o par amoroso em detrimento das demais relações e lealdades sociais, sobretudo as filiais.

Nesse repertório o cultivo do amor pertencia ao universo da sociabilidade masculina, a ser cultivado com escravos e cortesãs, enquanto diferentes valores e etiquetas de comportamento eram requeridos ao lidar com a esposa. Já a relação das mulheres com esses valores e ideias sobre amor e sociabilidade é praticamente desconhecida no mundo indo-islâmico segundo Orsini. A própria história de Layla e Majnum nos dá, contudo, uma pista sobre isso: é justamente pelo fato de se apaixonar por Majnum que Layla é impedida de se casar com ele. A proibição "provém simplesmente do desafio que esse amor, por sua simples existência, traz ao poder dos homens da geração paterna de controlar a sexualidade de suas filhas" (Lobato, 1994: 103), um desafio que fere a honra da família. Não há aí outro impedimento qualquer, como havia no caso das demais histórias pungentes de amor analisadas por Lobato: diferentemente de Isolda, que já estava comprometida com o rei Marcus quando se apaixona por Tristão, Layla não estava prometida a nenhum outro homem. Tampouco Layla e Majnun são de famílias rivais, como na história de Romeu e Julieta. No mundo não-ocidental o amor não deve ser o motivo para as uniões conjugais, sobretudo no caso das mulheres em que o amor traz desonra por desafiar o poder paterno.

Já no gênero poético e musical denominado ghazal, a função do amor seria preparar o coração para a dor, operando uma equação entre amor e dor (ishq e shauq). Novamente a aproximação entre amor e loucura aparece, e surge o tema da morte pelo verdadeiro amor como êxtase. 0 ghazal não especifica o gênero do ser amado, por conta

\footnotetext{
${ }^{38}$ Foi uma grata surpresa saber que Patrick havia assistido ao filme Layla and Majnun, um filme em hindi, em seus tempos de escola. Hemanshu, outro morador da PG, também me indicou a leitura da história de Layla e Majnun e do mito de Radha e Krishna quando soube que minha pesquisa buscava entender os sentidos do romance na Índia. Ambos comentavam o aspecto enlouquecedor que o amor pode ter.
} 
disso muitos autores levantariam a questão da natureza homossexual do amor no gênero ghazal (Orsini, 2000: 19).

Esses diferentes repertórios teriam sido sobrepostos e sintetizados no que a autora chama de "fertilização cruzada", de maneiras complexas e sofisticadas, alcançando o máximo de sofisticação nos versos de Malik Muhammad Jayasi, poeta sufi do século XVI. À sobreposição dessas construções se somariam as construções coloniais modernas do amor.

"The valorisation of shringara [o amor no teatro, dança, música e poesia sânscrita] ishq and bhakti as cultural ideas in early modern India went hand in hand with a patriarchal system which structured institutions and practices concerning marriage, sexuality and property, and informed beliefs and values. [Não obstante as variações regionais e de casta] the constitutive institutions of this patriarchal system were extended family households, child-marriage, separate spheres for men and women, enforced widowhood and accepted polygamy in order to beget sons. (...) Within this patriarchal system, female sexuality was strictly controlled, while men had a freer hand." (Idem: 30)

Seria nos desdobramentos desse ambiente que a modernidade colonial interferiria:

"The 'colonial climate' brought a number of direct and indirect changes to the economic basis of the extended family and the cultural values associated with marriage and love in the patriarchal system. Colonial bureaucracy sent young educated men to live apart from the extended family, either alone or with their wives, bringing unprecedented intimacy between the couple, while Western education and contact with Europeans often led to internalising their racial critiques of child marriage, polygamy and enforced widowhood as 'barbaric' or 'degenerate' practices, and the 'treatment of women' became a general yardstick to measure the cultural degeneration of India and Indians. The Bengali reformist religious group Brahmo Samaj, though a tiny minority in absolute numbers, came nonetheless to exert a disproportionate influence as a model of absorbed Westernisation, and Brahmos not only spearheaded women's education but also were the first to introduce the new notion of companionate marriage. The reformists' general process of cultural reorientation, with a view of forming individuals who would fulfil their human (and national) potential, had momentous consequences for the relations between men and women and the formation of the couple." (Idem: 31)

Mody também cita a influência dos Brahmos como reformadores sociais na moralidade, nos casamentos e no sistema de castas: renunciando suas insígnias das altas castas, sendo, por isso, expulsos de suas famílias e comunidades de casta e advogando casamentos que pudessem ser realizados de modo secular. Essa autora tributa ao 
ativismo desse movimento a passagem da primeira lei que permitia os casamentos civis na Índia, chamada "Native marriage Bill", escrita por Henry Maine, e que culminou no Act III de 1872, que permite o casamento consensual e de livre escolha entre adultos no país desde então (embora, como a autora afirma, a lei só começasse a ser popularmente conhecida após a independência do país):

"The main significance of this Bill was that it was not restricted to the Brahmos, and that it introduced civil marriage to India. Any two 'natives' (crucially, 'not professing the Christian religion' [havia já outra legislação britânica que assegurava o casamento cristão]) who 'objected to be married in accordance with the rites of the Hindu, Muhammadan, Budhist, Parsi or Jewish religion' could legalise their marriages under this law." (Mody: 2008: 65)

Regressando ao desenrolar das noções em torno do amor na Índia, Orsini afirma que o deslocamento de prem (noção de amor oriunda do repertório Bakti) para romantic love teria se dado quando escritores do século XIX e do início do século XX passaram a se distanciar de um ideal explicitamente sensual e sexual do amor para imaginar um novo ideal de amor, um ideal ético e estético de amor romântico.

"This urge was mediated through expressive codes: even the extremely sensuous and erotic spectacle offered by Parsi theatre (...) was contained by the way plotting and fast tempo cut short the moment of romance. The sensual heroine of erotic poetry was replaced by other, more demure and spiritual figures, and the first modern women poets often chose to fit into this mould. Courtesans came to embody the old ideal, and could now only figure in literature as instruments of sexual corruption or as golden-hearted victims of society and objects of elite pity." (Orsini, 2007: 32)

Esse novo ideário romântico, no entanto, permaneceu para a maioria das pessoas como apenas um ideal, do qual podiam compartilhar tão somente nas páginas de novelas e, crescentemente, nas telas da TV e do cinema, onde o amor era narrado infinitamente e os relacionamentos amorosos também apareciam num espaço discursivo que é mais propagado que praticado. A independência econômica e o casamento consensual, embora demandados como duas das condições para mudar efetivamente as instituições do casamento e da família, eram veementemente refreados e vieram a figurar como tema de muitas narrativas ficcionais no século XX. Na prática, esses movimentos lograram também conquistas:

"Further concessions could include, at least in North India, a greater gap between the first marriage (or engagement) and the second ritual ceremony inaugurating actual cohabitation, so as to let the young man (and then, 
gradually, the young woman) pursue his studies. But, significantly, the romantic ideal came to invest also arranged matches, translating into romantic love after marriage (...). Plentiful evidence indicates 'a new intensity of emotion in conjugal relationship for which there is little precedent in the pre-modern past' and which now became part of life experience of the educated middle classes." (Idem: 33)

Ainda assim, embora o amor romântico, quer expresso pelo uso da palavra inglesa love ou por seu equivalente sânscrito prem, tenha se estabelecido como um ideal no começo do século XX o sistema patriarcal fez poucas concessões para a emergência do que Orsini chama de "casal moderno", isto é, aquele formado por amor no qual os enamorados se escolhem para o casamento.

"Further, at the time when the colonial state made allowance for marriage based on individual choice with the Special Marriages Act of 1872, community concerns vociferously claimed precedence over individual choice in the emerging Hindu nationalist discourse. These tensions, usually narrativised as a clash between love and the family, between romantic aspirations and the duty of loyalty to the kin (or to the nation), have been at the heart of modern novels and films dealing with love." (Idem: 33-34)

A tensão a que Orsini refere brevemente aqui é extensamente explorada por Uberoi (2006) como o impasse fulcral quanto ao amor e ao romance no cenário indiano contemporâneo: entre o dharma (dever moral) de seguir o casamento arranjado, endogâmico do ponto de vista da casta e escolhido pelos pais, e o desejo (desire) de casar seguindo sentimentos amorosos se movem os personagens de filmes e romances literários analisados pela autora.

Por fim, quanto ao cenário atual do amor na Índia, Orsini cita que nada contribui mais para as "fotografias simbólicas" do amor quanto os filmes e vídeos indianos. No que concordariam Uberoi (2006), Abraham (2011), Dwyer (2000) e Mody (2008), as duas últimas citadas pela própria Orsini. Como Orsini lembra, Mody afirma que os jovens de sua pesquisa que se casaram por amor utilizavam explicitamente os filmes indianos para expressar suas próprias visões do amor. O cinema provê uma linguagem por meio da qual o amor pode ser expresso.

No que respeita à acepção contemporânea dos termos para o amor na região norte do país, Grover (2011) aponta que continuam a ser usados: ishq, muhabbat e prem, termos com mais de uma acepção e que podem significar amor romântico, paixão e desejo; e pyar, amor e outros diferentes tipos de apego emocional. Prem seria atualmente, de acordo com essa autora, o mais usado para o amor romântico. Esse é, 
inclusive, o nome próprio recorrente dos personagens do famoso ator Salman Khan, que interpreta protagonistas heroicos ou engraçados em tramas de amor e paixão do cinema indiano.

Pyar também pode ser determinado por um adjetivo que o acompanha, como no caso de adhyatimik pyar, o amor espiritual; ou sharirick pyar, o amor físico. Premi e premika seriam os termos hodiernos para namorado e namorada. ${ }^{39}$ Como nos lembra Uberoi (2006), não há previsão cultural para a fase que vai da puberdade ao casamento e, portanto, para o namoro, já que os casamentos se faziam com crianças. Assim, não é estranho que não haja palavra específica em hindi para designar namoro.

Além disso, como dito, a visão corrente atual é de que o amor não precede, mas sucede o casamento. Numa sessão de sua etnografia que se chama The Metropolitan View of Marriage, Mody esclarece que na região norte do país o casamento hindu é visto como uma união religiosa.

"Thus marriage is an occasion wherein religious ritual (in the case of Hindus) and community celebration (in the case of Hindus and Muslims) sanctify and acknowledge the relationship of the boy and the girl as man and wife. Marriage, then, is not concerned with whether or not the couple are 'in love' - in fact, in the case of Hindus it is geared around the assumption that ideally the girl and the boy are strangers to each other and that it is their obligation to their parents that makes them sometimes reluctant, though consenting, parties to the marriage." (Mody, 2008: 7)

Assim, segundo a autora, a relação entre casamento e amor que é construída nesse contexto é de que o amor não deveria preceder, de forma alguma, o casamento; mas, o casamento também não impede uma relação íntima e amorosa na vida conjugal. Mody cita a fala de um brâmane a quem ela entrevistou no trabalho de campo:

"Love is a gift from God, gifted to two people on the day of their marriage. Love isn't something that one does, that is lust. Love is given, only by God." (citado por Mody, 2008: 7)

Em 2013, numa viagem de trem entre Agra e Jaipur, um senhor que viajava sozinho na mesma cabine em que me encontrava contou-me o modo como seu casamento fora arranjado, o qual já dura algumas décadas, com filhos e filhas jovens.

\footnotetext{
${ }^{39}$ Essa informação me foi dada por Rajendra ji, um de meus professores de hindi. Em diferentes dicionários dessa língua, a tradução de premi é feita como lover. Pyari era a expressão usada por meus amigos para se referir à pessoa amada, faziam sua tradução para o inglês como beloved.
} 
Sobre a primeira vez que viu sua esposa por uma fotografia, tendo que escolher entre vários perfis sugeridos pela família, ele disse:

- In that moment I recognized that it was her. I liked her since the very first time I saw her, I felt it inside.

As palavras emocionadas desse senhor davam conta de que, nesse caso, ele fora presenteado com o amor pela esposa antes mesmo do casamento, sendo esse sentimento que o fez selecionar (select) aquela moça, mas apenas pela fotografia, ele sequer a viu pessoalmente antes de selecioná-la. Ele se apaixonou por uma imagem, provavelmente a mais tocante, dentre as várias à sua disposição, apaixonou-se por um ícone com valor em si mesmo.

\section{A Question of Silence? 0 dilema da sexualidade na Índia contemporânea}

$\mathrm{Na}$ pesquisa bibliográfica que empreendi, algumas autoras e autores tratam o tema da sexualidade em separado, outros em conjunção, com o tema do amor/romance. $\mathrm{Na}$ maioria das vezes, na convivência com meus interlocutores, a noção de romance trazia a noção de intimidade que vinha acompanhada das experiências, ou das preocupações, com a sexualidade. Opto por fazer também nesta seção a discussão da literatura sobre sexualidade no contexto indiano, uma vez que a literatura problematiza de que modo a construção atual da sexualidade, sobretudo feminina, está ligada a desdobramentos da manipulação do tema na modernidade colonial.

Sobre o período colonial, de modo geral, aponta-se que costumes e modos de vida foram desafiados, sufocados e comandados pelo estado colonial, que discursivamente afirmava estar buscando civilizar costumes tidos como bárbaros (Dell, 2005; John and Nair, 1998; Menon, 2007; Srivastava, 2007). Ao mesmo tempo, movimentos indianos nacionalistas e de reforma social ecoavam o discurso evolucionista do colonizador. Nesse período, tem-se, por exemplo, ataques estrangeiros e nacionais às práticas do casamento infantil, da imolação das viúvas (sati), aos arranjos não monogâmicos e poliândricos, caso das mulheres da casta Nayar do sul da Índia, e à prática do purdah (no sentido do isolamento, "seclusion", das mulheres), ou, num movimento contrário, tem-se a imposição do uso de blusas cobrindo os seios entre os grupos em que esse não era um costume. Para Menon, é impossível se engajar no debate da sexualidade indiana 
contemporânea sem reconhecer (i) a complexidade de práticas que foram homogeneizadas sob o signo da modernidade e (ii) como a suposta emancipação trazida pela modernidade implicaria a criação de outras sujeições.

“The elites who championed 'social reform measures' such as widow remarriage, women's education, ban on child marriage and Brahmin polygamy, denounced this popular culture as vulgar and common, and viewed it (correctly perhaps) as a threat 'to the newly emerging cultural integrity of their own domestic lives' (Banerjee 1989: 132).” (Menon, 2007: xvii).

Contudo, continua a autora, a "sanitização" da sexualidade redundava, por exemplo, na redução das devadasis (mulheres que esposavam um deus e cuidavam do templo daquela divindade), as quais tinham direitos de propriedade que outras mulheres hindus não possuíam, à condição de prostitutas, fazendo-as perder direitos num discurso que afirmava tentar protegê-las e terminou por relegá-las a uma condição pior que a anterior, pois passaram a ser vistas como uma ameaça ao domínio doméstico patriarcal e não como adjunto a ele, como havia sido até então; ou no banimento legal da matrilinearidade em Malabar (Malabar Marriage Act, 1896), fazendo desse costume que era amplamente difundido no sul do país - aproximadamente $50 \%$ da população malayali, de diferentes castas e comunidades, eram matrilineares no século XIX - o único sistema de parentesco, no mundo todo, a ter sido legalmente abolido, pois foi visto pelos reformadores sociais como um vestígio de um passado selvagem, visão que era influenciada pelo evolucionismo social da época e pelas normas de conjugalidade da moral vitoriana. (Idem: xix-xxi) Na prática, apesar dos discursos da criação de direitos, os desdobramentos desses movimentos foram também outros:

"It is also significant that the restructuring of matriliny was conducted within a discourse positing a new set of 'rights' for women, as Praveena Kodoth points out. The end of matriliny and the introduction of the conjugal family unit were supposed to bring an end to the tyrannical hold of the eldest maternal uncle, the karnavan, and to entitle the wife and children to a share of the self-acquired property of their husbands/fathers. However, this process of producing new 'rights' also (...) meant the sexual control of women within the conjugal family and 'served to define women and children in a dependent relationship within a patrilineal framework' (Kodoth 2001: 384)." (Idem: xxi)

É igualmente debitado a esse período o cerceamento e a tentativa de aniquilar, por parte dos movimentos nacionalistas indianos, uma sexualidade indiana (ou hindu), a qual teria sido mais libertária em período histórico anterior e da qual encontraríamos 
registros na mitologia, na literatura em sânscrito e nas artes, como apontado por Orsini e por Menon:

"It is now generally accepted that expressions of non-normative sexuality and desire, far from being 'western' imports, as Hindu right wing critics of feminism in India allege, have much older histories. Scholarship in several fields has shown that earlier forms of sexuality, family and property arrangements that did not conform to modern bourgeois patriarchal ideals, were reconstituted to fit these ideals by a strange partnership of British colonial institutions and the modernizing nationalist elites who opposed the British." (Menon, 2007: xvii)

Trago para o debate a obra de John e Nair (1998) que complexifica a visão da Índia como atualmente repressora da sexualidade, mas com um passado de grande liberdade sexual. Segundo as autoras, estudos acadêmicos sobre sexualidade na Índia foram por muito tempo silenciados. Ambas apontam que até a década de noventa havia como que um pacto de silêncio na academia indiana que impedia a discussão aberta da sexualidade moderna ou contemporânea na Índia. Clivava-se a condução do assunto apenas ao estudo da sexualidade apresentada em textos antigos, como o próprio Kamasutra, e/ou ao aspecto religioso da ascese alcançada pela negação do sexo, tema que ganhou nova relevância com Gandhi, que advogava a noção de "sexual swarajya", ou autocontrole/autogoverno sexual. ${ }^{40}$ No importante volume organizado pelas autoras elas indagam:

"Is there a way of charting sexuality in India that does not begin with the Kamasutra (the text) and end with 'Kama Sutra' (the condom), separated by an intervening period of darkness illumined fleetingly by the laborious pieties of erotic temple sculptures or miniatures? Can there be a history of our sexual economies which breaches the status enjoyed by these 'anomalies', emblems perhaps of artistic licence, but lodged within an overarching narrative of repression?" (John and Nair, 1998: 1) ${ }^{41}$

\footnotetext{
${ }^{40}$ Srivastava argumenta que a "sexualidade gandhiana", focada no ideal da superação do desejo, tem um corpo de estudos bastante desenvolvido e seria chegado o momento de a preocupação excessiva com a negação do sexo como ascese; com o tema da perda do sêmen (semen-anxiety) como perda da masculinidade e da força vital e com o celibato como um ideal cultural masculino hindu (brahmacharya) deixarem de monopolizar o debate no contexto indiano. Para ele, a religião, sobretudo hindu, embora incontestavelmente ainda importante, deveria passar a ser considerada apenas mais uma variável entre os distintos elementos da modernidade para pensar a sexualidade. (Srivastava, 2006: 5-7)

${ }^{41}$ John e Nair mencionam aqui, com a ideia de licença artística, uma dúvida que paira no debate histórico sobre esse passado de maior liberação sexual indiana. Alguns historiadores e estudiosos da arte indiana do período antigo trabalhariam com a hipótese de essa arte não ser representacional, mas fruto de criação e imaginação artística propriamente dita. Srivastava responde a esse raciocínio com a afirmação de que o campo dos estudos de história não é o proprietário dessa discussão e de que importa para a antropologia menos se tais obras seriam representação da realidade ou não, mas investigar a projeção delas num ideário corrente. Esse autor aponta ainda a necessidade de distinguir entre regras normativas de sexualidade e as práticas que são contingentes, num fluxo ditado pelas circunstâncias encompassadoras dos processos sociais e culturais. (Srivastava, 2006: 7)
} 
Tentando responder a essa questão, John e Nair apontam de passagem que a produção de Foucault não seria a ferramenta mais adequada para endereçá-la:

"If Michel Foucault's celebrated insights into the history of western sexuality, particularly of the Victorian era, may be usefully invoked in the Indian context at all, it is his suggestion that the common sense of Victorian puritanism must be read afresh as an incitement to discourse." (Idem: idem)

Considero útil também citar a definição que ambas dão para a sexualidade:

“(...) far from signifying biological genitality, 'sexuality' must connote a way of addressing sexual relations, their spheres of legitimacy and illegitimacy, through the institutions and practices, as well as the discourses and forms of representation, that have long been producing, framing, distributing and controlling the subject of 'sex'." (Idem: 2)

Srivastava (2007) concorda com John e Nair sobre o pacto de silêncio na academia a respeito da sexualidade na Índia e também aponta que a exceção se encontraria nos estudos, demasiados, sobre o passado de maior liberação sexual nessa civilização:

"Sexuality has, of course, been the subject of much popular and scholarly literature in one particular field of activity, viz., that concerned with the 'ancient' history of a 'liberal' sexual culture in India. This field was given a particular fillip through Sir Richard Burton's 1883 translation of Vatsayayana's Kamasutra; from Michel Foucault to the manufacturers of condoms in India (Mazzarella 2001), many have found satisfying uses for this text. Other less well known publications (...) have also added to the lustre of the East as a place of once-free sexual souls." (Srivastava, 2007: 10)

Para Srivastava a demasiada atenção a esse passado pode nos levar a uma armadilha, pois:

"In any case, (...) any link between the Kamasutra and an actually existing Indian sexual culture is highly tenuous. Apart from any intrinsic interest it might posses, the text's key significance may lie more in western concerns with the difference between a technologized West and a 'free-flowing' East (as reflected in Michel Foucault's work, for example), and in Indian middleclass nationalistic 'pride' in its 'great' civilizational past." (Srivastava, 2007: 11)

Considero que Srivastava, assim como John e Nair, estão corretos em criticar a desproporcional atenção dada a esse período nos estudos sobre sexualidade e romance. Tal período, no entanto, deixou um legado de ideias que são relembrados das maneiras mais inusitadas. Um dia em Khajuraho, com Pryia, o guia turístico que contratamos para 
nos apresentar o complexo de templos e esculturas eróticas da cidade, enquanto explicava as noções de kama (como sexo mundano) e de tantra (nesse contexto sexo com aspirações espirituais) expressas nas esculturas, disse-nos:

- This is how India was before Muslins arrive here.

O homem se referia justamente à ideia de a Índia ter tido esse passado de maior liberdade sexual, a qual teria sido refreada pela moral islâmica. A imposição da moral islâmica, mais severa quanto à sexualidade, aparece em obras como a de Basham [1954] que já no título de seu livro enuncia sua ideia a tal respeito: "The Wonder that was India: a survey of the culture of the Indian sub-continent before the coming of the Muslims". Como se depreende, o discurso sobre o Islão na Índia é dúbio, pode-se acusá-los de malícia e degeneração sexual e, em outras situações, culpá-los pelo refreamento de um passado sexual mais libertário.

Volto ao cerceamento da sexualidade que teria ocorrido no contato colonial envolvendo intelectuais, líderes políticos e religiosos dedicados a demonstrar a igualdade e até a superioridade moral da civilização indiana em relação ao ocidente encarnado pelos britânicos. Para evidenciar a elevada moral hindu exibe-se a castidade das mulheres, um índice dos mais altos valores morais hindus. A partir desse momento, passando pela construção do estado nação, essa é a visão que predomina na moralidade pública: a mulher é o recôndito em que residem a tradição e os valores morais hindus. Como aponta Uberoi (2006), a identidade feminina é projetada de modo a justapor a figura materna da mulher à da Mãe Índia (Bharat Mata). Assim a ideia da mulher/deusa/mãe/nação comporia o ethos nacional.

Nesse processo, aponta Srivastava, diversos grupos políticos articularam a oposição entre “'desexualised' reproductive bodies as the ideal norm of 'respectable' female sexuality and 'sexual bodies' as its other, representing 'immoral' and 'disreputable' sexuality". Assim, o que teve lugar nos movimentos nacionalistas dos séculos XIX e XX foi um discurso sobre sexualidade que implícita e explicitamente tratava de dessexualizar o corpo feminino, discurso no qual a procriação se tornava o objeto exclusivo da atividade sexual (Srivastava, 2007: 13-14). 0 quadro atual dos debates sobre a sexualidade teria começado a mudar apenas muito recentemente:

"Till quite recently, female desire - hetero or homoerotic - has not been part of the feminist agenda in the Indian context, feminist concerns (and 
those of non-feminist 'women's groups') having been largely focused on issues of the social, cultural and legal oppression of women." (Idem: 15)

Bastante esclarecedora é a formulação de Dell (2005) sobre a tendência a sexualizar o outro, de modo que a sexualidade é frequentemente projetada em outras nações - a expressão "French kiss", expressando um beijo ardente ou voluptuoso, seria um famoso exemplo disso. Dell lembra ainda que as nações colonialistas sempre imputaram aos povos colonizados acusações de inadequação e depravação sexual.

Na Índia a busca pela conformação da identidade nacional levou a tentativas de separação entre o que seria europeu ou britânico e o que seria genuinamente indiano, tendo-se como um dos desdobramentos dessa construção a estrangeirização de práticas sexuais indianas, imputando tais práticas aos britânicos, mesmo quando essas estavam, inegavelmente, presentes na Índia antes do contato colonial.

“Oral and anal sex are not new to India: such 'newness' is an invented absence because these practices have been depicted in books, paintings, and temple sculpture in India for centuries. (...) Hence what is now thought of as saheb's (European) way has played some part in Indian culture for a long time. The 'foreignization' of such practices is a major way in which 'a nation can consolidate its identity by projecting beyond its own borders the sexual practices... it deems abhorrent' (Parker et al. 1992: 10)." (Dell, 2005: 188)

Ao fazer pesquisa com profissionais do sexo em Kolkata e analisar a afluência de vídeos pornôs ocidentais (chamados de "English videos"), que estariam gerando demandas por sexo oral e anal, Dell apresenta como essas práticas são pensadas como inglesas por prostitutas, clientes e esposas. ${ }^{42}$ Para entender a dicotomia prostituta $\mathrm{x}$

\footnotetext{
${ }^{42}$ Dell aponta como, mesmo quando são produzidos na Índia, esses vídeos são chamados de "English sex videos" por conterem posições sexuais que seriam "inglesas", graças a esse processo de estrangeirização. Em seu trabalho ele demonstra ainda, etnograficamente, como trabalhadoras do sexo se recusam a executar algumas dessas práticas e como as esposas, por seu lugar de grande sujeição no interior do casamento, veem-se com menor poder de negar as demandas dos maridos. As trabalhadoras do sexo que se engajariam em tais práticas seriam as com mais dificuldades financeiras, isto é, que se sujeitariam a tais práticas como modo de atrair clientes, mulheres tidas como menos atraentes (por estarem se tornando mais velhas ou por terem o tom de pele mais escuro) executariam esses serviços por se verem em dificuldades de obter clientes se não por essas práticas. As que podem dar-se o luxo de recusar o que chamam de "non-ordinary sex" forneciam ao autor dados como: "(...) I found that some see themselves as respectable enough to reject the growing demand for 'English' sex. 'Young educated men,' said a sex worker, 'they see English movies and they even bring books with them. They want oral and anal sex. But, we refuse.' Echoing the discomfort of some middle-class wives, prostitutes in Kalighat [área central da cidade de Calcutá] officially disparage the practices as disgusting. Remarked one prostitute, 'I refuse anal and oral sex ... even kissing [on the mouth]. How is it possible to indulge in this [anal sex] when one uses it to pass stools? I pray every night, how can I put this thing in my mouth?' What bothers her is this mixing of incompatible territories of the body. Much like the separate sovereignty of India and Britain, these territories do and should have separate functions." (Dell, 2005: 199) Para a autora, a negação dessas trabalhadoras do sexo em realizar tais práticas é uma afirmação de que se colocam do lado da nação ou como mulheres da nação, "they count themselves less as border subjects and more as women of India -
} 
esposa no cenário indiano contemporâneo, Dell recua ao período colonial quando essa dicotomia foi acirrada e transformada em análoga à dicotomia moralidade/sexualidade inglesa x moralidade/sexualidade indiana.

"The opposition was succinctly set out in the 1874 publication Advice to Women (Stridiger Prati Upadesh): 'the good wife, patribrata [Bengali para pativrata, isto é, devota ao marido], is shy silent, does her duty and is totally undemanding, stays away from men, keeps her whole body covered and does not wear flashy clothes.' In contrast: 'The beshya [prostituta] is loud mouthed, always restless, bares special parts of her body, falls on men, demands jewellery and continuously wears revealing clothes' (anonymous, writing in 1847; quoted in R. Chatterjee 1993: 167). This formulation of the beshya in specific ways echoed Indian elite critiques of Western women as 'fond of useless luxury, car[ing] little for [the] well-being of the family, ... immodest, and somewhat coarse mannered' (P. Chatterjee 1990: 630)." (Idem: 192)

$\mathrm{Na}$ construção da separação entre a mulher indiana e a mulher ocidental a modéstia e a castidade, imputadas às esposas nativas, eram cruciais às alegações do nacionalismo indiano de que as mulheres indianas eram culturalmente superiores e afastadas das mulheres ocidentais. Decorre daí a ênfase na mulher como guardiã e protetora da moralidade indiana, ou, a construção da mulher hindu idealizada como representação da nação indiana (Idem: 190). A estrangeirização de certas práticas sexuais na Índia teria, entre outros efeitos, a perpetuação da visão do sexo oral e anal, até os dias de hoje, como tabu por não gerarem filhos (Idem: 197), o que seria condizente com a visão da sexualidade feminina como destinada apenas à procriação, uma sexualidade apenas materna, como citado anteriormente.

Voltemos ao amor e ao romance, os quais, segundo Uberoi (2006), teriam uma estrutura invertida em relação ao ocidente. Enquanto nas construções euro-americanas o romance começaria com um grande amor e terminaria com um casamento, na Índia o romance começa com um casamento e culminaria num grande amor. É à essa estrutura que meus amigos apresentam um contraponto importante com suas histórias e experiências românticas. 0 amor que meus interlocutores expressam em hindi pela palavra pyar e em inglês por love aparecia em histórias que falavam da tensão entre dharma e desire, tão premente na vida de Lovania, como já veremos.

Por fim, lembro ao leitor que as ciências humanas lidaram com o amor como objeto de reflexão em duas correntes opostas, mas igualmente falhas, como bem aponta this, they work to resist being othered or foreignized themselves." (Idem: idem). 
Lobato (1994), isto é, ora o amor foi visto como universal, ora como particular. Penso me alinhar à autora quando ela procura se situar entre a abordagem particularista do amor romântico, que vê esse amor como uma especificidade histórica e cultural do mundo ocidental, ou euro-americano para ser mais precisa, e a visão universalista desse amor, que veria o amor romântico como um sentimento encontrado em todos os lugares e culturas. Sobre isso Lobato pondera:

“Aceitando a possibilidade da noção de amor romântico vigente no mundo euro-americano ter uma particularidade própria, afirmo, todavia, contrariamente a alguns dos adeptos dessa posição, a necessidade dessa particularidade ser teoricamente construída e não definida tão genericamente que se torna relativamente fácil negá-la. A ideia oposta, de que o amor romântico é uma experiência humana universal, defendida pela posição contrária, falha igualmente, não só por apreendê-lo de modo tão amplo, tão desvinculado da trama da cultura, da ideologia amorosa que o sustenta e do movimento histórico que o modelou, tornando de antemão demonstrável sua extrema generalidade, como também por não captar nenhuma experiência amorosa que já não fosse familiar ao pesquisador." (Lobato, 1994: 3-4)

Intento etnograficamente o que Lobato executou por meio da análise de mitos e histórias pungentes sobre amor nas tradições ocidental (Tristão e Isolda), árabe (Layla e Majnun) e indiana (Radha e Krishna). Busco "apreender a variabilidade das experiências amorosas vivenciadas em contextos culturais diversificados", afastando-me da visão particularista que vê "um vazio onde existem experiências amorosas inegáveis" e também dos autores da posição contrária, universalista, que em face de experiências amorosas distintas "as reduzem a uma homogeneidade uniformizada" (Idem: 4).

Para tanto, passo a apresentar os experimentos existenciais de meus interlocutores na intenção de que permitam vislumbrar como meus amigos amam e de que modo relacionam o amor ao casamento, esse o fim último das noções de amor que são colocadas em movimento por eles. Inicio com a história de um namoro em que o par romântico apresenta visões bastante antagônicas da relação entre amor e casamento.

\section{O amor de Shubhi e Patrick}

Alguns dos moradores da PG têm expectativas de que conseguirão demover seus pais da ideia de casá-los de modo arranjado. Outros esperam retardar o momento do casamento até que atinjam algumas conquistas nos estudos ou nas carreiras - esse 
argumento é uma grande estratégia à disposição das moças hoje em dia para prolongar a espera dos pais pelo casamento - e poder intervir um pouco no processo de arranjo. Há, ainda, os que estão ávidos para se casar, o que expressam como "find a company for life", "find someone special", "fall for someone" e "have a family". Esses jovens querem viver, no sentido de provar da existência, e descobrir emoções, e contam, via de regra, com pouco tempo para fazê-lo e, ao mesmo tempo, trabalhar e estudar, antes que os pais os casem. Em muitos casos isso dificulta tudo, pois como me disse Patrick em 2013:

- It takes time to love someone.

Ele se referia ao romance de pouco menos de um ano com Shubhi, a qual completava 27 anos em maio daquele ano. Após cerca de um ano coabitando a PG, os dois começaram a se aproximar com interesses outros que a relação de vizinhos que já nutriam entre si. Logo que cheguei em 2013 ele disse que estava "saindo" com Shubhi. Naqueles dias Rekha e Patrick estavam muito unidos e ficávamos, os três, muito juntos. Em uma de nossas conversas ao tomar um café no Aurobindo Market, Rekha e eu começamos a satirizar o fato de Patrick ser um Don Juan, ambas dizíamos o quanto ele é paquerador e como engana as moças com quem faz isso, isto é, qualquer pessoa do sexo feminino que chegue perto dele.

Rekha: - Most part of the time you are just faking interest. But some girls don't realize it.

Fabíola: - Ya, like in Amélie's case. I remember that last year she was falling for you, poor her.

Rekha: - Exactly! You are a monster Patrick!

Patrick: - Why?

Rekha: - Because you flirt with girls just for fun.

Como meus amigos eram muito indiscretos, eu aproveitava para também sê-lo, mas não fazia perguntas que não fosse fazer a qualquer outro amigo. Tampouco realizei uma entrevista com qualquer deles, mas fazia questão, de um modo ou de outro, de mencionar minha pesquisa constantemente para que eles não se esquecessem de que eu observava e vivia tudo que fazíamos como amiga e como pesquisadora. 
Fabíola: - And what does Shubhi think about your behaviour?

Patrick: - Oh, I don't behave like this in front of her. - (risos) - But she knows me...

Fabíola: - So what's up between you guys? Is this serious?

Patrick: - Naa... we are just hanging out together...

Rekha, interrompendo Patrick: - Shut up devil! She would not agree with you, that is for sure! I have seen you guys together, she is in love with you.

Patrick: - No, no...

Fabíola: - Patrick, I agree that she must be thinking differently. I have my doubts that she is okay with your idea of just hanging out together.

O tempo encarregou-se de mostrar que Rekha e eu estávamos certas quanto à expectativa divergente de Shubhi sobre o namoro. Em onze de abril de 2013 anotei no diário de campo a primeira confirmação disso e o prenúncio do impasse entre eles. Num dos finais de semana em que Rekha viajara a trabalho, Patrick e eu, que nos cansávamos facilmente da comida da PG, fomos andando em direção ao Green Park Market em busca de algo para jantar. Acabamos indo parar no Ananda Bhavan, restaurante de comida do sul e vegetariano, para desgosto de Patrick. Em dado momento, perguntei sobre o relacionamento dele com Shubhi.

- We are about to break up.

- What? Why?

Patrick disse que o pai dela estava querendo casá-la e eu inquiri se ela não queria se casar. Ele respondeu:

- She wants. But she wants to marry me, not another person.

Patrick iniciou a contar que Shubhi havia vindo lhe perguntar se ele queria se casar com ela, caso quisesse, iriam lutar juntos pelo casamento deles. Patrick tirou todas as esperanças dela quanto a isso, segundo ele, e afirmou categoricamente que nem 
pensava em se casar por agora. Na verdade, ele sempre diz, pensa em não se casar, nunca. Eu disse:

- I knew it! I told you that you and Shubhi had different views on this relationship.

- But things were ever clear between us.

- If things were clear, why she came to ask you if you want to marry her?

- Well, you can always ask.

- Ha, ha... Ok, good one! - disse sendo um pouco sarcástica.

Argumentei que o pai de Shubhi estava querendo casá-la já há algum tempo, eu me lembrava dela dizendo isso na sala de jantar em 2012. Na ocasião ela afirmou que tentava postergar o casamento, que não queria se casar tão cedo. Lovania e Patrick diziam que ela afirmava isso no primeiro ano na $\mathrm{PG}$, mas todos foram percebendo que era um discurso vazio. Lovania que conviveu com ela por vários anos, desde uma outra PG em Délhi, disse que quando a conhecera ela já era "louca pra se casar". Em 2014 Lovania chegou a dizer: “I keep telling her that I don't know why she is in a rush to get married. She should enjoy her life because once you are married it's done. There is no way back from marriage." Segundo Patrick, contudo, agora o pai estava realmente disposto a fazer o matrimônio da filha, estava de fato pressionando-a, já inclusive procurando um noivo. Perguntei se ela não iria se opor ao pai, ele disse que ela acabaria cedendo e querendo se casar porque queria ter filhos. Indaguei por que ele não queria se casar com ela, respondeu que não queria se casar agora, que além do mais eram diferentes, ela queria ter filhos e ele não. Disse algo como: "people think that if they get married they have to have kids, I highly disagree". Não pude evitar e disse que era uma pena o fato de que ela estava apaixonada por ele e ele não estava apaixonado por ela. Patrick respondeu:

- But I'm in love with her.

- Então por que não se casar com ela? - perguntei. Ele voltou a repetir a cantilena do não interesse no casamento e dela querer filhos e ele não. Perguntei o que eles decidiram fazer depois disso, ele disse que ainda não haviam decidido nada. Lembrei-me 
de tê-los ouvido discutindo na noite anterior e perguntei quando havia sido essa conversa, ao que ele respondeu: “- A couple of weeks ago." - e me pediu que não contasse a ele que sabia o que se passava entre eles. Quando íamos pra casa, Patrick comentou que o pai de Shubhi estava decidido agora porque ela já iria fazer 27 anos, nessa idade ainda seria possível encontrar um bom noivo para ela, "since she is beautiful and educated", mas passando dessa idade o relógio começaria a correr contra ela, "a good match will be more and more difficult then". Contava para Patrick e outros rapazes da PG considerarem Shubhi uma moça bonita o fato de ter a pele bem clara, cabelos longos e lisos e ser magra, havia sempre elogios a essas características e também ao modo cuidadoso de ela se vestir, que era "trendy" como eles diziam.

Nas semanas que se seguiram, Shubhi disse a Patrick que precisavam tomar uma decisão, ela estava gostando muito dele ("I was very much into him") e sua idade a estava preocupando, pois para o pai ela estava passando da hora de se casar. Patrick quase caiu das pernas ("I felt a weakness on my knees"). Ele disse a ela, como sempre repete aos quatro ventos, que não estava pronto para se casar. Ambos haviam chegado a um impasse, que eu agora ouvia de ambos os lados. Ela amava Patrick e estava pronta para se casar e ter filhos, algo que considerava importante que ocorresse antes dos trinta anos de idade, pela pressão familiar e por "razões médicas", pois os médicos na Índia apregoam que após essa idade as chances da mulher conceber diminuem drasticamente, conforme ouvi de todas as minhas amigas da PG. Ele, segundo me contava, não sabia se gostava dela a ponto de se casar e não estava pronto para o casamento. Shubhi, por seu turno, estava disposta, inclusive, a enfrentar a família para ficar com Patrick. Ela disse ao rapaz que, se ele estivesse de acordo, iria falar com seu pai e ele deveria falar com sua família também.

Um complicador se somava ao impasse entre ambos, o romance deles não seria facilmente aceito pelas famílias, uma vez que se tratava de um namoro inter-religioso, sendo ela hindu e ele muçulmano. 0 relacionamento amoroso entre um muçulmano e uma hindu é narrado na literatura antropológica e nas páginas dos jornais como o maior tabu de todos os romances, não raras vezes culminando em assassinatos por honra (honour killings), um desfecho comum em aldeias (Chowdhry, 2007).

Antes dos ingleses, os grandes outros dos hindus, internamente à Índia, são os muçulmanos e, em alguma medida, os povos tribais do país. 0 conflito com o Islão se acirrara no período da independência culminando na partição da Índia e a animosidade 
continua no período pós-independência em que os novos movimentos nacionalistas agrupados pelos críticos sob a nomenclatura Hindutva - almejam criar uma identidade nacional calcada no hinduísmo, daí o termo Hindutva que costuma ser traduzido por hinduness (Srivastava, 2007; Mody, 2008; Menon, 2007; Uberoi, 2006). Recentemente os partidos políticos hindus vêm chamando os casamentos entre muçulmanos e hindus de "love jihad", querendo dizer com essa expressão que esses casamentos inter-religiosos seriam uma estratégia das comunidades muçulmanas para converter moças hindus ao islamismo. ${ }^{43}$

Patrick e Shubhi passaram a tentar se afastar, embora todos nós à volta, os que sabiam do romance, percebêssemos a dificuldade deles nisso. Eu continuava morando na PG quando a conversa entre ambos e a decisão de se afastarem aconteceu, o que não se deu em brancas nuvens. Do primeiro andar, Rekha, Lovania e eu podíamos ouvir Shubhi com a voz elevada alternando frases ríspidas em inglês e hindi desde o terceiro andar, onde os dois conversavam. Depois disso, num dia pelo final de maio, na antessala do cinema, enquanto aguardávamos para assistir ao filme $O$ Grande Gatsby, ambos estavam sentados bem próximos um ao outro e seus ombros se tocavam. Comiam pipoca do mesmo balde e cochichavam, deixando a mim e Dileep de fora da conversa. Para provocar perguntei:

- Why you guys look so much like a couple? - todos rimos e Patrick respondeu:

- Good question, I don't know!

Naquela noite, Shubhi estava empolgada para ver o filme, segundo ela porque se tratava de uma estória de amor. Os garotos protestaram dizendo que era a história de vida de um homem que faz fortuna e guarda um grande mistério em seu passado e não "a love story". No intervalo do filme, perguntei se todos estavam gostando, Patrick fez cara de que não e Shubhi disse que sim, era uma verdadeira estória de amor, Dileep, que havia lido o livro, disse querer esperar até o final para dar sua impressão. Shubhi estava encantada com a intensidade do amor do protagonista por sua amada Daisy. 0 filme narra a saga do jovem pobre Jay Gatsby para se tornar um homem rico e conquistar a

\footnotetext{
${ }^{43}$ Sobre esse assunto a professora Janaki Nair publicou uma crítica no jornal The Hindu, sob o título "Why Love is a Four Letter Word". No artigo pode-se ler, na visão da autora, o motivo pelo qual hindutvas torcem os sentidos dos casamentos inter-religiosos desse tipo: "That many Indian women are no longer the passive bearers of caste, religious and ethnic meaning, but the makers of meaning, causes dismay among those who feel their grip is loosening". O artigo, publicado em 06/10/2014 pode ser acessado em: http://www.thehindu.com/opinion/op-ed/why-love-is-a-four-letter-word/article6473438.ece
} 
bela e sofisticada Daisy, que é casada com outro homem e abandonara Jay por ele não ter dinheiro. Cenas que vão desde a sedução e conquista de Daisy até a consumação física do amor desta com o protagonista compõem o romance na primeira metade da película. $\mathrm{Na}$ segunda parte do filme, Daisy se transforma na anti-heroína, pois abandona novamente Gatsby quando percebe que os segredos que guarda sobre seu passado podem arruinálo financeiramente. Ao final da sessão, Dileep havia adorado o filme. Patrick definitivamente não gostara muito da produção hollywoodiana. Shubhi, contudo, havia detestado a segunda parte, pois Daisy acabara com todo o romance construído no início do roteiro. 0 final triste da história, com a morte do protagonista e o abandono em que a anti-heroína incorre pela segunda vez, contrariavam sua visão e sua ânsia por uma estória de amor, já que os amantes não ficavam juntos para sempre ao final. Além de Dileep, eu também gostara do filme, exceto pela trilha sonora que coloca músicas dos anos 2000 num filme ambientado nos anos vinte, contrariando minha estética careta e purista, isso era justamente o que Patrick havia gostado. Voltamos pra casa no carro de Shubhi, os dois conversando baixinho na frente e Dileep e eu discutindo o filme no banco de trás.

No dia seguinte, estava lendo no quarto desde a manhã quando Shubhi me mandou uma mensagem perguntando onde eu estava. Disse-lhe que no meu quarto. Ela afirmou que queria me encontrar e eu pedi que viesse me ver. Ela chegou comendo uns salgadinhos de milho. Ofereci a poltrona para que se sentasse e liguei o ar-condicionado. Perguntou-me como eu estava, o que fazia naquele momento etc., fui respondendo ao mesmo tempo em que fazia as mesmas questões a ela, até que seu telefone tocou e ela ficou uns dez minutos conversando com alguém do outro lado da linha. Eu continuei sentada em minha cama até que ela desligou e pediu desculpas. Seguimos falando. Como sempre, toquei no assunto da relação entre ela e Patrick. Shubhi disse que antes estava muito triste, mas agora lidava melhor com o fato de eles não poderem ficar juntos. De início ela não citou o fato (segundo a versão de Patrick) de que ela queria se casar e ele não, disse que não podiam ficar juntos porque ela é hindu e ele muçulmano, por isso, seria muito difícil para os dois enfrentarem as famílias para se casarem. Comentou nesse momento que muçulmanos não são bem vistos na Índia, por isso sua família não permitiria que ela se casasse com um. Disse que ele também teria dificuldades com a família dele e que ela teria que se converter ao islamismo, o que não seria nada fácil para ela, pois representaria uma mudança de vida muito grande. 
Depois falou da pressão do pai para que ela se casasse: "now there is this pressure on me". Perguntei como ela se sentia em relação a isso. Começou a me contar então que estava se comunicando com um rapaz de Délhi, mas que vivia em Mumbai para trabalhar. Ele teria sido encontrado pelo pai dela que os colocara em contato e já haviam se encontrado algumas vezes em Délhi. Indaguei se ela gostava dele.

- I'm trying. See, I want to marry, I want to have a family, but you have to do your part for this. It is not easy, is not only think I want to marry and then it happens, you have to put yourself into it to make things work. So we are talking, we are trying to know each other and I'm trying to like him.

- Ok. And how are these dates? I mean you guys talk and so. Just talk or did you kiss him?

- No, no, no... No kisses, we talk only. It's a step-by-step process. We are going very slowly.

Perguntei se Patrick sabia disso. Ela disse que sim, que eles conversaram, decidiram terminar o relacionamento e estavam tentando conviver com isso. Emendou dizendo que era difícil, mas que eles seriam sempre amigos, que gostavam e se preocupavam um com o outro. Em seguida falou:

- Patrick is a very complicated guy, he is complex, he is not at all an easy guy. His mind is different. He thinks differently about life, it's not easy to have a relationship with him.

- That's why you gave up on him? - arrisquei perguntar.

Ela respondeu falando longamente sobre idade na Índia, que havia idade para se casar e idade pra ter filhos, afirmou que não podia mais esperar por Patrick, estava agora na idade de casar. Perguntou se eu não queria ter filhos. Eu disse que talvez, mas apenas depois de concluir o doutorado. Perguntou com quantos anos eu estaria, respondi que trinta e seis, ela achou que era muito tarde, "in India 36 is too late for the first baby".

- In India people get married young. I'm almost twenty-seven. I'm getting old to marry. Usually girls get married around 25, 26 years old. If I delay more to get married it 
will be very difficult for my father to get a good match for me. Also for having kids, after you marry you should have a baby soon. Thirty years is considered late to have the first baby. That's why I am thinking. I can't wait more to get married, because after marriage there is also the pressure to have a baby.

- Do you want have a baby soon after getting married?

- Yes, yes, I want. After I get married I will have a baby in one year. That is what I'm thinking. I will get married and have a baby before I get thirty. After thirty you are very old to have the first baby, thirty is the limit. How is it in Brazil?

Então eu disse que os processos eram muito diferentes, que eu havia me casado aos vinte e cinco anos, mas André e eu ainda não tínhamos tomado a decisão de ter filhos. Ela disse que eu havia me casado cedo, mas ainda não tinha filhos, o que parecia incompreensível para ela.

Ao contrário de Lovania e Patrick, com quem já tinha proximidade desde 2012, essa foi a primeira conversa longa que tive com Shubhi. No primeiro ano, ela parecia não ter gostado muito de mim, ou talvez eu tenha estado mais próxima de um grupo com o qual ela não simpatizava tanto naquele tempo. Alguns na casa a criticavam por pensar que a vida era feita de festas. Era uma crítica menos severa que a que todos dirigiam a Soumita. No caso de Shubhi era mais como se pensassem que ela era fútil ou tola, não necessariamente vulgar. Tanto Patrick quanto Dileep se expressavam sobre ela dessa maneira em 2012. Lembro da frase do segundo na sala de jantar certa feita, quando Shubhi deixou o aposento ele disse:

- See, she thinks that life is just a party, I can't have a serious conversation with someone like her. I don't take my life that way so I have nothing to talk to someone like her.

Dileep respondia à minha pergunta sobre o motivo que o fazia indiferente a algumas pessoas na casa. 0 namoro de Patrick e Shubhi fez com que nós duas nos aproximássemos bastante, saí com eles muitas vezes, acompanhados de Lovania, Rekha e Dileep em 2013. Nesse ano fiquei mais afastada de Kaushik, de quem Patrick, Shubhi e Lovania haviam se distanciado desde o final do ano anterior. Rekha, por sua vez, ainda não era tão ligada à Kaushik quanto ficaria no ano seguinte, depois que Patrick, então seu melhor amigo, mudou-se para Gurgaon ao fim de 2013. Shubhi e eu estreitamos cada 
vez mais a relação até que em 2015 voltei à Índia para comparecer a seu casamento como uma de suas melhores amigas. Mas não falemos sobre isso ainda. Voltemos a Shubhi e Patrick.

No dia do aniversário de Shubhi, um mês e meio após romperem, ambos ainda não haviam conseguido se desvencilhar de seus mútuos sentimentos amorosos e, como dito, ela estava já em contato com o moço de Mumbai. Era domingo e acordei tarde. Patrick veio me dizer que estava indo à casa de sua irmã, que também residia em Délhi nesse ano, mas que eu ficasse a postos, pois à noite iríamos sair para comemorar o aniversário de Shubhi. Ele partiu e fiquei escrevendo e lendo um pouco. Quando Patrick voltou, eu falava com André no Skype e ambos conversaram por algum tempo. ${ }^{44}$ Combinamos de nos encontrar às onze, para sair e cortar um bolo de aniversário para Shubhi. Ele e Lovania haviam comprado uma torta e iríamos parti-la no India Gate, monumento histórico da cidade, em meio a uma praça e um jardim em Central Délhi e um dos tantos belos lugares abertos da cidade, para o qual afluem turistas e transeuntes locais. Quando eram quase onze horas, Patrick veio do terceiro andar, bateu à minha porta e descemos para o quarto das meninas. Ele comprara para a aniversariante um colar Swarovski. Entregou em nossa presença, minha e de Lovania, e ela prometeu usar no sábado seguinte, quando sairíamos para de fato comemorar o aniversário, porque naquela noite iríamos "just cut the cake".

Antes de partir, tiramos algumas fotos com Shubhi e dela com o buquê de rosas com que Patrick havia também lhe presenteado. Quando fazíamos isso, Mrs. Kapoor, que mora no quarto ao lado, apareceu no corredor e comentou: “- Oh, the birthday girl!" Shubhi foi até o lado de fora do quarto, que se encontrava com a porta aberta, com as três moças no interior e Patrick do lado de fora, para receber os cumprimentos da senhora Kapoor. Em poucos minutos, entramos no carro de Shubhi e partimos para o India Gate. No caminho, ouvíamos música no tablet de Patrick conectado ao som do carro de Shubhi. Ela coordenava as músicas, e reclamava quando ele colocava algo de que ela não gostava, o que o fazia mudar imediatamente a música para outra que ela pedisse ou que ele soubesse que ela gostava mais.

\footnotetext{
${ }^{44}$ André havia ido me visitar e conhecido a maior parte de meus amigos, deu-se bem particularmente com Anirudh e Patrick. Sua visita foi importante ainda para demonstrar que eu era de fato casada, que meu marido se importava comigo e que, apesar de meu trabalho atípico, eu tinha família e uma "vida normal", era, portanto, do ponto de vista local, uma "boa mulher".
} 
Ao chegar, a avenida em que o monumento se encontra estava cheia de carros estacionados de forma irregular, não obstante a presença da polícia. Estacionamos e vi uma multidão, famílias inteiras com crianças, grupos de rapazes jovens, casais, balões, carrinhos de picolé, água, refrigerante etc. Somamos à multidão e fomos andando em direção a uma área em que o chão era de terra. Passamos por uma mulher que mexia com um cachorro de rua enquanto comia e os outros à sua volta riam, fiquei olhando a cena e Patrick me disse:

- Don't look at that, you will get impressed.

- Why? It is just a dog and a young lady.

Meus amigos lidavam de modos diferentes com aspectos da paisagem que eles julgavam que fossem me impactar durante nossa convivência e atividades cotidianas. Naquele momento Patrick tentava me proteger de ter uma impressão ruim de alguns aspectos de seu país, não queria que eu fosse afetada pela cena de uma mulher comendo junto a um cachorro de rua. Eu explicava que no Brasil cenas de rua podem ser igualmente ou mais tristes e chocantes, mas eles não me levavam muito à sério, a não ser Pryia, que visitara alguns países latinos americanos a trabalho e sabia das condições semelhantes de injustiça e desigualdade social na Índia e no Brasil. Shubhi, em outros momentos, quando estávamos em lugares lotados demais, em Délhi ou fora da cidade, mantinha sempre um olho em mim pra ver se eu não me perdia e se me sentia bem, "are you fine?", “are you ok?”, “thik hai [ok]?”, eram suas palavras afetuosas para comigo, em seguida dizia: "-This is India! Hauz Khas is not the real India baby-" ela se referia ao fato de aquela vizinhança ser menos populosa, mais limpa e com casas enormes e luxuosas. Depois de andarmos uns cinco minutos, meus pés já estavam imundos dentro da sandália, olhamos para o outro lado da avenida onde ficava o India Gate e reparamos que estava fechado por cavaletes de ferro e vigiado pela polícia. Do lado onde estávamos, havia uma fumaça que parecia de churrasqueira sem ser, muito lixo no chão, garrafas, sacolas plásticas e papel. Shubhi começou a falar da sujeira e que as pessoas que estavam ali eram "uneducated people". Eram claramente pessoas da classe popular e ela os chamava ininterruptamente de "uneducated people". Voltamos para o carro, que agora tinha uma moto parada atrás, a qual Patrick tirou do caminho para que saíssemos. No carro, ela reclamava do lugar, da sujeira e das pessoas "uneducated". Lovania disse para ela se acalmar e parar de reclamar. Eu achei que ela estava desdenhando a ideia de 
Patrick de ter vindo até ali, ou pior, culpando-o por arruinar seu aniversário. Ele estava visivelmente desconfortável.

Sugeri ir até o India Habitat Center e ela gostou da ideia. O lugar, uma espécie de centro cultural, com teatros, galerias de arte, restaurantes e auditórios, tem também um espaço aberto em que poderíamos nos sentar. Rumamos para lá enquanto ela dirigia e atendia o telefone que não parava de tocar, com pessoas querendo dar os parabéns pelo aniversário. Ela ria, falava alto e dirigia ao mesmo tempo. Estacionamos no interior do India Habitat Centre e fomos para o meio do lugar onde há um jardim e umas escadas do lado oposto ao restaurante American Diner. Colocamos o bolo no muro que ladeia a escada, Lovania ajeitou as velas e cantamos Happy Birthday to You. Servimos pedaços de torta na boca da aniversariante e ela fez o mesmo conosco, como tenho testemunhado sempre nos aniversários durantes os últimos quatro anos.

Saavala (2010) aponta como costumes de cortar bolos de aniversário, comemorar o dia dos namorados (Valentine's Day) com presentes, rosas e cartões, dentre outros, são novos à Índia, mas já contam com a adesão em massa de jovens das classes médias urbanas. Essas novas tradições geram, como afirma a autora, retaliações de grupos políticos hindus que veem nessas práticas o que chamam de "westernization of Indian culture", entre o que incluem o uso de roupas ocidentais como o jeans e de batom, que seriam vistos como símbolos da "americanização" da juventude indiana. 0 dia dos namorados seria uma data pivô para censuras morais, em que a moralidade e a "indianidade" são conjugadas, graças ao fato de que a ideia dos namoros está em flagrante contraste com a centralidade da escolha dos pares conjugais como prerrogativa dos pais e desafiam, assim, a hierarquia na relação entre pais e filhos. A autora traz casos em que o dia dos namorados foi posto como uma das mais questionáveis influências morais estrangeiras no país:

"Every year, for example, the Bajrang Dal, a Hindu nationalist youth league, arranges campaigns protesting against the celebration of Valentine's Day. The institution's stress on individualism, love and romance, mediated by consumerism, runs counter to 'traditional' Hindu values of arranged marriage, women's sexual modesty and hierarchical social relations. 'This shameless festival... is totally contrary to Indian culture', said Bal Thackeray, the head of Shiv Sena in Mumbai in 2001 when his party burned Valentine's Day greeting cards and protested against the annual event. In 2005, the New Delhi unit of Shiv Sena termed Valentine's day, 'Prostitution Day', to emphasise its degenerative influence on Indian youth." (Saavala, 2010: 43) 
A autora afirma que não obstante essas sejam manifestações de um grupo minoritário com visões extremistas o barulho causado por eles é grande e os jovens que se engajam na comemoração da data aproveitam para se distanciar dessa visão. Mas Saavala também afirma que a influência dos partidos hindus que conjugam moralidade e "indianidade", como o que seria propriamente tradicional na cultura indiana, é crescente. Ela cita um exemplo em que:

"In Kanpur the student wing of the Bharatiya Janata Party in 2000 announced that college girls would not be allowed to wear jeans or skirts - on the threat of physical assault by members of the organisation. Fearing retaliation, some college principals yielded to pressure and banned jeans." (Idem: idem)

O que se vê é que em situações pivôs como essas, tem-se tomado o lado da vigilância moral sobre, principalmente, as mulheres. E a autora escrevia num ano em que o referido partido, BJP (Partido do Povo Indiano), ainda não havia ganho as eleições ao cargo de Primeiro Ministro, o que ocorreu em 2014 com a eleição de Narendra Modi.

Na noite em que cortamos o bolo, Shubhi quis tirar fotos perto de uma árvore, num gramado que separa o lugar onde estávamos da entrada do restaurante American Diner. Tiramos as fotos, comemos cada qual seu pedaço de bolo e nos dirigimos para o carro novamente. Voltamos pra casa e ela agradeceu-nos por organizar a celebração de seu aniversário, ao fim de tudo, parece que estava feliz. Particularmente achei aquela comemoração muito inusitada. Geralmente cortava-se o bolo no terraço da PG, como fizeram Patrick, Rekha e Amélie, ou na recepção como me lembro de Pryia ter feito no ano anterior, e como Mitlesh fez com a torta que compramos para ele em 2014. Mrs. Kapoor também havia partido um bolo na recepção certa feita. Em todos esses casos vários moradores haviam cantado Happy Birthday e comido do bolo, que permanecia na recepção, caso alguém chegasse mais tarde poderia também pegar um pedaço. Talvez por querer se destacar sempre dos demais, Shubhi tivesse optado por cortar seu bolo com convidados seletos, longe dos olhos e da companhia dos demais moradores da PG. Algo que também chamou minha atenção foi a pontualidade em cantar os parabéns nessa ocasião e no aniversário de Rekha. Nos dois casos cantou-se e cortou-se o bolo apenas após a meia-noite, quando já era realmente a data do aniversário. Comemorar antes é considerado inauspicioso, pois não respeita a confluência entre a data do nascimento, a posição dos astros e o momento da celebração. 
Quando chegamos de volta à $P G$, por volta da uma hora da manhã, havia uma cesta de rosas, dessa vez vermelhas, com o porteiro para que fosse entregue a ela. Falei brincando: - "Hum, someone has a secret admirer" - Patrick disse com a voz séria:

- It's not secret.

Entramos, subimos as escadas e Patrick passou por nós indo direto para seu quarto sem dizer palavra, ficamos sem entender. Perguntei:

- Is he jealous?

Shubhi fez que não sabia com a cabeça e os ombros. No dia seguinte encontrei Patrick quando pegava meu jantar na cozinha, fomos comer no balcão da recepção, pois havia uma reforma na sala de jantar que começava a se transformar num escritório, e ele agia como se nada tivesse acontecido, acompanhei seu comportamento e comemos conversando trivialidades. Quando acabamos e devolvemos nossas bandejas à entrada da cozinha, Patrick perguntou se eu havia conhecido a nova moradora, que chegara há pouco para morar no quarto ao lado do meu. Respondi que não e ele disse:

- Let's welcome her!

Subimos as escadas e batemos à porta da moça. Tratava-se de Swarna, uma jovem bonita (pretty) e "really hot", segundo todos os moradores e algumas das moradoras da PG, que chegava de Mumbai para trabalhar como advogada em Délhi. Eu ficava sempre espantada, ao mesmo tempo em que me divertia, com a cara de pau de Patrick. Ele flertava com a moça tão espontaneamente quanto respirava.

No fim de semana seguinte, na sexta-feira, combinamos, Rekha, Patrick e eu, de ir ao cinema em Select City Mall, um shopping em South Delhi. Rekha recebeu outro convite no decorrer do dia e preferiu ir fazer um happy hour com sua chefe em vez de sair conosco. Patrick e eu decidimos ir ao cinema assim mesmo, quando saía para encontrá-lo no térreo avistei-o na porta do quarto de Shubhi e Lovania. Shubhi perguntou por que não a havíamos chamado para ir ao cinema. Disse que eu também era apenas convidada, que o plano inicial era de Patrick e Rekha. Sair em grupo na PG era sempre complicado, quem era chamado e quem ficava de fora eram decisões que eu deixava sempre para meus anfitriões, por mais que me esforçasse não compreendia a lógica de chamar alguns e não chamar outros, ou melhor, isso eu entendia, havia 
preferências e desavenças entre os moradores, o que eu achava curioso era como lidavam com isso, pois, via de regra, alguém era pego na saia justa de estar indo para um passeio sem ter convidado a alguém próximo, como era o caso naquele momento. Ela se virou para Patrick, que nada respondeu. Eu disse:

- Well, here we are. Let's all go to the movies then!

Lovania se esquivou rapidamente, como sempre. Shubhi ficou fazendo escusas, mas percebi que ela gostaria de ter sido chamada, então insistimos um pouco e ela se decidiu a ir. Eu disse que ainda tínhamos bastante tempo até a sessão e que ela podia se arrumar, nós esperaríamos. Fiquei no quarto com as meninas enquanto Patrick foi para o corredor atender uma ligação de seu pai. Os telefonemas de pais e mães eram diários para muitos dos hóspedes da PG e também faziam parte do que os filhos consideravam como esforços dos pais para vigiar e controlar suas vidas mesmo vivendo longe.

No shopping, Shubhi estava mal-humorada e nada lhe agradava. 0 filme a que estávamos indo assistir, Hangover III, só tinha ingressos em lugares separados, ela não queria ver Fast and Furious VI - não que eu quisesse também - por fim, ela disse que queria assistir Yah Jawaani Hai Deewani, o mais novo hit de Bollywood naqueles dias que, obviamente, contava uma história de amor. Patrick não queria ver esse filme, mas disse que concordava após eu dizer que estava tudo bem por mim. Fomos ao guichê do cinema e a sessão seria a das onze horas e o filme, com duração de três horas, acabaria tarde. Isso estava bem pra mim, já que era sexta-feira, mas Shubhi ficou fazendo careta e dizendo que era muito tarde. Desistimos do filme e resolvemos sentar para comer alguma coisa e ir para casa. Patrick sugeriu um café próximo à saída do cinema, o Mocha. Fomos até lá e eu simpatizei com o lugar. Shubhi torceu o nariz e pediu para ir ver a praça de alimentação. A essa altura eu já estava me esforçando para não demonstrar a sensação de que ela aceitara ir apenas para estragar o passeio.

Na praça de alimentação, Patrick e eu vimos um lugar chamado Beer Club, pensamos em ir até lá, ela novamente se opôs. Fomos para a seção das cadeias de fastfood, o cheiro de gordura e fritura no ar me fez ficar um pouco irritada com Shubhi, embora eu tenha disfarçado muito bem para ela, não para Patrick, a quem eu confidenciei quando fomos fazer os pedidos, enquanto ela permaneceu sentada a uma mesa do lugar: 
- What a mood!

Ele, para minha surpresa, respondeu:

- Why did you have to call her? - e riu-se. Em seguida desferiu:

- And do you ask me why I didn't want to marry her!

Em mais de um momento Patrick e Lovania faziam comentários quanto ao fato de Shubhi ser geniosa (moody) e mandona (bossy). No ano seguinte, com a crescente intimidade entre nós duas, eu também era comandada por ela em certas situações, mas nada que impedisse a diversão que era conviver com ela. Com os pedidos em mãos, voltamos. Na mesa, ela elogiou meu colar e perguntou quanto eu havia pagado por ele. Patrick a cutucou e disse:

- Don't ask that.

Eu ri e disse a ela que estávamos rindo porque eu comentara com Patrick, dias antes, que eu achava engraçado as pessoas me perguntarem quanto eu havia pagado por cada coisa que eu comprava. Ela falou:

- Yes, in India people ask too many questions.

Eu disse que havia percebido e pensei alto:

- Maybe it is because people share everything, there is no privacy.

Ela disse:

- Yes, that's it, people share everything, nothing is hidden, and everybody takes part in each other's life.

Patrick ficou bravo e disse:

- Oh this you can share, how much you spend, how much you earn, but you can't share this [beijou Shubhi no pescoço, próximo à orelha], you can't share your affection, this you can't. 
Patrick sempre ficava exaltado ao falar da moralidade que era esperada em público. Houve uma época em que ele perguntava a todas as meninas da PG, como provocação, se elas achavam que era proibido por lei beijar alguém em público, muitas respondiam que sim, devia haver uma lei que proibia isso, o que na verdade não há. 0 que há, segundo Anirudh e Hemanshu, é uma lei que fala de "atos obscenos em público", o que seria obsceno ou não era deixado a cargo do juiz, que poderia, dependendo do estado decidir ora de um modo ora de outro sobre a questão. 0 fato é que sabendo disso Patrick buscava me mostrar o quanto as pessoas ali, "modern educated people", ele dizia, não sabiam que não havia lei alguma que proibia beijos em público, essa era uma regra imposta pelo policiamento moral, não pela legislação. Em 2012, eu ficara impressionada com a afirmação de Ishita de que sexo antes do casamento era considerado crime na Índia. A moça, que havia vindo de Varanasi para estudar administração de empresas e contava dezenove anos à época, foi motivo de risos de Dileep e Patrick quando disse isso numa tarde em que tomávamos tchai em frente à PG. As declarações de Ishita e outras moças recém-chegadas à Délhi, e mesmo Lovania, que lá vivia há anos, faziam-me perceber o quanto a educação que os pais e a comunidade lhes davam era poderosa no sentido de inculcar nelas os ideais morais que orientam a sexualidade, como a regra que afirma que a moça deve ser virgem até o casamento. A cerimônia do casamento, chamada kanyadana (o presente de uma virgem), expressa justamente o ato em que o pai doa a filha, virgem, ao futuro marido.

Naquela noite, voltamos pra casa logo após comer uma porção de kabab de cordeiro e um chicken sizzler. Fiquei pensando no quanto Patrick e Shubhi ainda exibiam uma dinâmica do casal de namorados que haviam sido no modo de se relacionarem e no quanto tinham dificuldades em se afastar. Quando ele a beijou no shopping passou a mão por detrás do ombro dela e assim ficou, quase como que sem perceber, a discursar sobre a "hipocrisia moral indiana". Ela mostrava-se habituada ao carinho dele, não exibindo reação contrária ao beijo e ao abraço que ele lhe dava. Era impossível não ver o afeto entre ambos e a intimidade que seus corpos, acostumados um ao outro, expunham mesmo não intencionalmente.

Na noite seguinte íamos festejar o aniversário de Shubhi em grande estilo. 0 plano inicial era de comemorar no sábado anterior, mas Lovania a lembrou de que não era auspicioso celebrar o aniversário antes da data exata, que era o domingo, assim, Shubhi transferiu a comemoração para o sábado seguinte. Perguntei em que consistia a 
não auspiciosidade caso se comemorasse o aniversário antes da data, Shubhi não soube, ou não quis, explicar-me, limitou-se a dizer que Lovania é quem sabia e ela também quem havia feito Shubhi temer contrariar esse preceito. Ela e Patrick saíram na quintafeira para procurar o lugar onde começaríamos a noite. Decidiram-se por um lugar chamado Rock Café Bar que fica em Greater Kailash II, M Block, um endereço "descolado" da capital indiana. Lovania, que durante a semana toda havia insistido que talvez não pudesse sair conosco, já que trabalharia no domingo, finalmente se decidira a ir.

A maioria de minhas amigas e amigos trabalhavam aos sábados e, por vezes, aos domingos. Naqueles dias a empresa onde Lovania trabalha estava contratando novos funcionários. Como executiva no setor de recursos humanos, estava trabalhando sem parar. Rekha e Pryia viajavam constantemente a trabalho, não importando se era dia de semana ou feriado. Anirudh levava processos de clientes do escritório de advocacia onde trabalha para estudar em casa e atendia ligações de seus chefes no celular até mesmo à noite, quando estávamos fora em algum bar ou restaurante. Durante a semana, muitos chegavam em casa às oito ou nove da noite, e começavam a trabalhar as nove ou às dez da manhã. Sempre achei a carga horária de trabalho deles elevada e o nível de dedicação ao trabalho impressionante, inclusive pela pouca idade de alguns deles, a maioria com vinte e quatro, vinte e cinco anos.

Shubhi não convidara mais ninguém da PG além de nós três, nem mesmo Rekha, que era minha colega de quarto na ocasião. Adicionalmente ela pediu que eu não contasse a Rekha ou a Soumita que iríamos sair juntos. Finalmente, após as inquietações de Shubhi em relação ao sumiço de Patrick durante o dia e depois do atraso de Lovania em se arrumar, partimos para o tal Rock Bar. Patrick havia demorado a chegar porque fora ao shopping comprar um colete preto, que agora usava, junto com uma calça da mesma cor e camisa branca, além de um chapéu coco. Shubhi também usava um vestido novo, comprado para essa ocasião, na cor roxa.

O bar estava vazio quando chegamos e tinha decoração com motivos de rock $n^{\prime}$ roll que eu considerei forçada, pois o espaço era muito clean para combinar com os quadros do Metallica, Megadeth e outras bandas que eu não reconhecia. Pinturas em estilo marca d'água nas paredes brancas exibiam figuras de guitar heroes. 0 arcondicionado não estava funcionando bem e não haviam reservado a mesa que eles escolheram quando foram lá durante a semana. Comemos alguns petiscos, tomamos 
alguns drinks e, em pouco, os outros três convidados de Shubhi chegaram. Patrick fez cara feia quando soube que um rapaz que estudava com Shubhi viria. Os convidados que não eram da PG eram colegas de pós-graduação. Disse a Patrick que ele estava com ciúmes ao que ele simplesmente respondeu:

- This guy is dark, he has a dark complexion, he is short and not handsome, why should I be jealous of him?

- This answer is the proof that you are jealous, otherwise, why would you be so rude? - respondi repreendendo a afirmação preconceituosa de Patrick.

Outras pessoas foram chegando ao lugar e, finalmente, um casal de namorados, os últimos convidados esperados, chegaram. Em poucos minutos partimos para o clube Shiro. O lugar era requintado, para entrar é preciso ter o nome na lista, o que Shubhi conseguira através de um colega do trabalho. Os carros no estacionamento incluíam marcas como Jaguar, Ferrari e Mercedes. No interior do clube, estátuas gigantes de um bodhisattva e duas apsaras e a iluminação muito bem feita, com ar cool. ${ }^{45}$ No bar, a cerveja Heineken long neck era vendida a 500,00 rúpias, o que convertido para reais girava em torno de 25,00 reais e me fazia querer, subitamente, ser abstêmia. Patrick pagou 700,00 rupias por uma dose de vodca Absolut que misturou com água tônica. É preciso entregar um cartão de crédito ao pessoal do bar para pedir as bebidas. Em aproximadamente quarenta minutos de nossa chegada os garçons recolheram as mesas no meio do espaço próximo ao balcão do bar abrindo espaço para um pista de dança que rapidamente se encheu, e recebeu um DJ badalado da cidade. 0 piso é flutuante e os garçons apenas empurram a plataforma de madeira com sofás, almofadas e mesas para debaixo do piso de um balcão com mais espaço e mesas. Com algumas novidades, as músicas eram exatamente as mesmas que tocavam nos clubes quando saía com Pryia no ano anterior, o repertório majoritariamente euro-americano incluía, em momentos de muita empolgação do público, músicas de Bollywood pertencentes à trilha sonora do último filme a ser lançado.

Patrick e Lovania implicaram rapidamente com Shweta, a amiga de Shubhi. Talvez porque ela usasse uma saia curta e uma blusa tomara-que-caia, deixando bastante do corpo à mostra. Estava vestida de modo comum para uma ocidental, mas

${ }^{45}$ Bodhisattva, na tradição budista, é alguém que alcançou a iluminação e se dedica a ajudar que outros a consigam. Apsaras são figuras femininas das mitologias hindu e budista que representam espíritos das nuvens e das águas. 
talvez não para uma indiana. Mais tarde, Lovania comentava "this Shweta, she is kind of slut, I don't like her at all". 46

Shubhi dançava com todos os seus convidados, comigo e Lovania, com Patrick, com Shweta e também com os outros rapazes. Visivelmente Patrick foi mudando seu humor durante a noite. Em parte pela alteração provocada pela bebida e em parte pelo comportamento de Shubhi, que divergia das expectativas do rapaz. Ao sairmos da boate Shubhi ficou conversando com seus amigos que queriam ir comer, enquanto nós ficamos, os três juntos, um tanto afastados deles. Brincamos um pouco de escolher, dentre os carros luxuosos no local, aquele que usaríamos, e ela não vinha nunca. Ficamos impacientes e fomos nos sentar numa mureta ao lado da saída do lugar. Patrick começou a dizer: "She abandoned us". Encostou a cabeça no meu ombro, visivelmente cansado e um pouco embriagado e ficou uns instantes assim. Lovania e eu nos perguntávamos onde estava Shubhi, pois a perdêramos de vista. Uns dez minutos depois ela veio nos chamar. Fomos até o carro e quando Patrick fez menção de abrir a porta da frente e ocupar o lugar do carona, como sempre faz, percebeu um dos amigos de Shubhi nesse lugar. Sentou-se atrás comigo e Lovania fazendo caretas e dizendo: "- Can you see?"

Saímos do estacionamento e o rapaz foi para seu próprio carro que estava estacionado do lado de fora da área do clube. Shubhi disse: "- Patrick come to the front seat", ao que ele respondeu: "-No". Ela insistiu, mas ele disse não novamente, acrescentando: "- Call your friend to come there". Shubhi então pediu a Lovania que passasse para frente, ao que essa obedeceu. Paramos próximos a uma unidade da pizzaria Domino's em Lajpat Nagar, a vizinhança em que eu passara uma semana na primeira estada em campo em 2012. Patrick, Lovania e eu queríamos permanecer no carro, estávamos cansados e sem fome, mas Shubhi reclamou de ir sozinha e Patrick disse:

\footnotetext{
${ }^{46}$ Saavala (2010) em momentos diversos de sua etnografia sobre as classes médias em Bangalore também percebe dentre seus interlocutores questionamentos morais baseados na vestimenta. Ela traz a descrição de uma cena em que foi com uma de suas interlocutoras em campo fazer compras num shopping center: "I went to a department store with Lata, a young, unmarried, working woman from an economically and socially modest background. Young boys and girls in tight jeans and revealing tops loitered around the shopping centre, moving slowly up and down on the central staircase that is a perfect 'catwalk' for showing off and observing others who entered the ground floor. When we entered the courtyard Lata exclaimed, 'Oh no, it's Valentine's Day, we should have come some other day for our shopping!' Lata labelled the girls she saw there as 'bitchy'. (...) The internal class divisions among the middle classes were also clearly visible on this occasion with Lata, a lowermiddle-class girl, evidently feeling out of place in her modest but neat salwar kameez. She felt that the girls were morally questionable due to their way of dressing and exhibitionism, and she virtually wanted to sprint from the shopping centre where she started to feel sick." (Saavala, 2010: 43-44)
} 
- I will accompany this lady to the place and will come back, you keep your pepper spray in your hand - disse se dirigindo a mim.

Ele não voltou em breve e esperamos por uns vinte minutos, pelo menos. Quando voltaram o outro rapaz que sentara no banco da frente vinha junto e entrou no carro no lugar da motorista. Havia um buraco e um obstáculo no lugar onde ela parara o carro e parecia difícil tirar o veículo. 0 rapaz manobrou enquanto ela vigiava as rodas do lado de fora cuidando para que não esbarrassem no buraco ou no obstáculo de cimento. 0 rapaz desceu do carro, despediu-se de mim e de Lovania, abraçou Shubhi fora do carro e, gentil ou respeitosamente, deu a volta para vir apertar a mão de Patrick, que apertou sua mão com algum desprezo, dando o dedo do meio quando aquele virou as costas. Eu dizia baixinho:

- Don't do like this.

No meio do caminho ninguém falava, ouvíamos música e só. Toquei a mão de Patrick para chamar a atenção dele e fiz um gesto de "let it be". Ele novamente se inclinou para o meu ombro e quando percebi ele, surpreendentemente, estava chorando, bem baixinho. Virou o rosto para o banco e eu pude ouvir um choro abafado. Voltou à posição anterior, recostado ao banco, e enxugou algumas lágrimas. Shubhi e Lovania nada percebiam da tristeza do rapaz. Quando chegamos paramos em frente ao quarto das meninas, com exceção de Patrick que subiu as escadas rapidamente. Ficamos nos entreolhando e comentei, sem saber se fazia bem, o fato de ele estar chorando pouco antes. Eu disse:

- He is jealous of you.

Ela disse:

- Jealous because of what?

- Your friends - eu disse.

Ela fez uma expressão incrédula. Despedi-me das garotas e fui-me para o meu quarto. Rekha dormia profundamente quando cheguei, foi preciso ligar em seu celular para que abrisse a porta. Como Rekha não havia sido convidada por Shubhi disse a ela, 
com bastante desconforto, que iria sair com Pryia e cometi o gesto indelicado de não convidá-la para vir junto.

$\mathrm{Na}$ manhã seguinte Rekha saiu cedo para um encontro budista do qual participava esporadicamente, atividade que conciliava com visitas esporádicas a um templo hindu próximo à PG e com as orações que fazia em nosso quarto pelas manhãs. Shubhi veio ao meu quarto e falamos sobre a noite anterior. Ela disse não estar entendendo a reação que Patrick tivera poucas horas antes. Eu disse que achava que ele estava chateado porque ficara com ciúmes dela por ter dado atenção aos outros amigos e por ter dançado com os outros rapazes. Lembrei, sem vocalizar, do pensamento que tivera enquanto ela observava os pneus e o rapaz manobrava o carro, ela não fizera nada a não ser ter um pouco de diversão entre amigos, e isso magoava Patrick a ponto de este mandar uma mensagem ao celular dela dizendo que a odiava, como vim a saber por ele no fim da noite e o que Shubhi também mencionava em meu quarto. A diversão não havia sido mais que dançar em grupo e dividir a atenção entre os dois grupos de amigos que não se entrosaram muito. Ela começou a dizer:

- Fab, I don't know why Patrick is reacting like this. In the beginning I was much more into him than he was into me. We dated for almost one year and then I asked him: is this going somewhere? I want to go further. I want to marry you. And he was the one who said no. He said he was not prepared.

Nesse momento eu disse que desde que eu o conhecera costumava afirmar que nunca vai se casar. Ela continuou:

- Yes, he keeps saying that he will never marry at all. Then I said that I was intending to get married and that we should break up. My family has found a match for me, I'm in touch with him, I told you this. And he [Patrick] also knows this, so things were very clear between us. He was the one who told me 'you should move on'.

Disse que eu entendia tudo isso e que, na minha percepção após os acontecimentos da noite anterior, Patrick continuava esperando que ela se comportasse como sua namorada, e ele ainda se portava como o namorado dela. Ela disse:

- I know Fab, but this can't be, not anymore. I made the things clear for him sometime ago. 
Emendei dizendo que eu pensava, ainda, que agora ele havia percebido que a amava mais do que intuíra no começo, o que era evidenciado pelo ciúme e pelas atitudes exageradas que tomara na noite anterior. ${ }^{47} \mathrm{O}$ que eu também penso agora é que talvez Patrick se portasse em conformidade com a ideia de que as mulheres devem amar os homens de modo mais intenso, ele não esperava se defrontar com o fato de que Shubhi fosse capaz de esquecê-lo ou de tentar outro relacionamento tão cedo.

- Yes, I know, I also think this, but if this is true maybe I should back off. Because I can't do this, be in touch with the guy my family choose and be with Patrick. And Patrick doesn't want to marry me.

Shubhi me falava de algo que demorei a perceber, a ânsia de minhas amigas pelo romance tinha um destino certo: o casamento. Não era suficiente que ela estivesse apaixonada por Patrick e que a relação física entre eles fosse muito boa, como ambos me contaram, o que estava acima disso para Shubhi é que Patrick não queria se casar e ela sim. Como ela havia conhecido alguém que aceitava se casar, que lhe fazia a corte e tentava conquistá-la, estava disposta a esquecer Patrick. Foi no decorrer da convivência com as pessoas na PG que descobri que os jovens não rechaçam o casamento como uma instituição social que lhes seria imposta, o que inicialmente supus, mas o referendam como desfecho ideal e necessário do romance. Como ela falava do outro rapaz, perguntei se as flores que ela recebera no dia do aniversário através do porteiro eram do pretendente e ela disse que sim.

- See, this is not fair, I'm trying with this guy, I can't be with Patrick, this will be bad for him, it will be bad for me. The saddest thing is that we will lose our friendship. He will ruin this if he acts like this.

Shubhi foi para seu quarto depois que Rekha chegou, afinal não podíamos continuar conversando e delatar o fato de que havíamos saído juntas na noite anterior. Patrick veio ver como eu estava quando chegou da casa de sua irmã, a qual ele quase

\footnotetext{
${ }^{47}$ Faço notar ao leitor que Patrick exibia emoções que estão geralmente presentes quando se fala do amor romântico, "tais como a intensa atração erótica aliada à ternura, ao afeto e à idealização do outro, o desejo de exclusividade que se manifesta no ciúme, a angústia pela separação do ser amado e o desespero pela sua perda ou rejeição" (Lobato, 2001: 45). Como Lobato afirma, a presença de tais emoções não seria, entretanto, condição suficiente para se caracterizar uma ideologia amorosa como "amor romântico", do tipo desenvolvido e presente no mundo euro-americano, pois, aponta a autora, tais emoções "ocorrem com muito mais frequência em contextos culturais não ocidentais do que a maior parte dos antropólogos havia cogitado", e o reconhecimento desse fato seria "indubitavelmente, um avanço em relação à visão daqueles que a exemplo de Morgan e de Mead limitam a existência de tais emoções a determinadas sociedades". (Idem: 45-46)
} 
sempre visitava aos finais de semana. Ficamos conversando sobre a noite anterior. Perguntei se ele estava com ciúmes de Shubhi e ele disse:

- I was not exactly jealous.

- But you were expecting her to behave in a different manner?

- Yes.

Disse a ele que eu até entendia seu sentimento, mas que ela não tinha culpa pelo que ele sentia, não havia nada de errado no comportamento dela, pois os dois sequer estavam namorando mais. Ele disse:

- I know, but I was not expecting her to act like that.

Eu disse que tinha a impressão de que ele agora gostava mais dela do que quando conversamos logo que eu voltei para Délhi. Ele disse que sim. Eu perguntei o que havia mudado e Patrick respondeu:

- When you started dating André, did you love him the way you love now?

- No, I don't think so. For sure I love him more now.

- Exactly. It takes time to love someone.

Rekha voltou da rua, havia ido ao Select City Mall. Ficamos os três conversando e rindo e os dois, como sempre, fingindo rusgas. Dessa vez ele, que sempre insinuava algo sobre o sobrepeso dela, era agredido por Rekha pela quantidade de pelos em seus braços e pernas. As jocosas ofensas recíprocas faziam-me perceber o quanto eram amigos e como tais brincadeiras são comuns entre garotas e garotos, pois se repetiam com Kaushik, Anyndia e Rekha. Perguntei a Patrick se ele pretendia sair, pois eu precisava comprar água. Rekha logo disse: "- Yes, lets go out, lets take a walk!" Patrick se foi para se trocar em seu quarto. Rekha percebia, sem saber o motivo exato, a tristeza de Patrick. Também comentou sobre Shubhi estar ansiosa, parecendo diferente. Rekha assumia que o estado de ambos dizia respeito ao fim do relacionamento. Quando ele voltou partimos para o Green Park Market. Compramos picolés e ficamos sentados, no calor de uns quarenta graus à noite, do lado de fora, na mureta que encerra a calçada. 
Começamos a falar, não lembro como, de casamentos e sobre o fato de os pais escolherem os cônjuges dos filhos. Patrick sempre se rebelava contra isso com veemência. Rekha falou que percebia o quanto ele estava chateado, insinuando que queria saber se era por conta de Shubhi. Por fim, disse que ele não deveria desistir facilmente do que queria, que devia lutar por ela, se era isso que ele queria.

Patrick: - No, I am not prepared to get married. People think that marriage is a necessity. And once you get married they think you must have kids. Why? Why can't someone don't get married, and even getting married do not have children?

Rekha: - No, you can't live without someone, you say this now, but there is a moment in life that you need to find someone.

Eu me posicionei do lado de Patrick dessa vez, mencionei que minha irmã contava trinta e um anos de idade e permanecia solteira e feliz e aguardei a reação de Rekha. Ela disse:

- Yes, but there is the society pressure, the family pressure, specially for the girl, and it is good to have someone to share things, to share a life.

Patrick: - Ok. So Praveen is going to China and he is going to spend two years there, you will wait for him, and what if when he comes back, God forbids this, he says: I'm not ready to get married. What you are going to do?

Rekha: - I'm gonna kill him - e riu-se.

Patrick: - You will accept to marry someone else if your father asks you to?

Rekha: - Oh, I really don't know...

Rekha então perguntou se ele já havia namorado alguém antes de Shubhi, e ele disse:

Patrick: - Yes. But I always pick the wrong person.

Fabíola: - What you mean?

Patrick: - See, if you find the right person it is easier to know what to do. 
Lembrei imediatamente da paixão secreta e platônica dele por Pryia. No momento em que Patrick se declarou no ano anterior, Pryia era a mulher certa, ele chegou a dizer a ela que conversaria com os pais dele primeiro e então com os pais dela, se ela quisesse ficar com ele. Patrick praticamente a propôs em casamento no dia em que se declarou apaixonado por ela ao final de 2012, sem terem tido muitas conversas, segundo a própria me contou numa conversa pela Internet. Ele não tentara flertar com ela, como sempre fazia com todas as moças da PG, disse que ela era diferente, como diferente era o que sentia por ela. Já no caso de Shubhi, ela propusera o casamento e ele disse não com todas as letras, como ela também me confirmou. Ele pensava, e talvez ainda pense, em Pryia como a garota certa, pela qual ele não teve dúvidas de que faria o sacrifício de casar-se. Patrick a achava inteligente, incrivelmente bonita, admirava sua preocupação com questões políticas, tratava, como ele próprio, todas as pessoas de forma gentil e respeitosa e não maltratava os funcionários, mas cuidava, como o próprio Patrick, de Rani quando esta precisava de algo como remédios ou uma gorjeta extra. Agora, contudo, ainda assim, ele sentia ciúmes de Shubhi e parecia descobrir gostar mais dela do que havia imaginado. Naquele momento específico sua fala ecoava em minha mente a ideia de que ele escolhera Pryia, que não o quis. Depois se apaixonou por Shubhi que agora não queria esperar por ele. Um quadro diferente se desenhava pra mim, ele parecia então querer que Shubhi estivesse disposta a esperar por ele, até que ele estivesse pronto para se casar, mas, ao mesmo tempo, ele não parecia ter a certeza de que um dia quereria.

O tempo que Patrick e Shubhi passaram juntos e a sinalização da perda da namorada, por meio da corte que outro lhe fazia, parecem ter feito Patrick se dar conta de que embora ele achasse que não a amava o suficiente para se casar, ele a amava o bastante para sofrer e lamentar o destino de ambos. $\mathrm{O}$ amor que ambos me mostraram divergia do que eu lia em ensaios sobre os novos modos de fazer os casamentos indianos que autores chamam de love-cum-arranged marriage. Exaltados por alguns pesquisadores como novas e criativas maneiras de se fazer casamentos na Índia (Fuller e Narasimhan, 2008; Netting, 2010), eu pensava quando os lia: mas esse amor assim descrito não parece ser o amor de Shubhi e Patrick, que não pode redundar em casamento, mas aconteceu independentemente disso. Eu me perguntava, e ainda o faço, quantos amores como o de Shubhi e Patrick deixaram de ser captados por pesquisas que tratam do amor, do romance e dos novos modos de fazer casamentos na Índia? 
Continuo a meditar sobre isso tendo em vista a descrição das metodologias de algumas pesquisas. Mody com seu "stop-and-research method", no qual entrevistava casais, advogados e funcionários nas cortes de Délhi, não me parece ter convivido com os jovens em fuga para se casar de modo a perceber, como eu percebia entre Shubhi e Patrick, o cuidado, os carinhos, as discussões, os ciúmes, a convivência habitual e até a dissolução do namoro, que foram para mim fundamentais para compreender a dinâmica dos romances pré-conjugais na mesma cidade em que ela fez sua etnografia dos processos de casamento civil e das cerimônias religiosas em templos da Arya Samaj (Sociedade Ariana), movimento reformador que empreendeu campanhas contra a discriminação por castas e que admitia em seus templos o casamento intercasta, também chamado "casamento por amor" e "casamento por escolha".

Penso igualmente em Van Wessel (2001) que conversava com pais na pesquisa que empreendeu na cidade de Baroda em Gujarat, os quais contavam suas projeções para os casamentos dos filhos e filhas. Ela também ouvia dos jovens suas próprias projeções. Para os pais o casamento seria feito na mesma casta, ou quando muito em castas com status similares ou equiparáveis, afinal o escândalo de uma casamento intercasta, desde que sem uma diferença gritante de status, não era mais o que costumava ser antigamente. Havia também a preocupação com o rapaz e a moça serem de nível educacional e profissional compatível e, embora de modo muito disfarçado, com o dote, que assumia a forma de presentes substancialmente caros e não mais de quantias em dinheiro. Os filhos por seu turno, alguns deles, lutariam bravamente contra os imperativos paternos de casá-los de acordo com as escolhas parentais. Viriam eles a confirmar essas projeções? Ou seriam surpreendidos por acontecimentos e desdobramentos futuros, como aconteceu com Shubhi e Patrick?

Por ora avancemos para outras histórias de amor, romance, encontros e desencontros. Meu intento é que as tramas de vida de meus amigos ajudem a obter não melhores respostas, o que talvez eu não consiga prover, mas melhores descrições e, quem sabe, melhores insights sobre essas questões.

\section{Lovania e os paradoxos do desejo}


Conheci Lovania logo em meu primeiro ano de campo em Nova Délhi. Sempre a encontrava na cozinha quando ia pegar meu jantar e conversávamos um pouco quase todos os dias. Notei desde cedo que ela nunca comia com a maior parte dos moradores na sala de jantar, mas levava a refeição para seu quarto. Nesse mesmo ano tive contato com ela o suficiente para saber que tinha vinte e seis anos, formou-se em Gestão de Recursos Humanos na Delhi University e trabalha com recrutamento de pessoal numa empresa de telecomunicações. Apresentou-se como bengali quando nos conhecemos e isso fez com que eu pensasse que ela era de West Bengal por um longo tempo, até que ela esclarecesse que nascera em Rudrapur, uma pequena cidade no estado de Uttarakhand, mais ao norte do país. A informação de que ela era bengali chegava por meio de uma explicação sobre suas intenções matrimoniais:

- I am looking for Bengali boys only. My family is Bengali and my father wants me to marry a Bengali guy only.

Quando dizia que estava procurando por rapazes bengalis, Lovania se referia ao fato de que possuía um perfil num site de matrimônios e entre os requisitos para o noivo que ela buscava encontra-se ser bengali. Além disso, em suas preferências, ela mencionava aspirar por um rapaz que morasse em Délhi, pois ela gosta do emprego e gostaria de continuar a viver nessa cidade. Ademais, sendo o rapaz bengali e morando em Délhi havia a possibilidade de que ele não morasse com os pais, como ela própria, o que poderia significar morar longe da família do marido, isto é, ela alimenta esperanças de que constituirá com o marido uma família nuclear em vez de ir morar na joint family do marido seguindo a virilocalidade adotada em todo o norte do país.

Lovania é uma garota que todas as demais moradoras da PG consideram "a sweet girl". Sua forma de falar, lenta, suave e em tom baixo passa tranquilidade e serenidade e eu logo estabeleci com ela uma sincera amizade; gostava de me demorar em conversas com ela, mesmo para ouvir suas muitas tormentas emocionais. Tormentas que dizem respeito à busca por um marido, ou por um romance. No começo Lovania falava no casamento arranjado que teria, com um moço educado, distinto, que seria compreensivo e cuidadoso com ela, que a esperaria estar pronta para o sexo após o casamento, que moraria em Délhi, longe dos pais, com quem teria dois ou três filhos, mas apenas dois ou três anos após o matrimônio, pois ela queria aproveitar a vida de casada antes da chegada de crianças. 
- First the couple need to understand and get to know each other. To get used to the situation, then the kids can come, otherwise if you don't know the husband, the husband doesn't know the wife it's a mess. And also I wanna have time for ourselves. I never travel, and there are so many places that I wanna visit, so I wish I could travel with my hubby first before having kids.

- Why don't you travel right now? You don't need anyone to travel.

- See, I don't have anyone to travel along with me, if I go to a place alone all I can do is keep roaming alone. But when you have company then you can enjoy.

Foram de Lovania que vieram minhas primeiras impressões sobre o que as garotas indianas querem de um casamento, ou de um marido. Dela também sorvi primeiro a ideia de que a maioria dos indianos e indianas que conheci não apreciam fazer viagens, passeios, refeições ou planos sozinhos. Meus amigos faziam um grande esforço para nunca me deixar sozinha nas menores atividades, como ir a algum lugar comprar qualquer coisa, comer fora ou conhecer um lugar histórico. Quando descobriam que eu estava almoçando em Green Park Market ou Hauz Khas Village sem eles, perguntavam: "- Who is with you?" Quando eu dizia que ninguém me acompanhava lamentavam e sentiam pena de mim. E eu dizia: "It's ok, I like doing things by myself." Tomou-lhes tempo perceber que eu era sincera quando dizia isso, assim como, levei um bom prazo para entender que eles não me deixavam fazer várias coisas sozinha porque estavam cuidando de mim, protegendo-me da solidão, embora eu não sentisse o que eles achavam que eu sentiria quando ficava sozinha. Nesse cuidado Dileep, Patrick, Rekha, Lovania e Shubhi eram os mais ternos e obstinados. Quando dizia a Patrick que estava sozinha em algum canto de Délhi, ele dizia que eu devia ter esperado por ele para me acompanhar, ou pedido a Dileep para fazê-lo. Quando contava às garotas que tinha visitado esse ou aquele lugar sozinha, perguntavam por que não havia chamado uma delas. $\mathrm{O}$ fato é que estavam trabalhando, eu não podia, portanto, sempre esperar por eles. Com o tempo passei a fazê-lo, pois percebi que lhes dava prazer fazer companhia justamente porque também se apraziam em ter companhia.

Quando voltei em 2013, Lovania disse que estivera ansiosa por meu retorno. Foi quando eu percebi que ela era solitária e não queria ser. Em meados de abril, depois de 
uma aula de yoga e após o jantar fui com Anirudh e Elena tomar sorvete do outro lado da avenida, lateral à PG, a Aurobindo Marg. Na volta, como Rekha ainda não houvesse chegado, fui visitar Lovania em seu quarto, o que disse que faria quando a encontrei em meu caminho para a aula de yoga, ela sempre voltava do trabalho caminhando desde a estação do metrô a poucos quarteirões dali. No quarto estavam apenas ela e a colega de quarto de Elena, que segundo essa última vivia no quarto de Lovania e Shubhi. Ambas estavam olhando para o computador, vendo o perfil de um rapaz que manifestou interesse no perfil de Lovania no site de arranjos de casamento. Interessei-me logo pelo assunto e pedi pra ver também. Lovania me mostrou seu próprio perfil, a meu pedido. Há seis fotos dela em diferentes roupas e poses. Não pude ler as informações chamadas de "características de personalidade", que ficam em outra janela que não a das informações principais, onde constam idade, altura, compleição física, cor da pele, casta, subcasta, gotra (grupo consanguíneo patrilinear), ocupação profissional, formação educacional, rendimento, língua materna e lugar e data de nascimento para o cálculo astrológico da compatibilidade ou não do possível casal.

Em seguida me mostrou a lista de rapazes que sinalizaram interesse no perfil dela, que tem a opção de sinalizar interesse nos perfis deles também ou marcar como sem interesse. Ela não pode simplesmente ignorar uma demonstração de interesse, é preciso responder sim ou não. Por fim, mostrou-me seu preferido dentre os perfis que estava analisando, "the guy", comentaram as duas amigas rindo entre si. Imediatamente percebi a diferença gritante entre a aparência física desse rapaz e todos os demais: ele era o único que, pelas fotos, exibia pele clara, todos os outros tinham o tom de pele bem mais escuro. O tom de pele de Lovania é bem mais escuro que o desse rapaz, aproximando-se dos outros que haviam se interessado pelo perfil dela. Não obstante isso, no perfil dela e dos outros rapazes consta a palavra "fair" no item "cor da pele". 0 que pode ser facilmente controvertido, pois todos os perfis têm fotos.

A preocupação com o tom de pele na Índia é uma questão delicada e controversa. Em conversas informais com acadêmicos do norte ao sul do país ou em suas falas em workshops e seminários havia os que consideravam o tema da perspectiva do racismo e os que sempre negavam essa possibilidade em vista de outros elementos que intersectariam a questão, como casta e classe notadamente. Ressalto, contudo, que para além de uma construção estética que privilegia os tons de pele clara como mais belos, na Índia a cor da pele é tida, erroneamente muitas vezes, como um indicador de casta. É 
amplamente promulgado o preconceito de que pessoas de pele escura seriam de castas consideradas inferiores, sobretudo no norte do país, onde há pessoas de pele clara e de pele escura. No sul do país pessoas com o tom de pele escuro (chamadas dark skinned) são predominantes e, assim, evidentemente, pessoas de todas as castas podem ter a pele escura. Uma implicação entre casta e cor da pele foi construída também dado o fato de que o termo varna, que designa os quatro grandes agrupamentos de casta - Brahmanes, Kshatryas, Vayshias e Sudras -, teria entre suas possíveis traduções do sânscrito a acepção de cor de pele, havendo referências aos Sudras, varna considerada mais inferior na hierarquia entre as quatro varnas, como pessoas de pele escura. Especulações historiográficas dão conta ainda de que essas seriam classificações que datam da chegada dos povos arianos à Índia, estabelecendo divisões sociais entre os arianos chegantes e os ocupantes originários do Vale do Indo e os povos dravidianos do sul do subcontinente, que teriam a pele mais escura.

É notável que nos jornais, na seção de classificados matrimoniais, o que mais se lê seja um sem fim de moças se oferecendo, ou oferecidas pela família que anuncia em seu lugar, como fair e um mar de rapazes procurando por moças fair, slim e beautiful, dentre outros termos que são usados para caracterizar fisicamente uma pessoa, não só nos jornais, mas nos sites desse tipo e nas agências de casamento.

Embora eu tenha conseguido pouquíssimo acesso nesses escritórios, Dileep, que desenvolvera websites para marriage bureaus me dizia que os perfis de tais estabelecimentos não divergiam dos que se preenche em matrimonial websites. Os diferenciais das agências estavam em prover outros serviços que os jornais e sites não proviam, como lugares "neutros" para encontros entre as famílias depois de uma seleção prévia dos perfis, investigação da autenticidade das declarações prestadas nos perfis, fotos adicionais, contatos telefônicos para solucionar dúvidas de ambos os lados e até, no caso do Sycorian Marriage Bureau, que visitei e onde consegui entrevistar a gerente e até conversar brevemente com o proprietário, um café e uma academia de ginástica onde os jovens podiam, num ambiente neutro e controlado publica e profissionalmente, se encontrar sem a presença dos pais e conversar mais desinibidamente com alguma privacidade, como explicava mister Sombah, o proprietário do lugar. A gerente afirmara que hoje em dia os jovens estavam muito exigentes no arranjo de seus casamentos, se todos os requisitos convencionais do matchmaking fossem compatíveis, mas os jovens não se sentissem atraídos um pelo outro, não podiam fazer nada, tal era o nível de 
demanda dos jovens que ela atendia. Requisitos como "beleza", incluindo cor da pele e compleição magra, e ainda "características de personalidade" (se bebe álcool ou não, se é fumante ou não, gostos pessoais para música, cinema, comida, atividades de lazer como sair à noite - "party too much", "do not party" - e estilos de vestimenta), seriam os grandes desafios que aquela empresa se obstinava em solucionar a contento das famílias e dos jovens. Os clientes dessa agência eram pessoas de alto poder aquisitivo, segundo a gerente, motivo pelo qual ela não poderia permitir que eu ficasse observando o trabalho na agência, uma vez que os clientes desejavam discrição e se incomodariam com minha presença. Vim a saber semanas depois que Mantha ji, uma de minhas professoras de hindi, havia se casado há dez anos por intermédio desse exato bureau, contratado por seu pai dez anos atrás, época em que, ela dizia, "they were not the big and fancy bureau that they are today".

Retornando à Lovania, a razão que ela me deu para recusar os outros rapazes de pele mais escura, no entanto, é que eles teriam mais de trinta anos, entre 32 e 38 anos, e ela estava, naquele momento, procurando alguém que tivesse entre 25 e 30 anos. Ela própria contava vinte e seis anos e eu percebia, portanto, segundo a lógica local de que o rapaz deve ser pelo menos três anos mais velho que a moça, que sua exigência destoava da tendência corrente. ${ }^{48}$ Ela também disse na ocasião:

- I don't wanna marry a guy who looks like a man, I wanna marry a guy who looks like a boy.

Perguntada o que queria dizer com isso, respondeu:

\footnotetext{
${ }^{48}$ As idades legais para o casamento atualmente são, pelo menos, dezoito anos para moças e vinte e um anos para rapazes. Os casamentos infantis foram banidos por lei ainda no período colonial, o que não quer dizer que não aconteçam mais, sobretudo nas aldeias do Rajasthan. Há também idades ideais não impostas por lei, mas claramente vigentes socialmente para os rapazes e moças. Primeiramente considera-se que deve haver uma diferença entre a idade do rapaz e da moça de aproximadamente três anos, o que é também refletido na própria lei de casamentos civis (Special Marriages Act, de 1872). A moça é considerada em idade para casar entre os dezoito e os trinta anos, no máximo. Após essa data os pais podem ter dificuldades para encontrar um bom noivo ( a good match) para a filha, e ela tende a ser desvalorizada no "marriage market", termo usado na literatura antropológica e também nas agências de casamento com as quais tive algum contato. O ideal é que se casem até os vinte e sete, vinte e oito anos e tenham o primeiro filho até os trinta. Para os rapazes também vale o limite de trinta ou trinta e poucos anos para se casar, sempre respeitando uma diferença de dois a três anos entre ambos, sendo o rapaz idealmente o mais velho. Essas ideias são amplamente referidas por meus amigos, tanto os que concordam quanto os que discordam desse ideal normativo.
} 
- I don't enjoy my life now, I don't go out too much, I don't travel and so... But I do want to enjoy my life after marriage, so this is the reason I want a guy who looks like a boy, not like an old guy. So we can enjoy together.

Essa afirmação me fazia sentir muita tristeza e sinto novamente o que senti ao ouvir isso agora enquanto escrevo. 0 aperto em meu peito era por não conseguir entender como ela podia esperar tão compassivamente se casar para "aproveitar a vida" enquanto a vida estava passando diante dela naquele momento. Pedi para ver as fotos do rapaz, "the guy", em formato maior, ela hesitou em clicar para aumentar a imagem e eu brinquei:

- Come on, let me see. Or are you jealous of him? - e todas caímos na gargalhada.

Nesse momento o telefone de Lovania tocou e ela foi atender fora do quarto, era seu pai que lhe telefonava religiosamente todos os dias. Shubhi havia entrado há pouco no quarto, vindo do andar superior ao meu, onde ficava o quarto de Patrick, de onde pude ouvir que os dois discutiam novamente enquanto eu ia para o quarto dela. Ficamos falando da academia no subsolo, a qual ela, Rekha e mister Kapoor estavam frequentando e das aulas de yoga que eu fazia, e prometíamos sair pra dançar qualquer dia desses, como fazíamos desde o ano anterior, sem nunca cumprir.

Voltei a olhar para o computador e fiquei lendo o perfil do rapaz, que trabalha na área de tecnologia da informação, é do estado de West Bengal e tem 27 anos. Quando comentei o fato de ele ser bengali, como Lovania, a companheira de quarto de Elena, Debashree, falou que Lovania só estava procurando por perfis de rapazes bengalis, mas que estivessem morando em Délhi, pois ela queria continuar na cidade.

Olhei os interesses do rapaz e o texto que ele escreveu sobre si mesmo no perfil, que dizia coisas como: sou extremamente tímido, sou inseguro, tenho medo da interação com pessoas, não tenho senso de humor, se mesmo assim você quer me conhecer, entre em contato. Fiquei pensando o quanto era curioso um rapaz se desdenhar daquela forma num site em que supostamente deveria se fazer atraente para possíveis pretendentes. Talvez ele pensasse que sua "compleição física" e o salário que ganhava eram bons o bastante para atrair garotas. 0 que parecia ser bem verdade no caso de Lovania. Nos 
interesses dele quanto à garota pretendida, a maioria das respostas para perguntas sobre tipo físico e aparência era "no matter".

Perguntei à Debashree se ela achava que Lovania estava falando com ele ao telefone, ela disse:

- No, if she decides her parents will talk to the boy's parents. In fact the guy parent's must call first, is better that the guy's family give the first step.

Ela também me disse que as duas costumavam gastar horas vendo esses perfis e buscando possíveis noivos para Lovania. Quanto a ela própria dizia que ainda não estava interessada em se casar e que não confiava nesses sites, que os garotos podem escrever o que quiserem lá e pode não ser verdade. Mostrou-me, por exemplo, o perfil de um dos respondentes de Lovania onde se podia ler no item "Drinking Habits" a resposta "occasionally".

- What does it means? - ela perguntou. -It can be every two days or once a month. How can I know?

Tanto Lovania quanto Debashree preferem um rapaz que não beba e que não fume. Nesse ponto, Rekha chegou da academia e me ligou, já que eu carregara comigo a chave de nosso quarto, fui-me embora enquanto Lovania continuava falando ao telefone no corredor. Com o passar do tempo, meus amigos me confidenciavam que além de perguntar sobre as atividades corriqueiras de cada um no trabalho, ou na universidade, a condição climática em Délhi e se cuidavam bem da alimentação, os pais também interrogavam os filhos sobre suas buscas por um possível noivo ou noiva, bem como informavam sobre algum perfil que havia sido enviado a eles e do qual haviam gostado.

No dia seguinte, quando fui buscar água no filtro ao lado da recepção, encontrei Shubhi, Patrick e Lovania conversando no corredor do quarto delas. Ficamos nos falando um pouco. Marcamos de sair no sábado pra dançar, Shubhi compraria os convites, o que não aconteceu. Desci pra buscar minha água e quando voltei Lovania veio comigo para meu quarto, sem ser convidada, apenas veio andando do meu lado, não que eu me importasse evidentemente, apenas faço notar o quão fácil era me aproximar das pessoas em campo, pois elas se faziam próximas em pouco tempo. 
Entramos e ela sentou em minha cama, eu teria oferecido a poltrona, mas não houve tempo. Ficamos conversando meio sem assunto quando perguntei se ela havia olhado os respondentes de seu perfil novamente. Ela disse que não, não tivera tempo pra isso naquele dia. Então começou a falar sobre casamento, disse que estava receosa, perguntei de que. Ela respondeu que quando chega a hora de escolher uma pessoa, de encontrar a pessoa certa, surgem muitas dúvidas e ansiedades porque é com essa pessoa que se vai passar "o resto da vida". Continuou falando: nunca se sabe como vai ser com essa pessoa depois do casamento, seu comportamento. Outro motivo de preocupação era o sexo e a primeira noite após o casamento. Arrisquei perguntar se ela era virgem, ela disse convicta e rindo:

- Ya, I'm a virgin. That's why I'm so afraid - ri também e disse:

- Ya, the first time is a little bit difficult. I didn't enjoy my first time to be honest.

- Did it hurt?

- Yes, I felt some pain.

- I have heard that it is really painful.

- Not really painful, you can handle that. But of course it's different for each girl. Then it gets better and better every time you do.

E rimos novamente. Ela disse que era muito tímida e que não sabia como ia ser. Perguntei:

- But the couple don't have to do this in the first night they do?

- See, you don't have to do, but if the guy is desperate you will need to. Some guys are really desperate to do that.

Concordei com ela e disse para ficar calma, provavelmente ia dar tudo certo. Perguntei se ela veria o noivo só uma vez antes do casamento. Ela disse que depende, se o rapaz for da mesma cidade então, depois do noivado, eles podem se encontrar mais vezes, geralmente acompanhados, para estreitar o conhecimento um do outro. ${ }^{49}$ Seu

\footnotetext{
${ }^{49}$ Minhas amigas e amigos usam a palavra inglesa "engagement" para uma etapa do arranjo que acontece antes do casamento, e está também presente nos convites de casamento. A ocasião a que Lovania se referia aqui era o rokha ritual em que se afirma que determinado rapaz e determinada moça estão "reservados" um para o outro. No caso de Shubhi, por exemplo, seu rokha aconteceu em julho de 2014 e o casamento se deu no janeiro seguinte. Ainda assim, na noite anterior ao casamento, uma recepção para muitos convidados aconteceu e no convite essa ocasião foi chamada de "engagement" e trata-se de uma "tradição" recentemente criada nos casamentos pomposos das cidades. Em outros casamentos vi essa ocasião sendo chamada de "ladies sangeet" (sangeet: música), pois músicas são cantadas pelas convidadas para a noiva e o noivo com o intuito de diverti-los e aos demais presentes.
} 
maior medo, segundo ela, era justamente esse, casar-se com alguém que ela não conhecesse direito, não saber como a pessoa iria reagir a qualquer coisa que acontecesse, como o marido iria se comportar diante de qualquer situação.

Em dado momento ela disse que não conseguiria arrumar alguém por ela mesma, por isso era importante os pais arranjarem o casamento, o que estavam fazendo deixando os familiares, vizinhos e amigos saberem que estavam querendo casá-la. Ela, por seu turno, havia feito o perfil no site de matrimônios, embora afirmasse ali que os pais haviam preenchido o perfil, já que mesmo isso é perguntado, se o anúncio está sendo feito pelos pais ou pelo próprio pretendente. Perguntada porque ela não conseguiria arrumar um noivo por si só, disse que a família queria casá-la com um rapaz bengali, como ela, e ela queria que fosse alguém morando em Délhi, isso tornava as coisas mais difíceis, pois os pais não aceitariam qualquer um. Insisti na pergunta e ela afirmou que achava que não conseguiria atrair um rapaz com flertes. Essa fala me fez lembrar que Patrick comentara algo sobre isso, que Lovania estava fazendo contatos pela Internet porque não conseguiria um noivo de outro modo. Quando perguntei do que ele falava, disse:

- She is a person too much into religion.

Emendou dizendo que se ela conhecesse um rapaz e gostasse dele o fato de ser muito religiosa e procurar seguir esses preceitos para o casamento a impediria de namorar. Ele disse então que ela já fora apaixonada por alguém, mas não havia sido correspondida.

- So, see, if this happens once or twice again, she will give up and get an arranged marriage as per her father's wish.

Perguntei se ela havia dito isso a ele, respondeu que não, outra pessoa havia, essa outra pessoa, claro, eu só podia deduzir que era Shubhi. Lovania deixava transparecer, de todo modo, que queria muito se casar, apesar de ter lá seus medos de como iria ser. Três semanas depois dessa conversa encontrei Lovania novamente no caminho para a yoga, ela me deu uma bronca enorme porque eu não atendia ao telefone no sábado. Foi a ocasião em que fiquei sem bateria no celular enquanto estava com Anirudh e Pryia em Hauz Khas Village. Pediu que eu fosse a seu quarto quando voltasse da yoga. Na volta 
jantei no térreo e fui ter com ela em seu quarto. Ela me entregou um presente que trouxera para mim da cidade de Shubhi que ambas visitaram dias antes.

Nessa noite anotei em meu diário de campo que percebia que ela estava se mostrando cada vez mais triste e preocupada ultimamente, quando eu perguntava o motivo ela dizia que estava preocupada com o futuro, com a incerteza de encontrar um bom marido e se eles iriam se dar bem. Ao chegar a seu quarto, Patrick estava na porta com ela. Perguntei se ambos haviam jantado e ela respondeu que estava jejuando. Patrick e eu perguntamos, ao mesmo tempo, o motivo, como ela hesitou em responder, eu disse:

- Ok, it's a secret, I understand - e pisquei pra ela.

Quando Patrick se foi ela me contou, espontaneamente, o motivo do jejum:

- There's a thing here that you can do when you are looking for a husband, you pray for Lord Shiva and fast for 16 Mondays in a roll, then he will give you a good husband. Because Lord Shiva is seen as the perfect husband, he is strong, wise and good with Parvati. So you can ask him: give me a husband as good as you are.

Ela me falou que essa era sua décima quarta semana, faltavam apenas duas para completar o ciclo todo, a partir de então a qualquer momento Lord Shiva poderia enviar o marido perfeito. Mostrou-me o altar doméstico dentro do quarto com a imagem num pequeno quadro da família de deidades composta por Shiva, Parvati, Ganesha, e seu irmão Karthik (ou Karthikeya). Nunca ouvira falar desse último, embora já conhecesse o nome Karthik, pelo colega de quarto de Anirudh.

Contei a ela o que algumas mulheres da geração de minha avó e minha mãe faziam no Brasil com Santo Antônio para conseguir marido ou namorado, disse que ouvira histórias de moças que colocavam uma imagem desse santo dentro de um armário e só a tiravam de lá quando conseguissem o que queriam: o par ideal. Ela achou o máximo a ideia de castigar o santo até que ele arranjasse o noivo que a devota lhe pedia.

- Where can I get a picture of him? 
Disse que ela poderia encontrar na Internet. Continuamos falando sobre a mitologia que envolve Shiva e Parvati como, respectivamente, o marido e a esposa ideais, da qual os intelectuais indianos também tanto falam, só que para criticar o ideal de esposa inspirado por Parvati e a submissão feminina que essa ideologia impõe. Eu comentei que sempre havia pensado, antes de ler autores indianos, que Krishna fosse o deus para casamentos, já que era representado cercado de várias namoradas. Ela disse:

- See, Krishna and Radha are a romantic couple, they are famous for their romance, but for a good husband you pray to Lord Shiva, he is the perfect husband.

Essa declaração me remetia à já citada separação entre romance e casamento fortemente entronada no pensamento hindu. Ao que parece, Lovania refletia essa oposição em sua devoção à Shiva. Perguntei como estava a busca no site, ela disse que não havia novidades. Eu disse:

- Only bad guys responding?

Ela riu e disse que sim, apenas rapazes mais velhos, fora da faixa etária que ela queria. Perguntei se ela continuava procurando rapazes apenas em Délhi. Ela confirmou meneando a cabeça e disse ser mais fácil o casal dar certo e se acertar sem ter os sogros por perto "putting their nose between the couple".

Lovania perguntou se eu estava emagrecendo com a yoga, fez mais de uma vez comentários que demonstravam uma preocupação em perder peso, o que estaria ligado à busca do parceiro para o casamento. Semanas antes estávamos no corredor no andar dela e Shivani disse que achava que eu havia perdido peso desde minha chegada. Comentei que fazia Ashtanga yoga, uma modalidade acelerada e com movimentos (asanas) contínuos que me fazia suar bastante, e ela comentou que devíamos incentivar Lovania a perder peso para encontrar um bom marido:

- We need to push her to loose weigh so she can get a good match.

Eu disse à Lovania que estava emagrecendo, mas que esse não era o motivo pelo qual eu praticava yoga. Ela disse que queria experimentar, que não suava de modo algum e por isso não conseguia perder peso. Sugeri que ela começasse a frequentar as 
aulas comigo. Isso nunca aconteceu, nem naquele nem nos anos seguintes. Em 2015, contudo, fiquei surpresa, pois ela havia perdido dez quilos fazendo acompanhamento com uma nutricionista, algo que o pai lhe sugerira, visto que se preocupa cada vez mais com a busca do noivo para a filha. Mister Kapoor era outra pessoa que sempre dizia que ela devia emagrecer, pois tinha o rosto e os cabelos bonitos e acharia um partido adequado ("a suitable match") se perdesse peso.

Dois dias depois, conversávamos novamente em seu quarto quando contou de dois relacionamentos amorosos que tivera no passado. Começou dizendo:

- It's not that I am desperate to arrange a marriage, not at all, but sometimes it hurts.

Perguntei o que exatamente doía, como assim? Ela disse que doía não ter sido escolhida por ninguém e não ter alguém para dividir a vida. Foi então que ela disse que havia tido dois relacionamentos que acabaram mal, ou acabaram não dando em casamento. Um deles, o último, foi com um rapaz que ela conhecera na faculdade. Ela se correspondera com ele por algum tempo, mas ele não sabia quem era ela:

- I made a fake profile on Orkut, it was a game that I wanted to play with him.

Um bom tempo depois, quando eles haviam parado de se falar pela Internet e pelo telefone esse rapaz ligou pra ela, pois estava morando em Délhi novamente, havia se mudado ao término da faculdade, mas agora voltava. Os dois então se encontraram e começaram a se relacionar ("we started dating"). Por sete ou oito meses, ambos se viam para conversar e sair, ir ao cinema, comer e fazer compras. Ele vinha até a porta da PG, a pegava e ambos saíam no carro dele. Ele a tratava muito bem, era carinhoso, a respeitava, mas ela começou a perceber que ele não queria nada além de sair com ela, o relacionamento não avançava para algo mais sério. Segundo Lovania, nesses dois relacionamentos os rapazes é que terminaram o namoro.

0 outro rapaz, de quem ela falou menos nessa ocasião, também era um bom rapaz ("a nice guy") e se relacionaram por um ano e meio, ele não morava em Délhi e sim no Rajasthan, mas vinha à Délhi visitá-la. Ela disse que amou os dois, mas era louca pelo segundo, "I could die for him". Foi uma paixão nutrida desde os tempos de faculdade, 
transformada em correspondência virtual e finalmente em namoro. Ela enfatizou que não costuma falar do assunto com os amigos da PG, exceto com Shubhi, e me pediu para manter isso em segredo dos demais moradores.

A palavra love aparecia reiteradas vezes em minhas conversas com Lovania, "I loved them both", "I love Ujjwall [o segundo namorado] madly", "I miss him badly", "I am still in love with him", foram frases que escutei muito. Mostrou-me uma foto dele, era também muito mais claro que ela na cor da pele. Ela tornou a dizer que ele não queria nada sério, apenas curtir a vida, e o comparou aos rapazes de hoje em dia:

- They just want to enjoy life, date different girls, see which one is better.

Então contou que Ujjwall começou a sair com outra moça antes de romperem, ela descobriu que ele já estava saindo com outra quando terminaram. Desde então ele havia desaparecido. Nos anos seguintes, contudo, voltei a ouvir falar dele. Dois dias depois, fui me encontrar com ela em Dilli Haat [Feira de Délhi] ao entardecer. Trata-se de uma feira permanente de artesanato com expositores de vários lugares do país, idealizada e mantida pelo Ministério do Turismo. Lovania vinha se mostrando cada vez mais triste e frágil naqueles dias. Dizia que se sentia bem estando comigo, talvez pelo fato de que eu a escutasse com atenção, e pedia-me para ir visitá-la reiteradamente. Ao entrarmos me interessei por umas pinturas de artistas populares da Bengala. Ficamos olhando e ela ia me dizendo quem eram as divindades nas pinturas. Contou-me a história da deusa Kali e porque ela é representada com a língua para fora. Disse que é uma deusa muito brava, guerreira e poderosa. Certa feita Kali estava tão furiosa que matava a todos a sua volta, enquanto fazia isso Shiva, seu esposo, se aproximou sem que ela percebesse. ${ }^{50}$ Lovania continuou:

- You know we believe that husbands are like gods, in Hinduism a wife has to treat her husband as her god. So she was so furious and what she did? She stepped on Shiva, she touched her husband with her feet. And then she realized: what have I done? And she put her tongue out in despair. So this is why she appears with her tongue like this.

\footnotetext{
${ }^{50}$ Kali é o avatar guerreiro de Parvati, por isso é dito que é esposa de Shiva. Kali não é, no entanto, tida como exemplo de esposa, juntamente com Durga (outro avatar de Parvati) e outras figuras femininas e poderosas elas são temidas e adoradas como deusas e mães, mas não constituem modelos exemplares para as esposas terrenas.
} 
Fiquei fascinada com a deusa representada com a língua pra fora porque se assustou e caiu em si quando pisou o corpo do marido, o que ela não deveria nunca fazer, ela parecia tão forte que nem mesmo Shiva, o destruidor, podia com ela. Fiquei menos fascinada com a ideia de as esposas deverem adorar seus maridos ser algo tão naturalizado para Lovania, mas, evidentemente, pela literatura, pelos filmes indianos a que assisti e pelos estudos acadêmicos, sabia que a ideologia pativrata é bastante introjetada em muitas mulheres e homens.

Depois fomos comer, a feira também tem barracas com comidas regionais, e ela contou que estava com dor de garganta. Pediu que eu não contasse a Shubhi que havíamos estado em Dilli Haat. Por essa época comecei a sentir que havia uma certa tensão entre as duas em alguns momentos. Lembrei que Patrick dissera naqueles dias que Lovania estava chateada com ele. Perguntado sobre o motivo, respondeu que ela poderia estar com ciúmes dele e de Shubhi porque eles tinham um ao outro e ela não tinha ninguém. Naquela altura falei que achava que não, mas agora pensava que Patrick poderia ter um pouco de razão. Enquanto comíamos, perguntei como ela havia conhecido o primeiro namorado, de nome Vijay, disse que por amigos em comum. Como ela não deu seguimento ao assunto, deixei pra lá e sugeri que tomássemos um tchai ao final da refeição para esquentar a garganta. Quando acabamos, ela disse estar cansada, então fomos nos encaminhando para a saída do lugar. Tomamos um auto-riquixá e voltamos à PG. Enquanto isso, Patrick e Shubhi não paravam de telefonar me chamando para ir ao cinema, haviam convidado Lovania também, mas esta declinou dizendo que iria trabalhar no dia seguinte, era realmente difícil fazê-la sair de casa para se divertir à noite. Dileep iria se juntar a nós e eu deveria ir para a PG, de lá partiríamos juntos para o cinema no Select City Mall, onde já se encontravam Patrick e Shubhi. Perguntei novamente a Lovania se ela não queria mesmo ir conosco assistir ao Grande Gatsby. Ela reforçou que estava cansada e que sua dor de garganta aumentava. Quando chegamos, já Dileep me aguardava na porta do prédio. Eu disse que precisava de cinco minutos antes de partirmos, subi as escadas com Lovania deixando-a no segundo andar para alcançar meu quarto no terceiro piso. Peguei pastilhas para dor de garganta que Patrick havia comprado para mim e fui ao quarto de Lovania. Da calçada, Dileep já me ligava, provavelmente para me apressar. Entreguei as pastilhas à Lovania, que parecia querer me segurar ali com ela. Abracei-a e desci as escadas com um pouco da tristeza dela em $\operatorname{mim}$. 
No dia seguinte ela me chamou para ir ao templo que frequenta perto da PG. Além dos jejuns semanais que estava guardando para Shiva, ela ia ao templo aos sábados, sempre ao final da tarde, começo da noite. Era um templo no qual eu nunca havia reparado, não é fechado como os que eu gostava de fotografar, mas aberto, pequeno e com uma plataforma de mármore que se eleva da calçada. Estão dispostos sacrários (shrines) para Durga, Ganesha, Hanuman, Shanidev (que eu não conhecia) e ao centro do espaço, um shivalinga, tendo imagens de Ganesha e Parvati, um de cada lado, Karthik atrás, e o touro Nandi, a montaria (vahana) de Shiva, na frente. A imagem de Shanidev, a maior de todas, era impressionante e imponente, tratava-se de um deus de pedra negra ao lado de um touro, com inúmeras velas dispostas ao seu redor. 0 altar emanava calor com as velas derretendo. Lovania me mostrou uma árvore peepal (ficus religiosa), planta sagrada para hindus e budistas, nos fundos do lugar, fora da plataforma de mármore, na qual um japa mala com contas de madeira está amarrado. Ali, outras várias velas ao pé da árvore. As velas são na verdade espécies de lamparinas, um pequeno recipiente de metal com manteiga ou óleo em que é colocado um pequeno pedaço de barbante para funcionar como pavio. Lovania fez a lamparina dela de um modo diferente das demais, as quais continham apenas um pedaço de barbante como pavio. Na dela, colocou dois pequenos pedaços de barbante em formato de cruz, com os dois pontos médios dos pavios se encontrando e acendeu as quatro pontas, dizendo-me que ela estava fazendo seus pedidos nas quatro direções cardeais, esse o porquê das quatro pontas. Ela explicou que Shanidev é um removedor de obstáculos, ele corta todo o mal (evil) que está em sua vida, disse-me ela.

Em seguida fomos juntas percorrendo cada um dos sacrários e ela foi me explicando quem eram aqueles deuses, a maioria que eu já conhecia. Em frente a cada um ela fazia o sinal pranam e se detinha um pouco, com os olhos fechados, em adoração. Finalmente paramos em frente a Shanidev, que me impressionou sobremaneira, pois talvez fosse imponente demais pra mim.

Logo que chegamos ela colocou dinheiro numa caixa de vidro, essas sempre presentes nos templos. Um pandit fica sentado próximo à imagem de Hanuman, em frente à qual está a caixa de donativos. Ele nos ofereceu água de uma pequena colher de metal, objeto ritualístico que sempre observo nos templos hindus, um grão de prasad (açúcar branco em formato de bolinha que é uma benção) e pintou um ponto alaranjado 
em nossas frontes com uma tinta que escorria da imagem de Hanuman, essa toda tingida dessa cor.

No dia seguinte era domingo e fui ao Green Park Market com Lovania. De passagem por uma mercearia ela aproveitou para comprar um monte de pacotes de Haldiram's, salgadinhos industrializados cheios de gordura e carboidrato. Comentei que adorava aquilo também, mas evitava pelo alto teor de gordura e carboidratos, ela comprou assim mesmo. Quando caminhávamos de volta no sentido da PG, ainda em Green Park Market, passamos em frente a uma lanchonete de sucos e sanduíches naturais e Lovania disse:

- I used to come here with him. He likes this place. I am still into him. I'm so much into him.

Ela se referia ao último namorado, Ujjwall, a quem ela nunca esquecera. Disse que eu achava que a entendia, que não era fácil esquecer alguém que um dia se amou, falei no passado e ela me corrigiu:

- I still love him.

Aquela conversa se repetiu quando fomos, tempos depois, em junho de 2013, a um restaurante em Greater Kailash. 0 ambiente, com pouca luz, era um corredor largo no segundo andar de um prédio, com bancos de couro dispostos um de frente para o outro com mesas baixas entre um banco e outro, de modo a dar certa privacidade às pessoas que ocupam cada par de bancos. À direita, um pouco à frente dos bancos em que nos encontrávamos - Lovania, Patrick, Shubhi e eu - havia um banco virado para a sacada do lugar, de modo que não víamos quem estava no banco e quem estava no banco tinha a vista de fora do restaurante, uma praça do outro lado da rua. Ela comentou, cochichando em meu ouvido, que havia estado lá com Ujjwall e sentado naquele banco. Disse que eles haviam tido momentos de alguma intimidade, como ali, no cinema e no interior do carro dele, onde certa feita, quando se beijavam, ele havia levado a mão dela até as calças dele. Fiz, sem querer, uma cara de espanto e ela disse:

- But he was a good guy, he never tried anything without my consent. 
Perguntei como ela havia reagido.

- I got very scared and took my hand off him.

No ano seguinte, em 2014, como eu tivesse meu próprio quarto, Lovania ia até lá para conversar frequentemente. Em uma dessas vezes ela disse:

- Fab, do you know what? I realized that I am not a happy person.

Continuou dizendo que ela percebia que as pessoas à volta dela eram mais radiantes, gostavam de fazer várias coisas, eram desinibidas e que ela era "very shy and not at all expansive". Lembrei que dias antes havíamos conversado com ela, Rekha, Shubhi e eu, dizendo que ela poderia ser mais aberta a coisas e pessoas diferentes. As meninas disseram que a achavam muito fechada para novas experiências e também para conhecer pessoas. Quando ela perguntou, como assim? As meninas haviam dito que ela raramente aceitava convites para sair, nunca assistia filmes de Hollywood e só gostava de "Bollywood masala" - filmes nacionais que misturam romance, comédia e ação, daí o termo masala, que significa uma mistura de vários ingredientes. Perguntei, em meu quarto, o que ela achava do que as meninas haviam dito a ela.

- I think they might have some reason. I should be more expansive.

- If you think so, try to change, slowly. Go in your own pace, do something different, try to be more talkative with people here in PG itself.

-Ya, you are right, I should do that. Even my father says that I should not be so demanding with people.

- What does he mean with demanding?

- My father says that I keep a high expectation on my husband-to-be. He also says that as I am not very pretty I should not expect a very handsome guy as well.

- Oh my god! Your father told you this?

-Ya, but he said that in a good manner. Shubhi tells me the same that I am very picky about guys, that I always like handsome guys. Like Ujjwall he was fairer than me.

- Dear, let me tell you something, because someone is fairer or darker it doesn't mean that the person is beautiful or ugly. Don't think like that.

- Really? Do you think so?

- Ya, sure! This is a prejudice. 
- But people here think like this. Like Ujjwall he didn't want to marry me, the girl he married is fair, like him.

-What? Is Ujjwall married?

- Ya, he got married some time ago, he had a love marriage.

- How do you know that? I thought you guys were not in touch anymore.

- Yes, he disappeared for some time. But then he started talking to me on WhatsApp.

- Are you guys still in touch?

- Ya, we talk sometimes.

- Ok. And do you still like him?

- Yes, I am still into him. I think it is because after him I never had any other person in my life. If I had had someone new, I would forget him.

- What make you think so?

- When Vijay and I decided to end our relationship for some time I still liked him, then I met Ujjwall and I fell for him and forgot Vijay.

- And why did you and Vijay break up?

- He wanted to marry me, but I didn't want to marry him. I was too young then, and I didn't really felt that he was the one.

- How so?

- He was from a different community, he is from Rajasthan, I am Bengali. My father wouldn't like me to marry a Rajasthani boy.

- And what about Ujjwall, is he a Bengali?

- No, he is from Chandigarh, as Shubhi.

- Ok, but would you marry him if he wanted to marry you?

- For sure! I already told you I am crazy about him!

- So for him you would oppose your father's will?

- I would do anything for Ujjwall.

- So the thing is that you didn't love Vijay as much as you love Ujjwall?

- Ya, I think so. I liked Vijay, he is a really nice person. We are still in touch even if he married.

- He is also married?

- Ya, that's why we broke up, he said he wanted to marry me, his father was wanting him to get married. But I said no, so we broke up and he got married, as his father wanted him to.

- He also had a love marriage? 
- No, he had an arranged marriage. Vijay is very traditional. He never even tried anything on me as Ujjwall did.

- But you said last year that Ujjwall never tried anything against your will.

- Ya, he hasn't. I agreed doing things with him, but just from this part of my body till up here - [fez um gesto indicando do abdômen pra cima].

- Oh ok. Got you. So you guys had some intimacy.

- Yes we did. When he moved to Gurgaon he lived in a flat. He took me there twice. In the first time nothing happened. The second time I agreed doing some things from here [repetiu o gesto].

- Hum... The same rule worked for him? Or did you touch him bellow this area? [apontei a região do abdômen em meu corpo]

- Ya, I did, but only with my hands.

- Ok. And how was that? Did you like it?

- I liked, but I also felt uncomfortable. Than I got very mad at him!

- Why? What happened?

- We kissed for some time, we had some intimacy, then we lay down on his bed and he slept. He said he was very tired. He slept till the next morning. And I couldn't sleep at all. I never sleep outside home. So I kept there sitting in his bed the whole night doing nothing. When he woke up we had breakfast and he realized that I was mad.

- Then what happened?

- He said he didn't know that I would be up the whole night. He said that it was not his fault.

- Oh my god, what a funny story!

- No Fab, it was not funny. I got really mad at him!

- Oh, ok, sorry.

- It was when I realized that he didn't want anything serious with me.

- Ok, then you stopped seeing him.

- After a while he disappeared.

- And let me ask you something very personal. You tell me if you don't want to answer, please. Did you feel like making other things with him when you were together?

- Ya, sweetie, I did. But if you have physical intimacy with a guy you get too attached to him. If I had had sex with Ujjwall I would be even crazier for him. I would never be able to forget him.

- Ok, I think I understand. So you wanted to do but you refrained yourself?

- Ya, I will only have sex after marriage. 
- Can I ask you why? I mean why do you have it so clear?

- Because this is the way I was brought up. I grew up thinking that I would get married and then would have intimacy with my husband.

- Ok. I got you. Do you mind when I ask these questions?

- No sweetie. Not at all, I don't have people around me to talk about it, except for Shubhi, but she doesn't like talking about it. I mean she listens to me but she doesn't like me making questions about her life.

No decorrer daquele ano comecei a entender do que exatamente Shubhi não gostava de falar. Lovania me fazia perguntas como "how to please a man sexually", "how to turn on a guy" e se eu gostava de realizar sexo oral, essa última, ela assumia, seria algo natural no ocidente e, por isso, Patrick devia me fazer uma pergunta mais indecorosa que aquela quando jogávamos "Truth or Dare” no Zo Cafe em Hauz Khas Village, numa tarde que saímos para almoçar, Shubhi, Lovania, Patrick e eu. Shubhi havia sugerido a brincadeira porque queria, ela me segredou, fazer algumas perguntas a Patrick, como se ele ainda estava apaixonado por alguém com quem havia se relacionado, pergunta que, claro, tinha como objetivo saber se ele ainda gostava dela, o que Lovania e ela própria acreditavam ser verdade, embora ele negasse. Nessa mesma rodada do jogo, Lovania foi perguntada se ela se masturbava e com que frequência, ao que respondeu que não, nunca havia feito isso e não sentia vontade de fazê-lo.

Em duas ocasiões distintas essa brincadeira foi feita, uma vez proposta por mim, quando estava com Patrick e Rekha em 2013 e nessa ocasião. Todos aproveitavam para fazer as perguntas que queriam fazer em outros momentos e não encontravam oportunidade. Fui percebendo que o fato de as pessoas pedirem segredo disso ou daquilo que me contavam era um tanto quanto cênico, pois em inúmeras ocasiões eu percebia que outras pessoas também sabiam o segredo que havia sido confidenciado a mim. Desde 2012, eu sabia que as fofocas eram objeto de dádivas dentro da casa, quem tinha um segredo de um terceiro logo o passava para um quarto sujeito e assim o segredo virava apenas mais um incidente ou história pessoal. Eu continuava achando que algo que um deles havia me contado era segredo, até que o segredo chegava a meus ouvidos pela boca de outra pessoa. Em outros casos o segredo havia sido contado a outra pessoa e chegava a mim do mesmo jeito. Foi assim que aconteceu, por exemplo, com a história de que Shubhi havia conhecido Ravi por intermédio do pai dela. 
Quando eu já havia partido de Délhi, em outubro de 2014, conversava com Lovania no WhatsApp sobre o casamento de Shubhi, que se aproximava. Ela principiou a me contar que sua família havia colocado um anúncio procurando um noivo para ela no jornal da cidade onde residem.

- My family has given a matrimonial advertisement in a newspaper.

- Oh, nice!

- I hope you are also aware of this methodology for arranged marriages.

- Yes, I do! It is in a local newspaper?

- Yup!

- I think it's a good idea, lots of people do that.

- Yeah.

- What did they write in the add?

- My basic information. Age, complexion, height, working status, qualifications.

- Ok, it sounds good. And did they put your requirements too?

- Yeah. My brother did. I was not aware of it.

- Oh, yes? He did it without telling you?

- Yes, I didn't know. He told me today.

- I wish you get a lot of respondents!

- They are getting so many calls since yesterday. But Fab, you know what?

- Tell me.

- I want to love someone and then get married to him. Is it possible?? Can you please pray for me?

- Of course it is darling. And the other way around also is possible. To love after get married. But do you think it is better to love before and then marry?

- Yeah.

- The most common in India is the opposite, isn't it?

- Yeah.

- But why are you saying this now? Where this wish comes from?

- To love someone after marriage becomes a compulsion. Not a choice. You are not left with any other option.

- But would still be love, no? Or do you think is different?

- It's different.

- How so? What you mean? 
- Once you are married it is done for life. No matter whether you like that person or not you will have to be with him. And love him.

- And how it is when you fall in love first?

- When you fall in love with someone it is because you know that person. And you like things about him. You are compatible with him. You love him.

- Ok, I think I got.

- And these are the reasons why you want to be with him.

- But in this case will you say no to the person your family choose? I mean wont you go for an arranged marriage?

- I will have to go for an arrange marriage. Can't say no. Especially when you don't have a love in your life.

- Aw... The only way of avoiding an arranged marriage is to get a love before it? That's it?

- Yeah, that is right. I am very sleepy now. Talk to you tomorrow.

- Ok! Good night! Sweet dreams! Don't be sad...

No dia seguinte continuamos o chat que começou com uma mensagem dela à qual respondi:

- Yesterday I kept thinking about our conversation. When I first met you in 2012 you seemed do not have any problem with an arranged marriage. What have changed? Or it was just my impression?

- Oh... I still don't know many problems. But when you see people around you getting married to the person whom they have loved so this came in my heart too. Most of my friends have done love marriages.

- Ok. But maybe it started as arranged and then became love. Like Shubhi, it was kind of arranged too. Her family indicated Ravi, no?

- Why don't you ask her?

- I am saying that this is what happened, she told me that.

- Fab, just between you and me... it's a love marriage.

- Why you say that?

- She met Ravi through a common friend. Now listen carefully, I don't know what she told you exactly.

$-\mathrm{Oh} \ldots$ 
- But she hid some facts because she was with Patrick. So she didn't want to complicate things.

- Oh, I didn't know that.

- She wanted to depart from Patrick. And that time only she met Ravi.

- Yes, this I know. That she met Ravi before breaking up with Patrick.

- And both of them started liking each other.

- But I thought her father had indicated Ravi to her.

- No. It's a love marriage.

$-\mathrm{Oh} . .$.

- Yeah. But you don't show to her that you know all this.

- No of course not! But she didn't love him from the first time. She wanted to like him, she told me this.

- This I don't know.

- But coming back to you. This longing for love or love marriage is because of what you have seen with your friends? That's it?

- See, it is obviously easier and more comfortable to spend your life with a person whom you know and love.

- Do you say this in contrast to arranged marriage?

- Yeah.

- I am not sure that Shubhi's marriage is really a love marriage. Because she wanted to love him. I don't think it was a spontaneous love. She kind of forced herself to like Ravi, because she wanted to marry and Patrick wasn't able to offer her this. What I am saying is that maybe people overestimate the idea of love.

- No, I am telling you, it's a love marriage only. She loves him.

- Ok. If you say so.

- Yeah. You are really studying your topic carefully.

- Hehehe... I am trying. But it is very difficult to understand what people feel. It bothers you that I ask these questions? You please tell me the truth.

- Not at all. It's a good thing. I also get to analyse myself.

Desse período em diante Lovania sempre falou de rapazes que havia acabado de conhecer, de Ragavendra, amigo de Anindya por quem se encantou em 2014, às vezes de alguém do trabalho com quem estava flertando, até que um dia falou de um rapaz que havia respondido ao interesse dela no site de matrimônios. 
- Darling, I got a good response on matrimony. One good guy accepted my interest for the first time ever!

- Oh, nice! And what did you like about him?

- Everything. Profile, family... he seems to be a good option - [colocou corações vermelhos ao final da frase]

- Oh my god! It seems that someone is in love!

- Yeah. I will buy the membership in that site just for him. I must be a paying member to access his mobile number.

- Ok. And what about the add your brother have put? Any news?

- Interests keep coming.

- This is good!

- But those profiles my brother received are not according to my requirements.

- Oh, I hope you are not being too demanding...

- No sweetie. Really not anymore. There were few guys, but eventually nothing looks positive.

- You didn't like anyone?

- I liked only one profile, but our horoscope doesn't match. Few families have really liked my profile. And they are constantly trying to fix up. But we don't find them exciting enough.

- What you mean by trying to fix up?

- Fix up means things towards finalising marriage.

- Oh ok. So now what is next? Does the horoscope really matter to you?

- It does matter. Let's see... Someone is there for me.

As exigências de Lovania tomavam formas diferentes de época para época, para se casar com Ujjwall ou com rapazes que ela achava atraentes no site de matrimônio, horóscopo não era algo importante. No caso de Ujjwall nem mesmo a comunidade, ou a casta importavam, já no caso de Vijay, a diferença de comunidade havia sido a desculpa para desdenhar o moço tímido e "traditional" como ela própria. Lovania também oscilava em suas expectativas quanto ao casamento, ora parecendo estar de acordo em deixar a família arranjá-lo, ora ansiando por um namorado por quem se apaixonasse primeiro para então se casar, depois voltando a aceitar se casar de modo arranjado se o rapaz por quem ela já estava se apaixonando platonicamente através do site de matrimônios a escolhesse. 
Em 2015, nas três semanas em que fiquei em seu quarto, na cama que havia sido de Shubhi por quatro anos, assistíamos novelas todas as noites, algo que havíamos feito esporadicamente nos anos anteriores, invariavelmente a TV estava ligada e ambas assistiam novelas. Na TV indiana aberta por mais que se mude de canal as cenas e roteiros insistem em se repetir: mulheres chorando, cenas dramáticas com tempo arrastado e longos closes de faces tristes, espantadas ou em choro, complicações nos casamentos e dificuldades no relacionamento entre os esposos, os sogros e os demais parentes por afinidade como cunhadas e cunhados. Lovania me contou que a novela a que estávamos assistindo tinha como protagonistas um casal que havia sido submetido por vontade dos pais ao casamento arranjado. Naquela altura da trama a vida do casal era um dramalhão: a esposa havia se apaixonado pelo marido após o casamento, este, por sua vez, gostava de outra moça, a ex-namorada, a quem continuava perseguindo, os sogros implicavam com a esposa recém-chegada à joint family, que sofria duplamente, por não ser correspondida na relação conjugal e por ser submetida aos caprichos dos inlaws. Lembro que no ano anterior assistíamos a uma novela em que um casal que também havia se casado de modo arranjado estava se apaixonando após dois meses do matrimônio, no começo haviam se detestado. Ambos ainda não entendiam o que se passava com eles, a moça tinha borboletas no estômago devido à paixão e as pessoas da família começavam a desconfiar que ela estivesse grávida, pois passava mal e não comia. O par romântico, no entanto, ainda não tivera sua primeira noite de sexo, mas não queria confessar isso à família.

Na última temporada de campo, percebi que, de certo modo, as novelas tinham tramas paralelas à vida de Lovania no tocante aos dramas. Ela amava e chorava por Ujwall, que havia tido um casamento por amor com outra moça; Vijay a amava e chorava por ela, tendo se casado com outra de modo arranjado por vontade da família. Esse último ligou para Lovania na derradeira semana que permaneci em Délhi em 2015 e falou com ela por mais de meia hora dizendo que havia bebido e que ela precisava ter paciência com ele. Embora esteja casado e com uma filha, Lovania diz:

- He is too much into me, he never forgot me, when his daughter was born he called me and said: 'you became a mother'.

- What? I didn't get it.

- He meant that as he was then a father, for him I was also a mother from that moment on. 
- I'm sorry. I still don't understand.

- He always dreamt to have a baby with me, so when his daughter was born he thought that I could be the mom, got it?

- Oh, I think so. But this is too sad.

- Ya. These things happen a lot in India. See these soap operas...

Quanto à Ujjwall mesmo ele estando em um "love marriage", ainda sem filhos no momento, ela nunca o esqueceu, ainda que o tivesse visto pela última vez na primeira metade de 2013. Numa das noites que estive com ela em janeiro de 2015 eles se falavam no WhatsApp e ela foi narrando a conversa comigo a seu lado. Reclamou para Ujjwall que não tinha nem mesmo uma foto de ambos juntos para poder olhar. Ele prometeu: "I will fulfil this wish one day, it's a promise". "Really?", ela perguntou. "Ya, I promise you". A conversa seguiu enquanto estávamos ambas deitadas com as luzes apagadas, prontas para dormir, mas falando com alguém no WhatsApp, André, no meu caso, e Ujjwall, no caso dela. Ela disse a ele: "I wish we could be together". Ele respondeu: "We are together".

Ela: - I mean forever. What about you? Do you feel the same?

Ele: - I don't know. I never thought about it.

Ele some, sai do chat, aparece off line. Lovania me disse, depois de ler a conversa entre eles, parte em inglês, parte em hindi que ela traduzia após ler as frases no original:

- I was feeling so sleepy so was talking to him almost unconscious, I think our mind doesn't work properly when we are sleepy, you know?

- What you mean? Like when one is drunk?

- Yes, exactly! I was about to ask you this, I have never been drunk, but I think it is like this only.

- Ya, maybe...

- I should not have asked him such questions, he was talking to me nicely, now I scared him. He is not coming on line again. 
Eu disse a ela que havia sonhado algo muito estranho na noite anterior, um elefante do tamanho de um boi voava no céu e de repente caía desajeitadamente perto de mim, quase me atingindo. Ela disse:

- An elephant flying? Yeah, it's a very strange dream. You know what? I had an intriguing dream last night as well. I saw myself married. It was a function, like one two days after my marriage. I was wearing a red saree, people was coming to see me, giving me gifts, giving me money, greeting me... I could see everything perfectly...

- And who were you married to?

- Hahaha... exactly! This was exactly what I thought when I woke up: but who was the groom? I kept thinking, trying to recall, but I couldn't see any face, any name, nothing. I was married but don't know who was the groom. I could see everything in details... you were there as well... I could see my dress, people that I know, the gifts... but the husband was absent... You know, this is not considered to be a good thing in India.

- What you mean?

- It's not a good thing to see your wedding or your marriage in advance; it means it will get delayed. The marriage will take a long time to happen. But I don't mind. I don't have anybody in my life now so obviously it's gonna take some time.

Com esse sonho e com as outras histórias que Lovania me contava, ela me colocava desafios para entender a relação que se estabelecia na Índia entre amor e sistema matrimonial do ponto de vista dos jovens. Seria sua vontade de casar por amor próxima ao complexo ideológico de amor romântico ocidental em que o amor é o que legitima o casamento? Ou o desejo pelo casamento por amor viria por uma idealização desse tipo de casamento que ela agora via por todos os lados? 0 que me intrigava era a indagação: haveria um lugar destacado da ideia de indivíduo em sua busca por um casamento por amor? Ou seria a busca por romance próxima àquela descrita por autores que acreditam que no casamento arranjado das sociedades não individualistas o amor está longe de ser como o amor romântico, pois qualquer indivíduo indefinido poderia vir a ocupar o papel social do marido, necessariamente amado porque de dever da esposa?

No caso de Lovania, o casamento por amor, pelo qual ela passou a ansiar no decorrer de nossa convivência, inspirada, como ela diz, não só por romances e filmes, mas pelos amigos à sua volta se casando por amor, se aproxima do anseio por amar e ser amada, independentemente do rapaz que cumpriria o papel de marido, o qual poderia 
ser preenchido por qualquer indivíduo, desde que fosse um "husband material" como ela diz. Quando ela se apaixona por Ragavendra, após sairmos em grupo por duas ou três vezes e com poucas frases trocadas entre eles, ou por Jai, a quem conheceu recentemente por uma amiga em comum e com o qual começou a se corresponder pelo WhatsApp, ou pelo respondente no site de matrimônios a quem nunca viu pessoalmente, mas afirma que tem um perfil perfeito, e quando, em seguida, me conta seu sonho, tenho sinceras dificuldades em afirmar que não se trata de um tipo de amor pré-construído e não de um caso de amor em que o indivíduo amado seria único, especial e insubstituível para ela. Quando penso, contudo, no amor dela por Ujjwall penso que pesquisas que negam a existência do amor romântico na Índia, tal qual ele estaria presente no ocidente, possam ser atualizadas e afirmo que o amor romântico está sim presente na Índia, ele apenas não pode, nesse caso, redundar em casamento, pela recusa de uma das duas pessoas na relação. Lovania oscila assim, em sua trajetória, entre o amor domesticado (amor romântico por Ujjwall) e o amor disciplinado (variante do amor que teria se desenvolvido em contextos holistas) que poderá levá-la a se casar de modo arranjado com alguém que irá preencher o papel do marido que ela deseja amar, além de dividir a vida, como ela afirmou desde que nos conhecemos. Ou talvez eu esteja apenas maluca, o que faria perfeito sentido, pois malucos podem ver elefantes do tamanho de bois caírem do céu como se fora algo corriqueiro.

De todo modo, desde o início do trabalho de campo percebia entre os jovens com quem convivi um movimento de oscilação entre a vontade de se constituírem como indivíduos, com possibilidades de fazer escolhas autônomas para suas vidas, e a expectativa social e familiar de manter a obediência e a lealdade aos pais e demais familiares. Os anseios amorosos, por parte das garotas, e matrimoniais e profissionais, por parte do garotos, eram, desde o princípio para mim, formas agudas de tentar se individuar nessa fase liminar que vivem antes do casamento, na qual, como já dito, ainda não são considerados adultos.

Naquela mesma noite Lovania também disse que queria que eu colocasse seu nome na tese como Lovania, não porque não quisesse que as pessoas a reconhecessem, mas por que não queria que copiassem seu nome, que é incomum e ela quer que assim permaneça. Rimos e ela emendou:

- In any case I like the idea of having a thesis written about me. 
- And what is the meaning of Lovania?

- It means love and affection. It was the name I used in my fake profile to chat with Ujjwall.

- You naughty girl!

Rimos e fomos dormir. Já de volta ao Brasil, falávamos em um dia de maio de 2015 pelo WhatsApp sobre Jai, o rapaz que lhe fora apresentado por uma amiga em comum. Eles se viram algumas vezes, saíram para passear de carro pela cidade e para comer. Ela estava triste nesse dia.

- Why are you sad?

- I last saw him on 15th April. Since then we have not met. I so wanna see him. My inner desire is to kiss him.

- Aw...

- I am getting these thoughts. I don't know. What to do?

- And does he know that?

- No. He knows that I want to meet him.

- Ok. Dear, I don't really know what to tell you...

- Sometimes I feel that I might loose control and kiss him without saying anything.

- I probably would show him that I wanna kiss him. Or maybe I would even kiss him. But this is how I would act in Brazil.

- Take me to Brazil. I would be able to breath at least.

- What you mean? Can't you breath in India?

- I meant I could show my desires. Don't go by the literal meaning.

- But some girls show their desires in India no?

- Yeah. They do.

- So? Why don't you do the same?

- But they are not called good gals.

- Oh... But Gunjan, Shubhi and Rekha for instance, they are good girls, no? And they dated guys, they had boyfriends and they somehow showed their desires for them.

- Yeah. Having a boyfriend is not a bad thing. But I can't show my desires to him.

Com essa fala, Lovania me remetia à leitura de Sen (2010) sobre o estereótipo da boa garota. Ao dizer que garotas que expressam seus desejos não são consideradas 
"good gals", Lovania reafirmava o entendimento de que o desejo feminino é valorado negativamente, devendo a boa garota ocultá-lo sob pena de, como Soumita, ao expressálo ser taxada de "bold", expressão que era utilizada para indicar uma moça "atrevida" ou "atirada". O pedido de que eu a trouxesse ao Brasil para que pudesse respirar, isto é, para que se sentisse apta a expressar seu desejo indica que o problema não residiria no desejo em si, já que aqui, segundo o imaginário que ela faz do Brasil, poderia demonstrálo, mas se encontraria na moralidade que coíbe o desejo feminino. Era o julgamento moral do rapaz e da comunidade que Lovania temia.

No pensamento de Lovania aparecia com frequência, ademais, a noção de que a iniciativa para qualquer movimento amoroso ou erótico entre um homem e uma mulher deveria partir do homem. No primeiro capítulo mencionei que a temporalidade do romance na paisagem moral a que estava submetida era diverso daquele em que fui socializada no Brasil. Estou segura em poder afirmar nesse ponto do texto que a temporalidade dos relacionamentos sexo-afetivos dos quais tive conhecimento na Índia depende do ritmo empreendido pelo rapaz, em demonstrar interesse, declarar amor, tomar a iniciativa do primeiro beijo, propor intimidade sexual etc., e da moça em recusar. Se a garota desafia essa prerrogativa, ou mesmo se aquiesce à vontade do rapaz rapidamente, não será tida como uma boa garota, o que me levou a, no início, pensar nos jovens indianos com quem convivia como não tendo muita urgência por sexo. Pareciame naquele momento que o espaço de tempo decorrido entre a primeira aproximação e a intimidade sexual levava uma eternidade, o que se deve ao complicado jogo de sedução e resistência estabelecido no momento em que um rapaz se declara a uma garota - o que meus amigos referem como "propose". Desse instante até o momento em que, pelo que pude perceber, o rapaz, e não a garota, expressa o desejo pela intimidade sexual podem decorrer vários meses ou até dois, três anos como no caso que veremos no capítulo seguinte. Em crônicas de jornais e em romances ficcionais vi mais de uma vez referências ao que se chama em inglês norte-americano de "one night stand", e que no Brasil poderíamos chamar de "ficar com alguém". Esse conceito, contudo, não faz, definitivamente, parte do repertório prático ou mesmo discursivo de meus amigos, quer entre as garotas quer entre os garotos, seja por rechaço moral à ideia, seja por falta de oportunidades.

Evidentemente, corporalidades e temporalidades em relações afetivo-sexuais adquirem formas e conteúdos necessariamente distintos em diferentes contextos. Aqui 
desejo qualificar a temporalidade e o modo que encontro é descrever os tempos do namoro indiano. Incidentalmente, o que faço é, embora não o desejasse, cotejar os tempos da aproximação sexo-afetiva dos casos que conheci na Índia com os tempos de meu lugar de socialização, isto é, eu só conseguia pensar que a temporalidade dos romances a que eu assistia era arrastada porque no Brasil urbano de 2015 o ritmo de aproximação sexo-afetivo seria muito mais acelerado. Foi preciso colocar-me em perspectiva para entender que minhas perguntas sobre ansiar ou não por sexo não faziam sentido para meus interlocutores, pois não havia como acelerar o processo de se conhecer, de investir e de negar, necessário à aproximação afetiva e sexual.

Essa questão ficou mais clara ao pensar na pesquisa de Bozon e Heilborn (1996) que examina a paquera em perspectiva comparada entre Brasil e França. Segundo os autores, no Brasil a paquera, como abordagem do sexo oposto com intenções eróticoafetivas, é feita de modo a mobilizar mais a comunicação corporal que a conversa, o contrário se dando no contexto francês, em que a comunicação verbal seria mais importante que aquela encerrada pelo corpo. Os autores veem a diferença entre as duas tendências como fazendo parte de modelos civilizacionais, a la Elias, distintos: no Brasil haveria uma expressividade do corpo ao passo que um apagamento deste se daria na França fazendo com que o lugar que o corpo ocupa na interação amorosa entre os sujeitos aqui e lá não seja o mesmo. Haveria ainda uma clivagem de gênero no Brasil, pois os homens utilizariam o corpo nas abordagens amorosas/sexuais e as mulheres clamariam por mais diálogo. Na França a troca verbal desempenharia papel central nas aproximações entre os parceiros e ainda que o contato sexual possa ocorrer num espaço de tempo mais curto, em relação ao Brasil, ele seria precedido pela performance verbal. Outra diferença apontada pelos autores existiria no modo de falar sobre o assunto: brasileiros falariam mais abertamente sobre sexo, mostrando que a "interioridade não é um domínio claramente demarcado na pessoa brasileira", pois ao falar devassam sua intimidade; os franceses por outro lado abordariam a sexualidade de maneira indireta e metafórica. A breve exposição do trabalho dos autores evidencia que pela comparação, pelo contraste que emerge, podemos qualificar corporalidades e temporalidades distintas.

A convivência com Lovania e as histórias de seus experimentos existenciais me informavam ainda de outra dimensão de como se lida com o amor na paisagem moral em que vivíamos. Curiosamente, embora o amor seja um tabu, sobretudo na ligação com 
os matrimônios em que esse sentimento, como venho tentando demonstrar, não desempenha papel algum como prerrogativa do ponto de vista da moralidade dominante, não é difícil perceber os jovens expressando-o.

Dizer eu te amo não me pareceu constituir motivo de hesitação ou de medição de palavras. Testemunhadamente, diz-se eu te amo muito facilmente, inclusive sem conhecer a pessoa por meio de conversas ou de algum tempo passado junto. Patrick se declarou a Pryia em vez de flertar com ela, como fazia com as outras garotas, sem que houvesse conversas entre os dois, sem um tempo passado a sós, sem idas ao cinema ou qualquer outro tipo de aproximação que não fossem os jantares coletivos na antiga sala de jantar da PG e duas visitas à lugares históricos da capital indiana feitas em grupo. Pryia me disse em 2013, logo que regressei, que não entendia como ele podia afirmar amá-la se não a conhecia.

Lovania, por sua vez, desde que voltei ao Brasil pela última vez em fevereiro de 2015, contou-me de três rapazes que haviam se declarado a ela, ou como ela diz "proposed her". 0 primeiro era um colega de trabalho, se viam ocasionalmente, pois não trabalhavam juntos diretamente, até que um dia ele se declarou a Lovania numa conversa pelo WhatsApp. 0 segundo era o vendedor de uma loja de quem ela comprara seu perfume preferido que estava saindo de linha e à quem, para fim de obtenção do perfume, dera o telefone para que entrasse em contato caso houvesse alguma unidade do produto no estoque. 0 terceiro, um morador da PG com quem ela nunca conversava mais que assuntos triviais quando na cozinha para apanhar as refeições, chamou-a para um café e também declarou seu amor por ela.

Quando Lovania me disse pela primeira vez, no caso do rapaz do trabalho, "a guy proposed me today", imaginei que ela houvesse sido pedida em casamento. Apenas na segunda vez, achando muito estranho que um vendedor propusesse casamento a uma cliente pelo telefone, o qual lhe havia sido informado por motivos comerciais, ela explicou que tratava-se de uma declaração de amor e não de um pedido de casamento, "he confessed his love for me". ${ }^{51} 520$ fato de que a expressão é exatamente aquela que

\footnotetext{
${ }^{51}$ Clark-Descè (2014) também encontra entre seus interlocutores na pesquisa em Tamil Nadu a expressão "propose" querendo dizer declarar ou expressar amor: "Of course, one does not talk to parents about katal [love]. But expressing it to the loved one, or rather "proposing", as the youngsters I knew put it in English, is no less difficult." (Clark-Descè, 2014: 131) Embora os jovens de Tamil Nadu pareçam achar difícil declarar ou expressar seu amor ao ser amado, contam, como os pretendentes de Lovania, com um facilitador: "Many enlisted
} 
designa um pedido de casamento na língua inglesa faz-me entrever, novamente, que o amor é pensado por esses jovens como prelúdio ao casamento, esse o sentido e a razão do romance. A maioria das pessoas com quem convivi, liga o amor ao casamento de um modo que poderiam, parafraseando o filósofo, afirmar: amo, logo me caso. Se é verdade o que dizem, que a exceção confirma uma regra, Patrick seria a exceção que confirmaria que a relação estabelecida entre romance e casamento é de que, embora o casamento não necessite do amor para acontecer, o amor precisaria de um casamento para se tornar bem sucedido.

No capítulo seguinte continuo a desenvolver por meio de histórias de meus interlocutores as noções que se sobressaem dos experimentos existenciais que pude acompanhar e exploro o modo como a assimetria entre os desejos, preocupações e deveres entre homens e mulheres quanto ao amor e ao casamento aparecem nos romances pré-maritais e nas expectativas dos rapazes que não namoram e que pretendem deixar a cargo dos pais o arranjo de seus casamentos, fazendo-me perceber que uma diferença é mantida no modo de individuação de garotas e garotos.

the help of trusted friends or younger sisters of simply relied on the safe technology of cell phones and text messaging to say 'I love you'." (Idem: 132)

${ }^{52}$ Considero digna de nota a variabilidade de reações a essas declarações de amor. Lovania ficou lisonjeada com o gesto dos rapazes que "propuseram" a ela e, mesmo não tendo inclinação alguma de engatar um relacionamento com os moços em questão, ouvia-os, respondia-os e fazia negativas com cuidado para não ofender ou frustrar os declarantes. Já no caso de Pryia, quando da declaração de Patrick, ela o ouviu atentamente, respondeu que não havia o mesmo interesse da parte dela e que os dois poderiam ainda ser bons amigos. Com a insistência de Patrick ao mandar-lhe flores no trabalho, Pryia considerou a atitude como assédio e cessou, terminantemente, qualquer tipo de contato com ele. Já Lovania não parecia achar que os casos eram de assédio. Tanto na ocasião com o colega de trabalho, onde tal comportamento seria certamente coibido pelos superiores, quanto na do vendedor que usava uma informação comercial para se aproximar de uma cliente, ela não cogitou a hipótese de que a estariam assediando. 


\section{Capítulo IV}

Yeh Jawaani Hai Deewani! 53

\section{Da busca pelo amor romântico e a busca pela individuação}

Desde cedo no trabalho de campo comecei a intuir que a possibilidade, ou mesmo o anseio, de viver uma história de amor se ligava de alguma forma ao desejo de proceder a certa individualição no processo de constituição desses jovens como pessoas. Pode-se, com razão, indagar: por que o amor constituiria indivíduos na paisagem moral indiana? Diria que por transformar relações predominantemente sociais/coletivas, isto é, os casamentos, em relações pessoais duais. Na Índia, a assertiva de que os casamentos constituem alianças entre duas famílias e não uma relação entre os dois nubentes é expressão nativa e não só analítica. Meus amigos da PG, colegas da Délhi University, a família Kapoor e os acadêmicos assumiam tal proposição da mesma maneira. Patrick chegou a achar engraçado que houvesse na antropologia algo chamado "teoria da aliança", já que para ele essa teoria era absolutamente familiar e de um senso comum opressor.

A aposta interpretativa esboçada aqui é a de que o movimento de valorização do indivíduo em face da família e da comunidade tem sido realizado por meio dos namoros e romances e, mais tarde, mobilizando e manipulando as noções de arranged e love marriage. A ideia da escolha do parceiro no romance e, consequentemente, no casamento é central nessa formulação, pois meus interlocutores realizavam experimentos existenciais por meio do namoro/romance ou da idealização do encontro amoroso que vão na direção da individuação. 0 amor esteve presente no trabalho de campo como o que possibilitava aos interlocutores nessa investigação serem únicos, especiais e insubstituíveis para o ser amado na mesma medida em que esse o era para eles próprios.

\footnotetext{
${ }^{53}$ Título de filme em hindi lançado em 2013, cuja tradução foi feita para o inglês como "This Youth is Crazy", ao qual assisti na companhia de Rekha e Patrick e que foi assunto de conversas com Shubhi e Lovania também. Voltarei ao conteúdo do filme e aos desdobramentos de nossas conversas ao longo do capítulo.
} 
Nesse capítulo a noção de segredo volta a aparecer com o sentido de um elemento importante na constituição dos indivíduos por meio do romance. 0 segredo acerca do amor e do namoro era certamente uma estratégia encontrada pelos jovens com quem convivi para garantir que família e comunidade ficariam de fora dos limites do indivíduo (selfhood). Esse entendimento me ocorreu quando, em campo no ano de 2013, relendo algumas partes do trabalho de Mody (2008), deparei-me com a afirmação de Veena Das de que a individualidade (selfhood) na Índia seria constituída por meio de dois processos: uma tentativa individual de romper os limites da comunidade e viver em suas margens, bem como uma tentativa comunal de colonizar a vida do indivíduo. Ao tratar o modo como comunidades definem um passado comum e coletivo que homogeneiza os diferentes tipos de memória preservadas em diferentes visões no interior da comunidade, como regulam o corpo e a sexualidade pela codificação dos costumes e de como operam a consubstanciação entre atos de violência e atos de solidariedade moral, a autora afirma:

"(...) I would go so far as to state that the community also colonizes the life-world of the individual in the same way as the state colonizes the life-world of the community. (...) the community can become a revitalizing force within India's public culture only if it recognizes its own paradoxical links of confirmation and antagonism with its members. Collective existence is necessary, for the individual's ability to make sense of the world presupposes the existence of collective traditions. However, equally, selfhood depends on the individual's capacity to break through these collective traditions and live on their limits. Just as communities need to resist the encompassing claims of the state, individuals need to resist the encompassing claims of even the most vital communities as a condiction of their human freedom." (Das, 1995: 16-17)

Mody se inspirava nessa asserção para sua própria pesquisa e ao utilizar o termo indivíduo para falar de seus "informantes", nas palavras dela, explica que tem em mente que os casais em fuga que intentam se casar por amor recorrendo às cortes de Délhi precisariam ser ao mesmo tempo divíduos e indivíduos, sobre o que ela diz:

"In the case of love-marriages, circumstances demand that persons maintain a capacity for being both, biomorally affected 'dividuals' and 'individuals' acting as such. The dialectic for love-marriage couples is that they must juggle these two categories such that in some contexts they explicitly need to act as indivisible bounded units (often to safeguard selfhood), while in others their selfhood is transactional and dependant on their ability to transform themselves both internally (for instance, in transforming their romantic love into a sense of obligation) and socially. I retain the use of the term 'individual' because I do not wish to imply that 
love-marriage couples as 'dividuals' transcend the historical facts of legal personhood in urban Delhi, or that they are somehow subsumed within a Dumontian collectivity, but ask the reader to bear in mind that when I speak of individuals I mean both the capacity for boundedness, and the capacity for expansiveness." (Mody, 2008: 195)

Leio a afirmação como tendo duas implicações, a primeira a de que a autora consente que os jovens que aparecem em sua investigação não constituiriam indivíduos, isto é, pessoas orientadas mormente na direção de sua interioridade como sujeitos, mas sim compartilhariam uma ética coletivamente orientada de pessoa; a segunda é que embora reconheça que os jovens estejam se movendo na direção de uma individuação na empresa de se casar por amor - Mody afirma que eles passam a constituir "noncommunities" quando se casam nas cortes de Délhi e nos templos da Arya Samaj - a autora evita a nomenclatura divíduos e evita igualmente falar em um processo de individuação para não consentir que as pessoas que compõem o casamento por amor estivessem, antes dessa empresa, "subsumidos numa coletividade", com o intuito, ao que parece teleológico, de negar Dumont. ${ }^{4} 0$ empreendimento que realizo se distingue do da autora, pois enfoco justamente a transformação na constituição da pessoa por meio do amor.

A presença do amor romântico como construção social que tem sua conformação atrelada ao desenvolvimento de sociedades ou contextos individualistas permitindo ligar, de modo idealmente arbitrário, duas pessoas que passam a ser únicas e insubstituíveis uma à outra (Lobato, 1994; Gell, 1996; Piscitelli, 1990; Viveiros de Castro e Benzaquem de Araújo, 1977) e que pude observar em histórias de amor das pessoas com quem convivi em Délhi poderiam indicar que uma transição de uma ética coletivista para uma ética individualista estaria em curso e, por sua importância já pronunciada, estaria desencadeando uma "guerra ao amor" que assumiria novas formas a cada dia, como afirma Wani (2013): “honour killings, Hindu fundamentalists' campaigns against

\footnotetext{
${ }^{54}$ Uma leitura de Dumont que considero, de todo modo, equivocada, pois Dumont não negaria a existência do indivíduo empírico na sociedade indiana, ele apenas insistiria no fato de que aquela sociedade seria predominantemente orientada pela ideologia holista. Discordo de Dumont, como o fazem muitos autores indianos, em outros desdobramentos de sua obra: como a de que i) a Índia seria uma só, de que comporia um todo social, pois o autor desconsidera, assim, as grandes diferenciações regionais; ii) o fato de que construiu sua obra fiando-se na ideologia que lhe era apresentada pelos brâmanes e a generaliza como sendo constitutiva de um todo que constituiria a sociedade indiana; e iii) a insistência em enxergar na Índia o domínio da tradição a despeito da modernidade já desenvolvida no país à época de seus estudos. Desenvolvo essas e outras críticas ao pensamento de Dumont no artigo "Louis Dumont e os Subaltern Studies: desconstruções de um cânone", (Gomes, 2014).
} 
Muslim youth for 'waging love jihad', communal and caste violence triggered by sings of individual agency in love are taking place" (Wani: 2013: 6).

A ideia da transição de um tipo de ética para outra é, já sabemos, a aposta de Yan para a China urbana contemporânea. Mas é também possível pensar, e talvez esse seja o mais acertado, que as ideias dos múltiplos ordenamentos de realidade, citada acima, ou das múltiplas orientações para o mundo, também desenvolvida por Tambiah (1996), são mais amplas e nos permitem entender que não necessariamente formas de socialidade holistas precisam ser suplantadas pela socialidade individualista como decorrência direta ou inescapável da modernidade e de outros rótulos como globalização. 0 uso das noções cunhadas por Tambiah aqui não é exatamente aquele desenvolvido pelo autor, mas penso poder estender os sentidos do que o autor propõe para uma noção mais ampla do que significa engajar-se em múltiplas orientações em relação ao mundo. Talvez, e meu uso aponta nesse sentido, seja possível ser divíduo e indivíduo num mundo aberto a múltiplos ordenamentos de realidade. ${ }^{55}$

Na convivência com os moradores da PG, pude perceber que aquelas pessoas se encontravam justamente engajadas em mais de um ordenamento de realidade ao mesmo tempo e de modo não excludente. Alguns deles não queriam mais dividir quartos com roommates, reivindicavam privacidade para suas atividades cotidianas, insistiam com os pais na profissão que desejavam seguir em detrimento daquela que os pais haviam escolhido, namoravam, governavam a própria sexualidade e viviam relacionamentos sexo-afetivos ocultados da moralidade pública. Outros deles faziam questão de continuar vivendo no lugar que emulava características da vida em uma joint family, de dividir quartos, fazer refeições em grupo, fazer toda e qualquer atividade de lazer na companhia de outras pessoas, tomar decisões - das mais banais às mais sérias - em conjunto com os amigos e a família e deixar que os pais e demais membros mais velhos

\footnotetext{
${ }^{55}$ Nos dois artigos aqui citados, de 1990 e de 1996, Tambiah desenvolve uma série de reflexões sobre como a tendência à racionalização por parte dos cientistas de nosso tempo, herança que se arrasta até nós desde o Iluminismo, acaba por obscurecer e promover um descarte de sistemas inteiros de pensamento e de modos diversos de existência por considerá-los irracionais, ocultistas, mágicos etc. No artigo de 1996, o autor aponta: "My intention in reviewing these debates and attitudes is not so much to defend or rehabilitate Paracelsus and others of the so-called Neoplatonist occult tradition or to describe in detail their cosmologies or to declare invalid the scientific attainments of Enlightenment rationalism, but to make the different point that insofar as the new 'scientists' and 'protoexperimentalists' charged and dismissed the 'occultists' with false reasoning, they also may have thrown out as irrational and indefensible a whole other mode (or modes) of orientation to the world and of world making." (Tambiah, 1996: 37) Na obra de Tambiah a busca em afirmar a racionalidade de todas as sociedades e de recuperar as diferenças criativas humanas nos traz de volta a um mundo com muitas possibilidades de pensamento e de existência, é a essa busca que faço eco aqui.
} 
do grupo familiar escolhessem seus pares e arranjassem seus casamentos. 0 mais interessante e desafiador era que havia sempre sobreposições nesses alinhamentos, de modo que eu nunca conseguiria, caso desejasse, separar os amigos que estariam, de um lado, buscando a auto-realização e o cultivo de si (características importantes da construção da pessoa no individualismo) e, de outro, seguindo a manutenção da orientação mais coletiva de suas vidas (sugerindo um apego ao holismo). Faço mais clara minha afirmação: interlocutores que bateram o pé no momento de escolher o curso universitário pretendido para a carreira profissional não davam importância alguma ao romance pré-marital ou ao fato de que os pais escolheriam suas parceiras conjugais e arranjariam seus casamentos; ao mesmo tempo, interlocutores que haviam tido sua profissão escolhida pelos pais eram categóricos ao afirmar que não se casariam da maneira que esses queriam, mas fariam um casamento a seu modo e a seu tempo.

Em todo caso, encontrei mais frequentemente pessoas que, segundo a literatura antropológica, seriam chamadas de divíduos e não de indivíduos - até porque tal constituição não depende exclusivamente do indivíduo empírico, mas da relação desse com a comunidade à sua volta, que no presente caso é preponderantemente holista e não individualista - e esses divíduos tentavam desenvolver sua individualidade ao buscar o amor romântico, seja em um namoro, seja na escolha do parceiro para o matrimônio, pois assim procedendo buscavam ser únicos e especiais para alguém. Nessa busca realizavam experimentos existenciais que os colocavam em contato direto com sua interioridade como sujeitos opondo-se ou, no mínimo, afastando-se da coletividade por meio do segredo. Faço notar ao leitor que a noção de divíduo consagrada na literatura antropológica por Marilyn Strathern teve inspiração no trabalho de McKim Marriott sobre a pessoa sul-asiática, de quem Strathern tomou de empréstimo o termo. Ao explicitar que "longe de serem vistas como entidades singulares, as pessoas na melanésia são concebidas tanto dividual como individualmente" (Strathern, 2006: 40), a última esclarece a origem da noção:

"A frase provém de Marriott. Suas observações sobre as teorias do sul da Ásia sobre a pessoa são pertinentes: 'pessoas - agentes singulares -, no sul da Ásia, não são pensadas como 'indivíduos', isto é, indivisíveis, unidades limitadas, como o são em grande parte da teoria social e psicológica ocidental e no senso comum do Ocidente. Ao invés, parece que as pessoas são geralmente vistas pelos sul-asiáticos como 'divíduos' ou divisíveis. Para existir, as pessoas divíduas absorvem influências materiais heterogêneas. Elas precisam também liberar partículas de suas próprias substâncias 
codificadas - essências, resíduos ou outras influências ativas - que podem então reproduzir em outras algo da natureza da pessoa da qual se originaram' (Marriott, 1976, p. III)." (Strathern, 2006: 40, nota 7)

Desse modo, o que faço não é utilizar de um conceito de pessoa melanésia para pensar a pessoa sul-asiática, mas de um conceito de pessoa sul-asiática que foi, por empréstimo, utilizado para pensar os melanésios. 0 curioso é que a sociologia/antropologia indiana deu pouca atenção à noção de divíduo, optando por incorporar a noção de indivíduo para as pessoas indianas, talvez como o faz Mody para negar que a pessoa indiana esteja "subsumida num coletivismo dumontiano". Em todo caso, meu ponto é que há um processo em que divíduos estão se individuando e passando a conformar indivíduos, mediante seus experimentos existenciais com as ideias e vivências do romance.

Os experimentos existenciais em tela são conflituosos e dolorosos é certo, como é próprio do contado com a existência. Já diria Mounier em sua introdução aos existencialismos que todo existencialismo se caracteriza, não por um pessimismo, "mais par une conception singulièrement dramatique du destin de l'homme" (Mounier, 1962: 28). Como também informam outros dois expoentes da reflexão sobre a aventura humana de existir, o sentido da existência não está dado, não temos dela ou de seu sentido qualquer clareza até sermos confrontados por situações-limite, que fazem desaparecer o chão de baixo dos pés do sujeito, como afirma Karl Jaspers, ou pelo absurdo da existência, como propõe Albert Cammus. Tanto situações-limite quanto a defrontação com o absurdo da existência poderiam ser conceitos aplicáveis a meus interlocutores. Não desejo, contudo, colar as estratégias, sofrimentos e descobertas desses sujeitos em seus experimentos existenciais às ideias de luta e fracasso cuidadosamente expostos por Jaspers, ou da confrontação com o absurdo da existência, como elaborado por Camus. Meus interlocutores seguramente buscavam, contudo, um sentido para a existência que não aquele previsto e apontado pelos pais, avós e outros membros do grupo familiar e da comunidade.

Como já sabemos a essa altura, meus interlocutores guardavam seus romances, namoros, e mesmo amores platônicos, em segredo dos demais moradores da casa e, mais ainda, da família. ${ }^{56}$ Ao fazê-lo eles dizem se proteger do julgamento dos colegas da

\footnotetext{
${ }^{56} \mathrm{O}$ uso do termo "amor platônico" nesse texto tem o sentido corriqueiro, de senso comum, de um amor não consumado, mas vivido em segredo ou à distância do ser amado. Não tomo o "amor platônico" aqui como
} 
PG e da família. Mais do que isso, no entanto, em minha leitura, eles abrem possibilidades nas quais podem ser indivíduos em relação com outro indivíduo, o par romântico, sem a mediação da comunidade, de modo que viagens, saídas às escondidas, telefonemas, flertes virtuais e mesmo praças e parques públicos, como afirmava no capítulo II, provêm espaços e tempos de privacidade propícios às experimentações existenciais que ajudam meus interlocutores a desenvolverem suas individualidades.

Nesse capítulo, é com as experiências existenciais de Rekha que realizamos nosso aprendizado sobre o segredo como instrumento que serve à busca da privacidade e que pode permitir o desenvolvimento da individualidade nas experiências amorosas. É também de Rekha que podemos sorver a noção do ser amado como aquele que é singular e especial para o amante por deter um mana que o diferencia de todas as demais pessoas, como querem Viveiros de Castro e Benzaquem de Araújo (1977) e explicitarei adiante. Quase que oposta à importância dada pelas garotas ao romance e ao amor como possibilidade de se individuar está a despreocupação - majoritária, mas não unânime - dos garotos quanto ao casamento e ao romance, relegando a outros aspectos de suas vidas a possibilidade de individuação, notadamente na escolha da carreira e na trajetória profissional. Essa diferenciação está intimamente ligada à uma diferenciação na formação da pessoa conforme o gênero e pretende-se que isso fique claro na exposição justaposta dos subitens desse capítulo.

\section{Rekha, “you won't have an inter-caste marriage”}

Como disse nos capítulos anteriores, fui colega de quarto de Rekha por quatro meses em 2013. Começo a contar de nossa convivência pelo dia em que cheguei à PG em 19 de março daquele ano, às cinco da manhã. Naquela madrugada tomei um táxi para chegar à PG no balcão à saída do aeroporto. No caminho, eu prestava atenção às placas que indicavam direções buscando ter certeza de que o motorista estava indo para o lugar certo.

Em minha cabeça ressoavam histórias ouvidas recentemente sobre estupros coletivos de mulheres indianas e estrangeiras em Délhi que eram veiculadas em jornais

remetendo ao amor como expresso por Platão, em "O Banquete". 
brasileiros. Vez ou outra olhava para o retrovisor e via o olhar do motorista, em dado momento notei que este fechava quase completamente os olhos e tornava a abri-los enquanto diminuía a velocidade do veículo. Segundos antes havia refletido sobre como me dirigir a um rapaz desconhecido daquela idade, achei que não seria adequado chamá-lo de sir e lembrei do que Pryia havia me ensinado quando dividíamos o quarto no ano anterior: os indianos chamam-se uns aos outros por termos de parentesco: bhai, palavra que significa "irmão", era o modo como ela chamaria o motorista em questão, dada sua idade; se fosse mais velho, ela o chamaria uncle ou bhai ji, pois a partícula ji acrescentada ao final de um nome próprio, de um termo de parentesco ou mesmo uma resposta como sim (han ji) ou não (nahin ji) indica que se está tratando a pessoa com respeito ou reverência. Quando o vi quase dormindo ao volante, rapidamente disse: “Bhai! -" Ao que ele respondeu: “- Yes, yes! -" mais ou menos sobressaltado. Então continuei: “- Are you almost sleeping? -" “- No, no. -" disse ele. Eu sorri e disse: "- You seem very tired. -". Dessa vez a resposta foi um aumento na velocidade do carro. Em algum tempo percebi que devíamos estar chegando, havíamos passado uma placa que apontava para o campus da JNU, que eu conhecia, e avistara placas indicando Green Park. Em pouco tempo ele dobrou a esquina numa avenida larga e imediatamente reconheci a fachada da PG, pedi-lhe que parasse.

Um porteiro que não conhecera da última vez, com o barulho do carro, acordou de seu sono numa cadeira enrolado num cobertor. De outras vezes, quando meus amigos e eu voltávamos de passeios noturnos, encontrávamos a mesma cena com os outros porteiros. Ele abriu o portão e permitiu que eu entrasse. Eu disse algo como: "Sorry waking you up", na verdade imaginando que ele não entenderia, por não falar inglês. Eu não sabia como dizer isso em hindi, mas me senti compelida a dizer alguma coisa, ainda que imaginando que ele não entenderia. Dentro do edifício perguntei, novamente em inglês: "Could you help me with this? " Apontando a mala e fazendo um gesto pra cima, indicando que queria ajuda para subir com ela até o andar em que ficava o quarto que seria meu pelos próximos quatro meses. Ele disse: "No". Eu disse: "I can pay you". Ele respondeu "no" pela segunda vez. Então disse: “Ok, thank you, sir". Ainda não estou certa de que ele tenha realmente entendido o que eu dizia, mas acredito que tenha. Penso que ele não quis entrar na casa porque mister Kapoor não gosta que os porteiros fiquem dentro do edifício. Subi os três lances de escada arrastando a mala que agora parecia mais pesada que estivera até aquele momento e bati à porta, esperando que Rekha a abrisse às cinco da manhã para sua nova companheira de quarto. Ela o fez e foi assim 
que pela primeira vez cheguei à Índia sentindo estar praticamente em casa. Pedi desculpas à Rekha por acordá-la, ela mal respondeu e voltou a dormir.

Mais tarde nesse primeiro dia Rekha perguntou o que eu fazia em Délhi. Respondi-a dizendo do objeto de minha pesquisa que envolvia os casamentos e os romances pré-conjugais. Quando terminei ela afirmou que entendia bem o tema que eu buscava investigar. Ela sentia, segundo me disse, toda a pressão da família em relação ao casamento, pois seu pai estava procurando um pretendente para casá-la. Rekha dizia, contudo, que não estava certa de estar pronta para esse grande passo. Contou-me que tinha um namorado, mas nunca se sentira confortável para contar à família sobre ele e mantinha o namoro em segredo. Acrescentou que perguntariam, caso soubessem do namoro, se ela, uma vez que estava namorando, pretendia se casar com esse moço, ao que eles iriam se opor, pois a escolha não caberia a ela. Muito provavelmente iriam, ainda, adiantar o casamento arranjado com outro rapaz para por fim ao relacionamento corrente. Ela disse que achava que não estava pronta para se casar e "passar o resto da vida" com uma determinada pessoa, que precisava de mais tempo para primeiro entender ela mesma e depois entender outra pessoa. Faço notar ao leitor que Rekha, assim como Lovania, Shubhi, Anyndia e Patrick, externavam a mesma preocupação com o entendimento de si mesmo e do outro como necessário à harmonia do casal, o que também entendo como um movimento na direção da formação e valorização de uma interioridade mais aguçada e própria de contextos individualistas.

Perguntei se ela achava que os arranjos matrimoniais eram mais fáceis para os rapazes, uma vez que os noivos que conhecera até então (pensei em Hemant que morava na PG em 2012 e em Dileep, jovem indiano que morou no Brasil por quase um ano e voltava à Índia para se casar com uma moça que vira apenas uma vez durante o noivado (rokha) seis meses antes e que viera comigo no voo desde Johannesburg). Esses estavam muito ansiosos para se casar e não apresentavam preocupações sobre como seria a vida após o casamento. Eu nunca encontrara, contudo, uma moça na mesma situação. Ela disse que sim, pensava que para eles era mais fácil, afinal, contava ela, não são eles que têm de mudar tanta coisa em suas vidas para se adaptar ao casamento e à nova família, como fazem as moças.

Era a primeira vez que a via e não queria interrogá-la de modo impertinente, mas aconteceu que eu estava falando sobre minha pesquisa e a conversa foi fluindo 
espontaneamente. Como as demais moradoras da PG, Rekha conversava facilmente sobre assuntos íntimos comigo. Ela disse que transformações estavam ocorrendo no modo de ver o casamento e o namoro, haviam mudanças, mas lentas porque essas estavam acontecendo "aqui" e não no país todo. Como eu perguntasse aqui onde, Rekha falou algo sobre o norte do país ser mais progressista ("progressive") e informou que ela é de Madhya Pradhesh, estado que fica na região geográfica denominada Central India. As mudanças, segundo Rekha, estariam acontecendo nas grandes cidades do norte e não no país todo. Essa informação é controvertida por outras etnografias que mostram como no sul mudanças nos afetos e nos arranjos matrimoniais também estariam em curso, caso das pesquisas de Abraham (2011) em Kerala e de Clark-Descés (2014) e Fuller e Narasimhan (2008) em Tamil Nadu. De todo modo, a fala de Rekha parecia apontar para uma visão, corrente no norte, de que essa região seria mais progressista e desenvolvida, o que não posso afirmar que seja mais que um estereótipo, já que estados como Kerala, no sul, têm os melhores níveis de alfabetização e escolaridade do país e que no norte estados como Haryana e Rajasthan figuram em jornais e relatórios censitários como estados em que "honour killings", casamentos infantis e "female foeticides", isto é, o aborto seletivo de fetos identificados como femininos, aconteceriam em maior número. ${ }^{57}$

Desde o início de nossa convivência, Rekha parecia bastante angustiada com a própria situação, chorara ao telefone mais cedo e voltou a fazê-lo enquanto eu escrevia o diário de campo à tarde. Fui descobrindo no decorrer de nosso convívio que os choros frequentes de Rekha diziam respeito a complicações no relacionamento com Praveen. Lembro de ter perguntado se ela estava triste com a partida do namorado, que iria fazer o mestrado em engrenharia eletrônica na China, e dela dizer que sim, que gostava muito dele, mesmo achando que ainda não estava pronta para o casamento. Foi quando ela disse que precisava de tempo para se entender primeiro e depois entender outra pessoa, com a qual passaria "a vida toda". Referiu-se à situação de seu namoro, com o rapaz indo embora e o fato de ter de esconder o relacionamento do pai, como "a really tough situation". Depois disso houve um silêncio, ela passou a mexer em seu computador e eu me lembrei de continuar a escrever meu diário. Apaguei as luzes e permaneci

\footnotetext{
${ }^{57}$ A legislação indiana permite o aborto, mas proíbe, contudo, o chamado teste de sexagem, alegadamente, na tentativa de coibir o aborto de fetos do sexo feminino. Desnecessário dizer que o teste é feito por médicos e clínicas particulares que desobedecem a lei mediante pagamento.
} 
escrevendo quando ela demonstrou sua intenção de dormir, mas seu celular tocou e ela ficou falando baixinho ao aparelho, chorou novamente e em seguida dormiu.

No segundo dia daquela estada, acordei de repente, meio atordoada pelo jet lag, com Rekha já desperta e sentada em sua cama. Senti o cheiro agradável de sabonete e shampoo, ela acabara de tomar banho. Ouvi o barulho de uma sineta de bicicleta e sorri mentalmente. Fui ao banheiro e notei que havia inundado outra vez. Rekha me contou mais sobre sua vida e quis saber sobre mim também. Começou com uma pergunta sobre meu casamento:

- Did you have a love marriage?

Disse que sim, que no Brasil os casamentos raramente eram arranjados, quase sempre eram "por amor". E continuei falando que, embora os chamássemos assim, os casamentos no Brasil não eram desprovidos de uma certa "lógica", pois no fundo as pessoas iriam escolher seus parceiros por achar que têm características e gostos em comum, poderiam ser pessoas do trabalho, da universidade, da vizinhança e dificilmente alguém se casava com uma pessoa totalmente diferente de si em questões como classe social, status e até cor da pele. Disse concluindo:

- We also look for a suitable match, we don't marry any one just out of the blue.

E então ela disse que entendia isso, mas que na Índia 90\% dos casamentos eram arranjados e isso significava que os pais escolhiam os cônjuges para os filhos e filhas e tal se devia ao fato de os mais velhos acharem que são os "chefes" dos mais novos e quererem impor suas vontades. ${ }^{58}$ Poucas famílias, que ela chamou de "liberal families", iriam aceitar o fato de a moça escolher o noivo, mesmo se esse fosse um bom partido ("a good match"). Eu perguntei o que haveria de errado, se seria justamente o fato de a moça ter escolhido. E ela disse:

- Yes, that's it, they are like bosses and if they think that one thing is good for you they will impose that on you. Some liberal families will accept the guy she chose, but $90 \%$ will not.

\footnotetext{
${ }^{58}$ Corroboram a estatística de Rekha, de que cerca de $90 \%$ dos casamentos indianos são arranjados, as pesquisas de Uberoi (2006) e Netting (2010).
} 
Contou em seguida de uma amiga que conheceu um rapaz de outro estado, ambos teriam se apaixonado e se casado, mas não sem dificuldades. Usou nosso amigo Kaushik para me fazer entender a complicação de um casamento intercomunidade:

- It's like if me and Kaushik decide to get married.

- What you mean?

- Kaushik is from Kerala, I am from Madhya Pradesh, lots of things are different between us, like language, community, rituals, traditions, food, everything is different.

E tudo isso era levado em conta para os arranjos, como eu já sabia. Os pais da garota logo se opuseram, mas acabaram concordando porque, dizia Rekha, "- the guy was intelligent, smart, very educated, and also earn really well". Segundo ela, mais famílias estariam aceitando a escolha dos filhos, e ela usava as palavras "modernization" e "globalization" para ressaltar as influências nas mentes das pessoas para essas mudanças. 59

Falou de um namorado anterior ao atual de quem ela teria gostado muito, até conhecer Praveen. Em seguida corrigiu-se dizendo que, na verdade, já o conhecia da escola, mas eram apenas colegas naquela época, depois se encontraram algumas vezes em Indore, cidade de onde ambos provêm, e começaram a namorar, quando ele já morava em Mumbai. À noite, Rekha e eu falávamos sobre signos e horóscopo quando ela mencionou que pessoas do signo de Peixes eram muito atraentes para o sexo oposto. Amélie, ela citava o exemplo, "even being fat she attract guys, she is always falling for someone and the guys fall for her too". Disse ter outra grande amiga do mesmo signo e comentou: "she is very dark skinned, but people get attracted towards her". Por último ela comentou sobre seu namorado, também nascido sob o signo de Peixes, por quem ela

\footnotetext{
${ }^{59}$ Termos como "modernization", "globalization”, "liberal”, “developed” são acionados por muitos de meus interlocutores como rótulos valorativos. Esses termos não são utilizados por mim para explicar processos sociais ou circunstâncias de mudança, isto é, não os aciono como categorias explicativas para o que quer que seja nesse trabalho. Seu uso aqui é próximo daquele que Deshpande afirmou em seu trabalho ao tratar "modernidade" e "tradição": "On the one hand, what is modern for one generation will perforce become part of tradition for the next; on the other hand, the product that is passed on cannot possibly exclude the modern. Analytically, it seems futile to think of 'tradition' and 'modernity' as though they were the names of distinct pre-existing objects or fields of some kind; it is more fruitful to think of them as value-laden labels which people wish to attach to particular portions of what they inherit or bequeath. Descriptively, no purpose is served by this contrast after the thorough diffusion and domestication of modernity across every conceivable area of tradition." (Deshpande, 2003: 86)
} 
própria se sentia muito atraída. Sobre ele, no entanto, Rekha não enumerou nenhuma característica "não atraente" a despeito da qual ela gostaria do rapaz.

A maioria das pessoas com quem convivi não viam problema algum em dizer com todas as letras que pessoas "fat" e "dark skinned" seriam menos desejáveis e mesmo em fazer uso desses termos. Havia exceções. Pryia, por exemplo, ao me entregar o caderno de classificados matrimoniais num domingo em que fomos tomar café em Green Park Market em 2013, disse:

- See this and then you can tell me what is wrong with marriages in India.

Quando eu disse que a antropologia não olhava os fenômenos com uma carga julgadora e que eu não pensava que os casamentos arranjados eram de algum modo piores ou melhores que outros modos de se fazer casamentos ela disse:

- But all this search for fair skinned people, this is disgusting. It's insane.

Também não ouvia Anirudh e Anindya falarem de modo derrogatório sobre quem quer que fosse por supostos atributos físicos. Quanto aos outros, incluindo o senhor Kapoor, não evitavam usar termos como "dark", "fat" e "uneducated" para se referir a alguém de modo desdenhoso. 0 mesmo se dando com as palavras "fair", "educated", "slim", "skinny", "earn well", para estabelecer critérios positivos sobre as pessoas.

Nos dias que se seguiram eu ouvia Rekha discutindo frequentemente com Praveen ao telefone. No dia 11 de abril anotei que ela chorava pela manhã logo após uma ligação dele. Perguntei se haviam discutido ao telefone. Ela respondeu afirmativamente e acrescentou: "I am just too much stressed". Rekha trabalhava muito. Disse que naquele dia não queria ir ao trabalho, mas precisava terminar algumas coisas antes de viajar, naquela mesma noite, para a casa do pai. Foi-se visivelmente aborrecida pelo trabalho e penso que também pelo namorado. Não quis tomar o café da manhã, pois estava em jejum.

$\mathrm{Na}$ hora do almoço desci para a sala de jantar e a senhora Kapoor se encontrava no aposento, notei que ela tomava apenas um copo de coalhada e que não havia vestígio 
de seu almoço à mesa, apenas um prato, presumivelmente de mister Kapoor, estava posto. Quando eu disse: “- Let's have lunch ma'am?-" Ela respondeu que estava jejuando e, por isso, só devia tomar líquidos, o copo de coalhada havia sido seu almoço. Me explicou que o jejum dizia respeito ao festival Navaratri, em que as mulheres jejuam por nove dias e oferece-se poojas em honra das nove formas da deusa Durga por nove noites, donde o nome do festival (nava: nove; ratri: noite). Fiquei, desse modo, sabendo o motivo do jejum de Rekha. ${ }^{60}$ À tarde ela veio pra casa mais cedo arrumar as malas, parecia exausta e cochilou antes de enfrentar a tarefa que tinha vindo cumprir.

Ainda em meados de abril de 2013 vim a conhecer Praveen, o namorado de Rekha, quando esteve em Délhi para visitá-la. Numa tarde, após chegar da aula de hindi, recebi uma mensagem de texto dizendo que ela estava vindo para casa e convidando-me a ir jantar fora, se juntariam a nós Amélie, Praveen e dois amigos dele. Fomos à Hauz Khas Village. Após o jantar emendamos para o Rastha, um bar de reggae, e foi onde conversamos mais.

Um dos amigos de Praveen me perguntou o que eu fazia na Índia e falei da pesquisa que estava empreendendo. Praveen passou a falar de como era difícil namorar na Índia, que os casais não tinham espaço para privacidade e que mesmo os jovens que estavam em vias de se casar raramente tinham a chance de se conhecer ou ter intimidade antes do casamento. Até pouco tempo, segundo ele, não haveria sequer o conceito de divórcio, esse estaria começando a ser reconhecido nas cidades indianas, mas a visão predominante ainda era de que casamentos são pra sempre. Lembrei-me de que a própria Rekha falava que não estava certa de se casar agora, pois a pessoa escolhida seria para a vida toda. Falou da não aceitação do divórcio para caracterizar o

\footnotetext{
${ }^{60}$ Lembrei-me naquele instante de que em 2012, no dia em que almoçamos fora para minha despedida, Shine estava jejuando e não comeu, apenas tomou sucos. Em outros momentos, em 2013 e 2014, voltei a ver Rekha, Lovania, Shine e Mrs. Kapoor jejuando no festival Shivaratri (noite de Shiva) e nos dias de Navaratri. Eram sempre as mulheres que jejuavam nesses dias. No caso de Mrs. Kapoor, como era casada, havia ainda o Karvachauti, dia do ano em que as esposas jejuam e oferecem pooja pela saúde, segurança e vida longa dos maridos. Quanto aos rapazes não guardavam jejum nesses dias, mas alguns iam ao templo. Mister Kapoor, no entanto, sequer pode me explicar, enquanto almoçávamos na sala de jantar no dia seguinte, do que se tratava o termo que eu via no jornal em cima da mesa: kanyapooja. Ele se limitou a dizer: "_You have to ask Shweta, she can explain you everything about Navaratri." Em alguns minutos Mrs. Kapoor chegou e fiz o que mister Kapoor me aconselhara. Ela explicou que kanyapooja era um ritual em que nove moças virgens (kanya) homenageavam Navadurga (as nove formas de Durga). 0 senhor Kapoor, nesse momento, não perdeu a ocasião de fazer uma de suas piadas: “_Yes, but nowadays it is very difficult to find nine virgin girls so they pick nine little kids instead. That's the only way to ensure that they are virgins." E riu-se enquanto Mrs. Kapoor fez uma expressão facial de desaprovação pela brincadeira.
} 
que chamou de "a backward mindset", que seria comum na Índia em relação aos casamentos e ao romance.

0 amigo que havia iniciado a conversa então disse que estava inscrito em alguns sites de matrimônio. Perguntei a ele:

- Oh, really? Can you tell me about your experience?

- Nowadays couples that have profiles in these websites they want to meet twice or thrice first and test the compatibility between the couple. So you can have one or two dates with a girl and then say: I think you should keep looking, I am not the guy you are looking for.

Todos na mesa, inclusive o narrador, riram muito e, em seguida, Praveen fez uma observação se dirigindo a mim:

- Don't get the wrong idea, Fab, lots of people are serious about it, this guy is just a moron.

- No, I'm not! I'm telling her the truth. And I have friends who also do this respondeu o rapaz em questão. Eu emendei:

- In fact I have heard about it before. Some of my colleagues from DU [Delhi University] told me that some guys do that. They use this websites just to meet girls disse isso me lembrando de que até mesmo a professora Janaki Abraham havia comentado que rapazes faziam esse uso dos matrimonial sites. Talvez garotas o fizessem também, mas na convivência com as amigas da PG e com as colegas da DU não encontro evidências para afirmá-lo.

Naquela noite pude ver que Praveen exibia um comportamento que é considerado, naquela paisagem moral, atencioso ou carinhoso. Puxou a cadeira para que ela se sentasse no restaurante e no bar, a abraçava, mexia em seu cabelo. Eu já percebera que os rapazes indianos com quem convivia tinham um modo de agir que consideravam como próprio no comportamento para com as garotas: puxar cadeiras, abrir portas, pagar a conta, acompanhar até o Aurobindo Market à noite. Nem todos faziam todas 
essas coisas, mas se o faziam as garotas não rechaçavam essas atitudes, davam-nas por comuns ou desejáveis. Logo que cheguei em 2012, em um almoço com Patrick, Dileep e Shine no Karim's, famoso restaurante de comida moghul que tem uma unidade um quarteirão adiante do Aurobindo Market, tentei pagar minha parte da conta e fui impedida pelos rapazes. Eles disseram que eu os embaraçava com aquele gesto, que era vergonhoso para eles deixar-me pagar a conta. Em casa, entreguei a quantia que havia calculado como minha parte à Patrick, longe dos olhares públicos ele aceitou dividir a conta. Quase todas as meninas, contudo, como Shine naquele mesmo momento, não se incomodavam nem um pouco com o fato de os rapazes pagarem a conta. No mais das vezes, as meninas achavam galante e educado que os rapazes executassem gestos que, para mim e para Pryia, eram old fashion e machistas. Dessas condutas a única que aceitávamos eram as "escoltas" à noite.

Quanto à Praveen e Rekha, nada entre os dois naquela noite fez lembrar as brigas constantes ao telefone, comportavam-se de modo harmônico e alegre. Quando voltamos para nosso quarto, Rekha comentou que havia falado ao pai, na última visita à Indore, que estava gostando de Praveen. A família dela o conhecia, pois foram colegas de escola por muito tempo. Segundo ela o pai teria dito: “- No, don't do this, you will not have an inter-caste marriage". Perguntei se o pai ficara chateado com ela pela revelação de que gostava de Praveen de modo romântico, disse que não, mas somente porque ela não contou do namoro, só insinuou que gostava do rapaz e perguntou o que pai achava disso. Se ela contasse sobre o namoro, "then he would be pretty mad at me and would want to marry me with another guy right now".

Perguntei se ela e Praveen eram de castas com níveis diferentes de status, ela disse que não, mas que a família esperava casá-la de modo tradicional, na mesma casta, e que seriam altamente contra um casamento intercasta. No ano seguinte contudo, Rekha mudou um pouco essa versão, disse que seu pai era "a business man" e que Praveen era de uma família de "school teachers", querendo, dessa feita, dizer que o namorado era de família de status inferior. Além disso, comentou que seu pai se opunha à ideia de um suposto casamento com Praveen porque ele provinha de uma casta com fama de exigir altos dotes das famílias das noivas como requisito para o casamento, algo que o pai de Rekha considerava um absurdo, ele não estava disposto a casar a filha numa casta inferior, quando o contrário era o esperado - seguindo a tendência à hipergamia as famílias esperam casar as filhas numa família de status ou prestígio ligeiramente 
superior. Assim, pagar um dote caro por um casamento que não acrescentaria em status ou prestígio à família dela era algo fora de questão para o pai.

Ao fazer essa afirmação Rekha deixava de negar a prática corrente do pagamento do dote à família do noivo, como fizeram algumas outras pessoas durante o trabalho de campo, provavelmente tendo em mente certa visão pública dessa prática como espúria e ilegal. Apesar da negação discursiva do dote, isso não impede que ele aconteça por meio de presentes substancialmente caros que vão desde TVs, aparelhos de ar-condicionado e outros acessórios para casa, além de motocicletas, scooters, carros e ouro até terrenos e casas.

Rekha vivia chateada e apreensiva com o fato de que Praveen estava indo para a China em poucos meses. As brigas e os choros ao telefone tinham como tema a ida dele e a sensação de Rekha de que ela se dedicava bem mais à relação que o rapaz. Numa das vezes em que conversávamos em nosso quarto disse chorando que por mais que se esforçasse ela nunca conseguia o que queria, fosse no trabalho ou no namoro. Rekha perseguia uma promoção que havia sido prometida a ela havia meses e outro colega fora promovido em seu lugar naqueles dias. Ao mesmo tempo Praveen parecia cada vez mais excitado com a ida para a China e, ao deixar transparecer sua empolgação, fazia-a sofrer, pois Rekha pensava que ele não sentiria falta dela.

Nos dias em que Praveen estava na cidade, no entanto, Rekha estava feliz. De Délhi eles seguiriam juntos para Rishikesh e Haridwar, cidades mais ao norte da capital, próximas às montanhas e por onde o rio Ganges passa ainda limpo antes de chegar a outras cidades como Varanasi. O cenário, segundo Rekha, era perfeito para o romance e momentos de intimidade com o namorado, pelo que ela ansiava. Aproveito para registrar o uso da palavra romance em inglês de um modo diferente daquele encerrado em outros contextos anglófonos, a frase exata de Rekha foi "a perfect place to do romance", denotando o romance como algo que se faz. ${ }^{61}$

Para o pai e para os demais moradores da PG, contudo, Rekha estaria viajando a trabalho. Patrick, vez ou outra, também acabava por saber que eles estavam viajando

\footnotetext{
${ }^{61}$ Outro uso do inglês que chamou minha atenção foi o da palavra "sexy" quando proferida por Lovania e por Shubhi. Em diferentes momentos, ambas se referiram ao tempo chuvoso como "a sexy weather", em vez de "a romantic weather" como apregoa o uso corrente na língua inglesa. A insistência com que meus interlocutores usavam as palavras sexy e hot era reiterada em relação a pessoas, roupas e lingeries.
} 
juntos, como na vez em que ela supostamente estava com a chefe do trabalho em Mumbai e voltou de lá com uma marca roxa de um beijo no pescoço ("a love bite"), a qual denunciava que Rekha estivera com Praveen e o que ela escondia com uma echarpe. Como o uso de echarpes é corrente mesmo em altas temperaturas, esconder uma "love bite" não era difícil e sabe-se lá quantas outras garotas poderiam ocultá-las desse modo.

Mais para o fim do mês de maio de 2013, estávamos em nosso aposento quando Rekha começou a discutir com Praveen ao telefone. Ela foi para o balcão, fechou a porta de vidro detrás de si tentando isolar o som e começou a gritar com ele em hindi, num tom muito ríspido. Voltou para dentro do quarto em alguns minutos pisando forte e fechando com força as portas do balcão. Entrou no banheiro. Em alguns instantes saiu do banheiro e deixou o quarto, logo voltou, agitada e nervosa. Resolvi não falar nada inicialmente e continuei digitando no computador. Sentou-se em sua cama com um livreto na mão e me perguntou: "Can I chant for a moment?" Disse que sim e ela começou a entoar sons que para meus ouvidos pareciam mantras, de um tipo diferente dos hindus. Permaneceu assim por uns quinze ou vinte minutos.

Algum tempo depois ela puxou conversa e me contou que Praveen dissera que era melhor que ela não ficasse esperando por ele nesses dois anos em que estaria na China. Ela disse que Praveen falava isso por conta das brigas que tiveram na última passagem dele por Délhi, ocasião em que voltava do Himalaia, onde esteve fazendo trecking por quase dez dias. Viram-se no aeroporto onde ele permaneceria por algumas horas esperando a conexão até Mumbai. Quis mostrar as fotos da viagem para Rekha que acabou por ver que havia fotos dele com uma garota, posando próximos um ao outro sem mais ninguém na foto, apenas os dois. Ela fez um escândalo, brigou com Praveen e deletou as fotos dela própria e dos dois juntos do celular do rapaz dizendo que se ele tinha fotos de outra garota no celular ela não queria que ele tivesse as fotos dela mesma. Apagou fotos que, segundo ela, eram muito importantes pra ele, de momentos preciosos dos dois juntos. Esse gesto teria rendido uma briga enorme na sexta-feira anterior, dia em que ele seguiu viagem de volta à sua cidade, e nós duas, juntamente com Patrick, fomos ao Zo Cafe em Hauz Khas Village, onde ela tomou três ou quatro doses de vodca com suco de laranja e ficou dizendo que havia se arrependido de brigar com Praveen daquela forma e de provocá-lo deletando as imagens. Daí em diante 
ambos estariam brigando muito, segundo ela. Pensei comigo que desde que me mudara para aquele quarto eles sempre haviam brigado bastante.

Durante a discussão no balcão Praveen teria dito à Rekha que como surgiram problemas de confiança da parte dela e visto que estava indo para longe era melhor que ela não esperasse por ele. Praveen teria dito ainda que não teria tempo para ela quando fosse para a China, que não poderia colocá-la dentro de sua vida nesse período, pois estaria muito ocupado e que, pensando nela, preferia que ela não o esperasse porque não queria magoá-la. Rekha pediu que ele não colocasse a questão dessa forma, como dependendo dela, ou como sendo provocada por ela. Contou-me, ainda, que havia afirmado a ele que, se dependesse dela, o esperaria sempre, pois o amava muito.

A explosão de raiva, segundo Rekha, começou exatamente quando ele disse que ela não deveria esperar por ele. Ela gritava e esmurrava a parede do lado de fora do quarto, na sacada. Ficou bem mais calma após cantar as orações de um livreto budista, conforme me explicou. Disse que vez ou outra tinha esses acessos de raiva, se descontrolava e depois se arrependia, como fez no dia em que deletou as fotos do celular do rapaz: ficou pedindo desculpas a Praveen pelo WhatsApp e se remoendo em culpa para mim e Patrick no restaurante. Naquela ocasião ela nos contou que era virgem, que dormia com Praveen quando viajavam, mas sem fazer nada. Depois retificou e disse que o fato de ser virgem não queria dizer que nunca tinham feito nada. Patrick ficou dizendo o tempo todo que não acreditava nela, que ela estava mentindo. A assunção geral quando garotas permitiam alguma intimidade com rapazes era de que atividades sexuais estariam acontecendo entre o par, foi assim no caso de Shine com Dileep e no caso de Rekha, Patrick também considerava que ela mentia ao afirmar ser virgem. Patrick desacreditava, ainda, que Praveen fosse virgem, como Rekha dizia.

Dias antes, quando voltava de outra viagem com Praveen, dessa vez a Dehradun, outra cidade nas montanhas, Rekha comentara que suas outras amigas diziam que ela era louca ("they say I'm crazy") por viajar com o namorado sozinha e dormir com ele. Naquela ocasião disse que suas amigas eram muito conservadoras ("conservative"), ao contrário dela, que não via problemas em ter intimidade com o namorado.

$\mathrm{Na}$ noite seguinte à briga no balcão conversamos longamente sobre ela e Praveen outra vez. Ela dizia que ele parecia estar querendo terminar com ela, primeiro com a 
história de que ela não deveria esperar por ele, depois de que eles brigavam muito e que ela o teria magoado no caso das fotos deletadas. Rekha chegou a dizer que se arrependia de ter iniciado um relacionamento com ele, pois agora iria perder seu melhor amigo. Disse que ia ser muito ruim se eles terminassem porque seria o segundo namoro dela que não terminava bem. No primeiro, o rapaz a havia traído e ela justificava assim sua desconfiança com Praveen, pois teria tido a confiança atraiçoada pelo primeiro namorado, a quem ela diz ter esquecido da noite para o dia, sem nunca mais ter lhe falado após descobrir a traição. Então emendou:

- If I decide not to talk to Praveen, you can trust me Fab, I will never talk to him again. This is how I am. The moment I decided to forget my former boyfriend, I never spoke to him again.

Em seguida disse:

- But right now I love Praveen desperately, I'm so crazy about him, I love him more than anything.

Naquela noite me contou ainda que as tias que estavam na casa do pai e a quem ela veria no fim de semana seguinte em Madhya Pradesh ficavam falando em casamento o tempo todo.

- They say that I am in the right age for marriage now. That they wanna see me married, wearing sarees and blah, blah, blah...

Ao que parece as pessoas estavam sempre martelando a corrida contra o tempo que as garotas deveriam ter em mente. Rekha contou que vira a mãe morrer e que a sensação que tinha toda vez que intuía que ia perder alguém era a mesma que teve ao ver sua mãe falecer diante dela. Disse que foi uma sensação aterradora, e que a sentia até hoje. A profusão de sentimentos que ela demonstrava ao falar de Praveen era muito grande. Parecia que o conflito entre eles trazia à tona muitas questões, do presente e do passado. A frustração no trabalho, a oposição do pai ao namoro, a pressão das tias para vê-la casada, a morte da mãe, tudo isso vinha junto nessas conversas. 
Parecendo querer contrapor a personalidade dela mesma, que se dizia muito emocional, e a do namorado, afirmou em seguida que Praveen era muito racional, que se ele colocasse na cabeça que era melhor ir pra China e se concentrar apenas nos estudos ele não iria sequer sentir a falta dela. Também comentou que ele nunca se abria, não falava de seus sentimentos, o que a fazia sentir que o amava mais do que ele a ela. Quando conversavam sobre como seria se terminassem o namoro ele afirmava que iria esquecê-la em um mês e seguiria a vida. Ela disse então que temia que isso estivesse acontecendo naquele momento.

Contou que se ajoelhara diante dele no dia em que deletou as fotos no aeroporto e pedira mais uma chance, e que ele não se comovera com o gesto e teria ficado falando de como ela achava que tinha sempre razão, que ela se descontrolava quando brigavam e fazia coisas das quais depois se arrependia. Eu disse, após ouvir tudo, que achava que ela não devia ficar se mortificando, que se eles porventura terminassem não teria sido por culpa dela, ainda que ele quisesse fazê-la pensar que sim. Ela me disse:

- You know what Fab? Amélie and Elena always tell me the same thing. And I think you girls are right.

Quando ela disse isso, tive um estalo de que essa era a visão de três moças não indianas sobre como Praveen se portava no namoro. Tal visão não era corroborada pelas outras amigas de Rekha, tampouco por Shubhi ou Lovania. Quando, em 2014, conversávamos as quatro juntas, Shubhi sempre dizia que Rekha era muito "emotional", que não devia ficar se descontrolando, brigando com Praveen e demandando atenção, mas, ao contrário, "should give him some space". Essa era a resposta de Shubhi quando Rekha dizia que Praveen não devolvia na mesma medida todo o amor e atenção que ela dedicava a ele. Numa dessas ocasiões, disse que eu me achava mais parecida com Rekha nesse aspecto e Shubhi falou:

- Guys will be guys, you can't control them.

Quando Shubhi dizia essa frase ela dava a entender que os homens são como são e não há como mudá-los. Subjaz a essa ideia a concepção de que a moça deve ser a parte que cede, que se esforça para o relacionamento dar certo mais do que o rapaz o fará. Lovania, por seu turno, era mais uma a dizer que Rekha era louca de viajar sozinha com 
Praveen, de confiar nele a esse ponto, afinal ele podia terminar o namoro a qualquer momento e então, como ela ficaria? Rekha reiterava, quando saíamos do quarto das garotas ou quando elas saíam do meu quarto, que ambas eram "conservative" e "judgmental", sobretudo Lovania, e que por isso evitava contar sobre sua vida às duas.

No final da semana seguinte Rekha foi para Indore, voltou numa terça-feira bem cedo. À noite jantamos juntas no quarto, com Patrick à nossa porta. Quando ele se foi conversamos. Ela contou que Praveen e ela estavam bem novamente e haviam se encontrado todos os dias enquanto ela esteve na casa do pai. Além disso, haviam chegado à conclusão de que iriam tentar continuar o relacionamento enquanto ele estivesse na China. Rekha nunca tivera dúvidas de que era isso que queria, e afirmava:

- I don't feel that I could replace Praveen in my life, I can't even think about that.

Ela agora dizia que queria se casar com ele quando voltasse da China, que ele era a pessoa de sua vida e reiteradamente dizia:

- He has been my life for such a long time, I can't even think that another person could replace him in my life.

Essas afirmações me levavam sempre a pensar na individuação que o amor propunha a meus interlocutores. Como afirmam Viveiros de Castro e Benzaquem de Araújo (1977), a propósito da análise da obra "Romeu e Julieta", de Shakespeare, como mito de origem do amor romântico e do individualismo no ocidente moderno, o que passa a ser importante nos contextos individualistas é a dimensão interna do indivíduo, que o torna singular, "articulando o homem [e a mulher, eu diria] diretamente a uma ordem cósmico-natural, dispensando a mediação da sociedade" (Viveiros de Castro e Benzaquem de Araújo, 1977: 142). Quando Rekha dizia que Praveen era sua vida e que ela não vislumbrava a possibilidade de outra pessoa substituí-lo nesse lugar de importância, ela se emancipava, ao menos temporária e intimamente, da vontade do pai e das tias e os excluía do que realmente importava em sua vida, ficando muito próxima da concepção de mundo em que o indivíduo "existe por assim dizer de dentro pra fora (possuindo um "núcleo" o inner-self), ao contrário de outras formas de pensar a relação entre o ser humano e a sociedade, nas quais um processo de penetração dos homens pela sociedade os define como "homens", isto é, membros de um grupo" (Idem: 143). 
Parece-me apropriado pensar no amor que Rekha sentia por Praveen do modo como o fizeram Viveiros de Castro e Benzaquem de Araújo ao associar a noção de mana ao amor romântico. Para os autores o corpo pode ser visto como sede de um mana que serve como elemento de distinção marcando a diferença entre indivíduos e que se liga à personalidade. Ambos afirmam que essa associação permite recuperar a dimensão corporal "infra-sociológica" como material também submetido à esfera das representações e que teria sido negligenciado por Dumont (Viveiros de Castro e Benzaquem de Araújo, 1977: 165). Todos os amigos apaixonados contavam das características singulares de seus enamorados e exibiam o anseio de se fazerem especiais para aquela pessoa, o que se traduzia na escolha de presentes que fossem especiais e que caíssem como uma luva para o presenteado, demonstrando conhecimento do gosto ou da "personalidade" da pessoa; na busca de conhecer lugares ou ter experiências marcantes com o par romântico que permitissem uma inscrição definitiva na memória afetiva do ser amado; pelo uso de codinomes como Shubhi fazia ao ser a única a chamar Patrick por seu segundo nome etc. A meu ver buscavam sempre uma singularização de suas relações com seus eleitos, uma singularidade que implica separação, donde a relação do mana com o amor romântico, e que me fazia entrever movimentos, ainda que titubeantes, na direção de uma tentativa de individuação. ${ }^{6}$

O amor que Rekha expressava por Praveen, bem como o que Shubhi expressava por Patrick antes que esse rechaçasse o casamento, seria visto como do tipo que une indivíduos e não famílias, exatamente como o amor de Romeu e Julieta o fez (Idem: 147). A noção de amor romântico presente no ocidente moderno, e do qual os relacionamentos que eu via em campo tanto se aproximavam ou com o qual se confundiam, remete à ideia de um indivíduo livre de laços sociais que se relacionaria diretamente com um cosmos composto de indivíduos e no qual as relações sociais valorizadas seriam as interindividuais; um amor visto como "despido de qualquer referência ao mundo social, e mesmo contra este mundo". 0 que tornava tais namoros especialmente trágicos era o fato mesmo de que eram contra o mundo social, pois a “concepção de mundo onde o indivíduo é a categoria central” (Idem: 131) não parecia coadunar com a visão dos pais de meus amigos sobre a vida e sobre seus filhos.

\footnotetext{
${ }^{62}$ Nas palavras dos autores: "Essa singularidade implica separação. A 'personalidade' parece ser o lugar do mana em nossa sociedade. 0 mana, se seguirmos Mauss, é uma noção que marca a diferença geral entre categorias, sendo assim o símbolo de uma 'estruturalidade', do princípio de organização do mundo (Mauss [1903] 1950, p. 114). Muito a propósito, o mana ocidental marca a diferença entre os indivíduos." (Idem: idem, nota 80)
} 
Os relatos de como o amor de Rekha e Praveen era "contra o mundo" abundavam. Contou-me que as tias maternas que estiveram visitando seu pai, e razão manifesta de sua viagem, teriam ficado dizendo o quanto queriam vê-la casada e que ela devia fazer isso logo, pois estava na idade certa para encontrar "a suitable boy". Rekha afirmou que desconfiava que o pai havia chamado as tias maternas para inculcarem essas ideias na cabeça dela, já que a mãe não estava mais lá para fazer isso. Ela disse que nos dias em que estava em Indore com as irmãs da mãe, pedira a Praveen que desse a ela mais uma chance, e que ele estaria ainda chateado com ela por conta das fotos deletadas:

- He is not attached to photos but those ones were special to him. He was really upset, but I told him that even I was feeling guilty. I told him: you only need to give me one more chance.

Isso fazia Rekha sentir que era importante para ele, pois via como um gesto de amor ele querer guardar as fotos de ambos em momentos especiais. Depois comentou que sabia que seria difícil levar adiante o namoro, pois mesmo estando em um relacionamento à distância pelos dois últimos anos geralmente se viam com regularidade, fosse em Délhi quando ele a visitava, em Indore quando ambos iam pra casa dos pais, quando ela ia à Mumbai ou em viagens curtas como as de Haridwar, Rishikesh e Dehradun.

- Every two, three months we use to go for fantastic trips. I'm gonna miss this so much!

Rekha já me havia mostrado algumas fotos dessas viagens em que, segundo ela, os dois podiam agir como um casal: ficar juntos sem se esconder e ter intimidade. Os locais das viagens costumavam ser cidades que têm ambientes naturais como cachoeiras, trilhas, rios, e são destinos de jovens recém-casados. Para o pai, Rekha ia a outras cidades a trabalho, não imaginava, nem de longe, a filha em cenários de lua-demel com o namorado. Era o segredo criando tempo e espaço para que ambos interagissem como indivíduos enamorados.

Alguns dias depois, Rekha e eu conversávamos e foi quando ela disse que havia falado ao pai sobre Praveen novamente. $\mathrm{O}$ assunto começou porque o pai teria dito: "You should get married soon". Ela se viu compelida a falar que Praveen e ela se gostavam, ao 
que ele teria replicado: "No, this is not possible, such marriage is not allowed." O pai se referia ao fato de ser uma união intercasta e insistia que ela devia se casar no interior de sua própria casta. Rekha disse ainda ao pai que Praveen estava indo fazer o mestrado fora do país e que dentro de dois anos ele voltaria e ela pretendia esperá-lo. 0 pai se mostrou novamente contrário afirmando que ela não podia esperar tanto tempo para se casar, suas chances nunca mais seriam tão boas quanto agora "for a good match".

Reiteradamente minhas amigas e eu éramos postas frente ao discurso do tempo certo para se casar. Rekha, talvez por ser mais nova que Lovania e Shubhi, ainda não se convencia de que precisava se casar naquele momento. Rekha dizia que em primeiro lugar estava sua carreira:

- I'm intending to get a promotion, in first place it's my career, I keep saying this to my father. I can wait for Praveen and in this time take care of my career.

Além de realmente se importar com o trabalho, Rekha também procurava ganhar tempo adiando o momento do casamento. Eu percebia a estratégia que ela estava desenhando de tentar persuadir o pai, nos anos que Praveen estivesse fora, a consentir no casamento de ambos. Pensei naquele momento que, como os dois eram hindus, o caso deles talvez fosse mais fácil que o de outros casais, como Shubhi e Patrick, por exemplo, em que o pertencimento a comunidades religiosas diferentes complicava bem mais a situação. Isso dependeria, no entanto, dos planos do pai de Rekha. Se ele realmente decidisse que iria casar Rekha de modo a compensar a desvantagem de status que os doadores de esposas (wife givers) têm em relação aos tomadores (wife takers), isto é, num arranjo hipergâmico que contrabalançasse o sentido único dos bens e riquezas que seguem com os presentes e os dotes da família da noiva para a do noivo, seria muito difícil que conseguisse convencer o pai e o restante da família. 6364

Lembro de refletir que a agência dos casais, bem como o êxito ou fracasso das tentativas dos jovens em se casar "por amor", dependia também das categorias em que

\footnotetext{
${ }^{63}$ Ouvi casos, como os do professor de hindi Rajendra Ji e de um colega da Delhi University, em que as irmãs haviam decidido se casar "por amor" e se esforçaram para ganhar o apoio e a simpatia dos irmãos mais velhos para sua causa, o que fora decisivo na aceitação dos pais do casamento escolhido pelas filhas. Dentre as estratégias das moças para casar-se "por amor" com a aceitação dos pais, conseguir aliados simpáticos à sua escolha na geração mais jovem é uma delas.

${ }^{64}$ "The characteristic feature of affinity in north Indian kinship is the inequality of status between the inferior bride-givers and superior bride-takers which is expressed both in ritual and etiquette and in the asymmetrical flow of gifts from the bride's to the groom's family." (Uberoi, 2006: 158)
} 
se inseriam. Por exemplo, se seus parceiros por escolha são ou não da mesma casta, da mesma religião, de mesma situação financeira etc. Se Patrick e Shubhi não se casassem e Rekha e Praveen se casassem, não se poderia afirmar que isso dependeu exclusivamente da agência dos dois casais, mas também de uma conjuntura que desde o princípio deixava mais próximos Praveen e Rekha do que Patrick e Shubhi. Penso que o modo como Mody lidou com o tema da agência nos casos de tentativa frustrada de se casar por amor se coadune com o que intuí naquele momento do campo.

"Failed love-marriages highlight the actual dialectic of mediation in love-marriages. The negotiations of love-marriage couples are driven by the needs and exigencies of their social relationships; therefore, it is only correct that they should be examined in that light. Rather than providing solutions to the 'problems' of agency, Strathern points out that academic work provides a suitable range of issues that encapsulate a particular problematic with regards to 'agency'. As Strathern describes it, we need to explore the ways in which love-marriage couples make known to themselves their ability to act, but equally, we need also examine the ways in which others make known to them the limits of their actions and the fact that they will be brought to account. Thus, agency 'as effective action' is tempered with 'accountable action', and this makes explicit the ways in which love-marriage couples are constrained; both in the manner in which they build their relationships, and the ways in which they construct their actions." (Mody, 2008: 194) 65

Não obstante isso, reitero que do ponto de vista enfocado em meu trabalho, isto é, dos experimentos existenciais na direção do amor e, concomitantemente, da individuação, os romances não falhavam, mesmo não redundando em casamento eles permitiam a meus interlocutores uma transformação nas pessoas que estavam se tornando.

Como já referi, além de elementos como casta, religião, idade, horóscopo, gotra, e aspectos socioeconômicos que convencionalmente condicionam a escolha dos pares, na mente dos jovens outros elementos ecoam quanto às expectativas para o casamento. Em uma noite cheguei da aula de yoga, que terminava às 20:15, e encontrei Rekha no quarto espalhando um creme branco que cobria totalmente o peito dos pés. Perguntei para que

\footnotetext{
${ }^{65}$ Mody está se referindo ao trabalho de Strathern entitulado "Dealing with Inequality: Analysing Gender Relations in Melanesia and Beyond", de 1987, no qual a autora afirmaria: "Are persons the authors of their own acts? Or do they derive their efficacy from others? ... [W] hat is seen as the origin of particular events, outcomes, sets of behaviour? The concept of agency is a shortland for these questions. It refers to the manner in which people allocate causality or responsibility to one another, and thus sources of influences and directions of power. To ask about agency is also to ask about how people make known to themselves that ability to act. (Strathern 1987: 24)." (Cf Mody, 2008: 194)
} 
era e ela explicou que o creme removia o bronzeado deixado pelo sol na parte dos pés que a sapatilha não cobria. Perguntei porque ela fazia isso.

- To make my skin fairer - foi a resposta.

- Oh, ok. So you also have this preoccupation about making the skin fairer. Shubhi told me this too.

Rekha disse que ter a pela clara era importantíssimo para os matchmakings, sobretudo para as moças, pois os rapazes prefeririam garotas de pele clara, já que isso significava que a próxima geração da família seria de pele mais clara. Daí a preocupação de Shubhi, que queria muito se casar, segundo Rekha. Esse encadeamento de ideias apresentado por ela denotava o quanto as moças estão sujeitas à escolha do rapaz, digo, o quanto é tido como certo que no fim das contas o rapaz é quem escolhe as moças e não o contrário; a moça precisa esperar ser escolhida, como Lovania também me dizia, por isso as garotas se preocupam tanto em se fazer atraentes para os rapazes, não só com a obsessão pela pele clara, mas igualmente pela magreza e pelos cabelos bem longos, já que "Indian guys like long hair", como me disseram várias vezes. Além de manterem seus próprios cabelos longos achavam estranho quando uma garota cortava o cabelo mais curto, como Pryia, Kirti e Nayan, que ao cortarem os cabelos foram consideradas "less atractive" por isso.

Rekha também utilizava um creme cor de rosa para clarear a pele do rosto. Todas as noites aplicava uma máscara que deixava por alguns minutos, não podia sorrir nem falar enquanto esperava, e enxaguava em seguida. Usava sabonetes líquidos faciais com o mesmo intuito. Em todas as farmácias pode-se ver tais produtos e desde meus primeiros dias na Índia em 2012, na cidade de Calcutá, esse comércio não era novidade para mim. Rekha, no entanto, jogava nova luz sobre esse assunto: havia também uma noção de eugenia em casar-se com pessoas de pele clara, o que colocava um grande problema para pessoas de pele escura.

- It's not easy for dark people to find a good match, specially girls - sentenciava Rekha. 
A maioria de meus interlocutores não eram, contudo, críticos a essas discriminações negativas, mas ao contrário faziam coro a isso ao usar tais produtos e fazer afirmações como a de Rekha muito tranquilamente. Em seguida ela disse que duas coisas muito importantes para as garotas arranjarem um bom noivo eram a cor da pele e a idade. Disse que entendia Shubhi no impasse que esta vivia com Patrick, que ela estava certa em pensar em seu futuro dada sua idade.

- She is what? Twenty-seven, twenty-eight? It's time to get married otherwise it will be very difficult after this age. If Patrick doesn't take his decision, she is right to worry for her future.

Desde o começo, Rekha se posicionara a favor de Shubhi na dissolução do namoro, mostrava comungar a visão de que o casamento é o destino certo de uma moça e de que há uma idade para fazê-lo. Se Patrick não iria prover isso a Shubhi ela estava mais que certa em desistir do relacionamento. Patrick e Rekha tiveram muitas chances para discutir suas visões dissidentes sobre namoros e casamentos, uma delas ao final da sessão do filme Yeh Jawaani Hai Deewani.

Nos primeiros dias de junho de 2013, fomos assistir ao estrondoso sucesso de Bollywood, que estava causando um furor nos cinemas da cidade. Minha professora de hindi Mantha ji, Shubhi, Lovania, Rekha, todas falavam da ansiedade em ir assistir ao filme. Patrick e eu decidimos ir ao cinema com Rekha, pois ela estava louca por isso e eu queria mesmo ter a experiência de um filme bollywoodiano diante da grande tela. A produção de cento e sessenta minutos, exibida em três horas graças ao fato de que toda sessão de cinema que presenciei na Índia tem um intervalo de quase meia hora, era um musical cujas canções haviam sido lançadas anteriormente ao filme, algo que sempre alavanca a audiência. A sinopse indicava a história de um grupo de amigos, ex-colegas de escola, que vão numa viagem para Manali, famosa estação de montanha no estado de Himachal Pradesh, ao pé dos Himalaias. Os personagens principais são quatro amigos: um casal de namorados e uma moça tímida, apaixonada secretamente desde a escola pelo outro rapaz, um galã que flerta com várias mulheres ao longo do filme. No desenrolar da história o rapaz namorador acaba correspondendo à paixão da garota tímida e estudiosa e se casam por amor. Já o casal de namorados termina o romance, que era, aliás, escondido dos pais, e a moça tem um casamento arranjado com outro personagem, um tanto desajeitado e bobo, que aparece pouco na trama. 0 antigo 
namorado vai ao casamento e parece enciumado, mas sabemos de antemão que fora dele a decisão de ir trabalhar fora do país, seguindo uma bem sucedida carreira profissional e pondo fim ao romance. Julgo instrutivo citar o texto da capa do DVD que comprei para assistir com legendas em inglês:

"Yeh Jawaani Hai Deewani is the story of four characters, Bunny (Rambir Kapoor), Naina (Deepika Padukone), Aditi (Kalki Koechlin) and Avi (Aditya Roy Kapur) at two separate but defining times in their lives; first, when they are just out of college and standing on the crossroads of multiple decisions that will shape who and what they will become... and then later on, in their late twenties when they reunite at the wedding of the first of their bunch, now holding on to certain fulfilled and certain unfulfilled dreams, at a crossroads of another nature this time... YJHD is a cocktail of all the encounters and obsessions that form the exhilarating and terrifying journey of youth... an effort to somehow capture the spirit of the lives of these four characters as they navigate life, love and their search for what truly gives their lives meaning."

Como se vê, os temas chave de minha investigação - aqui representados como namoro, amor e experiências existenciais na busca pelo sentido da vida - estão presentes no filme, e, como afirmei acima, o cinema provê uma linguagem e, acredito, também formas de elaborar os temas conflituosos enunciados naquela sinopse. É pena que, de passagem, repercutam estereótipos e reforcem normativas de gênero e moralidade, como afirma Wani: "Despite some robust exceptions, the binary of 'good' and 'bad' women and the consequent punishing of 'loose' women and the rewarding of the 'pure' and 'chaste' heroine persist." (Wani, 2013: 4) 66

Nesse filme, como em todas as demais produções de Bollywood a que assisti, o que não faltava eram: i) dramas: a família que chora a desonra da filha ou a desgraça do filho apaixonado por outra moça que não a escolhida pelos pais; jovens que são compelidos ao casamento por vontade dos pais mesmo quando amam outras pessoas; a saga de casais apaixonados para convencer os pais a aceitar um casamento por amor; a comunidade que rechaça a moça que decide morar junto com o rapaz sem se casar etc. e ii) a longa duração dos filmes que os torna arrastados como que para dar densidade aos dramas e acabam por mimetizar a temporalidade do romance em que tudo leva tempo

\footnotetext{
${ }^{66}$ Quando comentei com Pryia e Meena que havia ido assistir ao filme Yeh Jawaani Hai Deewani, perguntaram sobre o que era, disse que falava sobre romance e casamento, sobre romances interrompidos, romances inesperados e casamentos arranjados e por amor. Ambas riram e disseram que esse era o enredo de praticamente todos os filmes de Bollywood, portanto não seria difícil arranjar material cinematográfico para minha pesquisa. Com a afirmação de ambas em mente fui, naquele ano e em 2014, assistir a outros filmes com enredos semelhantes. Ao final do capítulo apresento um quadro dos filmes assistidos, caso interesse ao leitor.
} 
para acontecer. 0 primeiro olhar, a demonstração de interesse do rapaz (que a garota precisa esperar para não ser considerada "bold" ou "easy"), a primeira dança dos enamorados, o convencimento dos pais, outra dança, a preparação da cerimonias, mais algumas coreografias, e, finalmente, o casório com mais uma dança, dessa vez com a música hit do filme.

Rekha se decepcionara com a produção em questão, disse que não era o que ela esperava. Ficara, ainda, incomodada com o cenário, a romântica Manali, no qual a garota tímida e o rapaz galanteador se enamoram. 0 motivo é que Manali era a mesma cidade onde Praveen havia estado e tirado as fotos em que aparecia abraçado a amigos e garotas que conhecera na viagem e com uma delas em especial fazendo poses juntos enquanto faziam trekking nas montanhas geladas. Rekha nos disse ao final da sessão:

- It seems that Manali makes people visiting the city become over friendly. There must be something different about this place.

Patrick e eu nos desmanchamos em risadas, pois percebemos que Rekha passara o filme imaginando Praveen nos cenários do filme com as garotas que estampavam as fotos em seu celular. ${ }^{67}$ Penso que também contava para o desagrado de Rekha a trama em que um namoro era interrompido pela decisão de um dos protagonistas de mudar-se para outro país seguindo planos de trabalhar e o fato de que a moça que ficava acabava tendo um casamento arranjado com outro rapaz. Quanto ao que Patrick disse ao final do filme:

- You see, this is what happens in India, girls who love one guy will marry another one arranged by the family. They won't even try to fight for their love.

\footnotetext{
${ }^{67}$ Quando estive em Manali, um mês depois, na companhia de Trisha - que havia conhecido em 2012 através de Meena e Pryia e que também trabalhara na ONG de orçamentos para políticas públicas - esta contou-me que Manali é uma estação de montanhas famosa como destino de lua-de-mel. Nos três dias em que estivemos lá, avistamos muitos casais jovens. Trisha me explicava que, além dos recém-casados, Manali é muito procurada por casais de namorados que desejam ter privacidade e intimidade longe das famílias, já que perto delas não têm essas condições. Ali, misturados entre os recém-casados, os jovens namorados podem passear pela cidade e pelas montanhas em seus arredores, além de hospedarem-se juntos, como faziam Rekha e Praveen em suas viagens românticas. Rekha fizera planos de acompanhar Trisha e eu nessa viagem, na última hora cancelou as passagens que já havia comprado, pois Praveen iria para China naqueles e dias e passaria por Délhi para despedir-se dela, ele queria surpreendê-la, mas teve de contar-lhe pra que esta não fosse conosco para Manali. Essa era, parece, uma característica dos namorados de minhas amigas, eles faziam planos para o casal sem consultar a namorada e ficariam "damn mad" com as garotas se elas não se conformassem aos planos deles.
} 
Patrick fazia novamente menção à sua história de amor com Shubhi. Ele agora considerava que ela não o havia esperado, não havia lutado pelo amor deles. Mas Rekha retorquia:

- They are left with no other option!

Patrick parecia cobrar das garotas que tivessem mais atitude ao lutar pelo romance e resistir à imposição do casamento. Rekha lhe mostrava que a garota não tem como agir se o rapaz não se decidir e ficar ao lado dela, ou como dizia Gunjan num outro momento, "if the guy doesn't stand for the girl ". Segundo Gunjan para que um namoro passasse disso para um casamento "the guy must stick to the idea of marrying that girl".

Gunjan é também moradora da PG. Após dividir um quarto com Kushboo por algum tempo, mudou-se para o quarto individual que fora meu por quatro meses em 2014. Quando eu parti em 2015 ela se mudou para o quarto de Lovania e continuava no aposento quando eu concluía a redação desse trabalho. Gunjan tem 23 anos, é contadora e chegou à PG por intermédio de seu primo Krishna que já morava na casa e indicou o lugar à Gunjan e seus pais, tios de Krishna. Numa noite em que jantávamos juntas na companhia de Anirudh no restaurante Beeryani, Gunjan contou que sua irmã mais velha havia se casado por amor com um rapaz muçulmano e quando ela própria, tempos depois, começou a namorar um moço também muçulmano os pais teriam dito: "Your sister married a Muslim, in no way this is going to happen to you! Forget about it! You will not have such kind of marriage, never!” Ela nos contou que as duas famílias haviam sido contra o casamento da irmã, mas cederam porque o casal disse que se casaria de todo modo, com ou sem o consentimento dos pais. Gunjan fez uma longa fala sobre esses casos, que anotei no diário de campo em janeiro de 2015 assim:

- Nowadays these things depends on the family, on the parents. Every case will be a different case, and it depends on the guy as well. It has to be something that the guy is decided to do, because if the guy likes a girl but he is not going to stand for that relationship the girl will not be doing anything, it does not depend on her. The guy must stick to the idea of marrying that girl. He will have to stand for her after marriage as well. This made my parents accept my jeeju [o marido da irmã mais velha]. Because they saw that he was decided to honour my sister. But they said that I'm not going to have a similar marriage. They can even accept that I marry a guy of my choice, but not a Muslim. They say: your sister made that to us, you are not going to repeat the story. 
$\mathrm{Na}$ época em que fomos assistir ao filme, Rekha temia que o destino da personagem, e mesmo o de Shubhi, estivesse se transformando no dela própria, isto é, temia que Praveen não fosse permanecer a seu lado no propósito de ficarem juntos. Quando retornei à Délhi em 2014, contudo, Rekha e Praveen continuavam namorando, mesmo após a partida deste. Ele viera à Índia nas férias do fim de ano e haviam estado juntos. Nesse ano Rekha e eu voltamos a conviver bastante. Como já disse, ela não gostava da roommate que ficou em meu lugar quando parti no ano anterior e vinha sempre ao meu quarto para conversar, assistir TV e falar com Praveen pelo Skype. Ela e Maya tinham horários diferentes, a primeira saía para trabalhar cedo, por volta das nove da manhã e voltava pelas oito da noite. Já Maya saía após o almoço e voltava as dez da noite, pois seu turno no jornal Hindustan Times, onde trabalhava como jornalista, iniciava no período vespertino e se estendia até a noite, de modo que elas não tinham que conviver muito.

Em meados de abril de 2014, enquanto falava sobre o relacionamento com Praveen, Rekha disse algo que chamou muito minha atenção:

- I'm not sure if I love him. I don't really know what love is about, I keep telling him: I love you. So this is what I think it is, but I don't know for sure.

Pela primeira vez, em lugar de dizer o quanto o amava, Rekha considerou a possibilidade de que não soubesse o que era o amor. Ela dizia que o amava, então provavelmente o que sentia era o que se denomina como amor, mas ela não tinha certeza. Com Praveen morando longe, Rekha parecia questionar seu sentimento, seria o que sentia por Praveen realmente amor?

É por Gell (1996) que nos chega a ideia de que o amor é algo secreto, ligado ao conhecimento, um conhecimento produzido pelo par em romance com a expectativa de que esse conhecimento não redunde em traição, isto é, o desvelamento do segredo. ${ }^{68} \mathrm{Em}$ sua introdução à edição da revista Terrain sobre o amor, Gell traz a ideia de que relações sociais produzem conhecimento e que "even sex is knowledge (of a lower type) and love, especially, is knowledge. Or, to be more precise, love is a knowledge system, a procedure for obtaining, distributing and transforming knowledge of preeminent social value" (Gell, 1996: 2). 0 autor desenvolve a ideia de que como um sistema de conhecimento o amor

${ }^{68} \mathrm{O}$ autor nos lembra: "Georg Simmel was certainly justified in embedding his brief discussion of love and marriage within a broader discussion of secrecy and lies in social life. Love is the ultimate indiscretion." (Gell: 1996: 1) 
informa modos de vida, ou ao menos modos de fazer casamentos. Assim, do mesmo modo como o sistema de parentesco entre os Umeda, grupo por ele estudado, define que o casamento deve ser realizado entre primos cruzados, os quais são prometidos em casamento ainda crianças, no ocidente o amor romântico seria uma estrutura que indica como os casamentos devem ser feitos. Entre os Umeda o amor romântico seria inexistente, a não ser na forma de adultério que constituiria um tipo diferente de amor, pois os Umeda se casam com alguém que lhes está predestinado de acordo com o parentesco: todo rapaz Umeda tem uma garota prometida a ele, só o que tem a fazer é esperar que ela cresça (Idem: 3). ${ }^{69}$ Assim, os Umeda sequer teriam uma palavra para amor, pois suas "instituições sociais operariam inteiramente sem a assistência do amor como um motivo", o amor seria "extra-structural" e sua única importância seria a de ser reconhecido como fator para mortes por feitiçaria.

Em outro polo, contrastando com os Umeda, estariam as sociedades modernas ocidentais, nas quais o amor seria estruturalmente essencial ou ao menos assim tido. Nessas sociedades pessoas são ensinadas a acreditar que "one day they will discover, through elective affinity, out of the indefinite number of social others of whom they have generic knowledge, some particular one to love, with whom they will live in predestined harmony, have children, and so on" (Idem: 4-5). Para deleite da leitora a conclusão a que Gell chega em sua exposição do amor romântico como um sistema de conhecimento e uma estrutura a organizar o modo de fazer casamentos nas sociedades por ele chamadas de modernas é que o amor romântico é tão arbitrário e fantástico quanto a feitiçaria entre os Umeda, mas seria necessário, no entanto, dado o fato de que "in modern society choice of mates is not institutionalised at the level of individuals (though of course it is highly institutionalised in others ways, i.e, by class, educational experience, locality, etc.)" (Idem: 5). 70

\footnotetext{
${ }^{69}$ Gell reafirma o entendimento de que o amor romântico é uma construção social desenvolvida no ocidente moderno e como tal estaria ausente em sociedades não individualistas, como entre os Umeda: "In Umeda, love as we know it is impossible, i.e. romantic love with a relative stranger whom one chooses, out of all the possible candidates, as the one to love. The Umedas married cross-cousins, by sister exchange, and prospective marriages were planned long before the girl was adult (usually boys were older, because of an unbalanced ratio between the sexes)." (Gell, 1996: 3)

70 "The effect of love, in modern society, is to reproduce, fictionally, the kind of pre-structured affinities which are taken for granted in a society like Umeda, thus converting the arbitrary into the inevitable. In Umeda, as Strathern (1990) has suggested in relation to Melanesian societies more generally, social relations are constructed directly out of other (pre-existing) social relations - who you marry is part of your personal make-up (...). In the absence of this structural predestination, modern couples have to convert abstract, generic, relations between categories of persons into specific, grounded, historically embedded relations between specific individuals which will bear the structural loadings which will be imposed on them. Courting and falling in love provide the means for endowing relationships with
} 
A noção de amor como sistema de conhecimento e como estrutura que faz com que namoro e paixão sejam o modo de se constituir os casamentos em sociedades ocidentais modernas parece apropriada para pensar a dúvida de Rekha quanto ao tema. É o próprio Gell quem afirma que para que o amor romântico funcione como estrutura é necessário que haja uma "educação sentimental":

"In Umeda, there was no love-fiction, no popular culture of love (...). But consider the modern situation. Each modern couple has to devise for itself a history which will justify its existence as a couple, on the basis of zero personal experiences. Hence it is necessary that sentimental education should take place via fictional rather than real exemplars, relayed via romantic novels, films and soaps on the TV. Fictions are plentiful, life-chances are few; (...) popular fiction proceeds and guides the actions of real-life lovers, rather than representing real life after the fact." (Idem: 6)

Ao falar dos jovens de uma comunidade Bengali em Londres e seu novo anseio por romance e pela escolha do cônjuge nos casamentos, Gell afirma que possivelmente esses jovens tenham percebido que as histórias de amor na Inglaterra seguem, lado a lado, as estórias de amor da ficção. A ficção do amor estaria também presente na Índia, mas de modo diferente:

"The cultures of the [Indian] subcontinent are no less replete with lovefictions (especially films dealing with doomy passions) then our own; the difference being that romantic fiction is much less structurally essential and much more transgressive in relation to real life on the subcontinent then here. The screen lovers of Bombay and Tollygunge are the anti-types of real life, impossible dream characters, not practical exemplars. Screen love is marginal, escapist, and fantastic, but nobody mistakes their life partner for such gods and goddesses." (Idem: 7)

É instigante notar que Wani, especialista em estudos sobre mídia e cultura na Índia, afirme algo muito próximo do que propõe Gell:

"Romantic love has always been a staple of Hindi cinema. (...) In a societal context where love is not a common experience and marriages are arranged along the lines of caste and family background, cinema's investment in romance is intriguing and has invited critical and scholarly engagement. The absence of cultural sanction to romantic love in the country's tradition-bound patriarchal social and family structures has meant a consequent absence of the conventions of courtship and dating. Thus cinematic romance has entertained and, probably, educated an audience in the ways of love, by producing romance that is often unrealistic, fantastical but also stereotypical." (Wani: 2013: 1)

histories which make subsequent commitment to their consequences (more or less) secure." (Idem: idem) 
Como as autoras que citei anteriormente, Wani reitera que o cinema indiano provê uma linguagem sobre o amor, uma espécie de educação fílmica para o amor, mas apresenta, ao mesmo tempo, "uma imaginação sobre o amor que é largamente divorciada das experiências vividas da maioria dos indianos" tornando a experiência do romance "acessível apenas a uma minoria de pessoas tanto corajosas quanto cultural e economicamente privilegiadas". (Idem: idem)

Ao que parece, entre meus interlocutores, as dúvidas quanto ao que seria o amor e quanto ao modo de se casar, ora ansiando pelo amor romântico que os leve a "atar o nó", ora capitulando frente à possibilidade do casamento arranjado, emergem porque o amor seria, nos termos de Gell, uma noção "extraestrutural". Rekha se via ante a incerteza do amor por Praveen poder levá-la ao casamento e a incerteza até mesmo de que o que sentia por ele era realmente amor. Talvez se possa dizer que isso se dava porque não fora ensinada, desde a mais tenra idade, a sonhar e esperar por um grande amor que ela reconheceria como o par ideal à quem estava, pela ficção do amor romântico, predestinada. 0 questionamento de Rekha e a indecisão de outros amigos eram índices de que, como entre os Umeda, o amor "está fora do sistema social", o contrário se dando em outras sociedades que Gell chama de "our", onde "love has licence and is supposed to make the world turn round, to be the very principle upon which sociality rests" (Idem: 5).

A ideia de que o modo de fazer casamentos na Índia e o lugar do amor nesse sistema seria próximo ao dos Umeda é expressa pelo próprio Gell ao comentar um dos artigos da edição da revista Terrain, intitulado "Du mariage arrangé au mariage d'amour: nouvelles stratégies chez les Bengali d'East London", em que a autora, Kate Gavron, fala justamente dos dilemas vividos pelos jovens de uma comunidade bengali, oriundos de Bangladesh, em Londres. Esses jovens estariam, de modo semelhante aos interlocutores de minha pesquisa, divididos entre o dever de obedecer aos pais e o desejo de escolher, eles mesmos, o futuro esposo ou esposa.

Apesar da dúvida e de por vezes questionar o amor que sentia por Praveen, ambos continuavam juntos. Ao final de abril de 2014, Rekha se mudou para Mumbai, pois fora promovida no trabalho e assumiria, naquela cidade, uma das sessões de marketing da empresa multinacional para a qual trabalha. Sentíamos muita falta dela, Kaushik, Anindya e eu já que estávamos bastante unidos nos meses precedentes. Fazíamos muitas atividades em conjunto, íamos ao cinema, cafés, restaurantes, bares, 
jantávamos juntos na PG e fofocávamos sobre os demais moradores. Talvez essa tese tenha certa leveza, mesmo falando das angústias que esses jovens experimentam, pelo fato de que tudo que aparece aqui me foi dado conhecer por meio de relacionamentos amigáveis. As amizades possibilitaram tanto aos meus amigos viverem sua dores de modo menos penoso por terem amigos à volta frequentemente, quanto à mim aprender de uma maneira mais delicada sobre aspectos sofridos dos namoros, do controle da sexualidade, do modo como as famílias dispõem das vidas e dos corpos de suas filhas, de como essas filhas são compelidas a agir de um modo ou de outro, a esperar que a família possa pagar um dote que lhes propicie uma boa entrada na família por afinidade e a serem sozinhas enquanto esperam ser escolhidas.

Voltei ao Brasil em junho de 2014 e continuei a falar com Rekha frequentemente. Em junho daquele ano, Praveen foi visitá-la em Mumbai e ela me escreveu. Perguntava se ter uma relação sexual utilizando preservativo era condição suficiente para evitar a gravidez. Disse que sim, contando que o uso fosse correto e não houvesse rompimentos naquela forma de proteção. Ela então disse que Praveen e ela haviam decidido, após mais de três anos de relacionamento, dar esse passo e, como ela não queria falar disso com suas amigas indianas, havia escolhido a mim para sanar suas dúvidas. Era fácil perceber que as meninas indianas com quem convivi, a despeito da origem abastada e de toda a educação formal que obtiveram, tinham muito pouca informação sobre sexo, seja nos aspectos da proteção contra gravidez e doenças sexualmente transmissíveis, seja nos aspectos do desejo e do prazer, o que as levava a fazer perguntas às moças estrangeiras que viviam na PG que eram vistas como invasivas e descabidas. ${ }^{71}$ No caso de Rekha e Praveen, no ano anterior ambos haviam tentado ter intimidade sexual, mas ela havia sentido grande desconforto físico e desistido. Agora ela dizia que havia sido bom e bem melhor que as tentativas anteriores, pelo que fiquei sabendo que haviam sido mais de uma.

\footnotetext{
${ }^{71}$ Garotas me perguntavam, por exemplo, no meio de um passeio pelo mercado em Lajpat Nagar em que fazíamos compras, com que frequência fazia sexo com meu marido desde que nos casamos e faziam indagações sobre as práticas sexuais consideradas não correntes na Índia, sexo oral e anal. Era como se elas esperassem que as garotas estrangeiras fossem experts em sexo. Eu, por meu turno, aproveitava para perguntar sobre elementos de sua sexualidade que não apareciam em nenhum texto da literatura antropológica, como se elas sentiam desejo por sexo, ou se o faziam por ceder à demanda dos rapazes, e como evitavam a gravidez. Descobri que a demanda por sexo era sempre iniciada pelo rapaz e que à moça cabia tentar resistir. Algumas delas afirmavam sentir desejo outras afirmavam não sentir. Quanto aos métodos contraceptivos, o mais comum era o coito interrompido, pois os garotos eram reativos ao uso de preservativo. Em conversas na academia e por artigos de jornal eletrônico era informada de que pílulas do dia seguinte são massivamente usadas como método anticoncepcional corrente e não apenas em situações de emergência. Minhas amigas, contudo, afirmavam nunca ter feito uso delas, nem de pílulas anticoncepcionais, as quais parecem ter baixíssima aderência entre mulheres solteiras, uma vez que a presunção pública é de que não fariam sexo.
} 
De meu ponto de vista, em seus experimentos existenciais, Rekha estava constantemente negociando diferentes dimensões da vida de jovens abastadas que vivem nas cidades do norte da Índia, ou que compartilham aquela paisagem moral. Havia as negociações de cunho moral, que ela fazia mantendo segredo de seu namoro de quase todos na PG, da família e das pessoas no trabalho. Assim procedendo Rekha mantinha a respeitabilidade e a honra que as garotas devem proteger para evitar a alcunha de "loose". Havia as negociações com o pai: na tentativa de fazê-lo aceitar Praveen como futuro noivo Rekha agenciava as barreiras e fronteiras do parentesco e da endogamia de casta, não desejava romper os laços com o pai, ou sequer magoá-lo, motivo que a leva a, pouco e pouco, se abrir com o pai sobre o namoro. Assim procedendo pensava poder conseguir convencê-lo a dar seu consentimento para que tivesse um casamento intercasta. Rekha agenciava, igualmente, sua sexualidade, embora a demanda por sexo surgisse de Praveen, ela me disse que também sentia desejo pelo namorado. Do mesmo modo que Shubhi, Rekha era mais aberta a experimentações com o próprio corpo e com o corpo do parceiro que Lovania, a qual dizia nunca ter sentido desejo sexual, motivo pelo qual nunca havia se masturbado. Eram muitos agenciamentos para uma garota de vinte e cinco anos de idade e outros, ainda, estavam por vir.

Foi com certo espanto que em maio de 2015, vim a saber que o namoro com Praveen havia acabado. Ambos teriam decidido que não seguiriam mantendo esperanças e criando expectativas mútuas. Imaginei que ela fosse estar devastada, mas surpreendi-me com uma Rekha muito mais madura e segura que aquela com quem dividira um quarto e vivências em 2013. Agora em Calcutá, para onde se mudou ao final de 2014 por conta de outra promoção no trabalho, Rekha estava tranquila e confidente ao explicar porque o namoro acabara.

- We realised that we are not compatible for each other.

- Oh... I'm sorry to hear this. I didn't know that. Are you okay? I hope you are!

- Yes. All good. I am happy with my decision.

- That's great then.

- Yeah! I am over guys. Life is about me now.

- Great to hear that dear! It's a wise thing to do...

- Yeah Fab!

- But tell me when did you break up with Praveen? Did you guys fight? Is he in China yet? 
- Oh, yes... It's been more than a month now. Yes, he's in China. No Fab. We didn't fight. We realised rather I realised that he's not the one for me. We can't be happy with each other. Though we had spent a lot of time together. But he is not the one.

- Because he was not good for you? I mean he didn't take care of you?

- Not good or bad. We are not meant for each other. Also... I guess I don't love him anymore.

- Really?

- Yeah Fab. I suddenly felt out of love. Then I decided to move on. But even he didn't stop me once. Then I thought to let it go. Not worth it.

- Oh... when we were living together you were so in love with him, and also he seemed to be in love with you.

- Yes. I guess he still does love me. But he's not the one for me. He's in love with himself more than me. Since always.

- And do you feel okay with the fact that you guys had intimacy and now you are not together anymore?

- Absolutely. I haven't met him for more than nine months now.

- You are much more mature than before dear!

- I am happy to let him go. I am sure he will be happier with someone else.

- It is touching to see how confident you are now!

- Oh Fab.

- Seriously I am really happy to hear this.

- You have seen me throughout. And yes, that's different. I am a different person now. Hence... I am not in love with him. Time change and so does people.

- Yes, I know. That is so true! So you don't regret anything?

- Not at all. I am happy. Now I know so well that I don't want him. I am happy that I had a really good time with him. That can bring a smile on my face. I lived that relationship fully.

- Yes, I know. I remember that. You are passionate about life.

- Yes Fab. Life is too short and there is so much to do.

- Remember that we used to talk to Shubhi, she was all rational and all... I always thought that I'm more like you.

- Me too Fab! Hence I could go with you girls so well - [Refere-se à Amélie, Elena e eu] - Thought I was always melodramatic. But that was my growing time.

- No, you weren't melodramatic.

- I lived now I laugh. 
- You were intense in your feelings.

- Yeah, I have always been.

- You are full of life Rekha.

- Powerful girls we are.

- Yes, that is true! We are powerful!

Nessa conversa, Rekha disse ainda que sua família continuava pressionando-a na direção do casamento ("they are still pushing me to get married"), mas como ela continuava conseguindo sucesso no trabalho acionava suas conquistas quando tinha que responder aos familiares sobre o motivo para postergar um pouco mais o matrimônio. A estratégia de que ela se utilizava ao acionar a progressão na carreira, fazia-me lembrar de uma conversa que tive com mister Kapoor logo que cheguei em 2013.

Numa manhã em que não conseguira pregar o olho a noite toda, devido à diferença de fuso horário entre Brasil e Índia, desci as escadas pra tomar café da manhã quando eram umas sete da manhã. Torradas, manteiga e um mingau que parecia de flocos de maisena eram o cardápio. Mister Kapoor estava à mesa na sala de jantar, cumprimentei-o e sentei-me. Em algum tempo Shine chegou, eles pareciam mais próximos que no ano anterior, como vim a saber depois, o pai dela pedia que o senhorio tomasse conta dela. Ficamos os três conversando e comendo.

Shine iniciou suas perguntas sobre minha pesquisa, disse a ela, enquanto mister Kapoor ouvia, que desejava trabalhar informalmente num marriage bureau, pois desejava compreender como estavam sendo feitos os matchmakings. Mister Kapoor começou a dizer, como sempre fazia, coisas ruins sobre casamento. Que o modo de entrar nos casamentos na Índia, no Brasil ou em qualquer lugar podia ser diferente, mas uma vez casados era sempre a mesma coisa: "work, stress, kids, complaints, problems". Ele dizia essas coisas rindo muito, mas era tão recorrente que penso que havia um fundo de verdade nessas brincadeiras em sua maneira de ver os casamentos, ele devia mesmo pensar assim.

Continuamos falando, Shine e eu, até que mencionei algo sobre "love marriages". Nesse momento mister Kapoor ingressou na conversa novamente e começou a me dar uma aula sobre casamentos por amor. Disse que na Europa os casamentos sempre foram arranjados, eram arranjos financeiros e políticos. Falou algo sobre o pós-guerra que não 
entendi bem e que assim teriam começado os casamentos por amor naquele continente e a partir de então os divórcios nunca pararam de se multiplicar. A visão de que casamentos "por amor" estão fadados ao divórcio é extremamente corrente, não é de espantar que em alguns casos que me foram narrados as dificuldades financeiras e de relacionamento do casal estivessem presentes, uma vez que o boicote familiar e comunitário ao casamento por amor é flagrante, como apontam Grover (2011) e Uberoi (2011). Ao prefaciar a monografia etnográfica de Grover sobre os casamentos por amor em bairros populares de Délhi, Uberoi afirma:

"The general opinion of her informants, and of several well-known feminist critics as well, is that love marriages are fragile unions for the reason that the couple's families have no investment in the outcome and no responsibility to mediate marital disputes. A woman who chooses to make a love marriage in defiance of parental approval is deemed to have forfeited her right of support and refuge in her natal home. (...) Paradoxically, however, and in contradiction to conventional expectations, love marriages work out to be more 'stable' and enduring than family-arranged marriages for the rather sad reason that the wives have no-one to turn to if things go wrong, and nowhere else to go: they can only stick it out as best as they can with the mates they have themselves chosen." (Uberoi, 2011: xiii)

Grover, por sua vez, aponta para a escassez de estudos sobre as dinâmicas conjugais, familiares e comunitárias no período após o casamento por amor, o que ela própria intenta suprir em seu empreendimento. Ao citar os trabalhos de Mody (2008) e Chowdhry (2007), que focavam a violência, as inadequações da lei, as dificuldades com trâmites legais e o rechaço das famílias e comunidades nos casos de casamento por escolha, Grover afirma:

"A productive way of refining and deepening the debate is by shifting the inquiry to the post-wedding phase of love marriages, which has until now received notably little scholarly attention. Exploring the nuances of the couple's interactions with their parents after marriage and investigating the dynamics of their everyday conjugal lives in the later years allows us to better understand the changing character of relationships between spouses and their kin, as these unfold over time." (Grover, 2011: 6)

Mister Kapoor continuou dizendo que na Índia esses casamentos eram campeões de divórcio. Mantive um semblante de aluna e perguntei se ele achava que o que ocorreu na Europa em outro período estaria ocorrendo agora na Índia. Ele disse que sim e falou: 
- What is happening in India is that girls are dating boys. They have sex with them and then marry another boy - riu e apontou para Shine dizendo:

- She knows that!

- Not all girls! - Shine respondeu.

- Yes, that's true. She is still a baby, she is not in the road yet.

Mister Kapoor fazia referência ao fato de Shine ser a mais nova de todos os seus hóspedes. Na hora imaginei se mister Kapoor teria ficado sabendo do romance de Shine com Dileep no ano anterior. Já que ele estava me dando uma aula de história, mencionei que os historiadores apontavam um processo de desenvolvimento da individualidade na Europa que estaria em confluência com as mudanças nos casamentos. Ele disse:

- This is all about financial independence. When people get financial independence they don't want to do what their parents want. Things are changing because we are in a transition; we are leaving the old, the traditional world and coming to the modern world.

Assim, mister Kapoor me informava que a independência financeira era algo que tornava os filhos indóceis e difíceis de controlar na visão dos pais, o que, parece, estava acontecendo com Rekha: dado o sucesso na carreira que estava trilhando, Rekha barganhava com o pai e o restante da família o direito de postergar um pouco mais o casamento para cuidar de si primeiro antes de assumir as responsabilidades que o casamento iria impor a ela.

Mister Kapoor é um senhor educado e viajado, viveu nos Estados Unidos e em Londres e viajou o mundo todo como representante comercial, tendo estado inclusive no Brasil nos anos 80. Não me espantava seu uso de uma linguagem apropriada das ciências sociais, algo como um senso comum do pensamento social. A oposição modernidade $x$ tradição era acionada por ele, e por outros interlocutores, para explicar as mudanças em curso nas instituições do casamento e da família na Índia. Patrick também mencionava essa chave quando falávamos sobre casamentos, namoro e sexualidade. Falava sobre como os jovens se expressam verbalmente e as gírias em inglês que seriam usadas para 
parecer "cool and modern", as quais segundo ele são informadas pelos meios de comunicação de massa. Na ocasião ele usou a palavra "exposed" para dizer que os jovens eram expostos à cultural ocidental constantemente pelo cinema, pela música, televisão e Internet. Disse que a Índia estava se tornando moderna, mas não era moderna ainda. As ideias de mister Kapoor e de Patrick de modernidade pareciam corresponder à ideia do novo e de um estilo de vida ocidental, valoravam, no entanto, de modo divergente as ideias de modernidade e tradição: o primeiro lamentando os tempos atuais em que com a importação da modernidade vinham também os "problemas e vícios" do ocidente; o segundo ansiando pelo momento em que a modernidade finalmente chegaria à seu país libertando os jovens do jugo da tradição supostamente seguida pelos pais. Reforço aqui meu uso desses termos como "rótulos valorativos" veiculados por meus interlocutores e não como categorias explicativas.

Quanto à Rekha, sua história me faz pensar, ainda, em uma conversa que tive com a professora Janaki Nair, em sua casa no campus da JNU. Contando a ela os rumos da pesquisa e pontuando o fato de que a convivência com meus interlocutores apontava para um processo de individuação no qual os casos de namoro e romance pré-maritais faziam parte de experimentos existenciais que os levavam a se constituir de modo mais individual como pessoas, Nair meneou a cabeça concordando, mas afirmou que o anseio por tal individuação era maior da parte das moças que de parte dos rapazes, esses esperariam arranjos mais conservadores para os casamentos. Eu intuía essa diferença observando os rapazes, com exceção de Patrick e Anirudh, em sua despreocupação quanto ao casamento, que deixariam a cargo dos pais decidir e organizar. Fui, contudo, chegando à conclusão de que os rapazes também ansiavam por alguma individuação, mas seu modo de proceder era diferente. Talvez não houvesse, ao menos na maioria dos casos, grandes esforços por viver romances, nem mesmo novenas e jejuns para Lord Shiva, esses seriam modos de individuação, isto é, de transformação na formação da pessoa, ligados ao universo feminino, mas os rapazes também empreendiam passos transformadores na formação da pessoa ligados ao universo masculino.

Em 2014, ao apresentar os desdobramentos do trabalho de campo até aquele momento para uma audiência de cerca de quinze alunos do Sociology Department, ouvi das alunas presentes a indagação de quais seriam as ideias de romance ventiladas pelos rapazes que participavam da pesquisa. Ao afirmar que esses eram menos assertivos a respeito do romance que as garotas e que as impressões que eu tinha de suas ideias 
sobre romance provinham também de brincadeiras sarcásticas que faziam com os demais moradores que estariam apaixonados, cheguei à conclusão de que eu tinha muito mais claras as noções femininas sobre o romance que as masculinas. Enquanto tomávamos o chá que se segue aos seminários dos estudantes em frente ao departamento, minhas colegas diziam o quanto os rapazes não se preocupavam com o romance porque quereriam que suas esposas fossem outras mães para eles, procuravam por mães e não por namoradas ou amantes nas esposas; mães que cuidassem deles, os alimentasse, cuidasse dos futuros filhos, da casa e de pôr a vida do casal em ordem. Patrick, que estava presente, perguntou, mais tarde, de onde elas tiravam tais afirmações, se de pesquisas que elas próprias empreendiam. Respondi que sim, das pesquisas que faziam vivendo suas vidas cercadas de rapazes que mostravam isso a elas.

Rekha pontuava o tempo todo que se esforçava mais que Praveen para que o namoro de ambos desse certo, isso é, para que viessem a se casar. Além disso, ela me mostrava ao fim do namoro que Praveen, como mencionado na discussão bibliográfica, portava-se, mesmo no romance pré-marital, em consonância com a assimetria entre homens e mulheres em relação ao amor. Ele amava a si mesmo mais que a Rekha e, a certa altura, mais que ela própria o amava. Gosto de pensar que Rekha foi tão bem sucedida em seus experimentos existenciais até aqui que pode transcender o objeto inicial dos experimentos, descobriu-se um ser em existência, única e especial, e não mais precisava de Praveen para se sentir assim. Encerro esta seção sobre Rekha afirmando que só posso esperar que ela continue trilhando o caminho bravio que tem trilhado até agora e que sua descoberta de que é "a powerful girl” a leve longe, bem longe, para perto de seus sonhos.

Em seguida passo a apresentar, mediantes histórias de meninos, como os rapazes se expressavam e se comportavam em face dos temas do romance, do namoro e do casamento. Na passagem também procuro evidenciar as diferentes formas com que buscavam se individuar e que diferem das garotas, dizendo respeito à manutenção das diferenciações de gênero no processo de transformação por que passa a formação da pessoa naquela paisagem moral.

\section{Entre amores e arranjos: o modo de se individuar dos garotos}


No começo de abril de 2013, almoçava frequentemente na antiga sala de jantar da PG e dois rapazes estavam sempre por lá também. Foi assim que conheci Isham, um rapaz de Haryana de dezenove anos que estava em Délhi para um curso preparatório para os exames de admissão na universidade, e Krishna, um moço bengali que cursava o terceiro ano da faculdade de arquitetura e era admirador das obras de Oscar Niemeyer. Ambos passavam a maior parte do dia na casa, com exceção do horário em que estavam nas aulas, pela manhã.

Num desses almoços na companhia de ambos, fui inquirida sobre o que fazia em Délhi. Depois de responder que estava interessada nos casamentos indianos, o primeiro começou a me contar que sua família estava procurando um noivo para sua irmã. Essa irmã é uma prima, mas, como disse antes, pessoas que crescem juntas em uma joint family geralmente chamam os/as primos/primas de irmãos/irmãs. Ele disse que eles estavam fazendo contatos com famílias de jovens que queriam se casar. Ficou me contando de todo o processo que é arranjar um noivo, pois é preciso checar o "background" do rapaz e de sua família, ele disse. Perguntado sobre o que seria isso respondeu:

- If they are good people, if there is no police case involved, if they are not trouble makers, if they have the money they say they have, if the boy doesn't drink, if they are a good family.

Referiu-se à sua própria família como uma "middle family", querendo dizer que são de classe média, e chamava de "big family" uma família rica. Dizia isso de passagem para esclarecer que rapazes procurando casamento às vezes mentem em seus perfis para tentar se casar numa posição melhor que a sua própria, por isso seria preciso verificar o background do rapaz e da família, pois um dos pretendentes de sua irmã (filha do irmão do pai) disse que era membro de uma "big family" e que ganhava muito dinheiro, o que se comprovou não ser verdade quando investigaram com os vizinhos da família do pretendente. Os perfis mencionados nesse caso dizem respeito à fichas que brokers apresentam às famílias que os contratam como mediadores nas buscas por noivos e noivas para sua prole.

Isham disse que sua família tem parentes em várias localidades do estado, então quando o pretendente era de outra cidade, normalmente alguém da família conseguia 
investigar o background checando as informações dadas nos perfis com conhecidos e vizinhos do rapaz que se oferecia como noivo. Perguntei se eles haviam contratado um broker [beech wala, em hindi], ele disse que sim, e que estes cobram uma porcentagem do dote pela execução do trabalho quando ajudam um par a ser formado. Isham não se lembrava do termo em inglês para dote, perguntou à Krishna que informou que a tradução para dahej, em hindi, era dowry.

Ele continuou: quando checamos o brackground e se está tudo certo, então olhamos se o casal parece bem junto, não pode ser um rapaz muito alto e uma garota muito baixa por exemplo. Um rapaz que queria se casar com sua irmã disse ter vinte e cinco anos, mas quando foram checar ele tinha trinta, o que também não era aceitável para a família de Isham, pois a união entre uma moça de vinte e um anos e um rapaz de trinta não é considerada "suitable". Ele acrescentava que até vinte e cinco anos era uma idade boa para o pretendente da irmã, que o futuro marido não deveria ter mais que essa idade.

Perguntado por Krishna, contou-nos que antes de vir para Délhi morava em uma cidade pequena, onde a família possui uma loja no mercado principal da cidade, fazendo deles uma família conhecida no lugar. Voltando-se para mim, disse que suas irmãs sempre andam acompanhadas quando saem à rua, da mãe ou de outras garotas da mesma idade, pois segundo ele, não é bom que as moças saiam sozinhas porque sempre há alguém pra tentar se aproximar delas com frases do tipo "I want to know you" ou "give me your mobile number". Contou que uma vez sua irmã ia para o colégio sozinha e um garoto havia tentado se aproximar dela, dizendo que ela era muito bonita. Um rapaz mais velho, conhecido de Isham, viu a cena e tomou as dores da família da menina, indo brigar com o rapaz falando, segundo Isham:

- Stop teasing her, she is a friend's sister! Get out of here!

Tentando me impressionar para bem, Isham disse que seu amigo teria inclusive batido no rapaz que importunava sua irmã. Segundo ele, embora na cidade muitos conhecessem a irmã por conta de sua família e, por isso, não a abordassem, garotos que vêm esporadicamente das aldeias para as cidades não conhecem os locais e se aventuram tentando falar com as moças da cidade. Essa parte da conversa se deu quando mencionei interesse também em "love marriages". Isham estava tentando me 
explicar que os casamentos por amor acontecem quando as famílias não tomam conta de suas filhas, isto é, não vigiam-nas dia e noite, ao que parece.

Em outro ponto da interlocução ele disse que só tem uma irmã, que é casada, e um irmão. Foi assim que percebi que a moça que estava para se casar agora era a filha de seu tio paterno. Como perguntei se ele vivia em uma joint family, respondeu que todos os irmãos de seu pai moravam juntos até uns cinco anos atrás com seu dada (avô paterno). A família tinha seis lojas ao todo, mas dividiram tudo e cada um morava agora numa casa e o dada havia ido morar com um dos tios paternos de Isham. Disse que em uma joint family costumam haver muitas brigas, porque um concorda com uma coisa, mas o outro discorda, então seria muito difícil tomar decisões, mesmo pequenas. Lembrei-me nesse momento de que viajando até Mumbai desde Johanesburgo, o rapaz ao meu lado no avião, Dileep, dissera a mesma coisa, que era muito complicado viver em uma joint family, pois haveriam numerosos conflitos com todos se metendo na vida de cada um. Dileep se casaria em breve e iria viver com a esposa na casa dos pais, os quais já não residiam com a família extensa. Decidira viver com eles porque era preciso retribuir aos pais, agora que estavam ficando mais velhos, todo o cuidado que haviam tido na criação dos filhos. Disse algo como:

- Now it's my turn to take care of them, so that they can live comfortably, with no worries.

Isham continuou falando da irmã e de como cuidavam bem dela. Em certo ponto disse que ela possuía muitos anéis de ouro, vinte e cinco no total, mais colares e alguns diamantes que estavam nos anéis, todos guardados no banco para evitar ladrões. Ele não me disse, mas deduzi que contava isso por entender, como se faz costumeiramente, que a única coisa que a noiva tem de seu quando acontecem divórcios ou quando os pais morrem são suas joias, isto é, pelo costume, mulheres não participam da partilha da herança deixada pelos pais, pois entende-se que elas teriam recebido sua parte dos bens da família natal aquando do casamento através do dote e de suas jóias. ${ }^{72}$ Esse seria, inclusive, o motivo pelo qual famílias natais veem o dote como um cuidado com a filha,

\footnotetext{
${ }^{72}$ Grupos de castas matrilineares, como os Thiyyas de Kerala investigados por Abraham (2011b), constituem excessão ao regime de herança apresentado por Isham. Nesses grupos, apesar da patrilocalidade ser um costume observado, mulheres herdam propriedade do lado materno e têm direito a retornar aos seus lares natais. Não obstante isso, como afirma Abraham, a patrilocalidade é acompanhada, mesmo no caso dos grupos matrilineares, pela ideia do "marido provedor" e do marido como figura de autoridade.
} 
pois tentam assegurar pelo dote a boa entrada dessa na família do marido, ou seja, intentam por meio do dote, que a filha seja bem recebida e bem tratada no novo lar (Mody, 2008; Clarck-Descés, 2014). Esse sentido é expresso ritualmente nos casamentos bengalis em que a noiva, ao adentrar pela primeira vez a casa do marido, pisa uma bacia com tinta vermelha e deixa suas pegadas rubras pela entrada da casa. Quando acompanhei o casamento do irmão de Meena em Calcutá, suas tias me explicaram que a noiva o faz porque naquele momento ela representa Lakshmi, a deusa da riqueza, pois traz consigo a riqueza do dote. A cor vermelha está diretamente ligada à própria Lakshmi e ao casamento também.

Isham lamentou o fato de que nunca dera um anel a sua irmã já casada, mas que o faria quando se encontrassem da próxima vez na casa dos pais para demonstrar seu amor por ela. Comentou que quando as moças vão à casa dos parentes natais visitá-los depois de casadas, na volta levam alguma quantia em dinheiro para os maridos. Krishna ouvia a tudo isso sem interferir e levantando a sobrancelha algumas vezes, com o que me dava a impressão de estranhar algumas falas de Isham.

Isham começou a falar de dotes, que mesmo não sendo uma "big family" sua família pagara um grande dote à família do marido da irmã já casada. Perguntei se ela estava feliz, se não reclamara de nada nesse processo todo, ele me disse que sim, que ela estava feliz, e que teve escolha, pois havia concordado com o rapaz que escolheram para ela. Disse isso lembrando do fato de que se um rapaz é muito alto para uma garota não vão obrigá-la a se casar com ele, ou se for gordo, ou se for magro para uma moça gorda. As falas de Isham faziam-me lembrar Mody quando afirma sobre as preocupações atuais das famílias nos matchmakings:

"(...) it is a sign of the times that families arranging marriages are increasingly careful to select not just 'socially', but also temperamentally suitable spouses. Sometimes these could consist of brutally honest assessments: such as a matrimonial advertisement on behalf of an 'impotent' man seeking a woman who wasn't interested in sex. In most cases, however, equivalence of educational qualifications, 'looks', wealth, job and 'cultured', 'traditional', 'modern' or even 'cosmopolitan' background are viewed as sufficient indicators of temperamental compatibility. Other than the commonplace preoccupation with matching horoscopes and skincolour, 'individual compatibility' in an arranged marriage also takes into consideration the aesthetics of how a couple (jodi) would look side-by-side. So, short women are considered suitable only for short men, and a fat woman would be loath to marry a skinny man." (Mody, 2008: 13) 
Compreendi, por fim, a que tipo de escolha Isham se referia, a irmã pudera ajudar a família a selecionar, dentre os possíveis noivos, aquele que mais lhe agradava, ou lhe desagradava menos, quem sabe. Como no caso do senhor que viajava comigo de trem para Jaipur, ela "selecionara" alguém, talvez igualmente por uma fotografia.

Isham emendou dizendo que geralmente as pessoas das duas "partes", isto é, de ambas as famílias, se encontram depois de checado o background do rapaz e discutem sobre o casamento. Isso tudo ele dizia do ponto de vista de quem procura um noivo para uma filha, evidentemente. Nesse encontro há um momento em que os dois jovens podem ficar a sós por alguns minutos para conversar, se estiverem ambos de acordo com o casamento está feito, se um deles não concordar então não haverá casamento.

Dileep, o rapaz do avião, também contara desses encontros entre as duas "partes". Disse que recusou uma moça certa vez, e também fora rechaçado por uma garota, a noiva com quem ele se casaria era a terceira tentativa de arranjo e encontro desse tipo e apenas após ambos concordarem em se casar é que as famílias haviam selado o arranjo. 0 casamento de Dileep, como disse antes, ia acontecer seis meses após esse primeiro contato. Ele a vira essa única vez e iria vê-la novamente, agora que voltava do Brasil, uma vez mais antes do casamento. Estava, contudo, contente com a futura esposa e esperançoso da nova vida feliz que teria na cidade de Mumbai, onde voltaria a trabalhar como profissional de tecnologia de informação. O Brasil ficaria no passado, ele gostara de algumas coisas, mas era tudo muito diferente e sentia muitas saudades da Índia.

Isham, continuando o assunto dos dotes, disse que em alguns lugares ele não era proibido e que em outros, onde é proibido, os parentes dão carros, terras, joias e todo tipo de "expensive gifts" no lugar do dote "in cash", isso quando se tratam de "big or middle families". Não sei bem o quanto Isham tinha em mente a legislação anti-dote indiana, mas as leis que o proíbem são federais, valendo, portanto, para todo o país. 0 que de fato não impede, como ele mostrava, a continuidade dos pagamentos de dote. Como também não impede o assédio moral e psicológico que muitas mulheres sofrem por parte da família por afinidade quando da ausência do pagamento, ou quando este não atinge as expectativas da família do noivo, tampouco impede as chamadas "dowrydeaths" em diferentes lugares do país, em aldeias e em cidades. 
Nesse momento Krishna quis saber por que eu estava pesquisando esse assunto. Respondi que era minha pesquisa de doutorado e que o tema dos casamentos me intrigara desde a primeira vez que estivera na Índia em 2009.

- What kind of PhD are you doing?

- In Sociology. - Respondi.

Então Krishna me disse que eu deveria viajar pela Índia para saber mais sobre tudo que Isham dizia, porque em cada parte da Índia essas coisas eram de um jeito. Respondi-lhe que havia escolhido Délhi para focar em meu trabalho e que estava aprendendo sobre as outras regiões do país pelos livros de autores indianos que lia. Como estávamos falando dos dotes quando este último se fez partícipe na conversa, ele disse que não sabia muito dessas coisas, mas que os dotes em alguns lugares e para algumas famílias eram negócios ("business") e que alguns casamentos eram compras de noivas, ("some people buy a girl, they literally purchase a girl").

Ambos me deram exemplos de como seriam casamentos que eram negócios: se uma moça é feia ("ugly, unatractive"), mas o pai é rico, tem muito dinheiro para despender com o dote, a família certamente arranjará um bom casamento para ela, porque muitos rapazes e suas respectivas famílias estão interessados apenas no dinheiro ou nos presentes do dote, e repetiam "land", "cars", "houses". Por outro lado, se uma garota é pobre e uma família tem dinheiro para "comprá-la”, "adquiri-la”, muitos pais irão entregá-la por "one lakh of rupees" e ela trabalhará como doméstica para essa família. Isso foi referido por Krishna para dizer que muitos pais não se importavam com a felicidade das filhas nas transações do casamento, ele disse que alguns pais estavam tão preocupados apenas com dinheiro que irão até vender suas filhas, como nesse último tipo de caso que ele citava. Krishna dizia ainda que nesses episódios, os pais provavelmente nem queriam ter filhas, quando o que importa é dinheiro, ter filhas seria uma desvantagem, pois significava uma perda de dinheiro graças ao imperativo de pagar o dote. Nos exemplos deles, contudo, isso acontecia com famílias pobres e moças dessas famílias é que eram vendidas pelos pais, ambos não imputavam um comportamento tão ruim a famílias ricas que casam as filhas "feias" com qualquer um apenas para se ver livre delas, nem vislumbravam os abortos seletivos de fetos do sexo feminino que eram feitos nas classes médias e altas. 
Krishna continuou a dar exemplos da transação econômica que seriam alguns casamentos. Contou-nos da conversa que ouvira dias antes do dono da barraca de Mother Dairy - empresa de laticínios indiana - que ficava do outro lado da avenida. 0 senhor estaria contando a outra pessoa que havia acabado de casar a filha e o quanto ele havia gastado para fazer isso, reclamava do preço da festa, dos presentes para a família do noivo e de uma alta quantia em dinheiro que teria tido que despender no dote. Quando os meninos falavam dessas somas em dinheiro usavam os termos lakhs e crohres, o que representa quantias altas. ${ }^{73}$ Krishna não me dizia, mas faço a leitura, tendo em vista outras experiências correlatas, de que embora reclamasse do dinheiro gasto, com aquele discurso o senhor em questão buscava afirmar que havia casado a filha muito bem, pretendia fazer notar, pelo alto dote pago, que supostamente havia casado a filha numa família de status superior, ou seja, levando em conta a hipergamia.

No desenrolar da conversa passamos desse assunto para o dos casamentos intercasta, os quais seriam um grande problema na visão de Isham, nem tanto para Krishna. A visão desse último nesses assuntos parecia ser ligeiramente mais moderada e crítica com relação aos casamentos, ao modo como são feitos, ao dote e ao preconceito contra "love-marriages" e "inter-caste marriages". Quanto a Isham tudo o que afirmava parecia bastante naturalizado. Essa naturalização era evidente ainda quanto à discriminação por castas. Isham disse, em dado momento dessa conversa, que há certas castas com as quais as pessoas de castas mais altas não devem manter contato, "because there are certain castes that people are not supposed even talk to". Não havia crítica nessa afirmação, mas um tom corriqueiro, naturalizado, de que certas castas eram inferiores ou impuras, embora ele não tenha usado esse termo. Isham, como outras pessoas recém-chegadas à $\mathrm{PG}$, ainda não havia incorporado o discurso público metropolitano que condena, no mais das vezes apenas retoricamente, a discriminação por casta e costumes como o pagamento do dote. Suas falas me faziam pensar, novamente, no fato de que as pessoas na PG, em geral, não conversavam e praticamente nem olhavam para os funcionários mais subalternos, como as arrumadeiras, o senhor da lavanderia e os porteiros. Todos se dirigiam ou cumprimentavam apenas Lakhan e o cozinheiro. Não se dizia bom dia ou boa tarde a nenhuma das faxineiras ou aos porteiros e ao senhor da lavanderia.

\footnotetext{
${ }^{73}$ Naquele ano, a conversão era mais ou menos a que segue: $1 \mathrm{Lakh}=100.000$ rúpias $=\sim 4.000$ reais.

1 Crohre $=10.000 .000$ rúpias ou 100 lakhs $=\sim 400.000$ reais.
} 
No decorrer de minha estada em 2013 e em 2014 fiquei mais próxima de Krishna. Isham não estava mais na casa quando voltei em 2014 e mesmo em 2013 afastou-se de mim quando soube que eu era casada e que tinha trinta e quatro anos. Uma vez perguntei a Krishna se ele tinha namorada, ao que ele respondeu que havia tido uma antes de vir para Délhi começar a faculdade. Disse que depois do fim do namoro, já morando em Délhi, voltou para sua cidade em West Bengal e a viu num consultório dentário. Ele não a reconheceu e ela principiou a conversar com ele dizendo:

- You are not recognizing me.

Perguntei por que ele não a havia reconhecido. E ele respondeu:

- I didn't know her in fact. I only saw her on Orkut. Do you remember Orkut?

Disse que sim e ele continuou contando que haviam por muito tempo conversado pelo Orkut. Falou que eram da mesma cidade e frequentavam a mesma escola, mas não se falavam pessoalmente e que após um bom tempo se correspondendo no Orkut ela teria perguntado a Krishna se ele queria ser o namorado dela e ele dissera que sim, mas que nunca se encontraram, a não ser naquela tarde no consultório do dentista, ocasião em que, segundo Krishna, ela fez muitas perguntas sobre a vida dele como porque havia saído da cidade, onde estava e o que fazia. Krishna fez um comentário que me apressei em anotar quando terminamos de almoçar naquele dia:

- I don't know why she was asking me so many questions. She seemed mad at me, maybe because I didn't recognize her. But we were not in a relationship anymore. And she was looking so different of her DP [display picture] on Orkut.

O que Krishna não percebia, mas estava claro para mim no modo como descreveu sua reação e a da namorada no encontro fortuito no dentista, era que ele desdenhava a garota que o pediu em namoro e que, muito provavelmente, havia cultivado um romance pelas conversas virtuais entre ambos, o que Krishna não parecia ter feito. Perguntei se ele havia tido outra namorada, disse que não, que não dava importância a romances. Foi quando eu perguntei se ele achava que teria um casamento arranjado e ele disse que sim, que não via problema algum nisso. Perguntei: 
- But what if they choose a girl that you don't like?

- They wont. I will participate in the choice.

- How so?

Para responder, Krishna começou a contar a história de um primo seu que havia rechaçado quinze moças apresentadas pela família antes de finalmente concordar em se casar com a décima sexta garota, algo que Krishna, ele me disse, também faria se fosse preciso, até que seus pais escolhessem alguém de quem ele gostasse, alguém que fosse “a good girl”. Quando perguntado o que isso significava ele respondeu:

- Someone like me.

- Like you? What you mean?

- Educated, sensitive, with the same background. A girl who likes the same things I do.

- Like what?

- I like to read, to travel, I like music. In fact I can play the guitar.

- Really? I would like to see you playing sometime.

Para Krishna tanto fazia que os pais fossem arranjar seu casamento, desde que ele pudesse opinar, isto é, aceitar ou vetar a garota, caso não gostasse dela. Não obstante a despreocupação com o arranjo do casamento pelos pais, Krishna demonstrava que características pessoais e gostos em comum eram prerrogativa importante para a realização de um casamento, reiterando, como a gerente do Sycorian Bureau me alertava, que os jovens, garotas ou rapazes, se preocupam com a personalidade do possível par. Talvez menos disposto a testar a compatibilidade com uma namorada, como o faziam minhas interlocutoras, Krishna não descartava a importância de tentar captar a personalidade da futura escolhida e fazia entrever uma diferença entre a "seleção" que havia feito o senhor que viajou comigo no trem até Jaipur e a "escolha" que faria Krishna juntamente com seus pais. É possível, portanto, perceber que a importância dada a encontrar uma garota com personalidade semelhante à dele coloca Krishna num processo de individuação, pois "só indivíduos concretos e singulares 
possuem personalidade", como também nos lembram Viveiros de Castro e Benzaquém de Araújo (1977: 165).

Algo que Krishna havia fincado pé para decidir e não voltava atrás era a escolha de sua profissão. Foi à contragosto dos pais que Krishna iniciou o curso de arquitetura, esses aceitaram sua vontade apenas quando ele disse que a culpa seria deles se fracassasse na vida profissional e que certamente se tornaria uma pessoa frustrada, pois a arquitetura era a sua vocação e não queriam deixá-lo seguir esse caminho. Os pais preferiam que o filho fizesse algo como direito ou engenharia, segundo Krishna, mas a facilidade com desenhos e a admiração pelas construções de diferentes estilos arquitetônicos de seu país lhe diziam que ele deveria perseverar na opção pela arquitetura. A veemência com que Krishna contou-me de sua escolha pela arquitetura apontava para uma visão de domínios autônomos da vida, como a que existe em contextos individualistas. A ideologia individualista ocidental moderna faria acreditar na independência das esferas emocional, profissional, política, econômica, religiosa etc. e era dessa espécie de ficção de autonomia dentre os diversos aspectos que formam o cosmos que Krishna se valia para persuadir os pais, ele apostava na realização profissional por meio do exercício de uma ocupação que estava em sintonia com seus gostos ou, por assim dizer, com sua interioridade.

Diferentemente de Krishna, mas em sintonia com o movimento de individuação, Patrick me apresentava outra preocupação quando falava que não queria se casar, menos ainda com alguém escolhido pelos pais e com quem ele não tivesse nenhuma intimidade ou afinidade. No caso dele, os pais haviam escolhido sua profissão. Patrick frequentou a faculdade de odontologia e trabalha como pesquisador consultor da GlaxoSmithKline na divisão de produtos odontológicos. Segundo ele, teria feito outra formação, ligada à administração de empresas, caso lhe fosse facultada essa opção. Agora ele dizia que não cederia também em seu casamento, embora os pais já o pressionassem para aceitar isso. Em 2015 ele recebia quase que semanalmente, em suas palavras, envelopes que chegavam pelo correio com perfis de garotas muçulmanas da Cachemira que um broker passava a seus pais. Segundo Patrick as moças eram todas tradicionais, "and you know that I hate traditional", dizia triste meu amigo.

Muitas vezes o que esses jovens me mostravam é que estavam buscando uma construção de si como sujeitos que passava pela vontade de fazer escolhas para suas 
vidas - ou talvez vidas que consideravam suas enquanto seus pais não estavam bem certos disso. Ocorre que diferentemente das escolhas individuais que fazemos, ou acreditamos fazer no ocidente, as escolhas na Índia seriam muito mais relacionais, fazendo com que escolhas intrinsecamente individuais sejam vistas como antissociais por excluírem os pais e o resto da família das tomadas de decisão.

Algo que Krishna e Isham deixavam implícito, mas para mim claramente indiciado, é que em suas concepções de uma "boa garota", que o primeiro esperava ajudar os pais a selecionar, e que o segundo afirmava sobre as irmãs, estava incluída a condição de "casta" e "modesta", já apresentadas antes. Dentre os garotos, entretanto, há os que pensam que a castidade exigida da moça deve valer para os dois sexos. Falemos de Kaushik a esse propósito.

\section{Os jovens podem escolher, desde que sejam razoáveis}

Em um jantar na PG em janeiro de 2015, Kaushik e eu sentamos na pequena mesa colocada em frente à recepção e ficamos muito tempo conversando mesmo após terminarmos a refeição. Tínhamos tido pouco tempo para estar próximos, já que uma semana e meia daquela estada eu havia gasto no casamento de Shubhi e nos momentos que passei com ela após as cerimônias no intervalo entre a lua-de-mel nas Ilhas Maurício e a mudança com Ravi para Mumbai. Kaushik, como quase todos os demais moradores da PG, não havia sido convidado para o casamento, pois Shubhi nunca o considerara um amigo. Naquela noite, Kaushik reafirmou, mas também expandiu, muito do que havíamos conversado sobre o tema de minha pesquisa nos anos anteriores, desde 2012 . Começou com sua pergunta:

- So now you are done with your research?

- I'm in the process of writing up the thesis. I want to write five chapters and I have two by now. So until June, July I have to write three more.

- Achha, achha [good, good]... and what are your conclusions for your thesis? Mutlab [I mean] what kind of conclusions did you find in your research? 
- Wow! Well... let me see... I initiated thinking about arranged marriages and love marriages, the differences between both these ideas... but then, I ended thinking of what kind of love is present in India. I mean, how is love in India. What does it mean? I think there is one idea of romantic love in the Western World that is not coincident with the one present in India. The basic difference for me is that in the West we give love a very powerful idea, better saying, we think that love is a very powerful feeling, we can do anything for love or we can change anything for love. Love is the main reason, or maybe the only acceptable reason for marriage. And here although love is also present, it's not a requirement for marriage, and love will not be the only reason for it as well, and it will not be enough. Love can happen between couples if other things are present. Like, they need to belong to the same religion, the same caste, the same socio-economic background... depending on the families, the parents, and the couple, love will be possible or not... let's say, Shubhi for instance, she just got married, and it was called a love-marriage. But there was more involved, the parents had to accept, to meet before, to give their permission, then they got married, if there was no such thing, marriage would not have been possible. What do you think about these ideas? It does make any sense or am I totally wrong?

- Achha! It does make sense. But your research is only about India or are you going to do any comparison?

- See, I am focused in India, and is not even the whole India, it's just North India, urban spaces, because I only did fieldwork in Delhi, so for me it's not possible to make inferences on other parts of the country, or about rural areas, or even about poor neighbourhoods, because I haven't seen any of this, so I can't say anything about that. But about the comparison, since I am Brazilian I would say that my initial point, my starting point of view is Brazil and the Western world so of course any thing that I say I might be thinking in a comparative way, but only because of that, because my ground is the Brazilian case, so I can't avoid having this point of view...

- Ham, thik hai [Yes, okay]. Ya, here love doesn't happen that way you were saying, like in the Western world you can marry anyone as per your choice, but here...

- But I didn't say that exactly. I said that this is the idea that we make about love and marriage. But is not true that we will marry any person, just like that... 
- Ok, but here, it's like parents will give you a lot of 15 girls for example, and out of those 15 you will choose one, or maybe you wont, then they will give another lot of... say 15 girls again, and again they will ask you to choose one... this is the kind of choice that parents give nowadays, you can choose whom you want, as far as it is one of those among that lot. Before parents use to tell their kids, see there is this relative, the daughter of my cousin... see, in South people marry their cousins, distant cousins, not first cousins, because you would have genetic problems.

- And maybe it would be too strange as well, no? Because here cousins are raised as brothers and sisters, $n a$ ?

- Ya, achha. So you marry someone not so close, I mean the ancestors should not be common. Like my ancestors should not be the same of my bride-to-be.

- Are you talking about gotra?

- Yes, exactly, gotra. So the bride-to-be should be someone distantly related and not from the same gotra. Do you know what gotra means?

- I think it's a blood relationship, na?

- Yes, exactly! Gotras are clans, family clans. So, yaar... in my case I would have to consider all these things for my match, gotra, caste, age, I would like to have someone with the same mind-set as mine, so... because it's important to have common interests, or at least some shared interests, and horoscope as well, I'm sure you must know that there is a thing called kundli.

- Ya, you told me about it before.

- Ya, so, horoscope also has to be done, and do you know what? You can find out your gotra and hers doing the horoscope. According to the day and time you were born and her as well, the astrologer can say if you are from the same gotra.

- Really? 
- Ya, it's all mathematics. According to these basic data the astrologer will know if a couple-to-be is from the same gotra or not. So he will make the maths and tell if the couple is compatible. And it will take into account some predictions for the future as well. So, lets say that in a certain period of life the guy will face a problem, like a decease, a problem with money, a broken leg, anything... they will see... ok, at this time in the girl's life, how will she be? Ah, ok, the guy will be down in ten years, and by the same time the girl will be up, so they will be able to balance each other, so that some stability will be possible.

- Really Kaushik?

- Ya, that is also the importance of horoscope. So I was telling you... this is the kind of choice the parents are offering to their children. They are basically saying, you can have your choice, you don't need to marry who I choose for you, you can choose, but be at least reasonable, choose someone among this lot, someone with these and those features, don't go beyond and pick someone too different from yourself. Just be reasonable.

- Like someone told me these days that a Hindu girl choosing a Muslim guy can be considered non reasonable. Eu pensava em Gunjan, sem revelar seu nome.

- Oh, $\operatorname{yar}^{74}$, that is considered an impossible marriage! See, in India we believe in living together, Muslins, Hindus, Jains, Christians, we all live together, and there is no such a thing as my religion is better than yours, or mine is correct and yours is wrong, no, there is no such a thing. Everything is correct if it is good for you, if it does not make you or others any harm. But we also believe that marriage is something that must be done among pairs, and I'm not saying the couple, because here is not about the couple, it

\footnotetext{
${ }^{74}$ Kaushik usa constantemente o termo "yaar" como uma interjeição, esse uso é corrente no modo de falar em Mumbai. Mody, que é proveniente de Mumbai, comenta que o uso dessa expressão em Délhi durante o trabalho de campo a fez ser mal interpretada por um motorista de auto-riquixá, pois esse leu a expressão como significando "amigo" ou "amante" em hindi. Kaushik, Anyndia, Rekha e uma das colegas de república de Pryia também utilizavam a expressão apenas como interjeição, uma espécie de gíria, e meu reconhecimento do que Mody queria dizer veio da convivência com essas pessoas. Essa passagem de uma conversa com Kaushik, da qual tomei nota no Costa Coffee em Green Park Market onde fui tomar um café logo em seguida àquele almoço, preserva algumas expressões em hindi porque Kaushik e Anyndia insistiam para que eu tentasse ao máximo me comunicar com eles em hindi para melhorar meu conhecimento da língua e acabei anotando a conversa desse modo. Como eu voltava depois de sete meses passados no Brasil sem praticar o idioma desapontava Kaushik que insistia em falar em hindi enquanto eu repetia: Kya? English men bolyé! [What? Please, talk in English!]
} 
is the family that get married as well. But some things should be compatible for the marriage. Otherwise it's just too much of complication.

- And what about love, Kaushik?

- See, I am not a guy into relationships. That's just not for me.

- Why?

- I don't feel like having a girlfriend and then getting involved, fall for someone and then marrying that girl or maybe not. Because I want to respect my parents. I want to follow their predictions for me. If you don't do that life is just too much complicated.

- Do you think this is the reason why many guys date a girl for a long time and then marry someone else of his parent's choice?

- No. I think it's not like that... see I don't like such things, I don't wanna fall for anyone, but some guys they will just think: Ya, I can have some fun now and tomorrow I will see what happens. If I were a guy into romance and stuff and fall for someone I would marry that girl. The guy should stick to what he feels and think. But some guys will just have some fun today and tomorrow marry someone else, not because of the parents pressure, but because that was his choice.

- Interesting! I agree with you. A lot of people were telling me the opposite until now, but I like the idea that the guy has a choice.

- Ya, exactly! It will go as per his idea and choice. That's why I'm not into relationships. It's my choice.

As ideias de Kaushik ressoavam falas de Krishna nos anos anteriores sobre um "lote de garotas" dentre as quais o rapaz pode escolher, como fez seu primo e ele diz que fará até encontrar uma candidata escolhida pelos pais que ele também aceite. De mesmo modo, Krishna e Kaushik não faziam o tipo que ficava atrás de garotas de modo afetivosexual, diziam não ser interessados em romance. Quanto ao contato físico com garotas me ofereceram respostas diferentes. Num dia que voltava com Krishna de uma ida à 
Mother Dairy em SDA Market, ele disse que não se aproximava de garotas porque pretendia se casar do modo como os pais queriam e se ele se tornasse íntimo de alguma garota iria se sentir ligado ("attached") a ela e isso seria uma complicação em sua vida que ele preferia evitar.

Quanto à Kaushik, desde 2012, num dia em que conversava com Patrick, Dileep, Shine e eu, dizia que iria se casar virgem porque esse era o costume que lhe havia sido ensinado. Naquela ocasião os meninos queriam assistir a uma partida de cricket pela TV em um restaurante em Green Park Market e Shine queria ir junto, mas só iria se eu fosse, para não sair sozinha só com rapazes, eu disse que precisava ler algumas coisas e tomar notas e que estava preocupada com minha pesquisa que não deslanchava. Kaushik disse:

- Come on, yaar! We can teach you everything you need to know about marriages in India.

- Haha... Okay, Kaushik let's go then! Let me take my bag in my room.

Enquanto aguardávamos o início da partida, Kaushik explicava-me o sistema de parentesco do sul do país (dravidiano) e falava do casamento entre primos, que Shine disse desconhecer e que pareceu-lhe um costume muito estranho. Então falou que a moça e o rapaz eram conduzidos ao casamento ainda virgens e disse tendo Patrick e Dileep como interlocutores:

- Come on guys, help me to explain this to her. That's it, na? - Dileep olhou para Patrick querendo rir e esperando que este dissesse algo.

- Dude, speak for yourself! - respondeu Patrick.

O jogo começou e a aula daquela noite se encerrou. Em 2014, num jantar no restaurante Beeryani, Kaushik e Anyndia ridicularizavam Rekha pela noite anterior em que ela havia bebido e, como o bar onde estávamos estivesse fechando, sugeriu que fossemos para outro lugar. Anirudh ofereceu sua casa e fomos para lá num auto-riquixá. No meio do caminho, Rekha começou a passar mal e, talvez pelo movimento do veículo, sentiu-se mais alta do que estava no bar. Repentinamente começou a chorar e chamar 
por Praveen. Ela dizia que queria falar com ele e me pedia para discar o número dele em meu celular, já que o dela ficara sem bateria, o que eu não fiz.

No dia seguinte, Anindya e Kaushik diziam que Rekha, que teve uma amnésia de tudo que aconteceu após entrarmos no auto-riquixá, teria ficado dizendo:

- Fab, call Praveen! I want him here! I want him in my bed!

Os dois primeiros períodos eram verdadeiros, mas o terceiro era uma invenção de Kaushik. Rekha dizia:

- Go to hell Kaushik! I'm a virgin I would never say that!

- A virgin? That's not what you told us yesterday - disse Anyndia fazendo dupla com Kaushik nas provocações à Rekha.

- I know I didn't say any of these. Come on Fab, tell them to stop!

- Leave her alone, guys. She didn't say these things and she is a virgin, I totally believe her. And I know that you are virgin too Kaushik!

Todos rimos e Anindya estendeu sua mão para que eu tocasse fazendo "hi five". Rekha então resolveu provocar Anyndia dizendo:

- What about you Anindya? Tell us about your sex life!

Anyndia disse que não era virgem desde os dezenove anos, ou seja, desde seis anos antes. Rekha perguntou novamente:

- How it happened?

- It was with a friend's friend, at her house. She was older than me. It was my first time, but not hers.

- And did you guys were dating? - perguntei. 
- No, it was just a one time thing. Enough about me. Tell us something Kaushik.

- There is nothing to say dude, I am going to have sex with my wife, that's it.

- I know - disse Anindya, que era colega de quarto de Kaushik naquele ano e já conhecia os propósitos do amigo.

Em agosto de 2015 quando estávamos, Kaushik, Anyndia, Rekha e eu, num chat pelo WhatsApp, Anyndia disse que em Délhi nunca ficava com garotas porque estava sempre acompanhado de moças comprometidas como Shubhi, Rekha e eu e desse modo nunca conseguia ficar com ninguém porque nós afastaríamos as outras garotas. Rekha disse que da próxima vez que vivessem na mesma cidade ela deixaria Anyndia e Kaushik livres para que pudessem tentar ficar com garotas, embora duvidasse que alguma quereria qualquer deles. Kaushik apenas respondeu:

- If you let me free I might just get married. I don't believe in petty fun...

Kaushik reiterava assim que sua visão sobre "ficar com garotas" é de que isso é uma distração insignificante. Kaushik não acionava a explicação dada por Krishna - e por Lovania em outros momentos - de que quando se tem intimidade física com alguém torna-se ligado emocionalmente àquela pessoa e isso leva a problemas, principalmente se é preciso se afastar. Ele tributava ao modo como os pais o haviam ensinado sobre casamento o fato de querer esperar pelo casamento para iniciar sua vida sexual.

Com essas e outras ocasiões eu tinha elementos para reafirmar minha impressão de que os rapazes fazem brincadeiras tanto com a sexualidade quanto com a expectativa de romance das garotas, mas falam menos de si. Quando falam, contudo, expressam despreocupação quanto ao romance e mesmo quanto ao sexo, ou porque estão convictos de esperar até o casamento, ou, como no caso de Anyndia, Patrick, Dileep e Anirudh, porque não têm nada a perder fazendo e confessando sexo antes do casamento. Os rapazes não faziam piadinhas com Kaushik por ser celibatário e pareciam, assim, afirmar que a sexualidade feminina é que é motivo de risos e suspeitas. Além do mais, a conduta de Kaushik quanto à castidade (brahmacharya) antes do casamento coincide com a ideologia amplamente promulgada no hinduísmo de que sexo fora do matrimônio não se destina à procriação e é algo mundano e potencialmente poluidor. Sobre isso Sudhir 
Kakar, o estudioso que se destacou por buscar analisar psicanaliticamente o que ele chama de mente indiana, sem perder de vista o aspecto cultural que não permite que a psicanálise seja simplesmente transplantada de um contexto cultural a outro, afirma:

"This ascetic ideal, intimately linked with the Hindu concept of purity and impurity, proposes that what is most pure needs the greatest protection. Semen, the purest bodily product of a man and the source of his power, needs to be protected from the woman's ferocious and insatiable desire. Innumerable myths equate bodily weakness of loss of spiritual power in a man or a god with a loss of semen. These myths and legends vividly demonstrate why the ideals of sexual restraint and celibacy enjoy such a high status in Indian culture." (Kakar, [2007] 2011: 170)

Kaushik talvez nos permita entrever o fato de que, não obstante a crítica feita aos estudos, demasiados, sobre a interconexão entre religiosidade e sexualidade na Índia, anteriormente apontada, essa relação continua a informar disposições práticas para a vida. Os múltiplos ordenamentos de realidade uma vez mais se faziam presentes na minha convivência com os amigos da PG.

A assimetria referida acima entre o amor esperado da esposa e o amor que o marido deve refrear em face de outros deveres morais parece estar em relação com o pensamento da maioria dos rapazes com quem convivi, estes eram menos preocupados com o romance antes do casamento ou no interior da vida conjugal, como Isham, Krishna e Kaushik faziam entrever. Uma noção de dharma também aparecia nas falas deles quando discursavam sobre a escolha das profissões que seguiriam ou sobre as carreiras que já haviam iniciado, essas eram escolhas que eram motivo de preocupação por parte destes em detrimento das preocupações com o amor. Por outro lado, Patrick, Anirudh e Anyndia, de diferentes maneiras, mostravam-se afetados pela ideia de amor e romance antes e após o casamento. Vejamos de que modo se afastam dos garotos precedentes.

\section{Yolo! 75}

\footnotetext{
75 "Yolo" é uma sigla e uma expressão em língua inglesa que significa "you only live once". Esse era o lema de vida de Anindya e Anirudh. Patrick, embora não utilizasse a expressão, seguia um estilo de vida próximo aos dois primeiros, os três fumavam, bebiam, saíam à noite com frequência, e ficavam com garotas. Tudo isso devidamente longe e escondido dos pais. Além deles, Ragavendra, amigo de infância de Anyndia, e Vishnu e outros amigos de Anirudh compartilhavam o mesmo estilo de vida. Entre as garotas algumas restrições, como visto, eram impostas, mas diria que Rekha, Shubhi, Kirti, Pryia, Trisha, Meena e eu poderíamos ser tidas como
} 
Começo por aquele que primeiro se tornou meu amigo na PG. Patrick tem um modo de pensar sobre namoro, casamento, família e moralidade que destoava das meninas e de alguns meninos da PG também. Em 06 de abril de 2013, tomávamos café da manhã no Southy, uma lanchonete próxima à PG. Na saída do lugar comentei que tinha a impressão de que as pessoas ficavam nos olhando quando andávamos juntos, perguntei se era por que eu era estrangeira.

- There's nothing to do with this. It has to do with the fact that you are a girl and I am a guy, so they think that we are dating. And this is what people here can't admit. Have you ever seen a couple kissing in public in India?

Eu disse que não, mal vira pessoas de mãos dadas ou se abraçando, quanto menos se beijando. E ele disse:

- Exactly! Of course you haven't, because people can't kiss, hug or hold hands in public, yet they can pee in the streets everywhere.

Ele continuou dizendo que isso era em Délhi, a capital do país: em outras cidades menores, o quadro seria bem pior. Em Délhi e outras cidades grandes, segundo ele, as pessoas até que não se preocupavam muito com essas coisas, não ficavam encarando ("staring") muito os casais, mas em cidades pequenas e aldeias, todo mundo participaria da vida dos outros. Perguntei como era em Srinagar, capital da Cachemira, onde ele nasceu e foi criado, Patrick disse que se parecia mais com as cidades pequenas que com Délhi.

Por essa mesma época, contei a Patrick que conhecera o rapaz chamado Dileep no avião quando vinha do Brasil. Disse-lhe que este voltava para a Índia para se casar e que havia vivido dez meses no Brasil, trabalhando com tecnologia da informação, e há seis meses não voltava para casa. Contei que o moço estivera em Mumbai pela última vez para ficar noivo e seria a segunda vez que iria ver a noiva pessoalmente, haviam se selecionado por perfis enviados pelas famílias a cada um deles, noivo e noiva. Dileep falara durante o voo sobre o novo casal residir com os pais como uma forma de retribuir tudo o que os pais fizeram pelo filho, uma vez que o criaram, educaram, fizeram o melhor que puderam e, após o casamento, com o envelhecimento dos pais, mereciam que os filhos cuidassem deles e lhes permitissem descansar, que dali em diante os filhos

garotas que compartiam desse estilo de vida, com a condição de que nossas vestimentas e sexualidade fossem discretas e respeitáveis. 
tomassem conta do lar, das decisões e tudo o mais. Patrick discordava de tudo isso. Para ele, embora os pais tenham cuidado, educado e pagado sua faculdade não deveriam esperar que ele agora fizesse a vontade deles por causa disso:

- It's my life, not theirs.

Ele dizia que mais cedo ou mais tarde seus pais iriam querer forçá-lo a se casar e ele teria que os desapontar e lutar ("struggle") contra a ambição que tinham de casá-lo a despeito de sua vontade. Patrick dizia sempre: “I hate traditional!” Referia-se às moças tradicionais, tanto muçulmanas, quanto hindus. Ele, aliás, nunca namorou uma moça muçulmana, todas as namoradas de Patrick foram e continuam sendo - enquanto escrevo essa tese conversamos regularmente - hindus. A exceção fora um amor platônico que Patrick desenvolveu por sua colega de escola quando tinha oito anos de idade. Acho essa passagem divertida e tocante todas as vezes que ele a reconta.

Naquela idade, Patrick pensava que a menina, para ele a mais bonita de toda a escola, seria um dia sua esposa. Para conquistar a garota resolveu escrever uma carta confiando seu amor e amarrá-la a um balão de ar quente para que pudesse viajar até a menina. Em sua mente lúdica tudo correria bem, o balão encontraria a destinatária e ela leria a carta que lhe escrevera. Quando se preparava para soltar o balão no quintal de casa, a mãe o surpreendeu naquela maluquice infantil, leu a missiva presa ao balão, rasgou os dois objetos e deu uma surra dolorida em Patrick para que ele nunca mais pensasse em meninas, amores e cartas. De modo talvez semelhante a um romance de Bollywood, Patrick, quando criança, pensava no amor como algo bastante fantasioso, que o fez imaginar que um balão solto a esmo chegaria por obra de mágica até a garotinha de seus olhos. Evidentemente, para mim, a pobre mãe de Patrick não logrou êxito com a surra, pois ele é, dentre todos os jovens indianos que conheci, o mais namorador e paquerador. Seu charme de Don Juan não funcionou, entretanto, com quem ele mais queria que tivesse dado certo, minha amiga Pryia, como já sabemos.

Como disse, Patrick repetidamente dizia que seu país ainda não era desenvolvido, dava como explicação para isso algo que Rekha também afirmava: que as pessoas mais velhas querem comandar e controlar os mais novos, decidir tudo por eles. Para o rapaz isso era sinônimo de atraso e de não desenvolvimento. Foi por isso, segundo ele, que me perguntou um dia se eu achava a Índia um país desenvolvido. Disse-lhe que esse era um conceito complicado porque não definia nada e era um rótulo imposto por países que se 
consideravam desenvolvidos e olhavam pra outros lugares com uma visão que chamávamos em antropologia de etnocêntrica. Completei dizendo que pensando assim eu poderia dizer que a Índia era desenvolvida ou não, dependendo de qual fosse o conceito de desenvolvimento empregado. Ele disse que eu podia dizer que sim, mas ele continuava achando que não seria um país desenvolvido enquanto as pessoas não tivessem liberdade para viver como elas queriam.

Quanto às visões de Patrick sobre o romance e o casamento, vimos nas discussões dele com Shubhi e com Rekha que ele apregoava não querer se casar. Quando teve uma paixão aguda e platônica por Pryia, no entanto, disse que se casaria com ela, caso essa o aceitasse como noivo, comportando-se àquela altura de modo inesperado para a garota e incompreensível para mim, que ao lado de Kirti, Anirudh e Pryia fomos os únicos a saber do ocorrido. Eu dizia a ele:

- I don't understand the love you feel for her. I think it's an idealized feeling, because you don't know her. She thinks the same by the way.

- Did you speak to her about it?

- Yes, a couple of days ago.

- And what did she say about me?

- She doesn't want to see you. She's mad because of the flowers you sent to her office, even her boss was questioning her about it.

Em outros momentos voltamos a conversar sobre o amor que ele nutria por Pryia e sobre porque ele me contava tantas coisas sobre sua vida, relacionamentos e sentimentos, mesmo sabendo que eu poderia publicá-los numa tese. Um dia em 2014 conversávamos pelo WhatsApp, ele em sua casa em Gurgaon e eu na PG, e Patrick disse:

- You remember when you once told me that I keep telling you about my personal life without fear and the reason you thought was that you belong to a different country and you were not going to stay here forever? I wanted to tell you today that this is not the reason why I tell you things and about my girlfriends etc. etc.

- So what's the reason? 
- The reason really is that the kind of thinking people here carry is different. You have seen and tested them yourself... we lie and hide things and you have seen people conspire, gossip and spread venom about people they hardly know.

- Oh my gosh! Don't exaggerate!

- You are not from this society and the fact that I know you a bit I also know that none of these characteristics dwell in you. You are different and you understand things.

- Oh, so sweet of you Patrick! But in fact that is my work, at least I try to...

- I can tell you things knowing that you understand me. I am not trying to please you but I wanted to tell you this for a long time now. My question is why do you think love can't exist between people who don't know each other so well?

- Oh... Let me see... In fact I don't really think that love can't exist in such a situation. I believe in your love for Pryia, for instance... It's real, you feel that... What I think though is that this love not necessary will lead to a relationship. In fact this idea came to me through her comments that she never understood why you fell in love with her knowing her so little... Another idea, this one is mine, is that when we love someone without knowing the person we tend to idealize the person, only seeing the good things, as if the person was perfect... I have this idea that love is when you know the person and even so you still like her, lol... Did I make myself clear?

- Quite so, yes. I feel it necessarily doesn't have to turn into a relationship...

- Ya, that's true... But I think what I told earlier was that your love for her was idealized, na? But love not necessarily will turn into a relationship, you are right.

- And that each man and woman on earth doesn't have to take this direction when they love. Marriage or union is not the final cut of the movie. It is the relay in between when one feels for someone. And this someone can be practically inaccessible.

- Ya, I got your point and I agree... Maybe I think the way I do because of my own fear of solitude... 
- I may never achieve what I began this journey for but this is not frightening. It may not make sense to many around but you professionally may understand this. That's all my lord.

- Sorry?

- No more witnesses. Case adjourned. Now tell me where were you last night?

- You are a character... I was in the Capitol, the club. With Shubhi, Rekha, Anyndia and Lovania.

- I know. Lovania called me up and told me.

- If you already knew why do you ask silly?

- I was playing daddy.

- Monster! But I think I understand what you tell me... And I agree... If the loneliness doesn't frighten you, you are really brave and have no reason to change your $\operatorname{mind} .$.

- I am prepared I guess.

Aos trinta anos, Patrick continua solteiro e afirmando estar preparado para a solidão que poderia surgir de sua disposição em não se casar, ou de só se casar se encontrasse outra Pryia, o que eu continuei sempre dizendo que era difícil, pois Pryia era uma idealização de sua mente, ao que ele respondia que iria se apaixonar novamente um dia. Em 2015 conversamos sobre os perfis que seu pai lhe envia frequentemente demonstrando que a imposição de que ele deve se casar não cessou.

- You know what? In my third chapter I tell the story of Patrick and Shubhi.

$-\mathrm{Sh}^{* * !}$ - lol [lots of laugh]...

- Why do you laugh? Till now I wrote that there was this couple, they were fine...

- Patrick piece of cr**! 
- Lol... No, it's not like that, I don't say so... They were fine, enjoying each other's company... Until the girl decided that was time to have some commitment. Then Patrick said: you know, baby, this marriage thing is not for me.

- Commitment is the funniest part.

- Then we could hear her shouts from the first floor. Then they started trying hard to separate and forget each other.

- Patrick, that piece of $\mathrm{cr}^{* *}$ !

- Let me finish my novel!

- Okay.

- The girl kept thinking that marriage and kids were a very important part of life. Then she found someone to marry and she started trying to work out with this guy. The new guy started making the courtship to the girl.

- Hehehe...

- And Patrick got jealous. Did he realize that he like her more than he thought initially? Did he fall for her? Who knows?

- Not at all.

- No? Ha ha...

- Patrick knows he didn't. Pat wouldn't have let her go if he did love her that deeply.

- I conclude saying that probably he didn't love her enough to marry her, but enough to get sad with the situation.

- He is not sad.

- I'm saying back in that time silly! You were sad. I could see.

- No. 
- Weren't you?

- I don't agree.

- And what about all that drama on her birthday?

- I didn't like the face of her friend. Just wanted to punch it once. Deform it. That's all.

- That was jealousy! So you disagree with my end? I'm not saying that he was madly in love with her.

- No, you can keep that ending.

- Or that he suffered a lot. I'm just saying that the love between them was not enough to marry but enough to live a story and get sad at the end from his part.

- Okay, maybe.

- Haha... maybe?

- Part agreed.

- Okay. The other thing about Patrick is that he is trying hard to avoid marriage.

- Running left and right to avoid falling into the trap.

- Haha... I'm gonna put this sentence in my work. Is his family making any pressure on him about that? Or no?

- Very much. But Pat is full of resistance.

- How his parents show this pressure? And what does he answer?

- Calling him thrice everyday. Telling him about a newfound proposal.

- Oh... Really, my dear?

- He only stores their pictures for his album. 
- Are they advising on Pat's behalf or just talking to family, friends and neighbours?

- When he is old, he'll look back at the pages of this album and think to himself how he avoided so many traps and lived a free life. There are middlemen visiting his home with proposals.

- Like brokers? With proposals?

- Yes, like brokers. Yes, like with pictures of gals and guys desperate to find a match so they could make kids.

- Like profiles of gals offering to marry? But these profiles you have were sent by your parents? You never talked about it.

- By brokers to my parents and from my parents to me.

- Ok, I know how it works.

- It's a very casual thing here.

- But I never knew that they were doing this to Pat. And you just ignore these profiles? This make you sad or you don't pay attention to this?

- Haven't really met anyone cute and smart in these proposals. They all look very traditional. And I hate traditional.

- But it does bother you? Yes, I know you don't like traditional.

- It does, yes.

- And you don't wanna go for an arranged marriage too.

- Yes.

- If our friend that you like, if she felt for you, would it be a problem to marry her? I mean your father would oppose?

- I will go to the end of the world to marry her. 
- So it would not be a problem for you. But what about your parents? Would they dislike it?

- No problem is a problem if you are willing to overcome it.

- Ok, but...

- My dad will give severe resistant but my mom may agree after a while. But that would not stop me.

- Ok, got you. I keep listening to these stories and I try to figure out how I would react in this case.

$-?$

- If my mom or dad were trying to marry me. But I don't have an answer.

- You mean, you don't know what it is like to marry the guy of your choice against your parents will.

- Yes, I don't. My mom has always liked André.

- Obviously your parents did not retaliate this much.

- And my dad is not alive anymore but I think he would like him as well.

- I am sure he would.

- And on the other side I wonder how it would be look at profiles trying to decide if the guy would be or not a good husband. Ya, I think so but who knows? My father would probably oppose to us moving in together without marrying as we did.

- Look at profiles like you are shopping for a husband... with no product return policy. Once sold is sold.

- Oh my god! It sounds so bad!

Em janeiro de 2015 quem estava também sendo sondado pelos pais para o casamento era Anirudh, que até então nunca havia comentado que os pais queriam casálo. Quando o conheci em 2012 ele contava vinte e quatro anos, seu colega de quarto à 
época, Hemant, de vinte e sete anos, estava para se casar. Perguntei à Anirudh quando seria a vez dele num dia em que conversávamos durante uma refeição na sala de jantar.

- Me? Oh, no, I don't think about marriage.

- No? Why not?

- I still have plenty of time to think about it in the future. Not now...

Passados três anos, Anirudh, Pryia e eu caminhávamos de Hauz Khas Village para a PG, de onde eles tomariam um auto-riquixá para que ele a deixasse em casa e depois seguisse para seu apartamento. Ele contou-me, enquanto Pryia andava à frente com um amigo dela, que da última vez que esteve na casa dos pais em Hyderabad, o pai lhe havia feito perguntas que nunca havia feito antes.

- So last time I was in my parent's place my dad came to ask me things, like: what's going on in your life? Are you seeing someone? When are you thinking to settle down?

- Ouch! And what did you answer?

- What is there to answer? I said I am not thinking about it. I'm sure it was my mom's idea.

- What was your mother's idea?

- To ask my father to talk these things to me.

- Oh, you think so?

- I can bet. It doesn't sound like my father's behaviour.

Anirudh me contara nos anos anteriores que havia tido namoros curtos desde a época da faculdade de direito, que havia cursado em Gujarat. Numa noite em sua casa, Shubhi perguntou-lhe quanto tempo tinha durado seu namoro mais longo, ao que ele respondeu que dois meses e meio. Ele contava quando estávamos só Pryia, ele e eu que não era muito sortudo com garotas e relacionamentos, os namoros acabavam sem mais nem menos. Diferentemente de Patrick, que eu e outras garotas considerávamos um Don Juan ou, na visão de Prya, era um "womanizer", Anirudh era mais tímido quando o 
assunto eram flertes. Eu diria que era também mais respeitador em suas abordagens, se ele fosse um "womanizer", Pryia não seria uma amiga tão próxima a ele e teria, em vez disso, conquistado a antipatia dela, como o fez Patrick. Por outro lado, Lovania e Shubhi já disseram de Patrick que era um "gentlemen", pelo que entrevejo que a leitura do que constitui "a good guy", "a husband material" ou "a harrasser", variava muito mesmo num pequeno grupo como aquele com quem convivi.

Anirudh sempre dizia, nos anos anteriores, que teria um casamento que ele escolhesse, que não iria aceitar um casamento arranjado pelos pais, pois não queria se casar com alguém que não conhecia e de quem não gostasse previamente. Lembro de ter perguntando um dia, em 2012, se ele respeitaria uma garota que tivesse tido outros relacionamentos antes dele e se casaria com uma moça que não fosse virgem. Em minha mente naquela ocasião corriam ideias sobre um artigo de jornal indiano que lera falando da expectativa masculina de casar com uma moça virgem à despeito de muitos responderem, segundo o jornal, que consideravam sexo antes do casamento desejável. Anirudh me respondeu:

- That is the only way that I respect a girl, if she has personality! So what if she had other relationships? So did I.

A noção de personalidade, explicitamente referida por Anirudh, remete novamente ao tema da individuação, como proposto por Viveiros de Castro e Benzaquem de Araújo, "pois só indivíduos concretos e singulares possuem personalidade". Para que a idéia de indivíduo não pareça demasiado exaltada por mim trago a reflexão em que aqueles próprios autores nos lembram que o indivíduo também é um papel social, diferente da ideia de persona, mas ainda assim um papel social.

"Queremos apenas lembrar que essa noção de "personalidade", de mana individual, do ponto de vista sociológico pode ser exorcizada: ela não se refere a alguma "coisa" "interna"; ao contrário, aponta para um papel social. O papel social "indivíduo", tão atribuído quanto qualquer outro." (Viveiros de Castro e Benzaquem de Araújo, 1977: 166)

Além de um amigo próximo, a quem eu podia ligar quando tivesse qualquer problema, como de fato o fiz várias vezes, Anirudh é um jovem inteligente, desenvolto, divertido e, como boa parte de meus interlocutores, absolutamente responsável. À despeito da pouca idade, Anirudh fazia parte de um dos melhores escritórios de advocacia do país e tocava sozinho grandes causas, como me diziam os outros 
moradores da PG que também eram da área. Motivo que me levava a recorrer a ele para me informar sobre aspectos da legislação indiana no chamado direito de família. $\mathrm{Na}$ noite em que estávamos no Beeryani com Gunjan falávamos das leis que regem casamentos e divórcios na Índia.

Perguntei a respeito da polêmica sobre não haver uma lei que considere sexo forçado dentro do casamento como estupro. De fato, segundo ele, isso não é claro na legislação, o que para ele era uma pena, mas, de fato, pela lei indiana não é crime forçar a esposa a ter relações sexuais, e essa ausência na lei está calcada na ideia de que certos papéis devem ser cumpridos dentro do casamento. A ideia de que o sexo consuma o casamento ainda é vigente e é inclusive aceita para pedidos de divórcio ("ground for divorce"), tanto para o marido quanto para a esposa. Ele diz que apenas quando um casal não quer de forma alguma permanecer mais junto, "let's say that they hate each other to an extent that they just can't stand being together anymore, then they will be allowed to proceed a divorce, otherwise a ground for divorce would be impotence in the men's case, or the impossibility of conceiving for women's case. So unless the couple hate each other so much that they could kill each other, or the marriage is not being consummated with sex, or the woman can't conceive there is no ground for a divorce. India has the lowest rate of divorces in the whole world. By the way I don't work in these cases. It's just too complicated, I think it's a too personal matter for me getting involved, so I would never want to take a case in this field. Also for sexual violence, because basically the law protects woman, the law assumes that the woman must be protected but depending on the state or on the judge the women will be screwed."

- But how can you say that the law is intended to protect women if there is no law against sexual violence inside the marriage?

- See, this is not clear in the law, it's a controversial matter. So this is what I am saying depends on each case, depends on the judge, depends on the state. It will take a long time for these things to change here.

Pergunto se, no caso dos divórcios, a mãe é quem costuma ficar com os filhos.

- The mother is always the one to stay with the offspring. In very exceptional cases the father will have the kids. 
- In Brazil nowadays parents that get the divorce are having something called shared guardianship, it means that both the parents can spend equal or almost equal time with the kids, depending on the availability of time and if they wanna do that. Do you think this is going to take some time to happen in India?

- Long, long time... see, raise children here is still seen as a women's task. Of course this is changing but I don't see a change in the legislation taking place soon.

- And what about the legal grounds for marriage?

- See, marriage is a matter of which law the marriage will fall in. You have Hindu marriage, Muslim marriage, Christian marriage, Sikh marriage, and Jain marriages. And you also have the Special Marriage Act, which is a civil marriage law. Each one follows the religious prediction for marriage and for divorce.

- What about inheritance?

- Same thing. It follows the specifications of each one of those marriages. If it's a Special Marriage Act, then husband and wife will have equal rights, in the other cases it will depend on the specific law. See, this was decided by the British rulers, they didn't want to interfere much in the local laws, so for family affairs they left the laws the way it was...

Apesar de pontuar falhas e imprecisões na legislação indiana, Anirudh não desacreditava o sistema de justiça de seu país, como o fazem as feministas, mas também não negava as críticas realizadas por essas com afirmações do tipo "it will depend on the judge", "it will depend on the state", deixando claro o personalismo moral do sistema legal.

Embora diferentes em comportamentos e modos de pensar a vida, Anirudh e Patrick tinham em comum a vontade de estar no comando de suas vidas, e de se verem livres das obrigações familiares. Ambos desejavam poder fazer escolhas para suas vidas: se casar ou não, como, quando e com quem. Agora eles compartilhavam também a aflição dos pais em relação às suas visões sobre o matrimônio, seus pais enfrentam o mesmo dilema: como casar os filhos? 


\section{A modo de conclusão sobre as diferenças apresentadas por garotos e garotas quanto ao romance}

Soumita, uma jovem de vinte e seis anos, acabara de sair de um relacionamento amoroso, em 2012, com um rapaz que a decepcionara, pois viviam discutindo e ao fim romperam o relacionamento que Soumita esperava redundar em casamento. Ela me dizia com todas as letras: "Men are dogs!" Para Soumita, o fato de ter tido um relacionamento de sua escolha por três anos e que não terminou bem, ou seja, em matrimônio, demonstrava que os relacionamentos têm mais chances de dar certo quando arranjados pelos pais, pois estes saberiam o que é melhor para seus filhos. $\mathrm{Na}$ visão dela os pais iriam checar todas as informações e intenções do rapaz e de sua família, o que também assumia Isham. Além disso, me disse Soumita uma vez em 2012, o rapaz respeitará mais a moça quando a mediação for feita pelas duas famílias que estão comprometidas em fazer com que a futura relação seja bem sucedida. Acima de tudo, dizia-me Soumita, nos casamentos arranjados se algo der errado, os pais também são responsáveis, pois a escolha foi deles. Soumita me apresentava assim o tema do failed romance/failed love, que aparece nos estudos de Uberoi (2006) e Mody (2008).

Soumita enfrentara os pais para viver o romance com um colega de faculdade. A essa altura já não é preciso repetir que o relacionamento afetivo e íntimo entre homens e mulheres que goza de legitimidade social, cultural, e até legal, é o que acontece no interior do casamento. O namoro de Soumita era, portanto, nos termos de Grover (2011), uma prática subversiva. Terminado o namoro, a jovem se encontrava recebendo perfis de rapazes indicados por sua família, que agora buscava recobrar o tempo perdido e casar a filha enquanto ainda estava longe dos trinta anos de idade. Ela dizia não ter opção, pois tentara por si mesma viver um grande amor e com ele se casar, mas como seu intento fora frustrado ela não podia se aventurar novamente a escolher outro rapaz e correr o mesmo risco outra vez, de se apaixonar por um homem que como todos, ela estava convencida, "are dogs"! Soumita iria, por essa razão, deixar que seus pais a casassem, ela não queria sofrer mais se entregando a outro rapaz que não a valorizaria.

Em 2013, logo que cheguei, notei a ausência de Soumita na PG e soube que estava passando uma temporada de dois meses na casa dos pais em Calcutá. Quando ela voltou nos encontramos um dia no horário do almoço quando buscávamos a comida na cozinha da casa. Vi que havia ganhado peso e ela explicava a mister Kapoor que isso se devia ao 
fato de estar tomando antidepressivos. Pouco mais de um ano após nos conhecermos ela não havia se casado e o trauma deixado pelo romance, talvez somado às dificuldades do arranjo, claramente ainda estavam por cicatrizar. Mister Kapoor dizia-lhe de modo complacente naquela ocasião:

- It will pass. Now what you need to do is to eat proper food, you need to eat well, especially because you are taking drugs.

Alguns meses depois, quando eu ainda estava em Délhi, Soumita foi novamente para a casa dos pais e eu nunca mais a vi. Os outros moradores diziam não ter notícias dela, a não ser Lovania que ficava sabendo dela por Shubhi e dizia:

- That girl was crazy, she was not in her sense when she left PG.

Segundo Shubhi, ela continuava solteira e, acrescentava-me ela, não achava que Soumita tinha um prospecto de se casar logo ou bem, pois com a doença emocional e com o tempo passando seria difícil conseguir um bom noivo. Recaía sobre Soumita, como já disse, o estereótipo da "loose girl", embora não usassem essas palavras quase todos na PG a viam com esse olhar. Seguramente não pesava sobre o ex-namorado de Soumita o mesmo estereótipo.

As garotas que conheci em Délhi tinham mais interesse e anseio em viver romances que os rapazes que viviam no mesmo lugar, não obstante eram elas que se vulneravam com os relacionamentos que viviam, o que exigia delas o dobro da coragem necessária a um rapaz para velejar pelas águas do romance. Os rapazes, tendo ou não interesse no romance, poderiam sair da experiência sem máculas morais. Patrick nunca terá que explicar que namorou várias moças quando, e se, decidir se casar. Shubhi, ao contrário, teve que ser hábil em esconder os relacionamentos anteriores da família dela e do noivo, do contrário seria julgada moralmente.

Às moças dá-se menos espaço para escolhas. Muitas vezes, segundo Dhawan (2011), o sim do rapaz é suficiente para que o casamento aconteça após o mútuo entendimento entre as famílias. A despeito da lei atual que prevê que o casamento seja uma união matrimonial consensual entre dois adultos, na prática, as famílias podem forçar a moça dado seu lugar mais sujeitado nas relações de dominação da família patriarcal (Dhawan, 2011: 152-160). Talvez por isso, as moças que conheci estivessem 
mais desconfortáveis e com tantas ansiedades e dúvidas quanto ao matchmaking que os rapazes. Esses, já noivos ou em negociações para o casamento, me pareciam bem à vontade com o processo dos arranjos.

Como Dhawan também chama a atenção, outra possibilidade é que a moça se preocupe mais por ser dela o dever de se ajustar ao casamento - como Rekha referiu em uma de nossas conversas - e dela a culpa no caso dos divórcios, ainda incomuns na Índia, mas crescentes. Nas leis e nos processos judiciais de divórcio, a autora afirma, paira como que uma naturalização dessa responsabilidade feminina por parte dos magistrados. Uberoi (2006) aponta igualmente como esse pensamento aparece nos romances de ficção e nas revistas femininas (women's magazines) em que cartas de leitoras são endereçadas à coluna de aconselhamento e respondidas pelos editores das publicações. Nesses casos, se a mulher se diz infeliz e pensando em divórcio, os conselheiros orientam que ela permaneça casada, em outros casos, mesmo após o divórcio, enfatizam que ela deveria ter tentando, com mais afinco, fazer com que seu casamento desse certo.

Distancio-me das autoras que tratam a ideia de failed romance/failed love pelo fato de que como experimentos existenciais os namoros ou romances que meus interlocutores viveram foram exitosos, pois transformaram essas pessoas, colocaramnas em contato com a existência, que de outro modo poderia jamais ser sentida. Como alerta o existencialismo são os sofrimentos, as lutas e o fracasso (Jaspers, 1973) que, ao colocar o sujeito frente às situações-limite (aquelas em que o chão desaparece de baixo dos pés do sujeito), permitem ter certeza da existência e impregná-la de sentido. Portanto, independentemente de redundar ou não em casamento, embora esse se apresente como o fim último do amor, o romance fez surgir uma experiência positiva, no sentido filosófico, onde poderia haver apenas vazio e incerteza da existência.

0 romance pré-conjugal, ao ser experimentado, adquiria uma importância robusta nas vidas das pessoas que conheci e devido à vivência íntima com elas não pude ignorar esse fato. Me permito afirmar que os romances vividos foram fulcrais na constituição dessas pessoas como indivíduos, pois os namoros implicavam, necessariamente, manter família, comunidade e amigos do lado de fora da relação romântica vivida pelo casal, evitando, desse modo, a colonização, ainda que temporariamente, da vida do sujeito pela comunidade, como diria Das (1995). Ao que 
me parece, os jovens com quem convivi que valorizavam, ansiavam e viviam o amor estavam justamente colocando-se contra a reciprocidade com os pais, o empreendimento que buscavam quebrava a expectativa de reciprocidade com a família e a comunidade que os havia criado, nutrido e educado em favor de um amor que lhes permitiria ser mais indivíduo e menos coletividade, esse o motivo pelo qual o amor era visto como antissocial pelas famílias.

Nos casos de pessoas que não valorizavam ou não nutriam expectativas amorosas pré-maritais a reciprocidade aparecia como o motivo para não se importarem com o amor. Como vimos nesse capítulo jovens como Isham, Kaushik, Krishna e o colega de voo, Dileep, os quais deixaram claro que fariam casamentos em conformidade com a vontade dos pais, acionavam o fato de que deviam tudo a eles e era preciso retribuir respeitando a vontade desses pelo que haviam recebido desde o nascimento. Como a literatura antropológica sobre casamentos na Índia aponta, nas classes médias e altas urbanas, uma tendência que estaria se tornando cada vez mais frequente é a tentativa dos jovens de exercer sua escolha sem romper com os pais, o que tem sido chamado de love-cum-arranged marriage. Shubhi fez um casamento que pode ser visto como exemplo desse tipo de arranjo. Passemos à história de sua trajetória e vejamos de que modo ela agenciou os assuntos caros à seu coração sem, na passagem, partir o coração do pai. 


\section{Bollywood}

Dos filmes a que assisti traço brevíssimas sinopses que, como Pryia e Meena sugeriram, apontam para a tendência a retratar a vida dos jovens nas metrópoles indianas exagerando um pouco seus contornos de forma quase didática permitindo ao público entrever que i) o amor nem sempre é possível e o casamento deve ser feito de acordo com os requisitos da família/sociedade ou, inversamente, ii) que o amor rompe desafios e se transforma em casamento, mas nesse caso a estória do filme é tão incrédula que todos percebem tratar-se de um conto de fadas (Kakar, [1989] 2011: 145), ou uma história puramente cinematográfica que não pode ser seguida na vida real.

Os enredos incluíam:

- Noivados arranjados sendo desfeitos e um subsequente casamento por amor entre o ex-noivo e a irmã da ex-noiva (Hasee Toh Fasee/She Smiles, She's Snared!). Esse é o caso exemplar de filme que será lido como fantasioso e sem pretensão de ser seguido na vida real. Como me disse Shubhi ao final da sessão a que assistimos juntas em um complexo de cinema em Greater Kailash: "People accept this because it's funny but everybody knows that such a thing happen only in a movie". Ela me respondia sobre o fato de a família das moças aceitar a dissolução de um noivado e, em seguida, casar uma das filhas apaixonada pelo ex-noivo da outra filha. A personagem principal, que se casa com o moço em questão ao final é uma divertida engenheira química que fugiu de casa há quinze anos indo para a China e se engajando numa pesquisa que pode salvar o mundo após ter roubado grande quantidade de dinheiro do pai, muito rico, para investir na pesquisa. Acresce que a personagem tem um inocente hábito de consumir drogas químicas que a fazem ficar com um trejeito engraçado que denuncia quando ela está "alta"; a adição em drogas, no entanto, é tratada como se ela fosse uma criança levada comendo chocolates; se torna divertida, não choca e nem causa maiores problemas, infantilizando uma mulher livre, complexa e contraditória que se torna palatável à audiência de Bollywood justamente por ser inverossímil.

- Uma noiva sendo abandonada na semana anterior ao casamento arranjado e 
indo descobrir-se na lua-de-mel, da qual não desiste, viajando sozinha para a Europa (Queen). A moça enfrenta a viagem como uma experiência de descoberta pessoal, faz amigos pelo caminho, ameaça um romance com um chefe italiano com quem troca experiências culinárias, é criticada jocosamente pelo hábito de ligar para os pais todos os dias mais de uma vez e por outros hábitos que indicam a interdependência entre pais e filhos indianos e retorna à Índia para rechaçar o noivo que a abandonara e quer voltar atrás pedindo para casar-se com ela, indicando que ela teria passado a ser mais autônoma e sujeito de sua vida após a viagem. 0 filme foi aclamado pela mídia como sensível a questões de gênero.

- Um casal de jovens lutando e negociando com as famílias para aceitarem um casamento por amor inter-comunidade, em que o rapaz do Punjab se apaixona pela moça de Tamil Nadu (Two States). Toda a complicação de um casamento realizado entre famílias de diferentes comunidades é tematizado aqui, e eu pude entender do que Rekha falava quando disse que era como se ela se casasse com Kaushik para exemplificar o caso da amiga que se casou com um rapaz de outro estado/comunidade.

- A história de um casal de namorados em que primeiro o rapaz abandona uma noiva minutos antes da cerimônia de um casamento arranjado, tenta se casar com a moça por quem está apaixonado, a qual o abandona do mesmo modo, depois ele foge dela numa segunda tentativa de se casarem e por fim, ambos fogem da terceira tentativa de casamento, decidindo viver o amor sem casamento (Shuddh Desi Romance). Não por acaso esse último foi detestado por todos os meus amigos que o assistiram, com exceção de Meena, muito provavelmente, como chegamos à conclusão Meena e eu, pelo fato de o filme rechaçar a obrigatoriedade do casamento. "Shuddh Desi Romance”, em inglês "Pure Indian Romance”, questiona desde o início do filme a instituição do casamento através de falas dos protagonistas, o casal que se apaixona e foge do casamento por três vezes. Esses fazem parte da equipe de uma pequena empresa que contrata convidados falsos para casamentos arranjados, se uma família não tem muitos membros ou se um rapaz deseja alugar parentes falsos para enganar a família da noiva a empresa provê os figurantes que atuarão como familiares no casamento. O filme abre com a fala da "heroína", nesse caso uma "anti-heroína" dizendo que casamentos deveriam ser um assunto pessoal, mas são, contudo, um assunto coletivo. Corta-se para uma cena em 
que dois personagens masculinos, contratados para encenar o papel de parentes do noivo, falam sobre o casamento arranjado do "herói" que estava prestes a acontecer com a ajuda dos falsos membros da família: “- An arranged marriage? _ I thought he'd go for love, I wonder what changed his mind. _ A man may look modern but when the call of tradition beckons..." Aos 16 minutos de rodagem do filme volta a protagonista e fala sobre o casamento que não acontecerá por conta da fuga do noivo. Olhando a câmera declara à plateia: “_He was getting married unsure of his choice of girl. That's India for you. No love. No romance, nothing. Say yes to marriage. Work it out later. Has it worked for anyone? So why would it work for me? I see many weddings. All sorts of marriages, all sorts. Weddings are to show off pomp and finery. But marriages? It shows up the lies and double standards of Indians." A cena revolve para o interior do ônibus que levava os convidados-atores - no painel do qual vemos um ídolo de Lord Shiva, o marido perfeito. 0 noivo hesitante pergunta à protagonista (pela qual ainda irá se apaixonar): e se não me ajustar à noiva? 0 chefe da empresa ao descer do ônibus com os falsos convidados diz: “_Life is all about adjusting.” A produção se desenrola com o casal se perguntando sobre o amor e o casamento até que, marcada pela terceira vez a cerimônia para seu casamento, ambos fogem e se encontram na casa dela, onde decidem que estavam fugindo, o tempo todo, do casamento e não um do outro, decidindo ficar juntos numa relação chamada na Índia, de modo sempre derrogatório, de "live-in relationship". Assisti ao filme pela primeira vez na TV com Lovania em seu quarto em 2014. Ela disse que era um filme que havia visto no cinema e que ela achava "a totally silly movie", do qual gostava das músicas apenas. Foi me contando o enredo, que me interessou bastante. Nos dias que seguiram eu perguntava aos demais amigos, durante jantares na recepção, se haviam assistido ao filme e se haviam gostado ou não. Ninguém havia gostado, diziam que era "a stupid movie", "a silly plot" ou "total nonsense", segundo Anindya, Kaushik, Shubhi, Rekha, Ashutosh, além da própria Lovania. Para minha surpresa o assunto do filme surgiu numa conversa sobre "Hindi movies" em Calcutá quando estive presente no casamento do irmão de Meena e ela me dizia que o filme recebera muitas críticas negativas e, para ela, isso tinha que ver com o fato de o filme descontruir duramente a ideia dos casamentos e celebrar um romance que não precisaria do casamento para ser feliz. 


\section{Capítulo V}

\section{Shubhi kee Shaadi 76}

Em seus experimentos existenciais, Shubhi realizou negociações e empreendeu estratégias que permitiram a vivência de romances e de sua sexualidade e que a levaram a casar-se de modo a contemplar suas aspirações pessoais. Shubhi se aproximou e se afastou dos dois polos extremos, como são tidos correntemente os casamentos "arranjados" e "por amor". Várias nomenclaturas são possíveis no cenário (e no mercado) dos casamentos contemporâneos na Índia, desde os "casamentos arranjados" até os, temidos (pelos pais) e desejados (pelos jovens), "casamentos por amor". Combinações criativas dessas duas formas têm sido nomeadas de diferentes maneiras, love-cum-arranged marriages, self-arranged marriages e choice marriages. Esses buscariam conjugar a escolha dos filhos e o arranjo dos pais. É o que passo a expor pela literatura sobre o tema e pela apresentação da história de Shubhi durante os últimos anos.

\section{Algumas nomenclaturas correntes para o casamento}

É corrente nas falas de meus interlocutores e nos livros de ciências sociais na Índia a assunção de que casamentos por amor (love marriages) difeririam radicalmente e estariam em oposição aos casamentos arranjados (arranged marriages). Como apresenta Mody logo no início de sua monografia:

"An arranged-marriage is rhetorically described as a religious ritual, sanctified and validated by kin and community and blessed by God with the gift of love from that day onwards. Love between husband and wife is expected to grow as the relationship develops, and it is predicated on the notion of devotion, both to God and to each other. In practice, this is arguably much more asymmetrical, with the wife assigned the task of devoting herself

\footnotetext{
${ }^{76}$ Em tradução para o português o título desse capítulo seria “O Casamento de Shubhi”.
} 
to God and to her husband who must (in the case of Hindus) be worshipped as if he were her God." (Mody, 2011: 8) ${ }^{77}$

Em outro polo, contrariando essas assunções, estariam os chamados casamentos por amor:

"Love marriages, on the other hand, are widely viewed as a most unholy union. They challenge 'natural' (that which kudrath or nature has created) caste hierarchy and social considerations of class, status and standing. Based on vasna, lust, and far from being social events, they are considered to be anti-social and kharab, bad. Simply put, arranged-marriages are seen to consolidate the community through what Dumont describes as 'endorecruiting'. Love-marriages represent the exact opposite - the deconstruction of the group or community through the two-fold rebellion of (a) choosing one's own spouse and thus exercising autonomy (i.e. ignoring the obligation to marry the person of your parent's selection), and/or (b) contravening the strict caste and community injunctions against out-marriage. The fact is that one of the most important defining features of caste (for Hindus and Muslins) is the obligation to marry within the group; and for this reason alone, lovemarriages do involve a substantial departure from the norm." (Idem: idem)

Embora sempre opostos no discurso corrente, love-marriages e arrangedmarriages poderiam ser melhor entendidos atualmente em uma relação de continuidade, como a própria Mody alerta, ao menos no que diz respeito a certas camadas da população indiana. Haveria entre as classes médias e altas das metrópoles indianas uma tendência a conjugar a escolha dos filhos com o arranjo dos pais (Uberoi, 2006; Van Wessel, 2001; Fuller and Narasimhan, 2008). Segundo os últimos:

"Competent academic discussion of arranged and love marriage recognizes that the dichotomy is fluid or fuzzy. Particularly in the urban middle class, however, and not only among the Vattimas [grupo de casta estudado pelos autores], the limited evidence suggests that a couple's prospective personal happiness has now become as important in arranged marriage as it is in love marriage. Although several anthropologists refer to this change, they still tend to reproduce their informants' preoccupation with the opposition between 'modern' love and 'traditional' arranged marriage." (Fuller and Narasimhan, 2008: 751)

O que Fuller e Narasimhan parecem não contemplar é o fato de que tal tendência pode se concretizar desde que o amor entre os jovens aconteça no tempo certo, ou seja,

\footnotetext{
${ }^{77}$ Embora em processo de transformação, como vimos no capítulo anterior, prevalece mais ou menos estabilizada a ideia do marido como um deus. Além da afirmação de Lovania nesse sentido e dos jejuns de Mrs. Kapoor e outras esposas que conheci para a saúde e vida longa do marido, os rituais de casamento a que presenciei também apontavam para essa assunção, como no casamento bengali de que participei em que a noiva ficara o dia do casamento inteiramente em jejum para estar pura ao ser recebida pelo marido, ou no caso de Shubhi em que poojas realizados nos dias que se seguiram ao casamento tinham o intuito de apresentá-la aos deuses como esposa que passaria, dali em diante, a se devotar aos deuses e ao marido.
} 
dentro das idades para o casamento, e com pessoas de background considerado apropriado, incluindo a endogamia de casta e de religião. Do contrário, na maioria dos casos, o que ocorre são complicações de diferentes magnitudes: desde fugas dos enamorados na tentativa de unir-se pela lei de casamentos civis, caso em que geralmente os jovens passam a ser rejeitados ou renegados pelas famílias (Mody, 2008; Grover, 2011; Chowdhry, 2007), até o espancamento e o assassinato dos enamorados por ambas as famílias ou pela família do par romântico da filha considerada desonrada (Mody, 2008; Chowdhry, 2007).

Como dito, Mody acompanhou jovens que buscavam as cortes de Délhi, vindos de diferentes lugares do país, intentando se casar "por amor" sem o consentimento da família sob os auspícios da lei que permite casamentos civis consensuais e de livre escolha entre jovens de mais de 18 e 21 anos, para moças e rapazes, respectivamente. A audácia da fuga não torna entretanto a façanha do casamento mais simples. Diante dos órgãos governamentais, os nubentes se colocam em um embate com o estado, pois mesmo tendo idade e autonomia jurídicas para se casar, há uma série de requisitos impostos pela burocracia e pelos magistrados que dificultam ou impossibilitam o casamento desejado. Os noivos precisam provar suas idades, o que por si só pode ser difícil, já que muitas pessoas na Índia não possuem documentos de nascimento ou identidade, isto é, nesse caso específico, os documentos, "esses papéis legais que infernizam, atormentam ou facilitam a vida do indivíduo na sociedade moderna", cumprem bem as duas primeiras funções da definição de Peirano (2006: 26). Além disso, precisam atestar que moram em Délhi há pelo um mês, exigência feita para evitar que jovens em fuga se casem facilmente. Segundo alguns, o estado procura, assim, dar tempo aos pais para rastrear os casais em fuga. Os pais costumam dar queixas na polícia como se as filhas houvessem sido raptadas. Além de contar com a ajuda das forças policiais e das dificuldades com a burocracia estatal impostas aos seus filhos, muitos pais colocam ainda detetives particulares no encalço dos filhos "fugitivos". (Mody, 2008; Chowdhry, 2007). ${ }^{78}$

Os chamados "runaway marriages" ou "elouping couples" foram objeto das pesquisas de Chowdhry que explora o fenômeno em que casais jovens fogem de aldeias

\footnotetext{
${ }^{78}$ As acusações de rapto podem ser vistas como remetendo ao momento da partição do país, em que os raptos e as acusações, com a decorrente intervenção do recém-criado estado nacional, geraram feridas abertas até os dias de hoje, como bem trabalha a questão Das (1995). A criminalização dos muçulmanos é um dos efeitos que pode ser observado nesse sentido (Mody, 2008).
} 
no norte da Índia para se ver livres das regras de casta e costume ("caste and customary rules") para se casar. Em tais casos, a autora afirma que a sexualidade feminina, inteiramente confinada à família, é colocada em aberto para julgamento na esfera pública, a qual é dominada por duas autoridades diametralmente opostas, uma informal e outra formal: "the informal is under the domination of the wider community (biradari) acting through the traditional panchayat with no legal standing; the formal is regulated by the state, based upon modern egalitarian laws" (Chowdhry, 2007: 173). ${ }^{79}$ Não obstante a definição dessa última esfera pública, a estatal, como baseada em leis igualitárias modernas o que ocorre é que:

"In the case of runaway marriages, the state apparatus becomes galvanized into action on the basis of a complaint generally made by the woman's male guardian. The police register an FIR [First Information Report, espécie de boletim de ocorrência] and accept such cases as criminal, involving abduction and kidnapping and very often rape. In police and judicial vocabulary these are termed as 'sex crimes' and are dealt with as such. The couple is hounded from place to place." (Chowdhry, 2007: 173)

Como as autoras que citei nos capítulos anteriores, Chowdhry reafirma a postura do estado em regular a sexualidade feminina a despeito das leis vigentes:

"The existing court cases show how the court passively accepts, as also actively promotes, the regulation of a woman's sexuality through marriage rather than challenging it in accordance with her legal rights. Such a stand reiterates that the male guardian has the right to settle and give her in marriage to a partner of his choice." (Idem: 178)

Quando os jovens são encontrados pela polícia, um julgamento pelos crimes sexuais cometidos pelo rapaz é instaurado. 0 casamento civil, acaso selado, é desfeito sob acusação de que a moça teria sido submetida à força ao casamento. A autora aborda julgamentos em que o próprio depoimento da noiva ou esposa afirmando a escolha de ir

\footnotetext{
${ }^{79} \mathrm{O}$ termo panchayat designa um conselho (geralmente de cinco [panch] membros) de lideranças locais nas aldeias. Os panchayats (Panchayat Raj) são uma forma de organização política tradicional do subcontinente indiano desde a antiguidade. Nos períodos colonial e pós-colonial os panchayats foram considerados uma forma de descentralizar o poder estatal e manter a organização política tradicional corrente nas aldeias. A Constituição da Índia, vigente desde 1950, institui um sistema de eleições para a escolha do líder panchayat que passa a constituir o poder local nas aldeias, chamado de Gram Panchayat. Ocorre que hoje em dia os dois sistemas convivem. Embora apenas o Gram Panchayati seja constitucionalmente investido de autoridade, a forma Panchayati Raj, o conselho tradicional, é usualmente consultado, respeitado e temido pelos membros das comunidades nas aldeias. Uma mesma aldeia pode ter mais de um panchayat, no caso de panchayats de casta (caste panchayat) cada casta pode ter seu conselho formado pelos membros mais velhos de uma determinada casta, quando há muito poucos lares de uma certa casta numa aldeia e essa casta não constitui um panchayat o panchayat da aldeia (Gram Panchayat) pode ser consultado, ou mesmo um panchayat de uma casta dominante se for um conflito intracasta. Já conflitos intercasta são decididos pelo panchayat da aldeia. Os conflitos submetidos ao julgamento de panchayats podem ser desentendimentos entre irmãos, divórcios, assuntos de herança, cobranças de dotes, roubos e quaisquer disputas que perturbem a ordem e a paz. (Chowdhry, 2007: 92100).
} 
com o rapaz para se casar é ignorado. Nesses casos, quando os jovens são encontrados, também podem ocorrer castigos, surras e até mortes. São relatados ainda casos de rapazes muçulmanos que estavam enamorados de moças hindus e foram mortos pela polícia, a qual alegava o suicídio das vítimas (Mody, 2008).

Panchayats tradicionais também realizam julgamentos em que condenam o casal a penas que variam entre a dissolução do casamento (por meio de cerimônias que anulam a união matrimonial), a expulsão da aldeia e até a morte. Em um caso analisado por Chowdhry, a disputa foi iniciada pelo próprio conselho de casta que considerou um casamento impróprio por se tratar de jovens de mesma gotra (clã patrilinear) o que, segundo o sistema de parentesco, constituiria incesto. Os nubentes contavam neste caso com a anuência de ambas as famílias. As famílias e os jovens se tornaram por isso réus no julgamento. Nesse caso, na aldeia Jondhi, distrito de Jhajjar no estado de Haryana, há 65 quilômetros de Délhi, ocorrido em 2000, o primeiro julgamento teve como decisão a dissolução do casamento, a consideração da moça como irmã do noivo (o que fazia com que ela continuasse a pertencer aos afins e não retornasse ao grupo natal), e o ordenamento de um segundo casamento da moça com as expensas pagas pela família natal, já que esta havia dado a moça em casamento de modo irregular e dessa forma se via punida com o não retorno da filha à família e com as despesas do novo casamento. A apelação de ambas as famílias e do casal fez reunir-se um novo conselho, mais amplo, isto é, com mais membros e com participação de ambas as aldeias envolvidas (chamado khap panchayat) que decidiu sobre o caso, conforme segue:

"The decision taken after a great deal of consideration was communicated publicly. The khap panchayat did not dissolve the marriage but refused to condone it. It also refused to review the decision taken by the Jondhi caste panchayat against the Gehlot family [família da noiva] of village Dabari. Darshana's [a noiva] natal family was thrown out of their gotra for giving their daughter to a Dagar [gotra do noivo] boy in marriage. They could no longer call themselves Gehlot. Socially boycotted for life, no member of the gotra was to associate with them in any way. All pleas for clemency were rejected by the khap panchayat. This panchayat further expelled the couple from Jondhi [aldeia do noivo] for life. They were not even granted visiting rights. Their male child was exempt from this punishment, clearly on the grounds of patrilineage and sharing of blood. The other forty members of this family in Jondhi were allowed to stay in the village but were expelled from the biradari [comunidade] for two years. (...) Till then there was to be complete social boycott of the family. Their hukka-pani (social intercourse) with other members of the village was banned. They could neither participate in any of the village festivities, nor could anyone else participate in theirs. Any infringement was to be severely punished." (Idem: 105) 
O objetivo de transcrever uma citação tão longa quanto essa é o de fazer entrever o quanto a paisagem moral das aldeias pode divergir daquela da cidade, que venho tentando qualificar. Como se depreende do trabalho de Chowdhry, comunidades de casta e panchayats exercem um poder coercitivo sobre pessoas e famílias nas aldeias que, por conta das relações sociais menos densas entre membros de casta e de vizinhança, não tem a mesma força nas metrópoles. Lembro que aldeias, cidades pequenas e metrópoles encontram-se muito próximas geograficamente e o fluxo de pessoas transitando pelas três é constante. A paisagem moral, no entanto, pode se distinguir grandemente de uma para outra graças ao fato de que a relação entre espaços públicos e privados é distinta em aldeias, cidades e metrópoles: enquanto na última os espaços públicos diferem do espaço privado pelo grau de anonimato e pela dispersão geográfica que faz com que pessoas morem em um lugar, trabalhem em outro e, talvez, estudem em outro; nas aldeias e pequenas cidades os espaços públicos estão muito próximos geográfica e moralmente do espaço privado (Abraham, 2010).

Chowdhry nos apresenta, assim, um cenário em que casamentos por amor, ou qualquer união matrimonial que transgrida regras de parentesco, como a exogamia de gotra no caso acima, e a endogamia de casta e religião são tidos como tabu e dignos de intervenção dos panchayats que guardam a "tradicional cultura indiana" com unhas e dentes. Nesse cenário os deslocamentos e combinações entre arranged e love marriage não são bem-vindos, diferindo vastamente do que apontam Fuller e Narasimhan para as classes médias urbanas.

Dada a resposta familiar e comunitária tão díspar entre casamentos realizados sob uma ou outra nomenclatura, isto é, "arranged marriages", de um lado, gozando da legitimidade e apoio dos pais, e, "love marriages", de outro, podendo resultar em prisões, rechaços, surras e mortes, concordo com Grover quando essa afirma que dizer que o modo como Fuller e Narasimhan buscam transpor a dicotomia entre as duas nomenclaturas talvez não seja a melhor opção, como ela afirma:

"While in concurrence with Fuller and Narasimhan that the dichotomy between 'modern' and 'traditional' marriages is problematic and untenable, my ethnography substantiates that these evolving marriage ideals amongst the Vattimas are class and context specific. The Vattima middle class evidence of change should not be read as transferable to other Indian cultural settings. Amongst Delhi's urban poor, there are differences in the way women experience their arranged and love marriages. Therefore, rather than coalescing or assuming that the dichotomy between arranged and love 
marriages 'is fluid or fuzzy', these marriages need to be subjected to independent analytical scrutiny." (Grover, 2010: 8)

Histórias que ouvia dos amigos da PG e da Delhi University faziam-me vislumbrar que casamentos "por amor" nas classes médias e altas urbanas também podem resultar em expulsão e desabono das famílias. Os casos exitosos, isto é, em que se lograram casamentos que atendiam expectativas emocionais dos jovens e, ao mesmo tempo, não discontentavam os pais mostram que foi necessária alguma engenhosidade dos filhos e concessões dos pais para que as uniões matrimoniais acontecessem. De igual modo, as asserções de Grover sobre como familiares reagem, apoiando ou rechaçando, os filhos a depender do modo de constituir o casamento é condizente com os relatos que ouvia de amigos de amigos que haviam se casado por amor e não contavam com a anuência e suporte familiares.

"Crucially, my chapters will also underscore that the type of marriage into which a woman enters affects her access to post-marital support. (...) women in arranged marriages have particularly strong claims on natal support structures. (...) First[ly] my case studies reveal that in arranged marriages, significant parental involvement can contribute to conjugal instability and disruption in a woman's marital trajectory. In other words, instead of stabilizing the conjugal union, complex and unpredictable dynamics between daughters and natal kin (specially mothers) may lead to marital breakdown. Second[ly], my data refutes the more widespread pan-Indian assumption that love marriages usually tend to fail. My evidence suggests that divorce and marital breakups are rarer in love marriages since women are deprived of the option of seeking parental shelter and support." (Idem: 10)

As discordâncias entre os autores é trazida aqui na tentativa de expor os limites do material bibliográfico utilizado e de possibilitar ao leitor situar-se no debate. Isso dito, passemos para outro ponto que intrigava-me nessas nomenclaturas todas: o quanto o amor na nomenclatura "love marriage" referir-se-ia, ou não, ao amor romântico como já qualificado anteriormente, isto é, como sentimento ou emoção que percebida, sentida, descoberta ou construída entre duas pessoas poderia levar, de modo socialmente legitimado, à união matrimonial do par enamorado.

Embora houvesse previsão para outros tipos de casamento que não o arranjado nos textos hindus, estes são considerados ilegítimos, ou não gozam da mesma legitimidade do casamento arranjado. ${ }^{80}$ Como demonstra Mody (2008), os jovens de

\footnotetext{
${ }^{80}$ Netting (2010) também se refere aos casamentos não arranjados como presentes na antiguidade indiana, mas indesejados socialmente: "Self-chosen marriage (gandharva viveha), based on sexual attraction, was also known in India, but judged unrighteous: lustful, disrespectful of parents, and dangerous to society." (Netting, 2010: 709)
} 
hoje não se reportam aos tipos ideais descritos em tais textos para legitimar seus casamentos por amor, eles, e a autora, não veem continuidade entre os casamentos não arranjados apresentados nas escrituras e os casamentos por amor de hoje em dia. Nesse sentido, os casamentos por amor na Índia tais como descritos nos estudos de Mody, Grover e Uberoi figurariam como algo relativamente novo no contexto indiano e que estaria contra o pano de fundo dos casamentos arranjados como norma e ideal. Quanto ao que alguns autores chamam de love-cum-arranged-marriage, acredito que esses possam ser equacionados ao que Fuller e Narasimhan chamam de companionate marriages feitos mediante arranjos:

"In the modern West, companionate marriage is closely linked to individual freedom of choice (...). In modern India, however, another option has emerged: parents and children together select the partners, motivated by an ideal of companionate 'emotional satisfaction' that is not premised on young people's unfettered personal choices. This Indian option partially reflects a rise in 'affective individualism' linked with relatively more concern than in the past with individual personality, self-expression, and free will, which is in turn, connected with improved education (especially for girls), the rising age of marriage, and reduced gender inequality. Plainly, though, affective individualism in India is less radical than its modern Western counterpart, which rests on 'possessive individualism' and presupposes that 'what makes a man [or woman] human is freedom from dependence on the wills of others'; this correspondingly means that individual freedom is compromised by any relationship with others (including parents) except one that 'the individual enters voluntarily with a view to his [or her] own interest' (Macpherson 1964: 263)." (Fuller e Narasimhan, 2008: 751)

Assim o que se teria hoje em dia na Índia entre as camadas médias e altas urbanas seriam matrimônios que visam acomodar a "felicidade pessoal" (Idem: idem) no interior dos casamentos arranjados, isto é, feitos não exclusivamente com base nas escolhas dos pais, mas levando em conta desejos pessoais dos noivos e, ao mesmo tempo, tendo em vista os requisitos próprios do arranjo/aliança.

Vejamos como essas nomenclaturas se antagonizam e se confundem ao analisar a história do casamento que Shubhi realizou em janeiro de 2015 com o namorado Ravi, com quem se relacionou desde o final de 2013.

\section{"Now it has turned into a love marriage"}


Como referi anteriormente, em 2012 tive pouco contato com Shubhi, nada além de conversas triviais em alguns jantares na sala de jantar da PG. Em 2013, com o namoro dela com Patrick e como Rekha e eu fossemos próximas deste, fomos colocadas em maior contato. Por vezes, eu percebia, ela sentia ciúmes de Rekha e de mim, pois fazíamos Patrick dividir a atenção que dedicava a ela conosco. Isso não impediu, contudo, que sobretudo em 2014 estivéssemos muito unidas, causando desta feita, ciúmes à Lovania, que tinha ciúmes de mim com todos os demais moradores e de Shubhi inclusive com os namorados desta. Com o tempo passei a entender indisposições e sentimentos que não eram narrados por meus interlocutores, mas dos quais estes me davam sinais claros quando passei a conhecê-los melhor, como significativos dos modos constitutivos de se relacionar entre eles. Os ciúmes sentidos por uns e dirigidos a outros tinham que ver com a habilidade ou inabilidade de manter todos os relacionamentos de modo equânime, de nutrir todas as relações de modo satisfatório, como convém à boa socialidade indiana, do contrário o risco é que alguém se torne antissocial por dar preferência a alguma relação em detrimento de outra, o que ficará claro a seguir.

No primeiro ano do trabalho de campo, formei uma impressão inicial de Shubhi que foi dada, em grande medida, pela visão que dela tinham os demais moradores da PG: alguém que saía muito pra balada ("party"), que conhecia os clubes noturnos mais badalados de Délhi, que se vestia de modo ocidental na maior parte do tempo e que os garotos da PG achavam bonita. Trabalhava desde o final da faculdade numa empresa chinesa e em 2014 se tornou a única entre os hóspedes da PG a possuir um automóvel.

Numa noite em que decidíamos para onde ir após o jantar, Pratyushi, Pryia e eu, fomos informados por Kirti de que deveríamos perguntar à Shubhi, que acabava de adentrar o aposento, onde poderíamos ir para provar de uma noite de Bollywood. Dela partiu a indicação do clube Kasbah para o qual nos dirigimos naquela ocasião, depois de uma parada no pub Route 04 em Cannaught Place para algumas cervejas, onde se juntaram à nós Abgail e Anirudh.

Em 2013 Shubhi se mostrava mais quieta que no ano anterior. Talvez porque estivesse namorando alguém de dentro da casa saía menos em companhia de seus antigos amigos de um curso de pós-graduação que ela cursara. Em nossas conversas nesse ano Shubhi me mostrava muito de sua visão sobre sexo, romance e casamentos. Numa delas disse que não era contra sexo antes do casamento, mas que a visão pública geral sobre o assunto era negativa na Índia. Como outros interlocutores, atribuía esse 
pensamento à mente atrasada das pessoas de seu país ("people here don't have a developed mind"). Dizia ainda que as pessoas negavam publicamente, mas deviam fazer sexo escondido, pois se casando aos trinta anos não era possível que ainda fossem virgens, "this is impossible". Um dia afirmou:

- People is getting married older, but they will not wait until marriage to have sex. People marrying at their thirties, they are not virgin, this is impossible because sex is just natural.

Perguntei naquela feita, se as pessoas estavam tendo relações sexuais, como elas faziam para não engravidar (eu nunca vira ou ouvira falar de uma mãe solteira entre meu círculo de amigos e conhecidos na Índia).

- No, no, no... in India is not allowed to be a single mother. People will not accept, they will kill the girl, they will kill her.

Perguntei: - Mas então como se faz, usa-se proteção?

- Yes, people use protection, even the boy will try to be sure that the girl doesn't get pregnant, but if it gets wrong, because sometimes it happens, nothing is completely safe, they will go for an abortion.

Perguntei novamente: - Sem os pais saberem?

- Yes, the parents can't know! If they know they will make them marry, they will obligate the girl and the boy to get married. See, this is the thing: the same baby that is a bless after marriage is a sin before marriage, the same baby. Because there is another thing: once you get married, the family expect that you will have a baby soon. Everybody will expect a baby soon after marriage, so the same baby that is a bless after marriage, is a sin before marriage. This is how people think in India.

Ela perguntou do meu casamento e geralmente eu me sentia contente em poder falar, pois tornava a conversa menos inquisidora de minha parte e passava a ser uma conversa de verdade. Disse que havia conhecido André quando ambos trabalhávamos num instituto governamental, o IBGE, e que passamos a sair juntos nos meses seguintes. Depois de dois anos nos relacionando decidimos morar juntos. Ela indagou se era comum no Brasil morar junto sem se casar. Disse-lhe que hoje em dia sim, que muitos 
casais faziam isso, alguns acabavam se casando depois, outros viviam assim mesmo e outros, ainda, se separavam e seguiam suas vidas, podendo vir a se casar ou não com outras pessoas. Ela disse ao final de minha resposta:

- Brazil must be more modern than India in this case because this is not allowed here, people will not understand, parents wouldn't allow this.

Nas frases de Shubhi havia fortes doses de normatividade, ao dizer que não havia mães solteiras na Índia e que os pais não permitiriam aos filhos morar junto com alguém sem se casar, ela reforçava essas regras. Havia, ainda, uma visão classista em suas afirmações, pois autoras como Grover (2011) e Gosh (2011) tratam as dificuldades e dilemas da maternidade entre mulheres solteiras nas camadas populares de Délhi e entre profissionais do sexo em West Bengal, respectivamente. Shubhi, contudo, desconhecia a existência dessas pessoas e descartava que essa condição fosse possível. Desconstruía, no entanto, a condenação do sexo antes do casamento por entender que sexo era tão natural quanto outras funções do corpo, ela dizia em diferentes ocasiões.

Uma característica do trabalho de campo que empreendi é que com o reiterado ir e vir à campo e com as conversas que se davam mesmo quando eu estava no Brasil, graças às cada vez mais avançadas tecnologias de comunicação (as quais, como aponta Harvey (1994), comprimem o tempo e o espaço), passamos tanto a nos conhecer melhor quanto a sofrer mudanças nas pessoas que éramos ao longo dos últimos anos. Se o trabalho de campo houvesse sido realizado nos mesmos onze meses, mas de modo contínuo muito do que aconteceu com os interlocutores - em decorrência dos experimentos existenciais que estão mudando essas pessoas - não teria sido captado nesse trabalho. Alguns assuntos não eram conversados no primeiro ano, os que eram sofriam mudanças de versões de histórias contadas de um ano para outro, um acontecimento colocava pessoas mais próximas ou mais distantes, e isso foi sendo etnografado de modos diferentes conforme as relações se transformavam. Shubhi, por exemplo, mudou sua versão sobre a proteção contra a gravidez indesejada no ano seguinte, dizendo que era muito difícil fazer os garotos usarem preservativos, estes prefeririam interromper o coito a ter de usá-los. De igual modo, no ano seguinte, ela só me contaria que teve quatro namorados antes de Ravi porque àquela altura éramos amigas e porque ela já era uma pessoa diferente, mais madura e confiante, da que era em 2013. A passagem do tempo no trabalho de campo se fez sentir na transformação i) 
de nossas relações, ii) dos discursos veiculados e iii) da minha própria escuta dos interlocutores.

Assim que voltei a campo em 2014 Shubhi me surpreendeu com uma afirmação quando conversávamos em seu quarto. Assistíamos a uma novela, com Lovania também presente, e ela me explicava que dois jovens recém-casados de modo arranjado estavam se apaixonando algum tempo depois do casamento e comentou:

- This is very common in India.

- Yes, that's true! - emendou Lovania se dirigindo a mim, enquanto eu assistia da poltrona uma cena em que, Shubhi me explicava, a moça sentia borboletas no estômago e por isso seus in-laws assumiam que estava grávida. Comentei provocativamente com Lovania:

- That's why you are watching? To see how it is after marriage?

- Yes! - respondeu Lovania e riu. Dirigi-me à Shubhi em seguida:

- What about you?

- I am already in love. Now it has turned into a love marriage.

- What you mean?

- Me and Ravi we fell in love.

Quando Shubhi pronunciou a afirmação de que seu casamento era agora um casamento por amor, comecei a pensar em quanto de amor haveria em alguns casamentos chamados de "love marriages" na Índia. A interrogação que pairava em minha mente era descabida, como quem inquire se o que veio primeiro foi o ovo ou a galinha, eu me perguntava: ela teria se apaixonado por Ravi porque queria se casar ou porque ele aceitara se casar ela se apaixonara? Como poderia ser um casamento por amor, se ela já estava certa de que se casaria com ele antes de se apaixonar? Me incomodava a maneira como tudo se encadeara de modo tão certeiro. Parecia que o destino havia sido tortuoso de menos nesse caso para tratar-se de um casamento por amor. Talvez ressoasse em meus pensamentos uma ideia que Milan Kundera expressa em "A Insustentável Leveza do Ser", obra literária em que o autor convida filósofos 
existencialistas para compor a ficção e na qual afirma sobre Tomas e Tereza - um dos pares românticos do livro, casados mas não exclusivos em suas relações sexo-afetivas que o amor de ambos era fruto de seis acasos e, mais que isso, que: "O acaso tem seus sortilégios, a necessidade não. Para que um amor seja inesquecível, é preciso que os acasos estejam presentes desde o primeiro instante, como os pássaros sobre os ombros de São Francisco de Assis." (Kundera, 1983: 55) Pensei assim por algum tempo. Depois, evidentemente, tratei de afastar a ideia dos acasos como imperativo para o amor, com certeza, haveria outros modos de identificar um amor inesquecível. ${ }^{81}$

Shubhi havia me contado ter conhecido Ravi por intermédio do pai. Como disse, foi de Lovania que soube que ambos foram apresentados por amigos em comum e do pai dela que ouvi, durante a recepção após o casamento, que Shubhi lhe contara sobre Ravi e pedia sua permissão para com ele se casar quatro meses após ter conhecido o rapaz. Shubhi nunca desdisse que havia sido o pai quem escolhera Ravi. 0 fato de que havia sido ela a conhecer o rapaz por amigos em comum parecia não mudar muito o modo como a relação entre ela e Ravi se desenrolou. Ela entrou no namoro com o rapaz certa de que um casamento sairia dali, e saiu. Antes dos quatro meses que se passaram para que ela contasse ao pai, Shubhi me afirmava no quarto que eu dividia com Rekha em 2013 que ela estava tentando fazer dar certo com Ravi, que se esforçava para gostar dele e esquecer Patrick. Para mim, o modo como Shubhi negociou sua vontade de se casar com alguém por quem tivesse sentimentos românticos tratou-se de um casamento autoarranjado, expressão que eu ouvi pela primeira vez quando presenciei o casamento do irmão de Meena. Esta dizia ao grupo de amigos dela que haviam se dirigido à Calcutá para o casamento do irmão que não comentássemos nas solenidades do matrimônio que aquele era "a self-arranged marriage", pois os parentes (relatives) e demais convidados pensavam se tratar de um casamento arranjado. Por "self-arranged" Meena queria dizer que o irmão e a cunhada haviam se conhecido num site de matrimônios e resolvido se casar e só então contado aos pais, que passaram às negociações familiares em seguida.

\footnotetext{
${ }^{81}$ Viveiros de Castro e Benzaquem de Araújo, no entanto, afirmam que a noção de "destino" se liga de modo constitutivo ao amor romântico ocidental, o que é evidenciado no mito de Romeu e Julieta. A identificação entre amor e destino "remete a uma ordem cósmica impenetrável aos desígnios humanos e que pouco leva em consideração as distinções sociais. Neste nível, a oposição pertinente é entre destino (amor) e lógica social, enquanto sistema de regras tradicionais que divide os homens em grupos e posições, prescrevendo relações entre categorias de pessoas. (...) esta associação entre amor e destino torna-se relevante para uma precisão da ideia de liberdade, enquanto associada à noção de indivíduo." (Viveiros de Castro e Benzaquem de Araújo, 1977: 149150).
} 
Quando viajei com Shubhi e Ravi para Udaipur em 2014 convenci-me de que estavam enamorados. Disso estavam também cientes ambas as famílias, o que não impediu que a viagem fosse secreta para os familiares e para os moradores da PG, que não sabiam que Ravi se encontraria com Shubhi, Lovania e eu em Udaipur, vindo direto de Mumbai. Naquela etapa do trabalho de campo fiquei pensando: o fato de estarem enamorados afastaria a ideia de que chamar seu casamento de "por amor" era precipitado? Seria mais apropriado chamar esse casamento de self-arranged, selfchoosen ou choice marriage que de love marriage? Para pensar essas questões as conversas que tínhamos em 2014, quando os acertos para o casamento estavam sendo feitos pelas duas famílias oferecem-nos ferramentas.

Nos relatos de Shubhi eu percebia uma tensão nos acertos que era provocada, do ponto de vista dela, pela família de Ravi. Por vezes, Shubhi comentava estar preocupada com a data do rokha que estava demorando a ser marcada. Para tanto seu pai viria de Chandigarh, junto a uma irmã, tia paterna de Shubhi, conversar com a família de Ravi. Se dessa reunião todos saíssem contentes com as discussões em torno de como se daria o casamento, quem arcaria com que parte do matrimônio e, provavelmente, negociações em torno do dote, o rokha seria marcado para logo em seguida. Nos últimos dias de abril de 2014 Shubhi veio ao meu quarto terrivelmente preocupada. A primeira reunião entre as duas famílias havia sido marcada para daí a dois dias, seu pai estava já dentro de um trem vindo para Délhi com a irmã. No dia seguinte, para desespero de Shubhi, Ravi, que deveria vir de Mumbai para a reunião entre as duas famílias perdera o voo e tentava conseguir outro. Shubhi estava irritada com o namorado e temerosa de que seu pai tomasse o acontecido como uma irresponsabilidade de Ravi e voltasse atrás na decisão de se encontrar com a família do rapaz. Nós duas falávamos pelo Whatsapp enquanto ela esperava que Ravi conseguisse assento em outro voo e chegasse de Mumbai.

- Fabs!

- Hi! Tell me: all solved?

- Yes! Ravi got another flight.

- Phew! That was close! Good to hear that.

- Yes, but I am still mad at Ravi. Tomorrow is a crucial day for me. All relatives are meeting tomorrow. 
Do lado de Shubhi na reunião haviam o pai e a tia paterna, do lado de Ravi, haviam os pais, um irmão mais novo, as avós e os avôs paternos e maternos e uma tia materna com o marido. 0 mesmo aconteceu quando Rekha teve de comparecer a um encontro como esse com um rapaz escolhido pelo pai dela naquele mesmo ano. Ela foi ao encontro com o pai e uma das irmãs mais velhas, já casada, ao passo que do lado da família do rapaz havia uma multidão de familiares que teria, segundo ela, feito perguntas sobre tudo que ela gostava e não gostava, seus passos diários e expectativas para a vida de casada. 0 rapaz teria se mantido com uma postura arrogante e, em dado momento, pedido a ela que perguntasse o que queria saber sobre ele, ao que ela disse ter querido responder que não gostaria de saber nada sobre ele e estava naquele almoço praticamente obrigada, mas limitou-se a sorrir de modo sem graça e dizer que era tímida e ele é quem deveria fazer as perguntas. Para a alegria de Rekha, as famílias não se deram muito bem e ela não teve mais de ouvir sobre aquele rapaz. No casamento do irmão de Meena em Calcutá, ouvi histórias que repetiam a informação de que constantemente havia mais pessoas do lado da família do noivo nos encontros entre famílias que pretendiam arranjar o casamento dos filhos, o que me fazia entrever que a família do noivo se comporta como sendo deles a tarefa de avaliar e aprovar ou desaprovar a noiva, ou seja, seria dos wife givers a função de agradar os wife takers.

A reunião entre as famílias de Shubhi e Ravi foi considerada bem sucedida por ela, pelo pai e por Ravi, mas o rokha ainda não havia sido marcado. Shubhi dizia que após o rokha havia mais segurança de que o restante do arranjo estaria bem, pois dificilmente se desfaz um rokha. Talvez seja difícil, mas esse foi o caso de Shine. Em 2014 falamos pelo WhatsApp e ela contava feliz sobre seu próprio rokha, que acontecera meses antes, explicando-me que esse era o momento em que as duas famílias envolvidas anuncivam para a comunidade que aquele noivo "was booked for that girl". Já em 2015 como não houvesse nenhum sinal, tanto no WhatsApp quanto no Facebook de Shine, de que havia acontecido um casamento, resolvi perguntar como estava indo o planejamento do matrimônio. A resposta foi de que aquele casamento não iria mais acontecer. Shine disse que o horóscopo de ambos não era compatível. Estranhei aquela justificativa porque não se faz um rokha antes de consultar o astrólogo, nos casos em que a astrologia é valorizada pela família. Não insisti, entretanto, em obter outra resposta de Shine. Eu já a conhecia um bocado para imaginar que alguma outra coisa havia dado errado nos arranjos, e talvez fosse o fato de que ela seria vista como "too modern" para algumas famílias, como já haviam comentado outros moradores da PG. 
Voltando à Shubhi, ela não contou a ninguém da PG, nem mesmo à Lovania, que sua família e a família de Ravi estavam em negociação para um casamento. Disse que não contaria até que o rokha acontecesse. Ainda na primeira quinzena de maio de 2014, havíamos combinado de almoçar juntas e ela me mandou uma mensagem dizendo que precisava cancelar o almoço do dia seguinte, pois um tio de Ravi chamara ambos para um almoço de última hora. Ela pedia desculpas e dizia que não podia recusar um convite da família dos futuros in-laws. Disse-lhe que entendia e que ela fosse com a consciência em paz. Foi ao almoço cheia de expectativas de que uma possível data para o rokha fosse discutida, o que não aconteceu. Perguntada por que estavam demorando para finalizar a data, Shubhi me respondeu que não sabia ao certo, mas que era a família de Ravi que não se decidira ainda. Ela demonstrava bastante apreensão com a indecisão sobre a data, pois com isso a família do rapaz mantinha em suspenso a decisão de torná-la publicamente a noiva de Ravi.

Duas semanas depois ela me contava que, após a família de Ravi desmarcar um encontro entre as famílias, o que a deixou arrasada na ocasião e pensando que tudo iria cair por terra, a data do rokha havia finalmente sido marcada. Shubhi estava radiante ao me contar que essa cerimônia aconteceria em 19 de julho de 2014. Pedia que eu continuasse mantendo segredo. Perguntei se ela não convidaria Lovania para a ocasião, ela disse que não, apenas pessoas pertencentes às duas famílias estariam presentes. Ao final de maio, ela me contou um dia:

- Tomorrow my father is coming for a family dinner with Ravi's family. Hopefully it will be a happy day.

- Oh! One more step to tying the knot I suppose.

- Yes! And in two days it will be my birthday.

Ela mencionara dias antes que em conversações do próprio pai com os pais de Ravi haviam decidido fazer um encontro entre as famílias por ocasião do aniversário dela. Nos dias que precederam o encontro, Shubhi me contava de seu nervosismo e ansiedade. Tentava acalmá-la dizendo que daria certo, todos iriam se encantar por sua doçura, não havia com que se preocupar. A reunião das duas famílias correu sem transtornos e tudo continuava certo para a formalização do compromisso entre as famílias de casarem seus filhos. No comecinho de junho foi o aniversário do pai de Ravi, 
evento a que Shubhi devia também comparecer. Embora ela me dissesse que se sentia testada o tempo todo nesses eventos e por isso se sentisse insegura quanto ao que usar e como se portar, Shubhi tampouco podia se furtar a comparecer a tais obrigações.

- Tomorrow is Ravi's dad's birthday.

- Are you going to celebrate with them?

- They have invited me but I have office work. So let's see if I am able to go but I have bought a shirt and a card for him.

- Can you skip the occasion?

- I shouldn't since it will be taken as an offense.

- I hope you can go then. Good luck!

- Ya, baby, please pray for me because I have to go.

Além de lidar com as obrigações no trabalho e com aquelas referentes ao estabelecimento de uma boa relação com a família de Ravi, Shubhi tinha de lidar com Lovania, de quem escondia o que estava acontecendo graças ao fato de que ela pressentia que Lovania iria sentir inveja e ciúmes do prognóstico de seu casamento com Ravi e isso não era auspicioso. Shubhi simplesmente desapareceu no dia de seu aniversário, depois desapareceu novamente quando do aniversário do pai de Ravi e por fim, na semana seguinte, sumiu quando viajou para Mumbai a negócios, ocasião em que se hospedaria no apartamento de Ravi, sem que os familiares de ambos ou as pessoas na PG soubessem. Tais sumiços deixavam Lovania desapontada e desconfiada quanto ao comportamento de Shubhi nos últimos meses, que se distinguia de seu comportamento usual. Em dez de junho Shubhi me escrevia pelo WhatsApp contando:

- I am good... came from Mumbai on Monday morning and Ravi came on Monday evening.

- Awn...

- So last night I was in Sheraton Hotel with him in Delhi. Had a good time since Friday. 
- Superb dear!

- But now I am back to PG.

- Back to PG? Ohhh...

- Ya, it sucks. Tomorrow my daddy is meeting his family for a discussion meeting.

- I want you to know the wedding date soon!

- Then on Thursday morning Ravi is leaving for Mumbai.

- Hum, so you have him around for some days: awesome!

- Just from yesterday till tomorrow in Delhi.

- How is Lovania?

- She is upset with me it seems. Because I suddenly went to Bombay and then last night also I was out so she is not talking to me properly. Oh gosh! Then I told her I was having meetings with Ravi's family.

- Oh... She knows that you will be leaving PG soon then.

- And since then she is like that. It shows the jealousy. She only writes to me that: it's good that you are happy and you please enjoy. That shows how happy she is. Lol...

- But she says that being ironic?

- I don't understand the meaning.

- Oh, ok ...

- It's just a little difficult to handle her for me.

- Don't take her bad... She might be jealous...

- Exactly! I guess so...

- Ya, don't pay too much attention it will pass. 
Havia uma tensão crescente entre as duas que eu de longe ouvia dos dois lados da relação. Lovania não entendia o que se passava, não sabia porque a roommate estava cada vez mais distante dela, eu podia apenas ouvir e nada dizer. Em primeiro de julho vim a saber que, antes mesmo da realização do rokha, a data do casamento havia sido definida.

- I have news that I am telling you only. Nobody else knows. Keep it with yourself please. Kahan ho? [Cadê você?] Baby? Suno, na? [Dorme, não?]

- Yes, tell me! I'm here, tell me darling... Shubhi?? Do you want me to die of curiosity? Lol...

- Promise me you'll not share it with anyone unless I disclose it.

- Yes, I promise.

- Good. My marriage date has been finalized!

- Yay! Tell me! When it will be?

-18 th of January.

- Wow! Congratulations!

- You are the first one I am telling... I am not planning to tell anyone before September. I love you that is why I am sharing. Now prepare yourself to come!

- Okay, I promise I will not tell anyone! And yes, I will come to your wedding.

- You are like my elder sister.

- Aw... So sweet! I'm glad our relationship is strong! I'm so happy for you my dear! And for Ravi too!

Já no Brasil recebi a notícia de que o rokha havia sido um sucesso. Dias antes falamos e, como sempre, Shubhi estava muito ansiosa.

- Are you anxious?

- Very nervous! So much anxiety I can't even tell you. Just two days for rokha! 
- Take lots of water to reduce your anxiety, ok? And keep calm, you're going to rock! Calm down dear.

- Lol... I can't...

- It will be lovely!

- Ok, sweetie.

- I have no doubts! You will make a pretty fiancé!

- Did you talk to Lovania lately?

- No, why?

- General talks?

- Ya, we spoke these days about my travel to NY. That's all.

- Be there on my wedding please. You'll surely enjoy.

- Yes, for sure I will enjoy! Best luck for you on your rokha! My best wishes are with you and Ravi!

- Thank you dear!

No dia seguinte ao rokha, não me contive e perguntei como havia sido a ocasião.

- Hey! How was your rokha? Tell me...

- Awesome! Too good baby! It was awesome... really missed you... It was a very successful rokha.

- Yay! I knew it!

- Everybody was very happy and satisfied.

- I'm so glad for you!

- How is my pic? 
- The pic is downloading, the connection is bad here.

- Aw... But baby, it was too good! I got many gifts.

- Ya? Like what? The pic opened. You were gorgeous!

- I got one suit, two saris, a gold chain, diamond earrings, Charles and Keith bag, cosmetics, dry fruits, fruits, sweets, and money. 82

- Oh, very fancy gifts! You look great in the pic.

- Lovania said I was looking matured. I didn't like her comment.

- So you are happy, no?

- Yes, I m very happy!

- This is the most important! Congratulations to you and Ravi!

Mesmo após o rokha Shubhi ainda não quisera contar à Lovania, Patrick e demais pessoas que conviviam com ela sobre a data exata e os detalhes do casamento que se aproximava. Nos comentários de Lovania, Shubhi via sempre algum sinal de ciúmes ou inveja por estar prestes a se casar, enquanto Lovania continuaria solteira. Num dia em que ela e mister Kapoor discutiram pelo novo aumento do aluguel, Shubhi estava chateada e conversava comigo pelo Whatsapp.

- Did Lovania speak to you about this?

- Yes. We talked about the rent. Why?

- Because I don't share much with her these days so that is why.

\footnotetext{
${ }^{82}$ Além de "fancy", como eu respondia a ela naquela ocasião, os presentes que Shubhi ganhou tem significados definidos. Ouro, frutas, frutas secas e dinheiro são considerados presentes auspiciosos em ocasiões como nascimentos e casamentos, ocasiões altamente auspiciosas e positivas (Madan, 1987). Os nascimentos embora poluam os pais, que precisam de pooja para se purificarem, são acontecimentos muito auspiciosos, diferindo dos acontecimentos de morte que tanto poluem quanto são inauspiciosos. Quanto aos presentes, em que pese o fato de alguns serem caros, demonstram que não há conotação ruim, ou tida como transação econômica, em presentear com dinheiro, ouro e diamantes. Nos pooja prévios e nas cerimônias do casamento oficiadas pelo pandit oferece-se dinheiro aos deuses e ao pandit demonstrando que o dinheiro não é espúrio, mas faz parte das transações entre pessoas e deuses. Há ainda um modo correto de se presentear com dinheiro, as quantias devem conter os algarismos que formam o número onze, fazendo de quantias como 11,101, 1001, 1100, e assim por diante, valores muito auspiciosos.
} 
- Oh, ok.

- I have not told her anything till now. So you be careful.

- About the wedding?

- Yes.

- Nor I said.

- Great!

- Nor I will because you asked me.

- Yes, don't tell about your trip to India also in January. Because then she will understand, she is clever.

- I know sweetie, relax.

- I'll disclose my dates to her in late September or October.

- You are a naughty girl.

- Karna padta hai. Kabhi kabhi [Sometimes].

- I didn't get. Padta kya hai? [0 que é padta?]

- It means: sometimes you have to do certain things. You must be thinking that we are so silly.

- No, I don't! You must have your reasons, right?

- Yes I do. If she feels envy or jealous inevitably she will have bad feelings or maybe bad thoughts about my marriage and this is not auspicious. It can spoil the arrangement.

- Oh, ok... I got you now! Trust me I won't say a word till you tell her first.

Inicialmente li os ciúmes de Lovania, dos quais tive mostras na viagem a Udaipur, como condizentes com a vigilância moral que se faz dos casais enamorados nas cidades 
indianas. Naqueles dias na cidade tida como a "Veneza indiana", ficamos hospedados no mesmo hotel. Lovania e eu dividíamos um quarto e Shubhi e Ravi se instalaram em outro aposento. Já no primeiro dia de estadia, Lovania parecia absolutamente preocupada em controlar o casal de enamorados. Havíamos chegado, Shubhi, Lovania e eu, pela manhã e Ravi havia alcançado o hotel de tarde. Naquela sexta-feira o rapaz trabalhou pela manhã, pegou um voo após o almoço e nos encontrou em Udaipur quando eram umas quatro da tarde. Como estivesse cansado e, eu deduzia, ansioso para estar com Shubhi, foram para o quarto deles e Lovania e eu fomos também descansar, pois havíamos andado pela cidade, visitado um templo e feito inúmeras fotos. Lovania queria ir a um mirante de onde se pode ver o sol se por. Disse-lhe que tomaria um banho e que iria com ela, poderíamos deixar Ravi e Shubhi descansarem caso quisessem. Ela disse que eles deveriam ir junto. Saiu de nosso quarto e foi até o quarto deles, que não responderam quando ela bateu à porta. Quando voltou eu disse que ela deixasse os dois sem serem incomodados, viviam longe um do outro e certamente gostariam de ter algum tempo juntos. Ela respondeu:

- In India it's not like that.

- What you mean?

Meu celular fez um som e era Shubhi que me mandava um SMS dizendo que Ravi se sentia cansado para ir ao mirante, motivo pelo qual ela ficaria com ele e nós duas poderíamos ir ver o pôr-do-sol. Disse isso à Lovania e ela respondeu:

- I did not come here to stay in a hotel room. I wanna go out.

- Yes, we both can go. We can leave them rest and later go for dinner, the four of us.

Ela não disse mais nada e eu fui para o banho. Do chuveiro pude ouvi-la ao telefone e depreendi que falava com Shubhi. Ouvi-a sair do quarto e voltar em pouco. Bateu à porta do banheiro e disse que eu me apressasse, ela também queria tomar banho, pois iríamos todos ao mirante. Fiquei irritada com Lovania porque ela perturbava não só o meu banho depois da jornada de uma noite no trem e um dia percorrendo lugares da cidade, mas também a tentativa do casal de ter privacidade. Saí do banho e escrevi para Shubhi perguntando o que havia acontecido, esta me respondeu que Lovania não apenas havia ficado ligando para eles, mas também batendo à porta do 
quarto até que Ravi acordasse. Eu disse a ela que havia tentado impedi-la, mas Lovania agira enquanto eu estava no banho.

Em outro momento, Shubhi me contou que ela e Ravi já haviam tido esse mesmo problema com Lovania quando estiveram em Mumbai na casa de Ravi. Nessa ocasião, Shubhi decidira levar Lovania à Mumbai porque a última vivia reclamando que nunca viajava, nunca conhecia lugares novos. Na primeira noite em Mumbai, Lovania insistia para que Shubhi dormisse ao lado dela no quarto de hóspedes porque ela não conseguia dormir sozinha. Como Shubhi dissesse que não podia, que Ravi não iria entender, Lovania teria retrucado:

- You know that I can't sleep alone, why did you bring me here then?

Shubhi teria deixado Lovania falando sozinha e ido dormir com Ravi em seu quarto. Agora a tentativa de Lovania de controlar o comportamento amoroso da amiga se repetia, motivo que fazia Ravi não simpatizar com ela, como Shubhi me contava. Antes que voltássemos à Délhi em dois dias, Lovania me disse que não gostava do modo como Ravi se portava quando estávamos os quatro em Udaipur.

- The way he treats her and us is not good.

- How so?

- The way he pamper her in public, calling her "pretty" and "love" all the time. Giving small kisses, this is not good. He doesn't talk to us properly. He is treating you okay, but when you are with a group you should treat everyone equally and give everyone the same amount of attention. I try talk to him, but he does not continue the conversation I initiate.

- Oh... but this is normal, he is her boyfriend. He has to treat her well. I mean in Brazil if a boyfriend treats all the girls equally his girlfriend will be very mad at him.

- Baby, you are in India. It's not like that. Like Patrick, he would treat her well but would give me and you the same attention and affection.

- But he does that because he is our friend regardless his relationship with her. Ravi is not our friend; he is Shubhi's boyfriend. 
- I am telling you that this is how it is in India. It might be different in your country but not here. Here a couple don't act differently because they are a couple. I am telling you this is not good for her as well, people will find it strange.

Após observar o comportamento de Lovania em Udaipur e ouvir o relato do que ocorreu em Mumbai, percebi que, mais que ciúme, havia no modo como Lovania tentava cercear os momentos de Shubhi e Ravi - e de Shubhi com Patrick também, conforme eu já ouvira dos dois últimos - uma certa noção de que esse era o dever dela como amiga, ela devia cuidar para que Shubhi mantivesse o comportamento esperado de uma garota solteira, isto é, evitar ter intimidade com um homem antes do casamento. Em minha leitura ela não podia conceber que Shubhi se permitisse o deleite de viver, com quem quer que fosse, aquilo que os jovens não devem viver antes do casamento. Lovania dizia ainda à Shubhi, com essas atitudes, que Shubhi não devia interromper, ou diminuir de importância, as outras relações existentes, como se seu relacionamento com Ravi fosse mais importante que seu relacionamento com a colega de quarto com quem vivia há anos. Creio que Lovania tentava fazer Shubhi se lembrar de que tinha outras relações que não deveriam ser deixadas de lado, pois se o fizesse não estaria sendo hábil em sua socialidade, esse o sentido da frase "here a couple don't act differently because they are a couple". Incomodava Lovania o fato de que a roommate estivesse sendo indivíduo quando devia ser divíduo, competindo para tanto que compartilhasse inclusive a socialidade do namorado com ela própria. Ao conter a socialidade dos que estavam à sua volta fechando-se entre eles mesmos como um casal, isto é, sendo indivíduos, Shubhi e Ravi desafiavam a orientação de vida de Lovania, para quem a porosidade das pessoas e das relações estava na base da relação entre divíduos.

Ocorre que para Lovania, Shubhi e Ravi estavam também, na viagem à Udaipur, se imiscuindo no relacionamento entre ela e eu. No início do ano de 2014, quando eu me encontrava ainda no Brasil, planejando minha terceira estada em campo, Lovania convidou-me a ir a Udaipur ou Goa com ela porque ela nunca viajava e como eu gostava de conhecer diferentes lugares na Índia poderíamos fazer isso juntas. Disse-lhe que precisava ver como ficariam minhas atividades na Delhi University primeiro e então poderíamos planejar. Ela dizia que queria fazer algo assim para ter boas memórias de uma viagem comigo. Eu já percebera antes que ela gostava de estar comigo sem outras pessoas, talvez aproveitasse para fazer seus experimentos existenciais em relação à mim também, isto é, já que não estava namorando ninguém no tempo que convivemos, ela 
parecia querer criar um espaço de privacidade e individualidade por meio de nossa amizade. Percebi que ela havia se ressentido com a atitude de Shubhi de querer se juntar à nós e convidar Ravi para a viagem quando, dentro do trem no trajeto de Délhi à Udaipur, ambas tiveram uma pequena rusga, referente aos planos para o dia seguinte e Lovania comentou comigo quando Shubhi já dormia em seu leito na cabine da terceira classe do trem:

- She started doing it. I wanted to come in this trip with you and she wanted to come along and invited Ravi, I did not oppose. But she always do that, she wants to make the decisions as per her wish and nobody else's. I hope she does not spoil our trip.

Como referi anteriormente algumas pessoas do convívio de Shubhi achavam-na mandona (bossy) e Lovania fazia alusão a isso naquele momento. Frequentemente eu me via enredada pelos conflitos entre os moradores da PG em suas tentativas de manter seus relacionamentos ou atividades em segredo, e, mais tarde pude perceber, era também enredada em alguns de seus experimentos existenciais, os quais contabilizavam para os processos de individuação a que eu assistia.

Em todo caso, era por essas e outras que Shubhi afirmava ter motivos que a levavam a esconder da roommate o passo a passo para seu casamento até que fosse certo e líquido que iria se casar com Ravi, isto é, quando sentimentos e pensamentos inauspiciosos já não pudessem causar atrapalhos para ambos. Ela não fazia a leitura dos ciúmes de Lovania como uma orientação para a socialidade que deveria seguir, mas como um ressentimento por ser sozinha. Para Shubhi todo cuidado era pouco com a falta de auspiciosidade que pudesse levar as "forças cósmicas" (Madan, 1987) a oporem-se à finalização do arranjo do matrimônio.

O tema da auspiciosidade merece uma explanação nesse ponto. Segundo Madan, a auspiciosidade é um conceito caro ao pensamento hindu e tem efeitos práticos no cotidiano de uma pessoa que leve em conta essa concepção. A auspiciosidade (subha = /shubha/) diz respeito à conjunção entre tempo - mais especificamente a passagem do tempo -, a trajetória de um indivíduo e a trajetória de um objeto, pessoa, acontecimento, astro etc., assim:

"In all the foregoing uses of the prefix subha, the focus is on the directional flow of time - on temporal sequences and critical points in them - rather than on time as such. The passage of time becomes significant through the 
conjunction or intersection of the trajectories of human lives and/or of such trajectories and the course of cosmic forces. The evidence of everyday speech indicates that the notion of auspiciousness is also associated with places, objects and persons connected with (...) events or actions (...)." (Madan, idem: 51-52)

Como Madan também nos alerta, auspiciosidade ou inauspiciosidade não residem num lugar, tempo, pessoa, objeto ou astro em si mesmos, mas em certa conjunção entre esses elementos. Assim, não era Lovania quem poderia causar qualquer inauspiciosidade ao casamento de Shubhi e Ravi, mas certos pensamentos que ela supostamente poderia ter num momento particular da trajetória de Shubhi, isto é, os preparativos para o casamento.

"The adjective subha is applied in everyday speech to actors (karta) when they are seen performing actions which are conducive to joy and well-being (subhakarya) or when they symbolize these states. For instance, and crucially, a subhacintaka (well-wisher) is one who entertains good thoughts about another's influence on the course of the latter's life. (...) the distinction between the state of auspiciousness and the creative agent (mangatakaraka or kalyanakaraka) is most important, as is the relation between the two (the signification). The point to note about these usages and similar others is that it is not the person himself or herself who is the auspicious, but rather his or her intentions, actions, or even merely the presence (and witnessing the same), which are so and are, therefore, expected to have happy consequences. The ultimate source of auspiciousness is, of course, the divinity." (Idem, idem: 53-54)

O que pode ser dito para conjunções auspiciosas (subha) também pode ser afirmado para conjunções inauspiciosas (asubha) uma vez que ambas estão em oposição, do mesmo modo que as noções de puro e impuro o estão. As conjunções auspiciosas seriam beneficentes (beneficents) e as inauspiciosas seriam tidas como "cruel, fierce, formidable, maleficent". Talvez por isso, Shubhi preferisse contar com a mãe de Ravi e com a amiga Shweta, que havia saído conosco para comemorar o aniversário de Shubhi em 2013 e de quem tanto Patrick quanto Lovania não haviam gostado, para fazer as compras relacionadas ao casamento. Ela considerava que essas eram pessoas que estavam felizes e desejavam o bem para seu casamento, eram, portanto, well wishers. De igual modo, ela me segredava todos os passos do arranjo do casamento. Talvez porque soubesse o quanto eu estava feliz por ela se casar: por gostar dela e de Ravi e por ter, doravante, um casamento por amor para analisar. 0 fato de, durante meu trabalho de campo, ela ter encontrado alguém para se casar justamente quando eu buscava escrever sobre casamentos fez do nosso encontro uma confluência auspiciosa, em minha leitura. 
Dada a descrição do processo de acerto entre as duas famílias penso restar claro que havia elementos próprios de casamentos arranjados e outros próprios de casamentos por amor. Enquanto as duas partes continuavam a se portar como wife givers e wife takers, checando reciprocamente o background das famílias, buscando por meio de vários encontros estabelecer-se como futuros afins, e negociando encargos a serem cumpridos nos arranjos em que presentes e despesas com as cerimônias tem uma prescrição bem estabelecida de quem arca com o quê, Ravi e Shubhi tinham, por seu turno, que convencer os pais a aceitar um casamento entre uma moça Kayastha e um rapaz Vayshia. Embora de comunidades próximas, pois ambos são punjabis, e de mesma comunidade religiosa, ambos sendo de famílias hindus, Shubhi e Ravi intentavam um casamento intercasta e inter-varna, em que, além do mais, a hipergamia era contrariada. Kayasthas tem status intermediário ou equiparável a Brahmanes e Kshatryas, ao passo que Vayshias tem status inferior a estes e seriam grupos de castas de mercadores e comerciantes sendo a terceira varna de maior prestígio, acima apenas dos Sudras, esses tidos como serviçais, empregados domésticos e trabalhadores braçais.

A família de Ravi, no entanto, exibia outros requisitos que acabaram por fazer o pai de Shubhi aceitar o rapaz: residem em Délhi numa vizinhança de classe alta, chamada Vasant Kunj, e o pai é um bem-sucedido profissional na área de arquitetura e design. Ravi, de mesmo modo, contava com um background que facilitava a tarefa de Shubhi em convencer o pai: era engenheiro eletrônico com bom cargo em uma empresa multinacional instalada em Mumbai, recebedor de um ótimo salário, com perspectiva, à época, de ir morar nos Estados Unidos após o matrimônio, tinha a pele clara e havia conquistado o coração de sua filha. De outro lado, os parentes de Ravi, apesar da vantagem socialmente estabelecida de casar o filho numa casta superior à sua própria, buscaram de várias maneiras conviver com Shubhi e seu pai para terem certeza da aliança, estendendo o tempo de seis meses, comumente adotado desde os acordos entre as duas partes e o casamento, para dez meses, enquanto testavam, como a própria Shubhi me dizia, o caráter e a moralidade da moça com quem iriam casar o filho mais velho.

Para contrastar o casamento de Shubhi e Ravi e os casamentos convencionais, apresento a seguir os casamentos arranjados como um sistema, isto é, do modo como foram pensados por inúmeros autores que se dedicaram ao estudo do parentesco e da aliança naquele país. 


\section{Dos casamentos arranjados como um sistema}

Os casamentos arranjados são a regra para a união matrimonial na Índia. 0 sistema que está imbricado com, e ao mesmo tempo reproduz, o sistema de castas e de parentesco, funciona mediante arranjos feitos pelas famílias, as quais escolhem os cônjuges dos filhos. Assim, quando chegada a "idade para o casamento" (que atualmente varia entre os dezoito e os trinta e poucos anos, no máximo) os pais fazem contatos e investigações com os vizinhos e demais membros da comunidade para encontrar um rapaz ou uma moça que tenha as características desejadas pelos pais e, algumas vezes, pelo filho e, mais raramente, pela filha. Os critérios primeiros para a escolha, no norte do país, são pertencer à mesma casta (endogamia de casta), mas não ser da mesma gotra (exogamia de gotra). Como dito, pertencem à mesma gotra os descendentes em linhagem paterna. As mulheres são consideradas da gotra de seu pai até o casamento e da gotra do marido após o matrimônio. Um casamento que não atenda as regras de gotra pode ser considerado incestuoso, como no caso tratado por Chowdhry e mencionado acima.

Karve (1993 [1953]), em seu clássico artigo sobre o casamento e o parentesco na Índia, define o mapa desses sistemas no país. Embora escrito há sessenta anos, muito do que ela sistematiza ali continua em vigência ou tem forte influência nos dias de hoje, sendo um artigo bastante citado, ainda que com algumas críticas e atualizações. ${ }^{83}$ Algo que ouvi de todos os acadêmicos com quem falava sobre minhas intenções de pesquisa é que existiriam enormes diferenças regionais nos casamentos indianos. Isso é algo que Karve esclarece quando trata das regiões linguísticas da Índia:

"The linguistic regions posses a certain homogeneity of culture traits and kinship organization. The common language makes communication easy, sets the limits of marital connections and confines kinship mostly within the language region. Common folksongs and common literature characterize

\footnotetext{
83 Uberoi aponta bem as críticas que são feitas a Karve: a romantização saudosista sobre a joint family; e a "hinduização" do parentesco na Índia, que não seria feito somente por ela, no entanto, mas trata-se de uma tendência geral nos estudos de parentesco na Índia. (Uberoi, 1993: 32-33 e 39) Uberoi, contudo, considera muito importante a contribuição de Karve para esse campo de estudos: "not only because it squarely confronts the important question of cultural pluralism, but also because I regard Karve as a pioneer of an indigenous 'feminist' perspective on the Indian family. Her central contrast of north and south Indian kinship revolved around differences in marital arrangements as seen from the viewpoint of women: marriage with kin versus marriage with strangers; marriage close by versus marriage at a distance; a more or less marked distinction between 'daughters' and 'brides'; and so on. Similarly, she evaluated modern changes in family life - for instance, the modification of Dravidian marriage practices in the direction of the northern model - from the viewpoint of their possible effects on women's lives." (Idem: 40) Optei por apresentar o sistema de casamentos neste trabalho por meio do trabalho de Karve porque considero que eles falam muito mais daquilo que vivenciei em campo que os demais trabalhos que li.
} 
such an area. This is inevitable as large numbers of people are illiterate and literary traditions are transmitted orally." (Karve, 2003: 50)

A autora apresenta as organizações de parentesco numa sequência geográfica: 1) norte, 2) centro, 3) sul e 4) zona ocidental. Essa divisão foi adotada intencionalmente para enfatizar o padrão espacial e a inter-relação entre a organização de parentesco e as divisões linguísticas. Ela afirma que, embora o padrão linguístico geralmente coincida com a organização de parentesco, nem sempre andam juntos. Em Maharashtra, estado onde se localiza Mumbai, por exemplo, pertencente a uma área de línguas sânscritas, a organização de parentesco é modelada pelo parentesco dravidiano, pertencente a seus vizinhos ao sul, isso indica que, embora haja um padrão, o mesmo se encontraria repleto de exceções. Julgo importante apresentar as características estruturais dos casamentos na região norte, onde fica Délhi e de onde vem a maior parte de meus amigos, pois tais características não deixaram de ser o ideal para os casamentos, como apontam estudos contemporâneos e minhas vivências em Delhi. Passo a resumir o argumento de Karve em seu célebre artigo.

A região norte na classificação da autora compreenderia a parte da Índia que está entre os Himalayas e a cadeia de montanhas Vindhya ao sul. A maioria da população dessa região fala línguas derivadas do sânscrito. Os estados incluídos nessa área são: Sind (agora parte do oeste do Paquistão), Punjab, Kashmir, Délhi, Uttar Pradesh, parte de Madhya Pradesh, Bihar, Bengala, Assam e o reino independente do Nepal. As línguas faladas são sindhi, punjabi, kashmiri, hindi, bihari, bengali, assami e nepali. Em toda essa zona o comportamento de parentesco variaria, segundo a autora, discretamente de uma região a outra e, no interior de cada uma delas, de casta para casta também. Para Karve, o estudo de tais diferenças é bastante interessante para a compreensão da estrutura social de cada região, mas haveria a necessidade de estabelecer certas normas/padrões para estudos comparativos. Assim, ela estabelece os seguintes padrões ideais para a zona norte que se referem a práticas e atitudes encontradas mais comumente entre a maioria das castas nessa zona:

\section{1) Gotra e sistema de clãs}

Karve afirma existirem grupos na Índia cujo prestígio faz com que suas instituições sejam copiadas, ao menos no nome. Os dois grupos mais importantes desde a antiguidade teriam sido os brâmanes e os kshatriyas (militares). 0 sistema de gotra dos brâmanes é como o sistema de clãs entre os não-arianos. Kshatriyas e vaishyas 
(mercadores) têm divisões sociais possuindo gotras. Muitas castas mais baixas também tem gotras e mesmo povos tribais falam sobre seus clãs como gotta ou gotra.

\section{2) Hipergamia e kulinism}

A tendência na direção da estratificação pela hipergamia seria encontrada entre todas as castas. Os brâmanes, por exemplo, seriam geralmente divididos entre 1) aqueles que não precisam oficiar rituais domésticos para ganhar a vida, os quais geralmente possuem terras e seguem carreiras de estudos literários e 2) aqueles que oficiam rituais para viver, os quais são padres familiares (family priests) ou em lugares sagrados (chamados de Ksétra em sânscrito). Esses últimos têm status inferior aos que são padres familiares. Entre ksétras, os que oficiam rituais funerários, por sua vez, têm status ainda inferior aos que oficiam cerimônias auspiciosas. Os brâmanes de cada uma dessas divisões casam apenas entre si mesmos, mas pode acontecer de às vezes receberem uma noiva de uma divisão de casta ligeiramente inferior, mas não de uma divisão vários degraus abaixo da sua própria. Assim, um brâmane de "primeira classe", pertencente a uma família cultivada intelectualmente, não casará com a filha de um brâmane que oficia ritos funerários. 0 costume de acordo com o qual um homem casa-se com uma moça pertencente à mesma divisão, ou à uma ligeiramente mais baixa em status, resultou em um fenômeno chamado kulinism na Bengala. Kulin é como é chamada uma classe de brâmanes na Bengala cujos membros são pessoas educadas/intelectualizadas. Sua origem é tributada à ascendência de um rei medieval.

Moças ricas cujas famílias reivindicavam ser kulin, mas cuja descendência kulin não era comprovada tinham esperanças de se casar em famílias kulin. 0 noivo kulin poderia demandar sempre um alto preço, algumas famílias que tinham apenas filhos homens são reportadas como tendo feito dos casamentos um negócio, casando os filhos a um grande número de esposas. Algumas vezes as esposas mais pobres ou nascidas em famílias de status um pouco menor nunca chegaram a ser trazidas às casas dos maridos como noivas efetivamente. Elas viviam na casa de sua família e eram visitadas de vez em quando pelo marido, o qual demandava sempre mais dinheiro por tais visitas. Os filhos podiam ser levados para a casa dos pais, mas geralmente permaneciam na casa dos parentes maternos. Esse tipo de fenômeno levou a uma onda de suicídios femininos, pois as garotas de pais kulin pobres preferiam a morte a trazer a ruína aos pais através do pagamento exorbitante de dote. 0 sistema teria sido rompido por reformadores sociais e pelo aumento da educação entre as mulheres. Entre os Kshatriyas existe uma 
hipergamia bem estabelecida, mas os melhores exemplos de hipergamia são encontrados na zona central entre Rajputs e Marathas.

\section{3) Regras de casamento}

A organização da família seria, segundo Karve, essencialmente similar em toda a região norte e a maioria das castas formariam o mesmo padrão básico que tem suas raízes na família patriarcal Indo-ariana de eras antigas. A autora também nota que os termos modernos de parentesco são mormente derivados dos termos sânscritos. As regras de casamento seriam baseadas principalmente nas considerações de consanguinidade. ${ }^{84} \mathrm{O}$ antigo costume de evitar o casamento com alguém que está a menos de sete graus do pai e cinco graus da mãe, ela afirma, é citado por todas as castas, da mais alta à mais baixa, quando se pergunta sobre práticas de casamento.

A verdadeira regra de casamento, entretanto, seria que a pessoa 1) não deve se casar na sua patri-family ou patri-clan; 2) deve evitar se casar a) com os filhos e filhas dos irmãos e primos de sua mãe e b) com os filhos e filhas da irmã de seu pai e com os filhos e filhas das primas de seu pai. Em quase todas as castas no norte o casamento entre primos (afastados mesmo por dois ou três graus) seria visto com grande descrédito, embora casos ocorressem como exceções. Essa regra seria formulada de modos diferentes em comunidades diferentes, entre brâmanes um homem se casa fora de sua própria gotra e também fora daquela de sua mãe.

O parentesco dravidiano, comum no sul do país, admite e prevê o casamento entre primos, sendo, por isso, geralmente contrastado ao norte. Entre meus amigos, majoritariamente do norte, havia sempre espanto quando eu falava dessas regras de

\footnotetext{
${ }^{84}$ Nesse ponto, Dumont é um grande crítico de Karve. Ele inicia seu artigo na mesma coletânea, editada por Uberoi, criticando Karve e seu achado de um contraste geral entre o sul e o norte. "Em particular, muitas das generalizações sobre o norte indiano em que foi baseado realmente não se sustentam: exogamia nas aldeias não é geral; nem é verdade que na região mulheres casadas não visitam a família onde nasceram; nem que grupos de exogamia unilateral estão ausentes; nem que a interdição do casamento com um parente sapinda seja característica da população como um todo e que seja uma barreira efetiva à repetição de intercasamento entre grupos descendentes locais (como implícito, se não afirmado, em sua teoria). Ao mesmo tempo o contraste se sustenta quanto ao vocabulário de parentesco e intercasamento: casamento entre primos-cruzados, preferido e até prescrito podemos dizer no sul, é proibido no norte (entre hindus), e é extremamente provável que no norte os casamentos ocorram a uma distância, espacialmente e estruturalmente maior que no sul. Mas esse contraste apenas negativamente caracteriza o parentesco do norte indiano em relação ao sistema indiano do sul e, ainda mais, não leva em conta as numerosas e importantes características comuns a ambas as regiões, que podem ser brevemente sumariadas a partir do casamento. Eu posso não ser capaz de definir o sistema de parentesco indiano do norte, mas tentarei expressar as similaridades entre norte e sul como um padrão comum pan-indiano. Formular esse padrão não é nada mais que simples: sua natureza aparecerá no curso do estudo.” (Dumont, 1993 [1966]: 91-92, tradução livre).
} 
casamento entre primos no sul do país. Kaushik, que vem de Hyderabad no sul, um dia falando sobre isso comigo, Shine, Dileep e Patrick na PG demonstrava naturalidade ao dizer:_In my community we marry cousins. Deixou, contudo, os demais integrantes da conversa intrigados com aquilo, sobretudo Shine, que é do Punjab.

4) Limites geográficos e espaciais de endogamia e exogamia

Karve explica que se uma filha é dada a uma certa família de uma certa aldeia, uma segunda filha geralmente não é dada à mesma família ou aldeia naquela geração, nem nas próximas duas gerações pelo menos. Também há um preconceito contra trocar filhas. No Rajasthan, os Rajputs seguem uma regra chamada de "the girl from the east, the boy from the west", uma forma hipergâmica de casamentos, em que a família que doa é de status inferior àquela que recebe, o mesmo valendo para as aldeias de noivas e noivos. Há uma direção no fluxo de troca de mulheres: aldeias do oeste provêm noivos e as do leste provêm noivas. Ao mesmo tempo, evita-se noivos e noivas que venham de muito longe e que afirmem ser de mesma casta, mas que podem, de algum modo, ser de outra um pouco inferior. Assim, o que se tem são duas tendências opostas que apontam para o interior e para o exterior dos grupos.

5) "Filhas" versus "noivas"

Garotas e garotos ("girls and boys") eram casados, geralmente, enquanto ainda eram crianças. A noiva não era mandada até a casa do noivo enquanto não atingia a puberdade. Durante esse tempo ela ia até a casa de seus sogros por alguns dias como uma hóspede. 0 noivo era chamado a levar a noiva ("take away the bride") em um dia auspicioso depois de a noiva ter tido sua primeira menstruação e uma cerimônia chamada gauna era realizada, na qual uma fruta é colocada no colo da noiva, ricos presentes são dados a ela, ao noivo e a seus pais. Entre o casamento e a cerimônia gauna um período de alguns meses até alguns anos poderia decorrer, dependendo das idades da noiva e do noivo. Em alguns casos a noiva era imediatamente levada à casa do noivo após o casamento, acompanhada por uma mulher mais velha da casa dos pais dela, e levada de volta após alguns dias. Quando a noiva era levada pelo noivo após a cerimônia gauna ela não voltaria à casa dos pais, apenas raramente para ocasiões cerimoniais. A separação de noivas jovens da casa de seus pais é tema de tristes canções e histórias populares. Casamentos de moças jovens com completos estranhos fora da aldeia nativa seria uma terrível crise na vida de uma garota. 
Segundo Karve, a cerimônia de casamento é pomposa e divertida, ainda assim, deixar a casa dos pais é um drama. 0 marido é uma figura envolta em sombras, as pessoas reais são os sogros, prontos a notar as falhas da noiva. Na casa do noivo havia ainda o medo presente de que o marido trouxesse outra esposa. Apenas quando uma garota se tornasse mãe de um menino é que se sentiria completamente em casa na joint family do marido. A relação entre as duas famílias unidas pelo casamento seria sempre aquela entre tomadores e doadores, em desfavor desses últimos. 0 pai raramente visitaria a filha na casa do marido, apenas em ocasiões formais, mas o irmão (bir) poderia ir sempre visitar a irmã.

A região norte tem termos distintos para "filha" e "noiva" em cada língua regional, com um duplo padrão de comportamento, e às vezes de moralidade, para cada categoria. Karve cita os seguintes pares em relações de inimizade: nanad-bhojai, seriam uma mulher e a irmã de seu marido e sas-bahu, uma mulher e a mãe de seu marido. Nanad (irmã do marido) é a filha de um lar; bhojai (esposa do irmão) é a noiva. A nanad tem que deixar a casa onde nasceu e seu lugar é tomado pela noiva. Sas é a sogra, a governante da joint family. Bahu é a jovem neta. Embora ambas sejam noivas, isto é, mulheres que vieram pra família pelo casamento, a sogra (sas) por ser mãe estabeleceu certos direitos. Bahu (neta) é uma estranha que seria vista como a presente escrava. Sas e bahu são rivais, numa rivalidade de gerações. A noiva (bhojai) é "vigiada" pela cunhada (nanad) e pela sogra (sas). Quanto à relação entre neta e avó parece ter havido mudanças, não encontrei outras referências nesse sentido e não me pareceu ser assim nas famílias que conheci. Quanto ao fato da noiva ser vigiada pela sogra e pela cunhada, Uberoi (2006) e Fuller e Narasimhan (2008) confirmam essa prática ainda hoje. Embora possam parecer estereotipadas para os dias de hoje, tais visões e as relações de tensão que se estabelecem entre as mulheres da mesma joint family apareciam amenizadas nos relatos de Mrs. Kapoor e de minha professora de hindi, Mantha ji.

Karve explica que o casamento é um sacramento e homens e mulheres comuns não devem morrer sem receber tal sacramento. É costume entre algumas comunidades que uma moça que morra solteira, tenha uma cerimônia matrimonial realizada com seu cadáver para que, então, ela possa ser cremada com as honras de uma mulher casada. Haveria uma maior liberdade para os homens, mas se ele chega a passar por cerimônias de iniciação e morre sem se casar acredita-se que ele se transforme em um fantasma. 
Outra visão corrente seria a de que "morrer sem ter filhos é perder o céu". Essa "crença" (nos termos da autora) firmemente estabelecida faz uma garota infeliz se ela não se casa, pois, teoricamente, não se pode ter filhos fora do casamento. 0 que me faz lembrar que, em mais de uma ocasião, perguntei às minhas amigas se havia mães solteiras (single mothers) em suas cidades de origem, ou em outro lugar que elas conhecessem. A resposta era sempre que havia, sim, mulheres com filhos e sem maridos: viúvas, divorciadas, mulheres abandonadas pelos maridos etc. Eu tinha que explicar, nessas ocasiões, que me referia a mulheres que eram mães sem nunca ter se casado.

6) Levirato, poliginia e segundo casamento

O levirato (casamento de uma mulher viúva com o irmão do marido) é uma prática que já se encontrava em desuso à época em que a autora escreveu o artigo. Em alguns casos a viúva era encorajada a adotar um menino, mas havia muitas disputas judiciais por herança e dizia-se, segundo a autora, que um dos motivos para forçar a viúva a se queimar junto ao marido morto era evitar a adoção de um estranho na família. Essa era também uma explicação acionada para a poliginia, quando uma mulher não concebia, ela às vezes preferia que o marido tivesse outra esposa para gerar filhos a ter de adotar uma criança estranha. 0 mais comum na poliginia, no entanto, era que a primeira mulher odiasse os filhos da outra esposa, uma vez que lhe lembravam seu "defeito" (não ter filhos) constantemente. Algumas castas proibiriam expressamente o casamento de viúvas.

O primeiro e o segundo casamentos têm significados completamente distintos. Para uma mulher, o segundo casamento é apenas viver junto com um homem, não precisa de votos e não tem a sacralidade do primeiro matrimônio. No caso dos homens não há um tabu quanto ao segundo casamento, apenas "a social dislike against it". Um homem pode ter seu status aumentado quando se casa mais de uma vez com a esposa ainda viva, mas o status da família que doa a filha para um homem com esposa ainda viva é diminuído. A legislação indiana atual deslegitimou essa prática tornando a poligamia ilegal. Entre as esposas existe uma primazia da primeira no controle do lar, dos empregados, da criação dos filhos etc. Dar a filha a um homem viúvo também não é o ideal de casamento. Há, nesses casos, suspeição de um casamento contraído por questões financeiras ou de algum 'defeito' da noiva. Um pai perde status social quando dá sua filha a um homem que está casando pela segunda vez. Lovania, no processo de busca pelo noivo, sempre rejeita homens divorciados que demonstram interesse no 
perfil dela no site de casamentos do qual ela é membro, independentemente da idade que tenham.

Papéis em uma joint family:

O padrão de comportamento de um grupo doméstico na família do norte seria que o homem viva com seu patri-grupo, no qual ele nasceu e foi criado, tendo contato com a família da noiva raramente. A mulher, por seu turno, levaria a vida em contato com seus afins, vivendo apenas a infância e adolescência com os pais. Nas falas de Isham encontrava ressonância com essa afirmação quando ele dizia que quando as noivas visitam a família natal levam dinheiro na volta para a casa dos afins. Em muitos casos, porém, essa distância entre as famílias natal e por afinidade parece ter diminuído consideravelmente, como já apontava Dumont (1993) no trecho citado acima. Haveriam, afirma Karve, padrões definidos de comportamento da noiva nessas relações com os afins: ficar de pé e cobrir a cabeça e o rosto na presença dos sogros, evitar estar no mesmo cômodo que o sogro ou os cunhados, abaixar-se para cumprimentar os mais velhos tocando-os nos pés.

Esses comportamentos não continuariam tão marcados assim, a não ser o, já referido anteriormente, uso do véu por parte das cunhadas de Lovania na frente dos sogros. Shubhi e a esposa de Adi, irmão de Meena, contudo, não observavam esse hábito. Tocavam, no entanto, os pés das avós e avôs dos maridos. Observo, ainda, que persiste na etiqueta familiar a evitação em chamar o marido pelo nome em público. Mrs. Kapoor sempre se refere a mister Kapoor como my husband e nunca por seu nome; meus amigos no Facebook dizem, quando conversando com membros da família: mere pati (meu marido); tumhara bhai (vosso irmão); apka bhai (seu irmão), apka bhabi (sua cunhada), evitando assim falar o nome do marido e, por vezes, o nome da esposa.

Segundo Karve, apenas quando a sogra é bem velha ou morre é que a nora poderia ter total liberdade de comportamento e fala. Seria algo comum que a personalidade da mulher casada, sempre submetida aos afins, ficasse mais forte com o envelhecimento (enfraquecimento) do marido ou a viuvez, situações em que poderiam ser mais elas mesmas. A morte de um marido jovem, contudo, é tributada à má sorte da noiva, que seria inauspiciosa, sobretudo se no primeiro ano do casamento. 
Essa passagem me faz lembrar que nos dias que seguiram ao casamento de Shubhi e Ravi, quando ambos voltaram da lua-de-mel, convidaram-me e à Lovania para um café da manhã na casa dos pais de Ravi. Na ocasião, em dado momento da refeição, o pai de Ravi, que Shubhi chama de papa ji, como o costume indica ao tratar com o sogro, chamou a atenção da nora por estar falando sem parar e por, em dado momento, escorregar no que dizia em inglês; oferecendo-se para aquecer meu tchai ela disse: "Let me hot it for you" em vez de "warm it" ou "heat it". O sogro disse algo como:

- Betee [filha], you should learn from your friend [referindo-se a mim]. She listen to others carefully and then, after hearing, she says something. Don't rush to say things, betee, listen and think first.

Embora tenha dito a frase sorrindo, Lovania e eu comentamos mais tarde que aquele era um comentário típico de um sogro para uma nora recém-casada, pois visava instruí-la a como se portar em relação aos in-laws, isto é, prestando reverência.

Segundo Karve, na joint family do norte cada um dos afins (maridos, esposas, noras, genros, sogros, cunhados) teria um lugar definido na relação com os outros afins. 0 trabalho de cada um e os prazeres que podem gozar estão mais ou menos fixados por convenção e devem ser aprendidos por todos os afins. Um homem se comporta com deferência com todos os parentes mais velhos de sua esposa e pode brincar com os irmãos e irmãs mais novos dela. Algo que Lovania sempre referia quando falava dos cunhados era que o comportamento destes com ela é ligeiramente paquerador, estes estariam sempre fazendo brincadeiras que tem um tom de flerte.

Para a autora, a família do norte de seu tempo seria uma continuação da família de eras antigas com pequenas modificações: patrilinear, virilocal e patriarcal. 0 casamento se dava geralmente fora do grupo familiar e fora do grupo local. As noivas seriam trazidas de fora e as filhas seriam dadas para longe. Os comportamentos seriam estritamente regulados de acordo com as gerações, de acordo com se um membro é nascido na família ou trazido a ela pelo casamento e, finalmente, de acordo com ser mulher ou ser homem. Costumes como levirato e sororato mostrariam, Karve afirma, que casamentos são muito mais relações entre duas famílias que entre dois indivíduos. A doação de presentes também confirmaria isso. 
A autora afirma por fim: são os pais dos noivos e noivas que arranjam os casamentos. Os noivos se veem apenas na época do casamento, a noiva deve se sentar com seus olhos e cabeça baixos. Mesmo após a festa, a noiva se senta rodeada por mulheres, muito tímida, de véu, geralmente assustada. A afirmação da timidez esperada da noiva é corroborada por estudos mais recentes de autoras como Uberoi $(1993 ; 2006)$ e Abraham (2011a), e por relatos de pessoas com quem convivi.

Uma preocupação recorrente entre os estudiosos do parentesco na Índia parece ter sido a de encontrar uma característica que fosse comum a todos os sistemas de parentesco indianos, algo que representasse a singularidade ou unicidade desses sistemas. Para Karve essa unicidade residiria em duas instituições presentes em todo o sub-continente indiano: a joint family e o sistema de castas. Para Trautmann (1993 [1981]) outra característica representaria a singularidade dos sistemas de parentesco indianos: a ideologia kanyadana ("the gift of a virgin"), que seria o motivo central do casamento hindu e estaria presente em todas as regiões. Partindo da teoria da aliança, Dumont (1993 [1966]), por seu turno, acreditava que o que aproximava os sistemas de parentesco do sul e do norte da Índia seria a semelhante importância dada às relações estabelecidas por meio do casamento, isto é, às relações de afinidade.

Tendo em vista a apresentação das características dos casamentos arranjados entendidos como um sistema penso restar claro que o casamento de Shubhi e Ravi não se tratou de um casamento arranjado nos moldes do que poderia ser chamado de convencional (Fuller e Narashimhan, 2008). E embora ela dissesse, e Lovania também, que era um casamento por amor, também não se tratava do amor que moveu os casamentos por amor descritos por Mody, Grover e Chowdhry, nos quais o jovem casal desafiou os pais e casou-se mediante fuga, casamento escondido e/ou rompimento com os pais. Donner (2008) e Grover (2011) em suas pesquisas em Calcutá e em Délhi, respectivamente, encontraram diferentes valorações do casamento feito mediante escolhas dos próprios jovens. No primeiro caso, a autora nos alerta, a expressão usada para tais casamentos é "self-arranged marriage", e nela a noção de amor não é a que ganha relevância, mas a noção da escolha autônoma dos cônjuges feita pelos sujeitos. Na pesquisa de Grover os casamentos por escolha tiveram um prelúdio ao matrimônio 
constituído pela história de amor e namoro vivida pelos casais que era tematizada e valorizada pelos interlocutores da autora.

Independentemente da nomenclatura que escolhermos para nomear o casamento de Shubhi e Ravi, sua união matrimonial passou pela eleição mútua de ambos como cônjuges e os dois foram hábeis tanto no convencimento dos pais quanto no manejo das "forças cósmicas", tendo em vista que se casaram em janeiro de 2015, com cerimônias deslumbrantes e alegres, que seguiam todos os preceitos rituais, como poojas, sacramentos e comemorações nos devidos momentos, com pandits, famílias, nubentes e convidados atuando em seus respectivos papéis prescritos para os rituais e, atualmente, vivem em harmonia em New Orleans, para onde Ravi foi efetivamente transferido em maio de 2015.

Em que pese a autoafirmação de um casamento por amor e o procedimento dos pais consoante com um casamento arranjado, o que importa para os fins da presente pesquisa é que mais uma vez meus amigos e interlocutores mostravam-se capazes do empreendimento que buscavam, seus experimentos existenciais colocavam-nos mais próximos de uma interioridade que os definia como indivíduos, portavam-se como sujeitos e não como instrumentos dos pais nos namoros e casamentos que empreendiam. Talvez se pudesse dizer que se sentiam seres em existência, em luta com os apoios do viver que já não forneciam abrigo e tentando estabelecer outros abrigos para a vida que queriam ter.

Ao cabo e ao fim o amor, insistentemente colocado como importante por meus amigos, não parece ter conseguido seu lugar ao sol no modo de ser fazer os casamentos. Apesar de sua presença inegável, a legitimidade que o amor já tem para os filhos ainda não foi outorgada pelos pais para se fazer matrimônios. Nesse embate geracional não há astrólogo ou cuidado possível com a auspiciosidade que dê conta de prever se, algum dia, ao amor romântico será dada, na Índia, a força que a ele se deu no ocidente: de ser condição suficiente e necessária para o casamento. Independentemente disso, os experimentos existenciais que os interlocutores dessa pesquisa empreenderam foram felizes em transformar essas pessoas e, de passagem, transformar a relação entre indivíduo e sociedade naquela paisagem moral.

Tomar o amor como unidade de análise numa pesquisa antropológica é algo que foi intentado por Viveiros de Castro e Benzaquem de Araújo para, ao isolar a concepção 
de amor presente em Romeu e Julieta como um mito, "perceber qual a lógica das relações sociais subsumidas por essa categoria" (1977: 131). Nos casos que pude observar o amor pode acontecer e redundar em casamento quando outros elementos estavam conjuntamente presentes. 0 casamento de Ravi e Shubhi constituiu uma união intercasta, mas esse conflito foi amenizado pela condição abastada das duas famílias, pela compatibilidade de aparência física entre os nubentes que se encontrava com as expectativas sociais e pela formação universitária que ambos tiveram, com pósgraduações e MBAs dos dois lados. De modo que, ao que parece, não foi o amor o possibilitador do casamento, mas antes as compatibilidades as facilitadoras para que o amor, como escolha do cônjuge, fosse permitido pelos pais.

Mathura, grande amiga de Meena que conheci durante o casamento de Adi, o irmão dessa última, foi-me apresentada como alguém com quem eu deveria conversar sobre minha pesquisa por ter tido um casamento por amor. Na cerimônia kanyadania do irmão de Meena, Mathura contou-me que quando seus pais descobriram que ela estava apaixonada e namorando um colega da faculdade em Délhi ficaram desesperados e a confrontaram para saber mais sobre o que se passava com a filha que morava num hostel no interior do campus da JNU. O temor e o susto dos pais só diminuiu quando foram, aos poucos, descobrindo o background do namorado da filha. Conforme Mathura disse, ao saber o nome do rapaz e ver, pelo sobrenome, que não se tratava de alguém de uma casta considerada inferior; que o rapaz cursava um doutorado, como a filha também fazia; que era hindu; e que ambos pretendiam se casar com a benção dos pais, a situação tomou outro rumo e os pais respiraram aliviados. A cientista política afirmava que teve sorte porque apaixonara-se por alguém que os pais puderam aceitar, não tendo que promover uma ruptura com a família, tanto em seu caso quanto no caso do marido, para casar-se. Ela enfatizava que as distâncias sociais entre eles não eram tão grandes e que tendo em vista o cenário de lentas mudanças nos casamentos em seu país os pais dos dois lados conformaram-se à escolha dos filhos sem maiores traumas além daquele do susto inicial, como me disse rindo.

Como bem aponta Abraham (2014) a endogamia de casta sendo, a um só tempo, uma característica constitutiva do sistema de castas e o que possibilita a perpetuação desse sistema deve, contudo, ser observada como dinâmica e flexível, como o próprio sistema de castas o é. Nesse sentido casamentos não endogâmicos e não hipergâmicos (isto é, hipogâmicos e intercasta, portanto, como o de Shubhi e Ravi) seriam 
desestabilizadores da ordem de casta. Não obstante isso, contudo, existem casos em que o dinamismo e a flexibilização da endogamia, de modo condizente com os contextos históricos de mudanças na hierarquia de castas, devem ser levados em conta. A autora aponta que muitas pesquisas demonstram que os círculos de endogamia, isto é, os limites até os quais os casamentos são considerados endogâmicos, foram se alargando de uniões entre famílias de mesma sub-sub-casta para a mesma sub-casta e, finalmente, para a mesma casta. Como apontam também Van Wessel e Fuller e Narasimhan, em alguns casos casar-se na mesma Varna já pode ser considerado endogamia na ausência de um noivo ou noiva de mesma sub-casta ou casta.

Em casos analisados por Abraham outras mudanças também foram incorporadas nas estratégias matrimoniais, como no caso das mulheres da casta Thiyyas que tiveram, durante o início da colonização britânica, ligações (liaisons) com homens ingleses, as quais geraram filhos. Tais filhos, por vezes brancos e de olhos azuis, foram com o tempo passando a ser estigmatizados como fruto de relações não legítimas do ponto de vista dos sistemas de casamento e parentesco indianos, fazendo com que essas mulheres e seus filhos fossem expulsas de suas comunidades. Recentemente, algumas gerações depois, a mobilidade social de algumas famílias dessa casta no norte de Kerala e a massiva valorização da pele clara - que antes era o estigma carregado nos corpos dos filhos e filhas das relações sexo-afetivas das mulheres Thiyyas com homens ingleses passaram a fazer das descendentes daquelas gerações do passado, moças desejadas para o casamento endogâmico entre os Thiyyas.

Abraham faz notar igualmente que no estado de Haryana, onde Chowdhry conduziu sua pesquisa, não obstante os casos trazidos por essa última, em que a endogamia de casta e a exogamia de gotra são forçadas com violência e mortes, casamentos intercasta e inter-comunidade ou cross-region, como os chama Abraham, são aceitos nos casos em que uma família não consegue encontrar uma noiva para o filho graças à diferença numérica entre a população feminina e masculina do estado, o que causa um desequilíbrio nos casamentos, pois para cada 1.000 homens haveriam apenas 877 mulheres (Abraham, 2014: 63). Nesses casos, moças de estados longínquos são trazidas pela família do noivo e características como não comer carne e ter a pele clara seriam tidas como indícios de que as noivas pertenceriam a "good castes", isto é, constituiriam casamentos hipogâmicos e intercasta, mas não ameaçariam o poder e o status da família graças ao fato de que alianças com as famílias das noivas não são 
estabelecidas, assim: "a woman can be fully incorporated into the family without upsetting local hierarchies", fazendo com que casamentos inter-comunidade, intercasta e hipogâmicos sejam aceitos.

O que Abraham quer chamar a atenção com a análise desses casos é que, embora propagada como a única forma de manter a pureza de sangue das castas, "the assertion of endogamy thus shows up starkly as not being about the purity of blood or the mixing of castes per se, but about mixing with groups in known hierarchical relationships" (Idem: idem). Abraham mostra como, para se manter, o sistema de castas faz concessões tornando a endogamia contingente de acordo com as necessidades da consciência de casta de cada grupo e com o momento histórico.

Assim, em meu trabalho, apesar de Shubhi e Ravi terem feito um casamento inter-varna é preciso levar em conta que "marriage strategies include several considerations, class being an important one" (Idem: 58). Ao citar o estudo de Karen Isaksen Leonard, Abraham aponta mudanças na endogamia tidas entre os Kayasthas, mesma varna de Shubhi, em Hyderabad em que, segundo Abraham, "marriage strategies sought to maximise economic and political opportunities" (Idem:idem), fazendo as famílias preferirem casamentos com famílias não-Kayasthas, mas que fossem de Hyderabad, num movimento que privilegiava o casamento intra-comunidade, ou intraregional, em detrimento da endogamia de casta. ${ }^{85}$ Nos casos que apresento, portanto, pode ser que os limites da endogamia estivessem também sendo expandidos ou que outros critérios tenham sido considerados mais importantes que a endogamia de casta, como a classe social notadamente.

Ainda do ponto de vista das estratégias matrimoniais, algumas características dos relacionamentos amorosos de meu campo me remetiam à pesquisa de Piscitelli (1990) numa pequena cidade de Minas Gerais em que a autora investigou o modo de fazer casamentos entre famílias das classes médias e altas. A autora afirma que a luta para poder escolher com quem se casar cabia sempre às mulheres em Serro Verde (Piscitelli, 1990: 174). De modo semelhante, minhas amigas precisavam fazer um esforço sempre maior para convencer os pais a aceitar o rapaz escolhido. Essa característica se coaduna com o jogo de poder e a estrutura do patriarcado em que, ao tentar escolher, a moça desafia o poder paterno (Abraham, 2014). Além do mais, as ideias iniciais de Piscitelli

\footnotetext{
${ }^{85} \mathrm{O}$ estudo a que refere Abraham é: "Social History of an Indian Caste: The Kayasths of Hyderabad”, de Karen Isaksen Leonard, 1978.
} 
em sua pesquisa e as conclusões a que chega fizeram-me saltar da cadeira enquanto as lia, como se a autora tivesse, duas décadas antes, assistido ao mesmo filme que eu via em Délhi:

"Adiantando-me as conclusões devo dizer que no transcurso de muitos meses de investigação - e decepcionando-me um pouco -, as promessas rebeldes iam remetendo-me mais à ordem do que à desordem social. As histórias de amor relatavam rupturas dramáticas e sugeriam, quando ouvidas pela primeira vez, alterações sérias na estrutura social local. Entretanto, a análise realizada, considerando-as na sua relação com as estratégias matrimoniais desenvolvidas, foi conduzindo esta dissertação por outros caminhos. Numa primeira leitura, o amor parecia ser um importante baluarte de resistência. Posteriormente, ao contrário, pareceu ser mais o motor de movimentos de reconversão de estratégias matrimoniais do que o detonador de ações profundamente subversivas da ordem estrutural." (Piscitelli, 1990: 9)

Nos casos dos casamentos que acompanhei ou que me foram narrados a promessa de rebelião do amor não se efetivou, mas ficou próxima do que também aponta Piscitelli, que o amor "aparece provocando maior ou menor grau de conflitos individuais sem no entanto desempenhar qualquer papel em alterações estruturais" (Idem: 7) quanto às estratégias matrimoniais. A diferença em nossas conclusões seria, no entanto, de que num contexto em que o amor é visto, do ponto de vista da moralidade hegemônica, como absolutamente negativo antes do casamento, esse o caso indiano, e as pessoas como divíduos, devendo submeter-se a uma socialidade preponderantemente holista, o esforço na direção de vivenciar o amor e de, por meio dele, constituir-se indivíduo, me parece merecer algum crédito no sentido, como já apontava acima, de que o amor permite observar o tipo de relação existente entre sociedade e indivíduo e seria nessa chave que reside a potência do amor entre meus amigos: observei o amor como um elemento transformador no processo de constituição da pessoa.

No caso de Mathura e no de Shubhi, além da possibilidade que tiveram de o amor redundar em casamento outra semelhança é marcante: o fato de que mudaram seus nomes logo após o casamento, adotando os sobrenomes, e isto equivale a dizer o pertencimento de casta, dos maridos. Ambas seguiriam ainda, caso necessário, a patrilocalidade. Shubhi temeu por algum tempo que Ravi não fosse transferido para os Estados Unidos, mas para Délhi e que tivessem que morar, se isso se concretizasse, com os sogros e com Yaman, irmão mais novo de Ravi. Já Mathura vive com o marido e os sogros em Calcutá graças ao fato de que o marido, professor universitário, conseguiu um emprego naquela cidade após terminar seu doutorado. 
Quero com essas histórias dizer que o amor não foi, por si só, suficiente para que os jovens em questão se casassem com a anuência de seus pais, foi preciso que houvesse outros aspectos considerados positivos e abonadores das escolhas dos filhos e filhas para que o casamento tivesse a aceitação dos pais. Mais que isso, no caso de Shubhi, de Mathura e de Adi, o irmão de Meena, os casamentos se deram como se fossem arranjados perante os familiares e os convidados, embora, para os amigos, amigas, primos e primas fossem tidos e celebrados como love marriages, o que demonstra como os grupos acionam e manipulam as duas noções em favor próprio. A seguir passo aos apontamentos finais de tudo aquilo que aprendi com meus anfitriões. 


\section{Apontamentos Finais}

Essa tese tratou o amor como um possibilitador da transformação de pessoas em indivíduos entre sujeitos abastados vivendo numa grande cidade da Índia. Esses indivíduos não querem, contudo, abandonar a comunidade a que pertencem, nem destruir sua instituição mais importante, o casamento. Estão dispostos, para isso, a manipular as noções de "love marriage" e "arranged marriage", essa a condição para construir suas vidas combinando criativamente a sua própria volição com a manutenção do arranjo feito pelos pais. Diferentemente do que imaginei nos primeiros passos dessa investigação, o amor e o romance não são uma recusa ao casamento, portanto, as teses que o citam como algo revolucionário/subversivo na Índia estariam apenas parcialmente corretas. Após o casamento, como apontado na literatura, as esposas passam a ser pativratas, isto é, devotadas aos maridos, e, depois, aos filhos, mantendo-se subordinadas ao poder patriarcal. Os casamentos que acompanhei não romperam, mas mantiveram, as lealdades familiares, alguns estereótipos de gênero e a estrutura patriarcal na qual estão subsumidos. Se é bem verdade que alguns fizeram casamentos intercasta, e outros ainda esperam fazê-lo, não podemos deixar de notar que a condição para que consigam a aceitação dos pais tem sido a de escolher pares que não destoem de si na classe social e no pertencimento religioso. Nesse sentido, Fuller e Narashimhan (2008) e Netting (2010) apostam numa nova lealdade que estaria em par de igualdade, para o primeiro, ou suplantando, para a segunda, as lealdades de casta para os efeitos dos matchmakings: a de classe social. Particularmente, acredito que a tendência seja de conjugar casta e classe social, não me parece que num cenário minimamente próximo as lealdades de casta sejam abandonadas.

A relevância do tema aprofundado nesta tese ficou patente na convivência com as moradoras e os moradores da PG e com as amigas e os amigos deles, as/os quais tive a oportunidade de conhecer. A preocupação, as angústias, as curiosidades e as apreensões sobre intimidade, sexualidade e romance faziam parte das vidas dessas pessoas de modo tão veemente que não lhes era difícil apresentar suas histórias, emoções e teorias sobre o assunto, pois que estavam sempre às voltas com o dilema posto pela divergência entre seus anseios e aqueles da família de cada um deles, tendo que encontrar modos de estar no mundo que atendessem a seus desejos e emoções sem romper completamente com 
os seus entes queridos, como fazem os casais em fuga apresentados por Mody (2008) e Chowdry (2014).

A literatura pertinente apontava que existe uma grande escassez de pesquisas de cunho etnográfico que versem sobre relações amorosas, romance e sexualidade na Índia. Há abundância de textos sobre o tema, mas do ponto de vista dos Cultural Studies: análises de filmes, de produções literárias, de revistas femininas (women's magazines) e da produção midiática em geral aparecem em grande parte da literatura que trata esses temas. Outra tendência é a análise de textos religiosos e a transformação de personagens da mitologia hindu: de como, por exemplo, o deus Rama estaria sendo transformado de um personagem terno e andrógino em uma figura musculosa e masculinizada ( $c f$. Menon, 2007). As etnografias que falam diretamente dos relacionamentos afetivos e íntimos, seja no interior do casamento ou fora dele, são poucas. Trabalhos como o de Grover (2011) e Leena Abraham (2002) constituem honrosas exceções nas quais me apoiei, mas das quais me distancio por tratar de outra classe social, os jovens de famílias abastadas que aqui aparecem, ao passo que aquelas autoras investigaram bairros pobres de Nova Délhi e estudantes de baixa renda de universidades de Mumbai, respectivamente.

Penso que a convivência com os jovens em Nova Délhi me propiciou escrever sobre o assunto de modo sensível graças ao tipo de relação que se estabeleceu entre nós, de amigos, conselheiros e confidentes. A conselheira e confidente nem sempre fui eu, ao contrário, todos eles me ensinaram muito sobre como viver e me cuidar naquela cidade, e me aconselhavam nos próprios rumos da pesquisa: sim, eu devia mesmo desistir dos marriage bureaus ou deixar que um deles fosse até lá comigo para fazê-los entender o que eu queria e que eu era uma pessoa confiável; devia conhecer essa ou aquela pessoa pois haviam feito casamentos por amor; devia assistir a tal filme pois tratava da temática de meu trabalho etc. Como dito, a todos que aparecem nesse trabalho pedi permissão para falar de tudo que me ensinavam, mesmo quando diziam: _Come on, we are like sisters, don't talk to me as a stranger.

Outro aspecto me faz acreditar que a presente investigação apresentou uma contribuição inovadora aos estudos sobre romance pré-conjugal e sobre novos modos de fazer casamentos na Índia é o fato de que, como diz Biswas (2011), o casamento afeta igualmente a vida dos casados e de quem não é casado naquele país: 
"Marriage is not merely a choice you make, or a private decision you take. It is a highly politicized statement that one makes about oneself and about those who stay outside it. It affects the lives of both who marry as well as those who do not. Therefore, we cannot not examine the privileges that accrue to marriage and that consequently are denied to others." (Biswas, 2011: 426)

Desse modo, investigar as vivências desses jovens solteiros (por ora?) e o modo como a obrigatoriedade social, moral e religiosa do casamento os afeta mostrou ter um bom rendimento no debate sobre o casamento e as mudanças em curso nessa instituição. Além do mais, a tese procurou mostrar que as novas tendências de combinar "love" e "arranged" nos casamentos, presentes em alguns estudos anteriormente citados, deixa escapar um outro tipo de amor, aquele que é sufocado pelos pais cujos filhos vivem histórias como as de Shubhi e Patrick, Rekha e Praveen e de Lovania pelo exnamorado. $\mathrm{O}$ amor que Shubhi buscou nutrir pelo pretendente com quem se casou não era da mesma intensidade e tão genuíno que aquele que ela sentia por Patrick e disso tínhamos certeza os que eram próximos dela. Nesse sentido aponto que o amor romântico como uma construção que permite ligar duas pessoas de modo arbitrário na união do casamento está presente na mente e nos corações dos jovens, mas na esmagadora maioria dos casos, a concessão para que essa ideia ganhe força e passe a constituir um modo legítimo de realizar casamentos na Índia ainda não foi outorgada. Meu trabalho consistiu em etnografar o amor dos jovens que, por ora, diferencia-se da ideia ocidental de amor romântico porque a assunção de que o amor é algo necessário, ou mesmo suficiente, para realizar casamentos exitosos não alcançou a condição de um sistema de conhecimento, para lembrar Gell, que permita às pessoas se escolherem livremente independentemente das famílias, da religião, da casta, da comunidade e da astrologia.

O que essa pesquisa logrou encontrar é que, diferentemente do que intuí no início de meu convívio com os jovens naquela cidade, é possível sentir atração sexual e afeto por alguém sem que, necessariamente, isso leve ao casamento, ou mesmo à assunção de que esse seria o melhor modo de constituir um casamento. É importante dizer que casais maduros e jovens que conheci, amigos e familiares dos que aparecerem no texto, exibiam contentamento e alegria nos casamentos que haviam feito de modo arranjado. Em alguns casos pude acompanhar a progressiva aproximação entre casais jovens que primeiro exibiam pouca intimidade em fotos e postagens nas redes sociais e, com o tempo e a chegada de filhos, foram passando a declarar seu amor publicamente e a 
comportar-se de modo íntimo e apaixonado. Entre casais mais velhos, nada permitia entrever apenas pela observação, do modo como se portavam e se apresentavam em público, aqueles que teriam feito casamentos por amor e os que teriam feito casamentos arranjados. Como eu disse, o amor após o casamento é uma aposta e uma expectativa dos sistema de casamentos arranjados indianos. Posso atestar que são também uma realidade entre aqueles com quem convivi, seja na pessoa dos pais e demais familiares, ou de jovens em sua mesma faixa etária. Evidentemente, histórias tristes de noivas sendo forçadas ao casamento arranjado e infelizes na vida conjugal já em curso chegaram igualmente ao meu conhecimento.

As novas maneiras de fazer casamentos permitem afirmar que, não obstante o anseio pelo romance e a individuação que pode advir daí, não estamos em face de um cenário de abandono de valores ditos tradicionais, mas de um cenário sui generis, eu diria, de orientação da vida por múltiplos ordenamentos de realidade. Foram os diferentes ordenamentos de realidade e a habilidade em mediá-los que levaram, nos casos que acompanhei, pais e filhos a resistirem e a fazer concessões para que todas as partes saíssem contentes. Não estamos, igualmente, diante de um processo de constituição de formas agudas de individualismo. Talvez o achado mais geral dessa tese seja o de que as pessoas com quem convivi estavam num embate entre ser divíduo e indivíduo concomitantemente e essa parece ter sido a opção que fizeram alguns de meus interlocutores.

Essa tese faz coro com a pesquisa de Grover (2011) ao poder atestar a crescente tendência ao romance pré-conjugal nas cidades indianas. Os contatos iniciais, como aponta a autora, acontecem na própria vizinhança, na escola, na faculdade e se expandem para outros lugares facilitados pela mobilidade propiciada pela vida na cidade, e que torna a vigilância familiar mais difícil. Como dito antes, as possibilidades abertas pela vida na cidade e pela distância dos familiares são horizontes que me mostraram meus amigos e sobre os quais essa investigação etnográfica rendeu reflexões que me permitiram afirmar que os namoros são um caminho sem volta na direção da individuação dos sujeitos que se engajam nessa prática.

Tive de enfrentar ainda o tema da noção do amor como escolha e de como isso se ligava ao tema do individualismo. A diversidade e heterogeneidade de experiências, discursos e impressões dos moradores da PG me permitiram analisar o tema de forma a não simplificar as realidades que se me apresentaram, espero ter fugido das elaborações 
de muitos estudos culturais, abundantes como já mencionado, que recorrem a polarizações e simplificações, talvez justamente pelo fato de lidarem com representações de papel e plástico e não com o sangue e os sentimentos que fazem pulsar os corações de pessoas em embate com a existência, com suas expectativas, aflições, ansiedades, afetos, desejos e amores.

A pesquisa pode, portanto, ajudar a preencher uma escassez de trabalhos etnográficos sobre o romance pré-marital, ou o namoro, na Índia e sobre as diferentes acepções de amor que estão sendo construídas e experimentadas no laboratório existencial que meus amigos faziam naquele momento morando naquela PG. Ao fazê-lo, desafiavam assunções como a de Orsini de que "spaces for love in Indian society still lie mostly in the literature or filmic imagination, in the interstices of ordinary life, when no one else is looking, or in the interval between dreams and expectations about the future spouse and the epiphany of reality at the wedding" (Orsini, 2007: 37).

Os casos analisados mostram como a noção de amor tem uma importância crescente entre os jovens da classe média alta urbana para o casamento ao mesmo tempo em que difere da ideia ocidental do amor romântico como o ingrediente principal a legitimar o casamento. Diferentemente do amor romântico ocidental, que seria, idealmente, o sentimento mais poderoso que existe e que venceria quaisquer obstáculos para colocar em união o par de apaixonados, na Índia o amor figura nas classes médias e altas urbanas como mais um dos requisitos que competem para a união matrimonial. Se todo o resto estiver de acordo com os ideais normativos do sistema de casamentos arranjados, então o amor pode redundar em casamento. No entanto, tendo ou não levado ao casamento, o amor vivido como um experimento existencial, desafiando os apoios do viver, possibilitou a transformação das pessoas em questão e deslocou a relação entre divíduos para um pouco mais próxima do tipo de relação existente entre indivíduo e sociedade. 


\section{Referências Bibliográficas}

ABRAHAM, Janaki. (2010) Veiling and the Production of Gender and Space in a Town in North India: a Critique of the Public/Private Dichotomy. Indian Journal of Gender Studies, 17:2. pp. 191-222.

(2011a) Weddings and Videos: Representing Conjugality in Contemporary Kerala. In: SEN, Samita; BISWAS, Ranjita and DHAWAN, Nandita. Intimate Others - marriage and sexualities in India. Kolkata: Stree. pp. 265-284.

(2011b) 'Why did you send me like this?': Marriage, Matriliny and the 'Providing Husband' in North Kerala, India. AJWS Vol. 17, n. 2, pp. 32-65.

(2014) Contingent Caste Endogamy and Patriarchy: Lessons for Our Understanding of Caste. Economic and Political Weekly, January 11, 2014. Vol XLIX, n. 2.

ABRAHAM, Leena. (2002) Bhai-Behen, True Love, Time Pass: Friendships and Sexual Partnerships among Youth in an Indian Metropolis. Culture, Health \& Sexuality, Vol. 4, No. 3 (Jul - Sep, 2002), pp. 337-353.

BÉTEILLE, A. (1986) Individualism and Equality [and comments and replies]. Currently Anthropology, Vol. 27, n. 2, April 1986, pp. 121-134.

BISWAS, Ranjita. (2011) Of Love, Marriage and Kinship: Queering the Family. In: SEN, Samita; BISWAS, Ranjita and DHAWAN, Nandita. Intimate Others - marriage and sexualities in India. Kolkata: Stree.

BORGES, Antonádia. (2009) Explorando a noção de etnografia popular: comparações e transformações a partir dos casos das cidades-satélites brasileiras e das townships sulafricanas. Cuadernos de Antropologia Social, Buenos Aires, n. 29, julho de 2009.

BOZON, M. \& HEILBORN, M. L. (1996) Les caresses et les mots: l'initiation amoureuse à Rio de Janeiro et à Paris. Paris: Terrain, no 27.

CLARK-DESCÉS, Isabelle. (2014) The Right Spouse: Preferential Marriages in Tamil Nadu. Standford: Standford University Press.

DAS, Veena. (1995) Critical Events: an anthropological perspective on contemporary India. Delhi: Oxford University Press.

DELL, Heather S. (2005) 'Ordinary' sex, prostitutes, and middle-class wives: liberalization and national identity in India. In: ADAMS, Vincanne e PIGG, Stacy Leigh. (eds.) (2005) Sex in Development - science, sexuality, and morality in global perspective. Durham and London: Duke University Press.

DHAWAN, Nandita. (2011) The 'legitimate' in Marriage - Legal Regulation and Social Norms. In: SEN, Samita; BISWAS, Ranjita and DHAWAN, Nandita. Intimate Others marriage and sexualities in India. Kolkata: Stree. 
DONNER, Henrike. (2008) Domestic Goddess: maternity, globalization and middle-class identity in contemporary India. Hampshire: Ashgate Publishing Limited.

DUMONT, Louis. (1992) Homo hierarchicus: O sistema das castas e suas implicações. São Paulo: Editora da Universidade de São Paulo.

(1993 [1966]) North Indian in Relation to South India. In: UBEROI, Patricia. Family, Kinship and Marriage in India. pp. 91-111. New Delhi: Oxford University Press.

DWYER, Rachel. (2000) All you want is money, all you need is love: Sex and romance in modern India. New York: Cassell. 216 pp.

FULLER, C. J. e NARASIMHAN, Haripriya. (2008) Companionate marriage in India: the changing marriage system in a middle-class Brahman subcaste. Journal of the Royal Anthropological Institute 14, 736-754.

GELL, Alfred. (2011) On love. Anthropology of this century, 2. Disponível em: http://eprints.lse.ac.uk/39003/

GHOSH, Shohini. (2008) The troubled existence of sex and sexuality: feminists engage with censorship. In: Mary E. John (ed.). Women's Studies in India - a reader. New Delhi: Penguin Books.

GOLDMAN, M. (1993) Os tambores dos mortos e os tambores dos vivos. Etnografia, antropologia e política em Ilhéus, Bahia. Revista de Antropologia, São Paulo, USP, v. 46, n 2.

GOMES, Fabíola. (2010) Comidas, pessoas e deuses: etnografia de eventos alimentares na Índia. 124 f., il. Dissertação de Mestrado em Antropologia Social - Universidade de Brasília, Brasília.

. (2014) Louis Dumont e os Subaltern Studies: desconstruções de um cânone. In: MORALES, Elena Nava e BONY, Frida Calderón (org.). La Otra Antropología: reflexiones sobre el oficio antropológico. Quito: Abya Yala Publicaciones.

GROVER, Shalini. (2011) Marriage, Love, Caste \& Kinship Support - Lived experiences of the urban poor in India. New Delhi: Social Science Press. 211 pp.

GUPTA, Narayani. (2003) The Indian City. In: DAS, Veena. (ed.) The Oxford India Companion to Sociology and Social Anthropology. New Delhi: Oxford University Press.

HARVEY, David. (1996) A Condição Pós-Moderna: uma pesquisa sobre as origens da mudança cultural. São Paulo: Edições Loyola.

JASPERS, Karl. (1965) Introdução ao Pensamento Filosófico. São Paulo: Editora Cultrix. (1973) Filosofia da existência. Rio de Janeiro: Imago Editora Ltda. 
JOHN, Mary E. and NAIR, Janaki. (1998) Introduction. In: JOHN, Mary E. and NAIR, Janaki (eds.). A Question of Silence? The Sexual Economies of Modern India. Delhi: Kali for Women.

KAKAR, Sudhir. [1989] (2011) Lovers in the Dark. In: KAKAR, Sudhir. The Essential Sudhir Kakar. New Delhi: Oxford University Press.

[2007] (2011) Indian Sexuality. In: KAKAR, Sudhir. The Essential Sudhir Kakar. New Delhi: Oxford University Press.

KARVE, Irawati. (1993 [1953]) The Kinship Map of India. In: UBEROI, Patricia. (ed.) Family, Kinship and Marriage in India. pp. 50-73. New Delhi: Oxford University Press.

LOBAT0, Josefina Pimenta. (1994) A Gestão do Amor: Domesticação e Disciplina. Tese de Doutorado em Antropologia - Universidade de Brasília, Brasília.

MADAN, T. N. (1987) Non-Renunciation: Themes and Interpretations of Hindu Culture. Délhi: Oxford University Press.

MENON, Nivedita. (2007) Introduction. In: MENON, Nivedita. (ed.) Sexualities. New Delhi: Kali for Women.

MODY, Perveez. (2008) The Intimate State: love-marriage and the law in Delhi. New Delhi: Routledge. 282 pp.

MOUNIER, Emmanuel. (1962) Introduction aux Existencialismes. Paris: Éditions Gallimard.

MUKHOPADHYAY, Madhurima. (2011) Choice and agency in marital decisions: a study among Hindu Bengalis across class in Kolkata. In: SEN, Samita; BISWAS, Ranjita and DHAWAN, Nandita. Intimate Others - marriage and sexualities in India. Kolkata: Stree.

NANDA, Serena. (2000) Arranging a Marriage in India. In: Philip R. DeVita (ed.). Stumbling Toward Truth: Anthropologists at Work. pp. 196-204.

NANDY, Ashis. (2004) The Changing Popular Culture of Indian Food: Preliminary Notes. South Asia Research, Volume 24, º 1, May 2004, pp. 9-19.

NETTING, Nancy S. (2010) Marital Ideoscapes in 21st-Century India: Creative Combinations of Love and Responsability. Journal of Family Issues, 31 (6), pp. 707-726.

ORSINI, Francesca. (2007) Introduction. In: ORSINI, Francesca (ed.). Love in South Asia a cultural history. New Delhi: Cambridge University Press India.

PAPPU, Rekha. (2011) Reconsidering Romance and Intimacy: The case of the single unmarried woman. In: SEN, Samita; BISWAS, Ranjita and DHAWAN, Nandita. Intimate Others - marriage and sexualities in India. Kolkata: Stree.

PARRY, J. P. (2001) Ankalu's errant wife: sex, marriage and industry in contemporary Chhattisgarh. Modern Asian Studies 35, pp. 783-820. 
PEIRANO, Mariza. (2001) Rituais como estratégia analítica e abordagem etnográfica. In: PEIRANO, Mariza. (org.) O Dito e o Feito: ensaios de antropologia dos rituais. Rio de Janeiro: Relume Dumará.

(2014) Etnografia não é método. Horizontes Antropológicos. Porto Alegre, ano 20, n. 42. Pp. 377-391.

PEIRCE, C. (1972) Semiótica e Filosofia. São Paulo: Editora Cultrix.

PISCITELLI, A. G. (1990) Amor, paixão e casamento: escolha de cônjuge em famílias de camadas médias e altas numa cidade do sul de Minas Gerais. Dissertação de Mestrado em Antropologia Social. Universidade de Campinas, UNICAMP.

SAAVALA, Minna. (2010) Middle-Class Moralities - Everyday struggle over belonging and prestige in India. New Delhi: Orient Blackswan Private Limited.

SEN, Rukmini. (2010) 'Neutral' Laws or 'Moral' Codes: Controlling and Recreating Sexualities/Intimacies. Disponível em: http://cequinindia.org - Revista eletrônica da Cequin, Centre for Equity and Inclusion.

SEN, Samita; BISWAS, Ranjita and DHAWAN, Nandita. (2011) Introduction. In: Intimate Others - Marriage and Sexualities in India. School of Women's Studies, Jadavpur University.

SERRANO, Carlos Moreira Henriques. (1998) Angola: nasce uma nação. Estudo sobre a construção da identidade nacional. Tese (Doutorado em Antropologia Social)) Universidade de São Paulo, São Paulo.

SRIVASTAVA, Sanjay. (2007) Passionate Modernity - sexuality, class and consumption in India. New Delhi: Routledge. 350 pp.

TAMBIAH, Stanley. (1990) Multiple Orderings of Reality: the debate initiated by LévyBruhl. In: Magic, Science, Religion and the Scope of Rationality. Cambridge: Cambridge University Press.

(1996) Relations of Analogy and Identity. Toward Multiple Orientations to the World. In: David Oolson \& Nancy Torrance (Eds.) Modes of Thought. Explorations in Culture and Cognition. Cambridge University Press.

TRAUTMANN, Thomas R. (1993 [1981]) The Study of Dravidian Kinship. In: UBEROI, Patricia. (ed.) Family, Kinship and Marriage in India. pp. 74-90. New Delhi: Oxford University Press.

TURNER, Victor. (2005) Floresta de Símbolos. Aspectos do Ritual Ndembu. EdUFF, Niterói, Rio de Janeiro.

UBEROI, Patricia. (1993) Introduction. In: UBEROI, Patricia (ed.). Family, Kinship and Marriage in India. pp. 1-44. New Delhi: Oxford University Press.

(2006) Freedom and destiny - gender, family, and popular culture in India. New Delhi: Oxford University Press. 
(2011) Foreward. In: GROVER, Shalini. (2011) Marriage, Love, Caste \& Kinship Support - Lived experiences of the urban poor in India. New Delhi: Social Science Press. pp. ix-xiv.

VAN WESSEL, Margit. (2001) Modernity and Identity: An Etnography of Moral Ambiguity and Negotiations in an Indian Middle Class. PhD thesis, University of Amsterdam.

VANITA, Ruth. (2010) Gandhi's Tiger and Sita's Smile - Essays on gender, sexuality and culture. New Delhi: Yoda Press.

VIVEIROS DE CASTRO, Eduardo e BENZAQUEM DE ARAÚJO, Ricardo. (1977) Romeu e Julieta e a origem do Estado. In: VELHO, Gilberto. Arte e Sociedade: ensaios de sociologia da arte. Rio de Janeiro: Zahar Editores. pp. 130-169.

YAN, Yunxiang. (2011) The Changing Moral Landscape. In: KLEINMAN, Arthur et al. Deep China. The Moral Life of the Person, What Anthropology and Psychiatry Tell Us about China Today. Los Angeles: University of California Press.

WANI, Aarti. (2013) The Provincial Self in the Town of Love. Economic and Political Weekly, Vol. XLVIII, n. 51, December, 21, 2013. 
Caderno de Imagens 




Fachada da PG com a placa da academia Fibre Fitness Gym and Spa, que funciona no subsolo. 




Vista do Aurobindo Market desde a PG. 




Playground infantil em Aurobindo Market: pela manhã era comum pessoas se aquecerem ali ao sol do inverno. 


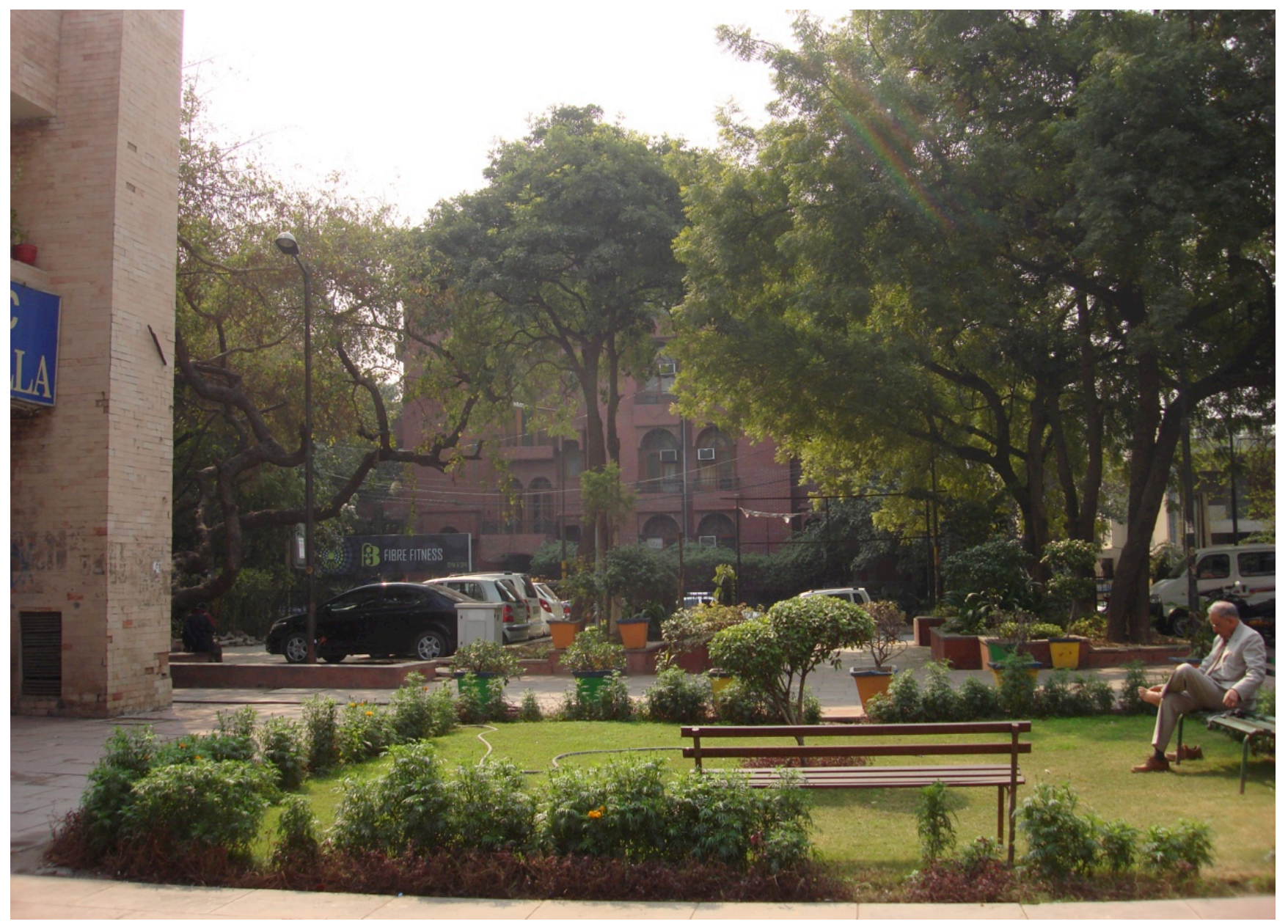

A PG vista desde o pátio do Aurobindo Market. 


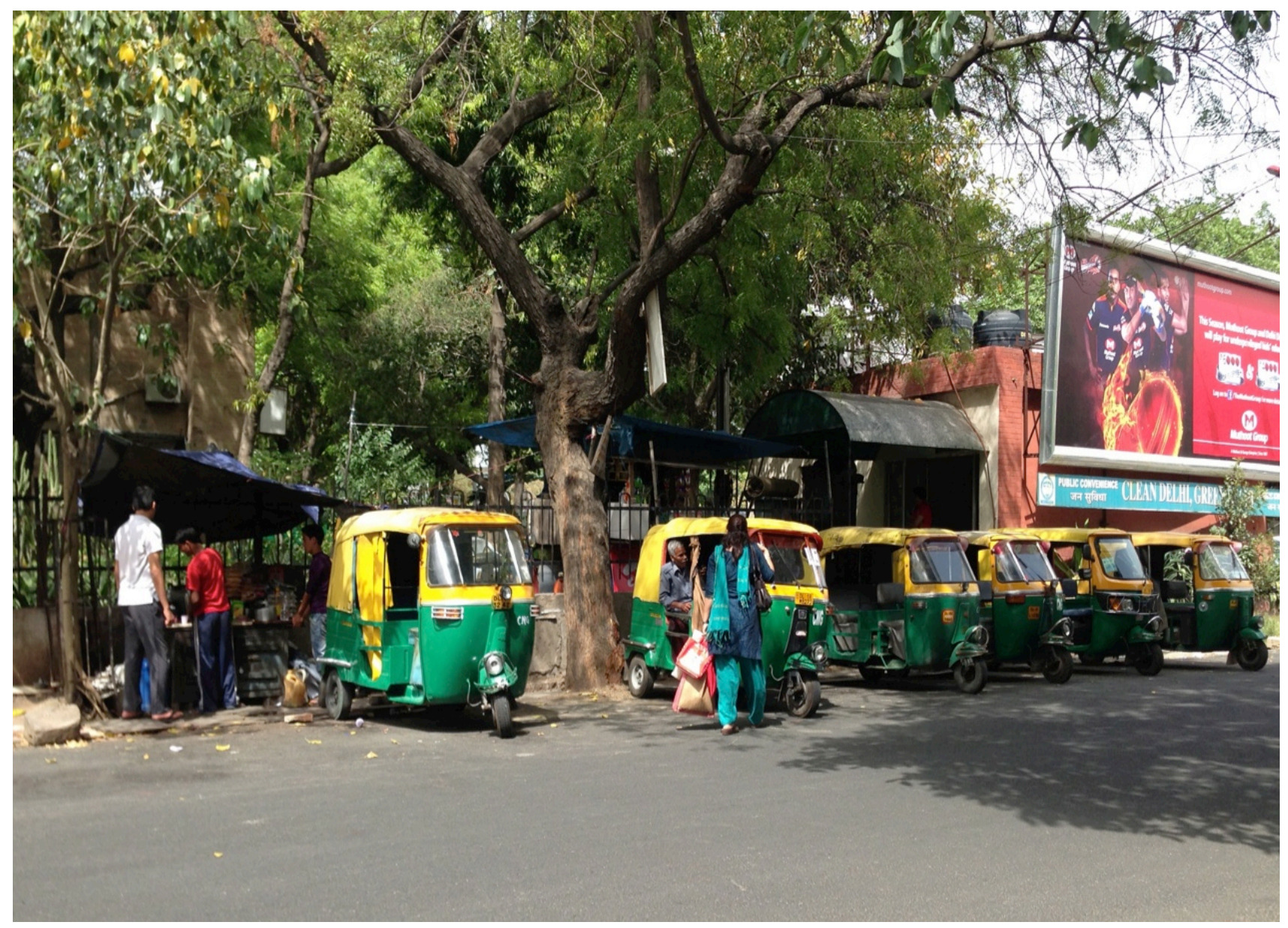

Ponto de auto-riquixás em Aurobindo Market, de frente à PG. Dileep (camiseta branca) compra um tchai. 


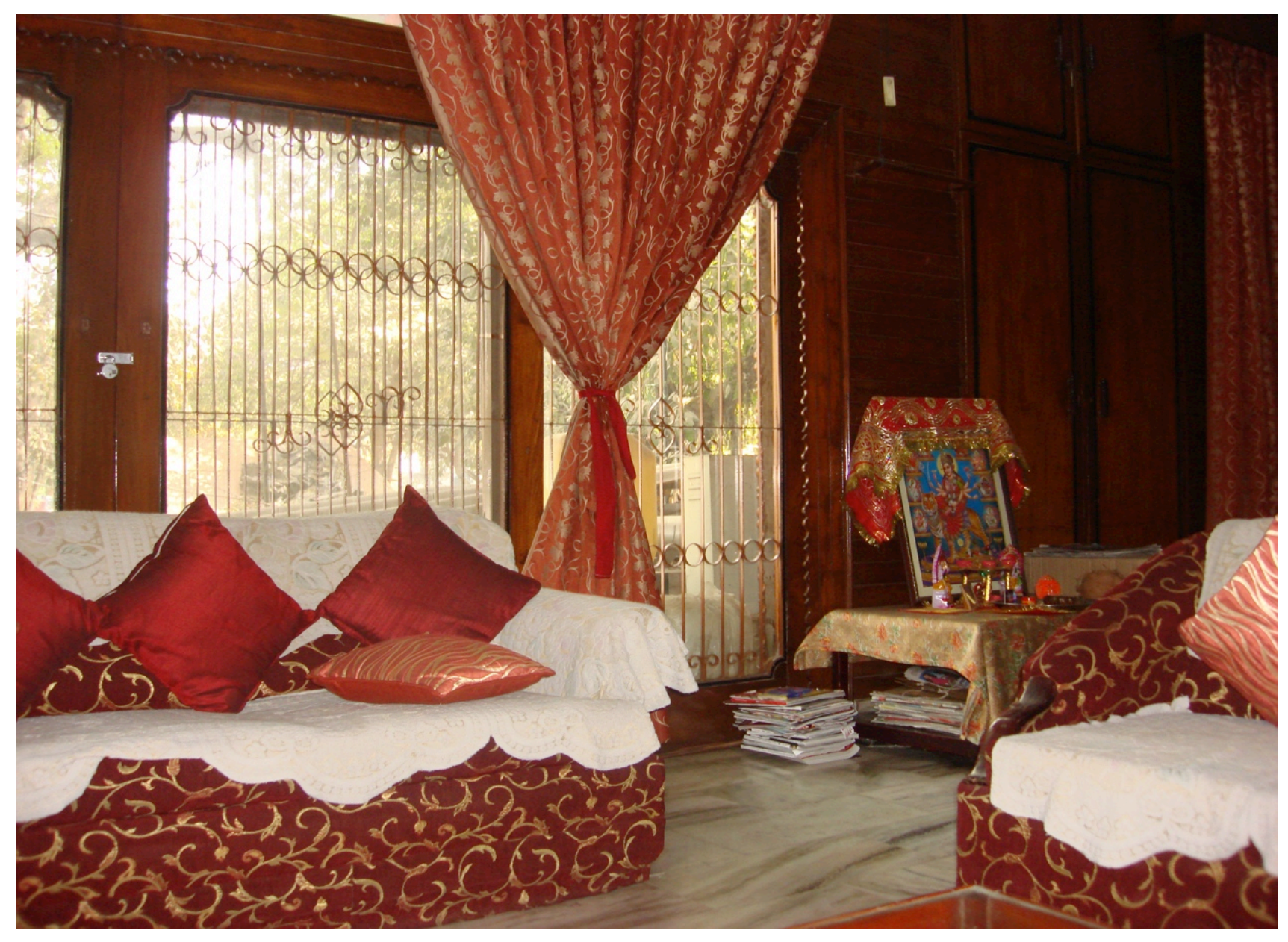

A sala de estar da PG em 2012. 




A mesa de jantar em 2012. 


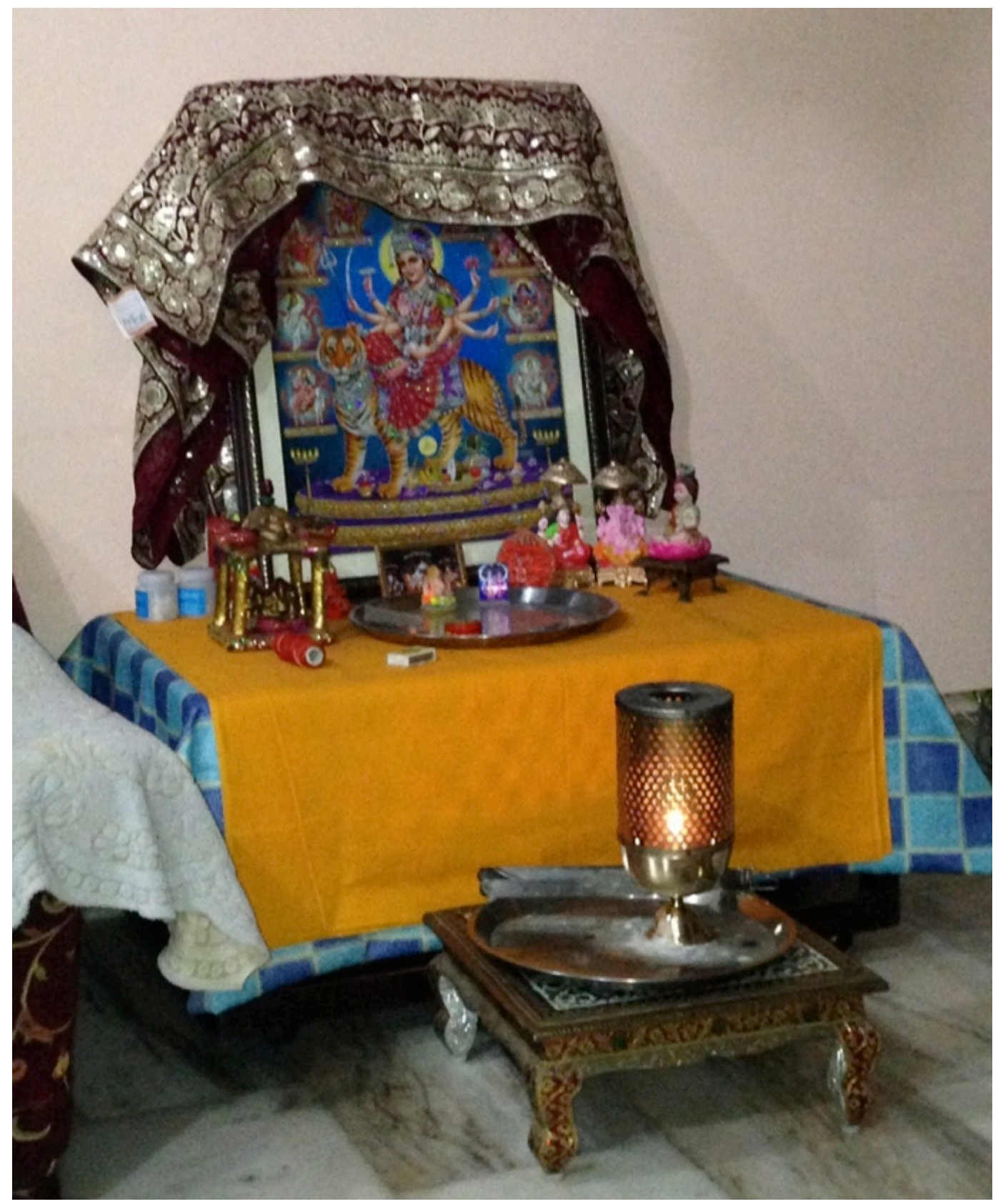

Detallhe com o altar de Durga em 2013 nos dias do festival Navadurga, nove noites em que se adoram as nove formas dessa deusa. A lanterna fica acesa durante todos esses dias e oferendas alimentares são feitas. Para se aproximar do altar é preciso descalçar os pés nos momentos de pooja (adoração). 


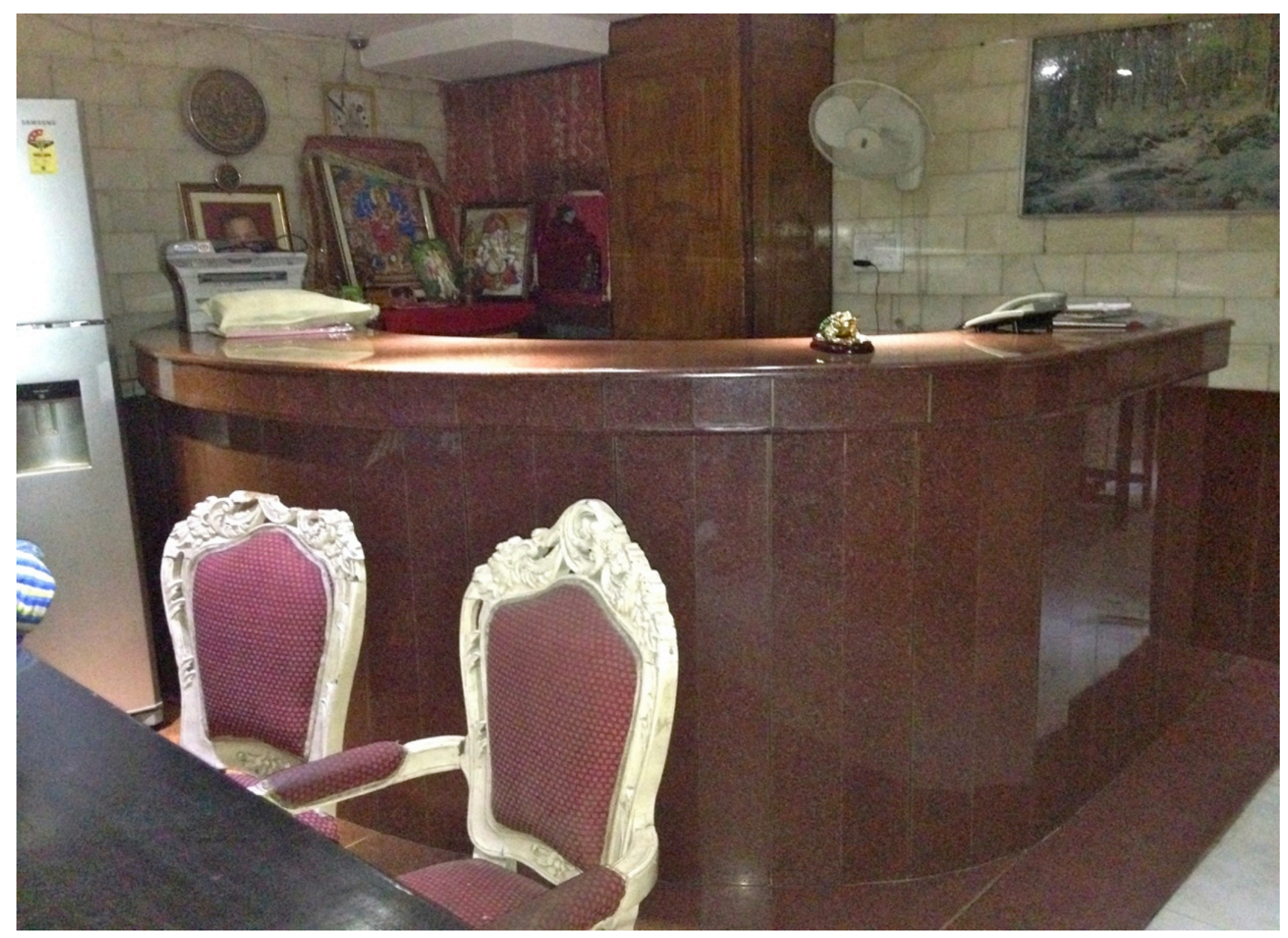

O balcão da recepção e a pequena mesa, com duas cadeiras, onde se fazem as refeições coletivas desde 2014. 


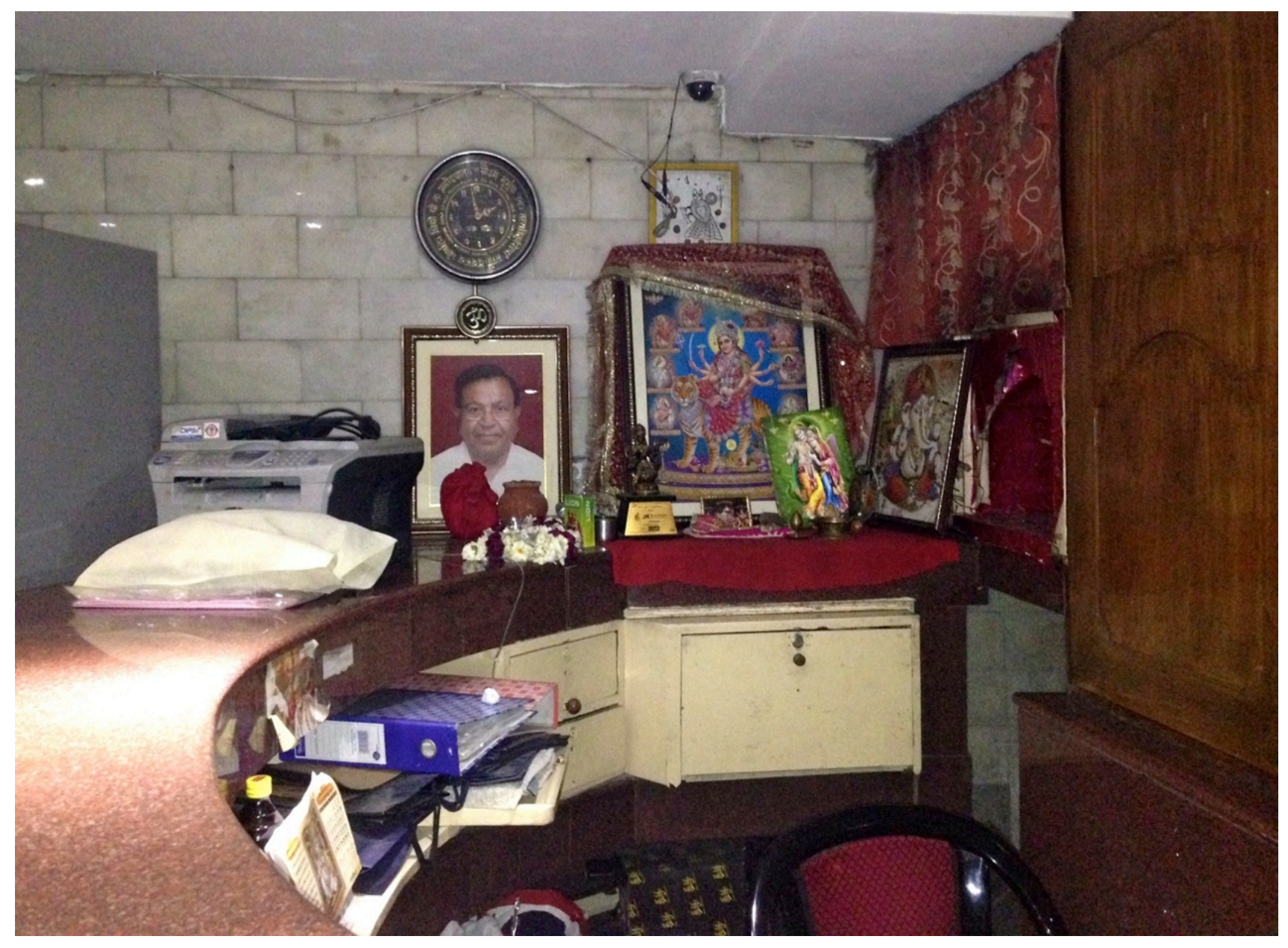

O altar de Durga também foi reposicionado e agora permanece ao lado do retrato do pai do senhor Kapoor e de outras divindades, como Ganesha e o casal Radha e Krishna. 




Da recepção, o corredor que leva à cozinha. 




Ruas de Old Delhi, vista da escadaria da Jama Masjid (Grande Mesquita), 2012. 


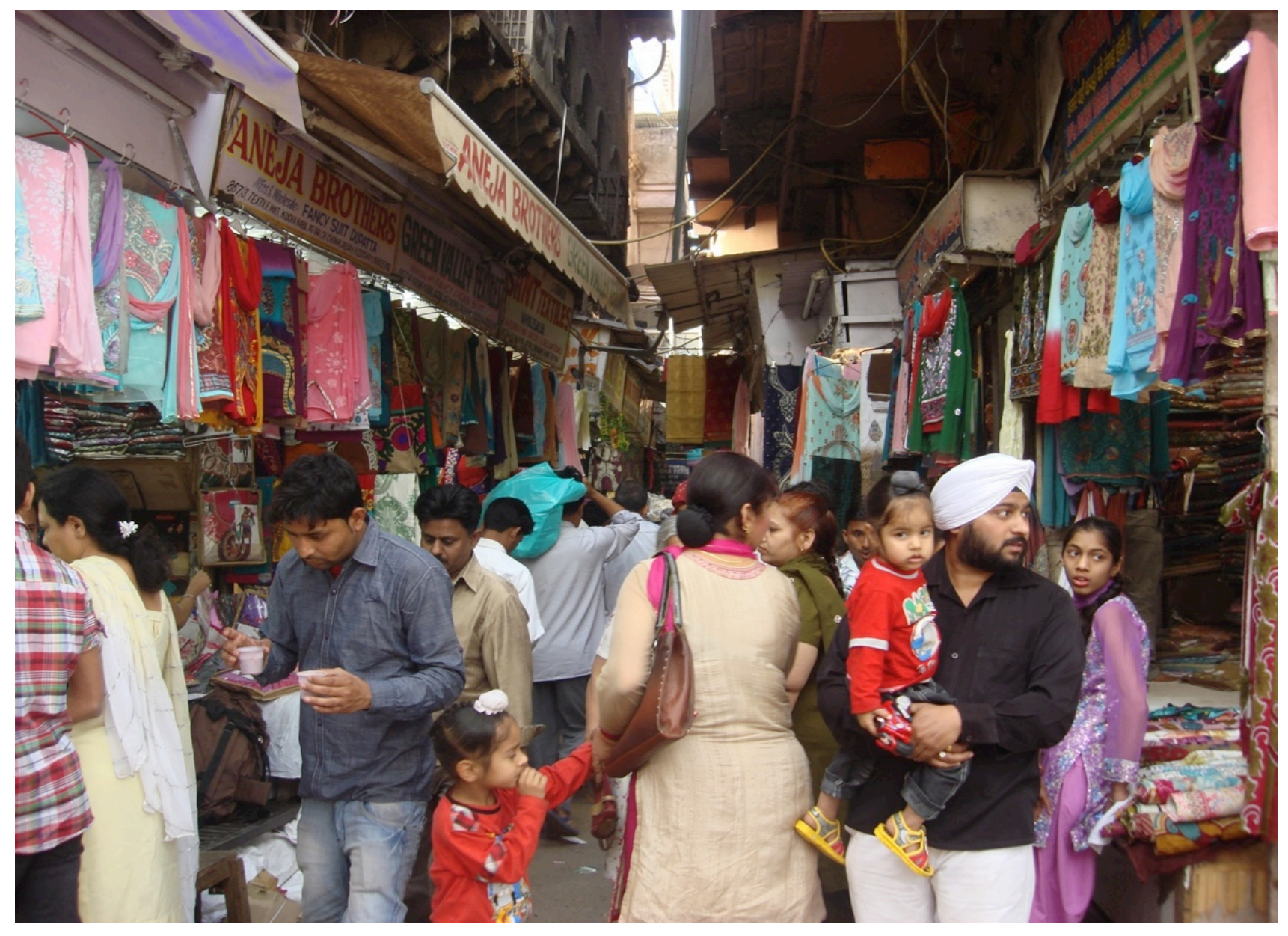

Uma das apertadas ruas de Old Delhi. Ano 2012. 


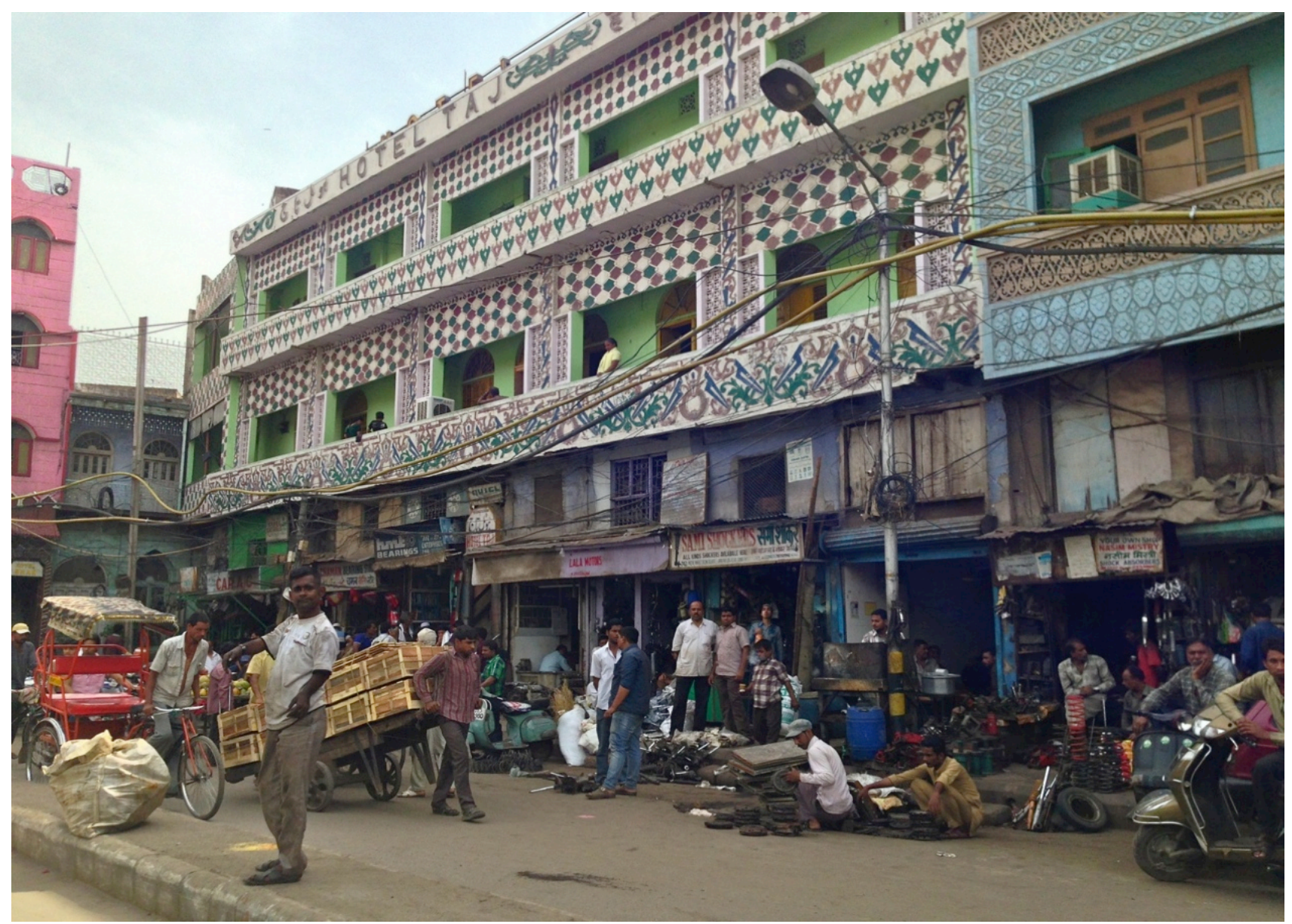

Cena de rua em Old Delhi, 2014. 




Cena de rua em Old Delhi, 2014. 


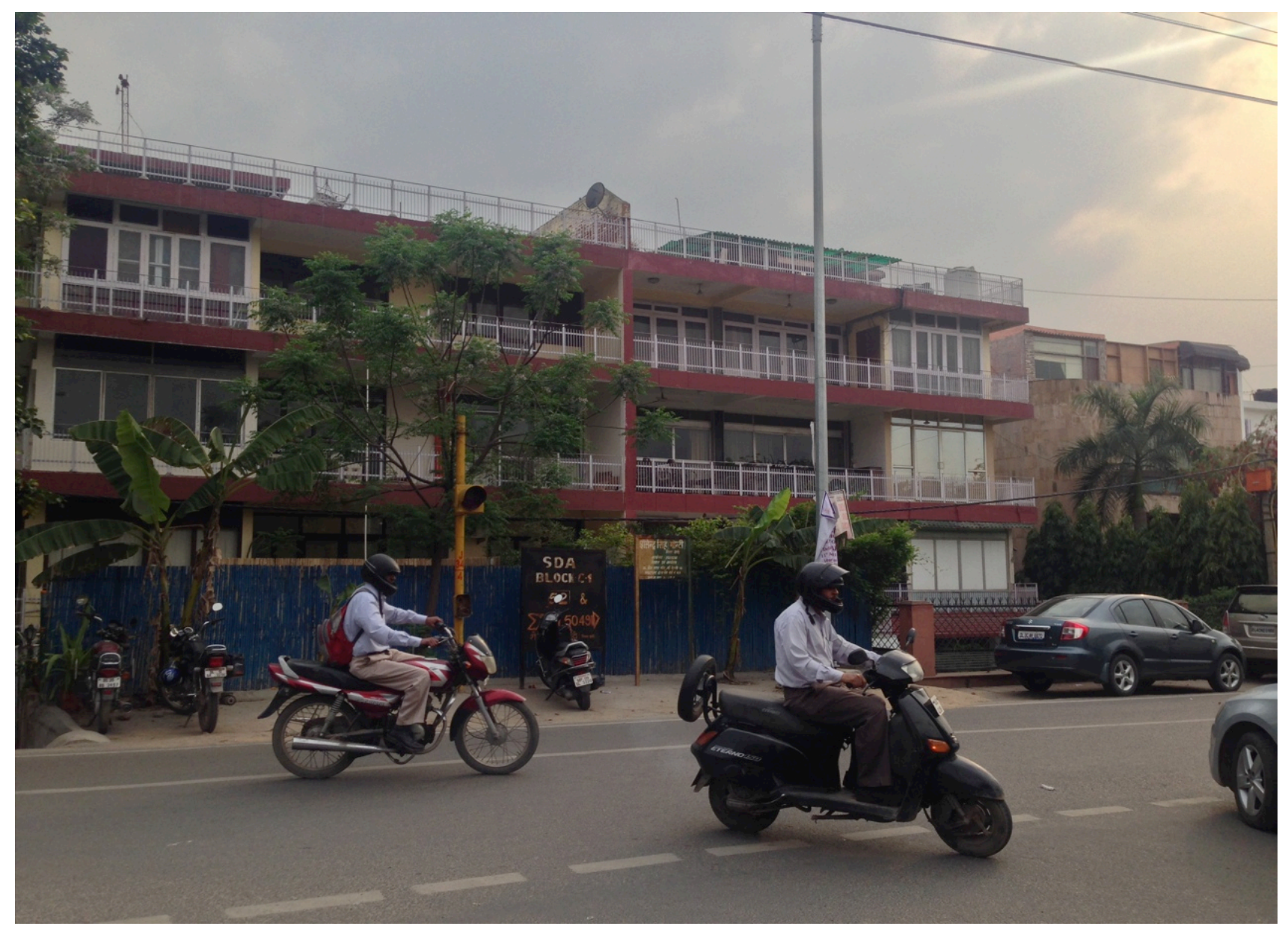

Rua próxima à PG no caminho para Green Park Market. 


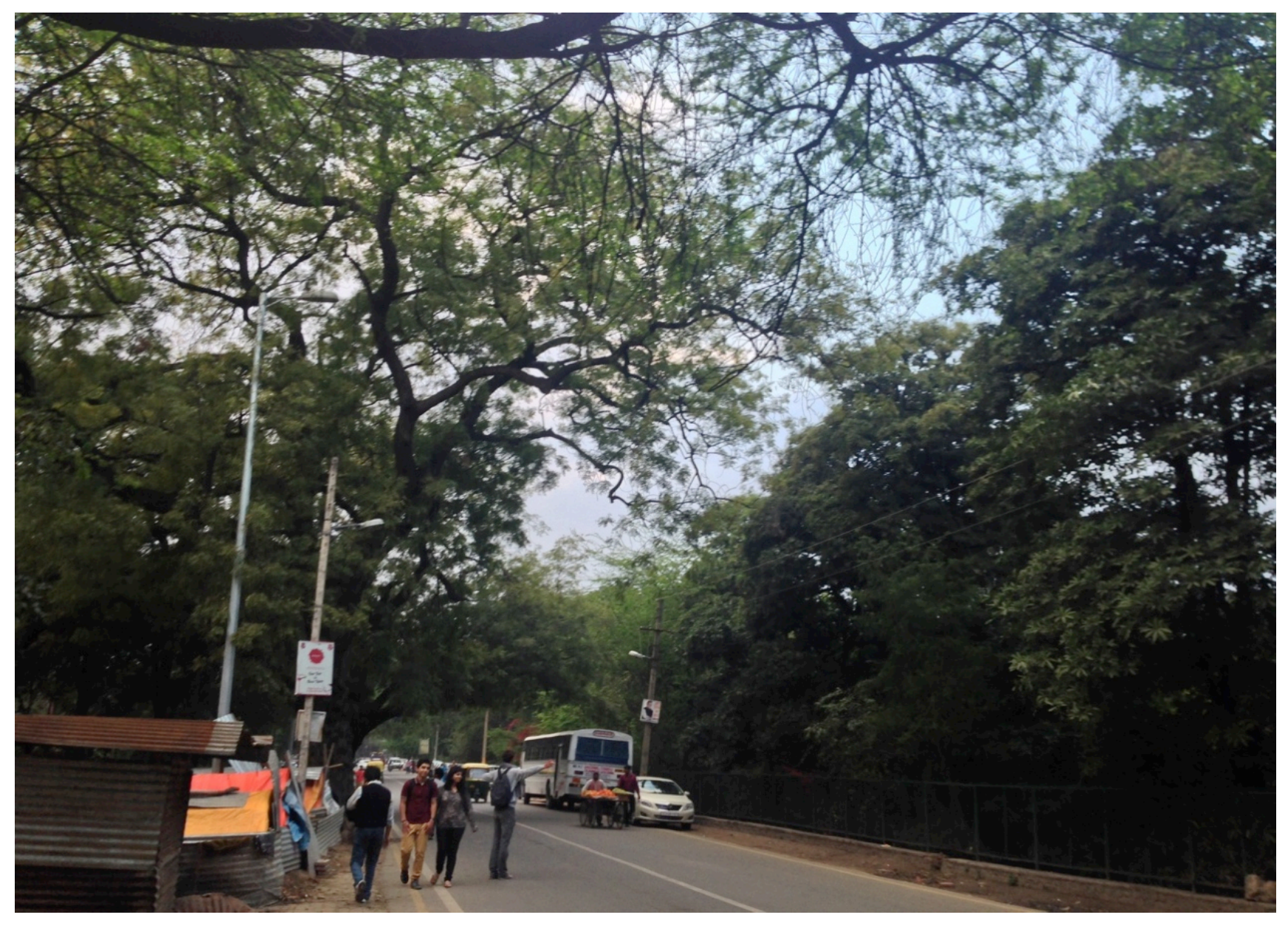

No caminho para Hauz Khas Village. As grades são do Deer Park, povoado por veados, esquilos, macacos, pavões e outras aves. 




Moradias improvisadas de trabalhadores quase à entrada de Hauz Khas Village. 


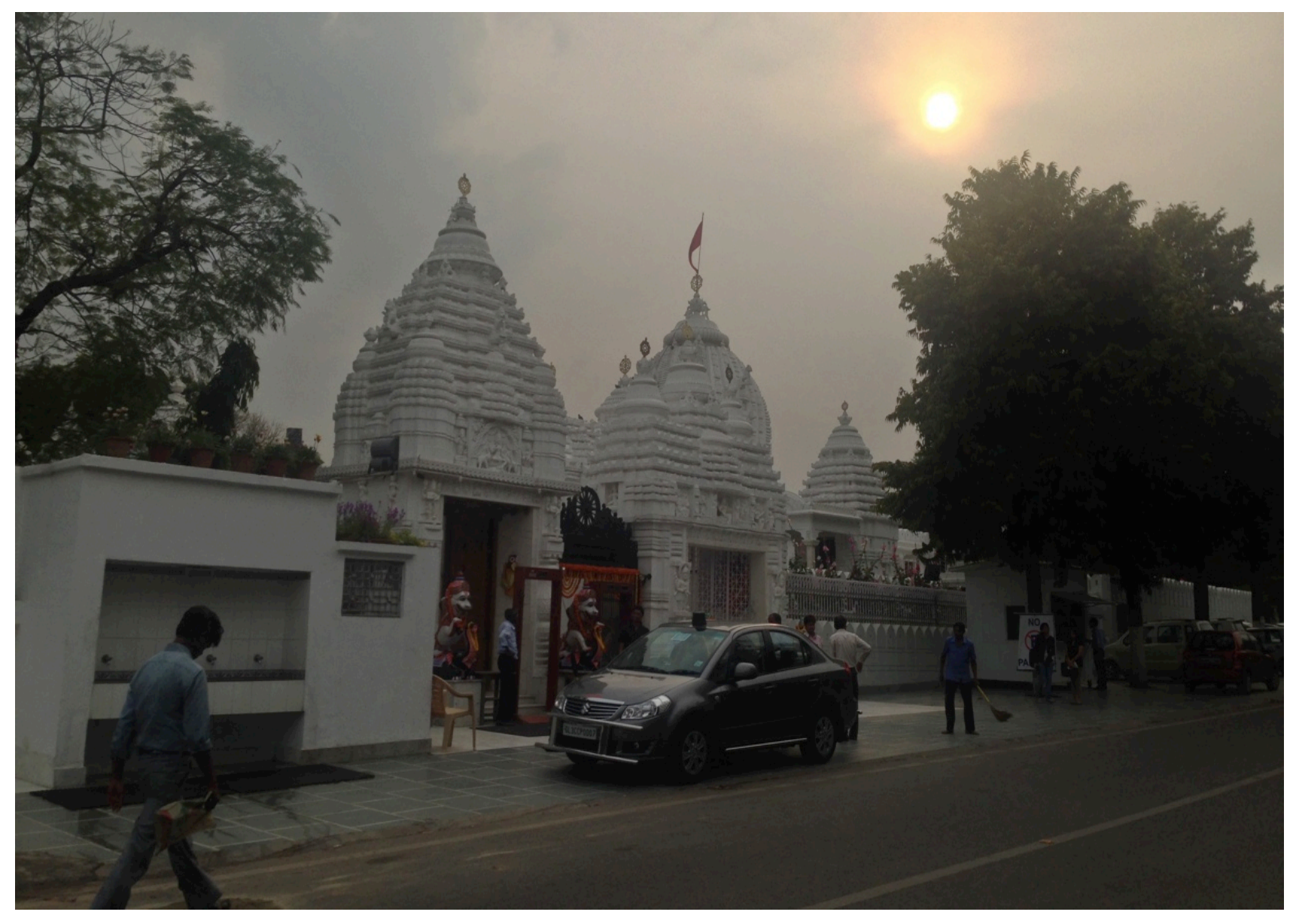

Templo do Senhor Juganath, no caminho para Hauz Khas Village. 


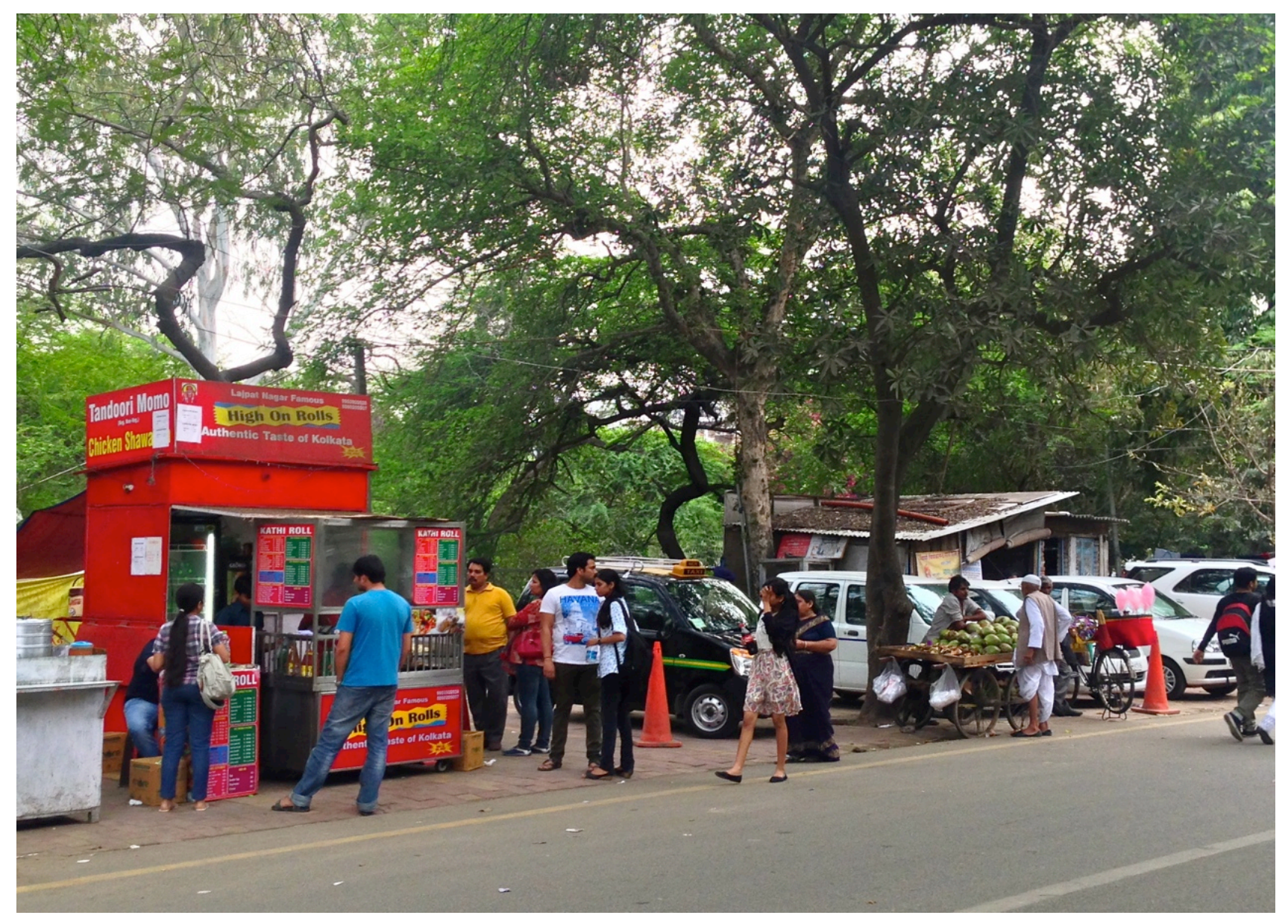

Ambulantes e transeuntes na entrada de Hauz Khas Village. 


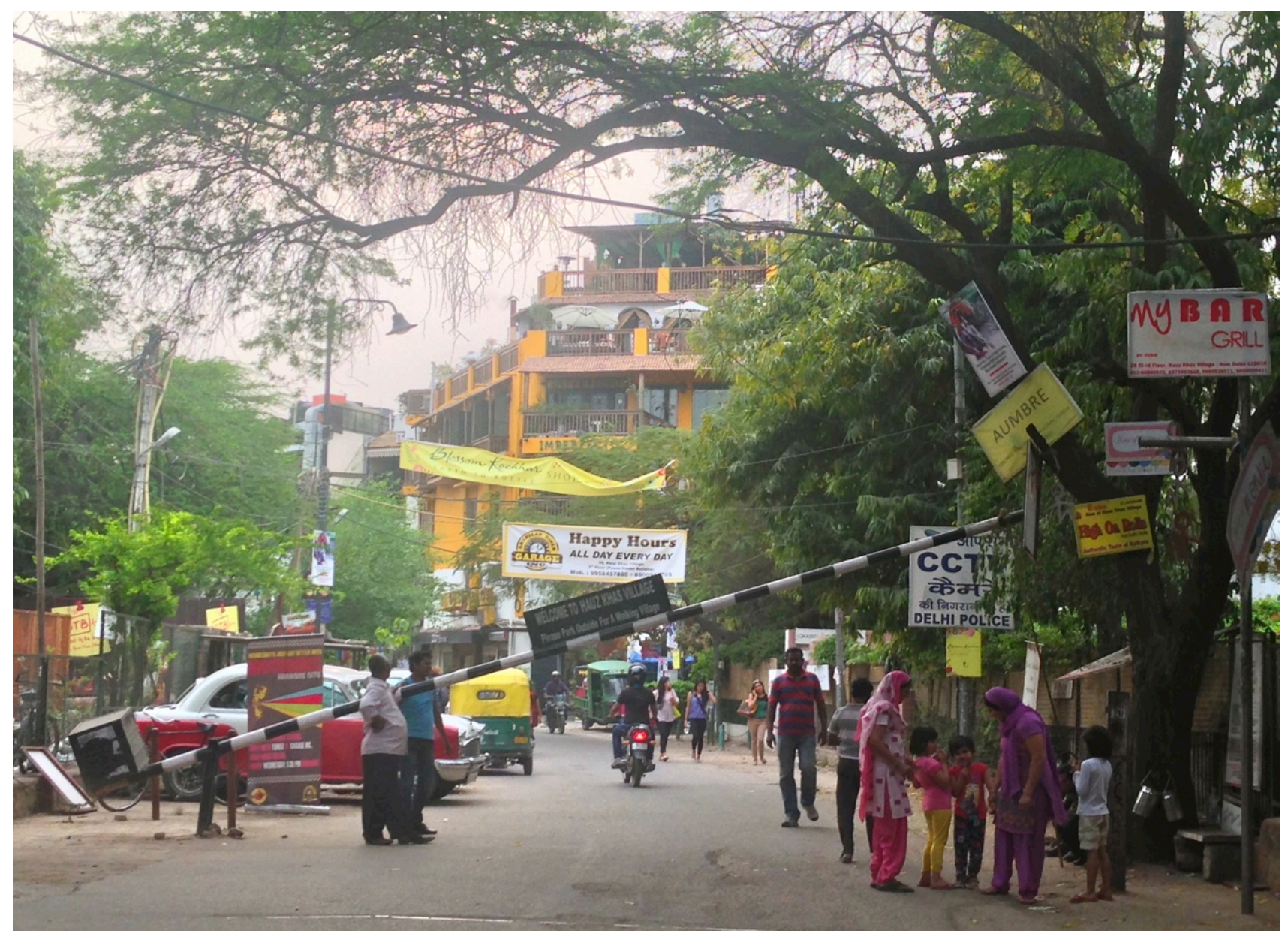

Uma cancela operada manualmente permite a entrada de veículos de moradores e impede a entrada de veículos visitantes em Hauz Khas Village. 




O primeiro estabelecimento que se avista à entrada da HKV é o Imperfecto, restaurante de comida espanhola e italiana. 




Alguns passos à frente do Imperfecto, a loja de roupas "Global Desi" (Indiana Global). 


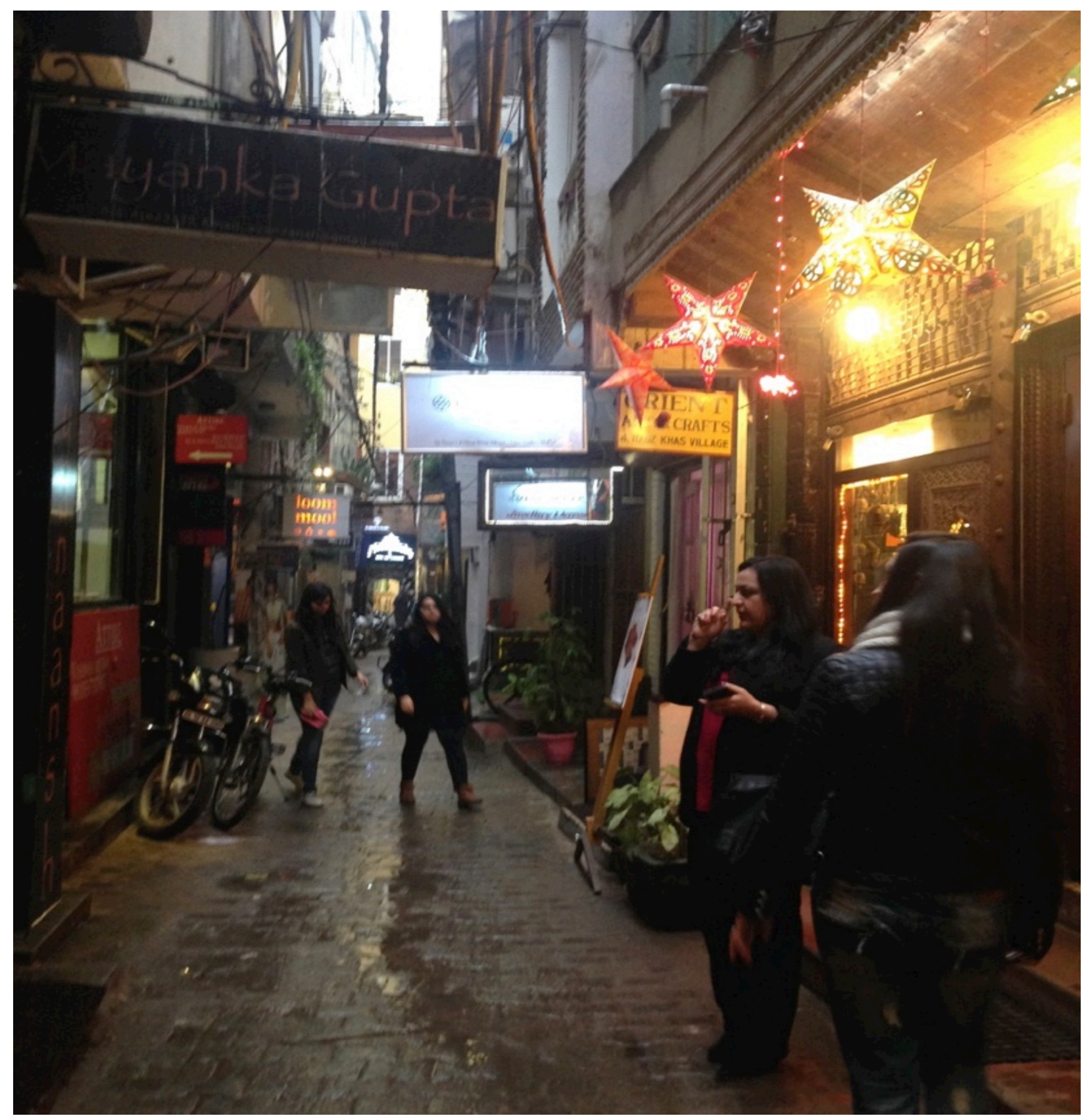

Ruela em HKV, se diferencia das ruelas em Old Delhi, não em estreiteza, mas na paisagem moral, a começar pela quantidade muito menor de pessoas nas ruas e pelas roupas que estas usam e compram nos dois lugares. 


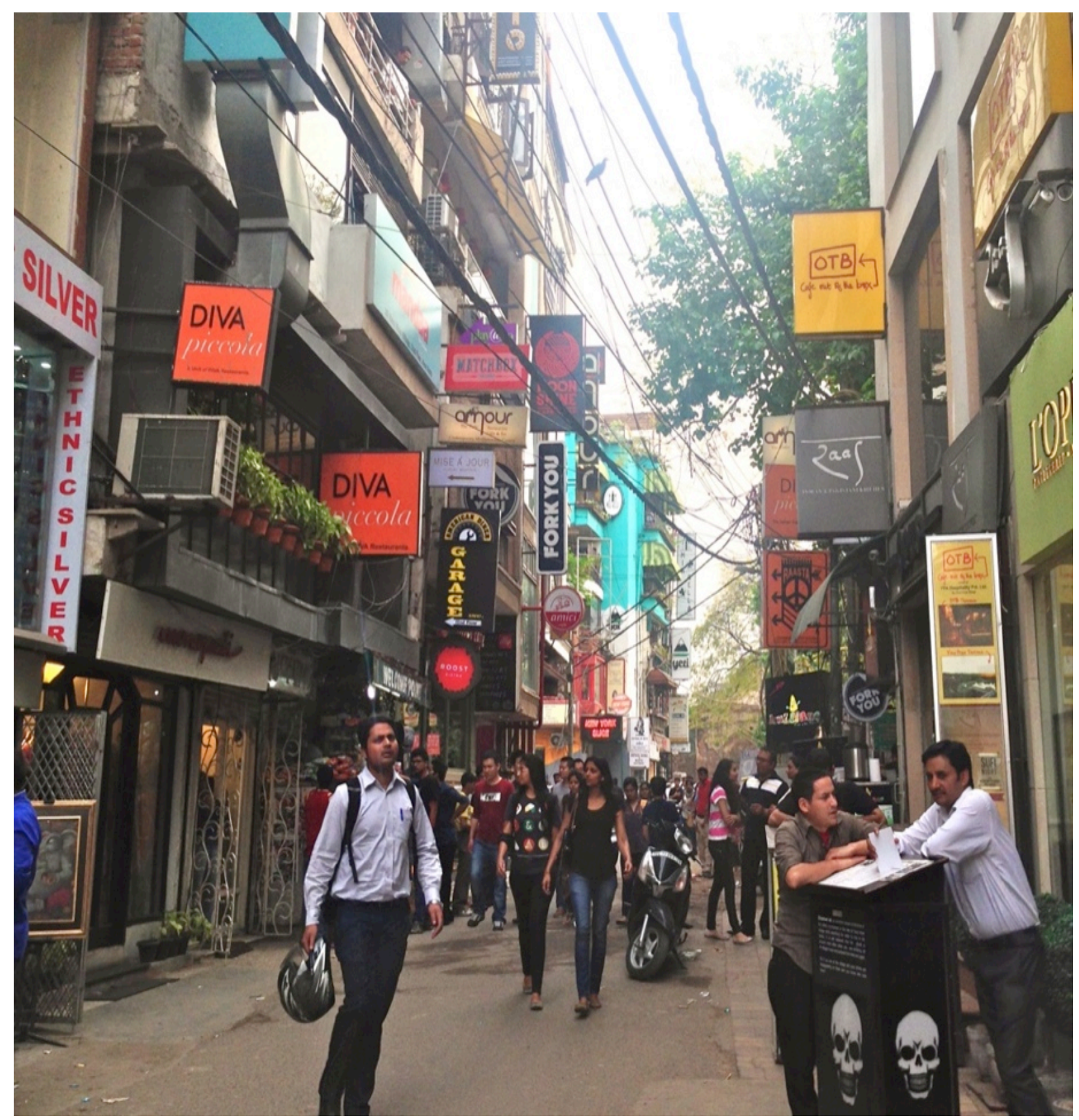

Uma profusão de placas disputa a atenção dos frequentadores da Hauz Khas Village. 


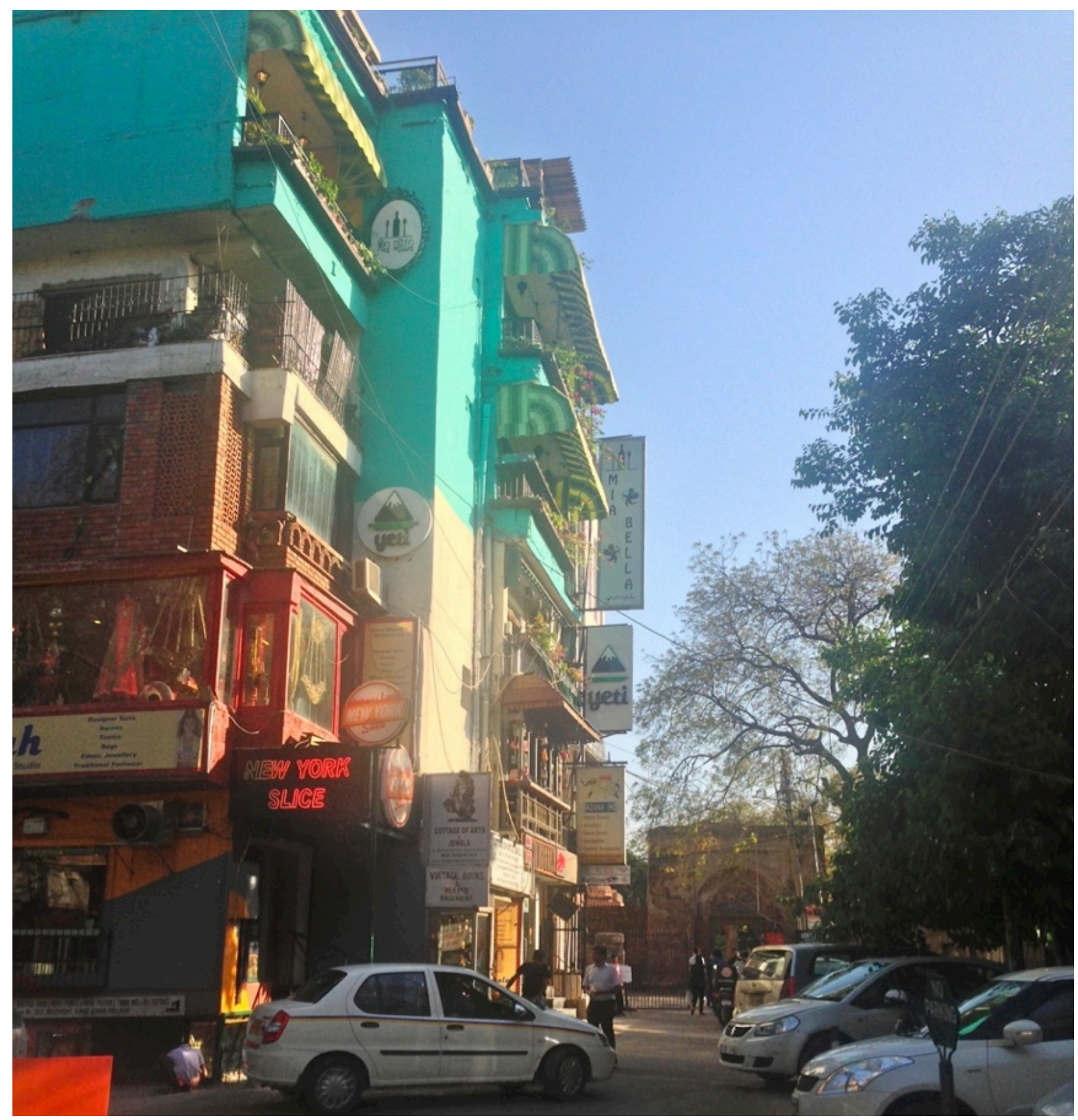

Acima pode-se ver a placa da torteria New York Slice e os balcões do restaurante Yeti (em verde),

que serve comida tibetana. Mais à frente a entrada para as ruínas de Haus Khas, onde há também um lago. 


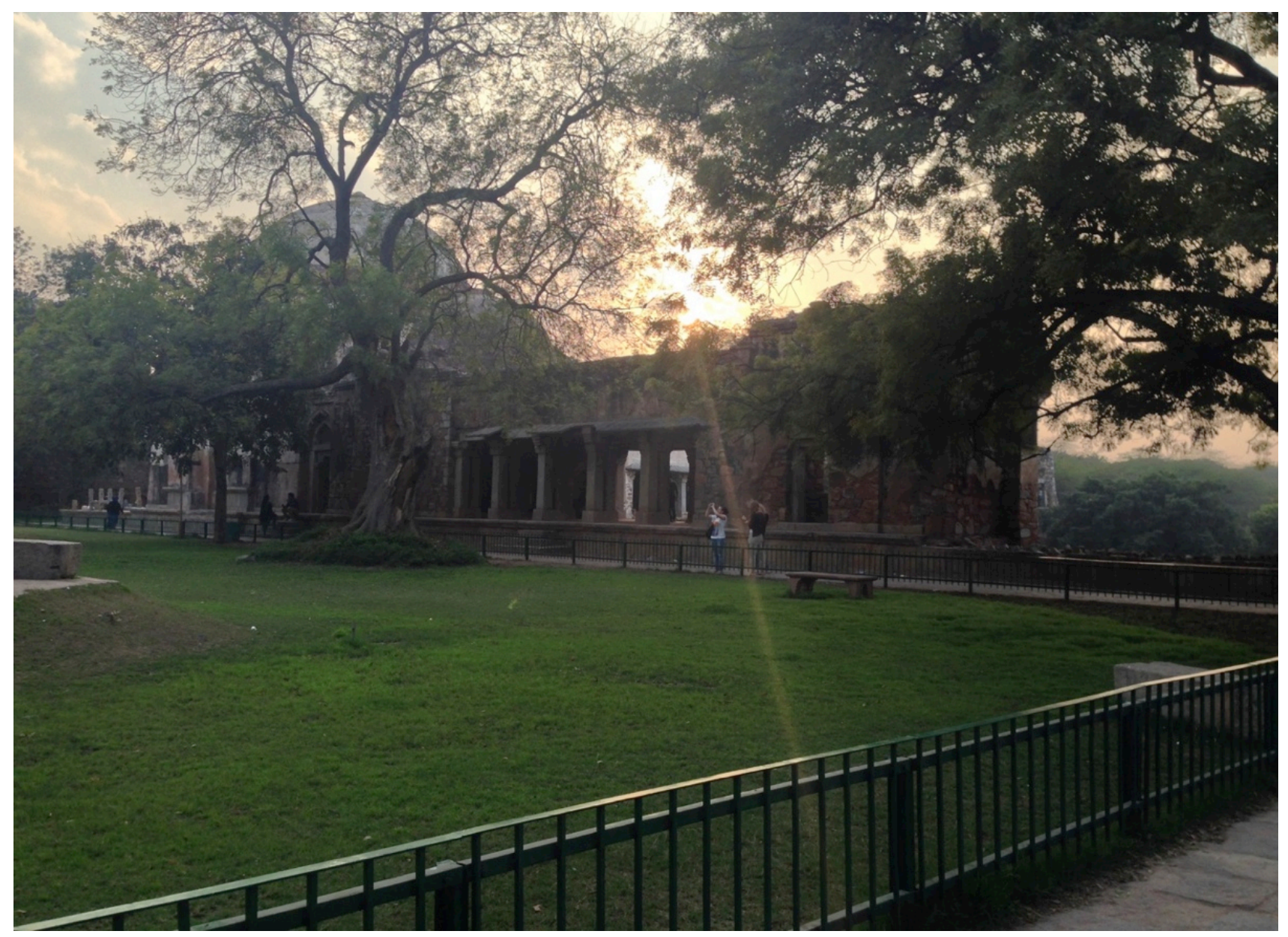

No interior do complexo arqueológico de Hauz Khas Village as ruínas de uma madrasa (escola Moghul). A este lugar acorrem inúmeros jovens todas as tardes. Ficam a caminhar, sentados conversando, tocando violão, fumam cigarros e tiram fotos. 




Nas reentrâncias da madrasa, um uso inusitado: a paisagem a céu aberto cria privacidade para flertes e namoro. 




Os jovens de Délhi acorrem a parques e jardins abertos, como esse, por considerar que ali têm um espaço para intimidade amorosa. 


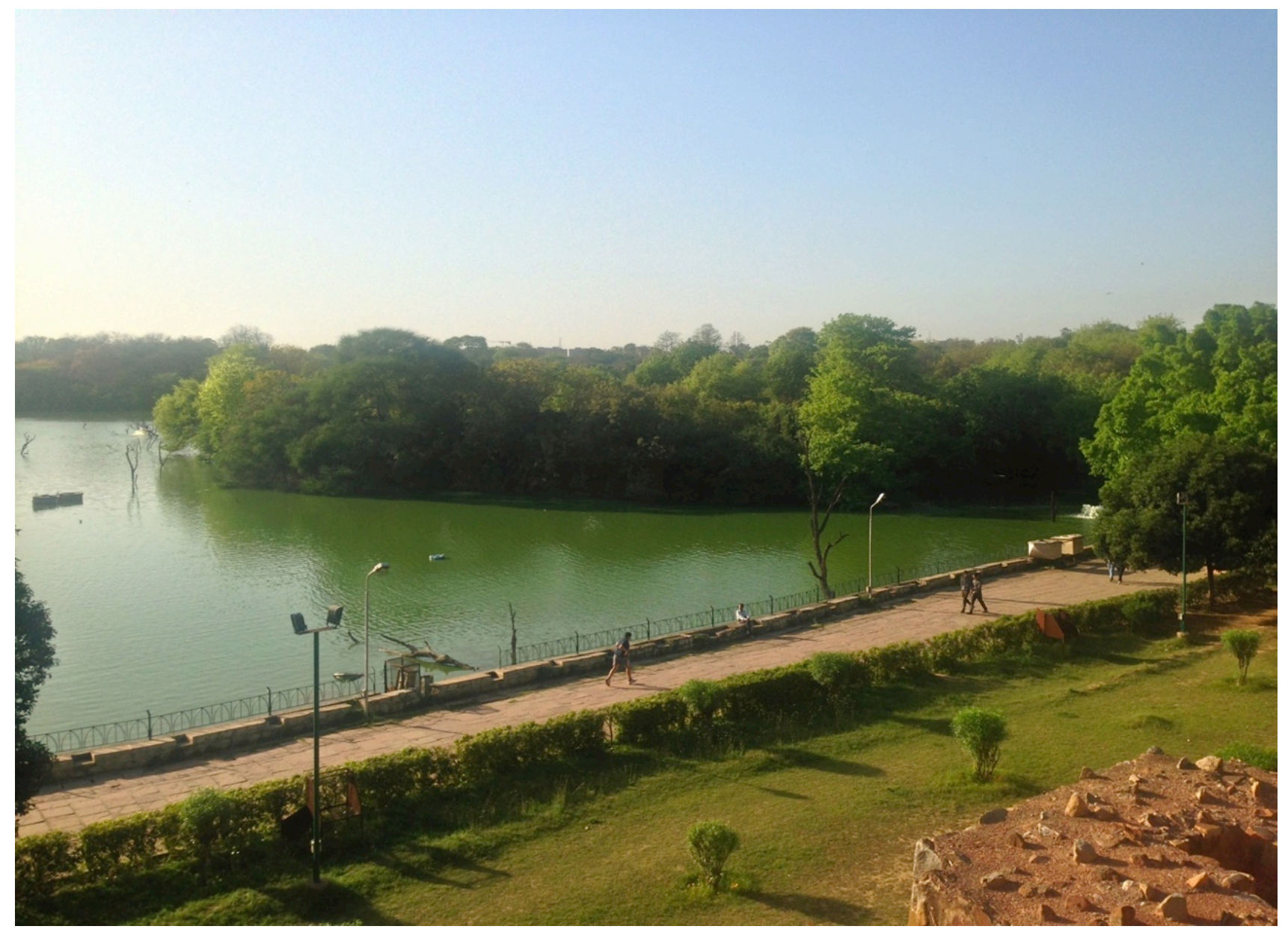

Hauz Khas Lake, em volta do qual muitos caminham ao entardecer. 


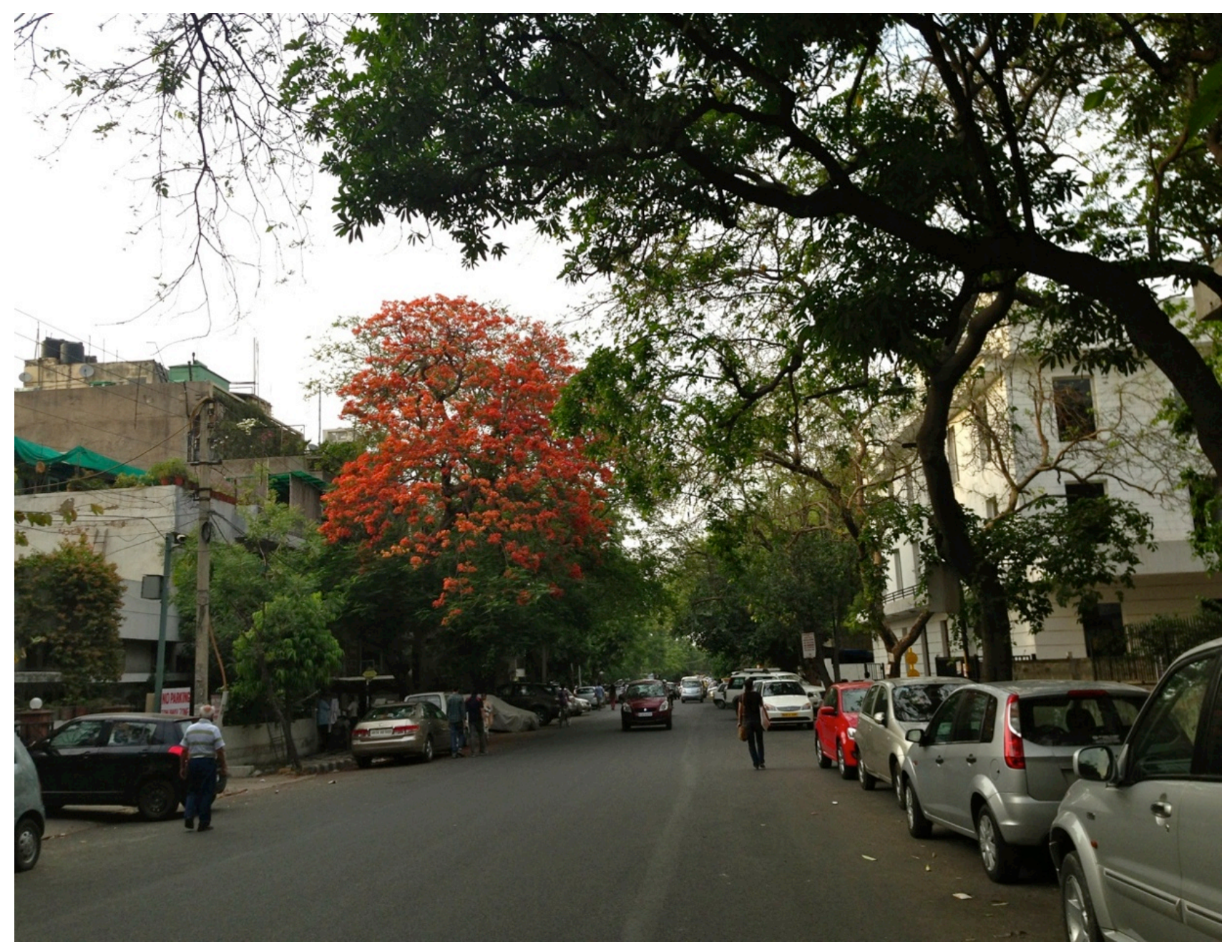

Rua que leva até o Green Park Market. 


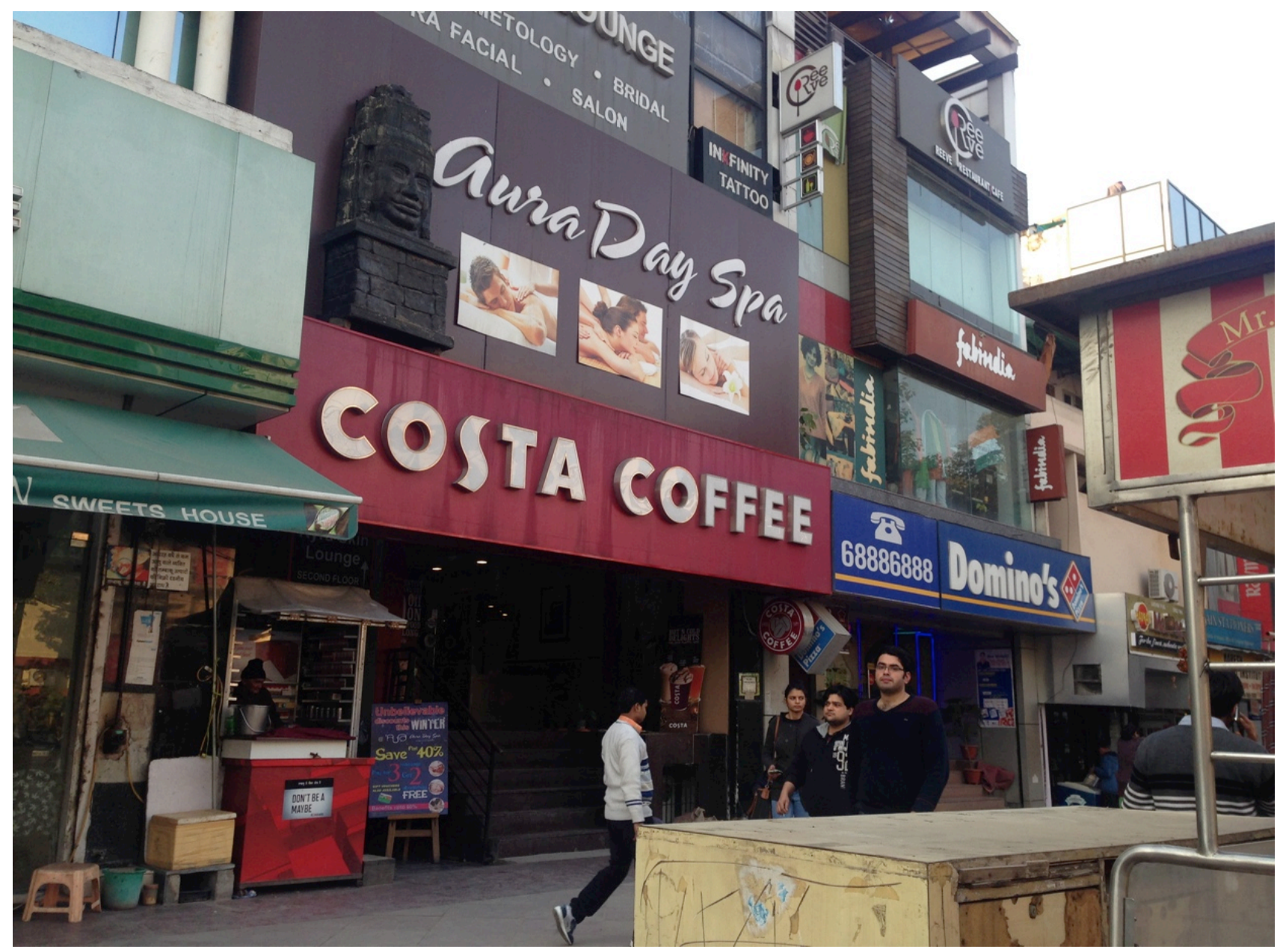

Restaurantes, cafés, pizzarias e lojas em Green Parket Market. 


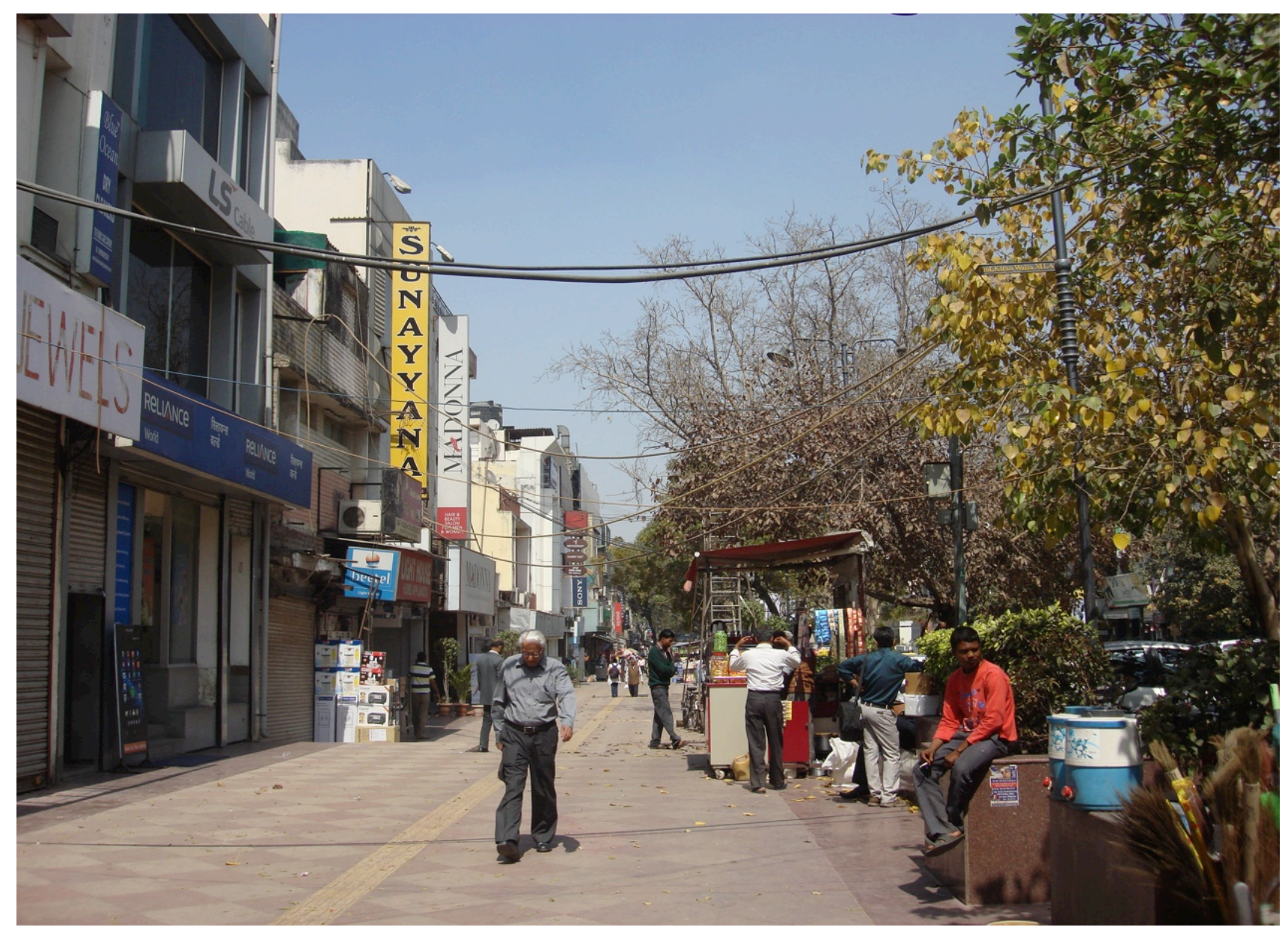

Green Park Market. 